\title{
Universiteit
}

Leiden

The Netherlands

\section{Xenophobia in Seventeenth-Century India}

Kruijtzer, Gijs

\section{Citation}

Kruijtzer, G. (2009). Xenophobia in Seventeenth-Century India, 315.

Retrieved from https://hdl.handle.net/1887/21362

Version: $\quad$ Not Applicable (or Unknown)

License: $\quad$ Leiden University Non-exclusive license

Downloaded from: $\quad$ https://hdl.handle.net/1887/21362

Note: To cite this publication please use the final published version (if applicable). 


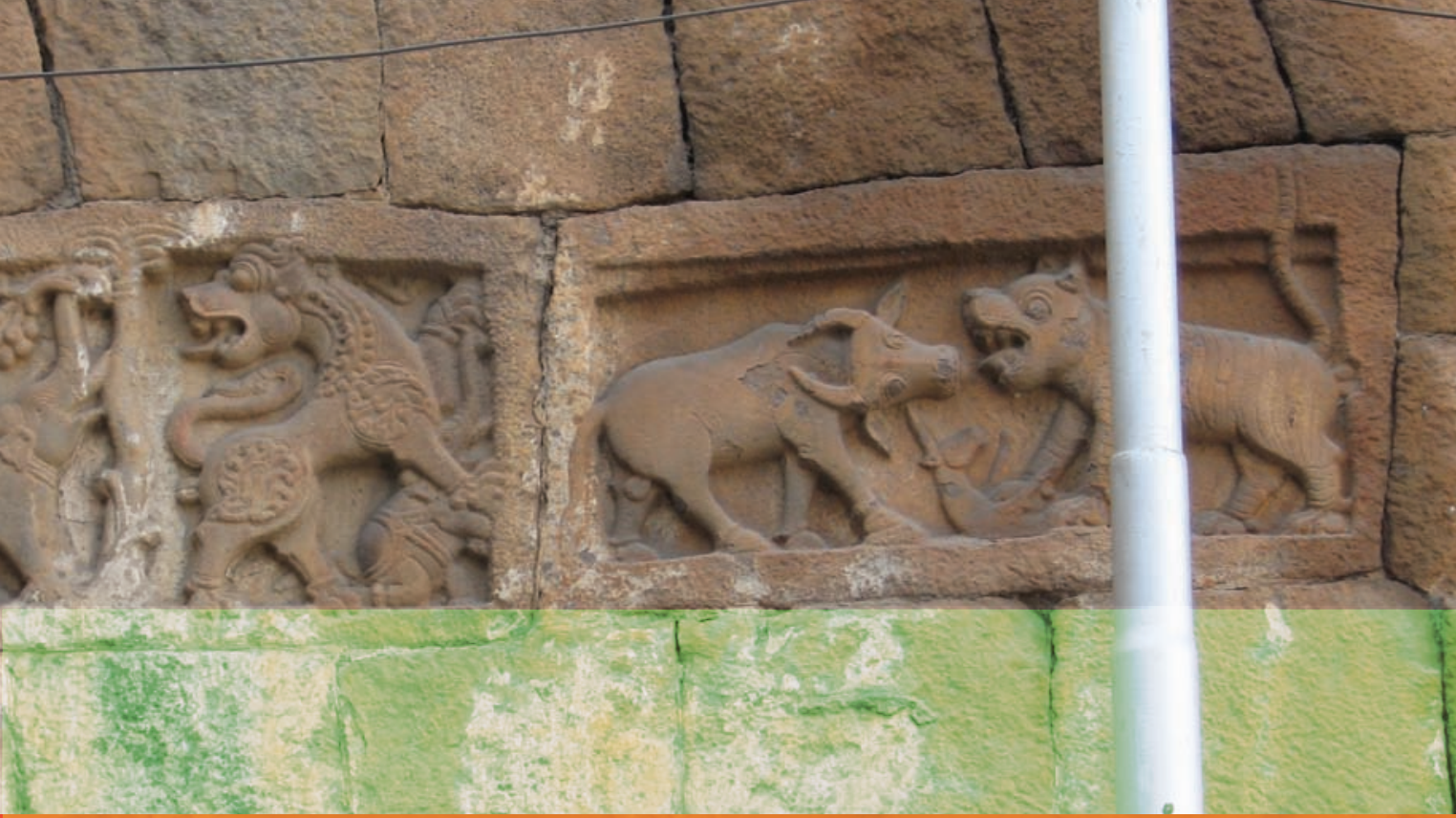

IN SEVENTEENTHCENTURY INDIA

GIJS KRUIJTZER

Leiden University Press 
Xenophobia in Seventeenth-Century India 



\section{XENOPHOBIA IN}

\section{SEVENTEENTH-CENTURY INDIA}

GIJS KRUIJTZER

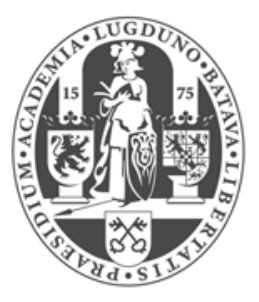

Leiden University Press 
First Leiden University Press edition, 2009. Entirely revised from the author's dissertation Xenophobia and Consciousness in Seventeenth-Century India: Six Cases from the Deccan, 2008.

Cover illustration: a relief in the wall outside the Banjara Gate of Golkonda fortress, made around 1560. It depicts a tiger and a bull fighting over a unicorn, and to the far left, a lion trampling an elephant. A modern lamp-post partly obstructs the view. Photograph by Robert Simpkins.

$$
\begin{aligned}
& \text { Cover design: Maedium, Utrecht } \\
& \text { Lay out: Gijs Kruijtzer } \\
& \text { ISBN } 9789087280680 \\
& \text { e-ISBN } 9789048510948 \\
& \text { NUR } \quad 680
\end{aligned}
$$

(C) G.C. Kruijtzer / Leiden University Press, 2009

The whole or parts of this book may be reproduced for non-commercial purposes provided that its authorship is properly acknowledged. The copyright of some of the photographs is held by others than the author, as mentioned in the list of illustrations and above. 
WHY THIS STUDY—SETTING AND OUTLAY-

THEORETICAL ISSUES-ACCUSATIONS AND

COUNTERACCUSATIONS-PRELIMINARY COMMENTS ON THE SOURCES

Part I

Chapter 1 A Dutch Painter in Bijapur: National Sentiment and European-ness as Reflected in the Relation between the Dutch and the Portuguese in the Early Century

INTRODUCTION-EUROPEANS AMONGST EACH OTHER (AN ARTIST AND A PATRIOT-JUST W AR AND JIHAD)— EUROPEANS AND INDIANS (THE BOUNDS OF ETHICSSEXUAL BOUNDARIES-BOUNDARY CROSSING AND DUTCHNESS)_EXPLAINING EUROPEAN BOUNDARIES -CONCLUSION

Chapter 2 The Queen and the Usurper: Deccanis vs.

Westerners in Bijapur around 1636

INTRODUCTION-A WEDDING AND A MURDER-

COSMOPOLITANISM AND TRUST-LOCAL TIES-THE

War Party vs. The Peace Party-The Patriotic

Programme: GOOD GOVERNMENT-THE ROLE OF THE MONARCH AND HIS CONSORT-CONCLUSION

Chapter 3 The Right and Left Hand Disputes in Chennapatnam 1652-55: A Minimal Group Experiment in Seventeenth-Century India?

INTRODUCTION-THE NEW TOWN AND ITS STATE OF DiARCHY-The Principal ACTORS-The Dispute AND ITS STAKES-PROBLEM 1: THE ROLE OF THE ENGLISH: TOO UNINVOLVED OR TOO INVOLVED?Problem 2: Under Whose GaZe? —PRoblem 3: The Minimal Group Hypothesis IN History, AND THE PROBLEM OF INVENTION-CONCLUSION 
Chapter 4 Saying One Thing, Doing Another? Shivaji and

Deccani Patriotism 1674-80

INTRODUCTION-SHIVAJI'S DISCOURSE ON “DECCAN FOR THE DECCANIS"-ACTIONS OF SHIVAJI AND HIS ANTAGONISTS-DISCOURSES OF CONTEMPORARIES ON SHIVAJI's MOTIVATION AND THAT OF His ANTAGONISTS-CONCLUSION

Chapter 5 Anxiety in Aurangzeb's Deccan: Marathas, Sidis and Keigwin's Rebellion 1683-4

INTRODUCTION-THE DECCAN ELECTRIFIED—THE EFFECT OF WARFARE ON THE NON-COMBATANT POPUlATION-THE REPUBLIC OF BOMBAY—FEAR OF THE SIDIS AND THE ANTAGONISM BETWEEN MARATHAS AND SIDIS (BOMBAY IN BETWEEN-CONQUEST, ENSLAVEMENT, CONVERSION-NUANCES)— CONCLUSION

Chapter 6 Madanna, Akkanna and the Brahmin Revolution in Golkonda 1674-86

INTRODUCTION-SOME BIOGRAPHICAL DATA-THE ECONOMIC CONDITIONS-THE FACTIONS-THE INVOLVEMENT OF THE EUROPEAN NATIONS AND THEIR RENEGADES IN THE FACTIONAL STRUGGLE-THE SOCIAL IDENTITIES-THE PROBLEM OF LOYALTYCONCLUSION

Conclusion Human Nature in a Seventeenth-Century Environment

Epilogue Aurangzeb/Shivaji and the Eighteenth Century

An Axial DeCade-A Bleak Century-The Ethics REVISITED

Appendix I Dutch Usage for Muslim and Hindu

Appendix II Aurangzeb on Stratagem 287

Appendix III On the Authenticity of Shivaji's and Sidi Mas'ud's 289 Letters to Maloji Ghorpade

A Note on Usage

List of Abbreviated References 293

Repositories of Unpublished Sources 294

$\begin{array}{ll}\text { Select Bibliography } & 295\end{array}$

Index (also serving as glossary and who is who) 306 
MAPS

The Deccan in 1600 . 4

The Deccan in $1650 . \quad 104$

Tentative Reconstruction of the Chennapatnam Area in 1650. 121

$\begin{array}{ll}\text { The Deccan in } 1680 . & 190\end{array}$

\section{FIGURES}

Chennapatnam/Fort St. George around 1653. 117

Intensity of the Left-Right Antagonism as a Function of Time: 147

Three Models.

\section{ILLUSTRATIONS}

Detail of the frontispiece of Havart's translation of Sa'adi's Bustan.

Courtesy Koninklijke Bibliotheek, catalogue number 895J66.

Dutch translation of the seal of Bari Sahiba Khadija Sultana.

Courtesy National Archives, The Hague, VOC 1241: 335.

Portraits of Khawas Khan and Mustafa Khan in the Witsen Album, numbers 42 and 43. Courtesy Rijksmuseum Amsterdam.

Right side of the façade of Khawas Khan's mosque. 80

Interior of Mustafa Khan's mosque. $\quad 81$

East face of the gate to the ceremonial core of the Raigarh fortress. 154

$\begin{array}{ll}\text { The Monarch of the Field gun at Bijapur } & 155\end{array}$

Upper portion of the entrance gate to Raigarh, with close-ups of the 161 reliefs.

Portrait of Shivaji wearing a boar-headed gauntlet sword, with detail. 162

Courtesy Musée Guimet, Paris, catalogue number 35.554.

Reliefs to the left and right of the inscription at the Sharza Bastion. 165

The fortress of Sindhudurg, built by Shivaji on an islet just outside 193 the port of Malvan, with tourists.

Image of the deified Shivaji (Shivarajeshvar) in a temple built by his 213 son Rajaram in the Sindhudurg fortress in 1695.

Akkanna and Madanna as represented in the Witsen Album, numbers 38 and 37. Courtesy Rijksmuseum Amsterdam.

Details of the Witsen Akkanna and Madanna. 229

Portrait of Akkanna in Havart's Op-en ondergang, 2: opposite 220. 238 Courtesy Leiden University Library, catalogue number 456 B7.

Madanna as represented in the The Smith-Lessouëf 233 album, folio 271 12. Courtesy Bibliothèque Nationale de France.

Modern statues of Shivaji in Sholapur, Hyderabad and Bijapur. 281 Photographs 2003. 


\section{ACKNOWLEDGEMENTS}

This book has been a long time in the making. I did not begin to research and write it in earnest until 2002, but some parts (Chapter 6) go back as far as 1997. In March 2008 it earned me a PhD and I have revised it once more since. Needless to say, it has benefited greatly from the input of the large number of people whom I have talked to and corresponded with in the period. First among them is Jos Gommans of Leiden University. I cannot express better the great role he played in my (intellectual) life than he himself did in the so-called laudatio he spoke at my thesis defence in Leiden in March 2008. Dirk Kolff, also of Leiden, has also been a wise and sharp commentator during the writing process. Connoisseurs of Deccan history will notice the similarity in the set-up of Eaton's Social History of the Deccan and the present work. Although I believe we arrived at this set-up as a series of case studies independently, Richard Eaton has been a great influence on my work and his advice, together with that of Gommans and Kolff, has been invaluable.

I should like to thank a number of people for critically reading chapters and giving both their honest opinions on them and suggestions for improvement: Vasant Bawa, Stefan Kras, Matthijs Lok, Sheldon Pollock and Sanjay Subrahmanyam. I am also indebted to a great number of people for suggesting literature, sources and angles, or for helping me obtain or decipher sources: Irfan Ahmad, Ari Anand, Anna Livia Beelaert, Aditya Behl, Shailendra Bhandare, Mark Brand, Lennart Bes, Benjamin Cohen, Kim van Dam, Linda Darling, Kavita Datla, Sebastiaan Derks, Nirmal Devasiri, Simon Digby, Anne Feldhaus, Jorge Flores, Daniel Friedrich, John Fritz, Femme Gaastra, Stephan van Galen, Tracy Goode, Nile Green, Sumit Guha, Najaf Haider, Ebeltje Hartkamp-Jonxis, J.C. Heesterman, Jan Houben, Thibaut d'Hubert, Eugene Irschick, Martine van Ittersum, Hester Jansen, Stéphane Jettot, Janet Kamphorst, Simin Karimi, Omar Khalidi, Gerrit Knaap, Dick Kooiman, Marijn Kruk, Remke Kruk, Leo Lucassen, Pauline Lunsingh Scheurleer, Ruby Maloni, Gajanan Mehendale, George Michell, Renaud Morieux, Ghulam Nadri, Amina Okada, Gert Oostindie, Zareena Parveen, Carla Petievich, Gyan Prakash, Om Prakash, Remco Raben, David Shulman, Louis Sicking, Robert Simpkins, Anjana Singh, Kamran Talatoff, B.N. Teensma, Sebastiaan Tijsterman, Ananya Vajpeyi, Peter van der Veer, Tycho Walaardt, Douglas Weiner, Lucia Werneck Xavier, Rik van Welie, Ian Wendt, André Wink and Paul Wormser. Peter Longbottom I thank for the final editing and correction. I should also like to thank my parents and Louise Nanning for creating the framework to work from and Ruud van Leeuwen and Tieke Stuurop for providing me with a workspace. For moral support I must further thank Nicolet Schrama and Kirsja Oudshoorn. 
On the institutional side of things I should like to thank the Reiman-de Bas Fund for providing me with funds for a "field trip" to the archives of the Deccan a long time ago, the Gonda Fund for providing a year of funding for my writing, and Leonard Blussé for helping to bring the latter about. I am also grateful to the University of Arizona for giving me a scholarship and later a TA-ship to do my pre-thesis coursework, and Leiden University for the small teaching position which subsequently kept me afloat. I thank the Institute of Netherlands History and its director Donald Haks for providing funds towards the final editing and correction work.

I am also grateful to the staff of the many libraries and archives I visited, especially the helpful staff of the Kern Institute Library in Leiden, the Douza room and the Oriental Languages and History room in the Leiden University Library, the National Archives in The Hague, the old prints room in the Koninklijke Bibliotheek in The Hague, The University Library in Utrecht, the Indian Institute Library in Oxford, the APAC reading room of the British Library, the British Museum Library and the National Geographic Society in London, the Oriental and Occidental Manuscripts sections of the Bibliothèque Nationale and the Musée Guimet in Paris, the Andhra Pradesh State Archives and the Salar Jung Library in Hyderabad, the Archaeological Museum in Bijapur and the Maharashtra State Archives in Mumbai. I should also like to thank the royal family of Mudhol at Pune and Bheemasha Natikar at Gulbarga for opening their family archives to me and allowing me ample time to peruse and photograph them.

Finally, I would like to emphasise here that the arrangement and interpretation of the material in this book, including the sections on the controversial topics of Shivaji and of the relation between Hindus and Muslims, are solely my responsibility, and that some of the people whom I thank for their input wholly or partially disagree with certain parts or have even well-meaningly advised me not to publish them.

The Hague, January 2009 



\title{
INTRODUCTION \\ THE ETHICS OF WRITING THE PRECOLONIAL
}

\begin{abstract}
Even the project of remembering the gloomiest of memories is a hopeful project.
\end{abstract}

Avishai Margalit, $2002^{1}$

\section{WHY THIS STUDY}

This is not a history of love, although that occurs a few times in these pages and there would have been enough seventeenth-century Indian love to fill a book with, had I chosen to write about the subject. The century opened with the reign of the famous lover Muhammad Quli Qutb Shah, sultan of Golkonda, whose personality inspired a work of fiction by his court poet about a prince who falls in love with a Bengal princess. ${ }^{2}$ Muhammad Quli also devoted a large part of his own poetry to love:

The man who is not acquainted with love is a half-wit; don't ever have anything to do with him. ${ }^{3}$

Much more love of all kinds could have been turned up, especially from mystical and devotional poetry, which are deservedly popular subjects among academics.

Yet I am afraid that this book has become a history of hatred. It embodies an attempt to understand xenophobia, the fearful distrust of the strange $(\mathrm{r})$, in general. In this respect, the precolonial is often made to stand in blatant contrast to the colonial and postcolonial eras with their undeniably violent clashes. But are the sharply marked boundaries between groups in present-day India as well as in the rest of the world only the product of certain modern/Western notions that spread with colonialism, or are such mental boundaries also found in precolonial India? In other words, what do we have in common with precolonial Indians, and is that commonality human nature?

Stemming as it does from my general dissatisfaction with the treatment of the historical evidence, this study is first and foremost empirical, but of course certain modern writers have had an impact on my perception of the primary sources. Especially important were the radical constructionists who hold that all human action (including thought-action)

${ }^{1}$ Avishai Margalit, The Ethics of Memory (Cambridge, Mass. 2004) 82.

2 Abdul Haq "Muqadima” in Mulla Wajhi, Qutb Mushtari, ed. Abdul Haq (Delhi, 1939) 1-3.

${ }^{3}$ Quoted with translation in Narendra Luther, Prince, Poet, Lover, Builder: Mubammad Quli Qutb Shab, the Founder of Hyderabad (Delhi, 1991) 72. 
is merely constructed out of other actions inscribed, as it were, on the blank slate that would be the human mind, creating completely different minds across the globe and across time. This is the world view that Michel Foucault announced as "the end of man" and Steven Pinker calls "the denial of human nature." 4 Viewing the primary sources against the foil of constructionist theory, however, has led me to believe more and more strongly that precolonial Indians were not so different in their practices and ideas from our present-day selves. Thus I feel more affinity with people like the biologist Edward O. Wilson, the cognitive scientist Pinker, the historian Anthony Smith (with qualifications), and the philosopher Kwame Appiah, who all in different ways contribute to the understanding that altruism and xenophobia are two sides of the same coin (call it identity or group behaviour) that is to an extent universal or part of human nature. ${ }^{5}$

More precisely, this study takes on the view that precolonial identities were fluid constructions. ${ }^{6}$ In this view, identities were constantly in flux and adaptable to each situation, while also constructed in the sense that they were not inborn. Since claims of common descent such as that implied in the term Rajput (literally son of a king) have been sufficiently deconstructed (for the case of Rajputs in Dirk Kolff's seminal Naukar, Sepoy and Rajput), this study does not deny that precolonial identities were constructed. Neither does it deny that those identities changed (were fluid) over time. The only aspect of the "fluid constructions" view that this study contests is the idea that group boundaries could not be experienced as rigid at any given point in precolonial time. It is therefore necessary - to use the filmic analogy — to zoom in on cases of conflict and freeze frame.

\section{SETTING AND OUTLAY}

The six cases of this study are taken from the history of the Deccan, a

${ }^{4}$ Michel Foucault, The Order of Things: An Archaeology of the Human Sciences (New York, 1971) xxii-iii; Steven Pinker, The Blank Slate: The Modern Denial of Human Nature (London, 2002).

${ }^{5}$ Edward O. Wilson, Sociobiology: The New Synthesis (Cambridge, Mass. 1975) and Consilience: The Unity of Knowledge (New York, 1999); Anthony D. Smith, The Ethnic Origins of Nations (Oxford, 1986); Kwame Anthony Appiah, The Ethics of Identity (Princeton, 2005). To be sure, Pinker uses the term human nature for both commonalities and differences between individual humans that may be attributed to genetic make-up, but here we will concern ourselves with the commonalities and use the term in that sense, which is the more common. Neither, for that matter, are we here concerned with the possible interaction between cultural variation and (epi)genetic variation, but see Eva Jablonka and Marion J. Lamb, Evolution in Four Dimensions: Genetic, Epigenetic, Behavioral, and Symbolic Variation in the History of Life (Cambridge, Mass. 2005) 161 and passim.

${ }^{6}$ For historiographical introductions to this view from a historicist and postmodernist angle respectively see Susan Bayly Bayly, Caste, Society and Politics in India from the Eighteenth Century to the Modern Age (Cambridge, 1999) 1-24 and Nicholas B. Dirks, Castes of Mind: Colonialism and the Making of Modern India (Princeton, 2001) 3-42. 
carousel region between North India, South India, the Arabian Sea to the west and the Bay of Bengal to the east. The term "Deccan" is a rather vague one, but I am defining it for the purpose of this book as the area encompassed by the sultanates that originated in the early sixteenth century from the break-up of the sultanate ruled by the Bahmani dynasty. As the lingua franca of these states was Persian, the rulers were often referred to by ancient Persian titles such as padshah or shabinshah (king of kings), but the Arabic term sultan was also used and has currency in modern academic writing. ${ }^{7}$ While the majority of the population was always Hindu, the elite of these sultanates consisted mostly of Iranians, Turks and Muslims of local, Deccani, origin. The concept "Hindu" is problematic for this period, but not as problematic as is often suggested, as will be seen below. The Dutch and the English, from the beginning of the seventeenth century, established trading factories on the littoral and some in the interior of the Deccan. The centre of the Portuguese "state" in Asia was located on the west coast of the Deccan, in Goa. The French established themselves at Pondicherry on the south-east or Coromandel coast from 1676. From the north, the Mughal emperor and his nobles, often termed "Mughals," were encroaching on the area of the sultanates throughout the century, in a slow process that culminated in the fall of the Bijapur sultanate in 1686 and the Golkonda sultanate the next year. This history explores the identity claims and clashes of the set of people finding themselves in the Deccan in the seventeenth century.

At times, however, our narrative spills over into the Mughal province of Gujarat to the north-west of the Deccan and into the parts of the Coromandel coast to the south-east that came under the sway of the Deccan sultanates only in the course of the century, but were in the first half of the century ruled by the Hindu dynasties that succeeded the Vijayanagar great kingdom. Gujarat and Coromandel were at both ends of the high road crossing the Deccan diagonally, which was called Dakshinapatha by the ancients and is an important key to understanding the history of the Deccan. ${ }^{8}$ All the Mughal campaigns to subdue parts of the Deccan were launched through the mountain passes of southern Gujarat giving access to the Deccan, while in times of peace throngs of poor pilgrims (who could not afford the haij to Mecca) from the Deccan made their way through Gujarat to India's most important Sufi shrine at Ajmer. ${ }^{9}$ At the other end of the Dakshinapatha we find the harbours of the

\footnotetext{
7 Muhammad Husain ibn-i Khalaf Tabrizi, Burban-i Qati', ed. Muhammad Mo'in (Teheran, 1951-63) s.v. padshah.

8 Jos Gommans, Mughal Warfare: Indian Frontiers and High Roads to Empire, 1500-1700 (London, 2002) 17-20.

${ }_{9}^{9}$ According to a Dutch source of ca. 1625. W. Geleynssen de Jongh, De Remonstrantie van W. Geleynssen de Jongh, ed. W. Caland (The Hague, 1929) 71-2.
} 
Coromandel coast, including Masulipatnam, the main port of Golkonda, and Pulicat, where each month a trading caravan from the north-west called. ${ }^{10}$

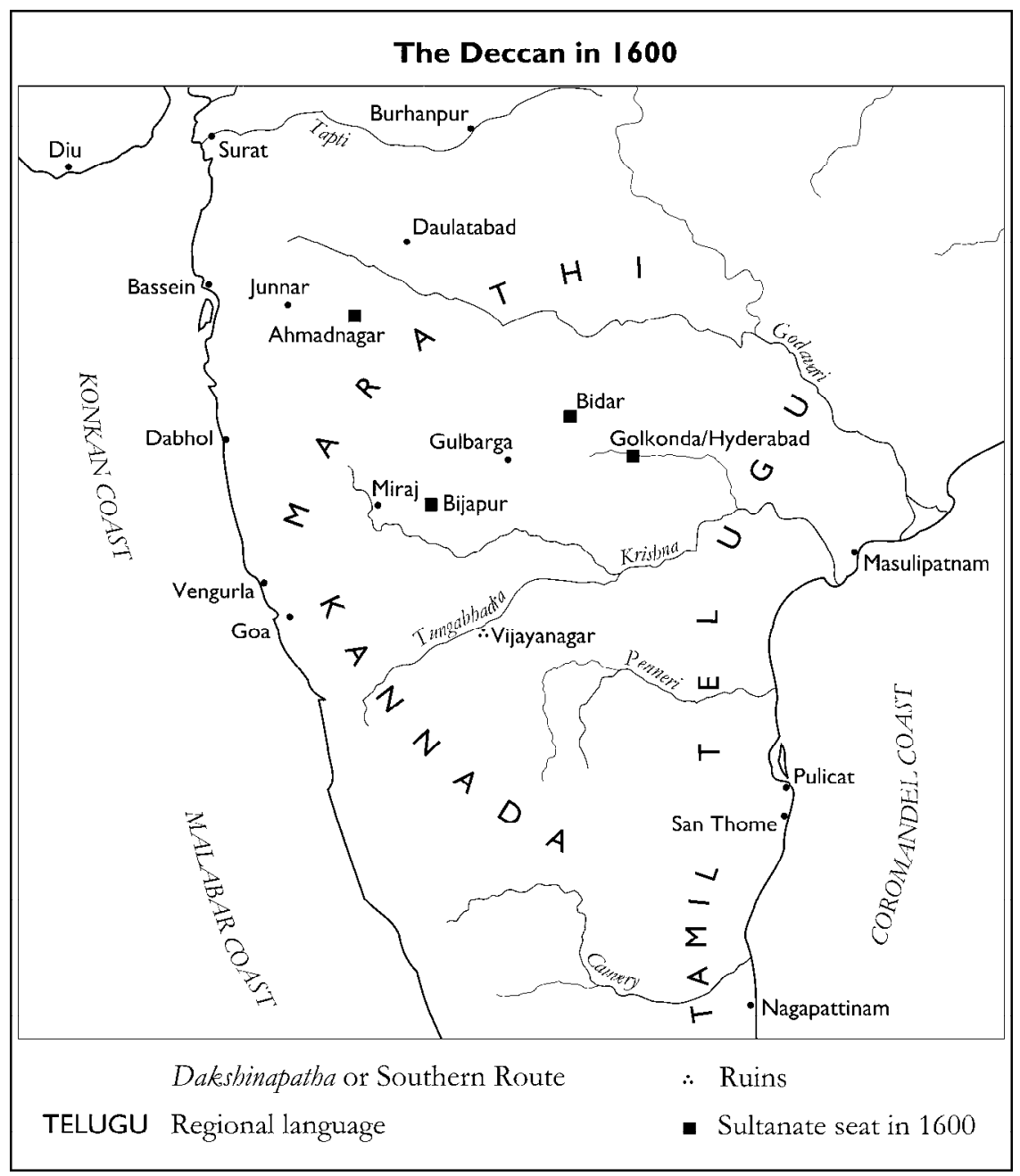

Part I of this study describes three antagonisms that are still present today but in very muted forms. Dutch and Portuguese identities are still here but the antagonism between the two has long subsided. Similarly the antagonism between Deccani and Foreign Muslims no longer plays much of a role among South Asian Muslims. The division between Right Hand and Left Hand castes in Tamil Nadu is still known but not imbued with 
much significance today. Part II describes, also in three chapters, the rise of a number of antagonisms in the third quarter of the seventeenth century that are at the root of some present-day identities. Maratha identity is still a strong force in Maharashtra, the identification of some Europeans with their Indian habitat described in Chapter 5 continued to play a role throughout the colonial period and has produced many a nostalgic picture of the Raj and a continuing commonwealth link between Britain and the Indian Republic. More generally the relation of the post-colonised to the post-colonisers is still sensitive, especially in academia. Finally, the opposition between Hindus and Muslims that runs through all three chapters of Part II is a large-looming factor in Indian politics and life today.

The chapters are laid out on three grids, or can be read on three levels. Firstly, each chapter discusses the historical context and "content" of the antagonism in question, and in that way contributes to the chronological narrative that issues in the Epilogue. Secondly, each chapter addresses questions relating to the available source material. Because of the diversity of the sources used here it is not possible to draw one conclusion about them, but the direction of the arguments is indicated in the last section of this introduction, which at the same time introduces a number of terms. Finally, each chapter addresses one or more dimensions of the main theoretical question, namely how fluid were precolonial identities? The strands relating to that question are tied up in the Conclusion.

\section{THEORETICAL ISSUES}

An identity may be any feature an individual is thought to share with at least one other individual. There is no such thing as an individual identity; identity is always shared, making members of a group 'identical' as far as that particular feature is concerned. Through identification an individual conscribes to a group or is ascribed to it by others. Identity may therefore be seen as composed of three dimensions, to wit categorisation, identification and comparison. ${ }^{11}$ The main challenge here is by some means to measure the identification of individuals with certain groups and to measure the related rigidity of group boundaries. ${ }^{12}$

11 That is, at least, how Yan Chen and Xin Sherry Lee interpret the broad sweep of the "school" of Tajfel and Turner. Compare Yan Chen and Xin Sherry Li, "Measuring Identity" (2005) www.si.umich.edu/ yanchen/papers/identity_20051112.pdf, 2 and Michael A. Hogg, Deborah J. Terry and Katherine M. White, "A Tale of Two Theories: A Critical Comparison of Identity Theory with Social Identity Theory," Social Psychology Quarterly 58 (1995) 255-69.

12 Rawi Abdelal, Yoshiko M. Herrera, Alastair Iain Johnston, Terry Martin, "Treating Identity as a Variable: Measuring the Content, Intensity, and Contestation of Identity" (2001), available from www.people.fas.harvard.edu/ johnston/identity.pdf. 
The testing of boundaries and identification continues to exercise our attention throughout the chapters: (1) introduces the method of measuring identification by relating different boundaries to each other and looks at the pay-off for identifying with a group, (2) explores how a group boundary could be relative to another group boundary, together with the role of trust, (3) examines the possibility of invention of social groups and explores the twin aspects of identification, namely ascription and conscription, while (4) examines the role of consciousness, (5) the role of anxiety and (6) the role of comparison. Comparison is in the context of identity often referred to as "othering," which I am defining as "evaluating the perceived differences between one's own group and another group." The concept of othering plays an important role throughout this study, because it stems from and is tied up with ideas about the colonial and modernity, on which we will touch in last section of this introduction. Concerning categorisation I would like to make some preliminary remarks here.

It is often said that people did not categorise things, let alone people, before the onset of European modernity. This postmodern cliché seems to have originated with anthropologists like Bernard Cohn in the late nineteen-sixties and was widely spread through Foucault's The Order of Things, which he prefaced by a spiel with Borges' Chinese dictionary - a dictionary that failed to classify animals according to modern Western standards. According to Foucault, seventeenth-century Europeans first began to order things and people by enumeration, in short by drawing up finite lists of differences within a collection with a common denominator (say humanity, or Indians)..$^{13}$ The notion that enumeration and classification according to perceived difference and identity were for a long time an exclusively European preoccupation has been widely influential in South Asian studies. Richard Eaton, Sheldon Pollock and Sumit Guha, however, have attacked it in various ways and it seems that Donald Brown's list of human universals rightly includes "classification." 14

13 Bernard S. Cohn, "The Census, Social Structure and Objectifation in South Asia," in idem, An Anthropologist among Historians and other Essays (Delhi, 1987) 224-54; Foucault, Order of Things, xv-xviii, 51-6.

${ }_{14}$ Richard M. Eaton, "(Re)imag(in)ing Other²ness: A Postmortem for the Postmodern in India," Journal of World History (2000) 11: 57-78; S. Pollock, "Deep Orientalism? Notes on Sanskrit and Power beyond the Raj," in Orientalism and the Postcolonial Predicament, ed. C.A. Breckenridge \& P. van der Veer (Philadelphia, 1993) 76-133; Sumit Guha, "The Politics of Identity and Enumeration in India c. 1600-1990," Comparative Studies in Society and History 45 (2003) 148-167; Donald E. Brown's list is reprinted in Pinker, The Blank Slate, 435-9. William Pinch also critiques the notion "that seventeenth-century Europeans and Indians inhabited separate cognitive universes." His critique is, however, mostly concerned with the epistemological gap Cohn and others allege between Indian thinking in terms of "substances" and European thinking in terms of "signs and correspondences," a concern that also stems from Foucault. Although thinking in terms of "signs and correspondences" 
Looking at the visual arts is a particularly fruitful way to uncover such classifications. In the early seventeenth century we find that miniatures of courtly scenes made for Mughal emperor Jahangir invariably depict Hindus with their jama tied to the left and Muslims with their jama tied to the right, a phenomenon that we continue to observe throughout the seventeenth century. ${ }^{15}$ Another case in point of the same period is the large painted cloth from the Coromandel coast now in the Brooklyn Museum. The fact that it was still in India at the time it was acquired by the museum suggests it was made for an Indian patron, and in any case it was made by Indian painters. The seven panels each depict a different social or ethnic group. There are Indian Muslims with turbans in different styles, there are Iranians or Turks from Persia, there are Europeans with their very distinctive dress, including a Madonna with child-like figure, and there are Hindus set in a courtly scene, some possibly Javanese people, as well as perhaps Thais. The central panel is occupied by a depiction of tribals, and seems to glorify forest dwelling. This theme may well be connected to the identity of the patron, as there were various little kings in the area calling themselves lords of the forest. ${ }^{16}$ The seven panels possibly constitute an elaboration on Islamicate ideas of the seven climes in combination with the five-region scheme along which Tamil poetry was conventionally divided into poems appropriate for the hills, the dry land, the jungle and woodland, the cultivated plains or the coast. ${ }^{17}$ In any case, the ensemble provides a neat classification of different groups and life-styles. ${ }^{18}$

or "representations" was seen by Foucault, Cohn, and perhaps also by Pinch as a precondition for categorising, cognitive scientific experiments on categorisation have in recent years, to my feeling, made the whole debate on substances or resemblances $v$ s. signs and correspondences or representations redundant. William R. Pinch, "Same Difference in India and Europe," History and Theory 38 (1999) 389-407.

15 For examples see the miniatures thought to have been made for a royal copy of the Jahangir Nama (where depicted persons are generally labelled with their names) e.g. the Submission of Rana Amar Singh reproduced in Susan Stronge, Painting for the Mughal Emperor: The Art of the Book 1560-1660 (London, 2002) 124-7. See also Henry Yule and A.C. Burnell, Hobson-Jobson: The Anglo-Indian Dictionary (2nd ed. 1902; photogr. repr. Delhi, 1994) s.v. cabaya.

${ }^{16}$ Rachel Morris, "Enter the Royal Encampment: Re-examining the Brooklyn Museum's Kalamkari hanging," Arts of Asia 34 (2004) no. 6: 95-107; Lennart Bes, "The Setupatis, The Dutch, and Other Bandits in Eighteenth Century Ramnad (South India), JESHO 44 (2001) 540-574.

17 A.L. Basham, The Wonder That Was India (3 ${ }^{\text {rd }}$ ed. 1967; London, 1988) 463.

18 In that sense it is comparable to an important seventeenth-century classification of religious groups, the Dabistan-i Mąhabib, as Aditya Behl's discussion of that text bears out. Aditya Behl, "An Ethnographer in Disguise: Comparing Self and Other in Mughal India," in Notes on a Mandala: Essays in Honour of Wendy Doniger, ed. Laurie L. Patton and David L. Haberman (New York, 2008). 
Other good examples from the turn of the seventeenth century are statements like the following by Muhammad Quli Qutb Shah, from whose work we have already quoted:

What rites are the Muslim's [Musalman] rite and the heathen's [kafir] rite, I know not these because the people of the world are abandoning rites and living Your way. ${ }^{19}$

This kind of Sufic poetry has a long tradition that goes back at least to Ibn Arabi of Andalusia, who famously enumerated the religions known to him in his oft quoted lines, "My heart can take on any appearance...It may appear in form as a gazelle meadow, a monkish cloister, an idol-temple, a pilgrim Kaaba, the tablets of the Torah for certain sciences, the bequest of the leaves of the Koran." 20 Yet in denying the importance of boundaries between religions, this genre is also betraying a consciousness of those boundaries. The explicit flaunting of boundaries does not mean that there were no boundaries. David Lorenzen has used precisely these kinds of statements to show that the categorical term "Hindu" was used to delineate a certain religious group already in the sixteenth century, and that it is not a British invention as is often claimed. ${ }^{21}$ Although it would be absurd to claim that I as a historian did not bring my own classificatory schemes to the sources, I have nevertheless made an effort to be sensitive to period classifications found in sources both European and non-European.

\section{ACCUSATIONS AND COUNTERACCUSATIONS}

Though I set out merely to investigate the strength of identity in precolonial India, I found that the decade demarcated by the visit of the Maratha king Shivaji to the sultan of Golkonda in 1677 and the fall of Golkonda to the Mughal forces in 1687 was an axial decade in Indian history. This decade, the stuff of Part II, issued into a period of fragmentation, which simplified British conquest. Moreover, I would argue that the roots of modern communalism (the antagonism between the

${ }^{19}$ Muhammad Quli Qutb Shah, Kulliyat-i Muhammad Quli Qutb Shah, ed. Sayyid Mohi ud-Din Qadri Zor (Hyderabad, 1940) first collection (Nazmẽ): 301.

${ }_{20}$ Compare Christopher Shackle, "Beyond Turk and Hindu: Crossing the Boundaries in Indo-Muslim Romance," in Gilmartin, David and Bruce B. Lawrence, eds. Beyond Turk and Hindu: Retbinking Religious Identities in Islamicate South Asia (Gainesville, 2000) 55-73, there 69 note 9. These and similar lines of Ibn Arabi can be found on many websites concerning religious tolerance and spirituality, e.g. www.nazorean.com/ MysteryTeachings/Islamic.html or www.dhushara.com/book/zulu/sufi.htm, this translation derives from Idres Shah, The Way of the Sufi (London, 1968) 87.

21 David N. Lorenzen, "Who Invented Hinduism?" Comparative Studies in Society and History 41 (1999) 630-59; Christopher Shackle leans towards a different conclusion, but also writes about the crossing of the boundaries of time, place, creed and class in Sufi poetry that, "the existence of worldly identities, rooted in the realities of everyday life, is essential for its structure and message." Shackle, "Beyond Turk and Hindu," 58. 
"communities" of Hindus and Muslims) are to be found in this decade in the interplay between Shivaji and the Mughal emperor Aurangzeb. In any case, all cases of riots between Hindus and Muslims in the Deccan and North India that are known to historians today have taken place after this decade. ${ }^{22}$ Such riots clearly distinguish modern-day communalism from previous manifestations of antagonisms between Hindus and Muslims. Although the historian Chris Bayly has argued that cases of communal violence in the eighteenth century were "contingent" upon local circumstances, this does not explain the pattern that one can perceive over the longue durée of no riots before ca. 1700 and an increasing number of Hindu-Muslim riots since then. ${ }^{23}$ While the first three chapters may seem an entertaining academic exercise in "funny" (though literally dead serious) identities of a faraway past, a mere probe into the innocuous likeness to ourSelves of the seventeenth-century Other, the exercise may appear more serious, because more politically sensitive, moving into the second part of this study.

Two rather extreme views on the later precolonial period have developed since the 1980s. On the one hand there is the Hindu nationalist view which led the way to the rewriting of textbooks for schoolchildren in the late 1990s under the guidance of Arun Shourie, Hindu nationalist politician and writer of Eminent Historians: Their Technology, Their Line, Their Fraud. On the other hand, a number of Western (mainly American) scholars and the Indian academics taken seriously by them (many Indian scholars are not taken seriously by Western academics) ${ }^{24}$ seem to have dug in their heels in emphasising the harmoniousness of this period in history when most of India was ruled by Muslim monarchs. ${ }^{25}$ Beside the view that social identities were fluid before the advent of the British, when Orientalists "invented" or "imagined" such things as caste and Hinduism that consequently came to be acted out in real life, ${ }^{26}$ scholars have introduced the notion that discourses of identity were already important before colonialism but

22 It must be noted that already in the fourteenth century there were frequent clashes between Muslim and other inhabitants of Mangalore on the Malabar coast. Ibn Battuta, The Travels of Ibn Battuta, vol. 4, trans. H.A.R. Gibb and C.F. Beckingham (London, 1994) 808.

${ }_{23}$ Compare C.A. Bayly, "The Pre-History of 'Communalism'? Religious Conflict in India, 1700-1860." Modern Asian Studies 19 (1985) 177-203 and Najaf Haider, “A 'Holi Riot' of 1714: Versions from Ahmedabad and Delhi," in Living Together Separately, ed. Mushirul Hasan and Asim Roy (Delhi, 2005). See also the Epilogue.

${ }^{24}$ Edwin Bryant, The Quest for the Origins of Vedic Culture: The Indo-Aryan Migration Debate (Oxford, 2001) 3-12.

${ }^{25}$ See Ian Wendt's analysis in a review of Catherine B. Asher and Cynthia Talbot's India before Europe in Journal of the Economic and Social History of the Orient 50 (2007) 582-5.

26 A view deconstructed in Eaton, "(Re)imag(in)ing Other ${ }^{2}$ ness" and Michael Roberts, "Submerging the People? Post-Orientalism and the Construction of Communalism," in Explorations in the History of South Asia: Essays in Honour of Dietmar Rothermund, ed. Georg Berkemer et al. 311-23 (Delhi, 2001). 
practices of identity were negligible, a fallacy that will be discussed in Chapter 4.

Because consciousness plays such a central role in the present study, we cannot avoid here the question as to whether the academic "blotting out" of precolonial practices of identity and difference in general is intentional. That the academic silence on precolonial identity clashes and more specifically on precolonial conflict between Hindus and Muslims is certainly to an extent conscious, is evident from the responses to the earlier attempts by Western academics to break the silence. Chris Bayly, who wrote a very carefully worded assessment of conflict between Hindus and Muslims in the eighteenth century, writes that despite its balanced outcome, his exploration was "decidedly unpopular in some Indian circles." Sheldon Pollock's article on the political uses of the Ramayana epic, was, he felt, woefully misinterpreted. While meant as a critique of Hindu nationalist ideology, and of the use of the Ramayana as an instrument of political manipulation and domination, the article was seen as a statement in support of those same Hindu nationalists. The background to that perception can only have been the idea that bringing out that kind of evidence was just not something decent, non-Hindu nationalist, scholars were supposed to do. ${ }^{27}$

Arun Shourie's simultaneous involvement with communalist politics and history writing show how closely any writing about the early modern period, when most of India was ruled by Muslim kings, is tied up with the debate on the nature of the present Indian state. Together with the Balkans, the Middle East, Central Asia and South-East Asia, South Asia is one of the regions where pre- 1800 history is very much engaged in current national or sub-national identity projects. In reference to the Middle East, Jacob Lassner speaks of an "oppressive yoke of collective memory, that is, ...the accumulation of remembrances, whether idealized or real, that resist historical analysis and impede dramatic breaks with the past." 28 Although somewhat strongly stated in that quotation, I would say that this characterisation at least partly applies to South Asia, demonstrated, as it was, by the "hooligans" who ravaged the Bhandarkar Oriental Institute in the name of Shivaji in 2004. ${ }^{29}$

If many people in South Asia indeed so tightly tie themselves to the heroes and villains of the early modern past, the historians and social scientists who like to smooth over some of the more blameworthy events in that past may seem right from an ethical perspective, because in doing so

27 Chris Bayly, Origins of Nationality, 44; Sheldon Pollock, "A Pre-Colonial Language in a Post-Colonial World," interview by Gijs Kruijtzer, ILAS Newsletter 36 (March 2005): 1, 4-5, there 4.

${ }^{28}$ Jacob Lassner, The Middle East Remembered: Forged Identities, Competing Narratives, Contested Spaces (Ann Arbor, 2000) 111.

29 "Hooligans Ravage Bhandarkar Institute," Maharashtra Herald 6.1.2004. 
they avoid creating memories of violence that may be turned into physical violence. By their silence, however, those historians and social scientists are contributing indirectly to that same heritage view of the past, the view that ties the past to the present. There are various problems with the heritage view of the past, but the main problem for the current study is that it hampers our understanding of human nature as it came to expression in a place and time different from our present vantage point, because it equates certain present day people with certain past people and present day differences with past differences. Heritage disallows questioning the past and is therefore undesirable from a scholarly perspective. Moreover, on the ethical side of things, conciliation perhaps precisely requires a conscious effort to unlink self and other from the chain of collective memory, which, in order to be conscious, would require an open debate of the past..$^{30}$ Besides this and some of the other objections to heritage to which I will come later, I agree with Jacques Derrida's adage that silence is the worst violence. So the balance of writing and silence seems to weigh in favour of writing. But the answer cannot be so short and my struggle with the ethics of writing is wrought, as it ought to be in Derrida's view, ${ }^{31}$ throughout the book, but is especially prominent in the ends of Chapter 4 and the Epilogue.

\section{PRELIMINARY COMMENTS ON THE SOURCES}

Unfortunately, blanket statements about the precolonial are too often made by those who have studied only sources from the colonial period, as other scholars of the precolonial period have remarked before this. ${ }^{32}$ The most useful sources for a study of human concerns can only be those that are produced in the era of which one wants to study the concerns, simply because later sources reflect the concerns of later times.

This principle of contemporaneity in combination with the way this book is set up, namely as a number of case studies focussing on particular events, entails the extensive use of sources from the European archive, because, for the seventeenth century, those sources are often the most contemporary with historical events. ${ }^{33}$ Sanjay Subrahmanyam has argued in various places that Asian sources are to be preferred over

30 For some considerations concerning the relation between "truth" and forgiving, see Margalit, Ethics, 1-6, 206-9 and passim. My argument differs from Margalit's in that I argue for unlinking rather than forgiving, see the Epilogue.

31 Derrida cited in Leonard Binder, Islamic Liberalism: A Critique of Development Ideologies (Chicago, 1988) 126-7.

32 Eaton, "(Re)imag(in)ing Other ${ }^{2}$ ness"; Cynthia Talbot, Precolonial India in Practice: Society, Region, and Identity in Medieval Andhra (Oxford, 2001).

33 In actuality, of course, the set-up was suggested by the sources already chosen as much as the sources were suggested by the set-up, but that does not invalidate the argument. 
European sources even if they were created a century or more after the events they speak of (and the cases he discusses concern eighteenth-century narratives about the sixteenth and seventeenth centuries); in other words he puts positionality above temporality. The problem with that stance is that it essentialises a local position or a position of "those who belong," by assuming that such a position would remain the same over a hundred years or more, or at least retain its essence, and as such the stance ties in with the idea of history as heritage, the problematic nature of which is discussed at length in the Epilogue. ${ }^{34}$

Yet, lest my argument be misconstrued as some sort of claim to a general superiority of European sources (as it already has been), ${ }^{35}$ let me note that it would be perfectly possible to write about seventeenth-century sensibilities in the Deccan entirely on the basis of "Indian" sources, e.g. literary sources, be it without the proposed focus on particular events. Therefore, an effort has been made throughout this study to bring as many sources as possible, from as many subject positions as possible, to bear on the cases - as long as they possess the requisite contemporaneity.

The relative preponderance of European materials, however, entails an elaborate set of problems. Since the publication of Edward Said's Orientalism, a whole industry has sprung up that deals exclusively with the representation by Europeans of "Others," even though some of Said's detractors show that the purport of "Orientalism," in the sense of dominance projected in discourses of "othering," can be extended ad infinitum, to all times and places. ${ }^{36}$ In any case, many scholars now see the dominant European "discourse" as determinative of all statements about non-western people in European sources. In the eyes Michel de Certeau, any statement picked up by Europeans outside Europe becomes a heterology "in which the discourse about the other is a means of constructing a discourse authorised by the other." 37 In the view of De Certeau, statements by natives are only quoted by Europeans when they confirm the dominant discourse about the native other (or are fabricated to support it) and Europeans are only looking for confirmation of the familiar discourse after they arrive in strange parts.

34 Sanjay Subrahmanyam, "Reflections on State-making and History-making in South Asia, 1500-1800," JESHO 41 (1998) 382-416; Idem, From the Tagus to the Ganges (Delhi, 2005) 20-1. In places, Subrahmanyam takes the heritage perspective quite explicitly. Concerning early modern Indian travelogues, he writes that educated Indians today are "not quite so accustomed to the idea that they too have written about and experienced the world at large." Idem, "Taking Stock of the Franks: South Asian Views of Europeans and Europe, 15001800," IESHR 42 (2005) 69-100.

35 Subrahmanyam, From the Tagus, 20.

36 Eaton, "(Re)imag(in)ing Other'ness"; Ulrike Freitag, "The Critique of Orientalism," in M. Bentley ed. Companion to Historiography (London, 1997) 620-38; Pollock, "Deep Orientalism." ${ }^{37}$ Michel de Certeau, Heterologies: Discourse on the Other, Brian Massumi, trans., foreword by Wlad Godzich (Manchester, 1986). 
One should, however, take care to distinguish the prejudices of Said's own days, which he incorporated into his idea of Orientalism, from the prejudices of the period of European expansion that Said studied. At first sight the following statement of Daniel Havart - in which he expressed his surprise over the shame-cultural way to achieve tolerance of homosexuality among Muslims in India - might be seen as utterly orientalist in the Saidian sense and heterological in the Certeauian sense:

When one asks them why they do not punish that vile sin, which is so strictly and severely forbidden, in public to set an example for others, they profess not to be qualified or pious enough, because there is no imam, that is apostle or successor from the offspring of Muhammad, in their midst; but it is indeed because all are scabby and the big are contaminated as well as the small..$^{38}$

Thirty years after the publication of Said's Orientalism, with gay liberation well on the way in the West as well as in India, however, "orientalist" descriptions of the practice of homosexuality start to look less unrealistic or grotesque in the light of publications that try to highlight India's tradition of tolerance in this respect. In this new world view the liberty of India becomes "Indian heritage as well as world heritage" 39 and becomes the norm, while the restrictiveness of the West since the Middle Ages becomes the exception (the so-called "Boswell thesis").

One way out of this conundrum of value judgements is to put European and non-European texts side by side, something that is often deemed unnecessary. An example of where a refusal to compare sources may lead is Nabil Matar's Turks, Moors and Englishmen in the Age of Discovery, written at the end of the last century. One chapter of this work is devoted to showing how the remarks about homosexuality in the Muslim world in European narratives were part of a discourse making the Muslim world ready for conquest. On the one hand it tries to show that this discourse was merely the European discourse on the widespread homosexual activity of American Indians projected onto Muslims and on the other it declares an investigation of a possible empirical basis for the European claims concerning the Muslim world irrelevant, without apparently noticing that these two positions are mutually exclusive. Consequently the whole chapter comes apart in the light of a short phrase in a long appendix quoting a seventeenth-century Arab traveller in France: "it is widespread among Muslims so much so that the Christian imagined that it was condoned by our religion, because it is so widespread and because it is not punished." 40

\footnotetext{
${ }^{38} \mathrm{D}$ [aniel] H[avart], Persiaansche secretaris (Amsterdam, n.d.) 59-61.

39 Ruth Vanita and Saleem Kidwai eds. Same-Sex Love in India: Readings from Literature and History (New York, 2000) xxiv.

${ }^{40}$ Matar, Nabil. Turks, Moors, and Englishmen in the Age of Discovery. (New York, 1999) 109-27, 193-4. Compare Stephen O. Murray ed. Islamic Homosexualities: Culture, History, and Literature
} 
Of late, there seems to be a slight trend, especially in Britain, to highlight the integration of Europeans in Asia before the onset of colonialism proper. Prime examples are William Dalrymple's White Mughals and the "Encounters" exhibition at the Victoria and Albert Museum. ${ }^{41}$ The extent to which the Europeans partook in Deccan society and indeed took to their new environment will be explored especially in chapters one and five. While William Pinch, drawing on Chris Bayly's work, makes a case for considering the British as a group within Indian society, and then extends his conclusion to the case of the Muslims in India, ${ }^{42}$ many scholars seem to find the emphasis on the integration of Europeans in Indian society upsetting precisely because it reminds one of the narrative on the integration of Muslims in the early modern and especially the Mughal period with all its syncretic practises and nearly equitable treatment of Hindus and Muslims. That is to say, if both British and Muslims are Same and not Other, moral judgments on both these groups must be suspended, which may be (and indeed seems to be ${ }^{43}$ undesirable to those in some way invested in the project of Indian nation-building through the leverage of postcolonial guilt or shame.

An emphasis on the significant European presence in seventeenthcentury India does, however, in any case beg the question as to what extent the period can be called precolonial. Colonialism proper is very generally speaking associated with territorial control of non-European lands by European states. Such territorial control had already in the sixteenth century been established in Latin America. In India the Portuguese had carved out only a few tiny enclaves on the coast. Yet the Europeans controlled the high seas around India. Moreover, connectivist world historians like Eric Wolff have shown sufficiently that there is no such thing as untinged culture. And although the period before ca. 1800 is generally designated as precolonial in India, one could speak of protocolonialism. To give a sense of the protocolonialism already in place, I have chosen to refer to present-day Mumbai as Bombay for the purpose of this study. Though the name is probably a corruption of Mumbai, the Bombay of the seventeenth century was different from the village of

(New York, 1997); Mathew Kuefler ed. The Boswell Thesis: Essays on Christianity, Social Tolerance and Homosexuality (Chicago, 2006).

${ }^{41}$ William Dalrymple, White Mughals: Love and Betrayal in Eighteenth-Century India (London, 2003); Anna Jackson and Amin Jaffer, eds. Encounters: The Meeting of Asia and Europe 15001800 (London, 2004). Compare also Pauline Lunsingh Scheurleer and Gijs Kruijtzer, "Camping with the Mughal Emperor: A Golkonda Artist Portrays a Dutch Ambassador in 1689," Arts of Asia 35 (2005) no. 3: 48-60; Bhawan Ruangsilp, Dutch East India Company Merchants at the Court of Ayutthaya: Dutch Perceptions of the Thai Kingdom c. 1604-1765 (Leiden, 2007) 53 and passim.

42 Pinch, "Same Difference."

${ }^{43}$ Early oral responses to and reviews of "the Dalrymple book" seem to indicate this. 
Mumbai with the nearby town of Thana that were there before the Portuguese and English made it an important stronghold. Thus in analogy of the use of Istanbul, a corruption of Constantinople, for the period after 1453 when that city became part of a new power structure, Mumbai must be called Bombay for our period. ${ }^{44}$ Present-day Chennai (short for Chennapatnam), on the other hand, was yet to become the colonial Madras because the English there shared power with local rulers.

While one sense of the concept of othering as employed in colonial studies, namely the contrasting of different social formations to one's own in valued terms, is applicable to many of the materials in this study, both European and non-European, the secondary sense of the concept, lumping all outsiders into one Other, is borne out by our European sources to a lesser extent. From some sources written in the metropoleis of European colonialism it appears to many post-structuralist scholars that Europeans conflated American Indians with South Asian Indians, and Muslims with Brahmins, et cetera, into one Other, the Non-European, or into such large categories as the Oriental or the African. ${ }^{45}$ Not only does this idea contradict the other favourite post-structuralist idea that Europeans divided up the non-European world with their classifications, a survey of the terms found in the Dutch materials of the seventeenth century drawn up outside Europe, illustrated by many quotations throughout this book, reveals that it is quite untenable. In these sources the term "blacks" (swarten) was used only rarely to indicate the population of India. Instead the Dutch spoke of "these here nations," or most often of "the Moors and Heathens of this place." The latter distinction followed an established Indo-Persian usage classifying the inhabitants of India as either Muslims (Musalmans) or nonMuslim Indians (Hindus, literally Indians, or kafirs, meaning unbelievers). ${ }^{46}$ The contrast the Dutch drew between things Moorish and things Heathen or Gentu was also largely the same as that which some modern scholarship (especially in religious and literary studies) draws between Islamicate and Indic. Beside those two categories one finds many other group labels in use, such as Chettis and Komatis and Baniyas, for three of the trading groups Europeans interacted with frequently.

Whether or not one sees the way the Europeans employed these terms at that time as an overstatement of the salience or importance of the boundaries between Indian groups in day-to-day life (which is the question), it did represent a recognition of locally existing categorisations.

\footnotetext{
${ }^{44}$ Yule and Burnell, Hobson-Jobson, s.v. Bombay; New Encyclopaedia of Islam, s.v. Istanbul.

${ }^{45}$ Beside Said's Orientalism, a good example is Nabil Matar's Turks, Moors and Englishmen.

${ }^{46}$ See Haider, "A 'Holi Riot'," 136 note 13. Hereafter, the Dutch terms Heydenen/Heydens will be translated as Heathens/Heathen, Jentieven/Jentiefs as Gentus/Gentu, Mooren/Moorse as Moors/Moorish and Mahometisten/Mahomedaansch etc. as Mohammedans/Mohammedan. See Appendix I.
} 
Moreover, the biases of Europeans were far more particularistic and diverse than is suggested by post-structuralists, as can be seen from the proBrahmin/pro-Left Hand bias of a section of the Englishmen in Chennapatnam in the 1640s and 50s and the anti-Brahmin/pro-Right Hand biases of another section (Chapter 3), as from the pro-Hindu/anti-Muslim bias among the English at Bombay in the 1680s (Chapter 5) or the proMuslim/anti-Brahmin bias found among some Dutchmen and Frenchmen in chapters one and six. Prolonged proximity simply changed biases, even those of Europeans.

Moreover, the consciousness of prejudice that can be noted in the above verses of Muhammad Quli Qutb Shah (and perhaps even more in a verse of his quoted in the Conclusion) is also found with the more educated Europeans. At the end of the seventeenth century, in a context rather different from India, retired VOC employee Jan Willem van Grevenbroek wrote about the Khoi:

In the past my hasty muse, swept by my youthful prejudices, sang "though people they are hardly worthy of the name people." For that mistake I now ask forgiveness and sing a reverse song.

As the scholar of neo-Latin Albert van Stekelenburg observes, Van Grevenbroek's Latin letter is couched in classical references (just as a Sanskrit text of the day would be) and turns the tropes of Ovid against Ovid, who wrote about the Getes and Sarmatians amongst whom he spent his classic banishment, "they are hardly people worthy of that name." 47

With respect to the non-European sources used here I would like to say that I do not believe that there is such a thing as asking the wrong questions of sources. ${ }^{48}$ There are two possible replies to the belief in wrong questions held by some academics: 1) what then are the right questions? and 2) aren't all questions we are asking of sources the wrong questions?

The answer to the latter reply-question is quite obviously "yes" in our case; the world for which the sources were written is definitively gone, along with the intentions of its authors. But that will not satisfy the reader's and the writer's curiosity about the past, which constitute the push and pull of any historical narrative. To quote the seventeenth-century Italian Indiatraveller Niccolao Manucci:

\footnotetext{
47 A.V. van Stekelenburg, "Een intellectueel in de vroege Kaapkolonie: de nalatenschap van Jan Willem van Grevenbroek (1644-1726)," Tydskrif vir Nederlands en Afrikaans 8 (2001) 1: 334 , there 10 .

48 The most recent reiteration of this view is that by Muzaffar Alam and Sanjay Subrahmanyam, who argue that sources written by Asians should be read "along the grain." Alam and Subrahmanyam, Muzaffar Alam and Sanjay Subrahmanyam, Indo-Persian Travels in the Age of Discoveries 1400-1800 (Cambridge, 2007) passim.
} 
Maybe the reader would like to know who this Shivaji was, and to comply with such a reasonable wish I will place here what I meant to insert elsewhere...For he who writes to please others must satisfy those others' will, while ever keeping close to historical verity. ${ }^{49}$

To put it otherwise, even if we are asking all the wrong questions, our curiosity behind the questions is not unreasonable. It is reasonable that we want to know what the precolonial was like, especially when so much is made of the impact of colonialism in current academic writing.

The first reply-question, about what the right questions are, can only be answered politically, within the postcolonial arena. In an interview Sheldon Pollock has noted that there is a certain neo-orientalism or nativism that wants to disallow a critique or historical analysis of Indian precolonial sources because there was supposedly no historical consciousness or concept of lineary time in India. I agree with Pollock that even if that were true, it is irrelevant to a critical project in the present day, and that we have access to information that the historical subjects did not have to put past events and ideas in context. ${ }^{50}$ Neither do I subscribe to the related claim that textual heritage can only be interpreted by its rightful inheritors, ${ }^{51}$ as I do not subscribe to the heritage paradigm (see the Epilogue).

But this catalogue of errors does not exhaust all that needs to be said about the sources. Scrutiny of sources will be a constant concern in this study. Chapter 1 addresses the question of how European the European sources were, Chapter 2 compares European sources to Indian sources on a particular issue, Chapter 3 asks how we can compensate for the sources we do not have, Chapter 4 looks into the issue of temporal distance between source and event (and, in an appendix, into the issue of forgeries), Chapter 5 asks whether the European perspective was a dominant perspective, and Chapter 6 looks once more at the local inputend of European sources. There are no short cuts to the seventeenth century.

\footnotetext{
${ }^{49}$ Niccolao Manucci, Storia do Mogor, trans. William Irvine, 4 vols. (Delhi, 1981) 2: 22.

50 Sheldon Pollock, "A Pre-colonial Language in a Post-Colonial World." Pollock gives the example of the geocentric worldview which is interesting to describe, but we may also ask why people did not see that it was heliocentric. For historical consciousness in seventeenthcentury India see the references to Jan Houben's article in Chapter 4.

${ }^{51}$ Ruth Phillips for example makes much that claim concerning native American objects in museums in "Why not Tourist Art? Significant Silences in Native American Museum Representations," in After Colonialism: Imperial Histories and Postcolonial Displacements, ed. Gyan Prakash (Princeton, 1995) 98-125, there 98, 118.
} 


\title{
PART I \\ CHAPTER 1 \\ A DUTCH PAINTER IN BIJAPUR: NATIONAL SENTIMENT AND \\ EUROPEAN-NESS AS REFLECTED IN THE RELATION \\ BETWEEN THE DUTCH AND THE PORTUGUESE IN THE \\ EARLY CENTURY
}

\begin{abstract}
[the so-called Sea Beggars fighting the Spanish in the Netherlands] have two things on their minds: the freedom of the fatherland, and the tyranny of the Pope and his inquisitioners: because of which some at this time [1574] wore silver half moons, on which was written Rather Turkish than Popish [Liever Turcks dan Paus], because they considered the tyranny of the Pope greater than that of the Turk, who at least does not force people's conscience if they pay tribute, and for that reason is as - or more trustworthy than the Pope.
\end{abstract}

Jan Fruytiers, $1577^{1}$

\section{INTRODUCTION}

In the hall of mirrors at Versailles, Louis the Fourteenth's accomplishments are showcased in a pictorial eulogy stretching across the ceiling and upper walls. The ensemble can be read as narrative of how the glorious king, otherwise quite content to live a life of pleasure, was provoked by the envy of his neighbours. The lunette painting over the northern doorway, the start of the series, depicts the alliance between the Dutch Republic, Spain and various "German"' states against France in 1672, as inspired by an old hag with a rooster under her arm representing jealousy. The northerners are depicted as bare-chested barbarians wreaking havoc on the world, the Spanish as helmed forces of darkness, and the country maidens of Holland,

${ }^{1}$ Corte beschrijuinghe van de strenghe belegheringhe ende wonderbaerlijcke verlossinghe der stadt Leyden in Hollandt (Delft, 1577) 18r see http://dutchrevolt.leidenuniv.nl/nederlands/spreuken/

liever\%20turks.htm. Examples of these half moon medals are in museums in Leiden and Den Briel, see http://nl.wikipedia.org/wiki/Geuzen-_en_aanverwante_penningen, accessed 11.7.2007.

2 The states classed as "Germany" in the painting would have been the Austrian empire, Brandenburg and Denmark. 
Spain and Germany as ugly, abject and fearful women. In short, the panel is a textbook example of "othering." Only here the Others are natives of Europe, as were of course the commissioner of the piece and its executor Charles le Brun. ${ }^{3}$

The present chapter highlights some of the identity concerns that the Europeans brought to the texts they drew up in Asia. Were, in the Asian context, the boundaries between Europeans perhaps more strongly demarcated and "lived" than was the boundary between Europeans and Asians? The latter boundary is generally thought to have been paramount in the secondary literature. But is it not possible that the "othering" of Europeans by other Europeans was in fact reinforced by their being abroad in foreign lands? The central case of this chapter, that of the Protestant Dutch painter Cornelis Claesz Heda, certainly suggests as much.

The setting is a time when an alliance between Spain and the Dutch Republic such as the one that came about in the days of Louis XIV was quite inconceivable. The Republic, not yet known under that name but only as the United Provinces, was a fledging state that was emerging from the revolt of the Netherlands against the Spanish Habsburgs that had started in the late 1660s. The United Provinces were only the seven northernmost provinces of the seventeen Netherlands that remained unpacified by Spanish troops, including the provinces of Holland and Zeeland from where the VOC was launched in 1602. The year 1609 saw a de facto recognition of the United Provinces in the form of the Twelve Year Truce between the rebellious provinces and the Spanish house of Habsburg which, in addition to Spain, ruled parts of Italy and Portugal (between 1580 and 1640), along with the extra-European possessions in the western and eastern halves of the world that Pope Alexander VI had awarded to Spain and Portugal respectively.

\section{EUROPEANS AMONGST EACH OTHER}

AN ARTIST AND A PATRIOT - In the summer of 1610, the chief of the Dutch factory at Masulipatnam received a letter from Cornelis Claesz Heda of Haarlem, who would like to introduce himself to him, "unknown friend and countryman," by means of the letter and the oral testimony of its bearer, "a great friend of our nation... J Jew called Mansur." In the letter

\footnotetext{
${ }^{3}$ Musée National du chateau de Versailles, inv. no. 2911. Claire Constans, Musée National $d u$ chateau de Versailles: Les peintures, vol. 2 (Paris, 1995) 550. Nicolas Milanovic, Du Louvre à Versailles: Lecture des Grands Décors Monarchiques (Paris, 2005) 166-9, 301-2. Milovanovic provides a sharp insight into the highly politicised context of the Hall of Mirrors paintings and links its themes to the Éloge historique du roi written by Nicolas Boileau and Jean Racine shortly after 1678, exactly the same time that Le Brun oversaw the execution of the paintings.
} 
Heda explained how he had ended up in Nauraspur, the newly built capital of the sultanate of Bijapur, a few miles from Bijapur proper. While working for the German emperor Rudolf at Prague, he had volunteered for a diplomatic mission to Persia, but had never made it there because he was taken off the Portuguese ship carrying the mission at Mozambique, incarcerated, and put on the first ship to Goa on suspicion of being a Dutch spy (Hollandsche spie). Heda had however pretended that he was a German (een Hoochduits or person from High Germany as opposed to een Duits or Dutchman) and managed to pass the speech test administered in the presence of the viceroy by a German from Augsburg. ${ }^{4}$

The distinction between Germans and Dutchmen was important because while the Netherlands were in revolt against the Spanish Habsburgs under a Protestant leadership, the rest the German empire remained safely under the suzerainty of the Catholic Rudolf of Habsburg. ${ }^{5}$ The Augsburger who tested Heda's High German skills was Ferdinand Cron, who was a formidable presence in Goa at the time, but ironically extradited on the charge of spying for the Dutch in the early 1620s, together with the Van de Koutere brothers, who were Catholics from the southern, Spanish, Netherlands. ${ }^{6}$ Though Cron's enemies were able to use the argument that Cron was a foreigner (extrangeiro), Heda's account of the speech test shows that Sanjay Subrahmanyam's supposition that "the distinction between an Augsburg-born German and a Hollander could not have been all that clear on the face of it to the Portuguese of the period," does not apply. ${ }^{7}$ The Portuguese caution with respect to Netherlanders like the Van de Koutere brothers, however, was not unwarranted since there were Netherlanders in Goa willing to spy for the VOC, as will be seen below. Clearly, each European "nation" had brought its formal as well as informal European friends and foes along to Asia.

After Heda managed to pass himself off as a German and with that qualified as a friend of the Portuguese, he was briefly employed by the viceroy, but soon escaped to Bijapur where he was well received by Sultan Ibrahim Adil Shah II. Ibrahim was, as is well documented in the secondary

4 NA, Letter Cornelis Heda to Dutch at Masulipatnam 16.5.1610, VOC 1055: 83-5 (published as supplement B to A. van der Willigen, Les artistes de Harlem: notices historiques avec un précis sur la gilde de St. Luc (Haarlem/The Hague, 1870)). A brief translated extract is in Mark Zebrowski, Deccani Painting (London, 1983) 95-6.

5 When the United Provinces made peace with Spain in 1648 they also officially left the German empire.

6 Jaques de Coutre, Aziatische omzwervingen: het leven van Jaques de Coutre, een Brugs diamanthandelaar 1591-1627, ed. and trans. Johan Verberckmoes and Eddy Stols (Berchem, 1988) 26-7.

7 Sanjay Subrahmanyam, "An Augsburger in Ásia Portuguesa: Further Light on the Commercial World of Ferdinand Cron, 1587-1624," in Emporia, Commodities and Entrepreneurs in Asian Maritime Trade, c. 1400-1750, ed. Roderich Ptak and Dietmar Rothermund (Stuttgart, 1991) 401-25. 
literature and as Heda also remarked, a great patron of the arts, and Heda wrote that he had been looking for a painter from "our country" (i.e. all of the Netherlands) ${ }^{8}$ for a long time. Ibrahim was apparently most pleased with the first work Heda produced in Bijapur, a portable stucco depicting Bacchus, Venus and Cupid, a subject well suited to the Mannerist style in which Heda had been trained by Cornelis Cornelisz of Haarlem. ${ }^{9}$ It appears that Heda became an important noble at the court, since he is referred to in two places as "third counsel of the king." He also held the exalted title of Nadir uz-Zaman (the Most Excellent of the Age) though with the qualification Ma'ani Naqash (With Regard to Painting). He appears to have had access to the "royal wardrobe" for materials and in 1615 was able to procure a farman or royal order within days (while for people not close to the court the procedure of obtaining a royal writ normally took weeks or months) and that too signed in gold by the sultan's own hand, where most farmans of the period had a parwangi of one of the ministers. ${ }^{10}$

What is most interesting from the point of view of this study is that, remote as he was from the Netherlands and most things Dutch, Heda developed a very strong sense of patriotism as well as a complementary hatred of the Portuguese, perhaps reinforced by his treatment at the hands of the Portuguese between Mozambique and Goa, though as will be seen shortly, he was by no means unique in that hatred. After a correspondence had developed with the Masulipatnam factors, Heda offered to send them any news on the Portuguese at Goa - and so the Portuguese suspicion of espionage fulfilled itself. Heda even briefly became the head of something of a network of espionage when he transmitted to the VOC factors two maps of projected Portuguese fortresses at Galle and Nagapattinam sent by one Hans Broeck, a Netherlander to judge by his name and working for the Portuguese at Goa as an engineer. ${ }^{11}$ And, as if to underline his own loyalty to the Dutch cause, Heda noted that an order had gone out in Goa that no Portuguese person was to speak with him, on pain of banishment. ${ }^{12}$ Heda also offered the VOC his assistance with such things as obtaining a pass from the Mughal ambassador at Bijapur for a factor to go to Agra, and

8 To Heda "our country" did include the southern Netherlands or in any case Brussels. NA, Heda to Masulipatnam 20.10.1612, VOC 1056: $133 \mathrm{v}$.

${ }^{9}$ NA, Letter Heda to Masulipatnam 16.5.1610, VOC 1055: 83-5 and compare Pieter J.J.L. van Thiel, Cornelis Cornelisz van Haarlem 1562-1638: A monograph and Catalogue Raisonné (Doornspijk, 1999) 3-5, 165-6. For the efflorescence of painting under Ibrahim see George Michell and Mark Zebrowski, Architecture and Art of the Deccan Sultanates (Cambridge, 1999) 162-77.

${ }^{10}$ NA, Letter Lionaert Wolff at Bijapur to Samuel Kindt 28.11.1615; Letter Kindt at Pulicat to Heda 23.09.1615; Translated farman dated 1016 Shuhur San/1615 CE, VOC 1062: 24, 4850. Heda's title is given as "nadyerul saman manny naquas" in the translation.

${ }^{11}$ NA, Letter Heda to Masulipatnam 22.1.1614, VOC 1057: 169-v.

12 NA, Letter Heda to Masulipatnam 18.4.1613, VOC 1056: 136v. 
establishing a factory at Bijapur. ${ }^{13}$ The latter was indeed effected through the farman that Heda procured so speedily, and for about a year there was a VOC factory established in a rented building in Shahpur, the suburb in which the most important merchants resided. The factory was, however, closed when it became apparent that the same things could be bought more cheaply elsewhere, and the plot the sultan had donated for building a factory in Nauraspur was not utilised. ${ }^{14}$

Material rewards accrued to Heda and his relatives in the Netherlands in return for his efforts, but do not seem to have been his main motive in aiding the VOC - although he hinted that he would not mind if the factors were to recognise his efforts with the gift of a horse or the like, and one of the factors at Masulipatnam remarked that Heda was keen to make sure that his services were not forgotten. ${ }^{15}$ A few years after Heda's first contact with the VOC, his mother and four sisters were taken into the protection of the Company and granted a pension in recognition of his services. ${ }^{16}$ Heda also had things like pistols and a compass sent to him. ${ }^{17}$ Yet Heda himself did not cease to emphasise his patriotism and hatred of the Portuguese as his motives in aiding the VOC. Thus he writes: "Your Honours shall have me to command as a good patriot [een goet patrij], having nothing to expect of me but the fulfilment of it in service of the fatherland, as far as this tiny might [of mine] will reach."18 His usage "a good patriot" conforms to the general usage of those early days of the Dutch state when "patriot" was not generally used by itself but always in connection with an adjective, mostly "good" or "faithful" etc. (but occasionally also "bad"). ${ }^{19}$

The VOC was for Heda a way of maintaining a material as well as sentimental and intellectual link with his fatherland. In the first letter to the VOC factors at Masulipatnam his main request was that he be allowed to send a letter and package to his mother. He also sent to his tutor and fellow painter from Haarlem François Badens the very best ultramarine (a lapis lazuli-based pigment) he could find in the "royal wardrobe" (the palace

${ }_{13}$ NA, Letter Heda to Masulipatnam 30.11.1613, VOC 1056: 238; letter Pulicat to Governor General 20.2.1614, VOC 1056: 232v; resolution Masulipatnam 22.12.1615, VOC 1062: 59v.

14 Hans de Haze at Masulipatnam to Bantam 05.06.1616, VOC 1063: 68, 70v; The "instruction to Van Ravesteijn going to Bijapur" of 23.2.1616 speaks of the VOC presence at Bijapur as a proper comptoir, VOC 1061: 216-7.

15 NA, Letter Heda to Wemmer van Berchem at Masulipatnam 30.11.1613, VOC 1056: 237v; Letter Van Berchem to Governor General 20.2.1614, VOC 1056: 232v.

16 NA, Letter Samuel Kindt at Pulicat to Heda 23.09.1615, VOC 1062: 48. Van der Willigen quotes a few excerpts from the Amsterdam Chamber Resolutions relating to the honours bestowed on Heda's mother Maritgen in Les Artistes de Harlem, 154-5.

${ }_{17}$ Masulipatnam to Governor General 16.08.1614, VOC 1057: 133.

18 NA, Letter Heda to Masulipatnam 25.04.1617, VOC 1065: 102.

19 Woordenboek der Nederlandsche Taal, s.v. patriot. 
tashkhana)..$^{20}$ Moreover, at his request a VOC factor, Jacques le Febvre, became godfather to his eldest daughter Marije Cornelis. ${ }^{21} \mathrm{He}$ also hoped to see the fatherland again one day through the favour of the VOC, and requested and duly received a number of books from the Netherlands, to wit a Bible, the beautifully illustrated travelogue of the original Dutch spy in Portuguese India, Jan Huygen van Linschoten, the original Dutch (Flemish) edition of Rembert Dodoens a.k.a. Dodonaeus' herbal and the Dutch translation by Karel Baten a.k.a. Battus of Christoph Wirsung's originally German medicinal treatise. ${ }^{22}$

Heda waxed on how dear the messages from the VOC factors "in the fatherlandish pen" were, "to me as a stranger among strangers who only by wielding my paintbrush now and then shorten my time here and chase away the thoughts," and on how good it was to hear of the "wellbeing and prosperity of the sweet fatherland." "The sweet fatherland" or "our sweet fatherland" was to become something of a stock phrase in VOC correspondence in the late seventeenth century. He also writes how, "the sincere Netherlandish spirit [bet oprechte Nederlantsche gemoet], trust in and care for the unfeigned friendships of yours, has made me write so much more freely." Such words seem to have made an impression on the VOC personnel, and shortly after his arrival in Bijapur Lionaert Wolff was convinced that Heda was "naturally inclined [naturaelich geinclineert]" to the service of the VOC. Heda also refers to VOC ships as "our" ships. Since technically he was not part of the VOC, Heda's only connection to these ships was that they were also Dutch. Similarly, when asked to advance some money to Dutch prisoners at Goa, he speaks of them as "our" prisoners, though, in this case, one can imagine that he would empathise with prisoners in Goa given his own history of imprisonment there. ${ }^{23}$

20 NA, Letter Masulipatnam to Bantam 1.11.1610, VOC 1055: n.f.; Letter Heda to the Company directors 23.5.1617, VOC 1065: 104 (that letter transcribed in Van der Willigen, Les Artistes de Harlem, supplement C). Badens died in 1618, but Cornelisz may have received and used the ultramarine, though this has not been researched. I thank Jan Piet Filedt Kok for this information.

${ }^{21}$ NA, Letter Heda to Le Febvre at Masulipatnam 25.4.1617, VOC 1065: 101.

22 Perhaps the directors, when they sent the last three books on Heda's request, were not sure if Heda knew Latin, but he seems to have known it well judging by his use of Latin words and declensions. It appears that Van Linschoten's travelogue was sent to him twice, first by the Masulipatnam factors and then by the directors. NA, Letters Masulipatnam to Governor General 1.11.1610, VOC 1055: n.f., Heda to Masulipatnam 30.11.1613 VOC 1056: 237v and Masulipatnam to Governor General 16.08.1614, VOC 1057: 133. NA, Letter Company directors to Heda 8.5.1615, VOC 312: 183. NA, Letter Heda to Company directors 23.5.1617, VOC 1065: 104.

${ }^{23}$ NA, Letters Heda to Masulipatnam 20.10 .1612 and 14.1.1613, VOC 1056: 133v, 134v; Letter Masulipatnam to Governor General 16.8.1614 VOC 1057: 137v; Letter Heda to Masulipatnam 17.1.1616, VOC 1062: 35; Letter Wolff from Bijapur to Samuel Kindt 28.11.1615, VOC 1062: 49-50. 
And so Heda consciously became the Dutch hub of central India. He told Sultan Ibrahim that the VOC factors in Masulipatnam were his brothers. ${ }^{24}$ When one Abraham, a Dutch diamond cutter in the service of the Mughal emperor came to town in the train of a Mughal ambassador to buy diamonds, he made contact with Heda and Heda passed his heartfelt regards on to the VOC factors in Masulipatnam. ${ }^{25}$ Heda also sheltered Gerrit Gerritsz, a young man from Amsterdam, who had suffered a fate similar to his own at the hands of the Portuguese and who also managed to escape to the territory of Bijapur. Gerritsz wrote that his benefactor treated him "as if I were his brother, since he feeds and clothes me, which many a countryman would not have done," 26 thus emphasising, in a vein similar to Heda's phrase "as a good patriot," that patriotism should perhaps have been self-evident but never was. Gerritsz initially sought re-employment by the VOC but after that effort fell through for some reason, Heda helped him to find employment with Yaqut Khan, a high-ranking wazir of Bijapur. Heda also took into his care Hans Marcellis Verwers, who had run away from VOC employment, because he was being investigated for unauthorised private trade and exploiting his connections with regional grandees, at a time when such a thing still appeared a novelty to his colleagues on the southern Coromandel coast. But apparently for Heda, Verwers' Dutchness was more important than his (severed) ties with the VOC, and he admonished the factors at Masulipatnam because "we must help Man carry his weakness." 27

However, for all his patriotism, it turned out to be difficult for Heda to cooperate with his fellow Dutchman Lionaert Wolff, sent to Bijapur to reconnoitre the market there. Wolff had been highly recommended to the factors at Masulipatnam, probably on account of his connections in the Netherlands, but was later found to be incompetent by them, because of the enormous debt he was to accrue in Bijapur. Wolff was unable to return to Masulipatnam when prompted — "in order to pull the sheep from the mouth of the devouring wolf in time" his superiors punned - because he was more or less held hostage by a Komati trader who had advanced him some money. After Heda had blocked Wolff's access to credit by sending his mahalldars ${ }^{28}$ around to the Komati to say that Wolff

\footnotetext{
24 NA, Letter Heda to Masulipatnam 20.10.1612, VOC 1056: 133-4.

${ }^{25}$ NA, Letter Heda to Masulipatnam 13.5.1617, VOC 1065: 103.

${ }^{26}$ NA, Letter Gerritsz at Bijapur to Masulipatnam 2.10.1610, VOC 1055: n.f.

27 NA, Letter Thiruppapuliyar to Masulipatnam 26.7.1610, VOC 1055: n.f; Letters Heda to Masulipatnam 14.1 and 18.4.1613, VOC 1056: 135, 136v; Letter Adolf Thomas at Pulicat to Amsterdam 29.3.1616 and Pulicat resolution 1.3.1616, VOC 1061: 177v, 211v.

${ }^{28}$ Here meaning a message-bearer or representative of a noble or royal person inhabiting a maball in the sense of mansion or palace. Van Twist notes in the margin of his Bijpur diary: "mahalldars [maldaers] are the king's servants and overseers of the peons." Heda had several maballdars including a chief maballdar, who was "a man of trade" and made the return trip to
} 
and his assistants were "strangers and petty traders," Wolff wrote that Heda's status was not what he claimed it to be, or rather that he had fallen from grace and lost his income from land revenues as well as in cash just before Wolff came out and saved the day for Heda with the gifts to Ibrahim and his nawab (in Bijapur: chief minister). Besides defaming each other, Heda and Wolff also reported negatively on Wolff's under-merchant Huibrecht Cnooper and assistant Clement Pietersen. According to both Heda and Wolff, Cnooper was a drunk and inclined to fighting. Pietersen was good for nothing except chasing prostitutes, wrote Wolff in Portuguese (which his two colleagues could not read) with their names garbled to look like Portuguese words. Cnooper on his part wrote to complain about Wolff and Wolff himself was afraid of being murdered by his fellows at nighttime. Meanwhile Heda called the quarrels between the three VOC employees a comedy, but worried about what they might be writing about him. Company establishments becoming little hells in the pattern of Sartre's Huis Clos ("hell is the others") was to become a familiar phenomenon in the history of all East India Companies. The Europeans who suffered most under the passive aggression of their inmates were the ones with the fewest connections with local society, as will also be seen in the cases described in chapters three and five. ${ }^{29}$

Most of his arrows dipped in venom, however, Heda reserved for the Portuguese. The pages of Heda's letters are dripping with antiPortuguese or more generally anti-Iberian or even more generally antiCatholic sentiments. When he heard in 1617 that there was war in Italy between the German emperor, Spain and Venice, he noted the role of the Jesuits in the war and hoped that "God will arrange all for the best so that the popish kingdom [het papencooninckrijck] may be disrupted." 30 And while Heda signed most of his initial letters from Bijapur "Cornelio de Heda" a Lusification of his name that was not only more easily recognisable to other Europeans but also lent it an aristocratic tinge - he reverted to "Cornelis Claesen Heda" in 1615 at least for the purpose of his correspondence with the VOC. ${ }^{31}$ He also advised that there was no point in

Masulipatnam once, though Heda generally sent his boi (Port.: a palanquin-bearer, a menial etc.) there. NA, Letters Heda to Masulipatnam and Surat, VOC 1056:133, 134v, 237v, VOC 1062: 35, VOC 1068: 432; Van Twist diary 10.3.1637, VOC 1122: 493; Sebastião Rodolfo Dalgado and Anthony Xavier Soares, Portuguese Vocables in Asiatic Languages (1936; photogr. reprint Delhi, 1988) s.v. boi.

${ }^{29}$ NA, Letters Heda to Masulipatnam 17.1 and 11.3.1616, VOC 1062: 35, 51; letters Wolff at Shahpur to Masulipatnam 18.1 and 3.4.1616, VOC 1062: 36-v and 1061: 172; Petapoli resolution 10.2.1616, VOC 1062: 60v; Pulicat resolution 1.3.1616, VOC 1061: 211v; letter Pulicat to Amsterdam 29.3.1616, VOC 1061: 175; Letters Samuel Kindt at Masulipatnam to Amsterdam 15.4.1616 and to Bantam 27.4 and 8.5.1616, VOC 1061: 161v, 168, 170; Hans de Haze at Masulipatnam to Bantam 5.6.1616, VOC 1063: 68, 70v.

${ }^{30}$ NA, Letter Heda to Masulipatnam 25.04.1617, VOC 1065: 101.

31 NA, Heda at Nauraspur to Samuel Kindt at Masulipatnam 30.11.1615, VOC 1062: 32. 
entering into friendship with the Portuguese and "that one should not trust the shitheads [datmen de hefters geen gelooff sal houden]," because "they will all be absolved anyway" — that is to say, being Catholics, the Portuguese could break any promise without harming their prospect of heaven. ${ }^{32}$ So their Catholic religion was to Heda a convenient marker to beat the Portuguese over the head with. However, it should be remembered that not all Dutchmen were Protestant at this time either, and in an apparent effort to make the Iberians look even worse than the average Catholic he spoke elsewhere in the same letter of "the fidelity-breaking Spanish Moriscos [i.e. the ever-suspect (descendants of) converts to Catholicism from Islam] and Portuguese Jews." 33

Heda's sentiments were partly an extension of the patriotic sentiments that obtained in the Netherlands during the height of the revolt against Philip II, although it is often argued that after the peak of the bellicose activities in the 1570s the inhabitants of the northern Netherlands quickly withdrew into localism and regionalism and that the idea of the seventeen provinces of the Netherlands forming a whole and indivisible fatherland became marginal in the United Provinces. While almost from the start of the revolt there was debate over the question as to whether the revolt was for the purpose of religion or for the purpose of liberty, the two often went hand in hand, as can be seen in the quotation at the beginning of this chapter. During the revolt there was much emphasis on loyalty to the fatherland, and Protestant propagandists considered themselves better patriots than Catholics who were in some cases even associated with betrayal of the fatherland. ${ }^{34}$ There was also a remarkable ambiguity in the thinking about the relationship between religion and state in the Netherlands after 1576. Benjamin Kaplan argues that the Dutch on the one hand clung to the medieval notion that a state could have only one religion but on the other embraced the idea of freedom of conscience, and to that purpose invented the distinction between the public and private spheres now considered to be a hallmark of modernity. ${ }^{35}$ Seen in that way it is not

32 NA, Letter Heda to Masulipatnam 14.1.1613, VOC 1056: 135. The phrase "geloof houden," also used in the last clause of the quotation at the head of this chapter, is to be considered a Latinism in Dutch, see Woordenboek der Nederlandsche Taal, s.v. geloof.

${ }_{33}$ NA, Letter Heda to Masulipatnam 18.4.1613, VOC 1056: 136.

34 Compare Henk van Nierop, "Similar Problems Different Outcomes: The Revolt of the Netherlands and the Wars of Religion in France," in Karel Davids and Jan Lucassen eds. A Miracle Mirrored: The Dutch Republic in European Perspective (Cambridge, 1995) 26-56, there 34, 43-4, and idem, Het Verraad van het Noorderkwartier; oorlog, terreur en recht in de Nederlandse Opstand (Amsterdam, 1999) 7-8, 105-32, 276 and passim, and Jonathan I. Israel, The Dutch Republic: Its Rise, Greatness, and Fall 1477-1806 (Oxford, 1995) 410-20.

35 Kaplan, Calvinists and Libertines: Confession and Community in Utrecht 1578-1620 (Oxford, 1995) 295-6; Grotius was a particularly strong advocate of a state church and strictly circumscribed toleration for religious minorities, see Israel, Dutch Republic, 501-2. Further on it will be shown that the Dutch distinction between public and private was not so unique. 
surprising that Heda supposed his correspondents to be Protestant, being representatives not only of a company but also indirectly of the States General, the legislature of the United Provinces, which had transferred its sovereign rights for purposes east of the Cape of Good Hope to the VOC. Yet considering the fact that a large part of the population of the United Provinces remained Catholic it is rather surprising. So far, no study has attempted to investigate the proportion of Catholic to Protestant employees of the Company, ${ }^{36}$ although it seems that the former were a minority and found it impossible to practice their religion on board. ${ }^{37}$

Heda's emphasis on the faithlessness of the Portuguese certainly meshed with war party propaganda in the Netherlands during the peace talks with Phillip III of Spain, Portugal etc. in the years 1606-1608. The war party pamphleteers dreaded the unholy trinity of the king of Spain, the Pope in Rome and the ubiquitous Society of Jesus (which was perhaps also what Heda meant by his vague reference to "the Popish kingdom"). Because, in this view, the Pope could absolve Phillip III from a breach of promises made to the Protestant insurgents, a peace treaty would leave the United Provinces vulnerable, especially if the forces of Prince Maurice were to be disbanded. ${ }^{38}$ Heda explicitly relates this issue of trust and untrustworthiness to the lessons of Dutch history in speaking of the treacherous ways and "bloodhoundish" disposition of the Portuguese and Castilians "that...our credulous and overly trustful Hollanders and reasonable Dutchmen [Duijtze] have had to pay for with their lives on many occasions, which our annals [tijt en jaerboeken] are full of." 39

JUST WAR AND JIHAD—But Heda's outlook cannot be explained from his Dutch background alone, after all he learned at least one of the locally current languages, ${ }^{40}$ and moved in the highest circles of Bijapur, while referring to Ibrahim as "my king" or "our king." 41 Although it must be noted that the latter phrase ("our king" or "our queen") was also used, if uncommonly, by VOC personnel at the time to refer to Indian rulers in whose realms they dwelt, which is quite significant. ${ }^{42}$ Heda also claimed that he had a "very close friend [seer familiaer vrindt]" in the royal treasurer

\footnotetext{
36 Personal communication from Femme Gaastra, 2007.

37 Roelof van Gelder, Het Oostindisch avontuur Duitsers in dienst van de VOC (1600-1800) (Nijmegen, 1997) 68.

${ }^{8}$ Compare Martine Julia van Ittersum, Profit and Principle: Hugo Grotius, Natural Rights Theories and the Rise of Dutch Power in the East Indies, 1595-1615 (Leiden, 2006) 320.

${ }^{39}$ NA, Letter Heda to Van Berchem at Masulipatnam 20.10.1612, VOC 1056: 133-4.

40 Otherwise it would have been rather odd for him to suggest that the VOC send "sterling persons knowledgeable in language and land [duchtichge persoonen die spraeck ende landt condich waeren]" to the diamond mines. Letter Heda to directors 23.5.1617, VOC 1065: 104.

${ }^{41} \mathrm{NA}$, Letters Heda to Masulipatnam 23.5 and 30.11.1613, VOC 1056: 137v, 238.

42 E.g. NA, Masulipatnam to Bantam 1.8.1613, VOC 1056: 151v.
} 
Khwaja Muhammad Ahmadi, an Iranian. Moreover he found Bijapur a pleasant enough environment to help the Dutch drifter Gerrit Gerritsz find a job with Yaqut Khan and to invite the VOC to bring some "beautiful minds" - smiths, watchmakers, musicians etc — from the Netherlands to win the sultan's heart. 43

That notwithstanding, there is a somewhat disparaging tone in his speaking of the majority of the inhabitants of Bijapur, to whom he refers in one place as "these blacks [dese swarten]." 44 We also see this ambiguity in his evaluation of Ibrahim as "a good lover of all the liberal arts and very mild and kind-hearted, unlike all Moors, having also a good judgement of all arts." 45 And ten years into his stay in Bijapur, Heda had grown increasingly bitter about the Muslims and other Indians as well as the Portuguese:

Trade in Goa is very weak, the popish priests [papen] have a lot on their hands in turning the Kanarese Christian by force and baptising them, the people are very much leaving the place. Further, the news from Masulipatnam I expect you will have heard of the skirmish that has taken place there between the Hollandish Company and the Muslims. Mr Hans de Haes has been wounded behind the ear by a lance, two Hollanders have remained dead, but some 40 Muslims have remained dead and many wounded, the thanadar [chief constable] would also have been wounded; I am expecting further notice every day because I have sent my boi thither already 48 days ago to date, his long dwelling surprises me very. It is to be feared that all trade with this Barbaric nation in the Indian lands will come to like, for the Muslims and Indians think that our people need them greatly and therefore have to beg, even though they have been liberated by our people from the Portuguese rod, who knew how to live with them differently and who had made all these kings tributary to them, yes subject. May God open the eyes of the fatherlandish Company so that honour may be drawn to his holy name for the prosperity of the Christian nation. ${ }^{46}$

Heda's perspective on the Portuguese here is not quite as Dutch as it would appear at first sight. In fact it seems to have been heavily influenced by his Islamicate environment; not only does he use the term Indianen for the nonMuslim inhabitants of India, which was unusual for a Dutchman and a literal translation of the term Hindu that his Muslim conversation partners would have used for the people of Hind or India with their various religious beliefs, it is also extremely similar to that presented by Zain ud-Din Ma'abari who argued in his Tohfat ul-Mujabidin (Gift to the Performers of Jihad) that because the Muslims of Malabar, India's south-west coast, were ungrateful to God and sinned, "God sent the Portuguese to lord it over

\footnotetext{
${ }^{43}$ NA, Letter Heda to Masulipatnam 20.10.1612, VOC 1056: 133v.

${ }_{44}$ NA, Letters Heda to Masulipatnam 20.10.1612, 18.4.1613 and 25.4.1617 (quotation), VOC 1056: 133v, 137 and VOC 1065: 101.

45 NA, Letter Heda to Masulipatnam 20.10.1612, VOC 1056: 133v.

${ }^{46}$ NA, Letter Heda to Van Ravesteijn at Surat 19.1.1619, VOC 1068: 432.
} 
them, these Christian Franks - May God abandon them! - who tyrannized them, corrupted them, and practiced ignoble and infamous acts against them...they would profane the sacred sanctuaries of the mosques, incite Muslims to apostasy and to adore the cross." The emphases on both conversion and oppression by the Portuguese echo in Heda's piece of advice, as well as the emphasis on the hope that God may abandon the Portuguese and take "our" side. Both texts emphasise that the "we" must reform to get God to come over (or rather that God will make "us" reform ourselves), in the case of Zain ud-Din it is very explicitly the practice of jihad that is the way to achieve this, in the case of Heda it is only hinted at by the phrase "may God open the eyes of the fatherlandish Company." 47 Heda was clearly familiar with such ideas about the obligation of jihad against the Portuguese, writing that Ibrahim could be a powerful ally against the Portuguese if only he would - and if the VOC would show itself to be serious, then "I would stir things up a little and could also effect something and present the Malabarese as brave heroes." 48 Apparently, the idea that the Mappilla Muslims of Malabar were waging a jihad for which they, ideally, needed the support of all Muslims was current at the Bijapur court; this is also the key to what Subrahmanyam calls the "mystery" of the dedication of Zain ud-Din's text to Ali Adil Shah, Ibrahim's predecessor. If the idea that the Mappillas were the heroes of a jihad against the Portuguese and could therefore appeal to Islamic solidarity was not already current at the court of Ali, then it was certainly introduced there by Zain ud-Din's pamphlet. This pamphlet stated that in the case of an invasion of Muslim lands by infidels jihad ceased to be a farz kifa'i, an obligation of all Muslims that can be sufficiently performed by a few, and became a farz ul-'ain, an obligation that must be performed by all Muslims, "whether from within a three days journey or from beyond," Zain ud-Din added. ${ }^{49}$ The author set the stage for this appeal as early as the foreword to his pamphlet, where he said that Sultan Ali had already, "set an example of exertion [jihad] in eradicating infidelity." 50

But there are also close parallels between Heda's argumentation and the early works of the Dutch jurist Hugo de Groot, known to the English-

47 Zain ud-Din quoted and discussed in Subrahmanyam, "Taking Stock," 72-4 and From the Tagus, 29-32.

48 Heda, Letter to Masulipatnam 20.10.1612, VOC 1056: 133-4.

49 Zain ud-Din, Tohfat ul-Mujabidin edited by David Lopez as História dos Portugueses no Malabar por Zinadim (Lisbon, 1899) 9; Thomas Patrick Hughes, A Dictionary of Islam (1885; photogr. reprint Delhi/Ottawa, 1996) s.v. farz ff. Compare J. Rowlandson's translation as Tohfut ul-Mujabideen (London, 1833) 17.

50 Zain ud-Din, text Lopez, 6. Rowlandson suggests in his introduction to the text that this may be a reference to the conquest of Vijaynagar by Ali in alliance with the other sultans of the Deccan, but for the sake of brevity I shall avoid the debate over the motives of these sultans. For a recent discussion see Richard M. Eaton, A Social History of the Deccan, 13001761 (Eight Indian Lives) (Cambridge, 2005) 78-104. 
speaking world as Grotius. We must in this case speak of parallels, because direct borrowings are extremely unlikely, since Heda left the United Provinces for Prague well before Mare Liberum was published in 1609, the year Heda reached Bijapur, and that work was not included among the books the VOC directors sent Heda upon his request. Mare Liberum (The Free Sea) was a modified version of Chapter 12 of Grotius' unpublished very anti-Spanish/Portuguese/Pope and pro-VOC De Jure Praedae (On the Law of Booty) written some five years earlier. In Mare Liberum Grotius, perhaps in order not to be seen to derail the peace and truce talks with Spain in too obvious a way, moved away from the idea that the Company represented the Dutch nation and its war which was arguably just on the basis of natural law, to the idea that private individuals should be allowed to trade freely everywhere, also on the basis of natural law. Grotius' view of natural law (ius naturale) seems to have been based on, or oscillated between, the humanist tradition which grounded it in the concept of impetus naturalis, akin to what we would now refer to as human nature, and the Scholastic tradition following Thomas Aquinas, who saw it as the participation of rational creatures in the eternal law known only to God. ${ }^{51}$

As with Heda, we find with Grotius the paradox of underpinning empire and liberty in one broad stroke, a paradox or contradiction convincingly deconstructed by Martine van Ittersum in her Profit and Principle. The Dutch fight "for the freedom and liberty of all mankind," as Grotius put it rather neutrally in Mare Liberum, was necessary in view of the atrocities committed by the Spaniards and Portuguese worldwide upon which he waxed in his De Jure Praedae. As Van Ittersum shows, Grotius drew on the sworn statements of a number of Dutch returnees from Asia concerning "the cruel, treasonous and hostile procedures of the Portuguese in the East Indies," as well the Black Legend, which was the widely held idea in the Netherlands during the revolt that the Spanish were going to do or were already doing to the Dutch what they had done to the Amerindians as per the description of the Spaniard Bartolomé de las Casas. Heterology was a favourite tool of the Dutch editors of De la Casas as of Grotius, who, in Mare Liberum belaboured the Spanish with what "the principal doctors" among the self-same Spanish had said. Nevertheless, Grotius discriminated between the Portuguese and the Spanish: while the former were "much more notable for violence," the latter outdid them in "perfidy." The resulting cocktail of self-righteousness and prejudice against Iberians in general and Portuguese in particular was formulated by Grotius in De Jure Praedae:

51 Eric Wilson, "Erasing the Corporate Sovereign: Inter-Textuality and an Alternative Explanation for the Publication of Hugo Grotius' Mare Liberum (1609)," Itinerario 30 (2006) 78-103. 
The Dutch sailor knows that he is fighting in defence of the law of nations while his foes are fighting against the fellowship of mankind; he knows that they fight to establish despotism, but that he himself is defending his own liberty and the liberty of others; he knows that the enemy are motivated by an inborn lust for evildoing, whereas the Dutch have been provoked repeatedly and over a long period by calumny, cruelty, and perfidity.

However, in addition to the natural right to self-defence, Grotius also adduced the natural law principle that pacta sunt servanda (treaties must be honoured), which to him meant that the Dutch were allowed to use force against their Asian allies to enforce any treaties concluded with them, and to make sure they did not trade with others if those treaties so stipulated. While this latter principle baffled Grotius' English negotiating partners at the Anglo-Dutch talks on the Indies in 1613 and 1615, it later also became a pillar of English imperialism. ${ }^{52}$

With the example of the Portuguese sea-borne empire in the East before their eyes, many of the Dutchmen who found themselves in India in those very early days of the VOC started thinking about the future of the Dutch enterprise in Asia. Heda certainly felt himself to be a part of this informal think-tank that seems to have been motivated by a shared sense of the urgency of ousting and emulating the Portuguese.

Another member of this think-tank was Wemmer van Berchem, who was originally from the land-locked province of Guelders but became a captain or commander at sea of sorts, plying the Atlantic and Caribbean, before he was sent out to announce the Twelve Year Truce in Monsoon Asia on behalf of the States General and the VOC. After he completed (or, rather, sabotaged) his mission, he came to serve the VOC on the Coromandel coast where he founded a fortress at Pulicat in the name of his home province. ${ }^{53}$ The latter goes to show that his local patriotism did not preclude his national sentiment of which some telling examples will be given below. It is likely that, in contrast to Heda, Van Berchem had some knowledge of Grotius' arguments presented in Mare Liberum, which had come out half a year before the start of his mission and with which the VOC directors who selected and probably briefed Van Berchem had been most content. In one place, in any case, Van Berchem matches Grotius' bellum iustum (just war) with its Dutch equivalent rechtveerdige oorlooghe. ${ }^{54}$

\footnotetext{
52 Van Ittersum, Profit and Principle, passim, quotations taken from 78, 97, 330; "The principal doctors" taken from Wilson, "Erasing," 78.

${ }^{53}$ Compare L.C.D. van Dijk, Zes jaren uit het leven van Wemmer van Berchem, (Amsterdam, 1858) i-xii, 1-4; Nicolaes van Wassenaer, Historisch verbael van aller gedencwaerdiger gheschiedenissen, die bier en daar in Europa...voorgevallen zijn (Amsterdam, 1622-35) 13: 29-v.

54 Van Ittersum, Profit and Principle, 331 and passim; NA, Letter Van Berchem at Masulipatnam to Governor General 16.8.1614, VOC 1057: 129v.
} 
Heda hoped that "our fatherland would finally seriously undertake to pluck this golden apple of India." He was also in favour of establishing colonies - in the sense of settlements of people from the metropolis and was happy to learn that a ship with families had arrived from the Netherlands, noting that the Portuguese "would not have enjoyed this empire and unspeakable treasure," had they not created such "administrative order and fine cities and fortresses" as they did. Heda was also of the opinion that the king of Spain was to an extent justified in saying that he was keeping up the East Indian establishments in order to spread the Christian faith and that the Dutch should do the same with more fervour than hitherto. When the Portuguese were engaged in an attritional war with Malik Ambar of the Ahmadnagar sultanate, Heda hoped that the VOC would seize the opportunity to crack down on the Portuguese at the coast and even while the VOC seemed to think there was not much to be earned on the Konkan coast, he hoped that "honour would overcome the love of money." 55

Apart from pointing out trading opportunities in Bijapur, which he thought did exist — "for I don't think our Hollanders are starting to get so sleepy that they will pass up such fine booty" - Heda therefore suggested that the Company make its presence felt militarily, by means such as establishing a fortress at the tip of Ceylon. This also because the Portuguese were in Heda's view continually trying to "infect the kings, both the Muslims and Hindus, with gifts, to which these nations are very inclined, so that according to my limited understanding, the heartfelt favour of this nation [the Bijapur elite?] cannot be securely relied on... It would be better that it be kept friendly through fear rather than by begging." Wemmer van Berchem remarked in a similar vein, regarding the weakness of his replacement during his absence at Masulipatnam, that, "it is more necessary to appear like a lion than like a lamb among these Moors." Adolf Thomas, on the other hand, thought that allowing its factors to engage in private trade was the way for the VOC to make itself master of the India trade, harm the Portuguese and dispel the "pride of the haughty Moors of Masulipatnam." 56

In 1613 or '14 Wemmer van Berchem, perhaps upon the advice of Heda, at Pulicat embarked on a policy of marrying Dutchmen to local women who would accept Christianity, writing that "this is the only means by which we must hold on to and maintain India, as the Portuguese did

${ }^{55}$ NA, Letters Heda to Masulipatnam 20.10.1612 and 14.1, 18.4 and 30.11.1613, VOC 1056: 133-6, 237.

56 NA, Letters Heda to Masulipatnam 23.5.1613, VOC 1056: 137v-8; Wemmer van Berchem at Masulipatnam to Governor General 16.08.1614, VOC 1057: 139v; Adolf Thomas at Pulicat to Amsterdam 29.3.1616, VOC 1061: 176v. 
before our time." 57 Samuel Kindt also thought the Portuguese example should be emulated in this respect and wrote two years later: "within the fortress [at Pulicat] there are 11 Dutch married soldiers, 2 to Netherlandish and the others to local women, also 11 of the black soldiers [are married], in all 32 souls [are attached to the soldiers], both women married to our men and children from within and without the fort having taken Christian baptism, and 16 marriages confirmed the Christian way. In sum it appears that, with God's help, this place... will be turned into a good colony, to great grief of our enemies [the Portuguese] at San Thome, already in great decadence and definitely impoverished." ${ }^{58}$ And a resolution at Pulicat determined, also in 1616, that all unmarried Christians who had and would come over to Pulicat from the Portuguese towns on the coast would be given a small stipend for their upkeep until they could be sent to other places to be employed in VOC service, "in order that this place will be increased by Christians to the detriment of the Portuguese, our neighbourenemy." 59

\section{EUROPEANS AND INDIANS}

THE BOUNDS OF ETHICS-The most systematic thought on the topic of this subsection, the relative height of the boundaries within and around Christendom, is again found with Grotius, although his views in this respect do not match exactly the experience of the Dutch in India. Grotius gave some thought to the relative merits of keeping society with nonChristians (infideles) and heterodox Christians (beterodoxor) in some of his "juvenile" works, to wit the unpublished De Jure Praedae and De Societate cum Infidelibus, as well as his regulations for the Jews of Holland published in 1615. In De Societate he argued (with Thomas Aquinas) that one was not to harm anyone, whether believer or unbeliever, or take lands that were already occupied. Friendship and association with unbelievers was possible, if less close than with believers. From the heterodox, however, one should keep as much distance as possible, though dealings with them were not forbidden. Van Ittersum argues that in De Jure Praedae, Grotius in effect advocated a reordering of moral priorities, putting allegiance to one's fatherland and, at one remove, to humanity as whole before any moral obligations to Christendom. Grotius' treatment of the death of Sebald de Weert at the order of the king of Kandy in 1603 brings that out very clearly. In Grotius' view, De Weert had been misguided in releasing his Portuguese prisoners instead of handing them over to the king of Kandy to be killed, because he was in alliance with the king of Kandy against the Portuguese.

${ }^{57}$ NA, Letter Wemmer van Berchem to Governor General 16.8.1614, VOC 1057: 132v-3.

${ }^{58}$ NA, Letter Samuel Kindt at Masulipatnam to Amsterdam 15.4.1616, VOC 1061: 165v.

${ }^{59}$ NA, Pulicat resolution 1.5.1616, VOC 1061: 194. 
The king of Kandy was therefore justified in killing De Weert and the employees of the VOC owed it to the Dutch commonwealth to keep faith with Indian allies, whether infidels or not. ${ }^{60}$

Grotius also went furthest of all Western European jurists in his rejection of the right of the Pope to grant worldly dominion in general, and of the Papal donation of half the non-Christian world to the Portuguese and the other to the Castilians in particular. There is an important distinction here between the Dutch ideologies of conquest in the East and West and the English and French ideologies of empire in the same period. While the English and French were generally reticent to take parts of the world that were already under Christian powers, with the exception of the short period of the rule of the puritans in England under Cromwell, for some of the Dutch, it seems, ousting the Portuguese was the whole point of the VOC enterprise. ${ }^{61}$ Oddly enough though, in the secondary literature on Dutch overseas expansion only the West India Company, founded in 1621, is generally seen as a "fighting company," to wit against the Spanish and the Portuguese in the Americas. ${ }^{62}$

That said, the notion of a Christian community was not so easily dispensable in India as Grotius imagined it to be, even though the status of the Portuguese as members of it was certainly dubious to the Dutch, also in India. Religion seems to have been a paramount concern in the boundaries that Zain ud-Din and Heda sought to enforce. This section attempts to show that, at this time, religion was indeed seen by both Europeans and Muslims as the main marker of the boundary between these two groups (rather than skin colour or region of origin, etc.). Differences in skin colour and exotic dress as manifestations of spatially remote origins did not go unnoticed; European hats fascinated Indian makers of Islamicate art just as turbans fascinated Rembrandt. ${ }^{63}$ The court jester of Muhammad Qutb Shah of Golkonda found the apparel of Wemmer van Berchem sufficiently interesting to ask him for a set and then to ride to court in it, "looking more like a Frenchman or Englishman than a Persian" (and thus almost, but not quite, a Dutchman). ${ }^{64}$ The material manifestations of difference were, however, hardly a concern to the involved, whereas religion was.

\footnotetext{
${ }^{60}$ Peter Borschberg, “De Societate Publica cum Infidelibus': Ein Frühwerk von Hugo Grotius," Zeitschrift der Savigny-Stiftung für Rechtsgeschichte, Romanische Abteilung 115 (1998) 35593; Van Ittersum, Profit and Principle, 58-9, 98-104.

${ }^{61}$ For the relation of Grotius to other jurists with respect to the Papal donation, and English and French ideologies see Anthony Pagden, Lords of All the World: Ideologies of Empire in Spain, Britain and France (New Haven, 1995) 46-52, 90 and 33, 64, 76 respectively.

${ }^{62}$ See F.L. Schalkwijk, The Reformed Church in Dutch Brazil (1630-1654) (Zoetermeer, 1998) 3863.

${ }^{63}$ Compare Scheurleer and Kruijtzer, "Camping," 55.

${ }^{64}$ NA, Letter Masulipatnam to Bantam 1.8.1613, VOC 1056: 149v.
} 
Similarly, Dirk Kolff and H.W. van Santen have shown that in Surat in the 1610s and 1620s, relations between the Dutch, English and Armenian communities were very close. Kolff and Van Santen argue further that one could therefore speak of a Christian "nation" in Surat and other trading towns in India and that Indians in Surat would have regarded the Dutch, English and Armenians in Surat as members of such a Christian nation. ${ }^{65}$ To what extent Indians regarded all Europeans as members of one group and to what extent they were sensible to the intra-European divisions that Heda sought to enforce, is the subject of the next section. This section merely investigates the way seventeenth-century Dutchmen in India perceived the Christian boundary in relation to other boundaries.

Dutchmen at the time saw religion, it seems, as the second most important boundary between them and other groups in India, the foremost boundary being "Dutch-ness" as has already seen in the case of Heda and will be elaborated shortly. The layout of Pulicat made visible the two crusts around the VOC personnel. In his use of the term "colony" (see above), Samuel Kindt included the married Dutchmen as well as the black soldiers and their wives. But while the Dutch personnel mostly lived inside the fort in the early days, the remainder of the Christian colony, the black soldiers and their wives and the mestizo Portuguese defectors, were moved out of the fortress in 1615. Yet the living area of the non-Dutch Christians was again separate from the remainder of the town, "to be in that way partly cut off from the Heathens, so that I doubt not we shall in time have a fine city with Christian families," while a Portuguese-speaking minister was ordered to go there to bring these people from Roman Catholicism to "better knowledge." 66 The inner crust of the Christian colony was separated from the outer crust by the walls of the fort and Dutch Protestantism. Nevertheless, the Christian boundary was the one that defined the colony.

One can also find some examples of appeals to Christian (or Protestant) or European solidarity in the VOC archives. The most striking example I have come across is that written by the English president in Surat, William Methwold, to the Dutch president in Surat in 1636. When the English were under strain in Surat because of accusations concerning the capture of two ships, one of which belonged to the shabbandar (overseer of the port), Mirza Mahmud, the Dutch were in close contact with the Mughal hakim (district governor) Masih uz-Zaman. ${ }^{67}$ Methwold, however,

${ }^{65}$ D.H.A. Kolff and H.W. van Santen, "Inleiding," in eidem eds. De geschriften van Franciso Pelsaert over Mughal Indië, 1627 (The Hague, 1979) 18-31. See also D.H.A. Kolff, "La nation chrétienne à Suratte," in La femme dans les sociétés coloniales, ed. J.L. Miège (Aix en Provence, 1984).

${ }^{66}$ NA, Resolutions Pulicat 26.9 and 15.10.1615, VOC 1061: 204-5; Letter Hans de Haze at Masulipatnam to Bantam 5.6.1616, VOC 1063: 69-v.

${ }^{67}$ EFI, various documents, 197-203; Ali Muhammad Khan, Mirat-i Abmadi (translation by M.F. Lokhandwala, 1965) 183. 
noted that their talks were not as secret as the Dutch imagined them to be and showed himself very disappointed in the Dutch factors:

It surprises me highly in these times of extremity, that I have not for many days received a greeting from your honourable person or have been visited by anyone of the Netherlandish nation. Our old acquaintance and familiar conversation would (in my view) call for a better correspondence, and for that reason it is very difficult for me to find the contrary...I know the affection and favour that your honour bears the welfare of the honourable English company (which I serve), but that you would practice some prejudice against her alongside the Moors, does not accord (in my view) with the old alliance and friendship that was practiced in former times among our nation [sic], I can't understand what I have heard because it is at odds with what I would have expected of you and if God spares my life to see you, I shall bare my heart fully to you. ${ }^{68}$

The relations between the Dutch and the English in the East were, as Methwold's letter shows, ambivalent. They were weighed down by the memory of the Amboyna massacre of 1623, and certainly did not improve with the two Anglo-Dutch wars fought in the third quarter of the seventeenth century. Furthermore, although the English had tried to distance themselves from the Portuguese early in the century, Methwold engineered an entente between the two nations that was to last. ${ }^{69}$ The fact that Methwold concluded the agreement with the Portuguese viceroy a year before he wrote to the Dutch president as he did, makes his appeal all the more surprising. The relation between the Dutch and the English in seventeenth-century India is therefore perhaps best expressed by John Gayer, English president of Surat in 1695, when the English again stood accused of taking Mughal ships (see Chapter 5), writing that the Dutch "retained their Edomitish principles, and rejoice to see Jacob laid low." That is to say: the Dutch and the English were like the brothers Esau and Jacob respectively, fighting from the time they were in the womb, the first physically stronger, but the second the cleverer and sire of the chosen people.70 Still, in 1689 the Dutch factors at Surat identified (or felt they were being identified) with the English factors of the city sufficiently to express their shock over the manner in which city governor Mukhtiar Khan had the English factors arrested - in heavy chains — in connection with the then current war between the EIC and the Mughal empire: "[to make] a

\footnotetext{
${ }^{68}$ NA, Translation of letter Methwold to Dutch president Surat 12.4.1636 (o.s.), VOC 1119: 1055. There appears to be no copy of the original English letter in the EIC archives.

69 Thomas Roe, The Embassy of Sir Thomas Roe to the Court of the Great Mogul 1615-1619, as Narrated in His Journal and Correspondence, ed. William Foster (London, 1899) 506-8 and passim; F.C. Danvers, Report to the Secretary of State for India in Council on the Portuguese Records Relating to the East Indies (London, 1892) 32; George D. Winius and Marcus P.M. Vink, The Merchant-Warrior Pacified: The VOC... and its Changing Political Economy in India (Delhi, 1991).

${ }^{70}$ Gayer quoted in John Biddulph, The Pirates of Malabar (1907; photogr. repr. Delhi, 1992) 28; Bible, Genesis 25: 19-34.
} 
spectacle and eternal shame of the European Christian nations. O horror." It is noteworthy that in the extant original (i.e. signed) letter the Surat factors spoke of "European Christian nations," but two of the copyists (one in Surat and the other in Batavia) of this particular letter identified even stronger with the English and rendered this phrase "European Christian nation," while a fourth copyists (copying the text in the Netherlands from a copy made in a Dutch factory in Persia) apparently found "English Christian nation" the most plausible reading. To a clerk in Asia such a thing as "the European Christian nation" was a possible existential space, while to a clerk in the Netherlands Christendom may have been a boundary too remote to consider. ${ }^{71}$

But although the Christian nation was a concept with some salience among the Europeans, even Dutchmen, in India, it was limited in its compass. For Heda the term "Christian nation" only applied to his, the Protestant, division of Christendom, as is clear from the last sentence of his jihadist call to arms above. Heda did have some contact with other Christians in Bijapur including an Italian who provided him with the latest news from Europe by the land route from Venice. Another was an Armenian who had served with Emperor Rudolf of Habsburg and the Duke of Saxony and been to the Netherlands and was "inclined to the Hollanders." His disfavour with the Portuguese, however, seems to have cut him off from part of the resident and transient European community. He spoke of an Englishman who came to see him twice, but when he heard that such did not please the Portuguese he stopped coming. ${ }^{72}$ Similarly, when Johan van Twist was on his embassy in Bijapur in 1637 (about which more below), he had friendly contacts with a number of Europeans, but not with the Portuguese there (except two mestizo harpists and a convert to Islam who complained about the viceroy). ${ }^{73}$ When he held a dinner on the eve of Lent he invited only Anthonio de Wit, a painter from the southern Netherlands, and the English ballistics expert Thomas "Treijbeck" (both in the service of Bijapur nobles), noting in the margin of his diary "the Christians in Bijapur come to our house, whom we treated to a Shrove Tuesday banquet." ${ }^{74}$ Similarly, when Jan Tack went to Agra a year earlier,

\footnotetext{
71 NA, Letter Surat to Amsterdam 7.4.1689, VOC 1448: 430-1/1475: 43-9/1464: 484-97/ 10406: 177-89.

${ }^{72}$ NA, Letter Heda to Masulipatnam 30.11.1613, VOC 1056: 237-v; Letter Wolff from Shahpur 28.11.1615, VOC 1062: n.f.

${ }^{73}$ He complained that the viceroy had not done enough to obtain his release so that he had been forced to convert. NA, Diary Van Twist sub dato 18.2.1637, VOC 1122: 485.

${ }^{74}$ Van Twist was initially wary of contact with Anthonio de Wit a.k.a. de Vitto, who was known to have links with the Portuguese, but after a meal at his house relations improved, although even afterwards he was kept at arm's length. Thomas Treijbeck was taken into confidence right away. NA, Diary of mission to Bijapur by Van Twist sub datis 10, 13, 14, 16, 22.2 and 3, 9.3.1637, VOC 1122: 480v-93.
} 
the Surat factors instructed him to beware of all that might compromise his Christianity, such as conversation with "Portuguese or Italian Christians or apostate renegades nor with the Portuguese padres," and was only allowed conversation with a certain Frenchman. ${ }^{75}$ Indeed, one would have to search long and hard in the archives to find an example of amicable conversation between a Dutchman and a Portuguese or Spaniard in India in this period.

As was seen, Heda was very well integrated in the Islamicate society of the Deccan, and he was by no means unique; the number of Europeans serving the kings and nobles of the Deccan must already have been quite significant at the time. The VOC personnel were not dependent on a local employer, but nevertheless, once the VOC had established itself on the Coromandel it did not take the factors too many years to discover that a local network was quickly built, as in the case of the aforementioned Hans Marcellis Verwers. By 1615 Hans de Haze warned against excessively close relationships with local traders and grandees in Masulipatnam and nearby Petapoli, precisely because these relationships undermined loyalty to and profits of the VOC or could even be used against the VOC (as in the case of the Dutchman who escaped investigation by his fellow VOC-men by escaping into the house of a Muslim resident of Masulipatnam in 1614). ${ }^{76}$ De Haze warned especially against "the conversation with the great Moors and Persians" of Masulipatnam and nearby Petapoli; "the ones [of the VOC personnel] who are guilty also take little pain to deny that their friendship is giving the Company no benefit but great harm." Apparently many were "guilty" of "conversation," going far beyond the "good day and good evening only" that De Haze prescribed. ${ }^{77}$

Part of the explanation for this may lie in the then existing measure of consciousness of social class across groups from different regions. As David Cannadine argues for the case of the British empire, social hierarchy was understood as well in Europe as in Asia. ${ }^{78}$ Wollebrant Geleynssen de Jongh, VOC factor in Gujarat, wrote around 1625 "daily intercourse between them [Muslims] and our nation is reasonable and largely like that in other places where there are Moors, the merchant with the merchant, the man-at-arms with his kind, the great men with their counterparts and so everyone with his equal," adding that the Dutch merchants were put somewhat higher on the scale than their nominal class justified: "our nation are (when coming to them) reasonably honoured, and treated well, [and] are held in greater respect and esteem than those of their own nation that are merchants." 79 Perhaps the many Dutchmen who established friendships

\footnotetext{
${ }^{75} \mathrm{NA}$, Instruction to Jan Tack going to Agra 12.5.1636, VOC 1119: 1081.

${ }^{76}$ NA, Letter Van Berchem to Governor General 16.8.1614, VOC 1057: 136.

${ }_{77}$ NA, Description Masulipatnam and Petapoli 18.7.1615, VOC 1059: 67-v.

78 David Cannadine, Ornamentalism: How the British Saw Their Empire (New York, 2001).

${ }^{79}$ Geleynssen, Remonstrantie, 59
} 
with Iranians and other great Muslims of Masulipatnam found it so attractive to "converse" with them precisely because, as De Haze put it, they "will not stoop for a small thing [and] keep a great state and splendour," 80 while most of the Portuguese the Dutch encountered were poor. An example of that association is given by the two VOC factors who around 1612 made their way over land from Petapoli to Pulicat, but judging that the land beyond the border of Golkonda was so infested with of robbers that it merited the qualification "thievish land of the Heathens," they decided to strip themselves but for a loincloth and pretend to be poor Portuguese who had lost a ship. ${ }^{81}$ And a few years later many Portuguese mestizos started coming over to the fortified VOC establishment at Pulicat because of the worsening conditions in San Thome and other Portuguese towns along the Coromandel coast.

The "conversation" between Dutchmen and Muslims on occasion took the form of conviviality and commensality, to use two terms well known from the anthropology of India. When the Dutch ambassador Van Twist was on his mission in Bijapur and had some harpists playing for him one night, the youngest, valiant, son of prime minister Mustafa Khan dropped in with his retinue, attracted by the music, and they had a friendly chat (seer vriendelijck van verscheijde saken discourerende).82 Generally speaking, Dutchmen were quite often invited to dinner by Muslims in India. ${ }^{83}$ But it must be noted that this was something of a one-way traffic. I have not found any examples of Muslims having a meal at a European's house, although there is the well-known example of the Persian assistant envoy to Thailand who left an elaborate description of the party he attended at the English lodge in Chennapatnam. ${ }^{84}$ The rules of halal and other considerations of purity apparently stood in the way of reciprocal dinners. As Geleynssen noted "they will not eat anything that has been killed or

${ }^{80}$ NA, Description Masulipatnam and Petapoli 18.7.1615, VOC 1059: 67v.

${ }^{81}$ NA, Letter Pulicat to Amsterdam 29.3.1616, VOC 1061: 177v.

82 NA, Diary of mission Van Twist to Bijapur sub dato 14.2.1637, VOC 1122: 482v. Van Twist did not mention explicitly any meals he may have had with Mustafa Khan during the long sessions at his house, but did mention a meal with Abdul-Karim, "governor" of a small town on the way.

${ }^{83}$ Examples of invitations of Dutchmen to dinner parties thrown by Muslims in Hyderabad and Masulipatnam: NA, Report of visit of Backer and De Bont to the Hyderabad factory 18.1.1663, VOC 1242: 858v (each served enough food for fifty people); François Martin, Mémoires de François Martin, Fondateur de Pondichéry (1665-1694), ed. A. Martineau (Paris, 1932) 2: 252 (with large quanitites of alcohol, and dancing girls); EIC consultations at Masulipatnam 31.12.1682 and 2.1.1683, Masulipatnam Consultations book of 1682-83. Records of Fort St. George (Madras, 1916) 25 (receiving a "civill entertainment").

${ }^{84}$ For two contrasting views of this visit, see Michael Pearson, The Indian Ocean (London, 2003) 37-40 and Alam and Subrahmanyam, Indo-Persian Travels, 161-3. 
cooked by a Christian or other person not of their faith," nor would they eat any European food products except (NB) wine..$^{85}$

Many Hindu and Jain groups, most noticeably the Brahmins and the Baniyas originating from Gujarat, however, had still stricter rules and would only eat with a certain set of people, which did not usually include Muslims and Christians. Abdur-Razzaq, the ambassador of the Timurid court in Khorasan to the capital of Vijayanagar in the fifteenth century, already noted the restricted perimeter of dining circles in India as well as his own exclusion from them. ${ }^{86}$ And when in the 1670s Timmi Nayak, who had raised himself from his low birth (toddy tapper) to general and protector of the heir to the throne of one of the successor states of Vijayanagar, ate with the Afghan commander Sharza Khan of Bijapur, it was rumoured that he must be turning Muslim. ${ }^{87}$ Wouter Schouten noted around the same time that Hindus/Jains of Gujarat (Guseratse Heydens) were strict vegetarians and "would not for anything in the world eat with Christians; they would (it appears) much rather die, yes [they will] not even touch them." I have not found any example of Europeans eating with Hindus, although they were sometimes invited to Hindu weddings. ${ }^{88}$

The latter author also inserted a long anthropologically inclined narrative of an occasion in the 1670s on which he was assailed by barechested village women on the Coromandel coast after drinking from a well: "we were soon disturbed and surrounded by a small number of Hindu women, who, like Amazonians, with sticks and whatever they could find came bravely at us. But their physicality initially consisted in smashing to pieces the pitchers and jugs from which we had drunk; after which they confronted us, by yelling loudly, clapping hands and funny actions, and called us names because we, (who were Christians and therefore in view of their excellent faith and disdain for us) being such unclean and unbelieving people, had spoiled and polluted their pots thus, for not only touching them but also drinking from them." Schouten ended his account of this clash with an exposition on the proper way of drinking (without putting the lips to the water jug as opposed to the European way of drinking which was considered beastly) together with some ironic remarks on the poor pots and how the laughter of the Dutchmen had exacerbated things to the

\footnotetext{
85 Geleynssen, Remonstrantie, 67.

86 Alam and Subrahmanyam, Indo-Persian Travels, 74-5.

87 John Fryer, A New Account of East India and Persia being Nine Years' Travels 1672-81, ed. William Crooke (London, 1909) 2: 41-2.

88 Wouter Schouten, Aanmercklijke voyagie gedaan door Wouter Schouten naar Oost-Indien (Amsterdam, 1676) a: 243. Compare Geleynssen, Remonstrantie, 69, 79, 84, 91, 94, 101, 117. For Dutchmen attending Hindu or Jain weddings see: W.H. Moreland ed. and trans. Relations of Golconda in the Early Seventeenth Century (London, 1931) 70; NA, Diary Van Twist sub dato 23.3.1637, VOC 1122: 499v.
} 
point that the whole village was in an uproar and continued to yell at the group of Dutchmen until they were without hearing distance. ${ }^{89}$

Some Dutchmen found it easier, though not necessarily more pleasant, to deal with Hindus than with Muslims. After the Dutch had apprehended a ship owned by merchants from Surat with connections at the Mughal court and the Dutch factor at Surat Pieter van den Broecke strove to content the angry nobles with an agreement for compensation as soon as possible, an angry correspondence with sarcastic overtones ensued between him and Marten IJsbrants at Pulicat, who thought that Van den Broecke had given in too much and too quickly. While IJsbrants wrote that "the crafty and venal Moors," would henceforth, "never miss an opportunity to pester and exhaust us," Van den Broecke wrote back that dealing with their craftiness was his daily work and that he had twelve years of experience with it, but also that "these Moors are not all detestable people, they do to an extent have a point, let them not suffer damage by us and they will leave us in peace, as long as we don't harm their goods, they will let us keep ours." Van den Broecke met the charge of his incompetence with the words: "your honour is sitting in a place where a good output is ensured and do not have to deal with Moors as much as we do, since our trade partly resides under them and we cannot do anything without them, your honour on the contrary, we imagine, deals much with Gentus, which people [volck] is easier to give orders to than the Muslims, your honours can force them to be reasonable, whereas we have to bring about everything through civility, without which the Company's excellent trade here would not exist but perish completely." 90

While there was thus much variation according to region, circumstance and individual inclination, ${ }^{91}$ a case in point being the antagonistic relations between Muslims and Dutchmen on the Fishery coast and the Malabar coast after the Dutch had taken over the Portuguese position there, ${ }^{92}$ we may nevertheless say that, as far as the Deccan and the Mughal domains are concerned, there was a pattern in the relations between Dutchmen and Indians. From the time of Heda who was part of the Islamicate elite of Bijapur to the time of Daniel Havart who lived in Hyderabad and Masulipatnam in the 1670s and '80s, translated Sa'adi's Bustan, and wrote about the gossip his good Muslim friends had told him,

\footnotetext{
${ }^{89}$ Schouten, Aanmercklijke voyagie, a: 182.

${ }^{90} \mathrm{NA}$, IJsbrants to Van den Broecke 14.4 and 7.7 and Van den Broecke to IJsbrants 27 and 31.5 and 5.9, VOC 1094: 77-8, 105-9 and VOC 1098: 451-3v.

91 On the title page of Baldaeus' famous treatise Naanwkeurige beschryvinge van Malabar en Choromandel...en het machtige eyland Ceylon (Amsterdam, 1672), is written "with addition of a Malabar [i.e. Tamil] vocabulary, very useful for all those inclined to interact with that people/national character [voor alle die het lust met dien landaard om te gaan]."

92 Stephen Frederic Dale, Islamic Society on the South Asian Frontier: the Mappilas of Malabar 1498-1922 (Oxford, 1980) 45; Bes, "Setupatis," 550-2.
} 


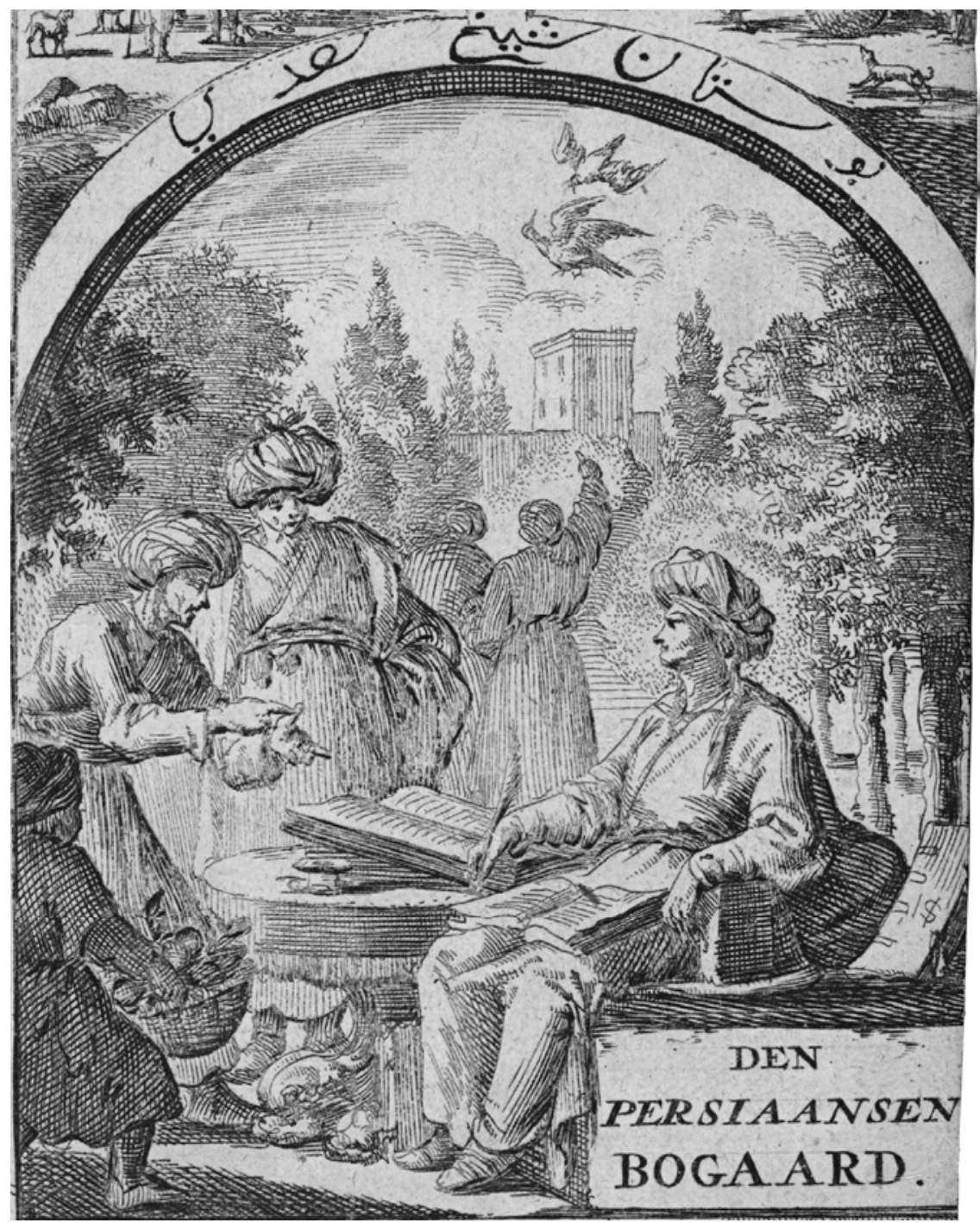

Detail of the frontispiece of Havart's translation of Sa'adi's Bustan. Courtesy Koninklijke Bibliotheek, catalogue number 895J66.

Dutchmen preferred the society of Muslims over that of Hindus in the Deccan and the Mughal domains. As Daniel Havart's father-in-law wrote from Hyderabad in 1682: "with the Moors it is rather easier to interact than with the Brahmins." 93 This means first of all that the views of these Dutchmen of events in India were more informed by Muslim "informants" than by others like the Brahmin "informants" who were so important in shaping the British view of India in the late eighteenth and early nineteenth

${ }^{93}$ NA, "Question points" answered by Jan van Nijendaal 3.5.1682, VOC 1378: 2038v-9. 
century ${ }^{94}$ Heda was in any case not the only example of a Dutchmen who developed his views in a dialogue with his Islamicate environment. The statement by Van den Broecke that Hindus are more timid than Muslims is also typically something that may have come out of conversation with Muslims; compare the rejection of Baniyas as messengers between soldiers by Sidi Qasim in Chapter 5 .

When an adventurer from Antwerp came to Masulipatnam in 1616 with nothing, not even clothes, Hans de Haze wrote that they had permitted him to stay at the factory for a while "for, otherwise, it would have been shameful for us if (since he requested it in God's name) he would have had to be maintained by the English or Moors." 95 There was apparently no question that he would be supported by the Hindus or the Portuguese in the town. From the various Hindu groups the Dutch expected not much more than commercial dealings and compliance with the minimal rules (right to self-defence, not lying, honouring treaties) that Grotius called natural law, from Muslims they expected a measure of participation in their ethical community, the circle of people to whom a more elaborate set of values (such as charity) applied. ${ }^{96}$ Although he praised the charity of the Jains and other Baniyas, Geleynssen did not link their charity to his experience as a Christian in India. About the Muslims of Gujarat, on the other hand, he wrote, "they like foreigners much, especially us and the English nation, are surprised that we come to their country from so far away, think and praise us to be very good soldiers, are very curious to hear the history of our country, also discuss other foreign histories, will dispute very little about their religion against ours nor discourse thereof, using amongst them a proverb kaun khub karte khub paega, which is to say: who does well, will obtain well, there is only one God who will reward everyone commensurate to his deeds." 97

This point about the bounds of ethics some Europeans felt they ran into in India is best illustrated with a quotation not from a Dutchman but from the famous French founder of Pondicherry and contemporary of Havart, François Martin. With him we find a positive and conscious hatred of Brahmins. It was mainly the perceived exclusivity of the Brahmins that

94 Havart mentions his Muslim friends as sources in a number of places (see the Introduction, the conclusion of this chapter and Chapter 6), as does Wouter Schouten, who talks of the opinion of "many sensible Muslims" about political events between the Deccan and the Mughal empire and the stories the Iranians told him of the lovely landscape and proud history of their fatherland (vaderlant) going back to Cyrus. Schouten, Aanmercklijke voyagie, a: 129, 231-7. For a further discussion of the role "informants" see Chapter 6.

${ }^{95}$ NA, Letter Hans de Haze at Masulipatnam to Bantam 5.6.1616, VOC 1063: 68v.

96 This concept is borrowed from Margalit, Ethics, 37-47, 141-6.

${ }_{97}$ Geleynssen, Remonstrantie, 59. The editor's transcription and Persian rendering of the saying are not correct, it should be read as Urdu. The manuscript has: con coeb carte coeb paijegae. NA, Collection Geleynssen de Jongh 28: 32. 
put him off: "One will perhaps be surprised that I throw myself, in seeming desperation, on this infamous tribe of the Brahmins, whenever I find occasion to do so ... Since they all possess cleverness (esprit) and all use that for the worst, they are the more dangerous for it; as for charity, that is only practised by the tribe with regard to those who belong to it, and even, in their religious dogmas, whatever they recommend there, is only in favour of the Brahmins." 98

All of which, however, is not to say that Dutchmen and Europeans in general advocated crossing the boundary between them and Muslims (though some did), nor that the boundary between Dutchmen and Muslims was not rigid in certain respects, such as the sexual. As far as the marriage market was concerned, the Dutch had to look toward certain Hindu groups (other than Brahmins and Baniyas) and the mestizo Portuguese. By whom Heda begot his daughter Marije Cornelis remains a well kept secret. ${ }^{99}$

SEXUAL BOUNDARIES - Sexual boundaries - perhaps the most important boundaries between groups from a biological perspective, since heterosexual boundaries may enhance the success of a group's genes (especially when putting stricter boundaries around the group's scarce ova than around its semen) - 100 largely ran along religious lines for Christians and Muslims in seventeenth-century India. Both Christianity and Islam had long traditions of codifications of restrictions on interfaith miscegenation. Although in the Bible Paul explicitly condoned marriages between Christians and non-Christians as lawful though second rate (1 Cor. 7.12-6), early Christian restrictions on intercourse with Jews first instituted by Roman emperor Constantius and enshrined in the Theodosian code inspired such later law manuals as that written by Joost de Damhouder from Flanders. This manual, first published in 1555 but long influential in the Netherlands, held that intercourse with non-Christians was approximate to sodomy, which again was in its main forms - also according to De Damhouder - punishable by death. ${ }^{101}$ In the case of Islam, restrictions on marriage to non-Muslims were already laid down in the Qur'an (2.221) with an explicit exception for marriages between Muslim men and "chaste

\footnotetext{
${ }^{98}$ Martin, Mémoires, 2: 241.

${ }^{99}$ Compare Van der Willigen, Les artistes de Harlem, 156.

100 I don't see how racial sexual boundaries would be qualitatively different from religious sexual boundaries in that respect as David Nirenberg argues (citing some anthropological literature) in an otherwise excellent exposition on sexual boundaries in medieval Spain which partly inspired the following discussion. David Nirenberg, Communities of Violence: Persecution of Minorities in the Middle Ages (Princeton, 1996) 149-51.

${ }_{101}$ Nirenberg, Communities, 129-31; D.J. Noordam, Riskante relaties; vijf eeunen homoseksualiteit in Nederland 1233-1733 (Hilversum, 1995) 31-4. By comparison to De Damhouder, Grotius' regulations for the Jews were mild, though in not in favour of intermarriage. Borschberg, "De Societate," 376.
} 
women among the people of the book [Christian, Jews and Sabeans]" (5.6). Our interest here, however, is in how these codified restrictions were operationalised in seventeenth-century India:

In Surat in the 1610s and '20s there were a number of marriages between Dutchmen and Armenian women, and there were also marriages between Dutchmen and (captured) Portuguese women as well as converted Hindu women. The Dutch perhaps went somewhat further in this respect than other Europeans (although the Portuguese were also renowned for their colony-building capacity as several Dutch observers noted above). In any case the Italian traveller Pietro Della Valle found their behaviour remarkable enough to note in his letter from Surat dated 1623 that Dutchmen would marry any woman as long as she was, or could be made, Christian. ${ }^{102}$ The situation Della Valle observed had not come about without deliberation, however. With a good sense of the sensitivity of the sexual boundary Wemmer van Berchem had, before embarking on his policy of turning Pulicat into a colony, made sure to gain permission from both the VOC Governor General in Bantam and the local administrators representing the king of Vijayanagar for Dutchmen to marry women "natural to the country" that would accept Christianity. ${ }^{103}$ William Hawkins, who stayed at the Mughal court from 1609 to 1611 as the first official representative of the English East India Company, showed himself more reserved when Jahangir promised to find him a wife "and he would promise mee she should turne Christian." Hawkins was not too keen and insisted on a wife of Christian birth, who was consequently found in the daughter of Mubarak Khan, an Armenian Christian, whom he did marry and take to his subsequent destinations. ${ }^{104}$ Though there was thus some divergence of opinion among European Christian men as to what

102 Kolff and Van Santen, "Inleiding," 18-31; Pietro Della Valle, The Travels of Pietro Della $V$ alle in India, ed. Edward Grey (London, 1892) 1:24.

103 NA, Letter Wemmer van Berchem to Governor General 16.8.1614, VOC 1057: 132v-3. From a statement of Nieuhoff, who passed trough Pulicat forty-five years later, it seems that the section of the population the Dutch (women as well as men according to Nieuhoff) intermarried with most were those calling themselves Cholas (Thiolen), Zee en lant-reize, 113. Tapan Raychaudhuri notes that he has not been able to trace any such marriages in the records, Jan Company in Coromandel 1605-1690: A Study in the Interrelations of European Commerce and Traditional Economies (The Hague, 1962) 203. The label Cholas may have applied to a broad class of people. Cholakulam and Chulavaru were reported as Telugu caste names in the 1881 census but do not seem to have been taken very seriously by the ethnographers of that era. K.S. Singh ed. People of India: National Series, vol. 8 (Oxford, 1996) 311, 315; R.C. Temple, review of edition of The Book of Duarte Barbosa by M. Longworth Dames, The Geographical Journal 59 (1922) 299-301. There were also "Chuliya” Muslims (Dutch: T'chulias Mooren) in southern Coromandel. NA, Resolution Masulipatnam 29.6.1615, VOC 1061: 191; Yule and Burnell, Hobson-Jobson, s.v. Choolia.

104 William Hawkins, "Relations of the Occurrents Which Happened in the Time of His Residence in India," in The Hawkins' Voyages, ed. Clements R. Markham (London, 1878) 389442 , there $404-5$. 
constituted a properly Christian wife (born Christian or turned Christian), the adjective Christian was the most important marker from the range of possible markers of suitability.

This principle appeared very natural to Jahangir, as another interesting case demonstrates. Jahangir had given the order to have his brother's children raised as Christians in the period that John Hawkins was at the court. Several stories seem to have circulated as to why Jahangir gave this order, but what is relevant here is that some years on, Jahangir and his nephews seem to have thought that being raised Christian entitled them to have, as vicar Edward Terry, who accompanied the well-known English embassy of Thomas Roe in the years 1616 to 1618, put it, "wives out of Christendome." But when Jahangir's nephews did ask for Portuguese wives, their request was turned down, or not immediately met by the Jesuits present in the imperial capital Agra, upon which the nephews returned to Islam. Terry wrote that after this fiasco (the failed royal conversion) the Portuguese added to the speculations about Jahangir's motives for the initial conversion this one, that it had been Jahangir's intention all along to have his nephews ask for European wives and then to take whichever he liked for himself (which inference Roe seems to take for a fact). ${ }^{105}$

Muslim men at this time were, on the whole, even less strict about the women they would marry than Dutchmen in India, as the case of Jahangir - born of a Rajput princess — demonstrates. There are many possible explanations for this - e.g. the possibility for Muslim men to marry more than one woman, or the example of Muhammad who had a wife who was and remained Christian — but it is doubtful that a lesser sensibility to religious boundaries was one of them, because in the case of Muslim women, Muslims in India showed themselves to be as strict as or even more strict than Europeans were about the religio-sexual boundary.

Europeans in India were very protective of their womenfolk, or in fact of any person liable to penetration. It was well known that the Portuguese kept their women effectively in parda, something that various travellers from European countries other than Portugal in the late sixteenth and early seventeenth century commented on. ${ }^{106}$ The Dutch did not screen their women off to the same extent, but were similarly concerned about

105 Hawkins, "Relations," 438; Roe, Embassy, 198, 315-6. Edward Terry, A Voyage to EastIndia (London, [1655]) 447-8. NB: Terry's reflections referred to here and below are not to be found in the 1625 edition, apparently published by Purchas without Terry's consent, on which the modern edition is based. See William Foster's introduction to that edition in idem ed. Early Travels in India 1583-1619 (Oxford, 1921).

106 For examples see Timothy Coates, "State-Sponsored Female Colonization in the Estado da India ca. 1550-1750," in Sanjay Subrahmanyam ed. Sinners and Saints: The Successors of Vasco da Gama (Delhi, 1998) 40-56, there 50-1. Ernst van den Boogaart, Het verbeven en verdorven Azië; woord en beeld in het Itinerario en de Icones van Jan Huygen van Linschoten (Amsterdam/Leiden, 2000) 68-71. 
sexual boundaries. In 1610 Jan van Wesick wrote to Gerrit Gerritsz who was being sheltered by Heda in Bijapur: "keep God and His fear before your eyes (without having yourself screwed from behind [te laeten vereersen] by the sodomitic Muslims so that you will not give your friends heartache from hearing the contrary)." 107 It is also possible that the manuscript of the letter reads "...without letting yourself be taken in [vereensen] by the sodomitic Muslims...," or that the original had vereensen but the copyist made it vereersen. ${ }^{108}$ In any case Van Wesick was worried (and perhaps the copyist even more so) that young Gerrit would lend either his eers or his ears to people across a religio-sexual boundary or a sexualised religious boundary (and as was noted in the Introduction the idea that Indian Muslims were generally more open to homosexual activity than most Europeans was not without empirical foundation). The warning seems to have fallen on deaf ears or to have had a contrary effect, because, as was already noted, Gerritsz ignored Van Wesick's advice to return to VOC service as soon as possible and instead took up employment with Yaqut Khan.

Returning to the procreative boundary, an interesting example of the sort of high-level tussle that the concern of both Dutch Christians and Indian Muslims for their womenfolk could lead to is the case of a woman of Masulipatnam who tried to rid herself of her Dutch husband while she was on a family visit to her home town with her husband in 1615. On August $10^{\text {th }}$ the VOC President for Coromandel, in council at Petapoli not far from Masulipatnam, resolved the following:

Further, as we understand today from a letter from Masulipatnam, the wife of Renier Willemsen Bedast, an ensign in the fortress Geldria, formerly of the Jewish faith and married to the aforesaid Renier of her free will and having taken the Christian baptism and religion on her grave request, has yesterday stealthily betaken herself, with her brother and mother, from our lodge in Masulipatnam to the bancksael [town court/custom house] ${ }^{109}$, where she complained to the governor I'timad Khan that she had been married to the aforesaid ensign and made Christian by force and against her will at the hands of Mr. van Berchem, for which her

107 NA, Letter (marked copie) Jan van Wesick at Masulipatnam to Gerrit Gerritsz in Bijapur 27.10.1610, VOC 1055: n.f.

108 The curve indicating the putative $\mathrm{r}$ or $\mathrm{n}$ is so slight as to make this question quite impossible to decide, although the curve indicating the $\mathrm{r}$ in the word eersaeme in the same hand on the previous page is exactly the same. However, vereensen is in the Woordenboek der Nederlandsche Taal and vereersen is not (but then again the list of derivations from the word aars is there cut short by "etc.").

109 The word is used by Europeans in India to indicate the place to which they had to bring their goods for clearance, but is of uncertain etymology. It was usually adjacent to the town's court of justice, as will be seen for the case of Chennapatnam in Chapter 3. A later report on the matter of Bedast's ex-wife speaks of her betaking herself to the "Muslim jusditia" of the city. Yule and Burnell, Hobson-Jobson, s.v. bankshall; NA, Letter Samuel Kindt at Masulipatnam to Amsterdam 15.4.1616, VOC 1061: 161. 
aforesaid brother and mother gravely and loudly requested the governor for remission of the wedlock of the aforesaid woman since they said they were all Moorish and suggested the aforesaid woman be given in marriage to a Moor of the governor's choosing, who having, on that account, put the same woman into the hands of the Moors, has declared to our people in Masulipatnam to want to keep her for now, until [there would be] a response on his letter, that he would write to the king concerning this case. Which being thoroughly considered by Mr. President and council, seeing that the same was at odds with the Christian faith and our reputation here on this coast among the blacks, it is resolved that Mr. [President] Samuel Kindt, with the chief merchants Raphael Olijva and Willem den Dorst will depart tomorrow as speedily as possible for Masulipatnam to mind the case there.

The passage evokes many questions, which are only partly resolved by subsequent notes on the matter. There seems to be no doubt that the woman and her family had once been Jewish, but did she claim to have converted to Islam (or "Mohammedan law," as Kindt put it later) before her marriage of after it? In the first case the marriage would have been illegal and Bedast would have had to pass for dishonest among the population of Masulipatnam, as he apparently did. In the second case the matter would be more complex. The Dutch understood very well that the time of conversion was a crucial point and resolved to write to the sultan, "by presenting what his land and kingdom could expect out of this, since our people will and shall not suffer such an aggravation, since she had not been a Moorish but a Jewish daughter and married of her free will and taken the Christian faith." The Dutch further resolved to halt their trade until the matter was resolved, but half a year later the situation remained unchanged. ${ }^{110}$

A case of the 1630 s illustrates the same principle, namely, that a Muslim woman should be left in the care of Muslims. On his embassy to Bijapur, Johan van Twist encountered a Muslim Dutchman, formerly known as Pieter Sachariassen, then as Ibrahim Agha. Pieter/Ibrahim had left the Netherlands as skipper's boy at the age of 12 in 1620 and been captured and taken to Bijapur the next year with three other Dutchmen. When the Dutch ambassador came to town fifteen years later, Pieter/Ibrahim asked him if he could ask the sultan for either a higher wage or permission to go to Batavia with the Dutch party. At first Van Twist found it unwise to speak for a renegade, "from the perspective of [the Company's] honour," the more so because he had information that Pieter/Ibrahim was not intent on abandoning Islam or to leave his wife and family. So Van Twist told him that he would not solicit for him, "because he has wilfully and intentionally forsaken his Saviour and taken the Mohammedan religion, but if he had still been a Christian, I would not only

110 NA, Petapoli resolution 10.8.1615 and letter Samuel Kindt to Amsterdam 15.4.1616, VOC 1061: 161, 199-v. 
want to procure his freedom but also to take him along to the fleet." Three weeks later, however, Van Twist had come around for some reason and asked the chief minister Mustafa Khan for permission to take Pieter/Ibrahim along to Batavia, to which the minister answered that Ibrahim was free to stay or go as he pleased.

Pieter/Ibrahim was, however, never to leave India with the ambassador, because a few days later the question of his family came to complicate the matter. The ambassador seems to have known that this would be a difficult point and asked not so much that Pieter/Ibrahim be allowed to take his family to Batavia, but only that his family be taken to Vengurla until Pieter/Ibrahim were to return from Batavia, "promising that we would properly care for the same [family] and not ship it with us to Batavia." Nevertheless Mustafa Khan answered: "that their law did in no way allow any Moorish woman to be transported to other countries. If he in person desired to go with us his highness [Mustafa Khan] would permit it, but concerning the woman his majesty himself should speak." It was then agreed on that Ibrahim would accompany the ambassador to the coast and speak to the general of the Dutch fleet there and return later with the Dutch surgeon requested by Mustafa Khan, and that Mustafa Khan would shelter Ibrahim's wife and children in his court in the meantime. It must be noted that Mustafa Khan had been very keen to have one or more Dutchmen remain at his court as a surety for the treaty he had entered into with the ambassador, which might partly explain his reluctance to release Ibrahim's family. Nevertheless his appeal to Muslim law was made with little hesitation (allowing only for the possibility of a royal exemption) and repeated twice. ${ }^{111}$

Women were, however, not always obstacles on the boundary between Dutchmen and Muslims in India. When in 1683 the Dutch chief factor of Masulipatnam instructed a junior factor taking up residence in Hyderabad about the dos and don'ts of that place, he wrote that as long as his wife kept the curtains of her palanquin down while on the road in the Hyderabad area, bringing her was unobjectionable and might even "enhance [your] reputation, because the Moors use to pay great homage to the female sex in regard to their husbands." 112 This mechanism, but in the reverse direction, was clearly demonstrated by the Dutch in 1661 when they took Bari Sahiba Khadija Sultana, queen mother of Bijapur and sister of the ruling sultan of Golkonda, across to Mocha to perform the hajj. Her parda was scrupulously maintained through a tent on the beach, a cotton screen from there to the sloop and a tent on board the ship that was to take her across the Indian Ocean, and the Dutch went out of their way to please her

111 NA, Diary of embassy by Van Twist sub datis 20.2, 12.3 and 16.3, VOC 1122: 485v-6, 493v, 496-7.

112 NA, Instruction by Willem Hartsinck to Michiel Janszoon 12.1.1683, 1387: 1378. 


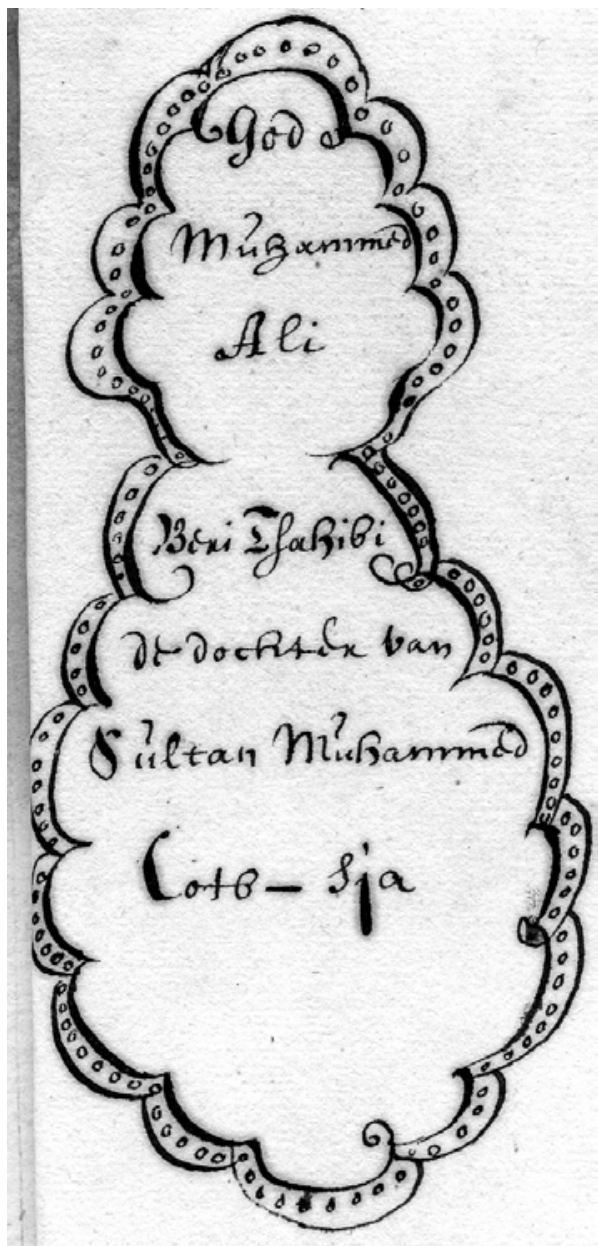

on this trip as well as on her later trip to Persia. Although she was not going to the non-Muslim lands forbidden according to Mustafa Khan, she was going on a Dutch ship, and that to her full contentment judging by the letter through which she expressed, upon her safe return, a "profound friendship" and "very great affection and fondness" for the Dutch Governor General in Batavia, addressing him with various beautiful titles (to be discussed below). ${ }^{113}$

Dutch translation of the seal of "Bari Sahiba, the daughter of Sultan Muhammad Qutb Shah." Courtesy National Archives, The Hague, VOC 1241: 335.

boundary between Dutchmen and Muslims was easily bridged among the higher classes of both. At the bottom of the class hierarchy, however, we see more actual boundary crossings. The skipper, for instance, who took Khadija Sultana across to the Red Sea appears to have converted to Islam somewhere on the trip and disappeared from the VOC records. ${ }^{114}$ The absconding of the badly paid Dutch soldiers to take up service with other European organisations or with Indian states was a constant headache for the VOC factors in the subcontinent.

The Sachariassen episode shows, however, that Christianity remained a necessary condition for being Dutch in the eyes of all parties. Van Twist turned Pieter Sachariassen down in the first instance and

113 Johan Nieuhoff, Zee en lant-reize, 77; M.A. Nayeem, External Relations of the Bijapur Kingdom (Hyderabad, 1974) 256; NA, Translated letter Bari Sahiba to VOC, 18.10.1070 [sic; 1073?]/25.5.1663, VOC 1241: 335.

114 Nieuhoff, Zee en lant-reize, 77. 
Mustafa Khan wondered whether upon reaching Batavia he would not be punished for having voluntarily left his religion and undergoing circumcision (Islamic jurisprudence generally regarded apostasy as punishable by death, except when the conversion had been forced and the apostate had remained faithful at heart, but perhaps Mustafa Khan also had in mind the practices of the inquisition at Goa, about which more in the next section). ${ }^{115}$ In the end Sachariassen was stuck with his new life in his new hometown and that was the case for almost all European converts to Islam in India. In a peace treaty concluded between Jahangir and the Portuguese in 1615, the principle that converts relinquished their original group was acknowledged by excepting from the stipulated exchange of captives those that had taken the religion of the other side. ${ }^{116}$ An exchange, somewhat comparable to that about Pieter Sachariassen, but forty years later and taking place at the court of Ekoji, who governed part of the Coromandel coast for Bijapur, had a somewhat puzzling outcome. The Dutch had not wanted to bring up the matter of their defectors with Ekoji himself, "not to give offence to the Moors [of Ekoji's entourage], since three [of the defectors] have already taken that religion," but broached it with some of his ministers, who promised to return the other three of the Dutchmen who were with Ekoji's troops, and had not been circumcised. The three, however, begged in tears not to have to go back to VOC service, afraid of punishment of which they cited some examples. Finally they asked of the city governor, who was in charge of the transfer, to be released with permission to make their way to the English! This was granted by the governor, who apparently deemed it a suitable compromise that the three should serve under a Christian regime, be it not the Dutch regime that they feared. ${ }^{117}$

Christianity was, however, not a sufficient condition for Dutchness or for unconditional trust on the part of the VOC personnel. The spatial layout of the colony at Pulicat illustrates this point very well. Inside the fortress were the Dutch factors, and beside it the other Christians, black and mestizo, who were part of the VOC colony but not part of the Dutch community, and still farther removed was the (largely) Hindu population of the town. Moreover, the mestizos with their Portuguese names and connections, remained suspect. When their numbers grew in 1615, the Pulicat council contemplated some sort of secular conversion of this group to the Dutch cause. They were to "commit themselves to remain forever

115 Ibidem; S.P. Sangar, Crime and Punishment in Mughal India (Delhi, 1967) 27. The inquisition was instituted at Goa in 1560. Délio de Mendonça, Conversions and Citizenry: Goa under Portugal 1510-1610 (Delhi, 2002) 317-21.

116 Danvers, Portuguese Records, 25-6.

117 NA, Report on mission to Ekoji by Thomas van Rhee and Pieter Outshoorn van Sonnevelt 6.1.1677, VOC 1329: 1174-6v. 
under the flag of His Princely Excellency [the red, white and blue flag of the United Provinces] and the governor of the fortress of Geldria in all occasions for which their service might be commanded."118 Many of them were hired to serve the fortress as soldiers in 1615, but when a Dutchman called Pieter Polack, shortly after he joined the Pulicat force - having turned up out of nowhere and claiming he had served with the Ottoman janissaries - tried to defect to the Portuguese (but was delivered back to the Dutch by a local raja), there was a major investigation in which a Castilian who had been serving at the fortress was questioned (and threatened with torture) amid suspicions that there was a ring of soldiers was conspiring to defect to the Portuguese. Though the suspicion was on all soldiers, either "Dutch or black Christians," it seems that it fell mainly on those with Iberian-sounding names. Over the next year the council decided not to hire any more defectors from the Portuguese for the troops of the fortress, but to keep attracting them with a temporary stipend (as was noted above) and send the bachelors off to be employed elsewhere, on VOC ships etc. ${ }^{119}$

\section{EXPLAINING EUROPEAN BOUNDARIES}

The hostility between the Dutch and the Spanish/Portuguese was natural and self-evident to Heda. In his first letter to Masulipatnam Heda wrote that the Portuguese were saying that peace had been reached between Spain and the Netherlands, "but I can hardly believe it." 120 To what extent were this rift — so self-evident to Heda - and other rifts between European nations understood and exploited by Indians? A question that becomes crucial if we consider that such an understanding of European rifts would also reflect on Indian society.

Not long after they had first established factories in the Mughal empire at Surat (1606) and in Golkonda at Masulipatnam (1605), the Dutch became very unpopular in both Islamicate states. In Masulipatnam they were blamed for the taking of two ships of local merchants by the Portuguese in 1608. Not only were the hawaldar (farmer of the area's revenues) and the shabbandar (king's representative to oversee the harbour) giving them trouble, the townspeople, "have pelted us ... with stones from the windows a number of times." 121 That, however, was not because they

118 NA, Pulicat Resolution 26.9.1615, VOC 1061: 204 (italics added). In the comparable situation of the English in Bombay, Henry Gary tried to oblige the Roman Catholics on the island to take an oath denying the jurisdiction of the Pope over them (see Chapter 5).

119 NA, Pulicat Resolutions 21.9, 26.9, 3.12.1615 and 8.3, 1.5.1616, VOC 1061: 194, 202v-4, 207, 212v; Interogatorium of Bastiaen Couteres 29.12.1615, VOC 1062: 67-v.

120 NA, Letter Heda to Masulipatnam 16.5.1610, VOC 1055: 83-5.

121 NA, Letter Masulipatnam to Amsterdam May 1608, VOC 1055: n.f. 
were thought to be identical to the Portuguese, but because they were known to have ruffled the Portuguese, and the local inhabitants thought they would bear the brunt of retaliation by the Portuguese whom they feared. The shabbandar told the Dutch in a meeting in the customs depot "in the presence of many Moors" that they should leave, but if they were to stay they should bring some people and guns on land to defend themselves if the Portuguese came "because they would have enough on their hands protecting their women and children and would not fight for us." 122 Meanwhile in the north the Portuguese set the governor of Surat as well as the population of that region against the first Dutch factor in the Mughal empire, or so the latter thought, and in his fear of the terrible deaths he might die at the hands of the locals he apparently killed himself by gunshot. ${ }^{123}$

By 1610 the hostility toward the Dutch in the Golkonda ports had turned into "indignation." The Dutch were said to be the ruin of the country as they were not bringing any spices or other goods, while the Portuguese were not bringing any either as they used to, telling the inhabitants they were boycotting the place precisely because of the presence of the Dutch factors. Golkonda Muslims, both in Masulipatnam and at the court in Hyderabad, were telling Jan van Wesick that the Dutch, through such actions as burning a captured Portuguese ship at the dock in Masulipatnam, were turning the Portuguese, "who are close to them [Golkonda Muslims]," against them. ${ }^{124}$ In short, the Dutch had disturbed the uneasy equilibrium that had been established between the Indian states and the Portuguese in the century of Portuguese dominance of the seas.

To mend relations with the Golkonda elite, Wemmer van Berchem betook himself to the court at Hyderabad in 1612. There, the discontent of the merchants at Masulipatnam echoed loudly. When the news reached that the Portuguese had plundered the VOC factory at Pulicat, a great buzz went up "among the Moors, in esteem of the Portuguese and disparaging us." Meanwhile, Portuguese envoys were working hard to have the Dutch ejected from Golkonda. Among the tall tales Wemmer van Berchem was spreading in Amsterdam years later was also one in which he had actually tried to stab the Portuguese envoy who vied with him in front of the sultan. The sultan berated him for acting in this way in a place "where all were to remain standing in devotion without tumult." But after Van Berchem made his point that he would not stand there and let the Prince of Orange be offended and that the Portuguese were tyrannising foreign nations and he

122 NA, Letter Masulipatnam to Bantam 31.5.1608, VOC 1055: n.f.

${ }_{123}$ H. Terpstra, De opkomst der Westerkwartieren van de Oost-Indische Compagnie (The Hague, 1918) 22-5.

124 NA, Letter Nizampatam to Tengapatnam 1.2.1610, VOC 1055: n.f.; letter Masulipatnam to Bantam 15.6.1610, 1055: n.f. 
would pursue them to his last breath etc., the sultan is supposed to have said that in that case Van Berchem should "cut them like the dust or the grass," and he would so be pleased. The original report by Van Berchem, which does not mention a stabbing incident, has it that the sultan indicated with a sign of his hand that the Dutch should cut the throat of any Portuguese they engaged if they did not want to have them complain about the Dutch at court in the future. Be that as it may, a large faction at the court was inclined to accept the Portuguese offer of a substantial payment for having the Dutch denied access to Masulipatnam, although another faction, consisting mainly in the person of the peshwa Mir Muhammad Mu'min Astrabadi, was more favourably inclined to the Dutch. While the latter saved the Dutch from complete expulsion, the result of the mission was meagre for the VOC. ${ }^{125}$

Despite frequent unsuccesses such as the above, alliances with local kings and groups played a very important role in VOC policy against the Portuguese in Asia, as did to some lesser extent the ideal of establishing alliances with the Amerindian co-sufferers of Spanish oppression in the West. ${ }^{126}$ After the conclusion of the Twelve Year Truce treaty, which was exceedingly vague on the East Indies, the Dutch reserved, in a side-letter to the truce signed by the French and English envoys to the negotiations as well as in a secret instruction sent to the VOC factories, the right to defend the VOC interests as well as those of the "kings, princes, peoples and citizens of the Indies, that are in friendship or commerce with those [VOC employees] of our side, or should engage in such hereafter, or those with whom more comprehensive alliances, agreements and contracts have been made." It should not have come as a surprise, then, that the twelve year cease-fire, which in Europe was observed to the day, broke down progressively in Asia and was declared to be at an end for that part of the world by the Dutch States General in 1614. Wemmer van Berchem considered the truce a dead letter even before he had officially announced it (because "those of Spain seek not but to cheat us") and presented it as such at the court of Golkonda, saying that though it supposedly applied also to "all kings and princes of East India our allied friends," the "hostile proceedings of the Castilians from the Manilas [sic] in the Moluccos and [of] the Portuguese in Ceylon... Pulicat, Arakan and other places against the kings of India and our people," had effectively broken it. ${ }^{127}$

125 Wassenaer, Historisch verhael, 13: 28v-9v; NA, Letter Wemmer van Berchem at Masulipatnam to Bantam August 1613, VOC 1056: 146-9v.

126 For the latter see Benjamin Schmidt, "The Hope of the Netherlands: Menasseh Ben Israel and the Dutch Idea of America," in Paolo Bernardini and Norman Fiering eds. The Jews and the Expansion of Europe to the West 1450 to 1800 (New York, 2001) 87-106, there 93-5.

127 Ibidem and Van Dijk, Wemmer van Berchem, 1-5 and 74-5 (text of resolution of the Company directors 5.9.1609); Israel, Dutch Republic, 404, 408. 
The Dutch saw the Indies as a chess board with pro-Portuguese pieces and pro-Dutch pieces, and closely monitored who was for them and who against them. As has been seen above, Heda was well aware of the enmity between the Portuguese and the Mappilla Muslims of Malabar, noting explicitly that the "Malabarians" were deadly enemies of the Portuguese. ${ }^{128}$ Neither had this fact escaped other Dutchmen. When earlier in 1610 the VOC factors at Masulipatnam had heard that the Portuguese were preparing a great fleet at Goa they had asked their friends in Masulipatnam to write to the ambassador of the Adil Shah and other contacts in Goa to explain the situation, upon which the ambassador answered to "our very great friend" at Masulipatnam (probably Mir Kamal ud-Din) ${ }^{129}$ how "the Malabarians have captured diverse ships of the Portuguese....and struck dead all that was Portuguese on them, upon which the Portuguese have sent their armada twice, which instead of chasing the Malabarians from the coast has lost approximately 40 ships in fighting, about which there is a great scare in Goa, whither all that is able-bodied has been summoned." 130 The Dutch also kept taps on the struggle between Malik Ambar of Ahmadnagar and Portuguese. Heda reported on this frequently because he thought it was a good opportunity as was already noted. ${ }^{131}$

While the antagonisms between Malik Ambar and the Mappillas and the Portuguese were seen in these Dutch sources as given and to be put to advantage, some other courts were considered to be unstable in their preference for either one of the European nations. Heda thought that the Portuguese were busying themselves in corrupting the kings and bringing them to enmity towards the Dutch: "this Indian nation is not to be trusted in any way and who gives the most is the best [to them]." 132 The court of the Aravidu dynasty, successors to the great kings of Vijayanagar, then seated at Vellore, was deemed especially prone to the machinations of the Portuguese. This led Wemmer van Berchem to the following comparison of the two evils in explaining why the court had not followed up on an agreement with the Dutch for some action against the Portuguese: "the falseness and knavish deceit of this nation is not to be plumbed by any

128 NA, Letter Heda to Van Berchem at Masulipatnam 20.10.1612, VOC 1056: 133-4.

129 Who was apparently known to be a friend of the Dutch also at court, which forbade him from communicating with the Dutch and the English for a while. He also corresponded with Heda. NA, Letter Pulicat to Bantam 20.2.1614 and Letter Heda to Masulipatnam, VOC 1056: 232v, 237v.

130 NA, Masulipatnam to Bantam 15.6.1610, VOC 1055: n.f.

131 NA, Letter Heda to Masulipatnam 18.4.1613, VOC 1056: 136; Letter Masulipatnam to Bantam August 1613, VOC 1056: 158v.

132 NA, Letter Heda to Masulipatnam18.4.1613, VOC 1056: 136v. 
Christian person [bij geennige chrijsten menschen], although the nature [aert] and uncivil procedures of the Portuguese are sufficiently known to them." 133

Yet despite on occasion rating the trustworthiness of Indians even lower than that of the Portuguese, the Dutch kept trying to build alliances with the former against the latter by trying to avoid the things that had made the Portuguese unpopular at some courts and emphasising how different they thought themselves to be from the Portuguese. ${ }^{134}$ In Pulicat the VOC factors decided to stall the baptism of prospective converts to Christianity (but not of children of people converted in the days of the Portuguese), in order "not to give rise to annoyance among the Gentu nation," as they understood from some local lords that the Portuguese practice of converting Hindus and drawing them to Christianity and thus to themselves was not appreciated at the royal court. ${ }^{135}$ This conscious effort to do things differently from the Iberians (and refrain from their way of missionising) had also been formulated by Grotius thus:

The Indian peoples must be shown what it means to be a Christian, in order that they may not believe all Christians to be as the Spaniards are. Let those peoples look upon religion stripped of false symbols, commerce devoid of fraud, arms unattended by injuries. Let them marvel at the faith which forbids that even infidels should be neglected. In achieving these ends we shall be preparing men for God. ${ }^{136}$

In 1614 Heda reported that the Portuguese were now engaged in a proxy war with the Mughal emperor and had landed at Cambay, burning many villages and robbing many inhabitants, "so that all citizens of this land wish much for our nation."137 Indeed, it appears that that year signified something of a turning point in the relation between the Dutch and the Muslim elites of the Mughal empire and the Deccan sultanates, which seem to have started to realise that the Dutch could be a useful ally against the Portuguese. "In proximity to" the emperor, the subadar (provincial governor) of Gujarat Muqarab Khan wrote a letter, addressed to "the captain general of the Hollanders, the best [captain general] of all of Christendom," saying that the emperor was very annoyed with the Portuguese and the Dutch should send ships thither speedily, upon which the Mughals on their behalf promised "to drive all Portuguese from our lands and give you the best place." That notwithstanding, in 1615 the Portuguese managed to conclude the peace treaty with Jahangir already mentioned above, in which it was stipulated that the Mughals would not have any commercial relations with the Dutch and English "thieves" nor

\footnotetext{
133 NA, Letter Masulipatnam to Bantam August 1613, VOC 1056: 151v; Raychaudhuri, Jan Company, 20-1.

${ }^{134}$ Contrast Alam and Subrahmanyam, Indo-Persian Travels, 351.

135 NA, Pulicat resolution 13.11.1615, VOC 1061: 206v.

136 De Jure Praedae, quoted in Van Ittersum, Profit and Principle, 81.

${ }^{137}$ NA, Letter Heda to Masulipatnam 22.1.1614, VOC 1057: 169-v.
} 
shelter them or the Malabar "pirates" in their ports, although the English, then represented at the court by Roe, would be allowed to upload goods to the empire via Masulipatnam. ${ }^{138}$ But Malik Ambar, who had also entered into a peace treaty with the Portuguese two months earlier, was nevertheless keen to hear from some Dutchmen passing through his camp about "the sea war between the Portuguese, us [Dutch] and the English," while Ambar's right hand Mir Abdul-Fath offered the VOC a base at Rajapur, "a very suitable place, according to him, to harm the Portuguese on both land and sea."139 And even from the harbours of Golkonda, the VOC factors felt able to note by 1615 that "among all the foreigners here we are the best esteemed, although that is still bad enough since if they can do something to our disadvantage they will not neglect to do it." 140

With the capital of the Estado da India at its doorstep, the court at Bijapur, even more than Golkonda and the Mughal empire, was hesitant to displease the Portuguese by making deals with the Dutch and English. The main reason seems to have been the fear that the state would be cut off from the sea, which not only was the route to the pilgrimage sites in the Hijaz as well as to Iran, whence part of the elite of the sultanate came, but also provided access to raw materials, textiles, spices and the exotic luxury goods that were as much in demand in Bijapur and Golkonda as they were in Europe at the time and necessary to keep the segment of the gift-giving system that revolved around precious rarities (tohfa) going. ${ }^{141}$ Although still in Heda's time Venetians managed to get fine crystal glassware to Bijapur by the land route, the Portuguese had been the main providers of many foreign wares for some time in Bijapur and Golkonda, which is why their staying away was felt so strongly at Masulipatnam. At Bijapur, the right to establish a VOC factory was granted quite quickly because of Heda's connections, but that was not before the nawab had found some objections "on account of the alliance that this king has had since many years with the Portuguese," and the Dutchmen had promised to provide the country

138 NA, Translated letter Muqarab Khan to Masulipatnam 14.9.1023/18.10.1614, VOC 1059: 112; Danvers, Portuguese Records, 25-6.

139 Ravesteijn, "Journael," in Terpstra, Opkomst der Westerkwartieren, 176-7.

140 NA, Description of Masulipatnam and Petapoli 18.7.1615, VOC 1059: 65.

${ }^{141}$ In 1613 Wemmer van Berchem shortlisted the luxury goods from Europe that the sultan of Golkonda and his mir jumla complained were no longer arriving and Heda commented on the arrival of a ship with Chinese wares at Goa, which had not happened for a few years: "yesterday our king ordered the purchase of some beautiful objects for 25,000 hons, because there has been a great desire here for Chinese wares for 3 or 4 years." Johan van Twist defined tohfa as rarity ("tofas ofte vreemdigheeden" and "tofas ofte rariteijten"). NA, Letters Van Berchem to Bantam August 1613, VOC 1056: 146-9v; Heda to Masulipatnam 23.5.1613, VOC 1056: 137v; Diary Van Twist sub dato 15.2.1637, VOC 1122: 483. Compare Raychaudhuri, Jan Company, 25-7. 
plentifully with goods from the Netherlands as well as Asia, and that the sultan and the nawab would have first choice. ${ }^{142}$

Skipping to the mid-1630s, the setting of the next chapter, we find the Dutchman Johan van Twist in Bijapur in order to establish an alliance between the VOC and Bijapur against the Portuguese at Goa. The idea was that the Dutch would blockade Goa and attack it from the sea and the sultan's troops would attack it on land. When Van Twist explained his mission to the Ali Rasa thanadar of a small place on the way to the capital, Rasa was very amused and said that Van Twist's coming would "not only be most pleasing to his majesty but also to his subjects in general." Pir Muhammad, governor of Dabhol, wrote a few days later that he loved the Hollandish nation and was convinced they would not rest until they were complete masters of "our enemies." Also still on the way Van Twist received a letter of adherence from an envoy of the sultan of Malindi on the African coast who had, he wrote, just concluded an anti-Portuguese pact with the sultan of Bijapur. ${ }^{143}$ Despite these early signs of support for his cause, Van Twist had to take a considerable amount of trouble to alleviate the hesitance on the part of his main negotiating partner, the first minister Mustafa Khan, an Iranian, and to convince him that the Dutch were completely different from the Portuguese, but that too with some success it seems.

Van Twist took every opportunity to point out how deep the rift between the Dutch and the Iberians ran. When Mustafa Khan wondered whether Pieter Sachariassen might not be punished upon reaching Batavia, Van Twist answered "that with us one will not find restraint of conscience [consientie dwanck], but everyone may live in his faith provided that they remain always in obedience to their subaltern authorities and the bounds of an undisturbing life. With the Portuguese or inquisition on the other hand, when one forsakes his religion, he is mercilessly punished by fire, for which scrutiny and restraint of conscience, as running counter to our conscience, we started the war against the said Portuguese in the first place." The idea that the Dutch war on the Portuguese in Asia was an extension of the Dutch war for liberation, originally directed against the Spanish, is here clearly articulated at a Muslim court with the suggestion that there were certain affinities between Dutch Protestants and Indian Muslims in respect of religious matters. ${ }^{144}$

${ }^{142}$ NA, Letter Heda to Masulipatnam 30.11.1615, VOC 1062: 31-2; NA, Letter Wolff from Shahpur to Samuel Kindt 28.11.1615, VOC 1062: n.f.

143 Van Twist, Diary sub dato 5.1.1637 and translated letter of Pir Muhammad to the commander of the Dutch fleet before Goa 19.8.1046/16.1.1637 and translated letter of Ramazan ambassador of Sultan Muhammad of Malindi to Van Twist 28.8.1046/25.1.1637, VOC 1122: 470, 472-v, 477. For the complicated relationship between the Portuguese and Malindi, see Pearson, Indian Ocean, 140.

${ }^{144}$ NA, Daily record of mission to Bijapur sub dato 16.3.1637, VOC 1122: 496v. 
These affinities were twofold. Firstly, as can be seen from the quotation at the top of this chapter there was the idea in the Netherlands that even the Ottoman sultan compared favourably to the Pope because he left Jews and Christians undisturbed in their faith as long as they paid the jiriya or poll tax for non-Muslims. So too in the states ruled by Muslim dynasties in India, the status of Hindus as people deserving protection (zimmis) just as peoples with revealed books, was not seriously questioned after the first Arab conqueror to broach India had noted that "the idoltemple is similar to the churches of the Christians, to [the synagogues] of the Jews and to the fire-temples of the Zoroastrians," although the question of the collection of the jiziya continued to be an issue, as will be discussed in Chapter 5. ${ }^{145}$ The overall religious tolerance of the Muslim-ruled states of India at this time did not escape the Dutch. Their understanding of it was implicit in Van Twist's argumentation before of Mustafa Khan and was stated explicitly by his contemporary Wollebrant Geleynssen: "nobody is hindered or impeded in his belief or religious practice, on the contrary, everybody lives freely." A further factor that may have contributed to the mutual respect - such as it was - between Protestant Europeans and Muslims was the aversion to the use of images in the worship of the divine. Wollebrant Geleynssen noted that: "they like the Roman or Catholic religion even less than they do the Reformed, and that because the adherents of the Pope have images in their churches - which is against their law." 146 Geleynssen went on to note that the aversion to graven images gave both Protestants and Muslims an inclination to ornamentation made of precious metals, and with that places himself at the head of a long tradition of Protestant writers who made the comparison of Sunni Islam and later Wahhabi Islam to Protestantism in such respects, but what is interesting here is that, according to Geleynssen, Indian Muslims also made this comparison.

Some Europeans were therefore concerned about the impression Indians would gain of the Christian religion if Europeans were to look too divided over religious and secular matters. When Roe appeared at the Mughal court, the then representative of the Portuguese there, a Jesuit of Florence called Francisco Corsi, "told him that they were both by profession Christians, though there was a vast difference betwixt them in their professing of it," and that while there would be no point in trying to

\footnotetext{
145 Yohanan Friedmann, "Islamic Thought in Relation to the Indian Context," Purusartha 9 (1986) 79-91, there 80-1 (Muhammad b. al-Qasim quoted there). Marshall G.S. Hodgson, The Venture of Islam: Conscience and History in a World Civilization (Chicago, 1974) 3: 66, 71, 95, 125-6.

146 Geleynssen also remarked in an ironic vein that if the stories of long fasting by Jogis and Jains were true, as even the Muslims believed, they would make for a welcome addition to Popery ('t pausdom) because then it could finally boast of some convincing miracles. Remonstrantie, 55, 59-60, 100-1.
} 
reconcile the two viewpoints, he desired that there would be a fair correspondence between him and Roe and that, "those wide differences 'twixt the Church of Rome and us might not be made there to appear, that Christ might not seem by those differences to be divided amongst men professing Christianity, which might be a very main obstacle, and hindrance unto his great design and endeavour, for which he was sent thither, to convert people unto Christianity there." 147 Perhaps Roe agreed to this, in any case he saw Corsi on a weekly basis and tried to remain on friendly terms with the Portuguese unlike Hawkins who went to great lengths to distance himself from the Portuguese in the eyes of the Mughals and lived in constant fear of being poisoned by them, which was also the reason that Jahangir offered to find him a wife so that she might oversee the preparation of his food. ${ }^{148}$

When what seemed to be a Portuguese ambassador on his way to rival the reputation of the English ambassador Thomas Roe at the Mughal court passed through Bijapur in 1617, Heda wrote "with the arrival of the English [at the Mughal court] they have received a blow there by the king; their churches have been walled up for 3 or 4 years, so that the papists had all left the place, but now they are all again on their way there, time will tell what their intention is." While Roe noted with contentment that this Portuguese envoy was refused an audience with the emperor as an ambassador, he did not mention in his diary or letters the closing up of Portuguese/Catholic churches that Heda spoke of. Roe did, however, mention that there were some rather acrimonious disputes touching on religious matters between the Jesuits at Agra and Jahangir, including the one concerning the European wives for his nephews, and that the crown prince Khurram was "a most stiff Mahometan and hater of all Christians." In his letter to the Archbishop of Canterbury Roe also noted dryly, and it seems with slight disapproval, that the Jesuits had received from Akbar a freedom "to build, to preach, teach, convert, and use all their rites and ceremonyes, as freely and amply as in Roome, bestoweing on them meanes to erect their churches and places of devotion. So that in some few cittyes they have gotten rather templum then ecclesiam." Clearly Roe was also of the opinion that churches should be a places of gathering more than places of (idol) worship, contrasting a Latin (language of Rome) term to the originally Greek ekkelesia, as used in the Gospel of Matthew (16.18).149

\footnotetext{
147 Terry, Voyage, 445.

148 Ibidem and Hawkins, "Relations," 389-442, especially 404.

149 Roe, Embassy, 313-8, 471, 483. Terry placed a similar pronouncement in a slightly different context, namely the Portuguese failure to convert more than a few Indians, "despite the large tales the Portuguese have sent into Christendome... so that in one word I shall speak this more of the Jezuits in East India that they have there templum, but not ecclesiam." Terry, Voyage, 449-50.
} 
Returning to case of Van Twist, it seems that his efforts at convincing Mustafa Khan reaped some fruits towards the end of his stay, although the sultan still wondered whether the Dutch might not make peace one day with the Portuguese and re-conquer Goa for them. The Dutchman, however, ensured him that this was not the case "since we deemed it more likely that we would reach the sun or sky with our hands than that we (Netherlanders) would live in peace with the Portuguese." Mustafa Khan answered "that is also what I think, and for that reason I have reassured his majesty," and some days later the sultan also appeared convinced. On taking his leave from the sultan Van Twist presented him with two pistols, with which the sultan amused himself for a while by firing them, "saying, among other things: Mr. ambassador, this is good armament for [taking on] the Portuguese, when you return I shall personally take to the field and wage war on them, since I trust that you will keep your word and will never again conclude peace with them." 150 Although nothing came of the promises of Mustafa Khan and the sultan to have the army ready the next season, the point here is that it was possible to convince Indians of an antagonism between two groups that ran as deep as the Dutch-Portuguese divide and that it was possible to convince them that Europeans did not constitute one Christian nation.

Still later in the seventeenth century, by the time of Aurangzeb, who was very interested to hear from the various ambassadors to his court about the political rifts of Europe, ${ }^{151}$ we have definite evidence that the Dutch were regarded as a separate qaum, which is very much the Persian equivalent of the European term nation, as will be discussed in Chapter 4. After a lengthy stay at Aurangzeb's camp in 1689, Dutch ambassador Johannes Bacherus was rewarded with a farman (royal order) and a number of parwanas (orders of ministers etc.). One of these parwanas concerned among other things the return of runaway Dutchmen, a matter about which Company officials were always rather concerned. It was stipulated that if "an individual of the Dutch nation [az qaum- $i$ Valandes shakbsi, translated as van de natie der Hollanderen eenige in the contemporary Dutch translation]" should abscond, he should be apprehended and sent back to the Company. Aurangzeb's farman confirming various privileges the Dutch had held under the sultans of Golkonda further distinguished the Dutch from among Europeans, saying that the fortress of Pulicat was under the administration (tarf) of the Hollanders (Valandes), while other Franks (Farangiyan-i digar) had no part in its administration. The contemporary translation glosses Farangiyan as Europeans, and that indeed seems to have been the most commonly-used term for Europeans in Islamicate languages in India, 
derived as it was from the encounter between Arabs and Franks during the European Middle Ages. ${ }^{152}$

Though the term Farangi in itself refers to spatial provenance rather than religious adherence, Farangis were closely associated with Christianity. The Burban-i Qati" dictionary written in mid-seventeenth-century Golkonda glosses Farang, "Europe," rather briefly: "is famous and in Arabic called Christendom (Nasara)." 153 Similarly, while eulogising his father Akbar and his "total peace" (sulh-i kull) on all religions and the harmony thus created, Jahangir writes: "Sunnis and Shicis met in one mosque, and Franks (Farangi) and Jews (Yabudi) in one church (kalisa), and observed their own forms of worship."154

Though Jahangir in this early part of his memoirs presented the Franks as a religious unity, already by 1615 , which was presented as a turning point above and in which year Jahangir granted the Portuguese a farman banishing the Dutch and English from his harbours, it was sufficiently clear to him as well as to Malik Ambar and harbour governors etc., that the Europeans were not a political unity even if Roe and Corsi tried hard to keep up appearances on the religious front. So that by the mid-1630s, when Van Twist was working hard to convince the Bijapur court of the depth of the chasm between the Dutch and the Portuguese, many no longer needed such convincing. The combination of the political divisions of Europe with the political divisions of India gave rise to a dizzying array of alliances and cross-alliances. When the Mughal governor of Surat suspected the English of the capture of certain ships, touched upon above, he wrote straight away to the Dutch governor general at Batavia, because "you are a great friend of mine, and [because] I love the Netherlandish nation like my own heart for its true-heartedness." The "mendacious nation of the English" on the other hand, he hoped would "be ejected completely from these quarters along with its trade and all its adherents," upon which Methwold wrote his appeal to Christian solidarity but later decided to accord with the Portuguese. Meanwhile at the court of

152 NA, Copy of farman of Aurangzeb 12 Muharram 33 Julus/26.10.1689 CE and copy of parwana of Asad Khan $7 \mathrm{Zu}$ '1-Hijja 33/21.9.1689, HR 42 and 43.1; Contemporary translations of the same, J.E. Heeres ed. Corpus Diplomaticum Neerlando-Indicum (The Hague, 1907-55) 3: 512-3, 516-23. It must be noted, though, that the translations of these documents used the word nation also in places where qaum did not occur in the text, that is to say the Dutch translator Joan van den Bergh was keener to use the word nation than the Mughal clerks were to use the word qaum. For instance, Van den Bergh rendered the title of address for the Company as eene der grootste Compagnieën onder de natie der Hollanderen (one of the greatest Companies among the nation of the Hollanders), where the Persian had Kbulasa'ulAmsal Kumpani Valandes (the Essence of its Equals, the Dutch Company).

153 Tabrizi, Burban-i Qati', s.v. Farang. Compare Yule and Burnell, Hobson-Jobson, s.v. Firinghee.

154 Corinne Lefèvre-Agrati, Pouvoir et elites dans l'empire moghol de Jahangir (r. 1605-1627) (PhD thesis EHESS Paris, 2005) 360-1. Translation adapted from Alexander Rogers' translation of the Tuquk-i Jahangiri, ed. Henry Beveridge (photogr. reprint; Lahore, 1974) 1: 37. 
the erstwhile kings of Vijayanagar, always thought to be more favourably inclined to the Portuguese than to themselves by the Dutch, a priest associated with the Jesuits called Paolo Mercio wrote to the English factor at Armagon that he had notified the king that the English were good friends of the Portuguese and that the king sent word that they should stay friends with the Portuguese and should not tolerate any Dutchmen or anything having to do with them at Armagon. Francis Day, the English factor at Armagon considered something of a friend by the Dutch, however, covertly forwarded Paulo Mercio's letter to the Dutch. ${ }^{155}$

Which brings us to a striking quotation that seems to answer the question asked at the outset of this section and is a curious reflection on both the cohesion of the Christian community and that of the Muslim community, the subject of the next chapter. The context were some English overtures towards governor Mir Muhammad Sahih of the Masulipatnam region in order to have the Dutch ejected from the area with the help of the Portuguese. The Dutch heard of these overtures soon enough through a Chetti merchant (just as Methwold could note that the talks between the Dutch and the governor of Surat were not as secret as the latter supposed them to be) and the news made them wonder if their friend Day was also involved. While they set out on a charm offensive over and against the English campaign, "making every effort to make friends," the Dutch factors observed bitterly:

our Christian nation has in past times had good repute and respect here, because we were intertwined with each other in friendship, and could rely on each other in danger, but now that the Moors see that we are separating and trying to ruin each other, they not only think it strange, but the insatiable governors also seek to fish in these troubled waters. 156

\section{CONCLUSION}

In 1622 the English factors at Pulicat wrote about the Dutch married to Indians: "all those thatt soe marry here to blackes are bound and tyde to everlastinge service in India and cannot returne to there cuntrye... and to speake truly most parte of this base nacion desyer nott to see moore there owne cuntrye; yea, there carryadge and manners of lyvinge is more heathenlicke then the people of the cuntry themselves, whoe take much notice thereof; to which brutishness we leave them." ${ }^{157}$ Though racist in

155 NA, Translated letter hakim Masih uz-Zaman to Batavia 21.4.1636, VOC 1119: 1036; Translated letter Paolo Mercio at Vellore to English at Armagon 5.6.1636, VOC 1119: 1178; Letter Pulicat to Batavia 2.7.1636, VOC 1119: 1117.

156 NA, Letter Masulipatnam to Batavia 25.7.1636, VOC 1119: 1144-6.

157 Quoted in Raychaudhuri, Jan Company, 204. 
themselves, equating the Dutch to Indians and with that to brutes (a hyperbole that the Dutch also used on occasion in respect of the Portuguese), these words, taken down only twelve years after the VOC had established a factory at Pulicat, not only show how quickly local roots could be struck, but also testify to the by now over-belaboured (in the Introduction and above) point that Europeans in India were often not mere onlookers but very much participating observers.

But such integration in local society did not generally spawn a rosy view of local culture or all of the people of India, as in William Dalrymple's White Mughals, where the protagonist is envisaged as a born and raised Englishman falling in love with the Islamicate culture of late eighteenthcentury Hyderabad. Hans Marcelis, quick to spin himself a local network and corresponding with the local grandees by ola (inscribed palm leaf), and so in many ways more integrated in South Coromandel society than his fellow factors already by 1610, was in that year observed by two fellow factors hurling Portuguese insults at the textile painters. His colleague reported: "I said: you must not speak to those people like that, to which he answered us: we must address them this way otherwise we will not get our due from them." 158 Heda also grew increasingly wary of "this Barbaric nation," though he made no concrete plans to leave (as the English also remarked about the Dutch nation at Pulicat in the last paragraph). Familiarity did not necessarily breed sympathy in seventeenth-century India, as the other cases in this book will also show.

Who was the main target of prejudice and othering varied from situation to situation over the expanse of the subcontinent and the course of the seventeenth century, however. It was precisely in the "colonies," where Europeans settled and married local women, that the opposition between black and white mattered within the Christian community. Goa and other Portuguese colonies had their elaborate classification of (in order of distance from Europe) reynols, castizos, mestizos and converts, which the Dutch inherited to an extent in settlements such as Pulicat. The racial inequality among Christians in the Dutch colonies was institutionalised in 1649 by a plakaat (by-law) issued from Batavia forbidding Asian and mestizo women married to Dutchman and those husbands themselves to go to the Netherlands on any ship, whether VOC or non-VOC. ${ }^{159}$ Still, even in the enclaves that were to a greater or lesser extent under European administration, the situation was much more complex than "white vs.

${ }^{158}$ NA, Letters Thiruppapuliyar to Masulipatnam 26.7.1610 and Hendrick Cloeck at Pulicat to Masulipatnam 7.10.1610, VOC 1055: n.f.

159 Plakaat 30.9/6.10.1649 in J.A. van der Chijs, Nederlandsch-Indisch Plakaatboek 1602-1811, vol. 2: 1642-1677 (Batavia, 1886) 132-4. Compare Anthony D. King, "Colonial Cities: Global Pivots of Change," in Robert J. Ross and Gerard J. Telkamp eds. Colonial Cities (Dordrecht, 1985) 21. 
black," as will be seen in chapters three and more especially five. Outside the colonies, Europeans were confronted with many different groups and the terms used to refer to the local population shifted from "blacks" to "Moors and Heathens," or to more specific terms. ${ }^{160}$ Taken together with the dividing lines between and within the European nations, these perceived lines running through society yielded a matrix of possible antagonisms and affinities between groups that was much more complex that a binary schema of European vs. Indian.

Yet two of the most notable phrases used to characterise the European presence in Asia before 1750, Holden Furber's "Age of Partnership" and Sanjay Subrahmanyam's "Age of Contained Conflict" (the latter developed as a response to the former) presuppose the dualism of black and white: they meet and become partners or enemies engaged in a contained conflict. While the former term poses a radical disjuncture between the era of partnership and the subsequent colonial era, the latter characterisation is teleological: it supposes that Europeans were looking to topple Asian polities from the start of their naval incursions into Asia, but only got around to doing it in the colonial era. As Subrahmanyam puts it: "even before the age of high imperialism, other more subtle forms of conflict and violence shaped both the relationships and the consequent representations that emerged." 161 As will be argued elaborately later, the nexus between conflict and representation is indeed a crucial one and the stability of the relationship between the groups that do the physical violence and the representing is crucial to it. Yet it is only the possibility of overcoming the other group that breeds the desire to contest with the other group. If the possibility of overturning the other is absent, there is not conflict but acquiescence and the idea of the other as Other is relatively irrelevant. ${ }^{162}$

It seems that the Islamicate states of the subcontinent accepted European dominance of the seas, where the system of demanding protection money of Indian ships (the cartaze system) practiced by the

160 Thus, while the troops at Pulicat, all made up of Christians, were simply divided into black and white heads, the "native" armed retainers of Bacherus' embassy to the Mughal imperial camp in the heart of the Deccan - also later in the century to be sure - were not just opposed to the "Netherlandish" soldiers but also enumerated as Rajput, Moorish and Gentu (Sjentiefse; here meaning Telugu), more or less in conformity with the Mughal practice of classifying the military. NA, Resolution Pulicat 27.12.1614, VOC 1059: 73v-4v; Account of expenses of embassy to Aurangzeb 4.12.1692, VOC 1510: 438v-49v. Compare Sumit Guha, "Politics," 152 and passim.

161 Subrahmanyam, The Political Economy of Commerce: Southern India 1500-1650 (Cambridge, $1990)$ and "Forcing the Doors of Heathendom: Ethnography, Violence and the Dutch East India Company" (Amsterdam, 2002 Wertheim Lecture) 23 and passim.

162 Amartya Sen remarks more or less the same with relation to economic inequality in $O n$ Economic Inequality (enlarged ed.; Oxford, 1997) 1. See also Pierre Bourdieu, Outline of a Theory of Practice (Cambridge, 1977) 77. 
Dutch as well as the Portuguese and English, was quite literally a containment of potential violence against those ships. To these states with their nomadic traditions of warfare and their capitals far from the shore, the littoral remained for al long time a natural frontier as Jos Gommans has argued. ${ }^{163}$ The Dutch on their part realised quickly that the Islamicate states of India were too strong to contend with. Although Subrahmanyam argues that the VOC administered little doses of violence to Golkonda throughout the seventeenth century, ${ }^{164}$ the relationship between the Dutch and Golkonda as well as Bijapur and the Mughal empire was actually quite stable during the half century between ca. 1630 and the 1680s when the Dutch mounted an unwarranted siege of Masulipatnam and the Mughals launched a new fleet (see Chapter 5). This balance of power is beautifully visualised in Joan Nieuhoff's eyewitness description of the arrival of Bari Sahiba on the seashore. On one side we see the splendid entourage of the queen with her escort of four thousand horsemen with their horses gleaming like mirrors and their imposing outfits, on the other side some Dutch ships that were readying themselves to renew the blockade of Goa and the smaller yacht that was to take the queen across. The queen herself, who dictated some last minute letters in different languages "from which one can see her intelligence and linguistic skill," was somewhat disappointed with the size of the yacht, but was soon convinced of its suitability for the shallow waters of the Red Sea. Among the titles she employed in her address to the Dutch Governor General, we find "A Crocodile of the Sea and a Lion of the Water." Implicit there but explicit in other places is of course that her son "the essence of joy for my eyes" was the lion of the land. 165

Much of the "colonial" and "imperial" designs that the Coromandel factors and Heda thought up in the heady early days of Dutch expansion were reversed later in the century. The aggressive attitude of the Company was replaced by a strict policy of non-interference in the affairs of Indian states that is so notable in VOC correspondence of the later seventeenth century, ${ }^{166}$ and the colony at Pulicat was broken up in 1690 with the stroke of the pen of Hendrick Adriaen van Rheede as part of his

163 Gommans, Mughal Warfare, 162-6.

164 Subrahmanyam, "Forcing the Doors," 6-8.

165 Nieuhoff, Zee en lant-reire, 77. NA, Translated letter of Bari Sahiba 25.5.1663, VOC 1241: 335. For an example of the representation of Ali II as a lion see Chapter 4. The Dutch commander of the fleet before Goa was also addressed as "lion of the sea" in the letter by Pir Muhammad cited above (VOC 1122: 472).

166 In fact the dovish/economic voice is so highly noticeable that George Winius and Marcus Vink argue that “the VOC's very policies, enforced from Amsterdam/Middelburg and Batavia, always ensured that the merchant in the Company's make-up dominated and controlled its warlike side." They see the pacification of the VOC as a process that was completed by ca. 1680 , but also note that those wanting to make military conquest on land were rebuffed even in the early century. Merchant-Warrior, 16, 31-2, 40, 149. 
efficiency drive on behalf of the Directors of the Company. ${ }^{167}$ This development is observable in the difference between the way the VOC factors treated the case of "the Jewish girl" in 1615 and the way Van Twist handled the matter of Sachariassen and his family in 1637. In 1615 the factors went all out to win back the girl, being very concerned about "our reputation here on this coast among the blacks." In 1637 Van Twist realised it was a lost cause from the start, finding it unwise to speak for a renegade, also "from the perspective of [the Company's] honour," and only made a limp effort, probably lest it would seem to his superiors that he had not fulfilled his commission which stipulated that he should bring back all Dutch prisoners. And when a year earlier, during the episode of strife with the English at Masulipatnam outlined above, the English told the governor that the Dutch would not be satisfied until they were masters of everything (the same charge the Dutch had always brought against the Portuguese) and adduced the examples of Pulicat, Bantam, Batavia, Banda etc., the Dutch at Masulipatnam thought their refutation of these charges well-founded (met fondament). ${ }^{168}$

But even during the period of aggressive Dutch expansion in Asia, the early part of the seventeenth century, the struggle that mattered most to Dutchmen in India was the violent conflict with the Portuguese and to a lesser extent the competition with the English (also violent on occasion). The war against the Portuguese was to the hawks Heda, Van Berchem and Grotius the cause of the Dutch in Asia, because it was a just war and the foundation of colonies and intimidation of Asians they chose to see only as a necessary step in the extension of the Dutch struggle for liberty and redress of the, in the words of Grotius, "manifestly unjust...situation in which the Iberian peoples hold the entire world tributary." 169 The sense of extended struggle of these Dutchmen is comparable to the widely held Spanish views of the conquista of the Americas as an extension of the reconquista of the Iberian Peninsula from the Muslims. ${ }^{170}$ But with the important difference that Muslims were potential allies, not old enemies.

The othering of other Europeans by Europeans in Asia that went alongside the struggle between the Dutch and Portuguese and other such conflicts is for some reason taken much less seriously in the secondary literature than the othering of Asians, over which a whole academic industry has sprung up. As has been shown throughout this chapter, the

167 Marion Peters and Ferry André de la Porte, In steen geschreven; leven en sterven van VOCdienaren op de kust van Coromandel in India (Amsterdam, 2002) 47-8.

168 NA, Letter Masulipatnam to Batavia 25.7.1636, VOC 1119: 1144-6.

169 Quoted from De Jure Praedae in Wilson, "Erasing," 96.

170 Compare Pagden, Lords, 41, 73-4. Pagden's view that the Dutch harboured no ideologies of empire needs some modification for the early period along the lines of this paragraph, though it is largely applicable to the later seventeenth century. Ibidem, 4, 114. 
rifts between the European nations in Asia were very serious, and very often more serious than those between Europeans and Indians, which was the ground on which the alliances between the European quasi-states in Asia and Indian states against other European quasi-states were built. One more example will illustrate this very clearly. After remarking that the English "are not a little in the way" of the VOC on the Coromandel coast, Daniel Havart closes his chapter on Pulicat with a reference to Robert Knox's Historical Relation of the Island Ceylon. Knox wrote that the Dutch in India persisted in their habit of drinking themselves drunk. What slander, argued Havart:

We, who have spent many years among the English and French on the Coromandel coast, can testify to the contrary, and say verily that the Hollanders (by which I mean people of decency) are as little and less guilty of drunkenness as those of the just mentioned nation [sic]... and about how often those foreigners, have, to their own disrepute and to nausea, filled themselves with drinks, and are reputed among the Moors to be drunkards, I shall keep my silence so as not to avenge evil with evil, only to warn the reader that he, pray, not lend credence when he may read every now and again an Englishman or Frenchman, who, in order to cover his own dirt, taints the Hollanders with the slander of drunkenness. For this is sure, that the Mohammedans (who are by definition enemies of drinking to drunkenness) esteem the Hollanders above all other nations. ${ }^{171}$

The first part of the statement (the Dutch in India drink less than other Europeans) was empirically dubious (as the contrary was reported from all quarters) ${ }^{172}$, wherefore Havart turned it into a tautology (decent Dutchmen in India drink less than other Europeans). However, it is the last part that commands our attention here. It is what De Certeau would call a typical European heterology, but with an interesting twist: the Muslim is called upon as witness of the sins not of "natives" but of Europeans. Though the Muslim is called upon as an outsider, he is closer than the French and the English, who become the Others of the statement (as the Hindus were called upon to "take much notice" of the brutishness of the Dutch in the quotation at the beginning of this conclusion). It is, moreover, an observation on the nature of othering as a mechanism of ascribing to the other the sins of the self, "to cover one's own dirt," but it is Europeans heaping dirt on other Europeans, just as in the painting over the entrance to the Hall of Mirrors at Versailles.

This chapter has tried to demonstrate that the strong Dutch national sentiment in India came about in a double movement of the confrontations with the non-European environment and with the other Europeans in it. Through the confrontation with the Muslims and Hindus

171 Havart, Op-en ondergang van Cormandel (Amsterdam, 1693) 1: 134-5.

172 See Raychaudhuri, Jan Company, 205-6; Subrahmanyam, "Forcing the Doors," 6. 
of India, the Europeans came to feel more like members of a Christian community than they would have felt if they had stayed in Europe like the copyist who, sitting or standing at his desk in Holland, did not pause to see that the word starting with a capital $E$ and ending with a lower case $e$ was not the word Engelse that had already occurred in the text but Europese, because "European Christian nation/-s" was just not a plausible frame of reference to him. But above that, they came to feel more Dutch through the confrontation with the other nations of Europe in the Indian arena, which in many cases forestalled Christian solidarity. Bari Sahiba was quite on the mark of the Dutch self-image in India when she addressed the Governor General at Batavia as "The First among the Christians, Pillar of the Hollandish Nation."173

From a material point of view there were two factors intrinsic to the situation in Asia that fed into these sentiments: firstly the possibility of overtaking the Portuguese empire which, as was seen, many Dutchmen thought of as crumbling and secondly the advantages of membership of the Dutch nation in Asia, which entailed/afforded many "capabilities," more so than in the Netherlands. Amartya Sen accords capabilities, broadly speaking the set of options a person has to survive and thrive or a person's access to advantage, ${ }^{174}$ an important place in thinking about social equality and inequality. He deems the concept broadly applicable, and it does indeed seem useful in our seventeenth-century context. Two of the most important capabilities, for instance, that being Dutch in Asia entailed were access to the trading network of the VOC and the backing of the quasistate that the VOC was. Both were made use of even by Dutchmen and women who were not VOC employees, like Cornelis Heda who was able to send things to and receive things from the Netherlands and some wives of VOC factors who were able to utilise the VOC network for their private trade. ${ }^{175}$ When a Dutch adventurer called Joost Marcellus Verves arrived in Masulipatnam via the land route, he wrote that his enterprise had not been much of a success so far but that he wanted to try his luck one more time across the Bay of Bengal and seek the service of the king of Arakan, presenting his plan as a win-win situation to the VOC factors who would have to take him across, because his serving the king of Arakan as a military advisor would "enhance my own honour as well as the service of the fatherland." The factors tried to lay this principle down in some quasi-

${ }^{173}$ NA, Translated letter of Bari Sahiba 25.5.1663, VOC 1241: 335. Compare and contrast the argument of Michael Hardt and Antonio Negri that European nationalism arose from the confrontation with the non-European Other alone. Empire (Cambridge, Mass. 2000) 103, 114-36.

${ }^{174}$ For a thorough investigation of what exactly the concept may encompass, see Amartya Sen, "Capability and Well-Being," in Martha Nussbaum and idem eds. The Quality of Life (Oxford, 1993) 9-29.

175 Peters and André de la Porte, In steen gescbreven, 48-9. 
legalistic terms. Verves was to "stay with his majesty [the king of Arakan] without employment by the Company or costs [on the part of the Company] and always represent the honour of our nation as well as of persons employed by the Company and if necessary assist the same to the best of his ability," but he was to vacate Arakan and have himself shipped to the Netherlands if he would show himself to be of a class of people that was defined in the following terms:

while all persons who are governed by honour and shame will not in time fall into or attempt anything improper which would diminish their honour and especially do disservice to the fatherland to which everyone is obligated by inborn laws [door aengebooren wetten verplicht, many are subject to change and, through accidental misunderstanding and conversation with godless highly variable persons and other causes, come to decline their nature $[$ nateur $] \ldots{ }^{176}$

It would therefore appear quite unobjectionable to use the term nationalism for the sentiments expressed by Heda and other Dutchmen of his day, were it not for a mountain of literature that I am not going to ascend any further than is necessary to give a small impression of it. Niek van Sas, who argues that nationalism in the Netherlands did not arise until the 1760s (which is still early by many standards), lays down as the main criterion for calling loyalty to the nation or the fatherland "nationalism," that this loyalty be valued above loyalty to one's ruler or religion. Since the Prince of Orange was not much talked about and the sense of belonging to the Dutch nation often came before that of belonging to the Christian nation in India (though those two identities were closely interconnected), all the talk of the Dutch nation and the fatherland by Dutchmen in India might qualify as nationalism. One may further recall Heda's statement that he was a good patriot and promised wholehearted service of the fatherland. Van Sas argues that the term patriot in the seventeenth and eighteenth-century Netherlands had distinct party-political connotations and that it was only the increasing frequency of the use of the term fatherland, along with the claims of pining for and rendering service to it, in the 1760s and 1770s that signified the transition to the era of nationalism. ${ }^{177}$ But Heda's application of the term patriot to himself cannot have been party-political, since the party struggles in the Netherlands that erupted in full force after the Twelve Year Truce with the king of Spain had been signed were too far away to command his attention (if indeed he knew about them at all), while his promise of wholehearted service to the fatherland is also quite

$176 \mathrm{NA}$, request by Verves and his promise in the form of a contract, after 15.5.1612, VOC 1055: 243-5.

177 N.C.F. van Sas, De metamorfose van Nederland; van oude orde naar moderniteit 1750-1900, (Amsterdam, 2004) 69-128, there especially 70-1 and 100. 
unambiguous. Moreover the phrase "the sweet fatherland" that Heda used was to become something of a stock phrase in VOC correspondence later in the seventeenth century. ${ }^{178}$ In order not to get further entangled in the literature on nationalism, however, I will reserve the term national sentiment for the seventeenth-century sentiments related to the Dutch nation and the term patriotism for the sentiments related to the Dutch fatherland. Both of these terms will also prove useful in describing other identities in the Deccan as will be seen in chapters two and four.

The fact that this early Dutch national sentiment in Asia has gone unremarked in histories of the rise of nationalism in the Netherlands shows that it was a rather context-dependent phenomenon, as are all identities in my view (certainly the ones discussed in this book). However, despite being to a large extent dependent on the context of Asia, the far away expressions of loyalty to the fatherland we have seen in this chapter must have left some impression on popular as well as elite consciousness in the United Provinces, if only because some Dutchmen did return. Van Ittersum shows that Grotius, for instance, was strongly influenced by the testimonials of Dutchmen on the ground in Asia he was fed by the directors of the VOC, and a century later Daniel Havart, returned from Golkonda, wrote a poem in praise of the Dutch language $O p$ het Duitsch. ${ }^{179}$ To gain more of an impression of this effect we may also consider the reception of some of Wemmer van Berchem's deeds in patria. Upon his return in 1616, the Company's Directors expressed their displeasure about his wasteful practices while on the Coromandel coast as well as about the way he excused himself for those "behaving as if he had not been stationed there as a merchant but as a Governor and Signor Magnifico," in which sarcastic words the use of Spanish may be noted. However, Van Berchem went on to become a vice-admiral of the fleet of Holland (again) as well as a hero well before his death in 1663. In 1628 the chronicler Nicolaes van Wassenaer praised him boundlessly. Van Wassenaer probably based his account of Van Berchem's career on interviews with the man himself, for they were both residents of Amsterdam at the time and the level of detail provided about his visit to Hyderabad - "three times the size of the mightiest Dutch mercantile town" - suggests as much. Van Wassenaer started by noting that it was very rare to find two great virtues united in one person, but that Van Berchem was such a near unique specimen. The virtue of vromicheijt (which term encompassed the same "manly" virtues as the Latin virtus) ${ }^{180}$ he had demonstrated around the turn of the century when he was trading in the Caribbean but encountered a Spanish armada and ordered a boy (nick)named Vriesje to blow up his own ship. This action

\footnotetext{
178 See e.g. the headings of the lists of contents of VOC inventory numbers 7529, 7531-3.

179 Peters and André de la Porte, In steen geschreven, 77.

${ }^{180}$ Compare Woordenboek der Nederlandsche Taal, s.v. vroombeid.
} 
cost the lives of a great number of Spaniards and almost the entire Dutch crew, except for Van Berchem, a twelve-year-old moortje and Vriesje, all wounded. Van Wassenaer held up this example of how one can be victorious when defeated to "those going on a commission." In his view it showed Van Berchem's ample qualification for service to the fatherland and the public cause (in subsidium patriae... in publico quaestu) and was in line with the custom of (the putative Dutch ancestors) the Batavians to blow themselves up with powder (!) in the face of enemies who thought themselves secure in their victory. All of which, incidentally, recalls the nationalist admiration for the nineteenth-century Dutch hero Van Speyck who is also reputed to have blown himself up rather than surrender. Still later in the seventeenth century, Arnold Moonen devoted a poem to the explosion that Van Berchem had caused to happen between enemy ships "which air and earth, day and night/mixed and Dutch and Spanish souls [Duitsche en Spaensche rielen]." The parts of the equation speak volumes of othering: air/day/Dutch over and against earth/night/Spanish. ${ }^{181}$

But the story of Van Berchem continues: after he had exploded his ship the Spanish captain invited him to surrender, apparently stressing the identity they shared, namely that of men of arms, in an episode that recalls Rudyard Kipling's (nineteenth-century) Ballad of East and West. "But there is neither East nor West, border, nor breed, nor birth / When two strong men stand face to face, tho' they come from the ends of the earth." What the Spanish captain is supposed to have said according to our seventeenthcentury source, while slapping his sword, was that he was a soldier and would therefore keep his promise even "against the will of the Pope and the king of Spain." That will was evidently to kill interloping Protestants in the hemisphere granted the Spaniards, as the Spanish captain's men did behind his back to Vriesje while calling him a Lutheran (Lutbriano being the Spanish catch-all for Protestant). But captain Juan Adama himself even went so far as to save Van Berchem from his death sentence by helping him escape from Cuban prison to a Dutch ship. After Van Berchem had destroyed another Spanish armada off the Congo in 1607, for which the king of Congo was allegedly most grateful, he was sent on his mission to announce the Twelve Year Truce in Asia, and to stop over at Lisbon. While in Lisbon Van Berchem had occasion to display his second great virtue, gratefulness, by declining the gold chain the viceroy offered him and requesting that Juan Adama be rewarded instead.

181 Moonen, oddly enough, situated the explosion at Dunkirk, between Dunkirk pirate ships, but nevertheless retained the anti-Spanish flavour of the story. Van Dijk, Wemmer van Berchem, i-xii, 3, 55-67; Moonen's poem of 1686 and the letter of the Company directors of 1616 to Hans de Haze quoted there, ii and 66; Van Wassenaer, Historisch verbael,13: 25v-30 and 14: dedication and $90 \mathrm{v}$. 
Which brings us to the issue of crossing boundaries. Many Dutchmen did not develop the sense of patriotism demonstrated by Heda and Van Berchem, and did precisely what Verves' contract warned against, they went over to Indian nobles and rulers, mostly to the Muslim nobles and rulers. In the process many of them converted (which is not to say that their conversion was only an outward show; Sachariassen was "daily instructed by a mulla or pope") 182 and with that they lost their "nature" or Dutchness. Havart, who was somewhat sympathetic to Muslims and Islamicate culture, is not very positive about those Europeans who actually crossed the boundary such as the surgeon Arthur Simmor at Hyderabad. ${ }^{183}$ Perhaps this was a contrast between the Dutch elite and the common soldiers and sailors, since the latter were the ones who ran or stayed away from VOC service the most, as did the sailor Gerrit Gerritsz despite the dire warnings from Van Wesick. The Dutch defections are reminiscent of André Wink's hotly debated fitna thesis, which accords defection in general an important place in state formation processes in South Asia. By way of fitna (used by Wink in the sense of sedition) one ruler would try to lure away people who were part of another ruler's state structure. Though Wink's idea of fitna was hotly debated on various counts at the turn of the 1980 s, ${ }^{184}$ the idea that group boundaries were no impediment to state formation in India was widely received at the time. And the idea that group solidarity did not account for much in India in pre-modern times is still prevalent among a large group of scholars (see the Introduction). One can see the idea also transpiring in the doubts of Muhammad Adil Shah that the Dutch would not renege on their treaty with Bijapur and suddenly enter into an alliance with the Portuguese against Bijapur. Yet among the Dutch in India we see that a strong sense of belonging to the Dutch nation and the forsaking of that nation existed side by side. Moreover, the fact that Muhammad eventually recognised as lasting the Dutch enmity toward the Portuguese, as many other Indians also recognised the intra-European fissures, reflects on South Asian society itself. The, not so new, question as to whether India was more of a society of individual agents or more one of agents operating as groups is a matter that will continue to exercise our attention throughout this book.

182 NA, Diary of embassy by Van Twist sub dato 20.2.1637, VOC 1122: 485v.

183 See Havart's "epithaph" for Arthur Simmor quoted in Peters and André de La Porte, In steen geschreven, 81 .

184 André Wink, Land and Sovereignty in India: Agrarian Society and Politics and the EighteenthCentury Maratha Svarajya (Cambridge, 1986) 21-34; M. Athar Ali, "The Mughal Polity - A Critique of Revisionist Approaches," Modern Asian Studies (1993) 27: 699-710. 


\title{
CHAPTER 2 \\ THE QUEEN AND THE USURPER: \\ DECCANIS VS. WESTERNERS IN BIJAPUR AROUND 1636
}

\begin{abstract}
Human groups composed of more than three persons have the seemingly spontaneous tendency to divide themselves in two hostile sub-groups.

Michel Houellebecq, $2001^{1}$
\end{abstract}

\section{INTRODUCTION}

In their efforts to have the Portuguese ejected from the Deccan sultanates, the Dutch encountered the ideology of cosmopolitanism that was upheld by the sultans and their ministers. Wemmer van Berchem was told at Golkonda that the harbours of the sultanate were "open and free to all Moorish merchants and traders," including those trading with the Portuguese. ${ }^{2}$ And one of the first officials that Van Twist spoke to, well before he arrived at the court, told him that his mission would be quite pointless, because "the king of Bijapur's land is an enclosed wilderness, in which lions, boars and tigers must live together in peace." 3 That is to say, Dutchmen and Portuguese and what have you who were established in Bijapur had to abide by a sort of Pax Bijapurica.

The same sort of symbolism was employed around the same time by the Mughal emperors, especially Jahangir and Shah Jahan, as the art historian Ebba Koch has shown. The Mughal emperors seem to have identified their rule with that of King Solomon, Sulaiman in the Islamic tradition, images of whose rule made at the early-seventeenth century Mughal court show predatory and grazing animals enchanted by an allpervasive peace. ${ }^{4}$ But that symbolism derives its power partly from its opposite, the symbolism of animal fights (see Ch. 4).

${ }^{1}$ Michel Houellebecq, Plateforme (Paris, 2001) 74.

2 NA, Letter Van Berchem 1.8.1613, VOC 1056: 147v.

${ }^{3}$ NA, Diary of embassy to Bijapur in dato 11.1.1637, VOC 1122: 471v.

${ }^{4}$ Ebba Koch, Shah Jahan and Orpheus: The Pietre Dure Decoration and the Programme of the Throne in the Hall of Public Audiences at the Red Fort of Delhi (Graz, 1988). The theme of sages pacifying their environment, and especially animals in their vicinity, by their sheer presence, occurs in both the Islamicate tradition and in the Sanskritic tradition. See ibidem and Jan E.M. Houben, "To Kill or Not to Kill the Sacred Animal (Yajña-Pasu)? Arguments and Perspectives in Brahminical Ethical Philosophy," in idem and Karel M. van Kooij eds. Violence Denied:Violence, Non-Violence and the Rationalisation of Violence in South Asian Cultural History (Leiden, 1999) 105-83, there 141. 
In addition, what looks like cosmopolitanism from one angle may look like empire from another. ${ }^{5}$ The question that is implicit in much of today's writing concerning the Indian states ruled by Muslim kings and emperors is to what extent they were empires in the sense of states in which a group rooted in one locality is dominant over groups rooted in other localities. A profitable way to explore the question to what extent the Deccan sultanates were imperial states is to look at the antagonism between those Muslims who considered themselves or were considered Deccanis and those Muslims who considered themselves or were considered Foreigners (Afaqis) or Westerners (Gharbis). This chapter aims to investigate the significance of the rift between Deccanis and Foreigners in the mid1630s.

As Richard Eaton shows, the Bahmani and Vijayanagar states that arose in the fourteenth century differed from the regional states that preceded them. Whereas the regional kingdoms of the Kakatiyas, Yadavas and Hoysalas for the most part encompassed only one of the three major linguistic areas of the Deccan each (the Telugu, Marathi and Kannada areas), and the king and the people spoke the same language, the Bahmani sultanate was in a sense cosmopolitan, encompassing different language groups, though it leant heavily on one section of the population in particular, namely the Muslim elite. ${ }^{6}$ This elite originated in the men who conquered the Deccan for the Delhi sultanate, from which the Bahmani sultanate was an offshoot, and was continually replenished with foreign recruits, both Westerners of Arabic, Turkish or Iranian origin (mostly the latter), and East Africans recruited as slaves to serve in the elite corps of the sultan. The East Africans were called Habshis or Sidis, the former term referring to Habash or Abyssinia and the latter of more uncertain etymology. The terms were largely interchangeable but Sidi was perhaps sometimes used specifically for those hailing from the southern part of East Africa. ${ }^{7}$

Just how divested the Bahmani sultanate was from its locality is illustrated by the remark made by the sultan in 1458 that his state required a chief minister "who should be well known the world over and who should excel in wisdom among the Arabs as well as the Persians." The sultanates that succeeded the Bahmani sultanate in a sense inherited this cosmopolitanism, although they also took a turn towards regionalism, with

${ }^{5}$ Compare Hardt and Negri, Empire, xi-xvii and passim. For an evaluation of modern theories on the relation between cosmopolitan languages and empire with reference to the uses of Sanskrit in late-medieval and early-modern India, see Sheldon Pollock, The Language of the Gods in the World of Men: Sanskrit, Culture and Power in Premodern India (Berkeley, 2006).

${ }^{6}$ Compare Eaton, Social History, 13, 22-6, 59-77.

7 At the end of the seventeenth century J.J. Ketelaar rendered Sidi as Angolen and Habshi as Abissijn. NA, Grammar of Hindustani and Persian by Ketelaar, Sypestyn Collection (suppl.) 2: 11-2. 
the use of regional languages in the administration and sultans well versed in the local language. ${ }^{8}$

Yet already in the Bahmani era local roots were struck by a section of the Muslim community, and the opposition between Western and Deccani Muslims originated in that era. As Richard Eaton shows, the opposition between these groups was relative to the context but nonetheless on occasion deadly. The Habshis especially took to the Deccan very quickly and often sided with the Deccanis in their conflicts with the Westerners, perhaps because the institution of slavery had severed the ties to their homeland as Eaton suggests. Even the Iranian Mahmud Gawan, who was appointed prime minister by the Bahmani sultan with the words quoted in the last paragraph, wrote to a learned man in Khorasan: "the land of the Deccan is superior to any other country," but was, despite such sentiments and his attempt to reconcile Deccani and Western Muslims, killed as the result of a plot by the Deccani party. ${ }^{9}$

Moreover, a certain tension between rootedness and cosmopolitanism was quite unavoidable for anyone with an education in the early modern world, and it is found in European Renaissance humanism as well as well as in the Deccan, ${ }^{10}$ where at the end of the seventeenth century it was expressed beautifully by the poet Wali:

Vali is well known in Iran and Transoxonia, Although he is a poet of the Deccan. ${ }^{11}$

\section{A WEDDING AND A MURDER}

Of the protagonists of this chapter, three have already been encountered in the last chapter: Van Twist's negotiating partner Mustafa Khan, Khadija Sultana the future Bari Sahiba (meaning grande dame or queen mother) ${ }^{12}$, and her husband Muhammad, son of Ibrahim Adil Shah, Heda's patron. Khadija Sultana won her place in the triangle of power at the expense of the fourth protagonist, Khawas Khan, who was the most powerful person

\footnotetext{
${ }^{8}$ Eaton, Social History, 59-77, 142-5. Quotation of Sultan Humayun there, 65.

${ }^{9}$ Eaton, Social History, 59-77, 112. Gawan quoted in Haroon K. Sherwani, Studies in Muslim Political Thought and Administration (2nd ed. Lahore, 1945) 204.

${ }^{10}$ See the case of Grotius in Chapter 1 and Pollock, Language of the Gods, 237-58, 452-67 and passim.

${ }_{11}$ Wali Iran wa Turan méhai mashhur / agarcha sha'ir-i mulk-i Dakan hai. Quoted, with the above translation in Muhammad Sadiq, A History of Urdu Literature (London, 1964) 56.

12 At the birth of Muhammad the title was still held by the mother of Ibrahim. Bhagwat Dayal Verma, "History in Muhammad Nama," in Shivaji-Nibandhavali 2 (Pune, 1930) 71-134, there 79 .
} 
in Bijapur between the death of Ibrahim Adil Shah in September 1627 and his own death in the first half of $1636 .{ }^{13}$

Two elaborate accounts of Khawas Khan's violent death are those furnished by Van Twist in his description of the Deccan first published in 1638 and in the chronicle of the reign of Abdullah Qutb Shah written by Nizam ud-Din Ahmad and entitled Hadiqat us-Salatin. A third narrative is found in the Mubammad Nama written at the court of Muhammad Adil Shah by Muhammad Zuhur bin Zuhuri, who antedated the death of Khawas Khan by some seven years, perhaps because his usurpation was the most embarrassing fact of Muhammad's rule, or as Zuhuri put it: Muhammad could only rule with ease (aram) after the removal of Khawas Khan. ${ }^{14}$ Of these three accounts, Van Twist's description is the only one that has anything positive to say about Khawas Khan and his career. The beginning of his career is described as follows:

In the time of the deceased king Ibrahim Shah, Khawas Khan was a slave of the chief musician of the king. The king remarking some hidden gifts in him, took the same [Khawas Khan] to him and installed him as overseer of the women. When at some point the king was demanding wine, it so happened that this Khawas Khan accidentally brought wine in a bottle in which earlier oil or other greasy things had been; which, when the king tasted it, made him angry and he ordered this Khawas Khan to get out of his presence. Still, he later honoured him with the gatekeepership of the castle and charge of the entire city. Upon his becoming sick and sensing that his day of death had come, the king discussed with the duke Mustafa Khan in whom he should confide the government of the kingdom and the charge of his underage children, especially of the young prince his eldest son, after his death. Mustafa Khan driven by an inner inclination and having excused himself politely from such a burden, recommended Khawas Khan, a man of great intelligence and alacrity to the king (although he was badly rewarded for this favour by Khawas Khan later) who sent for him and solemnly conferred upon him the government of the kingdom as well as the guardianship of the young prince, in the presence of all the grandees. After the king's death Khawas Khan governed the land very wisely for ten years during the minority of the young king, making, however, one big mistake in sleeping with the dowager queen, from which the first hatred between him and the present king arose.

13 The year of his death given in the Hadiqat us-Salatin is 1045 (which ran from June 1635 to June 1636). Van Twist said it took place 15 to 16 months before he wrote his description of Bijapur, but it is not exactly clear when that was. In any case Khawas Khan's death came not long before the Inqiyad Nama, which H.K. Sherwani dates as 6.5.1636. Nizam ud-Din Ahmad, Hadiqat us-Salatin, ed. Sayyid Ali Asghar Bilgrami (Hyderabad, 1961) 164; Johan van Twist, "Generale beschrijvinghe van Indien," in vol. 2 of Begin ende voortgangh der Oost-Indische Compagnie, ed. I. Commelin (Amsterdam, 1646) 70; H.K. Sherwani and P.M. Joshi eds. History of Medieval Deccan (1295-1724) vol. 1 (Mainly Political and Military Aspects) (Hyderabad, 1973) 358.

${ }^{14}$ PSA, Muhammad Nama, Persian Ms. M/727, 153v-4v. 
Some of the elements in this story seem to suggest that Khawas Khan, who was known as Daulat Khan before the accession of Muhammad, was a Habshi slave, but there are a number of indications that he was of local "Maratha," or at least mixed descent. The highest official position he attained was that of sar-i khawass, overseer of the royal "special" or slave corps. ${ }^{15}$ Such positions were generally reserved for Habshis in Bijapur and the guardians of Muhammad's father Ibrahim and Muhammad's grandson during their minority rule were also Habshis, and the latter guardian was also called Khawas Khan. ${ }^{16}$ In the caption of a miniature portrait our Khawas Khan that was made or copied some forty years after his death, he was identified as a Habshi, but that may have stemmed from a confusion with the identity of his later namesake. ${ }^{17}$ In this portrait he is depicted as darkish (the darkest of the portrait series, see the illustration below) but not necessarily African-looking. There are three contemporary references to his identity available to us. One Portuguese source described Khawas Khan as an Abyssinian, yet another said he was of the casta Azeiteiro, that is to say of a local oil-pressers caste. ${ }^{18}$ The latter version curiously echoed in Van Twist's narration of Khawas Khan's temporary fall from grace for bringing the sultan wine in an oily bottle. The third contemporary reference is by Nizam ud-Din Ahmad, who wrote that he was "a Deccani, who was of those who had received an education/promotion from Ibrahim Adil Shah." ${ }^{19}$ Finally, the Basatin us-Salatin, a history of the Bijapur sultanate composed in the early nineteenth century, described Khawas Khan as a Tambakar Maratha, the Tambakars apparently once being a Marathispeaking caste of artisans working with copper and brass. ${ }^{20}$ The majority of the sources thus seem inclined to an origin among the Marathi speaking

15 His position is called the sar-i khawass in the Muhammad Nama and a contemporary farman. PSA, Muhammad Nama, Persian Ms. M/727, 139v. Farman 9.6.1044/21.11.1634 in Ganesh Hari Khare, Persian Sources of Indian History, vol. 5 pt.1 (Pune, 1961) 188-9. During the reign of Ibrahim II this position appears to have been called khawass-i khawassan. BN, Taqkirat ulMuluk by Rafi' al Din Shirazi, Suppl. pers. 189: 293v.

16 Compare Eaton, Sufis of Bijapur 1300-1700: Social Roles of Sufis in Medieval India (Princeton, 1978) 90, 189. Shanti Sadiq Ali seems certain that the Khawas Khan under discussion here was a Habshi in The African Dispersal in the Deccan (Delhi, 1995) 115.

${ }^{17} \mathrm{He}$ is further identified as the peshwa of Sultan Mahmud (sic) of Bijapur, as is Mustafa Khan on his portrait in the series. Pauline Lunsingh Scheurleer, "Het Witsenalbum: zeventiende-eeuwse Indiase portretten op bestelling." Bulletin van het Rijksmuseum 44 (1996) 167-254, there 236 and 248. For the date of this miniature series see Chapter 6.

18 ACE, Letter viceroy to king 18.2.1630 and Anonymous relation of the kingdoms in the vicinity of Goa ca. 1629, 243, 317.

19 Ahmad, Hadiqat, 142, 159.

20 Muhammad Ibrahim Zubairi, Basatin us-Salatin (Hyderabad, 1892-3) 282. For the Tambakar caste see K.S. Singh, B.V. Bhanu et al. eds. People of India, State Series vol. 3: Maharashtra, (Mumbai, 2004) 1708 and J.T. Molesworth, George Candy and Thomas Candy, A Dictionary, Marathi and English (2d ed. 1857; photogr. reprint Delhi, 1989) s.v. tãbat(kar). 
producing castes of the western Deccan, but it is of course possible that he was of mixed descent, part African and part Maratha.
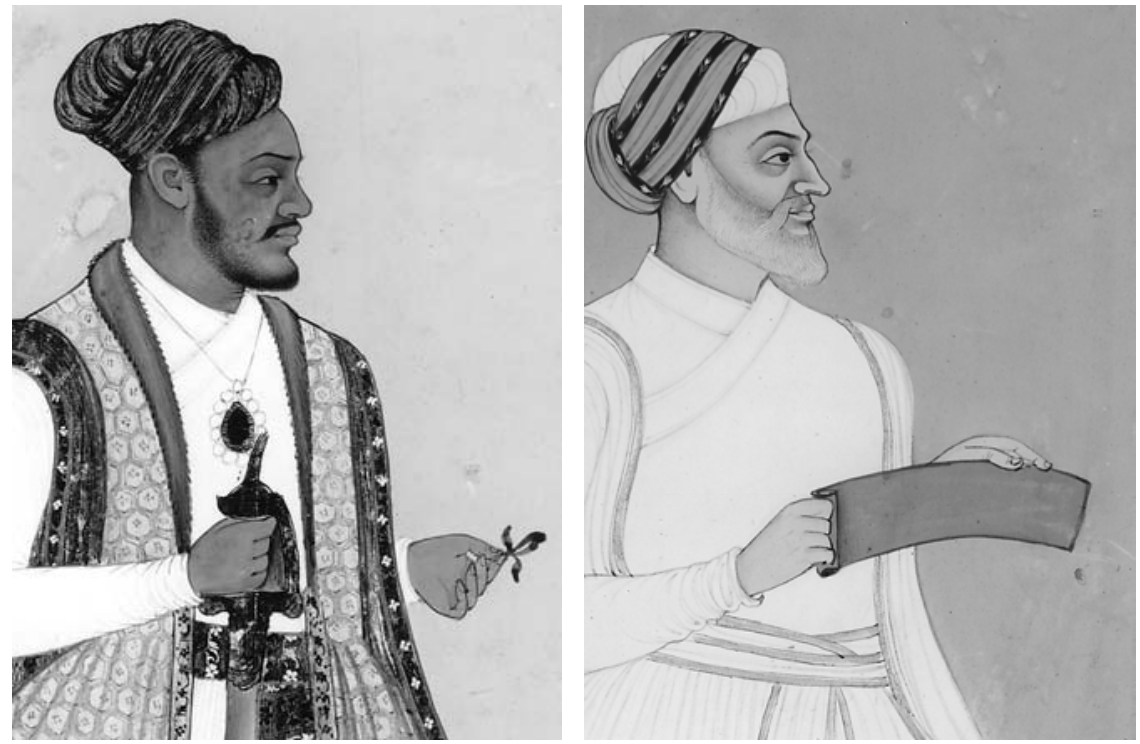

\section{Portraits of Khawas Khan and Mustafa Khan in the Witsen Album, numbers 42 and 43. Courtesy Rijksmuseum Amsterdam.}

Between a few ruins on a spot still known in the early twentieth century as Khawas Khan's mahall, there is a small mosque in a style that is somewhat exceptional in Bijapur. Henry Cousens writes that its style is that of the Ahmadnagar sultanate and that it must be dated around 1620, but it could just as well be from around 1630. This information begs the question: was this mosque built by Khawas Khan and why was it built in the style of Ahmadnagar? Cousens supposes that the nearby ruins must be of a palace by the Khawas Khan who flourished around 1670, but on a map made not long after the Mughal conquest of Bijapur there is a drawing of a palace in this location with a half-effaced legend that may tentatively be read as "this is the mahall of Khawas....the happy date of its beautification being 1037." The year 1037 (1627-8 CE) would link the mosque definitely to the mansion and was also the year Khawas Khan rose to power with Mustafa Khan. The palace complex of Mustafa Khan also included a mosque, which is of the same time but in fully developed Bijapur style. ${ }^{21}$ One possible ex-

${ }^{21}$ Archaeological Museum, Bijapur. As far as it can be read, the text on the map is "in mahall$i$ kh...s...tarikh-i khush-i mujammil sana 1037." The map gives a number of other such building dates. There is also in the Bijapur museum a drawing in European style of a palace with the legend "mahall-i khawass khan deshmukh," which does remotely resemble the palace shown on the map, though the latter image is smaller and more crudely drawn. Compare and contrast Henry Cousens, Bijapur and its Architectural Remains (1916; photogr. repr. Delhi, 1996) 88-9; 


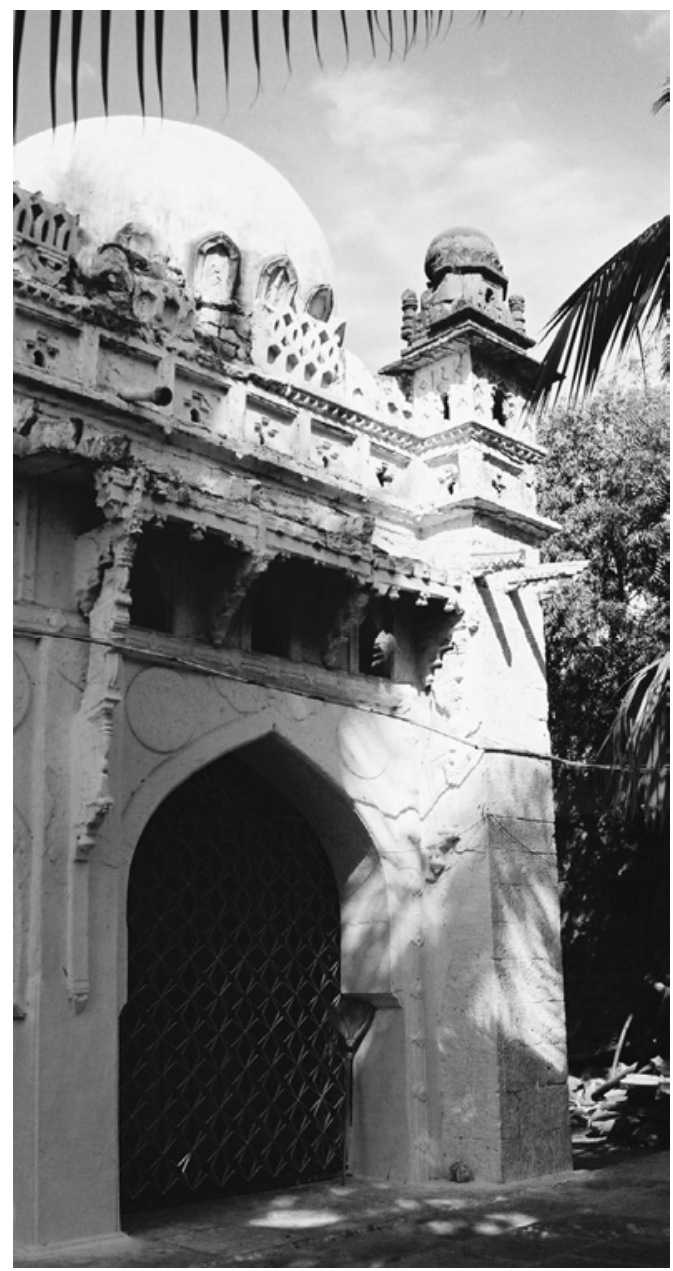

planation for the style of Khawas Khan's mosque is that he harboured a sentimental attachment to Ahmadnagar, which was in its final days very much a point of orientation for Habshis and Marathas. ${ }^{22}$

Right side of the façade of Khawas Khan's mosque, showing one of its nine domes above one of its three arched entrances.

Mustafa Khan (original name Mirza or Mulla Muhammad Amin) by contrast was proud of his Iranian ancestry, as we can see from his use of the nisba Lari, which is to say from Lar in the Persian Gulf region. ${ }^{23}$ The Portuguese sources that are in disagreement on the point of

Khawas Khan's identity, are in agreement concerning Mustafa Khan's Iranian identity. And in further contrast to Khawas Khan's slave origin, Mustafa Khan was closely tied to the nobility of the sultanate through marriage. His father-in-law was Mulla Muhammad Lari, who had been an important noble in the days of Ibrahim. His own daughter Taj Jahan Begam he gave in marriage to Muhammad Adil Shah, on which occasion the agents

V.S. Sukthankar, Descriptive Catalogue of the Bijapur Museum of Archaeology (Bombay, 1918) 31-2. For a brief analysis of the map see Susan Gole, Indian Maps and Plans: From the Earliest Times to the Advent of European Surveys (Delhi, 1989) 160-1.

22 Of course the matter of the relative influences of patrons and commissioned architects or other artists is controversial in art history. Compare the discussion on whether or not the Persianate style of miniature painting under the young Selim/Jahangir represented a deliberate distancing from Akbar in Lefèvre-Agrati, Pouvoir et elites, 151.

${ }^{23}$ E.g. in the inscription on the caravanserai he founded. M. Nazim, Bijapur Inscriptions. Memoirs of the Archaeological Survey of India 49 (1936; photogr. reprint Delhi, 1999) 75. 
(wakils) of the Safavid emperor of Persia accompanied the sultan in the wedding procession. ${ }^{24}$

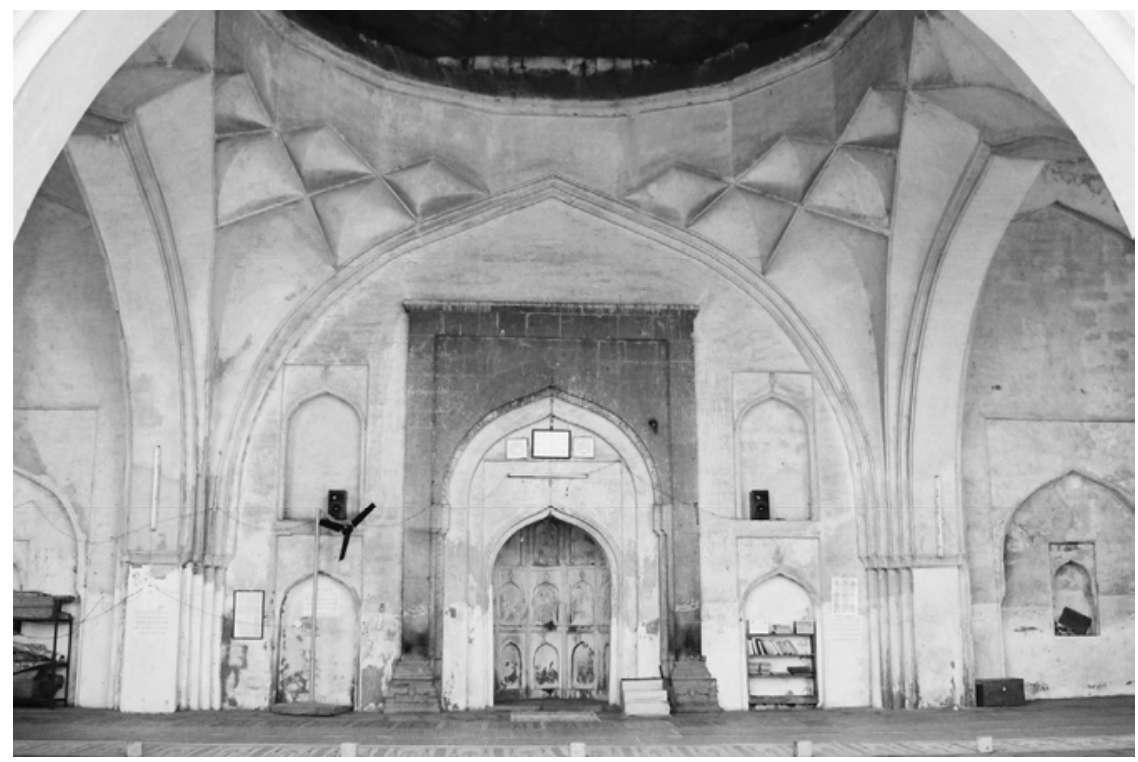

Mustafa Khan's mosque. Although it opens to the outside through three arches like Khawas Khan's, it is really one large space under a single dome.

Being from such entirely different backgrounds, the relation between Khawas Khan and Mustafa Khan deteriorated not long after they had jointly brought Muhammad to the throne (which incidentally did not go as smoothly as Van Twist suggested because Muhammad was not the oldest son). According to Nizam ud-Din Ahmad, Mustafa Khan was the mir jumla of Bijapur in the early period of Muhammad's reign, and the early farmans of the reign bear Mustafa Khan's parwangi, meaning that Mustafa Khan was the keeper of the royal seal. At some point, however, Khawas Khan sent his mahalldar round to Mustafa Khan to collect the seal, and upon his refusal besieged and bombarded his palace in the centre of town (for six days according to Van Twist and for seven according to Zuhuri) and confined him in the fortress of Belgaum far away from the capital where he was to spend about a year. ${ }^{25}$

24 ACE, Letter viceroy to king 18.2.1630 and Anonymous relation ca. 1629, 243, 317; Verma, "Muhammad Nama," 87-8, 96, 159; Ahmad, Hadiqat, 159. Contrast Sherwani and Joshi eds. Medieval Deccan, 1: 350-2.

25 Verma, "Muhammad Nama," 87-8; Ahmad, Hadiqat, 105, 137, 142, 159; Van Twist, "Generale beschrijvinghe," 73; Various farmans between November 1628 and October 1629 in Khare, Persian Sources, vol. 5 pt.1, 129 -30, 175-6; Compare Sherwani and Joshi eds. Medieval Deccan, 1: 351-2; D.C. Verma, History of Bijapur (Delhi, 1974) 27-8. 
In 1633 the marriage between Muhammad and Khadija Sultana was concluded, as his third or fourth marriage (it is not clear whether the marriage to Mustafa Khan's daughter took place before or after this one). ${ }^{26}$ From Bijapur were deputed the elder sister of Muhammad as well as Murari Pandit, a Brahmin who through his connection with Khawas Khan had risen to the rank of sipah-salar or commander-in-chief of the army. The marriage was concluded in the Qutb Shahi harem with the sister of Muhammad representing the groom. After one and a-half months of festivities it was time to go because Murari had to attend to the war with the Mughals, and he was given pan (betel leaf) by Khadija. Mustafa Khan and Khawas Khan came to greet her once she had crossed the border. The marriage was consummated in a tent on nauruz, after the performance of "the customs and foundations of presenting the bride [jilwa] that are polite in the Deccan" (which may in this case refer to the realm of Bijapur). ${ }^{27}$

Upon her arrival in Bijapur, Khadija "became aware of the state and ways of that court and did not find the shape of that place in accordance with her own elevated nature." According to both Ahmad's Hadiqat, whence this understatement derives, and Van Twist she played a key role in removing Khawas Khan and his "good friend" (Van Twist) or "key intellect" (Ahmad) Murari from power. With some funding from her brother, a large force gathered around the city in support of the royals against Khawas Khan about three years after the wedding. Khawas Khan, however, remained in control of the city and Muhammad "conferred with his queen (who is said to be a princess of great prudence and courage) what to do in this affair, who counselled him to take the life of this Khawas Khan without delay" (Van Twist). The murder was accomplished by Raihan, a Sidi or Habshi, and some other loyal servants of the sultan. Another Habshi, however, who had been in the service of Khawas Khan, ran to the palace with the intention of killing the sultan in retribution when he heard the news, and killed eight to ten men before he could be stopped. Part of the army was then still with Murari, but he was either defeated in the field (Ahmad) or deserted by his men after the sultan "who feared that Murari might raise a riot/revolt [oploop]," had proclaimed at drumbeat that anyone supporting him would be considered a traitor (Van Twist). Khawas Khan's head was suspended from the palace tower and a number of his family members and supporters were also killed, including his brother who had been made gatekeeper of the court. Only one of his sons was spared according to Zuhuri. Van Twist was put up in the vacant house of one of these people. One of the chronograms given in the Hadiqat to

26 Verma, "Muhammad Nama," 81, 84, 96.

${ }^{27}$ Ahmad, Hadiqat, 137-42. For different contemporary uses of "Deccan" see Chapter4. 
commemorate Khawas Khan's death was “a number ten there were less of traitors [haramkhwor]."28

Murari had made himself very unpopular with Khadija by either being rude to her brother at the time of the wedding on account of his belonging to the bridegroom's party (as per the Mubammad Nama) or having shown impoliteness (bi-adabi) to her when she was travelling in her palanquin (as per the Hadiqat). The couplet on his death given in the Hadiqat is "one who makes a disturbance in the haram of the Ka'aba." This was a double entendre playing on his disrespect to Muslims in general and to a woman in parda in particular, because a haram is not only the sacred enclosure around the pilgrimage sites of the Islamic world including the Ka'aba, but also the feminine space known to the West as harem. Murari's perceived impropriety was retributed with humiliation and brutality in his final hours. According to Ahmad, Murari was dragged through the streets by a horse, with his tongue, ears and nose cut off. According to Van Twist his hands were cut off first and his tongue cut out only after he was said to have cursed the sultan, and then put on a donkey, but all that not before he had begged Muhammad to make him "chief of the Brahmins" in exchange for an enormous rent. ${ }^{29}$

\section{COSMOPOLITANISM AND TRUST}

In the pre-modern cosmopolitan state, loyalty had to reside first and foremost with the monarch. There were various ideological metaphors in currency in Islamicate India to support this loyalty, including that of eating the salt provided by a patron and that of incorporation through the reception of robes of honour from the patron. ${ }^{30}$ These ideologies, however, competed with other ideologies of attachment to groups other than the set of inhabitants of a state, as well as with ties to lands outside the state.

In early modern Eurasia trust resided to a large extent in group networks; within group boundaries trust was more self-evident than outside, where trust had to be earned, by long years of loyalty to the salt for instance. Trading networks often relied on in-group members overseas, and the VOC was to an extent the most drastically formalised shape such a network could take. As has been seen in the last chapter, the Dutch were at a quandary as to which of the groups they encountered in Asia (Portuguese, Muslims, Baniyas, Brahmins etc.) was the least trustworthy. Heda's contemporary Muhammad Quli Qutb Shah also reflected on the issue of trust and group boundaries and the reason for the creation of hell. In a

\footnotetext{
${ }^{28}$ Van Twist, "Generale beschrijvinghe," 70-4; Ahmad, Hadiqat, 160-4.

29 Ahmad, Hadiqat, 163-4; Verma, "Muhammad Nama," 84.

30 Buckler, F.W. "The Oriental Despot," in Legitimacy and Symbols; the South Asian writings of F.W. Buckler, 176-187, ed. M.N. Pearson (Ann Arbor, 1985); Eaton, Social History, 114, 118.
} 
dirge (marsiya) commemorating the plight of the family of the Shici imams he wrote: "Having obtained promises [qaula] from the imams, the selfdegrading villainous infidels [kafir, here: Sunnis] / became faithless [bi-qaul] [so] for the sake of strength God made Hell." 31 In other words: outsiders were not to be trusted and hell was reserved for them.

This is precisely what a much discussed article by Robert Putnam argues for the future of the modern world: in the short run there is a negative correlation between diversity and solidarity — and with that trust - as a great amount of evidence from the United States of America shows. Nevertheless, in the long run diverse societies may create new forms of solidarity and "dampen the negative effects of diversity by constructing new, more encompassing identities." 32 Two ways of generating solidarity and trust - or "social capital" for short - seem to have presented themselves to people in the seventeenth-century Deccan: loyalty to a monarch and loyalty to the land. The former had a greater potential for inclusion than the latter. While loyalty to the monarch might include Hindus and Muslims of all hues, loyalty to the land excluded those Muslims who identified themselves as Iranians or Afghans.

Richard Eaton gives a very strong example of loyalty to the monarch in a discussion between some Iranian nobles of the Mughal empire and some Iranian nobles of the Ahmadnagar sultanate in 1596, when the former told the latter to stop fighting because their cause was lost and because they were persons of the same kind (abna'i jins). The answer came that "for forty years I have eaten the salt of the sultans of the Deccan [here: Ahmadnagar]...there is no better way to die than to be slain for one's benefactor, thereby obtaining an everlasting good name." In this example loyalty to the monarch won out, but in many cases it did not. Group loyalties, such as those to the Deccani or Westerner groups could undermine states in the Deccan, as Eaton also remarks. ${ }^{33}$ Moreover, there were networks of groups across states that could forestall loyalty to the monarch.

If loyalty was to be to the monarch and not to the state as a commonwealth, competing kings could solicit a transfer of that loyalty. Indeed, the boundaries between states and patronage networks - not to be confused with the boundaries between social groups - were somewhat fluid in early modern India, as André Wink has argued. So-called qaul namas, or letters of promise, were criss-crossing the Deccan at the time and promised the recipient continuance of his land revenue rights and of his rank and/or an improvement on these if he exchanged his allegiance from

31 Muhammad Quli Qutb Shah, Kulliyat, third collection (digar): 56/3.

32 Robert Putnam, "E Pluribus Unum: Diversity and Community in the Twenty-first Century. The 2007 Johan Skytte Prize Lecture.” Scandinavian Political Studies 30 (2007) 137-74.

33 Eaton, Social History, 7, 113-4. 
$\mathrm{x}$ to the sender of the letter. Some examples of such letters are preserved in the archives of prominent Maratha families. ${ }^{34}$ The Inqiyad Nama, the deed of submission to the Mughal emperor that was accepted by Bijapur after Khawas Khan's demise, explicitly tried to put a stop to this practice of sending qauls across the border. ${ }^{35}$ During the preceding collapse of the Ahmadnagar sultanate, however, a great number of Maratha sardars or nobles were absorbed with their contingents by both Bijapur and Golkonda, where they were welcomed with great honour. Ahmad wrote about one of them, Vithoji Kantia, sardar of two to three thousand Maratha small horse, that "his boastful head rubbed the sky," when he received the qaul from Abdullah Qutb Shah. ${ }^{36}$

The members of such mobile groups as the Marathas, however, maintained marriage networks as well as informal networks across state boundaries. Malik Ambar, the Habshi prime minister of Ahmadnagar of whose struggle against the Portuguese Heda had such high hopes, married his son Fath Khan to the daughter of Yaqut Khan of Bijapur, the highly placed Habshi noble who took Heda's protégé Gerrit Gerritsz into his employ. ${ }^{37}$ According to Van Twist, Mustafa Khan was in some way related to the Mughal emperor through marriage and had "great friends" among the emperor's entourage. ${ }^{38}$

Such links were seen as potential problems for the Deccan sultanates. When in 1637 Van Twist had disposal of the services of one of the Brahmin scribes of the court, who also translated the letters from the viceroy, Mustafa Khan said the Brahmin should be severely warned not to disclose any of the contents of Van Twist's proposal because, he said, "these Brahmins have their friends within Goa; and who knows if they are not being propped up with gifts by the Portuguese, so if anything of our mutual intention is discovered, I shall punish them as an example to the others." 39 Some also considered Mustafa Khan and other Iranians a danger to the Bijapuri state because of their external contacts. The Portuguese description of the realms around Goa of ca. 1629 wrote about the relation between Mustafa Khan and the former prime minister Ikhlas Khan:

And because the kingdom of the Adil Shah is full of Persians inimical to this state, and Mustafa Khan serves as secretary and treasurer of the state, he $[\mathrm{MK}]$ does not want to serve Ikhlas Khan, as he $[\mathrm{MK}]$ did before, because he $[\mathrm{KK}]$ is Abyssinian,

\footnotetext{
34 V.G. Khobrekar ed. Records of the Shivaji Period (Bombay, 1974) documents 76, 84, 91, 96.

35 Verma, "Muhammad Nama," 93-4.

36 Ahmad, Hadiqat, 112-5.

${ }^{37}$ Eaton, Social History, 119.

38 Van Twist, "Generale beschrijvinghe," 73.

${ }^{39}$ NA, Diary Van Twist sub dato 17.2.1637, VOC 1122: 489v-90.
} 
and since he $[\mathrm{IK}]$ considers the Persians to be governing, he $[\mathrm{IK}]$ does not want to associate himself with them because they would be traitors. ${ }^{40}$

That quotation clearly brings out the distrust between the different segments of the Bijapuri state's elite, but any placing of the Deccan sultanates as a whole on a scale of high-trust and low-trust societies, as Francis Fukuyama does for some modern societies, ${ }^{41}$ would have to remain tentative. There are a few examples of seventeenth-century South Indians expressing unusedness to truth-speaking across group boundaries beside the verse by Muhammad Quli already quoted in the second paragraph of this section. In a Sanskrit poem of the first half of the century, the English at Chennapatnam (just within the bounds of Bijapur) were criticised for many things, but among the explicitly positive points was this one: "they speak no falsehood."42 Muhammad Quli's nephew's grandson Abul-Hasan (r. 1672-87) also seems to have given some thought to the issue of trust and the strange (ghair). There is a verse in the work of one of his courtiers with the pen name Shahi that is sometimes attributed to the sultan himself, and runs thus:

They say you meet strangers, some tell the truth, others the untruth pray, tell me, whose mouth I should shut, for some say this and some that. ${ }^{43}$

The question is of course where people drew the line between the same and the strange.

\section{LOCAL TIES}

Constructions of the local in seventeenth-century Islamicate India drew on a number of tropes and symbols. Important ingredients of the local seem to have been dark skin, symbols derived from Hindu texts and practices, and Indic language. These three elements were linked in complex ways in contemporary literary expressions. Particular to the Deccan was further an infusion of Shici symbolism into this complex.

\footnotetext{
${ }^{40}$ E o Reino deste Idalxaa ficha cheo de parçios inimigos deste estado, e Mostafacão serue de secretr.o, e veador da faz: da do estado, e porq̃ a Calcão o não quer seruir, e dantes o era porq he Abexim, e como se ve gouernarẽ os percianos não quer meter na sua massa por serẽ traidores. $A C E$, Anonymous relation ca. 1629, 317. I thank Lucia Werneck Xavier and B.N. Teensma for their aid towards the above tentative translation.

${ }^{41}$ Francis Fukuyama, Trust: The Social Virtues and the Creation of Prosperity (New York, 1996).

${ }^{42}$ Quoted in Velcheru Narayana Rao, David Shulman, Sanjay Subrahmanyam, Symbols of Substance: Court and State in Nayaka Period Tamil Nadu (Delhi, 1992) 5-6. For the background of this text see the following chapter. Compare also the remarks by the Iranian assistant envoy Muhammad Rabi ${ }^{i}$ about the trust of Englishmen in Chennapatnam within their group, in Alam and Subrahmanyam, Indo-Persian Travels, 162.

${ }_{43}$ Quoted, with this free translation, in Sherwani, History of the Qutb Shabi Dynasty (Delhi, 1974) 609, 661.
} 
Skin colour implied a certain erotic quality in Indian Islamicate courtly discourse just as it did in what Said calls the Western discourse "exoticising and eroticising" the Orient (or for that matter in the in the Arab world as Said detractor Bernard Lewis remarks). While in the north Emperor Jahangir left his visitor Mutribi from Samarqand at a loss as to whether one of his dark slave boys was more "heart stealing" than a particular white slave boy displayed for the occasion, ${ }^{44}$ Muhammad Quli dedicated love poems to women called Gori (the light girl/woman) and Sanwali (the dark girl/woman). In a poem about Sanwali, Muhammad Quli played on the contrast of the dark skin to the eyes and smile - "the affluence of moonlight" - and her "pearl coloured transparent robes." This play reminds one of remarks like those by Wouter Schouten, a seventeenth-century Dutch traveller quite obsessed with skin colour, who found a redeeming quality in the contrast of the skin of the former queen of Cochin to her outfit: "it was an old and ugly woman, but adorned with gold chains and jewels, which contrasted wonderfully with her skin." 45

Such contrasting of skin colour with the ornaments upon it was something of a tradition in Islamicate literature; one need only think of the Hindu (i.e. dark) mole on the (light) skin of a Turk of Shiraz in a famous verse of Hafiz, with whose work Muhammad Quli was well acquainted.46 But Muhammad Quli went further in another poem on Sanwali and one on a male dark beloved, Sanwala. Apart from a play on the cascade of pearls that Sanwala's laughter revealed and the likening of the boy himself to a pearl (perhaps an oblique reference to the Qur'anic promise of male attendants like "well-guarded pearls" in heaven), ${ }^{47}$ these poems contained elaborate plays on the words colour, colourful and colourfulness. To Sanwali, Muhammad Quli addressed the following verse: "Your [or: my]

44 "Mutribi" al-Asamm Samarqandi, Conversations with Emperor Jahangir, trans. and introduction Richard C. Folz (Costa Mesa, 1998) 48-50.

45 Muhammad Quli Qutb Shah, Kulliyat, first collection (Nazmẽ): 232-4, 245-6. The phrases are quoted after the translation of one of the Sanwali poems in Luther, Prince, 72-4. Schouten, Aanmercklijke voyagie, a: 217-18 (other remarks on skin colour: a: 128, 243-44, 258, 179-180). In comparison to other Dutch sources of the time, Schouten's remarks on skin colour seem more frequent and more detailed.

${ }^{46}$ Hafiz, Diwan-i Hafiz, ed. Parwiz Natel Khanlari (2d ed. Teheran, 1362 Hijri Shamsi) 1: 22 (poem 3). Quli's familiarity with the work of Hafiz is remarked by Sherwani, Qutb Shabi, 324. ${ }^{47}$ Qur'an 52: 24; D.J. Matthews draws attention to Muhammad Quli's poems addressed to men that the editor of Quli's poetry has included in a section devoted to his putative twelve female beloveds. Some such poems are, as Carla Petievich points out, as it were addressed to the self by an imagined female admirer, but the poem to Sanwala contains no hint of a female perspective. Compare Matthews, "The Kulliyat of Muhammad Quli Qutb Shah: Problems and Prospects," in Urdu and Muslim South Asia: Studies in Honour of Ralph Russell, ed. Christopher Shackle (London, 1989) 46 and Carla Petievich, When Men Speak as Women (Delhi, 2007). 
colourful girlfriends are of many colours, but where is a woman of such colour as yours?" 48

Muhammad Quli associated Sanwali with a Hindi language (possibly Telugu), in a long tradition that associated dark with local and Indian or Hindu in Indo-Persian literature. ${ }^{49}$ Just as the dark boy was also the Hindu boy in Mutribi's relation, so Amir Khusrau's (1253-1325) face turned yellow from desire for (and in contrast to) a Hindu boy. ${ }^{50}$ Yet to Muhammad Quli, Hindu skin and Hindi language were desirable, not detestable as they were for instance to an Iranian India traveller of the 1670s, Muhammad Mufid Mustaufi Yazdi, who connected skin colour to both birth and merit in a way that we would now call racist, and also spoke of "the black land of the Deccan." The fifteenth-century ambassador from Khorasan Abdur-Razzaq referred to India (Hind) in a similar vein, as an iqlim-i zalmani or dark clime. He probably meant the word zalmani to describe both the skin colour and culture of the people he found in South India, certainly if that word embodies an oblique reference to the passage in the Qur'an (24.40) where the unbelievers' state is compared to the "darknesses [zulumat] of a tremendously deep ocean." 51

Perhaps the equation of the zulumat of the Qur'an with the religion of the Hindus had become something of a cliché by the reign of Abdullah Qutb Shah, for his poet laureate and champion of the Deccani language Ghawwasi turned it upside down in a poem in the Sufi genre which denies the boundaries between religions:

Let Ghawwasi be Khizr, having made the tress of the beloved into darknesses, because in blackness the tress of the beloved and the darknesses are one. ${ }^{52}$

Here Ghawwasi made a play of his own skin colour, which was apparently dark, ${ }^{53}$ as well as of the reproaches he apparently received for his frequent use of Hindu terms and symbols. In other words, by his use of Hindu tropes Ghawwasi associated the tress of the beloved, which is a Sufi trope for the beauty and majesty of God, with Hindu darknesses, and he was

\footnotetext{
48 Muhammad Quli Qutb Shah, Kulliyat, first collection (Nažmẽ): 232-4, 322.

${ }^{49}$ Zor in any case seems to think this Hindi is Telugu for he has entitled the concerned poem "one from Telingana" in his edition of Quli's work cited above.

${ }^{50}$ Amir Khusrau (1253-1325) quoted in a translation of Sunil Sharma in Sheldon Pollock, “The Death of Sankrit," CSSH 43 (2001) 392-426, there 421 note 51; for Mutribi see above.

51 Compare Alam and Subrahmanyam, Indo-Persian Travels, 58-60, 199-200, 209, 220. Alam and Subrahmanyam give a completely different interpretation to the iqlim-i zalmani passage but see my review of the same in Itinerario 31 (2007) 207-9.

52 Ghawwasi Khizr ho piyu zulf kõ qulumat kar paya / ki kalepan mépiyu ka zulf hor qulumat eki hai. Ghawwasi, Kulliyat-i Ghawwasi, ed. Muhammad bin Umar (Hyderabad, 1959) 167.

53 There is also a poem by Ghawwasi in which a light-skinned girl (gorr) turns black, scorched by her longing for the poet, implicitly cancelling the contrast between them. Quoted in Petievich, When Men Speak, 187.
} 
therefore proud to be black (kala) or green like the mythic Khizr, who embodied another mystic trope.

While many Iranians in India spoke highly to Europeans of the beauty and greatness of their native land, ${ }^{54}$ and South Asian Muslims in general looked up to the lands of the Middle East, ${ }^{5}$ there was also a strong attachment to the land of the Deccan among sections of the Muslim population of Ahmadnagar, Bijapur and Golkonda. The sultans of Bijapur and Golkonda also did not look back to an ancestral land in the way the Mughal emperors did, though there were some vague and contradictory genealogies linking them to the Central Asian Turks (a great contrast to the high-profile narrative of migration laid down by the founder of the Mughal dynasty himself). ${ }^{56}$ The sentiment of attachment to the land was expressed most clearly in the literature in the Deccani language, which came to flourish in the seventeenth century, starting with Muhammad Quli Qutb Shah. ${ }^{57}$

Another major poet of Deccani was the aforementioned Ghawwasi, who is connected to the events of this chapter through the diplomatic mission he undertook from the court of Golkonda to that of Bijapur. He was sent to Bijapur with gifts and souvenirs (tohfa wa yadgar) by Abdullah Qutb Shah in the aftermath of Khawas Khan's murder (which brought about an exchange of gifts and envoys between the two courts) and returned together with the new permanent ambassador of Bijapur to Golkonda. He was at some point styled the Malik ush-Shu'ara or poet laureate of Golkonda by Abdullah. ${ }^{58}$

The Deccani language was very much a "language of place." 59 It had an infinite capacity for absorbing Telugu, Marathi, Kannada and Sanskrit words, and became the medium par excellence for expressing attachment to the land. At the court of Muhammad Quli's grandson, Ghawwasi distanced himself from the Urdu poetical tradition of the north and its founding father Amir Khusrau, thus: "why would I be a second Khusrau in my own Deccani language." 60 Also in other respects he was something of a "popular" poet. The vocabulary of his Deccani Urdu poetry ranged from the highly Persianised in some parts of his works to the almost

\footnotetext{
54 As reported by Schouten and Havart (see Chapter 1) as well as Martin, Mémoires, 2: 250.

55 Alam and Subrahmanyam, Indo-Persian Travels, 328-9.

${ }^{56}$ For the latter see Richard C. Foltz, Mughal India and Central Asia (Karachi, 1998) 129-146.

57 Muzaffar Abbas, Urdu mẽ qaumi sha'iri (Lahore, 1978) 40-4; Sherwani and Joshi eds. Medieval Deccan, 2: 22-4

58 Ahmad, Hadiqat, 163-4; H.K. Sherwani and P.M. Joshi eds. History of the Medieval Deccan (1295-1724) vol. 2 (Mainly Cultural Aspects) (Hyderabad, 1974) 25-6.

${ }^{59}$ Compare Pollock, Language of the Gods, 474 and passim.

${ }^{60}$ Ghawwasi, Kulliyat, 109. I thank Carla Petievich for pointing me in the direction of such expressions by Ghawwasi.
} 
completely Indic in other parts. Abdullah is called both sultan and maharaja, and God is referred to as Niranjan in one place. ${ }^{61}$

Both Muhammad Quli and Ghawwasi saw the Deccan as a space for love and seduction. "You are the fitna of the Deccan, headstrong in every sense," 62 the former wrote about a beautiful and playful girl, which may be read as a political statement. Not only is the Deccan declared headstrong, the verse also gives a subversive twist to the perennial Mughal accusations of the fitna and fasad the Deccanis were making. ${ }^{63}$ Similar expressions are found with Ghawwasi: "The Majnun of today's times may be found; Ghawwasi has become famous in the Deccan," which is to say that Ghawwasi himself was the greatest lover to be found in the Deccan. ${ }^{64}$

Particular to the Deccan was the use of Shici symbols in the construction of local identity. For the sultans of the Deccan Shicism was perhaps a way of underscoring Deccani identity, or of distancing themselves from the Mughals, as André Wink has suggested. As was seen in the last section, Muhammad Quli Qutb Shah was a staunch Shici, but his contemporary Ibrahim II of Bijapur was raised as a Sunni. The copper coins struck during his reign, however, all bore the legend "the servant of Ali, the chosen one, Ibrahim, friend of the weak," a more explicit expression of allegiance to the champion of the downtrodden Ali than the coins of Muhammad Quli, some of which bear the name of the city he named or renamed Hyderabad after Ali "Haidar." Mark Brand notes that that the keen observer can even detect Shi'i symbols ("alams) in the decoration of mihrab of the great congregational mosque of Bijapur, the work on which was commissioned by Muhammad Adil Shah and completed in $1045 \mathrm{AH}$, the year of Khawas Khan's demise. 65

While the antagonism between Shicis and Sunnis ran deep on occasion, or as Havart put it "the Shi'is curse the Sunnis into the abyss and vice versa," it seems that it was not among the main ingredients of the

${ }^{61}$ Sherwani, Qutb Shahi, 531-3.

62 Hor fitna dakhni hai tũ sar-zor har yek bab mê. Quoted in Sherwani and Joshi eds. Medieval Deccan, 2: 23. Complete poem in Muhammad Quli Qutb Shah, Kulliyat, first collection (Nazmẽ): 321-2.

${ }^{63}$ Although it must be noted that Muhammad Quli harked back to Hafiz also here, compare Hafiz' verse: "thy eye's deceit cast a hundred fitnas into the world." Hafiz, Diwan, 1: 50 (poem 17). Translation adapted from Henry Wilberforce Clarke's, reproduced in Salehe Salehpur's edition (Teheran, 1382 Hijri Shamsi) 17.

${ }^{64}$ Ghawwasi, Kulliyat, 129.

65 André Wink, "Islamic Society and Culture in the Deccan," in Islam and Indian Regions, ed. A.L. Dallapicola and S. Zingel-Avé Lallement (Stuttgart, 1993) 1: 217-29; Matthews, "The Kulliyat," 44; Eaton, Sufis of Bijapur, 128-9; Stan Goron and J.P. Goenka, The Coins of the Indian Sultanates: Covering the Area of Present-day India, Pakistan and Bangladesh (Delhi, 2001) 3156, 335-40. For a discussion of the naming of Hyderabad see Sherwani, Qutb Shabi, 339-348; Mark Brand, "Re-Creating Islam in the Seventeenth-Century Deccan: The Political, Ritual and Architectural Importance of the Adil Shahi Cult of the Prophet Muhammad," presentation given at Oxford, July 2008. 
antagonism between Deccanis and Westerners in the seventeenth century. It is often assumed that the majority of the Deccani Muslims were nominally Sunni and most of the Westerners were Shi ${ }^{6}$ is, ${ }^{66}$ hailing as they did from Safavid Persia (that is before the great influx of Sunni Afghans into Bijapur which started in the later part of Muhammad's reign), but the situation was far more complex. On the one hand there were already riots between Sunnis and Shi is in the decades around 1600, though on a greater scale in the north than in the Deccan, and sharp polemics were waged at the courts. ${ }^{67}$ On the other hand it seems that, as Omar Khalidi suggests, Sufism acted as a middle ground between Sunni and Shici Islam, especially through the practice of tafizilliya (elevation of Ali and his lineage above the first three caliphs) by all the Sufi orders in the Deccan except the Naqshbandiyya order. Also, both Shici and Sunni Islam had been "indigenised" to the Deccan and were available to the common folk in popular festivals and texts. ${ }^{6}$

Moreover, it is not clear that the majority of the Deccani Muslims were even nominally Sunni. Havart's writings on Golkonda suggest that most Muslims outside Hyderabad were Shic is and that they shared their practices with their Hindu neighbours. The external signs of Shicism were omnipresent in the rural areas of Golkonda. Havart spotted many "hands of Murtaza Ali" in towns and hamlets between Masulipatnam and Hyderabad, and he records that the tenth of Muharram was celebrated by everyone in the villages, including Hindus. He also noted that mosques stood mostly empty by his time (ca. 1680) because of the religious policies Shah Jahan and Aurangzeb had enforced upon Golkonda (see below) and might serve the traveller as resting places. In their desolation these mosques:

look nothing like a church, except that one sees a devout faqir (monk) sit there sometimes and here and there a verse or saying from the Qur'an on the wall, also often something that is similar to the gospel of the spinning wheel and at the time of their days of mourning there are also hung some weapons and banners.

So the mosques in the countryside of Golkonda displayed both Sufi charkha namas or poems to accompany the movement of the spinning wheel and, at

${ }^{66}$ E.g. Eaton, Social History, 145 and Sufis of Bijapur, 41, 67, 71 and passim.

${ }^{67}$ The reformist Sufi Shah Sibghat-Ullah provoked a riot between his followers and Shicis in Bijapur during the Muharram processions in 1596, see Eaton, Sufis of Bijapur, 116. In a riot in Lahore (North India) in 1625 during the Muharram celebrations, fifty Shi' is and twenty-five Hindus were killed by Sunnis, which also illustrates the point below that the Muharram celebrations appealed to Hindus in seventeenth-century South-Asia, see Alam and Subrahmanyam, Indo-Persian Travels, 137. For the polemical literature copied or produced in the Deccan see S.A.A. Rizvi, "Shi'ite Religious Literature in the Deccan," Rivista degli Studi Orientali 64 (1990) 17-35.

68 Omar Khalidi, “The Shicites of the Deccan: An Introduction," Rivista degli Studi Orientali 64 (1990) 5-16. 
the time of Muharram, the symbols of the martyrdom of Husain and Hasan. This is an important testimony, precisely because the Deccan was Sunnified after the Mughal conquest, and modern views of Deccani religious practice may be coloured by hindsight. ${ }^{69}$

For Deccani patriot Ghawwasi also Sufi symbols and Shici sentiments went hand in hand. In several places he expressed allegiance to a preceptor named Haidar, who is perhaps to be identified as Sayyid Shah Abul-Hasan Ali Haidar II of the great Sufi lineage of Gisudaraz Banda Nawaz, ${ }^{70}$ but probably also as the original Haidar, Ali. And since Sultan Abdullah was a great patron of the Muharram celebrations all over his realm, Ghawwasi also wrote some three to six marsiyas as well as a nauba, a form of poetry that conveys the grief of Muharram without going into the details of the martyrdom of Husain. Ghawwasi's nauba is as rhythmic as the charkha namas, with the exclamation "ah wa-waila" or "oh! Alas! Alas!" at the end of every line. ${ }^{71}$

\section{The War Party vs. THE PEACE PARTY}

An early seventeenth-century history of the reign of Mughal emperor Akbar noted about the Deccan sultanates that, "if a foreign army entered their country they united their forces and fought, notwithstanding the dissensions and quarrels they had among themselves." Under Malik Ambar the allied forces of the sultanates assembled annually near the northwestern end of the Dakshinapatha, which afforded pretty much the only entry point into the Deccan for an army coming from the north. Pieter van den Broecke, passing through Malik Ambar's camp in 1617, noted that Ambar received the support of 6,000 horse and foot from Golkonda and another 10,000 from Bijapur every year during the campaigning season, commenting that "if the Ghats [here: the Vindhya mountain range] had not been so difficult to pass, the land would have been lost long ago, which is the reason why they have to be constantly vigilant near this hole in the Ghats." 72

The mainstays of Malik Ambar's force were, however, his own Habshi contingents and the troops of the Maratha sardars of the Nizam Shahi state. Under Malik Ambar's direction the Ahmadnagar sultanate became, in the words of Richard Eaton, "a joint Habshi-Maratha

${ }^{69}$ Havart, Op-en ondergang, 2: 65-95 and Persiaansche secretaris, 70-4, 86. For charkha namas see Eaton, Sufis of Bijapur, 157-64, 171-2.

70 Thus Muhammad bin Umar in his introduction the Ghawwasi's Kulliyat, 14-5. Two examples of allegiance to pir Haidar given there, another on 108.

${ }^{71}$ Sadiq Naqvi, Muslim Religious Institutions and Their Role under the Qutb Shabs, (Hyderabad, 1993) 205-13.

${ }^{72}$ Faizi Sirhindi quoted in Sherwani, Qutb Shabi, 450. Pieter van den Broecke, Pieter van de Broecke in Arië, 2 vols, ed. W.Ph. Coolhaas (The Hague, 1962-3) 149-50. 
enterprise." Although Malik Ambar was a Muslim and even somewhat puritanical in his strict anti-alcohol regulations, the Mughal opponents of this force at the gates of the Deccan could or would hardly see it as a Muslim force. ${ }^{73}$ The epitaph of a Mughal noble named Mir Muhammad Yusuf Niknam Alawi recorded that in May 1610 he "fought with the enemies from Dakhan who had blocked the way of the Muslims [Musalmanan] and attained the status of martyrdom [daraja-yi shahadat] along with his eldest son, relatives and servants." 74

Khawas Khan and Murari stood firmly in this tradition of opposition to the Mughals, while Mustafa Khan favoured them. The vicissitudes of the war with the Mughals in the early 1630s are exceedingly complex, but two patterns emerge. Firstly that most of the Maratha and Habshi nobles of the tottering Nizam Shahi state were in league with Murari and Khawas Khan, and secondly that Mustafa Khan, whose father in law had been killed by Malik Ambar's men, tried to reach an agreement with the Mughals to partition the Nizam Shahi state between Bijapur and the Mughal empire. ${ }^{75}$

A telling episode in these years is the case of Yaqut Khan, a Habshi noble of Ahmadnagar (not to be confused with the Yaqut Khan of Bijapur). According to Ahmad he considered himself a second Malik Ambar, but while he, Murari and Fath Khan, the son of the original Malik Ambar, were confronting the Mughal army he nevertheless defected to the Mughal side. Shah Jahan took him in for raison d'état (maslahat-i mulkgiri), but when he had to fight the Deccanis, Yaqut Khan had second thoughts and became a focal point of fitna, here obviously meaning the invitation to sedition of fellow partisans of the Deccanis and not of agents free from group ties. He was killed soon afterwards. ${ }^{76}$

A similar turnabout was effected by Murari at the Golkonda court. Murari, who was said by both Van Twist and Ahmad to have been

\footnotetext{
${ }^{73}$ Legitimating a war against Muslims was often problematic for Muslims in South Asia. When a stranded Ottoman admiral travelled through Sind in 1655 and witnessed a war between two local rulers, he was told by one of them: "Do not attack the Muslims, and make sure that there are no balls in your muskets, for all of us are one people! The greater part of our brothers and our children are over there [the enemy's stronghold]." Quoted in Alam and Subrahmanyam, Indo-Persian Travels, 109. Aurangzeb, who legitimated his war in the Deccan as a jihad (see Chapter 5), dismissed his chief qazi in 1689 for suggesting that a peace should be concluded with the sultan of Golkonda since he and his troops were also Muslims and the bloodshed was therefore contrary to the law of Islam. Ni'mat Khan Ali, Chronicles of the Siege of Golkonda Fort, trans. N.H. Ansari (Delhi, 1975) 7.

${ }^{74}$ Eaton, Social History, 121-4; Inscription after 19.2.1610 AH/13.5.1610 CE at Panchgawhan in northern Maharashtra, ed. and trans. by S.A. Rahim in Epigraphia Indica: Arabic and Persian Supplement (1966) 44-5.

75 Compare Sherwani and Joshi eds. Medieval Deccan, 1: 350-9.

${ }^{76}$ Ahmad, Hadiqat, 153-4.
} 
renowned for his prowess in war, ${ }^{77}$ demanded financial support for his war efforts from Abdullah Qutb Shah in 1631, and appealed to a promise of financial aid that had been made by his predecessor for the compensation of the peasants of a border district of Bijapur that had been plundered by Qutb Shahi forces. When this aid was not forthcoming, he started plundering some border districts of the Qutb Shahi realm. Abdullah raised an army, and issued an award of one hon for every nose or pair of ears of the "kafirs," but Murari then sent his nephew Narahari to the Qutb Shah, who made an eloquent plea that "a formidable enemy totally devoid of chivalry" had come to the Deccan and the sultans should unite in the spirit of their forefathers. ${ }^{78}$ This plea was well received and peace was made, and this seems to have been the run-up to the wedding of Khadija Sultana and Muhammad, which according to Zuhuri came about after some pressure on the Qutb Shah by Murari. ${ }^{79}$

Meanwhile the division between Khawas Khan's faction and Mustafa Khan over the relation with the Mughals came into the open. Khawas Khan sabotaged the tribute that Bijapur was supposed to pay the Mughal emperor. According to Van Twist he gave the money to the Mughal envoys but then had their train ambushed by his men pretending to be bandits, and put the money back into the treasury. According to Ahmad, a Habshi called Marjan, keeper of the city-fortress of Bidar, stopped the envoy in his tracks. At the same time, according to the Badshah Nama chronicle written at the court of Shah Jahan, Mustafa Khan was keeping up a secret correspondence with the Mughals and promised to let their forces into Bijapur. According to Ahmad, this was the pretext Khawas Khan needed to put Mustafa Khan away as he did. Van Twist noted that, as soon as he heard of the imprisonment of Mustafa Khan, Shah Jahan sent an envoy to Bijapur to obtain his release, and that this was duly promised by the sultan but was delayed by Khawas Khan. In 1636 the VOC factors wrote that Shah Jahan was so embittered over Bijapur that he was resolved to subdue it entirely before returning to Agra. ${ }^{80}$

To understand the bitterness of the war, one must know that Gujarat and the Deccan were struck by a severe drought in 1630 and floods in 1631 , which caused starvation on an immense scale. ${ }^{81}$ At a number of points in the war the Mughals had to withdraw because they were short of

\footnotetext{
77 Van Twist, "Generale beschrijvinghe," 71-2; Ahmad, Hadiqat, 162.

78 Ahmad, Hadiqat, 108-12.

79 Verma, "Muhammad Nama," 84.

80 Van Twist, "Generale beschrijvinghe," 72-3; Ahmad, Hadiqat, 117, 160; Badshab Nama in H.M. Elliot and John Dowson, The History of India as Told by its Own Historians (1867-77; photogr. reprint Delhi, 1990) 7: 28-31; NA, Letter Masulipatnam to Batavia 2.7.1636, VOC 1119: 1117.

81 NA, description of Gujarat and Hindustan by Van Twist 1634, VOC 1113: 181-94. Ahmad, Hadiqat, 113. Eaton, Social History, 130.
} 
fodder and food supplies. The war itself, however, compounded the desolation of the countryside. The Badshah Nama, written as it was from the Mughal perspective, devoted some space to the devastation the Mughals caused partly because they needed to forage and partly as revenge for what they saw as the betrayal of Bijapur. When Van Twist travelled up to Bijapur in 1637 the limits of the penetration of the Mughal army into Bijapur the year before were still clearly visible: "this [village near Miraj] was the farthest place to where the great Mughal came with his army last year, being not only this place but also most of the towns and the countryside miserably destroyed by that war." After the Mughals had consolidated their grip on the north-western Deccan through deeds of submission by the Adil Shah and the Qutb Shah, they set about making the land flourish again through a rigorous programme put in place by Murshid Quli Khan, in view of the fact that no revenue that could be collected from a great number of districts because they were too devastated. ${ }^{82}$

The death of Khawas Khan opened the way for the conclusion of peace with Shah Jahan. ${ }^{83}$ The treaty came in the form of the Inqiyad Nama or deed of submission that was solemnised in May 1636. The conditions were less harsh than those imposed on Golkonda, where the kbutba was in the future to be read in the name of the Mughal emperor instead of the Safavid emperor of Persia, and the names of the twelve Shici imams had to be replaced by those of the four rightly guided caliphs of the Sunnis (which according to Havart led to a situation in which there were no longer any services at all except in the mosque of the Mughal ambassador in Hyderabad), and the imperial rupee was made the currency of the sultanate. ${ }^{84}$ But also in Bijapur Shah Jahan must have wielded considerable influence not least through Mustafa Khan who was given a land revenue assignment in the newly conquered territories by Shah Jahan, which he held in addition to his considerable holdings in the coastal districts of Bijapur itself. 85

\section{The PATriotic Programme: GoOd GOVERnMENT}

Seen from above, from the vantage point of the court so to speak, and simplifying matters somewhat, there were three ways of collecting the land revenue in the Islamicate states of India. Firstly there was the most indirect

\footnotetext{
82 Sherwani and Joshi eds. Medieval Deccan, 1: 350-9; Badshah Nama in Elliot and Dowson, History of India, 7: 30-1; NA, Diary of Van Twist sub dato 9.2.1637, VOC 1122: 480; Rafi Ahmad Alavi, Studies in the History of the Medieval Deccan (Delhi, 1977) 63-72.

${ }^{83}$ Van Twist, "Generale beschrijvinghe," 72-3.

84 Sherwani and Joshi eds. Medieval Deccan, 1: 358-9; Sherwani, Qutb Shabi, 436-7; Havart, Persiaansche secretaris, 70-2; Verma, "Muhammad Nama," 91-5.

85 Van Twist, "Generale beschrijvinghe," 73-4; NA, Diary Van Twist 24.2.1637, VOC 1122: $487 \mathrm{v}$.
} 
way, through tribute collection from the zamindars, also known as samasthan rajas in the Deccan. Secondly there was the indirect collection through the assignment of temporary fiefs (known as jagir in the Mughal empire and as muqasa in the Deccan) in lieu of military or other service, or through the farming out of the land revenue collection for a lump sum payment. Thirdly, there was the more direct form of land revenue administration sometimes known as zabt. 86

The forms of the second category were the most common. They were generally condemned by contemporary Europeans as a nuisance and detrimental to the peasantry as well as to merchants, the idea being that because of the quick turnover the farmers and assignment holders would not have any long-term interest and would pluck their temporary holdings for what they were worth. ${ }^{87}$ The strongest articulation of the view of the revenue system of - in this case - Golkonda as exploitative is the following, with reference to the cultivation of the chay root (used to make red dye for painting cotton textiles) at Petapoli and the governor who farmed the right to tax its proceeds:

This chay-root is found on the island on the other side of the river opposite the city, it falls into no hands but the governor's, who pays a high rent over it. Almost no-one dares trade with us [VOC personnel] in coloured textiles without his knowledge, because they have to work for him since he usually pays his rent to the king in textiles, which are subsequently sent to the king of Persia and sold there; so that the Gentu is heavily subjected to this governorate through much oppression. ${ }^{88}$

This was an extreme view of a tiny section of the sultanate of Golkonda, and that too, a section which cultivated a sought-after commodity and was situated very close to Golkonda's gateways to the expanding world-market of the early-modern period.

What also transpires from the above quotation, however, is that differential capabilities for different groups were woven into this early capitalist system. That much also appears from a Dutch report of the year 1636, in which the Dutch factors at Petapoli complained about the farmer of the Masulipatnam region Mir Muhammad Sahih (with whom the English made some overtures to have the Dutch ejected from the area in the last chapter). "Seeing that he had a rent of 180,000 hons on his neck and the year [i.e. his term] was expiring he started scrubbing outrageously in all directions, including our direction." That is, he tried to extort money from

\footnotetext{
${ }^{86}$ For a still useful discussion of the term zabt see W.H. Moreland, The Agrarian System of Moslem India (1929; photogr. reprint Delhi, 1990) 234-7.

${ }^{87}$ For two contrasting modern receptions of these seventeenth-European views, see: Irfan Habib, Habib, The Agrarian System of Mughal India (1556-1707) (London, 1963) and Sanjay Subrahmanyam, "Aspects of State-Formation in South India and Southeast Asia," IESHR 23 (1986) 357-77.

${ }^{88}$ NA, Description of Masulipatnam and Petapoli by Kint 2.3.1615, VOC 1062: 44v.
} 
weavers and merchants who had traded with the Dutch because he did not have any income from the VOC trade itself, since that was covered by a forfeit directly to the sultan. According to the Dutch report Muhammad Sahih burst out in anger "that we [Dutch] and the ambassadors (by which he meant the ambassadors of the Mughal, and of the Persian king, who trade here largely as they wish and bring him little income) were the cause that he could not realise his considerable rent." Apparently he had miscalculated and overlooked the patchwork of privileges and extraterritorialities that applied to his governorate..$^{89}$

The differential capabilities are also apparent in an undated Adil Shahi farman in response to a petition by a Bijapur barber named Muhammad Ali (probably a Deccani Muslim) who made the case that the levy of certain duties from the barbers was unwarranted because the barbers were poor and because "in Khorasan and the city of Bidar nothing is taken from the workmen." 90 The comparison to nearby Bidar is unsurprising, but the reference to the situation in the Iranian region of Khorasan as a standard is interesting. ${ }^{91}$

Moreover, it was not only Europeans who thought of the system of assignments and especially farms as less than ideal. If we return to the year 1636, we see that, according to a Dutch source, the peasants around Surat were complaining about the intolerable extortions of the farmer of the area and that the amount of land under cultivation was diminishing. This farmer (bakim) was Masih uz-Zaman, whom we have met as a wellwisher of the Dutch in the last chapter. The Mirat-i Abmadi chronicle reported for the same year that the Saurashtra peninsula opposite Surat had been turned into a ruin on account of the unfitness (na-rasa') of the hakims and was given in tiyul, a type of holding under less financial pressure than a farm. A few years later Shah Jahan also rearranged the government of Surat into a form of direct administration by salaried officials (according to English and Dutch sources) and issued a farman to the subadar of all of Gujarat by which he was recalled on account of the continuous reports of the "ruination [kharabi] of province of Gujarat and its flock [ri'ayat]." 92

Efforts to bring land under zabt were generally applauded in the Deccan, while such efforts seem to have become a speciality of the Habshi

\footnotetext{
${ }^{89}$ NA, Letter Masulipatnam to Batavia 25.7.1636, VOC 1119: 1139-40.

90 The farman is inscribed on a stone now in the Bijapur Museum. Nazim, Bijapur Inscriptions, 85-6.

${ }^{91}$ Farmans often incorporated phrases from petitions that could be quite damning to the lower reaches of the administration. See, for instance, the next paragraph and the farman to the Dutch about the jisya in Chapter 5.

92 W.H. Moreland, From Akbar to Aurangzeb: A Study in Indian Economic History (1923; photogr. reprint Delhi, 1990) 251; Ali Muhammad Khan, Mirat, entry for the year 1045 and transcription of farman to A'zam Khan 12.1.1052/12.4.1642 (translation) 183, 191; (Persian text) 1: 210, 217-9.
} 
officers of the sultanates. Ahmad praises one of the maliks of the sultan of Golkonda named Malik Ambar for bringing a large district (worth 100,000 hon) under zabt around 1629,93 and it is not unlikely that he had the example of his famous namesake, the Malik Ambar of Ahmadnagar, in mind. The latter had undertaken a great reform of the land revenue collection, perhaps with an eye to the system of direct administration of the land revenue established on some scale, again thirty years before him, in the Mughal empire by Akbar's Hindu minister Todar Mal, though there is no direct evidence of such a connection. In fact, all the evidence we have of Malik Ambar's reforms is indirect and of a later date, though nonetheless compelling. His reforms were referred to as a standard in Maratha tradition as well as local revenue documents, one of which (dated 1678) spoke of Malik Ambar's method of assessing the yield of arable lands as the basis for direct taxation. It seems that Malik Ambar's reforms were well received, because he was remembered fondly in the region in the time this document was drawn up. And as will be seen in Chapter 6, direct administration was to remain an important item on the patriotic agenda. ${ }^{94}$

There is no evidence that Khawas Khan attempted any similar reforms, but we can see something of the difference between his programme and that of Mustafa Khan transpire in their respective great works. Khawas Khan had a tank constructed at Mamdapur, south-west of Bijapur, which for a long time was to remain the largest man-made reservoir in the western Deccan. It was completed in 1633, just after the famine that struck the western Deccan and Gujarat. Mustafa Khan had a caravanserai constructed in Shahpur. Though both projects were dedicated to the public - in fact the inscription on Mustafa Khan's explicitly offers the sara" $i$ to "the res publica of mankind, both high and low [jumbur-i anam az khawass-o-'awamm]" - they were to serve different publics so to say, the one composed of travellers and foreigners, the other of peasants and tillers of the land. ${ }^{95}$

Moreover, Khawas Khan wanted to be seen as a wise administrator by the common people, and thought he could rely on their support. The inscription on the revetment wall of his lake likens him to Asaf, the wise minister of Solomon in Islamic lore, and did not fail to mention that the construction cost 50,000 hons. Van Twist wrote in two places that Khawas Khan governed "very wisely" and that when events precipitated towards his

\footnotetext{
93 Ahmad, Hadiqat, 85.

94 B.G. Tamaskar, The Life and Work of Malik Ambar (Delhi, 1978) 258-81; Moreland, Agrarian System, 182-3. This is not to say that the land was precisely measured in Ambar's system. See Tamaskar, ibidem and Alavi, Studies, 63-72.

95 Inscription on the caravanserai at Shahpur 1050 AH/1640-1 CE in Nazim, Bijapur Inscriptions, 75; Inscription on the dam at Mamdapur 1.1.1043 AH/8.7.1633 CE, translated in Cousens, Bijapur, 89.
} 
dismissal as prime minister, with the force of 30,000 horse approaching the city, he decided to kill the king "and to have himself declared king by the commonwealth [gemeente] (by which his mildness and good government was much loved)." Ironically, his killer Sidi Raihan was also much loved by the common man according to Van Twist, "for his bravery and friendly attitude." 96

Another irony is of course that Khawas Khan's war effort had the perverse effect of destroying the land more than the peace deal with the Mughals closed by Mustafa Khan, which Van Twist thought prudent, and that it took the direct administration of the land revenue under the new viceroy of the Deccan, Shah Jahan's son Aurangzeb, yet to become the most expansive of all Mughal emperors, to make the north-western Deccan flourish again for the time being. ${ }^{97}$

\section{THE Role OF THE MONARCH AND HIS CONSORT}

The role of the monarch of a cosmopolitan state was to balance the factions at his court and the various groups in his realm, at the risk of becoming a puppet in the hands of one of the factions..$^{98}$ In Ahmad's Hadiqat one can trace very clearly the efforts of the Qutb Shah to balance the various groups. Each time Abdullah gave high positions to Westerners he also gave some to Deccanis. When he planned to send an army against Murari it was composed explicitly of Muslims (Musalmanan), but some Hindu sardars (sardaran-i Hindu) were added as well. The Malik Ambar of Golkonda who brought a district under zabt was also applauded for raising a mixed force composed of "Westerners and Deccanis and Pathans and Rajputs." 99 Muhammad Adil Shah likewise tried to keep a balance. The words of a Bijapur official likening the realm to an enclosed wilderness have already been mentioned at the beginning of this chapter. Van Twist gave the following description of the sultan himself:

The king Adil Shah is a short reasonably well-built and solid man, aged about 24 years, black-white and of pale complexion, of amiable conversation, and most friendly both to foreigners and to his subjects. ${ }^{100}$

Muhammad was, however, constrained by his nobles as well as, after May 1636, by Shah Jahan. A strange incident occurred on the first Id after the imposition of the Inqiyad Nama. After Muhammad, seated on a bastion of

\footnotetext{
${ }^{96}$ Cousens, Bijapur, 89. Van Twist, "Generale beschrijvinghe," 70-4.

${ }_{97}$ Van Twist, "Generale beschrijvinghe," 72-3; Alavi, Studies, 63-72.

${ }_{98}$ Compare Eaton, Social History, 76.

${ }^{99}$ Ahmad, Hadiqat, 85, 110-1.

100 Van Twist, "Generale beschrijvinghe," 69.
} 
the citadel hung with gold drapes and tapestries, had received the salaams of the great and the small on the $26^{\text {th }}$ of February 1637 , on the $27^{\text {th }}$ "all the grandees of the realm with their retinues made up most elegantly rode out to the palace to accompany the king to the masjid or church in which he used to perform his religion and prayers of thanksgiving for the completion of the days of fasting (but his majesty for I don't know what obstacles) stayed in the court without going out to the amazement of the common people, who had gathered with a thousand both on foot and on horseback in front of the square of the castle to accompany his majesty." ${ }^{101} \mathrm{Had}$ a dispute over precedence arisen with the Mughal ambassador? Was the Mughal ambassador making demands as to the content of the kbutba (sermon)? These would be the most likely explanations.

During the prime ministership of Mustafa Khan the Adil Shahi state embarked on a series of campaigns to the south, and the victories in these wars allowed Muhammad to style himself ghazi, a fighter on the frontier of Islam, for which role he was greatly lauded in the Muhammad Nama. ${ }^{102}$ A typical Mubammad Nama verse commemorated an occasion, not long after Mustafa Khan's restoration, when Muhammad himself delivered a khutba in the mosque:

he sowed strength and likewise the foundation of Islam that the pulpit became throne and the preacher king. 103

Mustafa Khan was closely involved with the commission of the book from Zuhur bin Zuhuri, and he gave him a copy of the Tazkirat ul-Muluk by Rafic ud-Din Shirazi, an Iranian immigrant to the Deccan, perhaps to serve as a template. The Akbar Nama by Akbar's minister Abul-Fazl served as a negative. When once someone praised that book at the court, Zahur raised his voice and said "Akbar Nama is really a specimen of literary productions, decorated with figures of speech and rhetoric, and written in a learned style, but my Muhammad Nama is characterised, from cover to cover, with the glorification of God and praise of the Prophet, not to be found in the Akbar Nama, in addition to the literary merits and embellishments." Upon which the sultan sent for a copy of the Akbar Nama from the library and

101 NA, Diary Van Twist sub datis 26 and 27.2.1637, VOC 1122: 488.

102 Compare Verma, "Muhammad Nama," 96-7. Muhammad's use of the title Ghazi is well attested, also outside the Muhammad Nama. See e.g. the inscriptions on pages 42, 54-5, 75-6, 81-2 and 89 of Nazim, Bijapur Inscriptions.

103 Qawi kisht anchunan bunyad-i Islam / ki mimbar takht wa wa'iz badshah shud. PSA, Muhammad Nama, Persian Ms. M/727, around fol. 163. These are two lines of an eight-line poem. The khutba was held on a Wednesday in Muharram, so it was not the usual Friday service khutba. The occasion seems to have been the inauguration of the new mihrab already referred to above. See also Mark Brand's forthcoming dissertation. 
likened it to the Mahabharata, the famous epic and source of inspiration for Hindu devotion. ${ }^{104}$

A balance was, however, maintained. On the occasion of the Hindu festival of Holi 1637, Mustafa Khan and other nobles went to pay their salaams to the sultan, though not on as grand a scale as during the Id after the fast. Moreover, "the queen has the custom on this occasion to have all the most prominent ladies of the court and the city called with her, who buy from some of the wives of merchants or jewellers (thereto despatched) all kinds of rarities and precious objects which is paid for by his majesty and makes for a considerable damage." So the palace was giving off mixed signals, in which the Id of Ramazan was the men's holiday and Hindu festival of Holi was the women's holiday, at which the sultan indulged the women of the town (which was not for want of funds on Khadija Sultana's part because she did have her own revenue assignment in the district around Raybagh). The masculine Islamic holiday was celebrated outside by the royals, the feminine Hindu holiday inside. ${ }^{105}$

Nevertheless, the slight shift away from the syncretism of Ibrahim was visibly present in Muhammad's rule after the death of Khawas Khan, if only in the change of styles. Ibrahim included among his titles the Sanskritic "Guru of the World," while Muhammad styled himself a second Muhammad in his coinage. ${ }^{106}$ It appears that, after Mustafa Khan breathed his last during one of the campaigns to the south in 1648, his position was taken over by Afzal Khan, who was to become a famous figure in Maratha lore as the first arch-enemy of Shivaji and a destroyer of temples. Not long after the demise of Mustafa Khan we find a qaul nama of this Afzal Khan inscribed in stone, according to which he had procured a farman from the sultan for "the jewellers as well as the collective of castes [aqwam, plural of qaum] of the Hindus [Hinduan]," giving them the right to dispose of the property of those who died without issue as they saw fit, instead of it falling to the crown as before. In the inscription he is referred to as a believer in the faith and breaker of armies (dindar sipab shikan). It is sometimes argued in the secondary literature that the Muslim rulers and officers of India varied their tone in matters religious with the choice of language, ${ }^{107}$ which is

104 Verma, "Muhammad Nama," 108-10; Sherwani, Qutb Shabi, 684-5.

105 NA, Diary Van Twist sub datis 11, 23.3.1637, VOC 1122: 493, 499v. For the inside and outside spheres as feminine/Hindi and masculine/Persianate respectively see also Shantanu Phukan, "The Rustic Beloved: Ecology of Hindi in a Persianate World," Annual of Urdu Studies 15, no. 1 (2000) 3-30.

106 The epithet Jagat Guru can be seen on the headband of Ibrahim in a contemporary miniature portrait, reproduced in Zebrowski, Deccani Painting. Most of the coins of Muhammad's reign read: "The world received beauty and dignity from two Muhammads; the one is Muhammad the apostle and the other Muhammad Shah." A rare (perhaps earlier?) type refers to Muhammad Adil Shah alone. Goron and Goenka, Coins, 316-8.

107 E.g. Brajadulal Chattopadhyaya, Representing the Other?; Sanskrit Sources and the Muslims (Eight to Fourteenth Century) (Delhi, 1998) 77-8; Eaton, Social History, 68. 
not improbable, but in this case the slightly later Marathi version of this grant of rights is even stronger, Afzal Khan becoming dindar as well as kufr shikan "breaker of infidelity." Thus this by-law was marked as a favour across boundaries, however well connected to the royal house the recipient jewellers were. ${ }^{108}$

\section{CONCLUSION}

It was noted in Chapter 1 that many Dutchmen incorporated Muslim elite views in their writings on India. In this chapter, however, we have seen that they also incorporated some views that may be called "subaltern." The Dutch factors witnessed the workings of the revenue system from close by and from below, even though they were themselves among the elite groups that managed to partly deflect taxation. Van Twist's view of Khawas Khan was entirely different from that presented by the court chronicles of Muhammad Adil Shah and Abdullah Qutb Shah. Being put up in the house of one of the men who were killed along with Khawas Khan perhaps made Van Twist more curious to know about the events that had unfurled just over a year previously and had resulted in the vacancy of that house. It also seems that he relied not only on the testimony of the Englishman Treijbeck who had served with Khawas Khan before he came into the service of Mustafa Khan, but also on that of Ibrahim Agha/Pieter Sachariassen who was a common soldier and had played a minor role in events when he was sent to defend the fortress of Parenda against the Mughals by Khawas Khan along with the other "captive Dutchmen."109 In Van Twist's version there is a reflection of a measure of popular support for Khawas Khan and Murari, something that the court chronicles will not allow. Only if one reads those chronicles against the grain one begins to wonder why Murari was meted the severe punishment and public humiliation that he was, and whom Khawas Khan was supposed to have betrayed the sultan to if he deserved the qualification haramkwor (eater of someone else's salt). Van Twist's statement about the fear that Murari would raise an oploop or popular revolt makes explicit Zuhuri's note that the corpse of Khawas Khan had to be displayed outside and his house destroyed to forestall fitna. ${ }^{110}$

108 Inscriptions dated 22.1.1063 AH/24.12.1652 CE and 27 Shawwal 1053 Shuhur San/20.9.1653 CE in Nazim, Bijapur Inscriptions, 81-2. But-shikan or idol breaker was already used as an epithet of Afzal Khan by 1649, see the inscriptions on an anonymous tomb at Rahmatpur 1059 AH/1649 CE, ed. and trans. M. Nazim in Epigraphia Indo-Moslemica (193334) $58-9$.

109 Van Twist, "Generale beschrijvinghe," 72; NA, Diary Van Twist sub dato 13 and 15.2.1637, VOC 1122: 482, 483v.

110 PSA, Mubammad Nama, Persian Ms. M/727, 154. Zuhuri also applies the term fitna to Khawas Khan's actions on fol. 148v. For Van Twist's narrative see above. 
The struggle between Mustafa Khan and Khawas Khan was not a struggle between Deccanis and Westerners in the way that the struggles at the Bahmani court were. In the course of the seventeenth century, the Deccani identity became more inclusive and truly patriotic. It became a label for Muslims like Khawas Khan and Ghawwasi who espoused a programme of decreasing the distance between the elites of the sultanates and the commoners, which categories corresponded to a significant extent to the categories of Muslims and Hindus. Hence Zuhuri's complaint that Khawas Khan gave precedence to the infidels (jama'at-i kufar) over the collective of faithful God-honouring men (jumlat-i dindaran-i khuda parast). ${ }^{111}$ The boundary between Deccanis and Foreigners was relative to the boundary between Hindus and Muslims, and being a Deccani was to an extent a choice of positioning oneself closer to that boundary. Other elements that played a role in Deccani identification with the local were language and skin colour and in some cases Shici symbolism. Deccani identity was relative to all these markers, though not necessarily at the same time.

Seeing the struggle between Deccanis and Foreigners at this period as a conflict between (at least partly conscious) strategies of inclusion and distancing also helps explain the slight retrenchment of Islamic orthodoxy at the court that became palpable after the death Khawas Khan. ${ }^{112}$ To quote Zuhuri once more: Muhammad was now able to turn his realm into a "garden of faith $[\mathrm{din}]$ and fortune". ${ }^{113}$ The consciousness of this development was also seen in the discussion at Muhammad's court about the relative merits of the Akbar Nama and the Muhammad Nama. But this is not to say that these strategies were wholly rational. The insights offered by the psychology of group behaviour into situations of shifting power balances, such as that caused by Khawas Khan and Murari Pandit, will be elaborated in Chapter 6. The decades that followed saw the rise of a new Foreign faction at Bijapur, not dominated by Iranians as before, but by Afghans. The rise of the Afghans at Bijapur gave a new impetus and shape to the centuries-old struggle between Deccanis and Westerners, as will be seen in Chapter 4.

111 PSA, Muhammad Nama, Persian Ms. M/727, 147v.

112 This retrenchment has also been noted by Eaton in Sufis of Bijapur, 194-201 and Verma in

"Muhammad Nama."

113 PSA, Mubammad Nama, Persian Ms. M/727, 154v. 


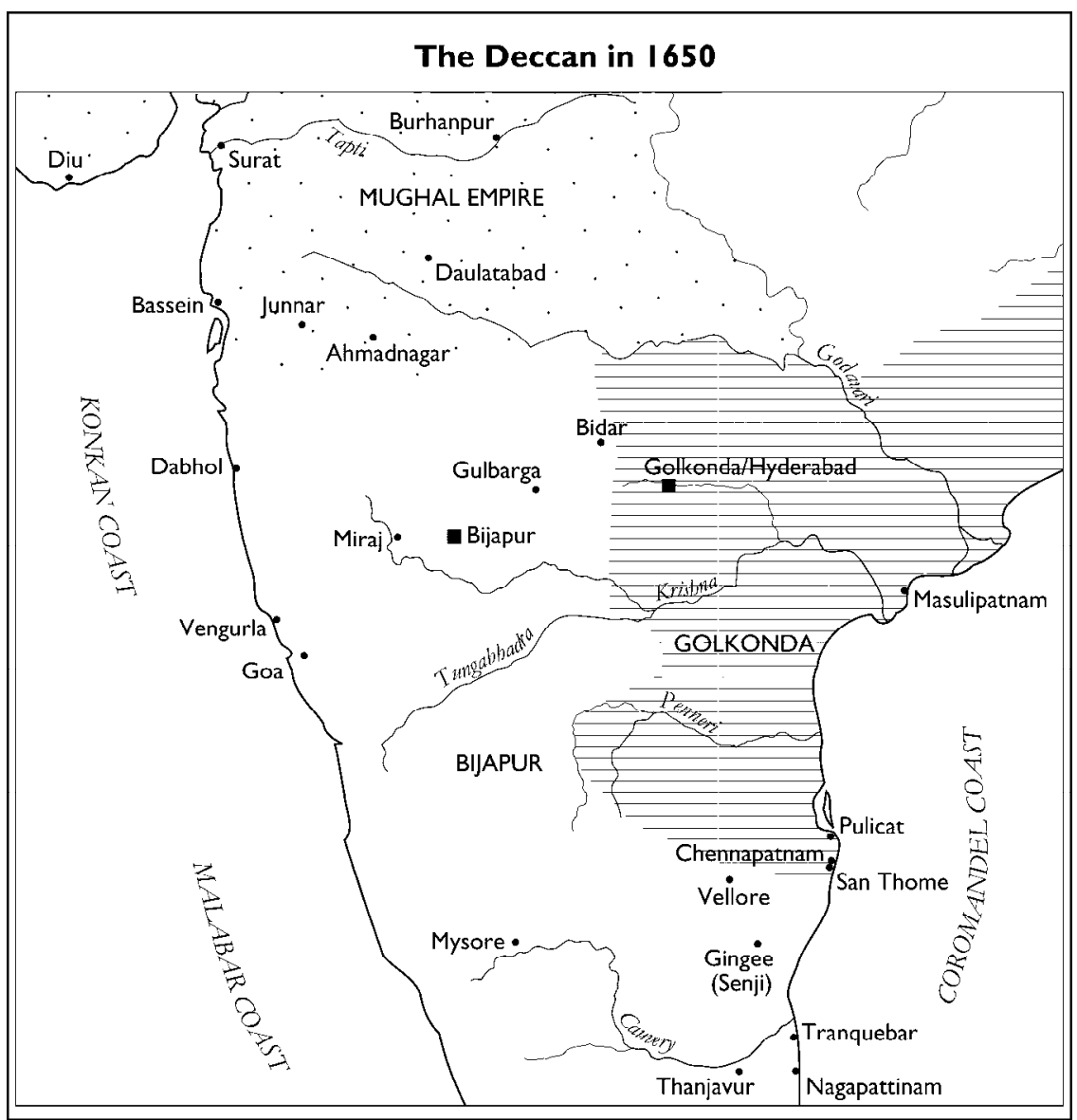




\title{
THE RIGHT AND LEFT HAND DISPUTES IN CHENNAPATNAM IN 1652-55: A MINIMAL GROUP EXPERIMENT IN SEVENTEENTH-CENTURY INDIA?
}

\begin{abstract}
We must, therefore, glean up our experiments in this science from a cautious observation of human life, and take them as they appear in the common course of the world.
\end{abstract}

David Hume, A Treatise of Human Nature ${ }^{1}$

\section{INTRODUCTION}

The town of Chennapatnam, today's Chennai, was for a long period best known as Madras, after the village where the English established a fort at the same time as the town was founded. The lives of the fort and the town were very much intertwined as will be seen presently. They were established in the remaining area of the once formidable Vijayanagar kingdom, but in 1647 what was left of the kingdom was conquered by Golkonda. With that, Chennapatnam became part of the Deccan as it was defined it in the Introduction. Another reason to consider Chennapatnam as part of the Deccan, even though today it is not considered as such, is the fact that the majority of the population was Telugu speaking, or as Fryer noted around 1673, "they are of the same nation with Metchlapatan [Masulipatnam]."2

Among the social divisions in the town was that now known as caste, which I am defining for the purpose of this study as any named status group of which membership was generally perceived to be based on descent. The term "caste" was at the time already in use by Europeans as a translation of the South Indian usage kula or kulam, as is evident from a Tamil Grammar by an anonymous Dutchman based in Coromandel, who noted that kulam meant "a caste, or lineage."3 Contemporary Europeans also used the term "tribe" for what we now call caste, and on occasion the

${ }^{1}$ David Hume, A Treatise of Human Nature, ed. David Fate Norton and Mary J. Norton (Oxford, 2001) 6.

2 Quoted in H. Davison Love, Vestiges of Old Madras (London, 1913) 1: 285. Compare Thomas Bowrey, A Geographical account of the Countries Round the Bay of Bengal, 1669 to 1679, ed. Richard Carnac Temple (Cambridge, 1905) 6. Richard Eaton, following the more implicit definition Firishta laid down around 1600, defines the Deccan as the area encompassed by the linguistic regions of Telugu, Marathi and Kannada. Eaton, Social History, 2.

3 "Kulam; koelam: een kaste, of geslacht." Universiteitsbibliotheek Utrecht, "Grammatica Linguae Malabaricae,” Hs. 1479 (1.E.22): 22. 
term "nation," but the latter only for larger interregional castes such as Brahmins, Rajputs and Baniyas. ${ }^{4}$ Especially when addressing themselves to a readership in Europe, Europeans sometimes preferred to use "tribe" even when they were familiar with the Portuguese-derived word "caste." François Martin, for instance, when copying the content of a letter by a Mr. Guesty from Hyderabad into his memoirs, replaced the latter's "bramens...autres castes de gentils" with "brabmes...autres tribus des gentils." 5 This chapter is, however, not so much about caste as about caste clusters. In the years under consideration here the castes in Chennapatnam, together with various individuals, became bitterly divided in two clusters under the headings of "Left Hand" and "Right Hand."

My initial impression of the main sources for this chapter was that they did not mesh with the view of the scholars who holds that caste and more especially ranked caste clusters in India were more or less invented by the British (see the Introduction), but then I stumbled across an astonishingly literal confirmation of this notion of "invention" — and that too in an environment where the English had some power - in a statement drawn up in 1654. ${ }^{6}$ There, the "Painters, Weavers, etc., inhabiting Chanapatnam" stated that the Brahmins Venkata and Kanappa, who held important positions in the town, "made the distinction on Right and Left Hand which hath beene noe small disturbance in the towne," by obtaining a ruling from the English factory president concerning the dissension between Right and Left. ${ }^{7}$ But what does this mean? Does this mean that English set about dividing and ruling from the moment they set foot in India, or does it mean that it takes very little to get people to divide themselves into two bitterly opposed camps, even in precolonial India? More concretely, who was the active agent here: the Painters and Weavers

${ }^{4}$ This will be seen in some of the quotations in this and the following chapters. See also my discussion of the term "nation" in Chapter 4.

${ }^{5}$ For Guesty's letter and Martin's rendering of it, see Chapter 5.

${ }^{6}$ This chapter is built around documents preserved in the archives of the English East India Company. Contrary to what most historians believe, not all the EIC archival material relating to seventeenth-century Chennapatnam has been printed. William Foster's English Factories in India, 13 vols. (Oxford, 1906-1927) (hereafter EFI) has useful summaries with fragmentary excerpts from most of the documents in the so-called Original Correspondence, while Love's Vestiges of Old Madras (hereafter VOM) has long excerpts from many documents of that and other series. However, there are many things of interest

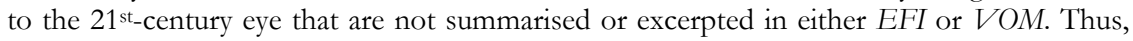
since most documents used here are represented in EFI or VOM in some way, references are here as much as possible to those edited versions, but only when they contain the relevant information. This leads to the situation that some references to a particular document are to (one of) the original manuscript version(s) while other references to the same document are to either one of the edited versions.

7 EFI, Declaration of the Painters, Weavers, etc. ca. 12.12.1654, [9]: 240 (my italics). This statement is also noted by Arjun Appadurai, "Right and Left Hand Castes in South India," IESHR 11(1974) 216-59, there 250. 
who felt wronged, the accused Brahmins or the English who were implicated in the accusation? And what about this notion of "invention"; how can that be when we know the distinction between Right and Left Hand was made in inscriptions well before the 1650s?

Burton Stein, in fact, traces the division back to the tenth or eleventh century. It occurred in the Tamil, Telugu, Kannada and Malayalam language regions of South India, but seems to have found its strongest expression in the Tamil country and the bordering areas to the north and north-west. ${ }^{8}$ In our sources the two divisions are often designated by the terms Balija-varu and Beri-varu (varu designating any group or collective) or rather their Anglo-Indian renderings "Belgewar" and "Berewar," the first using what seems to be a derivative of the Telugu term for right hand, ${ }^{9}$ the second bearing the same epithet as its leading caste of the Beri Chettis (perhaps because the label "Beri"10 was more desirable than "Left Hand," because the left hand carries negative connotations).

The EIC sources sometimes refer to the Right and Left Hand divisions by the term "castes" or "generall casts". ${ }^{11}$ Yet the term "caste" was also used, as has already been noted, to designate the smaller groups that constituted the Right and Left Hand as in the phrase "the Right Hand parties, or principalls of the Right Hand casts." 12 The use of the same term "caste" (perhaps following the use of the term kula) ${ }^{13}$ for groups of different magnitudes continued into the present in which caste is used to designate both the myriad groups also known as jatis and the four large categories also called varnas. In the following discussion the term caste will

\footnotetext{
8 Burton Stein, Peasant State and Society in Medieval South India (Delhi, 1980) 174-5; Brenda E.F. Beck, "The Right-Left Division of South Indian Society," JAS 29 (1970) 779-98, there 783.

9 Various etymologies are given in the literature for the term Balija, which in later centuries became the name of a caste in its own right (see below), the most common is that the term would be derived from Sanskrit bali (sacrifice) and ja (born). It is, however, more likely that the term is related to the Telugu vala ceyi, taking into account that in later centuries and most Balijas were Telugu speaking and considering the morphological complex derived from the Dravidian root val-which connotes such things as skill, excellence, possibility, right, possible, convenient and includes such derivatives as Tamil valiya strong, big; valiyan strong, powerful, skilful man, Telugu vali big, large; baliyu to grow fat, increase. http://starling.rinet.ru (Tower of Babel database; accessed 12.4.2006). Compare Edgar Thurston, Castes and Tribes of Southern India, 7 vols. (Madras, 1909) s.v. Balija. Contrast Niels Brimnes, Constructing the Colonial Encounter: Right and Left Hand Castes in Early Colonial South India (Richmond, 1999) 255. Mattison Mines also seems to see Balija as a mere rendering of Right Hand. Mines, The Warrior Merchants: Textiles, Trade and Territory in South India (Cambridge, 1984) 45.

10 The etymology of which is somewhat obscure. See C.S. Srinivasachari, "The Origin of the Right and Left Hand Castes Divisions," Journal of the Andhra Historical Research Society 4 (192930) 77-85; Thurston, Castes and Tribes, s.v. Beri Chetti.

11 VOM, Letter Baker, Gurney, Winter, Leigh to Surat 5.2.1653, 1: 120.

12 VOM, declaration of the Right Hand caste principals April 1655, 1: 122.

13 Talbot also refers to the different levels of social organisation to which kula can refer, but on the whole chooses to render it as clan rather than caste. Talbot, Precolonial India, 53.
} 
be reserved for the smaller groups, except in some quotations from the sources. The Right and Left Hand will be referred to as divisions or parties.

Over the past thirty-odd years there has been a debate of sorts about the interpretation of the division in South Indian society. Most cited are Brenda Beck and Burton Stein, who have argued that the division reflected a tension between landed, agricultural, interests on the one hand and commercial and artisanal interests on the other. That explanation can be traced back to the late-nineteenth century and may be called the classic interpretation of the division. ${ }^{14}$ Brenda Beck in her research of Right and Left groups in the Kongu region in eastern Tamil Nadu around 1970 also found that the division expressed itself in two different modes of aspiration to status: this-worldly and other-worldly. The Left division aspired to the ritualistic and renunciatory, Brahminical, mode, with an emphasis on vegetarianism, while the Right division aspired to a kingly mode, in which instrumental activism and meat-eating were required. The Right and Left labels are in this view "in a sense a new set of labels for the old Kshatriya and Vaishya categories," that is the second and third-rung in the ancient four-rung varna system, even though the latter aspired to the Brahmin model, that is to the first rung. The ascribed inferiority of the trading and artisanal groups is, according to Beck, also reflected in the label "left," being inferior to "right."15

Francis Zimmermann and Arjun Appadurai have, however, argued that there is no single property that underlies the appearances of the division over the centuries, which they see as very diverse, and they come to the conclusion that the labels "Left" and "Right" were more or less empty shells. Both see the division as a form that organised social space: there would be no two halves of society without the idea of a whole. The latter is incidentally also true of three of the other antagonisms under consideration in the present study: they are located on a boundary between groups that are supposed to be part of a certain body, namely the Bijapuri state (Ch. 2), the Deccan (Ch. 4) and Golkonda (Ch. 6). In Appadurai's functionalist view, then, the form of the Right/Left classification served to integrate society, an argument that is elaborated by Stein. ${ }^{16}$

Because the content of the division seems so insubstantial, at least to Zimmermann and the oft-cited Appadurai, the case of Chennapatnam in the 1650s may in fact be the closest we can get to a minimal group experiment in the seventeenth century. A minimal group experiment is an

\footnotetext{
${ }^{14}$ Francis Zimmermann, "Géométrie sociale traditionelle; castes de main droite et castes de main gauche en Inde du Sud," Annales E.S.C. 29 (1974) : 1381-1401, there 1387-8 note 14; Appadurai, "Right and Left Hand," 219 note 9.

15 Beck, "Right-Left Division," 779-98.; Burton Stein, Peasant State, 479, 483 note 276.

16 Appadurai "Right and Left Hand"; Zimmermann, "Géométrie"; Stein, Peasant State, 173 and passim.
} 
experimental set-up in which the people involved are divided into groups by means of a marker with which they were not labelled before the experiment, such as white and red tags or invented group names. One of the most famous such experiments was the Robbers Cave experiment in 1953. In that experiment two groups of eleven-year-old boys were housed in two camps not far apart. As soon as the groups became aware of each other, they developed quite an elaborate group culture and set of markers for the in-group and the out-group in the space of four days. The situation in Chennapatnam further resembles such a minimal group experiment in that it was newly founded and saw a rapid rise in population. Niels Brimnes therefore remarks that early Chennapatnam was "a virtual tabula rasa and an ideal battleground for competing groups in South Indian society." ${ }^{17}$ Let us therefore, for a moment, regard early Chennapatnam as a minimal group experiment.

\section{THE NEW TOWN AND ITS STATE OF DIARCHY}

The territory on which the English founded the factory of Fort St. George in 1639 came under the jurisdiction of Damarla Venkatadri who was a nayaka, or military/fiscal agent, responsible to the Vijayanagar dynasty then ruling from Chandragiri and Vellore. According to a Relation written by Thomas Chamber around 1660, the nayaka's brother Aiyappa invited the English (who had been looking for a place on that part of the coast) to settle there so that a town could be founded in the name of his father Chennappa. In a gold plated qaul, the nayaka gave the English the right to build a fortress in or about "our port of Madraspatam," for the building of which he would bear the cost until the English were to move into it. It was an agreement to mutual benefit; the English were to prop up the projected town by attracting trade and acting as a buffer against the Dutch and the Portuguese. As Ankbhupala Damarla, another of the nayaka's brothers, wrote in his Telugu fictional work Ushaparinayam, "the people of Pralaya Kaveri [i.e. the Dutch at Pulicat on the Cauvery river] were incessantly fighting with the Portuguese at San Thome and in order to put an end to that fighting, he [Venkatadri] founded Chennapatnam between them so as to prevent their mutual bickerings." The story of this chapter is thus connected in an unexpected way to the matter of Chapter 1: the antagonism between the Dutch and the Portuguese. ${ }^{18}$

\footnotetext{
17 Brimnes, Constructing, 36.

18 VOM, Thomas Chamber, "A Relation of Severall Passages since the Founding of the Towne of Madrassapatam," ca. 1660-1 (Chamber had been acquainted with the town since 1646) and translation of Venkatadri's qaul 22.7[/8?].1639, 1: 17-8, 188-92; Ushaparinayam quoted in Patrick A. Roche, "Caste and the British Merchant Government in Madras, 16391749," IESHR 12 (1975) 381-407, there 384 note 15; Love's notes in VOM, 1: 69, 176.
} 
In 1645 the Vijayanagar king confirmed and extended the privileges of the English at Fort St. George, while speaking of Chennapatnam as Shri Ranga Rayapatam "my towne," in an apparent effort to rename the town after himself. He granted the English the revenue of Madraspatnam and "the Jackal ground," which together seem to have covered the area south of Chennapatnam. Moreover, he surrendered the "government and justice of the towne" unto the English. However, it is important to stress here against a recurrent error in the extant literature — that Chennapatnam was not founded by the English, nor was it founded on ground that the English held the revenue rights to, let alone possessed outright. ${ }^{19}$ And although Shri Ranga did grant the English freedom from customs on their own goods and half of the customs that were paid in the town by others, Chennapatnam was not then a colonial town. ${ }^{20}$

So the area covered by the original Madraspatnam encompassed only the strip immediately around the fortress — where soon many Europeans came to build houses - as well as the fisherman's kuppam that continued to exist to the south of the fort. ${ }^{21}$ To the north then was the newly founded Chennapatnam and west of that a satellite settlement sprung up, which became known as Peddanaikpetta, or "the village without the towne."

Though not an English foundation or possession, the flourishing of Chennapatnam was of course intimately linked with the English establishing themselves at Fort St. George. From the start the Company personnel and their brokers set about inviting the economically important "painters" (i.e. dyers of the world-renowned Coromandel textiles), weavers and others from San Thome, Pulicat, Armagon, Triplicane and other places in the vicinity.22 While the fishing village of Madraspatnam had amounted to only ten to fifteen houses at the time the English started building the fort, ${ }^{23}$ by the 1670 s the granddaughter of the Damarla nayaka Venkatadri was able to write: "In the time when some of my relations begun to situate the towne of Chinapatam in the name of my grandfathers father Chinapanague, as your Worship's nation is a great and understanding people, and my said relation[s] having favoured and assisted in all what they

${ }_{19}$ Still in 1672, Neknam Khan while reconfirming the rights of the English on behalf of the sultan of Golkonda distinguished between the rights the English held to Madraspatnam and "the Jackal ground," on the one hand and their rights in the town on the other. VOM, Neknam Khan's qaul 23.2.1672, 344 and Love's notes, 1: 346-7. Love represents Neknam Khan's concession as an infringement on rather than an extension of the English rights.

20 VOM, Raja Shri Ranga's qaul (or more properly raja shasana) of 1645, 1: 67 and Papaiya Brahmin's memorandum 1749, 1: 71.

${ }^{21}$ As is evident from a remark about the "duties on the fishermen of Madraspatam" in the petition of 12.12.1654. VOM, 1: 148, see also below.

22 VOM, declaration of the Right Hand principals April 1655, 1: 122.

${ }^{23}$ NA, Letters Pulicat to Batavia 3.3 and 5.4.1640, VOC 1133: 432v, 435. 
could then to your Worship's nation, therefore they did so much with that towne that the name and memory of the said my Grandfathers father is spoken and known so much through all the countries, when your Worships nation have augmented the said towne so much; hereby have resulted so much honor and credit to my grandfathers father['s] ashes through the world." 24

From the time of the qaul of the Vijayanagar king then, the English held the "government and justice" of the town while the revenue administration remained in the hands of a representative of the ruling monarch, which after 1647 was the sultan of Golkonda, or rather his nawab or representative, Muhammad Sa id Ardistani, best known as Mir Jumla. Such a dual division of judiciary and policing duties on the one hand and revenue collection duties on the other was common in Indian states at the time, as will be elaborated for the case of Golkonda in Chapter 6. This division was of course never as strictly implemented as the modern observer would hope, and was in the case of Chennapatnam complicated further by the fact that the English had the right to half the customs, probably to defray the cost of their policing and judiciary duties. The location where the "government and justice" was to be exercised was the chavadi or hall, to which a jail was attached. The post of governor with the power to execute justice over Chennapatnam was delegated by the Company to an Indian, except for an interval at the end of our period. At the other end of the division of powers we hear of the diwan, chief revenue official, who was thus the nawab's chief representative in town. ${ }^{25}$ To complicate matters further it appears that the incumbents of both the latter positions were loosely referred to as adhikari (officer, one having authority), thus one the Company's adbikari and the other the nawab's adbikari.26

There were also a number of functionaries who did not clearly belong to either half of the government or were answerable to both halves. Most important was the town's kanakka-pillai or accountant. Also there were the night-watchmen. In the very beginning there was only a force of 20 peons to guard the town, paid for by the town's inhabitants, but after a few years a corps of talaiyaris was brought in. The talaiyaris were accountable for anything that might be stolen between dusk and dawn and were led by

24 VOM, Letter "Butche Paupana" to William Langhorn 8.3.1672, 1: 347.

25 It is possible that that Persian term diwan was already used in Sri Ranga's qaul, at least so it would appear from an early eighteenth-century translation of the qaul, but it may be that another term was used in the original which was translated with the by 1700 more familiar term diwan. The term diwan was in any case used in Neknam Khan's qaul of 1672. VOM, Transcript of ca. 1789 of early eighteenth-century translation of Raja Sri Ranga's qaul of 1645 and Translation of Neknam Khan's qaul 23.2.1672, 1: 70, 344-5.

${ }^{26} \mathrm{EFI}$, Greenhill's remonstrance to Baker over the Brahmins 1.3.1654, [9]: 236; VOM, Letter Baker to Greenhill 29.3.1654, 1: 133; Love, VOM, 1: 126; Molesworth, Dictionary, s.v. adbikari. 
the pedda nayaka or senior nayaka, the eponymous most important resident of Peddanaikpetta. They seem to have supported themselves mainly with the revenues from some "free grounds" in Peddanaikpetta, but also with some duties. The position of the talaiyaris is referred to as an office in our sources but it is also clear that the Talaiyaris who were brought in had some inherent quality that distinguished them from the "peons" who watched the town before they came and after they were forced to leave, a perceived inherent quality that we may perhaps call caste. ${ }^{27}$

\section{THE PRINCIPAL ACTORS}

The people who benefited most from the space that the diarchy allowed were the Brahmin brothers Kanappa and Venkata who were arguably the two most powerful people in the town in the period under consideration, although the same period also witnessed their fall. Because Kanappa was made adbikari of the town on behalf of the English and Venkata the most important Company merchant (or contractor for the Company), they controlled what power the Company formally held in the town. On that basis, however, they strove ahead and built the crevice between the two governmental structures into a small empire. The "nawab factor" loomed large in the town's affairs and the Brahmins were constantly accused of secret dealings with the nawab, and they in turn accused others of such dealings. ${ }^{28}$ Their contemporaries suspected that it was no coincidence that the rise of the brothers in the town's affairs coincided with troubles attending the takeover of the area by Mir Jumla (which was facilitated by the Damarla brothers' going over to his side), during which the whole of the Karnatak was struck by a famine which is reported to have carried off 4,000 inhabitants of Chennapatnam (compared to a reported 15,000 in both Pulicat and San Thome). ${ }^{29}$

The position of adhikari was merely the crown on a structure of multiple offices in the town accruing to the Brahmins in that period. They are to have cheated a man out of his right to be "measurer" and arrogated his dues. ${ }^{30}$ They also turned the pedda nayaka and the Talaiyaris out of the

27 Contrast Love's notes in VOM, 1: 126-7; BL, Declaration Painters, Weavers, etc. ca. 12.12.1654, E/3/24: 364-9; VOM, 118 points of Venkata and Kanappa 4.4.1654, 1: 142 (date of document given in EFI, [9]: 258); VOM, Greenhill's answer to the 118 points 10.1.1655, 1:145; Thurston, Castes and Tribes, s.v. Talayari.

28 BL, declaration of the Right Hand principals, E/3/24: 229; VOM, Greenhill's remonstrance to Baker 1.3.1654, 1: 130; EFI, 118 points of Venkata and Kanappa 4.4.1654, [9]: 258-66.

29 VOM, Letters Fort St. George to Surat 11.1.1647 and to Company 9.10.1647, 1: 75. VOM, Declaration Painters, Weavers, etc. ca. 12.12.1654, 1: 146-8. EFI, 118 points of Venkata and Kanappa 4.4.1654, [9]: 258-66. VOM, Greenhill's reply to the 118 points 1: 145. VOM, Letter Leigh to Company 20.3.1654, 1: 131; Love's notes in VOM, 1: 127, 273.

30 VOM, Declaration Painters, Weavers etc. ca. 12.12.1654, 1: 148. 
town and started raising the taxes due to them on their own behalf, substituting only a meagrely paid force of peons. The departure of the Talaiyaris was quite a dramatic event and it seems that the Talaiyaris came back from San Thome with a vengeance and a numerous force, blockading the town and taking people hostage, which led to some serious fighting with the Fort St. George troops. ${ }^{31}$ Among the offices the Brahmins gathered in the town were also the caste principalities of the Painters as well as of the "Cooly Painters" and the office of samayam mantri, 32 or minister of the congregation of Right Hand castes.

Ultimately the authority of the Brahmin brothers remained, however, a delegated authority and they partly depended on the favour of the English at the fort, especially after they had antagonised the Painters. They seem to have inherited that favour from their father who they claimed served the Company for forty years. ${ }^{33}$ In most of their doings Venkata and Kanappa seem to have enjoyed the full support of the "Agent" of Fort St. George Thomas Ivie. Henry Greenhill, who replaced Ivie in 1648, initially did not really assail their position but favoured other brokers more. As they later claimed, however, the prominent broker Seshadri, along with the Painters and the Talaiyaris as well as the kanakka-pillai, "raised stories against us to overthrow us, which the Agent examined not," upon which they fled to San Thome, "for being oppressed." Greenhill sent people to persuade them to return, which they did. ${ }^{34}$ That was not long before the arrival of the next head of Fort St. George, Aaron Baker. ${ }^{35}$ He was styled "President" and, like Ivie, favoured the Brahmin brothers over other eminent personalities in the town. But after it transpired that they, like many others around the fort, owed the Company money, their position became more tenuous. Greenhill apparently even offered to pay the Venkata's debt if he were to be handed over to him for investigation, but Baker refused. ${ }^{36}$ Greenhill's offer more or less compelled Baker to act, however, and in October 1653 Venkata and Kanappa were confined to the

31 VOM, Declaration Painters, Weavers etc. ca. 12.12.1654, 1: 146-9; VOM, Fort St. George to Portuguese at San Thome 27.10.1646 and Greenhill's reply to the 118 points 10.1.1655, 1: $77-8,145$.

32 BL, Declaration Painters, Weavers etc. ca. 12.12.1654, E/3/24: 364-9. The text has "Samiam Mantre" and "Samiamantre," which Foster (EFI, [9]: 238) renders as (Tamil) samyam-manthiri, minister of the faith. Kanaka Durga defines samaya as "socio-religious and economic congregations of the guild" that uphold a samaya dharma. P.S. Kanaka Durga, "Identity and Symbols of Sustenance: Explorations in Social Mobility of Medieval South India," JESHO 44 (2001) 141-74, there 152. See also Talbot, Precolonial India, 268 note 55.

${ }_{33}$ EFI, 118 points of Venkata and Kanappa 4.4.1654, [9]: 258-66.

34 VOM, Declaration of the Right Hand principals April 1655 and 118 points of Venkata and Kanappa 4.4.1654, 1: 122, 142, 144.

35 BL, Declaration Painters, Weavers etc. ca. 12.12.1654, E/3/24: 364-9.

36 EFI, Leigh's answer to Baker's protest against him 17.2.1654 and Letter Leigh to Company 20.3.1654, [9]: 230, 245-6. 
fort, but under a regime that Baker's English opponents found far too relaxed, and the brothers seem to have gone about their business more or less as usual. ${ }^{37}$

Meanwhile, the Right-Left dispute had erupted in full force. The role of the Brahmins in that dispute was one of the main elements in the charges the Painters and other Right Hand casts brought against the Brahmins in a series of petitions, but there were also many other charges of a diverse nature. After Baker departed, the charges that the Painters and Weavers had brought against the Brahmins in December 1654 were examined at a hearing presided over by Greenhill, with all parties present. The Brahmins confessed some charges and denied or extenuated many others, but were still found guilty of most of the charges on the testimony and evidence brought by the Painters and Weavers as well as by the Brahmin priests of the central temple, which meant the end of their career in the town. ${ }^{38}$

Like the Brahmins of the town, the English were also distributed over the two camps that came to exist in the town. Henry Greenhill had spent much time on the Coromandel coast since he first came to India in 1632, and served the Company at Fort St. George from 1642 until 1646 and again from 1648 onwards. William Gurney had similarly spent some time on the coast, and he was a staunch supporter of Greenhill against Baker and the Brahmins until his death in 1653. William Gurney's son John married Greenhill's daughter and lived in the town, though not employed by the Company. ${ }^{39}$ Baker on the other hand was very much an outsider, and he tried to strengthen his hand by bringing in other outsiders. He wrote to Masulipatnam, desiring Christopher Yardley, Edward Winter and John Leigh to repair to Fort St. George. Yardley did not come, but Winter became a loyal supporter of Baker along with James Martin, captain of the soldiers at the fort. Leigh, who seems to have been rather old even while he had come to the coast recently and spoke no languages, became very loyal to the opposing party. Baker also had a staunch supporter in Anthony Baker, his cousin or nephew. Yet on the council the Baker party was still a minority (two to three) and he found it pointless to bring anything to vote that had bearing on Greenhill, Gurney or Leigh or their Indian brokers, "for they are so lincked and combined together that I were better holde my peace then meddle with them," and the Brahmins suggested at various points that Greenhill, Gurney and Leigh were afraid that they would reveal their secrets to Baker. Yet William Gurney died in September 1653 and was

37 EFI, Protest by Baker against Leigh 16.2.1654, [9]: 229-30. EFI, Leigh to Company 20.3.1654, [9]: 245-6 and same document, VOM, 1:131-2.

38 BL, Public hearing of Venkata and Kanappa 31.3.1655, G/19/1: 4-9.

39 VOM, 118 points of Venkata and Kanappa 4.4.1654 and Leigh to Company 20.3.1654, 1: $132,143$. 
replaced on the council by James Martin, so that both parties had an equal vote (after Winter left once more). ${ }^{40}$

Raga Pattan and Naga Pattan were also important figures in the town, especially in the earliest stage. Ragava or Raga Pattan is also referred to by the Painters and Weavers as the founder of Chennapatnam because he played an important role in conveying to the English Ayappa Nayak's desire to found a seaport, and he became the town's first kanakka-pillai. ${ }^{41}$ He was sent out of town by Ivie, because he was supposed to have informed the nawab of some duties that the Brahmin brothers "cut off." But when Greenhill became Agent, he was allowed to return. ${ }^{42}$ Using the same title "Pattan" or "Bathudu" — a title often used by members of the "group of five" artisan castes and especially by goldsmiths — ${ }^{43}$ was Naga Pattan, who came from Armagon and was closely associated with the foundation of the Chennai Kesava Perumal temple in the town. Although Naga Pattan was part of the Panchala or group of five artisan castes (which are usually listed as: goldsmiths, braziers, blacksmiths, stone carvers and carpenters, although the Dutch contemporary observer Rogerius listed masons instead of braziers), ${ }^{44}$ his profession was not artisanal. He was a broker to Ivie and later a gunpowder maker to the Company. ${ }^{45}$ The difference between his profession and the traditional status of his Left Hand caste created a tension that will be discussed in more detail below.

The prominent townspeople who prevailed with Greenhill to let Raga Pattan return were Beri Timmanna, Rudriga and Seshadri Nayak. They were the main opponents of Venkata and Kanappa in the town. Rudriga and Timmanna had, along with Naga Pattan, come from Armagon with the EIC personnel at the time of the foundation of the town. In the period under consideration here, they were brokers for the private trade of Henry Greenhill and William Gurney. They were, however, also independently important in the town and seem to have been very wealthy.

${ }^{40}$ Love, VOM, 1: 114-5, 127-9; VOM, Leigh to Company 20.3.1654, 1:131-2; VOM, Baker to Company 18.9.1654, 1: 138; EFI, same document, [9] 292-3; EFI, 118 points of Venkata and Kanappa 4.4.1654, [9]: 263-4.

41 VOM, Translation 29.5.1639 of qaul Damarla Ayappa Nayak to Raga Pattan 3.11.1638, inserted in Petition 23.7.1788 (when the original was still extant), 1: 150-1.

42 EFI, 118 points of Venkata and Kanappa 4.4.1654, [9]: 259 and VOM, same doc., 1: 141.

43 Thurston, Castes and Tribes, s.v. Pattan; It is difficult to establish the precise contemporary form of "Pattan." Naga Pattan appears to have signed his name in Telugu as Nagabathudu, and in the Painters' and Weavers' English language petition speaks of "Nagabattanda" and "Ragabattanda." VOM, translation of gift deed of Naga Pattan to Narayana Aiyar 13.8.1646, 94-5; BL, Declaration Painters, Weavers etc. ca. 12.12.1654 and declaration of the Right Hand principals April 1655, E/3/24: 363-9. The title is related to the Brahmin title Bhatta discussed below.

${ }^{44}$ Rogerius, Open-deure, 6.

45 VOM, translation gift deed of Naga Pattan to Narayana Aiyar 13.8.1646 and 118 points of Venkata and Kanappa 4.4.1654, 1: 94-5, 143. 
Timmanna had founded the main temple of the town along with Naga Pattan and remained its custodian. While Greenhill was away on a venture to Pegu in 1653, Baker managed to steal a majority on the council through the temporary presence of a Captain Brookhaven, and confined Timmanna and Rudriga in the fort until they had disgorged a large amount of money they earned in activities such as taking toll that was due to the Company. ${ }^{46}$ Seshadri Nayak was the most important Company merchant before the rise of Venkata. The Painters etc. call him "a principall man in the towne." 47 Seshadri was associated with a colleague called Koneri Chetti. Together they came form Porto Novo or the adjacent Teganapatam. ${ }^{48}$ We do not get any specific information on any caste affiliation of Timmanna, Rudriga, Seshadri and Koneri, except that they were leaders of the "Belgewar" or Right Hand.

"Below" the big men that were just introduced people were on the whole seen to act as collectives in the dispute. This would confirm the theory of Mattison Mines and Vijayalakshmi Gourishankar that individuality is in (present-day) South India only recognised and socially valued in certain cases, namely leading figures dispensing extensive patronage through institutions (the "institutional big man") and worldrenouncers, or people combining renunciation and this-worldly leadership. However, it is not easy to draw a line between the level of the big men and the groups below them, or as Mines and Gourishankar write: "big-men come in many sizes." The groups that seem to act as castes in the present case were also made up of individuals organised in factions, which becomes evident from the Painters' accusation that the Brahmins obtained their caste principality by instigating strife among the chief Painters, and obtained Cooly Painters' principality by similar means. The Brahmins are also to have set the Cangaloone Weavers at variance so as to obtain their financial records. ${ }^{49}$

Though the higher castes are now generally considered to have been formally above the division of Left and Right, at least in the modern period, ${ }^{50}$ the distinction between the big men drawn from the higher ranking castes - as individuals — and the collectives below them is further complicated by the fact that the big men were very much involved in the

\footnotetext{
${ }^{46}$ Love, VOM, 1: 128; VOM, Leigh to Company 20.3.1654, 1:131-2.

47 VOM, declaration of the Right Hand principals April 1655, 1: 122.

48 VOM, Greenhill's response to the 118 points 10.1.1655, 1:145.

49 Mattison Mines and Vijayalakshmi Gourishankar, "Leadership and Individuality in South Asia: The Case of the South Asian Big-man," JAS 49 (1990) 761-86; BL, Declaration Painters, Weavers etc. ca. 12.12.1654, E/3/24: 364-9.

50 Compare Brenda E.F. Beck, Peasant Society in Konku: A Study of Right and Left Subcastes in South India (Vancouver, 1972) xv-i and "The Right-Left Division," 782. Brimnes argues that in the latter part of the eighteenth century the Indian elite in the European enclaves withdrew from engagement in the disputes. Brimnes, Constructing, 94.
} 
dispute in Chennapatnam. As is already becoming clear and will become abundantly evident in the next section, all the big men, including the Englishmen, chose or were forced to take sides. Greenhill for instance sided with the Right Hand and Baker with the Left Hand. The position of the Brahmin brothers was more complex. As has already been noted, they had insinuated themselves into some of the Right Hand castes as principals. At a certain crucial point, however, they "joyned with the Berewar," as will be elaborated below. We can draw up the following table of the division at the height of the dispute in Chennapatnam:

\begin{tabular}{|c|c|c|}
\hline \multicolumn{3}{|c|}{ Chennapatnam/Fort St. George around I653 } \\
\hline & Left & Right \\
\hline Englishmen & $\begin{array}{l}\text { Aaron Baker } \\
\text { Edward Winter } \\
\text { Capt. James Martin } \\
\text { Anthony Baker }\end{array}$ & $\begin{array}{l}\text { Henry Greenhill } \\
\text { William Gurney } \\
\text { John Leigh } \\
\text { John Gurney }\end{array}$ \\
\hline Brahmins & $\begin{array}{l}\text { Venkata } \\
\text { Kanappa }\end{array}$ & $\begin{array}{l}\text { Priests of the Perumal } \\
\text { temple (including } \\
\text { Narayana Aiyar) }\end{array}$ \\
\hline $\begin{array}{l}\text { Other "big } \\
\text { men" }\end{array}$ & Naga Pattan (by ascription) & $\begin{array}{l}\text { Beri Timmanna } \\
\text { Rudriga } \\
\text { Seshadri Nayak } \\
\text { Koneri Chetti } \\
\text { Raga Pattan } \\
\text { Naga Pattan (by conscription) }\end{array}$ \\
\hline Castes & $\begin{array}{l}\text { Beri Chettis } \\
\text { Pallis }\end{array}$ & $\begin{array}{l}\text { Komatis } \\
\text { Painters } \\
\text { "Cooly" Painters } \\
\text { "Mooree" } 52 \text { Weavers } \\
\text { "Cangaloone" Weavers } \\
\text { Paraiyans }\end{array}$ \\
\hline & \multicolumn{2}{|c|}{ Fishermen (Pattan-varu and Karai-varu $)^{53}$} \\
\hline
\end{tabular}

THE DisPuTE AND ITS STAKES

In an incisive historical study of the Left-Right phenomenon in European enclaves on the Coromandel coast in the eighteenth and early nineteenth

\footnotetext{
51 Love, $V O M, 1: 95$

52 "Moorees" and "cangaloones" were different types of textiles. Foster, EFI [9]: 258 note3.

${ }^{53}$ Love, VOM, 1: 119 note 9.
} 
century, Niels Brimnes argues that honour and honours (which he notes can serve an economic function as "symbolic capital") played a central role in the disputes and that the English were very much aware of that. Brimnes gives the example of Baker's treatment of the two divisions on the beach at the time of his departure for England. The principals of the Right Hand division complained that:

At the time of his going aboard ship wee went to bidd him farewell and wish him a prosperous voiage unto his country, as our custome in theise parts is with a little fruite, but hee would not soe much as looke upon us turning his back towards us, and by others asked what wee did there, and bidd us bee gone, which wee having attended him till noone did, and went away, but presently after the principalls of the Left Hand were received and had tashereifes [tashrifs: honorary gifts/robes] given them and after them the Braminees also...

That is only one example, however; the Right Hand caste principals further complained that Baker and the Brahmin brothers had encouraged the leading Left Hand caste to become malapert, that is in the New Oxford Dictionary definition of the word "boldly disrespectful to a person of higher standing," in this case to members of the Right Hand:

The President giving eare to the bramanees persuasions they framed a paper which distinguished the Right and Left Hand parties and endeavoured ther by to bring the Chittees to an uncustomed height of honour, which encouraged them to bee soe malipert. ${ }^{54}$

To that we can add the example of agent Greenhill who, according to point 107 of the 118-point petition of Kanappa and Venkata, struck one Ammappa Chetti with his slipper over some petty cause "upon which hee [Ammappa Chetti] would dye and 3 dayes eat nothing," when two other Beri Chettis prevailed with him to eat and for three months "made suite to the agent to favour him with a pishcash [gift] of a cloute [khil'at: robe of honour] in lieu of the disgrace but hee answered hee would rather $s[\mathrm{~h}] \mathrm{ame}$ then honour him now [nor] his cast for that they were not of his councell now should they look for his good word unto his successors." The latter example, however, shows not only that the English were aware of the local cultivation of shame and honour, but also that they chose to shame those who were not of their "councell." 55

Moreover the concern with "honour" was not restricted to the Indians in the Chennapatnam area; Baker complained to Greenhill that his broker Rudriga "not many years past was kept and imployed by some of your predecessors as a pympe and pander, having then hardly a pagoda in his purse; and yet now, under your imployment, is grown to such a height

\footnotetext{
${ }^{54}$ Brimnes, Constructing, 24-5, 68; VOM, declaration of the Right Hand caste principals ca. April 1655, 1: 122-3. The New Oxford Dictionary of English (1998) s.v. malapert.

${ }_{55}$ BL, 118 points of Kanappa and Venkata 4.4.1654, E/3/24: 159-69.
} 
that lately he durst come and tell me to my face that hee would turne mee out of my place, and come and sett in my chayre ere long, and make mee wayte on him. And for your other servant Tymana, you your selfe heard here in this Hall how hee snapt mee up, as if I had beene a boy or slave, and not worthy to have spoken or done anything without leave." 56

However, it was not only honours that were disputed, financial matters played a large role as well. A great part of the lists of charges that the parties are bringing against each other is about money: money wrongfully taken, not paid back, defrauded from the Company etc.. It would be too tedious to list or even summarise all those charges. Kanakalatha Mukund who chooses to explain the clash in 1650s Chennapatnam in economic terms notes rightly that the economic approach leaves more fundamental questions unanswered. ${ }^{57}$ It can be remarked, however, by way of a summary of the economic aspects, that also in financial matters there was a good measure of cohesion between the big men and the subaltern men in the respective parties. Greenhill championed the case of the Right Hand and "the poore people" in general. When some Painters were held, apparently at Baker's order, at the chavadi for some debt, Greenhill stepped in and said he would pay the Painters' debts "which hee [Baker] could not then but accept for shame." Greenhill also castigated Baker for allowing the nawab's adbikari to impose sales duties on petty things such as betel and herbs sold in the market. ${ }^{58}$

Just as in the Robbers Cave experiment, one party became very high-minded while the other remained businesslike. In the Greenhill party the humanitarian argument was very important. The Right Hand parties accuse the Brahmin brothers of allowing abducted people to be sold as slaves in the town and licensing gambling "to the undoing of some families." 59 Also consider the following words of John Leigh in connection with the charge that Kanappa was licensing slaves: "Some of us have children: it would greeve our soules to have them stolne and sould for slaves; and these people have as much right to their children and love to them as wee, and therefore ought to have justice on the trators or the manstealers or depeoplers of the countrey," or Greenhill's warning that laxity on the part of Baker encouraged Kanappa, "to domineer more and more in high language over the poore people." Baker on the other hand, against Greenhill's charge that he was allowing the nawab's adbikaris

\footnotetext{
56 VOM, Letter Baker to Greenhill 29.3.1654, 1: 134.

57 Mukund, The Trading World of the Tamil Merchant: Evolution of Merchant Capitalism in Coromandel (Chennai, 1999) 68 and "Caste Conflict in South India in Early Colonial Port Cities - 1650-1800," Studies in History 11 (1995) 1: 1-27, there 19 and passim.

58 VOM, Letters Greenhill to Baker 1.3.1654, Leigh to Company 29.3.1654 and Baker to Greenhill 29.3.1654, 1: 130-4.

59 VOM, declaration of the Right Hand principals April 1655, 1: 123.
} 
imposing taxes on small things sold in the market, made remarks like: "nor can I conceive, if these customes must bee paid upons such patty things as herbes and beetle, what prejudice the Company can susteyne thereby," and "I suppose the Company are neither gainers nor losers by it." 60

Finally, the dispute was about space, or perhaps we should say ceremonial or honorary space. Below is a more or less chronological narrative of how the dispute over space in the town developed. It is clear that caste played a role in the initial settlement pattern, and perhaps the Right and the Left Hand castes were clustered to an extent, but that division was apparently not implemented in a very clear-cut way. At the heart of the dispute as it developed in the late 1640s and first half of the 1650s, however, were a series of rulings made by the English and their representatives in the town concerning the division of streets between the Right and the Left.

In the beginning the person responsible for allotting plots to settlers in Chennapatnam and Peddanaikpetta was Timmanna, who seems to have acted rather autonomously in that, expropriating ground from those who "had lived thereon 100 yeares" and offered the Company "greater shares."61 A descendant of Timmanna wrote in 1820 that he allotted lands "for both Right and Left Hand castes separately," but that may be hindsight. ${ }^{62}$ In Ivie's time (1644-'48) a mud wall was built by public subscription, to protect the northern and the western sides of the town, while the southern side was protected by the river which left a progressively narrowing strip of land on which the fort stood. Peddanaikpetta was not walled in, and was therefore also known as "the village without the towne." 63 In Peddanaikpetta and the other outlying settlement, the kuppam south of the fort, lived some of the lower castes: the washers and the talaiyaris in Peddanaikpetta, and two castes of fishermen in the kuppam. ${ }^{64}$ Within the walls we hear of Pallis, and the trading castes of the Beri Chettis and Komatis as well as the Painters, Weavers etc. There were also a number of Europeans living in the conglomeration, including many Portuguese, who lived mostly at the south end, between the fort and the market street which ran east to west, while a few lived south of the fort. ${ }^{65}$

60 VOM, Letters Greenhill to Baker 1.3.1654, Baker to Greenhill 29.3.1654 and Leigh's declaration against Kanappa n.d., 1: 130-4. Another example: VOM, Leigh's declaration regarding the chavadi 16.12.1654, 1: 138-9.

${ }^{61}$ VOM, Fort St. George consultation 28.1.1712, 2: 1: 127; EFI, 118 points of Venkata and Kanappa 4.4.1654, [9]: 260.

62 B. Ramaswami Nayudu, Memoir on the Revenue System of Madras, quoted in VOM, 1: 95.

${ }^{63}$ VOM, Declaration Painters etc. ca. 12.12.1654, 1: 148-9; EFI, same document, [9]: 243.

${ }^{64}$ BL, Declaration Painters etc. ca. 12.12.1654, E/3/24: 364-73; VOM, Translation of award in caste dispute 5.11.1652, 1:118-20.

65 VOM, Fort St. George Consultation 10.6.1672, 1: 383. Love, VOM, 1: 129 note 2. VOM, 118 points of Venkata and Kanappa 4.4.1654, 1: 143; VOM, Fort St. George consultation 29.2.1676, 1: 388 . 


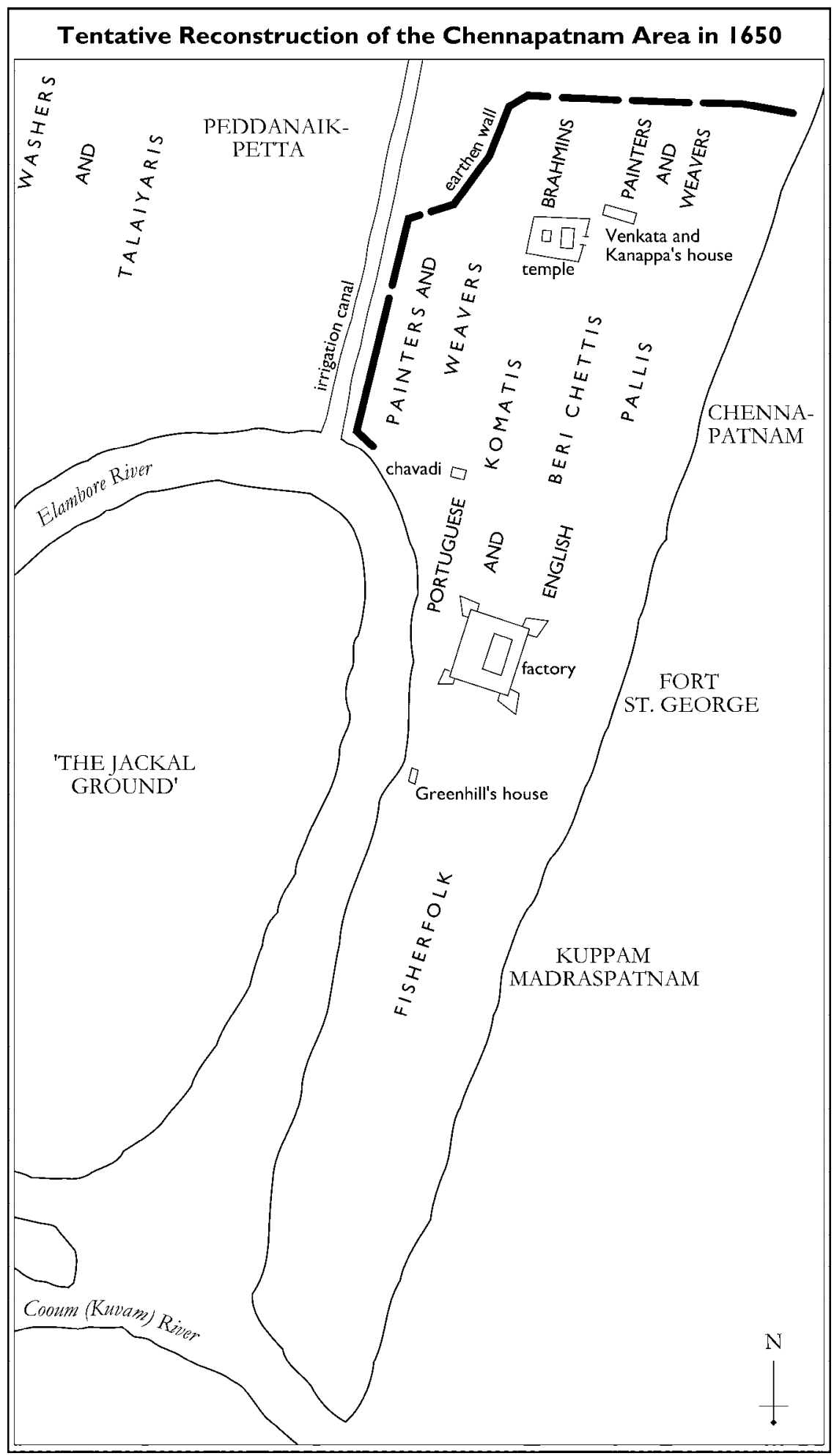


The pattern of the basic spatial division into a core living area for the higher castes and outlying areas for the lower castes is also familiar from other contexts. On a painting by an anonymous Indian painter of the encampment of a Dutch ambassador within the Mughal Imperial camp in 1689 one can see the sweepers relegated to the farthest corner of the camp/the painting. Of course one might say that must have been a matter of class rather than caste, but the sweepers were also referred to in the payroll of the mission as halalkwors, a euphemism for very low-caste persons "to whom all is lawful food." The only way to explain the presence of this term in that payroll would be that sweepers were at the time quite generally marked by the impurity of their eating habits. And while the sweepers are at the back of the camp, some Telugu Brahmins keeping the time are located to the right of the entrance at the front. ${ }^{66}$ Somewhat later, at the turn of the eighteenth century, Shahaji, the king of Thanjavur to the south of Chennapatnam, wrote a play about the infatuation of a Brahmin man with a married Madiga woman, and puts the following words in her mouth: 'We're untouchables. If you touch us, you become unclean / Don't come close. We're Madigas, working with leather / Our huts are to the east of the village." 67 But the least auspicious direction probably varied somewhat over time and space, since, in the 1960s, Brenda Beck observed that the west and south were generally allocated to the lowest-ranking members of a community. ${ }^{68}$

In 1640s Chennapatnam the northern end of the town was considered the most honourable or auspicious. The location where Chennapatnam was situated certainly offered certain constraints, the east being unavailable because of the sea, the fort lying to the south, and south of that an estuary (though there was enough space there for the small kuppam), but it is significant that Peddanaikpetta was not situated to the north which later became the site of an extension of the town housing mainly Left Hand merchants. But even if the location of Peddanaikpetta as a satellite settlement was entirely contingent on practical considerations such as access for the Washers to the river - and not on the ideological, it can be established from an incident that took place during Ivie's time that the west end of Chennapatnam was indeed considered less auspicious or

\footnotetext{
${ }^{66}$ Lunsingh Scheurleer and Kruijtzer, "Camping."

67 Shahaji, Sati-dana-shuramu translated as "Take my Wife," in Classical Telugu Poetry, an Anthology ed. and trans. Velchuru Narayana Rao and David Shulman (Delhi, 2002) 354-80, there 363-4.

68 Beck, Peasant Society in Konku, 152; Susan Neild also shows some "continuities with the pre-colonial order" of the spatial organisation of colonial Madras. Neild, "Colonial Urbanism: The Development of Madras City in the Eighteenth and Nineteenth Centuries," Modern Asian Studies 13 (1979) 217-46. Patrick A. Roche also sees some continuity but argues that the spatial separation of groups was to a large extent fostered by the English power and its "traditionalising" influence. Roche, "Caste and the British," 381, 399-400, 404.
} 
honourable than the north. While Ivie and Venkata were away for some time, Timmanna and Rudriga tried to persuade the two sections of the Weavers to put themselves under the protection of Seshadri, but only the "Mooree" Weavers consented, "upon which," in the words of the Brahmin brothers, "Sesadra made a broyle with causing the mooree Weavers to pass with burialls through the west gate." Thus that gate was clearly less honourable than the other gates which were the north gates, and we shall see that access to the north gates came to play a central role in the dispute over space. ${ }^{69}$

In Ivie's time the first ruling concerning Left Hand and Right Hand streets was made, which defined the second important spatial division of the town within the walls. It is probable that it accorded both the Right and the Left one south-north street for ceremonial purposes. That paper was, however, consequently concealed by Venkata and Kanappa for years, which is one of the more mysterious episodes in the dispute, but all the involved refer to it. ${ }^{70}$ The brothers themselves said they concealed the paper for fear that Greenhill would tear it up. ${ }^{71}$ After the Left Hand had prevented the Brahmins from riding a palanquin (a very honourable mode of transport) into their street during a wedding, the Brahmins apparently made Greenhill believe that there was no such paper by pledging a large sum of money if the Left Hand could prove them wrong. ${ }^{72}$

Yet in the time of Greenhill another paper was drawn up after a difference had arisen between the Painters and a Palli. It ruled that the Pallis were allowed to use any street for their wedding processions except the street of the Komatis which was to be reserved for the honour of the Right Hand. The Brahmin brothers, however, claimed that Seshadri "spoyled" the paper, and that Greenhill did not do anything against that although the paper was made up by the brothers upon his order. The brothers also claimed that "the paper is in our hands," which suggests that the paper was not physically spoiled, but its ruling obstructed..$^{73}$

After Baker arrived, the Brahmins produced the first paper again upon "strang [sic] intercession," "74 but in November 1652 a new ruling was made. The original Telugu document was still extant in 1707 and at that time translated into English, to aid judgment in the then current disputes. It stated that "there having been of late severall differences and disputes between the casts about their streets, which this day is settled." The paper

${ }^{69}$ EFI, 118 points of Venkata and Kanappa 4.4.1654, [9]: 258-9.

70 EFI, Greenhill's remonstrance to Baker concerning the Brahmin brothers 1.3.1654 and Baker to Greenhill 29.3.1654, [9]: 235, 253; BL, Examination of Venkata and Kanappa over articles of Painters 31.3.1655, G/19/1: 4-9.

${ }^{71}$ EFI, 118 points of Venkata and Kanappa 4.4.1654, [9]: 258.

72 BL, Declaration Painters, Weavers etc. ca. 12.12.1654, E/3/24: 364-9.

${ }^{73} \mathrm{BL}, 118$ points of Venkata and Kanappa 4.4.1654, E/3/24: 159-69.

${ }^{74}$ BL, Declaration Painters, Weavers etc. ca. 12.12.1654, E/3/24: 364-9. 
was signed by Baker, Greenhill, Gurney, Koneri Chetti and Seshadri, the latter as mediator. Basically it awarded the two easternmost streets running parallel to the coast, along with the eastern part of the perpendicular market street, to the Left Hand and the western part of town to the Right Hand. A very heavy fine was set upon either group passing through the other's part with matrimonial and funerary processions. But also more generally "the Right Hand cast are to reside in the particular streets appointed for 'em, where are to live or come none of the Left Hand cast; and the same with the Left Hand cast, where are to be none of the Right Hand cast." An exception was made for the two fishermen castes from the kuppam south of the fort, who were allowed to pass with their weddings and burials to the Portuguese church north of the town through both the central north-south streets, that of the Left and of the Right. The agreement basically gave all sections of the population access to one or more of the north gates, through an honourable route..$^{75}$

From all corners we gain the impression that this ruling was really the start of the troubles, though it was meant as a solution to the previous discontent. The Painters and Weavers felt betrayed by this document. They later stated that the Brahmin brothers had obtained their approval and signatures for (a draft) of the document by saying that each side was to be assigned one street, but the next day suddenly said that two streets had been assigned to the Left Hand. It is indeed rather odd that the translation of the final draft that is still extant adds in brackets "(being two street)" after the mention of the streets to be assigned to the Left. ${ }^{76}$ Shortly after the ruling some houses that belonged to Right Hand people were taken away from them. In particular, it seems, some of the Painters had to be relocated from the lower grounds to the higher grounds further away from the coastline. Apparently the Brahmins had promised alternative housing to them, because they were said to have "frighted" several people in the higher grounds to dispose of their houses but also to finally have let some of those people keep their houses in exchange for bribes. Disturbances broke out, which included the blocking of Left Hand funerals, and the English imprisoned two "ringleaders" in the fort, whence they were again released upon the order of Mir Jumla. ${ }^{77}$

Meanwhile, the house of Venkata and Kanappa came to play an important part in the dispute. It seems that it was located in the street "restored," as they put it, to the Chettis, but close enough to the Painters' street for a bell ringing in its yard to be heard there. Perhaps it was located

\footnotetext{
75 VOM, Translation of award in caste dispute 5.11.1652, 1:118-20.

${ }^{76} \mathrm{Ibidem}$ and $V O M$, declaration of Right Hand principals April 1655, 1: 122.

77 BL, 118 points of Venkata and Kanappa 4.4.1654 and declaration Painters, Weavers etc. ca. 12.12.1654, E/3/24: 159-69, 364-9; VOM, Letter Baker, Gurney, Winter, Leigh to Surat 5.2.1653, 1: 121 .
} 
in the part of the Painters' quarter that had to be yielded to the Left Hand. During the troubles they lost the house to Naga Pattan, to whom, it appears, was now ascribed the Left Hand status of a proper "Goldsmith," which would have occasioned his having to move into the Left Hand section of town. Venkata, as caste principal of the Painters, moved into the Painters' street. Venkata and Kanappa wrote that they vacated their house voluntarily "at the Presidents desire and to end the difference." But the Painters and Weavers wrote that Venkata continued to remind them that it was to the dishonour of the Painters that a goldsmith should live in the house that belonged to their caste principal and counselled them to leave the town in protest. ${ }^{78}$

This walk-out of the Painters was another important moment in the troubles and required some intervention by Baker. While the Painters suggested that Venkata had put them up to leaving the town, the Brahmins wrote that Seshadri encouraged the Painters to leave town, and Greenhill said that there had been a meeting between Seshadri and Venkata at Koneri Chetti's house to such effect. ${ }^{79}$ In any case part of the Painters left the town, but, they wrote, Baker persuaded them to return with a qaul that "hee with deliberation would enquire the country custome and afford each cast its due respect." 80

After attending to Company business for a while, Baker again found time to take up the question of the dispute between the two sides as well as Venkata's role in it. ${ }^{81}$ But the procedure was interrupted by the serious fighting that broke out on the $24^{\text {th }}$ of January 1653, when Seshadri was apparently offended by a Beri Chetti in an exchange of words that took place during a meeting with the English at the fort, in which the one said the other was not worth a "cash" (say a penny) and the other replied that if that was so the first was not worth two cash. Upon which Seshadri is said to have run into town and raised "the whole [Right Hand] cast with sword and clubs, who runn into the Berewar streets, and plunder their howses, and cut of $[\mathrm{f}]$ two mens heare [hair] of their heads, which is a far greater disgrace to them then if they had cut of $[\mathrm{f}]$ their heads and left them dead in place." 82

A few days later the Chettis brought word to Baker that Seshadri had brought forty or fifty armed men into town "to begin a new quarrell

78 EFI, 118 points of Kanappa and Venkata 4.4.1654, [9]: 266; BL, Declaration Painters, Weavers etc. ca. 12.12.1654, E/3/24: 364-9.

$79 \mathrm{BL}, 118$ points of Venkata and Kanppa 4.4.1654 and Greenhill's response to 118 points 10.1.1655, E/3/24: 159-69, 171-5v.

${ }^{80}$ VOM, Letter Baker, Gurney, Winter, Leigh to Surat 5.2.1653 and Declaration of Right Hand principals April 1655, 1: 121-2.

${ }^{81}$ EFI, Ft. St. George to Company 11.11.1653 and Baker to Greenhill 29.3.1654, [9]: 212, 253; VOM, same latter document, 1:121.

${ }^{82}$ VOM, Letter Baker, Gurney, Winter, Leigh to Surat 5.2.1653, 1: 120-1. 
with them againe" and a week later again it is reported that the parties had called in "all the countrey round about of both casts to fight one against the other," totalling some four or five hundred armed men.83 Meanwhile Venkata openly joined the Left Hand and moved into the Left Hand street, and according to the Painters and Weavers advised the Left Hand to betake themselves and their case to the camp of Mir Jumla. ${ }^{84}$ Indeed, shortly after the fighting broke out in late January the Left Hand castes left town, which led Baker to the decision to "lett the business of the streets lay dormant" until they returned. He assured Greenhill, however, that this was no acquittal of Venkata's "cryme" of concealing the document, which was Venkata's only crime in Baker's view. ${ }^{85}$

After that Baker was very careful not to upset the Left Hand and he supported it in upholding its reserved territory. The Painters etc. later wrote that "the President, rather then displease the Left Hand party, caused a mans wife to be buried at his doore, and a $2 \mathrm{~d}$ corps to bee burnt in the towne which unto us is very heinous." ${ }^{\circ 6}$ Meanwhile, Venkata rejoined the Right because, it is said, he was disappointed by the slow progress of the Left Hand case at the nawab's court. He proceeded to dash off five letters to people who could advance the Right Hand case at the nawab's court, including the nayaka Venkatadri, "the merchant for the Right Hand in the campe bazaar" and "the principall Paryars by the Nabob." The mention of the latter is interesting, since from the clashes in the eighteenth century Paraiyans have become known in the literature as staunch supporters of the Right, but in the dispute under investigation we do not hear of them except in this place (yet since they are thus mentioned, they have been included in the table above as members of the Right). Venkata is supposed to have said that these letters were meant to block the designs of the Left, ${ }^{87}$ but when in January 1654 the Chettis along with the rest of the Left Hand sent messengers to negotiate about their return to town, they were received outside the fort by Venkata (which was odd, according to Greenhill, as he was nominally a prisoner of the fort). ${ }^{88}$

Not long after that, still in the first half of 1654, the antagonism within the fort also reached fever pitch. Leigh, for instance, told Kanappa that he was prepared to "spend his life" for Greenhill and Gurney. ${ }^{89}$ And in the evening of the day in April 1654 when Baker had Greenhill, Leigh and

\footnotetext{
83 Ibidem and EFI, Baker to Greenhill at Pulicat 29.1.1653, [9]: 152-3.

${ }^{84}$ BL, Declaration Painters, Weavers etc. ca. 12.12.1654, E/3/24: 364-9.

85 VOM, Baker to Greenhill 29.3.1653, 1:121; EFI, same document, [9]: 253.

86 VOM, declaration of the Right Hand principals April 1655, 1: 123. It is also possible that this refers to the Right Hand blocking of Left Hand funerals Right after the November 1652 ruling, and that that is here blamed indirectly on Baker.

${ }^{87}$ BL, Declaration Painters, Weavers etc. ca. 12.12.1654, E/3/24: 364-9.

${ }^{88}$ EFI, Greenhill's remonstrance to Baker concerning the Brahmins 1.3.1654, 1: 236.

${ }^{89}$ Love, VOM, 1: 97; EFI, 118 points of Kanappa and Venkata 4.4.1654, [9]: 265.
} 
Captain Richard Minors arrested and confined, after all the drinking at the wedding party that also took place on that day, the members of the garrison were, according to Greenhill, "ready to cut one anothers throats" - while Baker and Captain Martin were out in the darkness, swords drawn. ${ }^{90}$

Problem 1: The Role of THE ENGLish: TOO UninVOLVED OR TOO INVOLVED?

Niels Brimnes, in his study of the Right-Left disputes in the eighteenth and early nineteenth centuries, argues that the British tactic of suspending honours worsened the conflict in the early eighteenth century. In the later eighteenth century and early nineteenth century the conflicts would have become less vehement and disruptive in the British enclaves (but not in Danish Tranquebar) because the British had consolidated their position whereby Indians, especially the brokers and big men then chose to maintain good relations with the colonial power rather than compel it to distribute honours through provocation, and because the British were by that time occasionally willing to intervene. ${ }^{91}$ The vehemence of the confrontations between the two groups would thus be directly correlated to a) the English/British willingness to intervene in disputes over honour and precedence, or - as Brimnes puts it - on their conforming to the role of the South Indian little king or not, and b) the measure of consolidation of British administration.

As we have seen, the English administration was not very consolidated in mid-seventeenth-century Chennapatnam. The issue of how much power the Company as adbikari should arrogate in the affairs of Chennapatnam was in fact one of the issues in the dispute between the two parties. Greenhill was in favour of curbing the power of Mir Jumla and his governor in the town. As has already been noted, he objected to Baker's assent to the imposition of duties on petty goods in the market by Mir Jumla's adbikari. The Brahmin brothers also accused Greenhill of hindering the building of a custom house in the town by the nawab (and then asking them to raise the money needed to reconcile the angered nawab from the inhabitants). ${ }^{92}$ Furthermore, Greenhill protected Seshadri from having to go to Mir Jumla, but when he was away, Baker, "through the said bramanees meanes sent him to the nabob, to his utter ruine, which they knew must thereon ensue." Thus also on this issue the lines between the parties were clearly drawn. The Painters, Weavers and other Right Hand people wanted as little involvement of Mir Jumla as possible and felt

\footnotetext{
90 VOM, Letter Greenhill to Baker 1.1.1655, 1: 134.

${ }_{11}$ Brimnes makes his point partly against Roche who had argued in the 1970s that "one senses the workings of a 'dominant power' conscious of its power to lay down the law." Roche, "Caste and the British," 407 and passim, Brimnes, Constructing, 75-6, 94, 240-2.

${ }^{92}$ EFI, 118 points of Kanappa and Venkata 4.4.1654, [9]: 260.
} 
supported in this by Greenhill. They felt that Baker should not have allowed the dispute about the streets to be taken to Mir Jumla: "which course must needs draw great prejudice to the companys affaires, distress to the inhabitants, and for the future indanger the privilege of principallty." 93

Because the customary dual structure of government was in the case of Chennapatnam reinforced by the fact that the two most important functionaries answered to two different state structures, the government of the town was perceived as being weak. The principals of the Right Hand castes noted that all those living in the vicinity referred to Chennapatnam as "the towne without government." 94 Or, as John Leigh remarked in connection to his charge that Kanappa was licensing stolen children as slaves at the chavadi, "to the great dishonour of the Honourable Company, to the shame of the Governor and Councell here, that Madras, the Companys towne, should bee a baud to procure stolne children to supply the Hollanders with slaves. Why were not the children carried to Pulicatt? Noe they durst not. Why not to St. Thoma? Noe, they durst not; but come to the English towne." 95

This fact of the somewhat confusing state of diarchy in Chennapatnam, in combination with the fact that the mid-seventeenthcentury confrontation does not appear to be less vehement than the eighteenth-century disputes — Greenhill spoke of "mutuall hatred"96 and we have seen instances of armed clashes, looting, destruction of property, and people leaving town by way of a "strike" - confirms the part of Brimnes' theory that argues that the weakness of Company government stimulated the disputes. Brimnes, however, undercuts the other part of his argument by saying that "it is true that both the settlement dividing the Black Town [sic] ${ }^{97}$ in two sections and Aaron Baker's undisguised distribution of honours on the beach before Fort St. George indicate that the English were in fact able to conform to the role of little king," but that, "this was not typical of the British attitude towards caste disputes in the eighteenth century." The latter may be true, or probably is true, since Brimnes has investigated the eighteenth-century cases in detail, but then the rising vehemence of the disputes under the European aegis that Brimnes assumes (we shall return to this point) cannot be explained from the English holding back on their role of little king and withholding honours. The fact that the 1652-4 dispute was very vehement and the English were

${ }_{93}$ BL, declaration of the Right Hand caste principals ca. April 1655, E/3/24: 228v-9.

${ }^{94} V O M$, declaration of the Right Hand caste principals ca. April 1655, 1: 123.

95 VOM, Leigh's declaration against Kanappa n.d., 131. The charge was supported by Greenhill and the Right Hand principals, see below.

${ }^{96}$ EFI, Greenhill's remonstrance to Baker concerning the Brahmins 1.3.1654, [9]: 235.

97 The appellation Black Town for Chennapatnam is first found in the early eighteenth century, but is not applicable to our period. Compare Love, VOM, 1: 85-6. 
very involved, invalidates the proposed correlation between low involvement and high vehemence. 98

The English were certainly expected to intervene during the 1652-5 disputes. The petition of the principals of the Right Hand castes is very interesting in this respect. On the one hand it charged President Baker with partisanship and intervention favouring the other party, and on the other it clamoured for more intervention. Above were already listed the charges that the President had been instigated by the Brahmins to divide the town and to give the Left Hand two streets, as well as his giving tashrifs to the Left while ignoring the Right on the beach. The petition contained many more instances of Baker's favouring the Left and maltreating the Right: releasing a Left Hand burglar, humiliating a Right Hand merchant etc. Baker was also supposed to have vowed to destroy the Right Hand and never to have intended to follow up on his promises to reconsider the November 1652 ruling on the division of the streets in the light of "the country custome." Then there was the complaint that after the "great difference" of January 1653 arose, Baker would not decide the issue of precedence and allowed it to be taken to Mir Jumla, who would also not decide it: "formerly all differnces were ended by the governor of this place, but the President respecting the chitees cast beyond the country custome hath continued this difference above these two yeares seeking to bring up new or uncustomed formes." And thus, in the view of the Right Hand principals the street issue "doth yet remaine undesided," while there obviously had been a decision, namely to award the Left Hand two streets. ${ }^{99}$

Clearly the Right Hand principals did not merely want intervention, they wanted intercession on their behalf, and they saw the possibility of that in the divisions among the Englishmen. But as has been seen in the last chapter, Indian royal courts also tended to be faction-ridden. It was not uncustomary to approach a court through a different faction when routing a request through the first approached faction did not work out - Chapter 6 will yield some examples of this. So far there does not appear to be anything unusually "English" about the situation in Chennapatnam in the 1650 s, or it must be the emphasis the petitioners put on custom and uncustom, to which issue we shall return.

The question of how exceptional the English involvement was can be investigated profitably by means of a comparison. In 1672 a wife of the then saijada-nishin or successor of the most famous Sufi of the Deccan Gisudaraz Banda Nawaz petitioned the Adil Shahi court about a religious procession by villagers in the vicinity of the tomb of Gisudaraz. As her

\footnotetext{
${ }_{98}$ Brimnes, Constructing, 24-25, 30, 45, 81, 241 and passim.

${ }_{99} \mathrm{BL}$, declaration of the Right Hand caste principals ca. April 1655, E/3/24: 228-31v.
} 
petition reached the court, a number of the villagers also reached the court and a farman was issued to the local authorities with a ruling concerning both the villagers and the sajjada-nishin family:

...that the Refuge of Chastity and the Handle of Honour Murtaza Bibi... has petitioned the court that her late son Shah Akbar had gone from Gulbarga to the village of Karsawali, which is an in'am for the langar of the Splendid Tomb, ${ }^{100}$ and on the way the headmen and some [other] infidels of the village Saraski of the district of Muhammadnagar commonly known as Muhammad Shahi [district] had assembled with some pomp having, according to the customs of the infidels, made an image of the accursed Ganesh for procession [and] having taken it from the aforesaid village to the gate [of the shrine?] were worshipping it. The lamentable infidels have been forbidden from the customs of infidelity. The infidels who [perpetrated] the lamentable villainy have been returned alive, in exception to the law [na-baq]. Since the lamentable [persons consisted of] three minors and three slave-boys and seven locals and these justice-seeking destitutes reached the elevated court, discerning justice has been passed befitting their condition. Concerning the petition by the Refuge of Chastity ... by way of Imperial compassions and an excess of favours Royal... [follows an award of various villages to the members of the sajjada-nishin family]. ${ }^{101}$

To the modern observer the procession of the villagers taking their elephant-headed god of beginnings Ganesha to the shrine of a Muslim saint, perhaps to partake in its barakat, might appear as an act of syncretism, but to Murtaza Bibi and the Adil Shahi court it clearly appeared as an invasion of the sacred space of the Rauzat-i Munawarra or Splendid Abode/Tomb. The case is therefore very comparable to the situation in Chennapatnam some twenty years earlier, in which ritual processions and the invasion of ritual space through them also played such a large role. ${ }^{102}$

The comparison shows that the Chennapatnam case and the rulings in it were not exceptional because in both cases a) the authorities were unashamedly partisan and b) one of the parties took the case to a level above the local level. In the Gulbarga case there was no effort at impartial mediation whatsoever, the villagers were condemned as kafirs from their first mention; they could only be justice-seeking destitutes who received the king's nazar-i inayat which may be translated as a beneficent view or, alternatively, a discerning gaze. The other party, however, is addressed by elaborate exalting titles (the titles applied to the husband of Murtaza Bibi and his forbear Banda Nawaz have been omitted for brevity's sake) and was the recipient of the compassions and favours of Ali Adil Shah II as padshah

100 I.e. the revenues of the village went towards the free feeding of pilgrims to the shrine.

101 APSA, Farman of Ali Adil Shah II 12.5.1083/5.9.1672, Banda Nawaz collection no. 109.

102 Compare also the case of the conflict over ritual boundaries in Chennapatnam in 1716 which involved the invocation of Ganesha cited by Brimnes, Constructing, 62 and Roche, "Caste and the British," 403-4. 
and Khusrau - the classical just king of Persia. The villagers were as separated from the court by class, religion and language as the court and the sajjada-nishin family were united by it. ${ }^{103}$

Staying with the issue of class for a moment, the possibility of taking a case to a higher authority was obviously more easily available to those possessing the right financial means and in fact local and even provincial governors were forever referring pleas that they were not very keen on granting to the higher authorities by way of a deterrent, because at the higher level one had to bring much more expensive gifts in recognition of the authority (nazr) as well as a tribute (peshkash) to obtain a favourable order on the plea. ${ }^{104}$ As has been seen above, it was a trip to Mir Jumla that ruined Seshadri, and the Right Hand principals' complaint about that tied in with their reproof of Baker's allowing the matter of the streets to be taken to the nawab's court. The Right Hand parties were, as they would have it, "workmen and (comparatively) the Companies children," but Baker called them "bastards." 105

\section{Problem 2: Under Whose GAZE?}

The argument that is generally made to argue that group boundaries became more solid in the colonial period is that through Orientalist scholarship, the census etc. Indians came to objectify their own culture and see it with the Western "gaze." Basically the idea, first propounded by Bernard Cohn, is that the way of seeing the world that Foucault thinks originated in Europe in the classical period (commencing in the early seventeenth century) was transplanted to India with colonialism. So was it that the people of Chennapatnam had absorbed European ways of looking at the world the moment they came under British administration? It is very doubtful that any of the people involved in the clashes between the Right and Left Hand in Chennapatnam in the mid-seventeenth century had read one line of Western literature or philosophy. There is certainly no evidence to suggest this, although there are indications that local people were aware of some of the European core values. The most significant indication is the statement by Right Hand parties in connection with a case in which Baker held a certain Komati responsible for a loss in his private trade and had the Komati locked up for a few days: "little sign of charity in such harsh

103 Compare also the remark by Schorer about Golkonda ca. 1615: "the king may not execute justice on Persians, especially those of Sayyid or Mir descent." Moreland, Relations of Golconda, 57.

104 The archives of the East India Companies abound in examples of Company requests and complaints being referred to higher-ups; for a more positive evaluation of the application of the principles of referral and appeal in the early modern Deccan see Eaton, Social History, 145-50, 193 note 45.

${ }^{105} \mathrm{BL}$, declaration of the Right Hand caste principals ca. April 1655, E/3/24: 228-31v. 
dealings on such a triffle, the like seldome acted by any Christian."106 But numerically the English were only a droplet in the ocean of the host society at the time. Therefore the acquaintance of the English with local values was probably far greater than that of the locals with English values. The idea that the European gaze created caste ultimately hinges on the idea that the British were able to influence society in India because they had the power. Yet the English were not all that powerful in 1650s Chennapatnam, and the transplantation thesis must appear wholly unsatisfactory. This section is an effort to deal with the questions of agency and authorship in a more satisfactory way, by asking who was responsible for creating the rift that ran through the town and who authored the texts in which it was laid down most importantly the 1652 ruling.

Having established that the division ran through Chennapatnam as well as Fort St. George and that the English were very involved, we must address the following questions: were the division among the Englishmen and the division among the Indian inhabitants really two distinct divisions and did the parties of the town and the fort respectively become aligned by convenience, ${ }^{107}$ or was either of the divisions the primal division, from which was created the other? To put it differently: there are two ways one can look at the role of the competition between the big men in the RightLeft dispute. One might say that the Brahmins or Seshadri or the British or the combination of them created the Right-Left antagonism, or one could say that all these big people were dragged into a division that already existed.

It is certainly the case that every one of the big men was accusing other big men of manipulating the lesser people as well as other big men to create a power base. Greenhill for instance wrote about Captain James Martin that "he is an incendiary and a factious person by indeavoring to mislead and seduce men to his partie, like the Divill, with large promises of preferment," 108 while Martin on his part accused Leigh of inciting William Gurney to join in the opposition to the President. ${ }^{109}$ Greenhill, in a letter to Baker, also accused the Brahmin brothers of inventing stories about himself, Leigh and Minors, which were then "spread abroad by Anthony Baker and other your creatures to amase the people and bring us into hatred."110 As far as the riots were concerned, Greenhill accused the Brahmins of "sowing divisions among the casts," 111 while the Fort St. George council as a whole (including Baker) wrote of its suspicion that the

106 BL, declaration of the Right Hand principals April 1655, E/3/24: 230.

107 Thus Appadurai, "Right and Left Hand," 252.

108 VOM, Greenhill's declaration against Martin 27.3.1654, 1: 132-3.

109 EFI, Martin's charges against Leigh ca. 15.5.1654, [9]: 283.

110 VOM, Letter Greenhill to Baker 1.1.1655, 1: 134-5.

111 EFI, Greenhill's remonstrance to Baker concerning the Brahmins 1.3.1654, [9]: 235. 
"rogues" causing the riots "are abetted, or at leastwise suffered" by Mir Jumla through his adhikari. 112

The Brahmin brothers meanwhile accused Seshadri of trying to win over the Weavers as well as the Painters. They also accused Timmanna and Rudriga of raising money to build and maintain temples and to provide for marriages of Brahmins (donating to Brahmins and temples being religiously sanctioned activities). The objection of Venkata and Kanappa to that seems to have been not so much that they were in this way levying a sort of tax but more that they were building and providing for the marriages "in their owne names," that is accruing merit and a good reputation for themselves by re-donating the money of others. They basically accused Timmanna and Rudriga of building a power base by conspicuous dharmic activities. Indeed, the Brahmin brothers saw the competition between the big men as a popularity contest. During the struggle over space in the town the Brahmins suggested an inquiry be made of "each cast" as to "whoe has taken pains for the good of the towne." They also seem to have had a very inflated idea of their own popularity. "All the townes people came and required to have us returne," they wrote about the time of their brief exile in San Thome.113

This idea of a charismatic contest between the big men as it was found among both the English and the Indians on the Fort St. GeorgeChennapatnam nexus is voiced most eloquently by an inebriated Baker in a conversation represented by Leigh: "but last of all burst out a passage [that] made mee smile, and shewed his weakness. 'Mr. Leigh, Mr. Leigh,' said the President, 'read the 15 chapter of the $2^{\text {nd }}$ booke of Samuell; doe not Absolonise, doe not Absolonise, and steale away the hearts of the people from mee. I would willingly give over the Presidents place if I could'." The reference is to David's handsome son Absolon who briefly succeeded in weaning away the people of Israel from his father, to become king instead of him, by the process that André Wink in the Indian context has termed fitna. ${ }^{114}$

However, despite all this talk in the sources of the agency of the big men, there are many indications that they were not able to control the situation and were dragged into things they did not want to get into. When the Brahmins said to Greenhill that when the people of the town complained to them about the religious collections of Rudriga and Timmanna mentioned above, he allegedly replied "that wee by envey one to another sought to trouble him being alwaise his answer," that is to say: please leave me out of this. ${ }^{115}$ To Baker, Venkata and Kanappa wrote that

112 VOM, Letter Baker, Gurney, Winter, Leigh to Surat 5.2.1653, 1: 121.

113 BL, 118 points of Venkata and Kanappa 4.4.1654, E/3/24: 159-69.

114 VOM, Leigh's account of his imprisonment ca. July 1655, 1: 135-6; Bible, 2 Samuel 14-8.

115 BL, 118 points of Kanappa and Venkata 4.4.1654, E/3/24: 159-69. 
they understood that since his arrival he had "by the many lyes and inventions of this townspeople, never injoyed a quiet howre."116

The case of the Brahmins themselves shows very clearly the possibilities and impossibilities of the big man, or the dialectic between manipulation from above and dragging in from below. Like all big men in the town and the fort, the Brahmin brothers tried to build a constituency or a client base. The Brahmins went somewhat further than others in this. At first they managed to enlist the Painters and Weavers, producers of most important export product of the town, who wrote in retrospect that "the bramanees by theire faire promises gott us to receive employment under them." 117 Venkata attached himself very tightly to the Painter communities by becoming their caste principal. But, perhaps thinking they could remain above the group divisions in the town, the Brahmins also tried to patronise groups with interests at odds with those of the Painters - and fell.

The fall of the Brahmins will be analysed more closely below, but first we must leave the issue of agency and turn to the issue of authorship, which is so closely related to the issue of agency for any situation to which we have access only through texts, that the two are quite impossible to distinguish (though Chapter 4 embodies a thought experiment attempting just that). Some modern observers are inclined to find that such petitions as we have in the EIC archives were not quite spontaneous, and were initiated by big men. This was certainly also the view of the Brahmins, who described in detail how they thought one of the petitions came about. According to them there was a meeting of Timmanna and a number of other prominent townspeople ${ }^{118}$ at the house of the Painter Chinnavandan Chetti, at which it was decided to take the Painters with their complaints to Greenhill. Once at John Gurney's house, still according to the Brahmins, "Tymana said hee desired that Mr. Leighs servant might be called to interpret and Thomas Clarke might write what they had to say." Although Leigh denied this particular charge, ${ }^{119}$ the petitions of the Painters can only have been part of a dialogue with the people they were directed to, as Eugene Irschick has shown amply for a later period. ${ }^{120}$

However, we may also see the two petitions we now have as the end products of a struggle to be heard. The three different preambles to the petition of December 1654 speak volumes in this respect. In total there

116 VOM, 118 points of Venkata and Kanappa 4.4.1654, 1: 144.

117 VOM, declaration of the Right Hand principals April 1655, 1: 122.

118 The other people present were "Nagana" (perhaps Naga Pattan, but a few points earlier he was still referred to as "Nagabattanda"), "Nallana," and Seshadri's kanakeka-pillai (the latter two designations may also refer to one person). That Chinnavandan Chetti was a Painter is seen from point 108 of the 118 points, EFI, [9]: 265.

119 VOM, 118 points of Venkata and Kanappa, 1: 143-4; EFI, Leigh's answer to the 118 points April 1654, [9]: 275.

120 Eugene Irschick, Dialogue and History: Constructing South India 1795-1895 (Berkeley, 1994). 
seem to have been six moments at which the Painters and Weavers addressed their complaints to the English. The first complaints to Agent Greenhill, which made the Brahmin brothers flee to San Thome, seem to have been delivered orally. Thereafter, the Painters seem to have addressed themselves to Baker with an inventory of complaints endorsed by Raga Pattan and written in English, "which hee received but never questioned them." Subsequently, the Painters addressed themselves to Greenhill once more, for his "longe experience with our condition," which seems to be the occasion to which the Brahmins alluded above. Greenhill meanwhile, in February 1654, promised to be responsible for the Painters' 800 hon debt to the Company, with an eye to pressuring Baker into doing something about the much larger debt (or what was construed as such) of Venkata and Kanappa. ${ }^{121}$ At the end of that year was made the draft that we have, which Greenhill was meant to pass on to Baker and in which Greenhill is asked to explain further the Painters and Weavers case to Baker, because the earlier attempt failed "by reason wee wanted some person able to declare our meanings unto the President in English." Then, after Baker's departure, the April 1655 petition was written, which incriminated not only the Brahmins but also Baker. The latter was certainly very convenient to Greenhill, as was Greenhill's promise to be responsible for their debt to the Painters, but we must not ignore the pent-up frustration that the petitions themselves put great emphasis on. The dilemma of the subaltern school in a nutshell. ${ }^{122}$

The Painters refer in a number of places to their subaltern position and their problems of communicating with the English. They refer to the problems encountered by the talaiyaris in getting their point across to the English Agent Ivie, when he and the Brahmin brothers wanted them to accept responsibility for indebted runaway workmen, "for that they had noe meanes of being rightly understood, left the place, and applied themselves to write unto Agent Ivie. But Vincaty, by meanes of wrong interpretation, made the breach worse." It is important to note though, that the Brahmins did not owe their position to a perfect command of English because it seems that they also required help in translating their 118 points from Telugu into English. ${ }^{123}$ The Painters and Weavers wrote that they themselves as well as other inhabitants found it quite impossible to

${ }^{121}$ EFI, Leigh's answer to Baker's protest against him 17.2.1654, [9]: 230.

122 BL, Declaration Painters, Weavers etc. ca. 12.12.1654 and petition of Right Hand principals April 1655, E/3/24: 228, 363; EFI, Greenhill's remonstrance to Baker concerning Venkata and Kanappa 1.3.1654, [9]: 236 (but contrast Foster's note ibidem). For the dilemma facing the Subaltern School concerning the "voice" of the "subaltern" see, inter alia, Ranajit Guha, "The Prose of Counter-Insurgency," in Subaltern Studies, vol.2, ed. idem (Delhi, 1983) 1-43; Eaton, "(Re)imag(in)ing Other²ness"; David Ludden, "Introduction: A Brief History of Subalternity," in idem ed. Reading Subaltern Studies: Critical History, Contested Meaning and the Globalization of South Asia (London, 2002) 18-20.

${ }^{123}$ EFI, Letter Baker to Company 18.9.1654, [9]: 292. 
complain of the Brahmins' abuses because the Brahmins possessed so many of the important offices in town, a fact that a letter by the nawab was found to confirm at the hearing of the Brahmins. In the words of the Painters and Weavers they were "abuseing their trust betweene wee that have noe meanes of redress but by their tongues, and our governor[s] that cannot but by them have any information." The Painters and Weavers also said that because the Brahmins possessed their caste principalities they were so entirely subjected to the Brahmins that they were at one point compelled to watch how two Painters were beaten and their houses demolished as punishment for "disaffecting." 124

The role of the Brahmins was thus crucial and we find something of a dialogue between European and Brahmin identities — as rival elites. In their 118 points Venkata and Kanappa wrote that: "such people as procure honour to our nation and the Company ought to bee honoured but such as occasion dishonour should be punished." It is not all that apparent what the brothers meant by "our nation" in that place, although it perhaps included Timmanna and Rudriga since they were the ones bringing the dishonour according to the points immediately preceding this forty-eighth point. Yet Greenhill seemed to deliberately misunderstand the point and commented snidely: "I never knew the Braminees to be of our nation before, yette I hold with their principles that whome honours it should be honoured but that's not the Braminees." The Brahmin brothers also suspected that Timmanna and a number of other prominent townspeople played along with Greenhill's sentiments and set afoot an anti-Brahmin conspiracy. They averred that at the gathering of a number of prominent townspeople at Chinnavandan Chetti's house (already referred to above) the expectation or hope was expressed that Greenhill and Leigh "will now never lett a Braminee, neither old nor new, continue." Although, as far as Timmanna is concerned, the accusation of anti-Brahmin sentiment somewhat contradicted the accusation concerning Timmanna's raising funds to wed Brahmins, the Brahmin brothers' suspicion of an antiBrahmin sentiment running through all segments of the Right party is nevertheless significant, and perhaps Timmanna and the Painters objected not so much to Brahmins but only to Brahmins who stepped out of their traditional occupation of priesthood and wielded worldly power. ${ }^{125}$

In a way the dialogic relation between the English and the Brahmins echoes what Heesterman sees as the perennial conundrum of the relation between king and Brahmin, the one mediating the this-worldly and

${ }^{124}$ BL, Declaration Painters, Weavers etc. ca. 12.12.1654, E/3/24: 364-9 and public hearing of Venkata and Kanappa over declaration of the Painters etc. 31.3.1655, G/19/1: 4-9.

$125 \mathrm{BL}, 118$ points of Brahmins 4.4.1654 and Greenhill's response to 118 points 10.1.1655, E/3/24: 159-69, 171-5v. For the negative attitude of some Europeans to Brahmins see also Chapter 1. 
the other mediating the other-worldly. ${ }^{126}$ At first sight it might seem that in the present case the Brahmins were mediating this-worldly power, just as the English, but Venkata and Kanappa did use their privileged ritual status to reinforce their positions. The Painters accused Venkata and Kanappa of silencing them time and again by feasting them with rice and milk only to make them swear not to let "any of their cast" complain. By this course of action Venkata and Kanappa would have made use of two received ideas in South Asian culture, namely that food distributed by Brahmins is pure and acceptable to all ${ }^{127}$ and akin to the prasada handed out at temples, and that eating someone's food means and entails loyalty. In their declaration the Painters etc. also wrote that when Venkata once defrauded Seshadri Nayak of a considerable sum of money, Seshadri did not pursue the matter with the English Agent and "only softly reprehended" Venkata, "for that hee was a Braminee." 128

Interesting in this respect is also the accusation that Kanappa went into the houses of town dwellers in the night to abuse their wives, which Kanappa denied by confessing "to have nightwalked but not to other men's wives." 129 Perhaps it was something of a cliché that Brahmins could, if they wanted, have their way with lower caste women. This was the main theme of Shahaji's play about the Brahmin and the Madiga woman, which is critical of caste through "parody by context" as the editors note. At twothirds of the play, the woman's husband decides to give her to the Brahmin as a gift, and one of his considerations is that, "he's a Brahmin, so this sort of gift to him will make the Madiga a hero among givers."'130

An interesting insight into the clashing power-knowledge systems of Brahmins and Europeans and the changing role of Brahmins is provided by Venkatadhvarin in his 1640s travelogue of parts of the Tamil country and disparate other parts of India voiced through two celestial creatures, one cynical, the other optimistic. What strikes the cynical voice most about the Europeans he finds in Chennapatnam is that they do not practice "purity" and "treat Brahmins with contempt, as if they were no better than blades of grass" and therefore these "Europeans [Hunas] and others devoid of purity get rich, [while] paragons of virtue win only misery." Yet it is not

126 J.C. Heesterman, "The Conundrum of the King's Authority," in Kingship and Authority in South Asia, ed. J.F. Richards, 1-27 (Madison, 1978).

127 With the notable exception of the stricter part of the Lingayats of South India, which exception Vijaya Ramaswamy calls a reverse process of sanskritisation. Vijaya Ramaswamy, “Artisans in Vijayanagar Society," IESHR 22 (1985) 417-44, there 442 note 156.

${ }^{128}$ BL, Declaration Painters, Weavers etc. ca. 12.12.1654 , E/3/24: 364-9 and Public hearing of Venkata and Kanappa over declaration of Painters etc. 31.3.1655, G/19/1: 4-9. See also Chapters 2 and 6 for the role of food in loyalty.

${ }^{129}$ BL, Declaration Painters, Weavers etc. ca. 12.12.1654, E/3/24: 364-9 and examination of Venkata and Kanappa over the same 31.3.1655, G/19/1: 4-9.

130 Shahaji, “Take my Wife," 373. 
just in the European enclaves that the cynic perceives a changing world order and a changing role for Brahmins in it. He makes almost the same complaint about the land of Andhra: Brahmins there have become accountkeepers subservient to Shudras, and even if one can find a Brahmin still versed in the Vedas somewhere in a remote place "he's sure to be busy scouring someone's dirty pots." Venkatadhvarin's satirical poem reflects how the playing field and the rules of the power game had changed in South India, perhaps more so in Chennapatnam than elsewhere, but the ideal for Brahmins - to be studied in the Vedas and generally "pure" and "priestly" — had not. ${ }^{131}$

So however tenuous the connection of Brahmins to the Vedas and priestly duties had become in practice, the link of the Brahmin brothers of Chennapatnam with the other-worldly was still feared. Both the Painters and Greenhill accused them of using sorcery to influence the minds of people. The Painters wrote that, "the brahminees Vincaty and Conappa have in their heads and about their body so many charmes, spells, rootes and other wichcrafts, whereby they endeavour to stopp the mouths of any that speake against them or take of the edge of anger, from those that may have power to punish them, in which case some course ought to bee taken with them." 132 Greenhill warned Baker that the Brahmins might have turned him into their puppet by means of sorcery. 133 When they were questioned on the charges against them in March 1655, their room in the fort was searched and a bag was found which seemed to Leigh and the other English investigators to contain materials for what we would now refer to as voodoo, including a paper with the names of all the more important Englishmen and pieces of their clothing. So the connection with the other-worldly could also be turned against the Brahmins. Interestingly, it was other Brahmins, those serving in the main temple, who were called upon to review the contents of the bag. The temple Brahmins confirmed that the contents were "sorceryes" and the brothers were "wiches."134 Unlike Hindu kings the English were not to be convinced of the Brahmin mediation of the divine, but they could be convinced of their mediating the diabolic.

There were thus two elites that the castes of Chennapatnam could turn to for recognition of their status, not just the "kingly" British but also

131 Venkatadhvarin, Un poème satyrique sanskrit: La Visvagunadarsacampu de Venkatadhvarin, trans. and intro. by Marie-Claude Porcher (Pondichery, 1972) 67-9, 89; Discussed in Rao, Shulman and Subrahmanyam, Symbols of Substance, 1-12, whence the above translations of fragments. Contrast Subrahmanyam, "Taking Stock," 88. Rao et al. date the text to the first half of the seventeenth century, but it must be after ca. 1640 for its description of Chennapatnam.

132 BL, Declaration Painters, Weavers etc. ca. 12.12.1654, E/3/24: 364-9.

133 VOM, Greenhill to Baker 1.1.1655, 1: 139.

${ }^{134}$ EFI, Letters Leigh and Greenhill to Company 20 and 21.4.1655, [10]: 31-2. 
the "priestly" Brahmins; which brings us back to the question of authorship and agency in the case of the reviled street ruling. Luckily for the modern researcher this question also came up at the time. At the outset of this chapter was already quoted the view of the Painters and Weavers etc. that Venkata and Kanappa "made the distinction on Right and Left Hand." In their later petition the Right Hand parties also squarely blamed the Brahmin brothers and said that they put Baker up to "parting or appointing the streets." Moreover, they wrote to Baker from their exile after the November 1652 ruling "that hee should not trust the Bramanees, who were the occasion of the difference." 135 The Brahmin brothers themselves, furthermore, wrote clearly that "the Chittees by our meanes has procured their two streetes." To which Greenhill responded that in that 79th article "tis confessed [that] by their own meanes and for their own hopes the Chitties gott 2 streetes, which is contrary to this countrey custome." 136 Venkata and Kanappa further argued that their opponents Seshadri, Rudriga and Timmanna were jealous or afraid of the backing, financial and otherwise, of the Chettis that the brothers had gained in this way, and were annoyed by the fact that the Chettis would not let them into their streets. ${ }^{137}$ Thus clearly the Brahmins had made the ruling to please the Chettis, and it is important not to ignore that nexus of agency. After the Brahmins rejoined the Right they are said to have spoken of the "designes" of the Left Hand, which they then promised to bring to naught. 138

There was thus clearly a dialogue between the clamouring for recognition of their status on the part of the castes of Chennapatnam and the willingness of the authorities to grant it. In fact it seems a universal rule that identity is construed in a dialogue between conscription and ascription, as Kwame Appiah suggests. One might wish to argue that the recognition that the castes of Chennapatnam demanded, was different from the ascription or imposition of the colonial period that is often referred to as the colonial "gaze," but — as Kwame Appiah also argues — any act of recognition, especially by authorities, can ossify the identity that is its object. Because in such cases a gaze can turn to stone, he calls this the Medusa Syndrome: "because identities are constituted in part by social conceptions and by treatment-as, in the realm of identity there is no bright line between recognition and imposition." ${ }^{139}$

At the conscriptive end of the caste spectrum in Chennapatnam we find the "big men" Timmanna, Rudriga, Seshadri and Koneri. The titles used among these men, Nayak (or Naidu) or Chetti, were also very 
unspecific, broadly designating a leading figure or one involved in trade respectively. ${ }^{140}$ It therefore seems that they, as leaders of the Right Hand, were simply that, "Belgewar," or Balijas. The designation of Balija seems to have developed in the early modern period into something of a caste in itself, but this category was open or fluid in the way that, as Dirk Kolff has shown, the status of Rajput was in this period. This group may be compared to or perhaps identified with another Right Hand group which the contemporary Dutch observer of Hinduism in Coromandel Rogerius called Cauwreaes: "under this lineage are accepted all those who have forgotten their lineage and are for that reason as it were without lineage. They compare this lineage therefore to the sea, which receives the water of the rivers, and is never full up." 141 It is significant in this respect that the Right Hand column in the table above is much fuller than the Left Hand column.

However, not all caste affiliation was by conscription or choice in Chennapatnam, and the case of the Balija category may have been exceptional. Caste was defined in the introduction of this chapter as any named status group of which membership was generally perceived to be based on descent. That definition does not take into account profession as many definitions of caste for this period do - in fact many prefer to speak of guilds rather than castes. That profession was associated with caste but not a necessary ingredient of it, is proven by the case of Naga Pattan, who the Brahmins label as a goldsmith even though he was clearly involved in a completely different profession, namely that of gunpowder production. ${ }^{142}$ During one of the more complex episodes of the dispute between Right and Left revolving around the house of Venkata and Kanappa (which will be elaborated below), the brothers are supposed to have reminded the Painters every day at the time Naga Pattan was ringing a bell for his puja in their sequestered house, "that twas their dishonour that a goldsmith should bee in that house and that rather ought to pull it downe and cutt of his haire." 143 In the eyes of the Brahmins as represented by the Painters, the caste of Goldsmith is thus associated with a certain ascribed status, a status

140 VOM, Translation of a Telugu qaul of Ivie to Raga Pattan 6.1.1647, 1: 152. Thurston, Castes and Tribes, s.v. Naidu, Naik. Talbot, Precolonial India, 58-9, 191.

141 Compare the statement by H.A. Stuart as late as 1891 that Balijas, "will admit, without much scruple, persons who have been expelled from their proper caste, or who are the result of irregular unions." Quoted in Thurston, Castes and Tribes, s.v. Balija. Kolff, Naukar, Rajput and Sepoy. Abraham Rogerius, De open-deure tot het verborgen heydendom, ed. W. Caland (The Hague, 1915) 5.

${ }_{142}$ EFI, 118 points of Venkata and Kanappa 4.4.1654, [9] 143. A comparable example of the tenacity of a caste label is the case of Papadu (ca. 1700), who, as Richard Eaton shows, could never shake off the label of Toddy-tapper even though he was a quite successful entrepreneur in banditry and most of his direct relatives were not directly involved in palm wine production either. Eaton, Social History, 174.

${ }^{143}$ EFI, Declaration Painters, Weavers, etc. ca. 12.12.1654, [9]: 240. 
not befitting the house of a Brahmin or of a Right Hand principal. Similarly, the Left Hand Pallis carried around a memory of their status of olden days. Although we lack information on the professional activities of the Pallis in Chennapatnam, Rogerius' information for Pulicat was that they, "are poultry and pork buyers and sellers, some sow, some paint and some are soldiers; in olden days, so they say, they were renowned for their prowess in warfare and used to be men of the field." 144

Rogerius' informant was the Brahmin Padmanaba, and we do have sufficient evidence to show that before the colonial gaze there was the Brahmin gaze. Yet, it is often argued that the Brahmin view of caste was not all that relevant to precolonial society, and only became relevant when the British, as power-holders, inherited the Brahmin view. ${ }^{145}$ Alternatively, it has been argued that the Brahmin view of caste rose to prominence along with the Brahmins themselves through the eighteenth-century regional kingdoms (see Ch. 6). Sheldon Pollock has argued against these views that Brahmin statements on caste were often formulated in proximity to the centres of worldly power, the royal courts, and that there was a particular efflorescence of prescriptive texts on dharma in the eleventh and twelfth centuries which, among other things, reformulated the exclusion of Shudras from knowledge and worship. ${ }^{146}$

An example of the Brahmin gaze in the Tamil country from precisely that period $(1118 \mathrm{CE})$ is found in a well-known inscription from the vicinity of Tiruchirappalli that spoke of a gathering of learned Brahmins (Bhattas) to determine the status of a group of artisans who were designated with the ancient term Rathakaras. On the strength of ancient authorities including Yajñavalkya and Gautama the Bhattas defined 1) a Mahisya as one born of the union of a Kshatriya father and a Vaishya mother, 2) a Karani as the daughter of a Vaishya father by as Shudra mother, and 3) a Rathakara as the son of a Mahishya father and a Karani mother. What all these unions have in common is that they are what the ancient authorities call anuloma, "following the hair (of the male)," that is unions of a man of a higher class with a woman of a lower class. It was further decided that being anuloma, the Rathakaras were superior to those who were pratiloma ("against the hair") and were entitled to upanayana (the sacred thread-ceremony), a distinguishing sign of the three higher varnas. Yet, while being granted the sacred thread, the ritual rights of the Rathakaras were to be strictly circumscribed. The Rathakaras were not to perform yajña or ceremonial worship of gods, names, or any living creature, and further forbidden from

\footnotetext{
144 Rogerius, Open-deure, 6. The Caunreaes are not to be identified as the Karavas (as the editor the Open-deure does) because the latter are discussed separately by Rogerius as Correwaes.

145 Compare Talbot, Precolonial India, 48-61; More examples mentioned by Pollock, "Deep Orientalism," 96-8.

146 Pollock, "Deep Orientalism," 98-111.
} 
the use of mantras during their upanayana ceremonies as well as from recitation of the Vedas. ${ }^{147}$ It is probable that the inscription was the outcome of a bid for recognition on the part of the "Rathakaras," but the inscription matches recognition with imposition.

This example also shows how difficult it was to claim any pure Vaishya or Kshatriya status before the Brahmin gaze — while Shudra status appears to have been less hard to claim and worn with pride by Telugu dynasties like the Kakatiyas. ${ }^{148}$ An exception was the powerful trading community organised in a so-called nakaram with its headquarters at Penugonda, whose claim to Vaishya status is well attested for the later medieval period. Yet a community like the Telikis, oil-pressers and oil merchants, encountered more obstacles in its collective upward mobility in the region of Vijayawada in northern Coromandel, and P.S. Kanaka Durga shows that they therefore aspired to both Kshatriya-like and Vaishya-like status. ${ }^{149}$

It was, in fact, very difficult even for kings to get their Kshatriya status acknowledged. Cynthia Talbot reasons that if the rank of Kshatriya had been crucial to social recognition and prestige during the heydays of the Kakatiyas (1175-1324), one would observe a greater number of royal and chiefly lineages claiming Kshatriya status in contemporary inscriptions. Yet that argument $e$ silentio may be turned around: perhaps access to the title of Kshatriya was blocked by the Brahmins, who mostly controlled access to the medium of epigraphy as Talbot also notes. ${ }^{150}$ In our period, or somewhat more widely between 1550 and 1750, there was a lively debate on rajadharma, or the dharma of the king, in which interpretations of authoritative texts such as the Manusmrti became progressively more literalistic. The problem for kings in claiming Kshatriya status was compounded by the belief, spreading in the seventeenth century, that no true Kshatriyas or Vaishyas remained in the world. One Brahmin author said he had to rely on the view of his father that some did remain, though in a concealed form since they had fallen away from their traditional duties, precisely as the Telikis of Andhra thought about themselves. ${ }^{151}$

Shivaji's successful bid for Brahmin recognition, which is often cited as an example of how caste was experienced in the precolonial period, presented a hard-won exception. At his abbiseka, or "coronation," in 1674 Shivaji had the Brahmin Gaga Bhatta instate him as a Kshatriya king linked

147 Annual Reports on Indian Epigraphy 1906-10 (photogr. repr. Delhi, 1986) 1909 para. 45; Stein, Peasant State, 197; Louis Dumont, Homo Hierarchicus: The Caste System and Its Implications (London, 1970) 126-7.

148 Talbot, Precolonial India, 51.

${ }^{149}$ Ibidem and Kanaka Durga, "Identity and Symbols," 153.

150 Talbot, Precolonial India, 49, 51.

151 Sheldon Pollock, The Ends of Man at the End of Premodernity. 2004 Gonda Lecture (Amsterdam, 2005) 63-76. 
to the Sisodia Rajputs of Rajasthan, a genealogical claim that was in the words of André Wink “destined to remain disputed forever."152 Susan Bayly views Shivaji's success in obtaining his desired caste as a sign of the "fluidities of caste" in the precolonial and a stage in a development towards the "rigidities" of the high colonial era, but more recently Ananya Vajpeyi has given the impact of rigid Brahmin views at the time itself centre-stage, asking: "from whose perspective was he [Shivaji] a low-caste person, an upstart trying to seize a royal title, and why did the existence of this point of view seem to affect Shivaji's perception of himself."153

In the elaborate report of Shivaji's abhiseka in the Dutch East India Company archives, we see that Shivaji's claim was already contested twice at the ceremony itself. ${ }^{154}$ Firstly the gathered Brahmins did not want to grant Shivaji the status of Kshatriya and then they did not want to allow him recitation of the Vedas, which dharmashastric texts reserved for the three higher varnas. This episode is reminiscent of the "Rathakara" inscription in which the Rathakaras were admitted to the fold of the higher varnas as far as the material sign of the sacred thread was concerned, but restricted in their use of the concomitant ritual rights including recitation of the Vedas. The Brahmin Paramananda by contrast, in his contemporary eulogising epic, takes the position that Shruti, the personification of Vedic recitation, was already present at the birth of Shivaji along with Smrti, the personification of the later scriptures. ${ }^{155}$ The Dutch report has it that, having gathered 11,000 Brahmins and Boots (Bhattas)"156 — "being their scriptural scholars and of the finest caste" — at Raigarh:

Shivaji announced to the principal and most learned of them his intention, and that he could not be crowned before he had left his present caste of Bhonsla [Bhousula] and had adopted the caste of Kshatriya [Kettery], and that they should give him that caste, to which the scriptural scholars replied that such could scarcely happen since

152 Wink, Land and Sovereignty, 36. Contrast Stewart Gordon, The Marathas 1600-1800 (Cambridge, 1993) 88. Ananya Vajpeyi encourages us to take Ramachandra Chintaman Dhere's hypothesis about Shivaji's pastoral ancestry seriously in "Excavating Identity through Tradition: Who Was Shivaji," in Traditions in Motion: Religion and Society and History edited by Satish Saberwal and Supriya Varma (Delhi, 2005) 240-71.

153 Susan Bayly, Caste, 24, 56. Vajpayi, "Excavating," 241.

154 NA, Letter Vengurla to Batavia 13.10.1674, VOC 1304: 406v-7v.

155 Paramananda, The Epic of Shivaji: Kavindra Paramananda's Sivabharata, trans. James Laine in collaboration with S.S. Bahulkar (Hyderabad, 2001) 99-100.

156 Both Gaga Bhatta and Paramananda's father, whom the latter refers to as Bhatta Govinda (verse 8.2-3), were evidently identified as Bhattas. Moleworth's dictionary glosses the word as a title for learned Brahmins or a word for a Brahmin who subsists by begging, but Susan Bayly, while speaking of the mid-eighteenth century, writes: "In both north and central India, some new dynasts encouraged the itinerant quasi-Brahman bards known as Bhats or Charans to attach themselves to these armed hill lineages... The idea of recruiting Bhats to sing praises... was that these hill chiefs could thereby be exalted in the heraldic style associated with Rajputs, thus becoming more plausibly 'royal'." Molesworth, Dictionary, s.v. Bhatta; Susan Bayly, Caste, 45. 
his ancestors had always been Bhonslas. Shivaji brought to bear against this that the Bhonslas were descended of the Kshatriya lineage and that such could rather happen, and that the other party [should] also consider that Shivaji could not be crowned lest he be a Kshatriya first, so that they, after he had promised not to act nor rule as tyrannically and badly as before, with great ceremony, on the $8^{\text {th }}$ of June last gave him the caste of Kshatriya and wanted to teach him those prayers as well, but he desired that they teach him the prayers of the Brahmins, to which they wouldn't comply, but one of the principals of that group did teach him those, to whom Shivaji had 7,000 hons paid in recognition. This day 17,000 hons of two rixdollars each were spent on the ceremony and distributed to the gathered.

Thus the mediation of caste status by Venkata and Kanappa was by no means exceptional in the seventeenth century, or even the early modern period as a whole. "Whatever act the Aryas [the three higher varnas] who know the Vedas claim to be dharma, is dharma," wrote Laksmidhara in the twelfth century Rajasthan, and so at the turn of the eighteenth century, in his play about the Brahmin and the Madiga woman, Shahaji let the Brahmin suggest that he as a Brahmin could bend the rules of dharma since it was Brahmins who made up all the rules. ${ }^{157}$

The Brahmins of our case had overplayed their hand, however; they had obviously not expected losing their house to the Left Hand or being manoeuvred out of their position by the Right Hand. One might argue that Greenhill would have removed the Brahmins anyway for their role in exposing his private gains to Baker. But even before Greenhill had the chance to remove them the dispute over space had issued into something of a revolt against the brothers in the town. The brothers' retreat from the town was symbolised by their breaking down a small temple or shrine that their father had built in front of the main temple. The Painters found that the black magic the Brahmins performed through that temple (and a copper plate supposedly buried under it) were such as "in these parts are punished with death." It is interesting that the Painters should suggest a death penalty for the Brahmins, since killing Brahmins was generally considered a great sin and forty years later upon the request of the inhabitants of Chennapatnam a death sentence for a Brahmin was commuted on that ground. ${ }^{158}$ In any case the Brahmins broke down the temple themselves in 1654, because, they are to have said later, they distrusted its effects and the magic was working against them rather than for them. Whether it was for that reason or because of the opposition of

157 Pollock, "Deep Orientalism?” 107; Shahaji, "Take my Wife," 366.

158 Love, VOM, 1: 497. 
the inhabitants to it, the removal of the shrine was a clear sign of the Brahmin brothers' downfall. ${ }^{159}$

\section{Problem 3: The Minimal Group Hypothesis in History, and the Problem OF INVENTION}

It would seem that by trying to look at the situation in Chennapatnam as a minimal group conflict I have created a problem for myself unnecessarily. Yet, as a matter of fact, the minimal group hypothesis is implicit in much of the writing about clashes between groups in South Asia. This is the case with much recent writing about caste (where Indians are seen to have started living the labels applied to them by the British) and even more so of the violent clashes between Hindus and Muslims of the twentieth and twenty-first century, most particularly the violence of the 1947 Partition, which are often seen to have been more dependent on particular circumstances that had recently arisen than on a structural antagonism between the two groups or constructs of groups. ${ }^{160}$ The question of flash flood vs. rising tide is not unique to the historiography of India, ${ }_{161}$ but in the Indian context the flash flood idea is often operated conjointly with the idea that "othering" as we know it in present-day South Asia is a European import. ${ }^{162}$ Those two ideas sit together uneasily; if there was a rising tide of communalism - sponsored by colonialism or not - the Partition violence would have been inevitable and there would be no need to stress the particular circumstances. While I think the insight from experimental psychology that groups can be formed quite instantaneously and on a rather random basis is a valuable one, there is a clear need to study groups in the real world over time. So let us think about the flash flood vs. rising tide problematic more closely in the context at hand, the Right-Left conflict in Chennapatnam.

The historical record very much resembles the memory of individuals, in which uneventful periods go unrecorded and events of great impact generate a flashbulb-memory, in which every detail still has a place. On some historical periods and events a flood of light is shed through

159 VOM, Declaration Painters, Weavers etc. ca. 12.12.1654 and Greenhill's response to 118 points 10.1.1655, 1: 145, 147; BL, Public hearing of Venkata and Kanappa 31.3.1655, G/19/1: 4-9; EFI, Letter Leigh to Company 20.4.1655 [10]: 32.

160 Compare Gyanendra Pandey, "Can a Muslim be an Indian?," Comparative Studies of Society and History (1999) 608-29 and Ayesha Jalal, Self and Sovereignty: Individual and Community in South Asian Islam since 1850 (London, 2000) 503 and passim.

161 Consider, for instance, the debate around Daniel Goldhagen's Hitler's Willing Executioners, in which the idea is put forward that Hitler's "final solution" was the natural outcome of a centuries-long build-up of anti-Semitism rather than a sudden burst of violence performed on command rather unconsciously.

${ }^{162}$ Compare Pandey, "Can a Muslim be an Indian?” and Ayesha Jalal, Self and Sovereignty. 
relatively abundant records and chronicles, while other periods and events are left in the dark - something historians know all too well. That is also why I have chosen this case rather than a case untinged by European presence, which some would find less problematic — as was already discussed in the introduction to this study. Thus we know very little about the Right Hand-Left Hand conflict before the European sources. Some, most notably Stein, have therefore tried to reconstruct the conflict and how it related to society at large in the Vijayanagar period from later sources, mostly from the eighteenth and nineteenth-century sources. ${ }^{163}$ We do, however, have a few sources of the earlier period itself, including the following inscription of $1072 \mathrm{CE}$, also provided by Stein:

....in the second regnal year of the king [Kulottunga I] there was a clash between the Right-hand and Left-hand communities in which the village was burnt down, the sacred places destroyed and the images of deities and the treasure of the temple [Mummudi-Chola-Vinnagar-Alvar temple] looted. ${ }^{164}$

This piece of evidence clearly militates against the application of the minimal group hypothesis in our case, because how can these groups have been minimal if they had existed for centuries? Yet, as has been seen, some of the sources for our case cried "invention" and "uncustom."

Could the seventeenth and eighteenth centuries, that is the early period of European involvement, still have constituted the high tide of the Right-Left antagonism, as some modern observers think?165 We do know that the intensity of the disputes the antagonism engendered grew considerably less in the nineteenth century so as to have almost disappeared at the time when Brenda Beck studied the phenomenon in a village in western Tamil Nadu. ${ }^{166}$ What we do not know in much detail, however, is how intense disputes along the Right-Left boundary could become at times and places outside the European gaze. The inscription quoted in the last paragraph certainly suggests that there may have been places and times before Foucault's classical age when the division was intensely lived. To argue that the European presence in some way intensified the clashes is therefore not feasible, and I would say it is better to err on the side of assuming that the antagonism was already important before the Europefactor came in. Let me illustrate the possibilities with three graphs:

163 Compare Stein, Peasant State, 196, 474-7.

${ }_{164}$ Quoted in Stein, Peasant State, 174.

165 E.g. Brimnes, Constructing, 30 and Stein, Peasant State, 179.

166 Beck, Peasant Society in Konku and "Right-Left Division." 


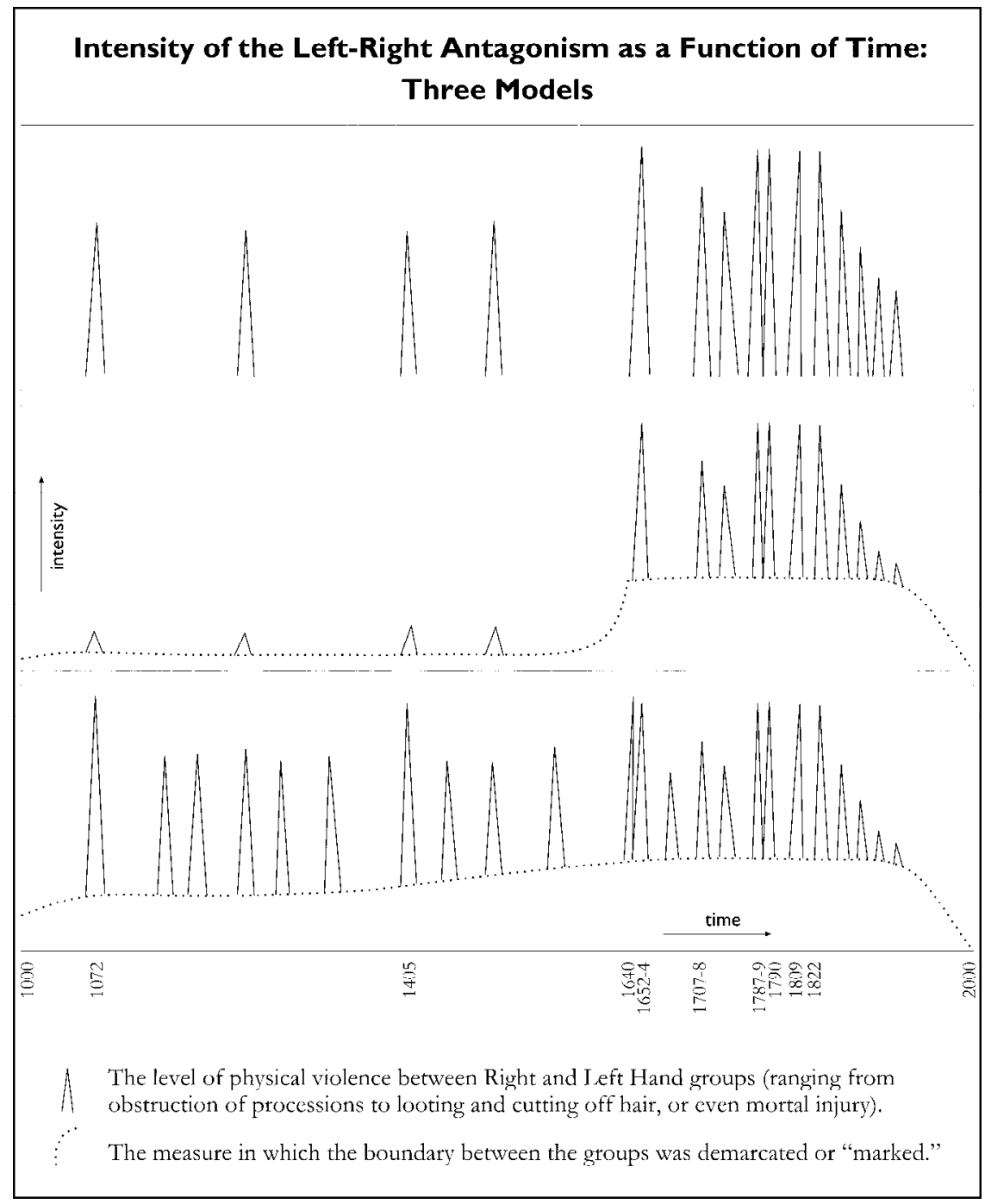

The first graph illustrates Appadurai's theory that the clashes were quite unconnected events, "widely varying local and contextual variants of a single cultural paradigm." This view is shared by Stein, although he disagrees with Appadurai that conflict was a major aspect of the division in the early centuries. Stein writes that "at any time and place, the composition of Right and Left divisions would vary according to the exigent condition which brought them into being, and they would lapse into latency with the passing of that condition." But Appadurai offers no substantive description or explanation of the state of latency of the "in between" periods, while Stein does not explain how the boundary between Right and Left could be both based on the measure of involvement with agriculture of each group 
and vary according to each "exigent condition" to the extent that he suggests. Appadurai and Stein also assume that the antagonism intensified with urbanisation, especially in the later Vijayanagar period and in the European enclaves, visualised in the graph as an upward trend in the peaks from 1500 onwards. ${ }^{167}$ Appadurai's view would accord with Sudhir Kakar's a-historical view of the Indian psyche, written around the same time, which holds that a "volatile aggressiveness which can quickly flare up and as suddenly die down" is inherent in Indian culture because of a weaker differentiation of the individual superego in comparison to Western culture. ${ }^{168}$ However, violence in the form of riots directed against groups was and is not confined to India, ${ }^{169}$ so any contribution to the frequency and level of rioting violence of the culturally determined "volatility factor" that Kakar suggests must be seen in relative terms. Moreover the image of volatility and unconnectedness represented in this first graph remains unsatisfactory, especially if one considers that the series of conflict peaks was sustained for a thousand years.

The second graph then represents Brimnes' view in which the clashes are not disparate events but sustained by a discourse (the dotted line) that received an impetus from the dialogue between Europeans and Indians after 1650 and even more so after 1700. This graph also illustrates the problem with the view of the scholars who blame the British for dividing India along caste and religious lines. Their view is limited to the British sources, and hinges on the relative dearth of sources for the precolonial period. Their view is that of the second graph. This study intends to show that that graph is incorrect.

The third graph is an alternative view, a filling in the gaps (but emphatically not a projecting-back in time) between the 1072 inscription and the clashes we hear of in the European sources. It is not entirely speculative. There is one Tamil inscription of around 1405 that - as far as could be made out by the government archaeologists unable in 1921 to read the ends of the lines obstructed as they were by a roof construction refers to the settlement of a dispute between the Right and the Left in the village of Malayampattu after some loss of life on both sides. ${ }^{170} \mathrm{We}$ do

167 Appadurai, "Right and Left Hand," 226-7, 247, 258; Stein, Peasant State, 179-80, 205, 214, 240-88.

168 The Inner World: A Psycho-analytic Study of Childhood and Society in India (2d ed. Delhi, 1989) 134-6.

169 C.S. Srinivasachari starts his article on the origin of the Right/Left division with a quotation from an unmentioned source that the members of the divisions "were as ready to fall out with one another on the smallest provocation as Orangemen and Ribbonmen were in Ireland, or the Montagus and Capulets in Verona." Srinivasachari, "The Origin," 77. For the early modern period one may also think of the regular invasions of the Jewish quarters of Central Europe or the plunder of the estates of the nobility and regent class in late eighteenth-century France and the Netherlands.

170 Annual Report on Epigraphy 1920-21 (Madras, 1921) 1921 no. 185 and para. 47. 
know also that between the foundation of Chennapatnam and the troubles of 1707 there were "four or five such troubles" in the town, ${ }^{171}$ so even in Chennapatnam there were far more clashes than the ones that receive all the attention, especially the 1652-54 clash as well as that of 1707-8 which Brimnes calls the best known and most spectacular of the eighteenthcentury clashes. Another clash that has gone unnoticed in the small pile of secondary literature on the Right-Left divide is one that took place in Pulicat in 1640, in which 15 Pallis were killed by Caunreas. ${ }^{172}$ Levels of violence similar to those of the 1072, 1405, 1640 and 1652-5 clashes, that is including attacks on habitations, plunder, arson or even killings, were attained in the Madras area in 1787 (one mortal casualty), 1790 and 1809 ("attended with bloodshed and proceeding to very dangerous extremities"173) as well as in Tranquebar in 1787-89 and 1822. Therefore the peaks of 1072, 1405 and 1652-5 in the graph are on a par with those of the mid-eighteenth to the early nineteenth century. In the second half of the nineteenth century and the early twentieth century, however, publications of the colonial administration reported that the violence attending clashes between the divisions had decreased. The 1907 Trichinopoly gazetteer wrote that the violence as it "occurred in days gone by" had declined, but "feeling still runs very high." The dispute had become ritualised and formalised to the extent that some observers in the late nineteenth century reported that women of certain castes belonged to a different division and would not sleep with their husbands during disturbances between the two divisions (something we do not hear of for our case or the eighteenth century). ${ }^{174}$ This decrease in violence but persistence of sentiment is represented in the graph by a steeper decline in the tops of the peaks than in the "boundary marking" curve. ${ }^{175}$

More importantly there are two thirteenth-century inscriptions that give a clear indication of the measure of identification and group demarcation taking place on the Left side of the division. An inscription of 1218 from a locality in the vicinity of Tiruchirappali in the heart of the Tamil country established that the members of the " 98 subsects" that make up the Left Hand must henceforward "behave like sons of the same parents

${ }^{171}$ Petition of the Left Hand division to the Madras council 6.11.1707, quoted in Brimnes Constructing, 70. Brimnes does not take these clashes into account, which is why a peak is added to represent the clashes between 1655 and 1707 only in the third graph.

172 Rogerius, Open-deure, 4-5. I have not found any trace of this clash in the Pulicat dispatches and resolutions over 1639-41.

173 Contemporary report of Madras government to Company, quoted by Brimnes, Constructing, 139.

${ }^{174}$ Even for the later nineteenth century reports of this phenomenon are rare, and Thurston could not find confirmation of it in his investigation of the Palli caste. Thurston, Castes and Tribes, s.v. Palli or Vanniyan.

${ }^{175}$ Compare Brimnes, Constructing, 4, 58, 82-3, 103-5, 139, 188, 220-1. 
and what good and evil may befall any one of us, will be shared by all. If anything derogatory happens to the Left Hand [idangai] class, we shall jointly assert our rights until we establish them." In this inscription we are thus witnessing a very conscious effort at community building, and the inscription continues to list a number of material manifestations of the Left Hand identity, like loose hanging hair, the feather of the crane and various honorary insignia and musical instruments. The inscription ends by clearly demarcating the boundary of the group: "Those who act in contravention to these rules shall be treated as the enemies of our class. Those who behave differently from the rules (thus) prescribed for the conduct of the Left Hand classes shall be excommunicated and shall not be recognized as srutiman [members of the community]. They will be considered slaves of the classes opposed to us." Another inscription (of 1227 CE from the vicinity of Vridachalam closer to the coast) deals with the admission of two castes to the Left Hand and ends with a similar demarcation of the group boundaries "if we violate this resolution, we shall be considered as wrongdoers to the caste." 176

\section{CONCLUSION}

Yet, if the outbreaks of the conflict were not so sudden or "minimal" there must have been some content to the antagonism. Most of the evidence points out that the focus or "content" of the disputes was not any "objective" fact like provenance, occupational type, ritual mode or pecuniary condition, but the relative fact of status, expressed through symbols of honour and precedence. It was the lag between ritual status and economic clout of such communities as the "group of five" and the weaver and painter communities of South India in the late medieval and early modern periods that was at the root of such collective status strivings as those manifested in the Right-Left antagonism, or as Vijaya Ramaswamy writes: "increasing economic prosperity resulted in their bid for a better status which revealed itself, unlike in the medieval North, not in caste negation but in caste exaltation." 177 The lag between ritual status and economic prosperity was maintained by the Brahmin gaze.

Precisely because honour was so central to the dispute and any line between honour and dishonour is marked by subtle material distinctions and nuances of address, ${ }^{178}$ the matters triggering the most violent reactions might seem minor to people partly or wholly outside the status loop of caste (the European participating observer then and the modern observer

\footnotetext{
176 Both inscriptions quoted in Stein, Peasant State, 182-3 (translation slightly adapted here).

177 Ramaswamy, “Artisans," 444.

178 Compare Bourdieu, Outline, 11. See for examples from South India relevant to our period: Ramaswamy, "Artisans," 435-42.
} 
now). The subtle material manifestation of caste worth that was the sacred thread, for instance, seems to have played an important role in the Right/Left dispute that led to some loss of life in Malayampattu ca. 1405. ${ }^{179}$ In 1640, the violent clash between Caunreas and Pallis, both classed as Shudras by Rogerius or rather by his Brahmin informant Padmanabha, was triggered by a particular use of a cloth for a funerary procession: "thus one sees how precisely every lineage of the Shudras insists on its due."180 Similarly, the Fort St. George council commented that the words exchanged between Seshadri and a Left Hand person that were the immediate cause of the January 1653 riots were "not worth the takeing notice of." 181

Yet, as has already been remarked, the concern with honour was not confined to the Indian section of the population. Seemingly trivial matters within the sphere of honour could also trigger violence among the English, who were very well able to understand the significance of small tokens of honour - as Baker's behaviour at his farewell ceremony signified. In fact, status and hierarchy were things the English/British understood very well, as David Cannadine has argued with respect to the colonial period. ${ }^{182}$ The commonalities between Englishmen and Indians were probably greater than the differences in 1650s Chennapatnam. In May 1654 there was an incident at the "Family" table in the fort that bears some similarities to the "not worth a cash" incident, though on a smaller scale. When a Mr Gardener remarked that the sausages that were being served "stunke," Anthony Baker, "struck down the old man and beat him" for complaining about the food served at his uncle's table. ${ }^{183}$

However, what made the Left Right competition unique at one level (though it was not so unique at a general level), was the fact that status markers had become a matter of group rivalry rather than individual rivalry, or rather that precisely status markers had become such an important element in people's identity. A whole reservoir of subtle status markers had accrued to each division and its constituent castes over centuries. As has been seen in the inscription from the vicinity of Tiruchirappalli, by 1218 the Left Hand had already become as marked by a ritual status with its concomitant behavioural and material manifestations as the out-group was by the absence of these. And in our 1650s case the Left were, in the eyes of the Right, marked by a status too low to have two streets reserved for their ritual purposes. Therefore Baker and his council should be taken seriously

\footnotetext{
179 Annual Report on Epigraphy 1920-21, 1921 para. 47.

180 Rogerius, Open deure, 4-5.

181 VOM, Letter Baker, Gurney, Winter, Leigh to Surat 5.2.1653, 1: 120.

182 Cannadine, Ornamentalism.

183 VOM, Leigh's account of his imprisonment, ca. July 1654, 1: 136; EFI, same document, [9]: 285-6.
} 
when writing to their colleagues at the Surat factory that "the countrey round about, as well as this and all other towns in this kingdome, are divided into two generall casts, namely the Belgewarras and the Bereewars, who for many hundred yeares together have ever had a quarrel one with the other who should be the more honnourable cast and have presidency of [precedence over] the other." 184

In a way this conclusion marks a return to Louis Dumont's view of ritual status as the essence of an enduring caste system (though an essence not so uniquely Indian), but the cries of invention - such as that quoted at the outset of the chapter - should also be taken seriously. Clearly there were some minimal group aspects to the division of Chennapatnam, especially the involvement as supporters on both sides of the English, who had quite obviously not been exposed to generations of discourse on the boundaries between Right and Left. In our case the centuries-old competition over status between the Right and Left Hand took on such vehemence that groups that were normally outside the domain covered by Right and Left were drawn into the conflict. How the existing boundary between the two groups could develop into a site of open and vehement conflict is perhaps best explained by the theory of Tajfel and Turner. This theory offers the most comprehensive insight into the link between longterm separation and short-term clashes of groups, and will be elaborated in Chapter 6 and the Conclusion. 


\title{
PART II \\ CHAPTER 4 \\ SAYING ONE THING, DOING ANOTHER? \\ SHIVAJI AND DECCANI PATRIOTISM 1674-1680
}

\begin{abstract}
These were words worthy of a great sovereign, if he also carried them in his heart. But I have always found, judging by a long experience, that he and all the Mahomedans direct their actions by their own convenience, and for the sole welfare of their own bodies.

Niccolao Manucci about Mughal emperor Aurangzeb's claim to do all for the welfare of his kingdom and the propagation of Islam. ${ }^{1}$
\end{abstract}

\section{INTRODUCTION}

Shivaji Bhonsla's father Shahji spent his lifetime as a military commander in the service of the Muslim dynasties centred at Ahmadnagar and Bijapur. Shivaji, however, famously built his inherited lands into a maharajadom, or great-kingdom, almost on a par with the realms of the Muslim padshabs of the Deccan. In 1674 he ascended the throne, becoming a maharaja, at Raigarh, which he had recently made his capital. This chapter focuses on the period of Shivaji's life starting with his abbiseka or "coronation" which was discussed in the last chapter. From the altercations at the abbiseka ceremony as represented by Abraham Lefeber, probably on the basis of a report by a Brahmin spy, we may conclude that Shivaji was not afraid to reinvent his identity along with tradition, and knew the price of things. Moreover it seems that he was to be a reformed man "not to act nor rule as tyrannically and badly as before," a break with the past which was underlined by the neo-traditional ceremony on the $14^{\text {th }}$ of June in which Shivaji distributed his body weight in various commodities to the gathering for the remission of his sins, and paid an extra 1,600 hons to two Brahmins who took upon them "the sins that he might have committed by arson and otherwise through which some women, children, cows and Brahmins might have died or been killed." 2 To the English ambassador present at the event Shivaji's minister Niraji Pant expressed the feeling "that the rajah would,

${ }^{1}$ Manucci, Storia do Mogor, 3: 275. For Aurangzeb's claims and actions see Chapter 5, the Epilogue and Appendix II.

${ }^{2}$ NA, Letter Vengurla to Batavia 13.10.1674, VOC 1304: 406v-7v. 
after his coronation, act more like a prince by taking care of his subjects and endeavoring the advancement of commerce and trade in his dominions." 3 Two and a-half years after having thus linked himself to the North Indian great tradition, Shivaji embarked on a tour of conquest of some parts of South India that had during the previous generation been conquered for the sultan of Bijapur, largely by Shivaji's father Shahji. It seems that Shivaji for this occasion reinvented himself as a patriot of the Deccan, or a Deccani patriot.

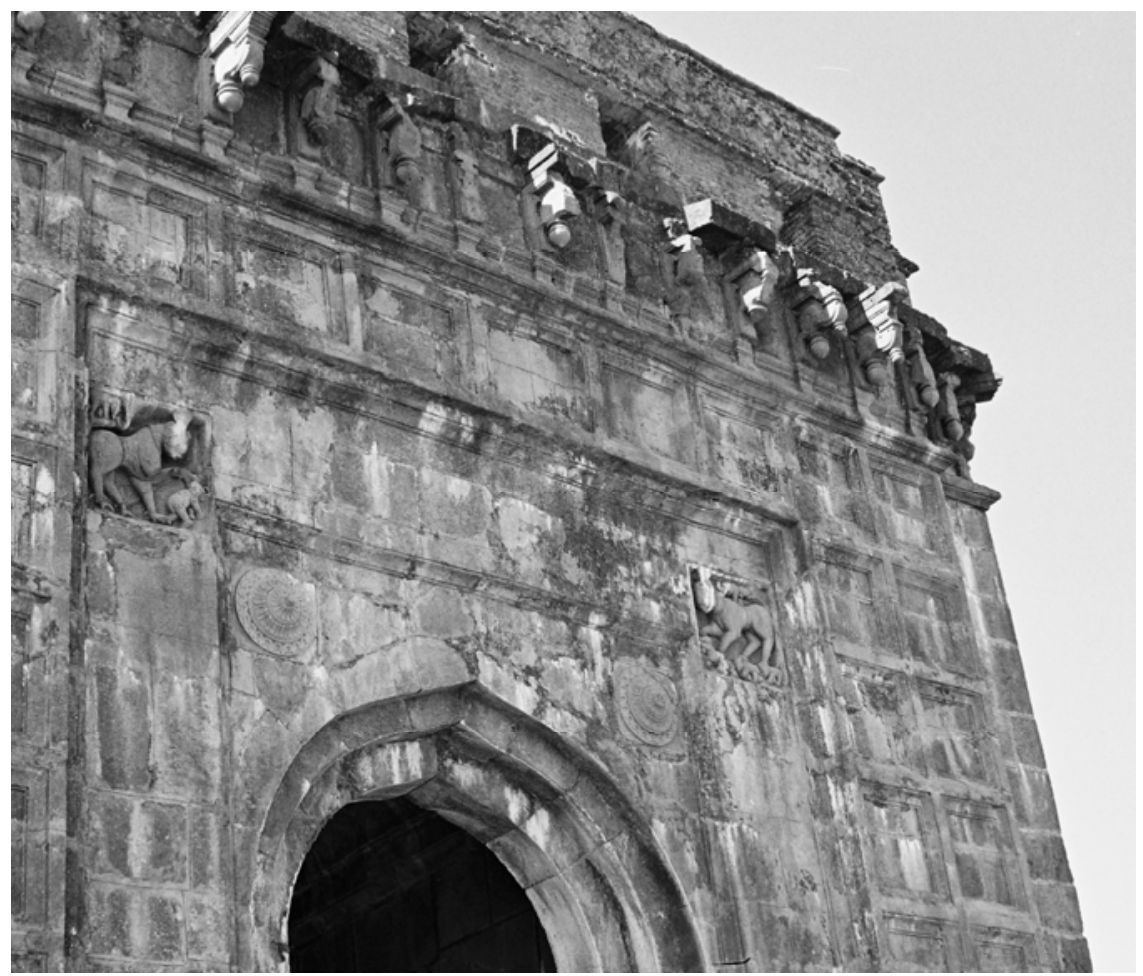

East face of the gate to the ceremonial core of the Raigarh fortress.

The entrance to the fortress of Raigarh, the abbiseka venue, displays two stone reliefs, one of a lion holding its paw over an elephant and another of a lion trampling an elephant. The gate to the ceremonial core of the complex has sculpted panels in the spandrels depicting lions crushing elephants (and a bird). ${ }^{4}$ The lion-crushing-elephant theme is of some

${ }^{3}$ ERS, Report by Henry Oxinden of embassy to Raigarh 13.6.1674, 1: 372.

${ }^{4}$ As to the date of these reliefs: the reliefs on the outer gate are clearly part of the original bastion, constructed as part of the original black stone fortifications built under Shivaji. The gate of a lighter stone at the core of the complex could be a later addition and/or the animal reliefs could be later embellishments, as at least the surface of the reliefs on the west face does not connect neatly to the surrounding surface. Compare ERS, Report by Henry 
antiquity in Indian art and literature, and symbolises the victory of celestial light over chthonic darkness. ${ }^{5}$ It was used by no means exclusively by Hindus, as at the Sharza bastion in Bijapur lies the amazing sixteenthcentury Monarch of the Field gun, the bronze embodiment of lion mauling a domesticated elephant, which was cast for the Nizam Shah of Ahmadnagar. At the entrance to this mid seventeenth-century bastion we also find a stone relief elephant crushed by a lion. ${ }^{6}$ Clearly elephants spelled evil and enemy in the contexts of both Shivaji's fortress and the bastion of his opponent, but one may wonder what the more specific connotations were in the context of Raigarh. It seems quite clear that the lions are to be identified with Shivaji and perhaps by extension his in-group, but who are the elephants that he is chasing?

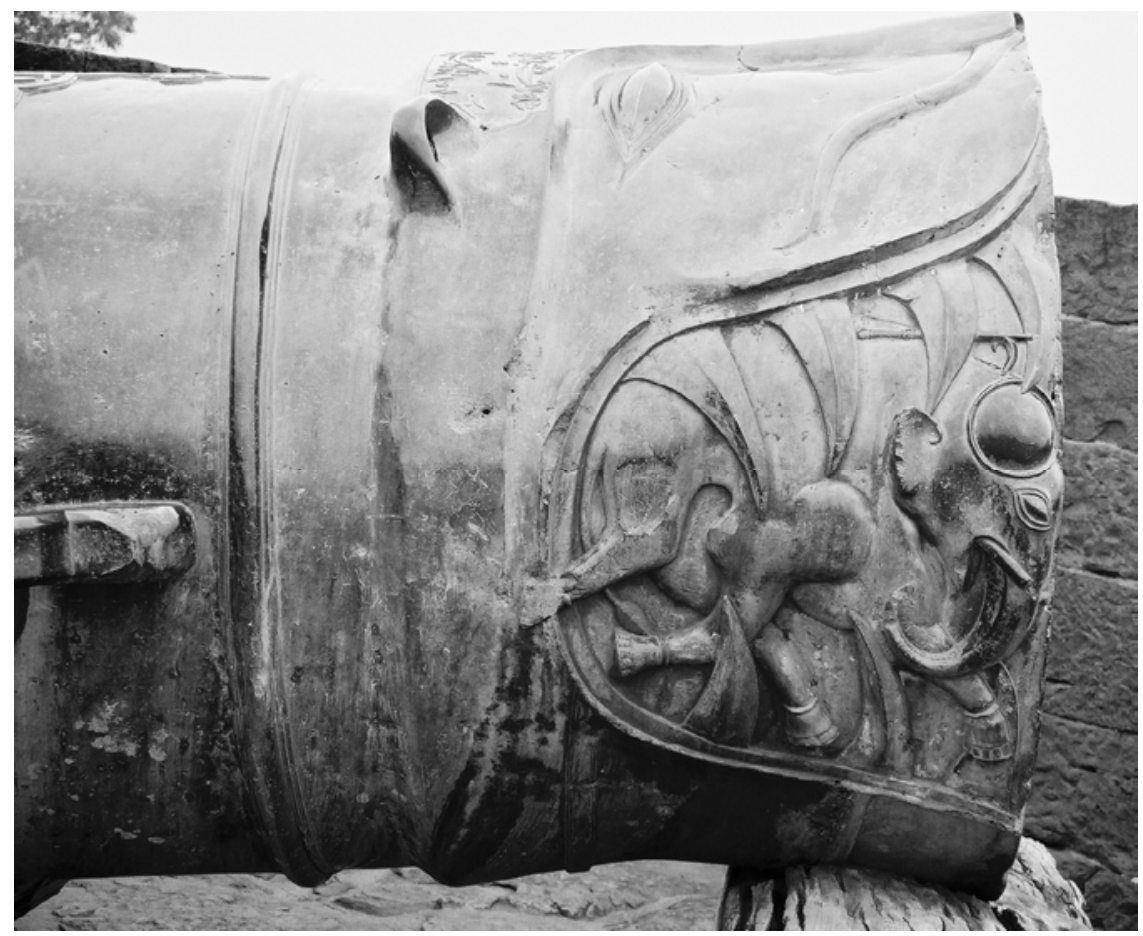

The Monarch of the Field gun at Bijapur: a lion eating an elephant and its goad. Such animal symbolism was all about relations between people.

Oxinden of embassy to Raigarh 13.6.1674, 1: 372 and Michell and Zebrowski, Architecture and Art of the Deccan Sultanates, 56-8.

5 Pramod Chandra, The Sculpture of India 3000 B.C. - 1300 A.D. (Cambridge, Mass. and London, 1985) 142. For some more depictions of lions or lion-like yalis, or even a lionheaded bird, chasing or trampling elephants in South Indian and Deccan art of this period, see Michell and Zebrowski, Arcbitecture and Art of the Deccan Sultanates, 119-20, 227, 234, 236 and George Michell, Architecture and Art of Southern India: Vijayanagara and the Successor States (Cambridge, 1995) 189-94.

${ }^{6}$ Cousens, Bijapur, 29-31. 
In some form or the other this question about Shivaji's enemies is one of the most debated in the historiography of early modern India. What this chapter aims to contribute is a reframing of the question in terms of the contrast or non-contrast between representations and practices. In many works on the medieval or Islamicate period of Indian history that focus on Hindu-Muslim interaction, the actions of a person or a group are contrasted to his/their discourse; the "tall tales" of eradicating kufr, infidelity, or adharma, disturbance of the divinely ordained order, projected by Muslim and Hindu rulers and their eulogisers are contrasted to their actions in real life. Although obviously problematic, ${ }^{7}$ the contrast is frequently highlighted, explicitly and more often implicitly, also by poststructuralists/ postmodernists - or maybe especially by the latter in order to show how far the discourses they discuss are removed from reality or "reality." An example is the recent book by James Laine in which the author states explicitly at the outset that he will only look at representations of Shivaji, but in the later chapters makes many positivist asides about what the real Shivaji "may have been" like on the basis of his practices. Stewart Gordon also contrasts the two more or less explicitly in the New Cambridge History of India volume on the Marathas. Both, by the way, conclude that Shivaji was not the fighter for Indian freedom or the Hindu nationalist that he is often made out to be. ${ }^{8}$

By making the distinction between representations and practices these scholars are in fact distinguishing between more and less realistic representations in sources, since the practices must be determined from the more realistic (parts of) sources. The operation of distinguishing more and less realistic representations has always been at the core of the historical method, as exemplified by Gordon's book, but is not unproblematic in the light of the writing of Michel Foucault, to which Laine pays homage with a quotation at the opening of his book.

The purpose of the present chapter is to investigate the validity of the distinction between representations and practices by taking it further in order to see if the distinction resonates in the phenotypes of human nature that we find in Shivaji's Deccan. The distinction is taken to its explicit extreme by dividing the sources along two basic lines, namely spatial and temporal distance to Shivaji. A rallying letter of Shivaji and a glorifying epic by his court poet, two sources very close to Shivaji in both time and space are contrasted with sources written at more distance from Shivaji and/or in the service of his antagonists. The latter sources are divided again along temporal lines. The most immediate documents are used here to gain a view of Shivaji's actions, and those at a few years or decades distance are

7 Pollock, "Deep Orientalism?" 102.

8 James W. Laine, Shivaji: Hindu King in Islamic India (New York, 2003) 7-19, 43, 52, 60, 61, 86, 89-100; Gordon, Marathas, 80-1. 
used to put both actions and motivations into perspective.

\section{SHIVAJI's Discourse ON “DECCAN FOR THE DECCANIS"}

In the run-up to his Karnatak campaign Shivaji wrote a lengthy letter to Maloji Ghorpade, a Maratha sardar of Bijapur, to enlist his support. The Ghorpade rajas centred at Mudhol in the northern Karnatak, within the Adil Shahi domains, were long-standing enemies of Shivaji's lineage: Maloji's father Baji played a role in the arrest of Shahji on behalf of the Adil Shah and was later killed by Shivaji. ${ }^{9}$ In his letter, written some two years after the death of Baji, Shivaji appealed to Maloji to lay aside the enmity of their elders and join his cause. The content of this letter will guide us in rephrasing the question as to who Shivaji's chief enemies or "elephants" were.

In his Maratha History Re-examined S.R. Sharma quotes extensively from that letter and italicises the following passage: "The Pathans should be destroyed and steps should be taken to keep the Padshahi of the Deccan in the hands of the Deccanis." This quotation seems to be quite well known among historians of Maharashtra. In 1944 Sharma used it to make his case that Shivaji was not merely after the freedom of Maharashtra but that his cause was that of Hindu civilisation. In 2001, in a talk at Aligarh Muslim University published in Deccan Studies, A.R. Kulkarni used the latter half of the quotation ("to keep...") to support the view that Shivaji propped up the Deccan sultanates against Aurangzeb and was more of a Deccan than a Hindu patriot. These two views of Shivaji's letter and his cause in general obviously imply a different view of Shivaji's chief ennemies, as Muslims or Mughals respectively, and sum up much of the ongoing controversy over Shivaji's heritage. ${ }^{10}$

Appendix III is devoted to the question as to whether the letter from Shivaji to Maloji Ghorpade is authentic. For those who are not convinced, there is at least one source that seems to confirm that Shivaji made such remarks as are found in the letter. The English East India Company surgeon John Fryer, stationed in various places on the west coast of India during the 1670s, observed in a "letter," purportedly written at the

\footnotetext{
${ }_{9}$ Compare D.V. Apte, Mudhol Samstancya Ghorpade Gharanyaca Itihas (Pune, 1934) 154-62; Bal Krishna, Shivaji the Great, vol. 2, pt. 1 (a.k.a. pt.3) (Kolhapur, 1939) 533, 539-40.

10 S.R. Sharma, Maratha History Re-examined (1295-1707) (Bombay, 1944) 183-205; A.R. Kulkarni, "Marathas in History: Excerpts from the Professor Nurul Hasan Memorial Lecture at Aligarh Muslim University, December 5, 2001," Deccan Studies 1 (2002) 68-71. For quotations from the letter, I have relied on Bal Krishna's translation (as does S.R. Sharma), except where I refer explicitly to the original Middle Marathi text as published by V.K. Rajwade and again by Pralhad Narahar Deshpande. See Appendix III.
} 
end of 1676, ${ }^{11}$ that "the disjointed members" of Bijapur did not trust one another nor united for the common good of the kingdom and that ever since Shivaji had shaken things up they could not decide who to side with, uncertain as they are of Shivaji's intentions, even though,

he tells them, his compeers the Duccanees, he is their champion, and that none of them besides himself has the heart to stand up for their country; and therefore if he chance now and then to rob them, it is but to reward himself and soldiers for his and their pains in endeavouring to free them from a more unnatural slavery.

Fryer also quoted Shivaji as having said to a messenger of the prime minister of Bijapur, the Afghan Abdul-Karim Bahlul Khan, who demanded to know why Shivaji had robbed so many places in the kingdom, that, "I did this only to let him know, I, not he am a member of Visiapour [Bijapur]." 12 In that phrase Bijapur is clearly seen as a space that is to an extent public, a connotation also carried, as Chris Bayly notes, by the term padshabi. ${ }^{13}$

Another good source for Shivaji's discourse in the period under consideration is the Suryavamsha Anupurana, ${ }^{14}$ because even though speaking only of the period up to 1661 and left unfinished, it was infused with the legitimising ideologies of Shivaji's royal period since it was probably composed as an accompaniment to the coronation. ${ }^{15}$ Also, we may assume that its perspective was approved by Shivaji for public consumption, in other words that Paramananda was an exponent of Shivaji's public discourse, which he couched in classical conventions. ${ }^{16}$ The Anupurana made clear how the different military confrontations that Shahji and Shivaji had in the past were evaluated at the court at the time of his coronation. It imparts the sense that there was a hierarchy of enemies of Shivaji's rule.

First and inescapably present was the discourse of "othering" Muslims, who were mostly designated by the author as Yavanas, which

11 Fryer's "letters" were probably revised for publication in 1698, see William Crooke's introduction to Fryer's text. Fryer, New Account of East India, 1: xi-xxxviii, 43-5.

12 Fryer, New Account of East India, 43-45.

13 Chris Bayly, Empire and Information: Intelligence Gathering and Social Communication in India, 1780-1870 (Cambridge, 1996) 181-2 note 6.

14 Hereafter references to this text are in brackets to the verses. I have relied mostly on Laine's translation but have in places added the Sanskrit terms or amended that translation slightly on the basis of the text published by Ranade and Marathe. I thank Jan Houben for his help in this. Paramananda, The Epic of Shivaji: Kavindra Paramananda's Sivabharata, trans. James Laine with S.S. Bahulkar (Hyderabad, 2001). Paramananda, Shrishivabharatam, ed. Purushottamashastri Ranade and Vasudevashastri Marathe (Pune, 1930).

15 Paramanda, The Epic of Shivaji, 239; Laine, Shivaji, 12, 21, 30; A clear indication that the text must have had something to do with the coronation is its title which claimed the protagonists, Shivaji and his father and grandfather, for the Suryavamsha, or "Solar (i.e. Rajput) lineage."

16 Compare S.S. Bahulkar, "The Sivabharata in the Context of Classical Mahakavya Literature," in: Paramanda, The Epic of Shivaji, 34-42. 
originally meant "Greeks." This usage is illustrative of what David Lorenzen (following Wilhelm Halbfass) calls the Olympian fashion in which Sanskrit literature written by Hindus treated foreigners and foreign religions before 1800, as it failed to register the differences between Greeks and Muslims and merely implied a vague connection to the north-western direction. ${ }^{17}$ The Anupurana reviled all the Muslims who were enemies of Shivaji on the grounds that they were enemies of dharma, destroyed temples, killed Brahmins and cows, were demons incarnate, etc. (e.g. 8.71-72, 13.2, $14.18,17.2,18.17-22,18.37-38,20.13-16)$. This comes out most clearly in the imagery surrounding the birth of Shivaji in canto five, when Vishnu announces that he will be born as Shivaji to redress the complaints of Mother Earth that she has been submitted to the rule of demons in the form of mlecchas, impure barbarians: "I will set everlasting limits / for dharma on this earth / I will subdue the Yavanas / and I will protect the gods" etc. A restatement of this mission we find in 16.65 and again as a heterology, in this case a discourse on the self authorised by the other, put into the mouth of the (sensible) counsellors of Shivaji's celebrated enemy Afzal Khan in verses 19.28-31. Afzal Khan himself even accuses Shivaji of destroying "mosque-places of Yavanas" (Yavananã mahasiddhinilayab; an embedded but nonetheless interesting recognition of the Islamic term masjid) and suppressing Yavana scholars in verses 18.52-54. These utterings of Afzal Khan himself, however, we are meant to take as mere accusations, for his accusations concerning the illegitimacy of Shivaji's golden throne and regalia were surely intended only as a mirror for other doubters of Shivaji's legitimacy.

That said, it is also clear that there was a hierarchy of evil and "otherness." Muslims were bad, but the Europeans (Phairangas, through Arabic and Persian from "Franks") were worse, as is borne out by the short passage devoted to them where they were, amongst other things, said to be: "walking beside the path, lower [than] Yavanas" (30.2). Less bad seem to have been the Maratha sardars, or military chiefs, who opposed Shivaji, as they were not demons incarnate, etc. When they supported the Muslim kings, they were merely misguided. Suryaji Rao, sardar of Prabhavali, for instance had "his wits destroyed by an evil fate" when he became a "repeated transgressor" by giving aid to Yavanas hostile to Shivaji (31.3537). But such acts were forgivable to an extent, as loyalty was also an important value in the Anupurana; the deeds of the same Suryaji Rao and Jaswant, sardar of Pallivan, were not considered entirely improper by Shivaji "for they both had another master" (29.72). In canto 16 there is what Laine calls a subtle critique of Shivaji's father Shahji, an implication that Shahji should have seen his latter-day master Muhammad Adil Shah for the enemy 
that he was. The Ghorpades were generally in this category of Maratha sardars following the Adil Shah and opposing Shahji and Shivaji (9.34, 12 passim, 17.55-58, 25.17-18). Canto twelve described a duel between Bajirao Ghorpade and Shahji at the end of which Bajirao captured Shahji, but the blame for the capture was put on Bajirao's master in the expedition, Mustafa Khan. At one point the author likened the Ghorpades to angry snakes that became peaceful after meeting Shivaji the snake charmer, just as other sardars (raja of Phaltan, Chandrarao) were tamed by Shivaji (13.43-45).

Moreover, the self-contradictory nature inevitable to the post-facto legitimising text that the Anupurana was, dictated that there was a scale of good and evil also within the Muslim category. The trend that the text laid out is that of a progressive worsening. This becomes apparent from the way the author described the successive Muslim rulers of the western Deccan. Ibrahim Adil Shah was "dignified" and his successor Muhammad "haughty" while his successor Ali was placed squarely in the demon camp $(8.5-8,17.2)$. The Nizam Shah who ruled the sultanate of Ahmadnagar, in the north-western Deccan, in the days of Shivaji's grandfather Maloji was still dharmatma, a man of piety and an upholder of dharma (1.59-60). A special position was occupied by the Habshis, whom the author at one point in the text called black-faced Yavanas (4.49-51). We see Shahji fighting side by side with the Habshis against the Mughals and Adil Shahs (4.49-51, 4.67-68). Malik Ambar, the Habshi prime-minister of Ahmadnagar, who led in this war was in fact portrayed as a defender of the Deccan, which seems to have been left orphaned after he was gone "like a brilliant setting sun" (8.5-8). The Habshi Sidi Johar, a leading general of the Adil Shah who fought Shivaji much later, was treated with more ambivalence. Shivaji's goddess Bhavani called Johar an evil soul at one point in the text, but he was also portrayed as loyal to the Adil Shah and was exculpated from accusations to the contrary by the Adil Shah (26.49, 28.22-26). Moreover the war between Shivaji and Johar was called "the brother of the Bharata war," in other words: a war between brothers, for the real enemy was the Mughal who was advancing from the north (25.25).

The text does however provide part of the answer to the question asked at the outset of this chapter as to who Shivaji's elephant others were. It compared both Muslim and Maratha enemies of Shivaji are compared to elephants who tried to oppose the lion Shivaji. Paramananda in fact constantly likened warriors of all parties to lions and rutting elephants and their war-cries to the roars of lions and the bellowing of elephants, but mostly it was Shahji and later Shivaji and sometimes their adherents who were the lions and their opponents who are the elephants (e.g. 4.63, 9.74, 13.46, 13.50, 13.74, 13.121-2, 14.2-3, 21.37-39, 30.1-4). Most clearly we see this in the verses: "By entering the terrible forest of Javli / the home of me, the lion / my enemy Afzal, the elephant / will come unto his death" 
(18.39). In verses 21.22-23 and 37-39 describing the same confrontation, Shivaji was not only likened to a lion but his beard to an elephant goad (with which he could tame Afzal). Many of the "elephants" in the text were, however, Maratha sardars such as the aforementioned Suryaji Rao who "turned his mind to the contest / [he faced] with wild Shivaji, as [if he were] an elephant / [about to fight] a lion." (30.37).
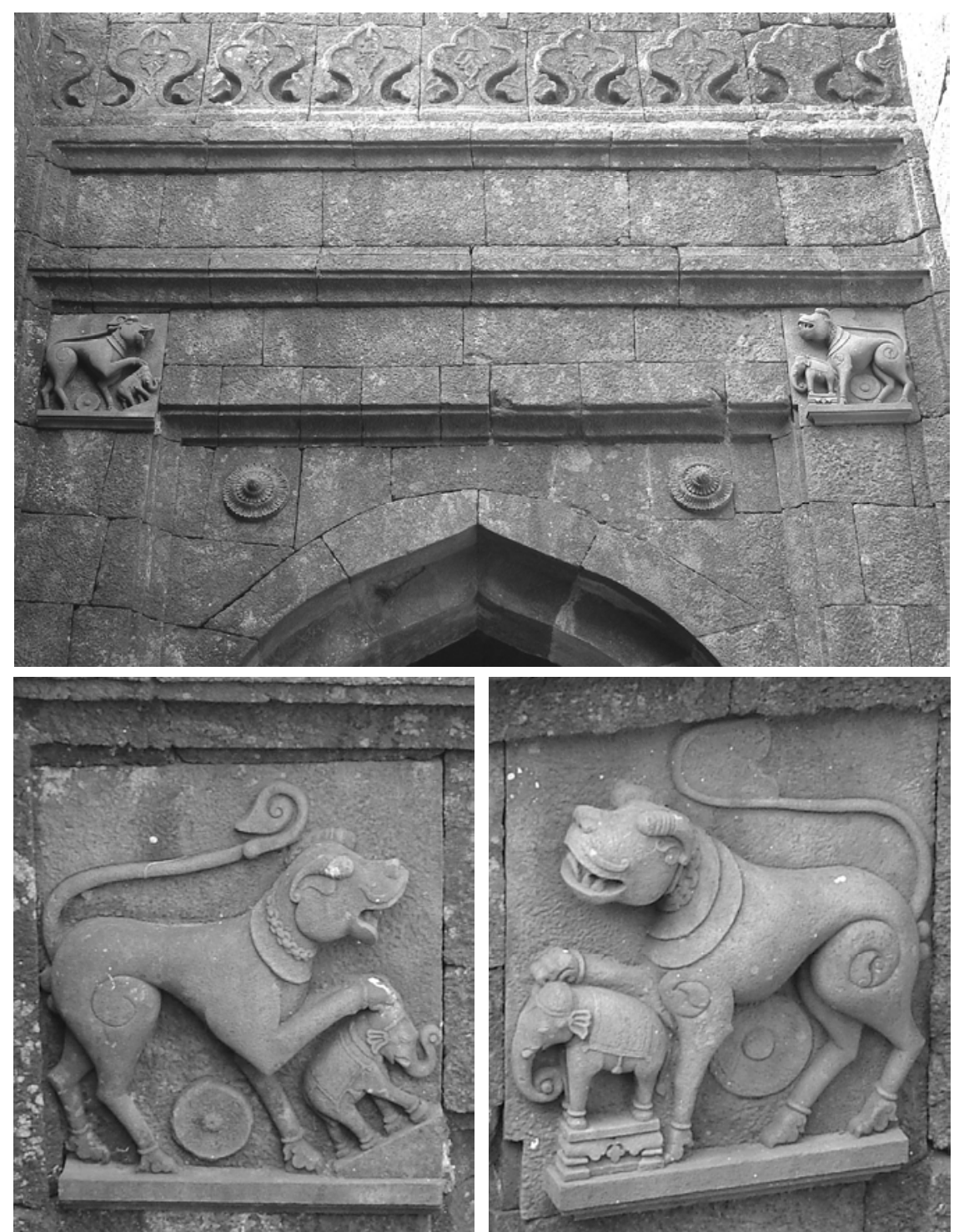

Upper portion of the entrance gate to Raigarh, with close-ups of the reliefs.

So even though there was a hierarchy of evil, all enemies of Shivaji were elephants, since enemies are ipso facto the adharma of a kingdom (16.50-53) 
and the potential for lasting alliances was limited since - as Shivaji quoted from the Mahabharata in Paramananda's text — "One should not trust the trusted / much less the untrustworthy / the danger produced by trust / even undermines one's foundations" $(13.18,13.25)$. The tension between realpolitik and the need to build lasting alliances is illustrated by the stone ensemble on the Raigarh entrance depicting a lion trampling an elephant walking up an incline (the Raigarh hill?) beside a lion shielding a small elephant on a diminutive pedestal or throne. We may read this pair of reliefs as follows: to some (foreign) elephants Shivaji is like a triumphant lion who tramples his enemies but to other elephants Shivaji is like a lion who allows them to stay on as protected vassals (hence the pedestal under the shielded elephant). Both lions are notably accompanied by a wheel symbolising world conquest. These architectural elements were there to see for all who entered Raigarh. They were public statements, with a much wider audience than texts.

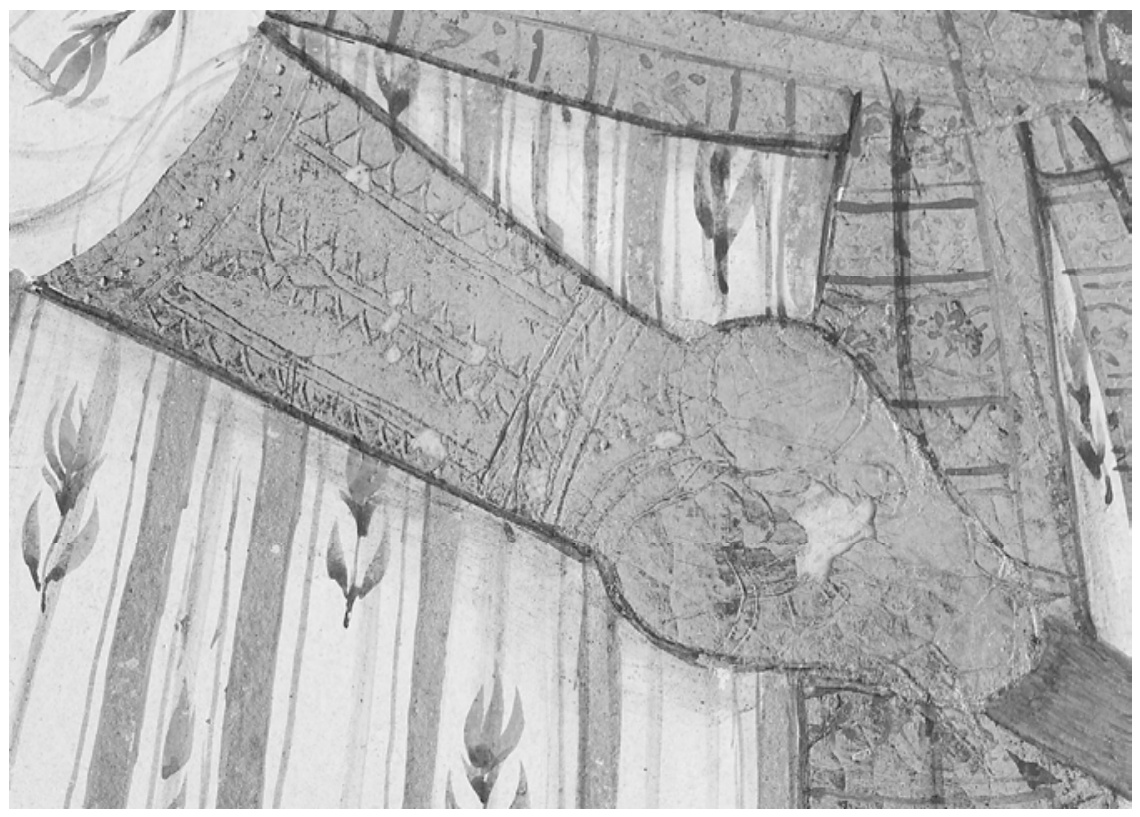

Detail of the facing image: the boar head. Courtesy Musée Guimet.

Nowhere did the Amupurana identify Shivaji as a boar, but since Shivaji was identified in the epic as an incarnation of Vishnu, he was naturally closely associated with the primeval boar Varaha, Vishnu's third incarnation. We find the image of the boar on the gauntlet sword of the patta type that Shivaji seems to have been wearing very often (a description in the Dutch East India Company archives also mentions him wearing such a sword with 


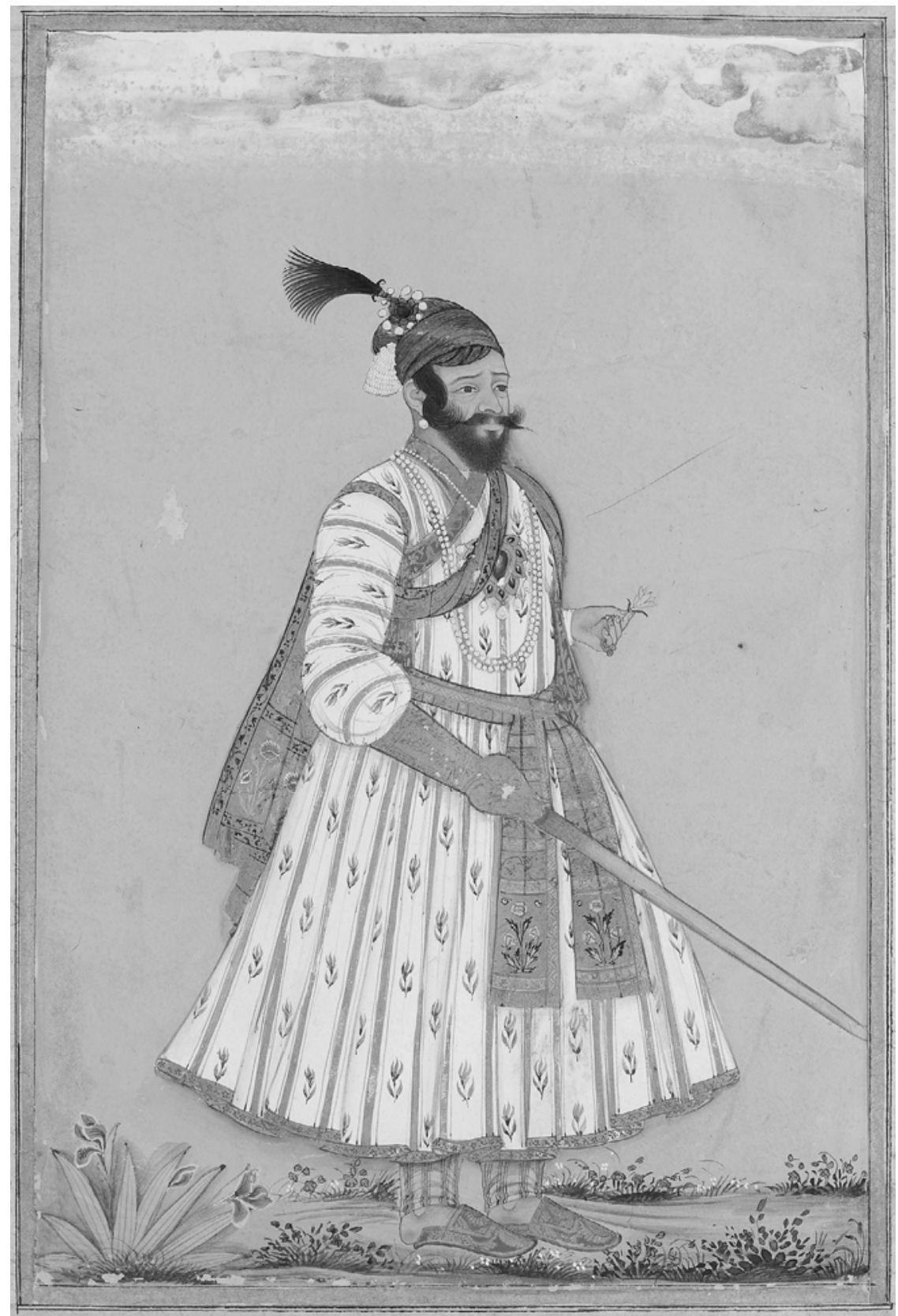

Portrait of Shivaji wearing a boar-headed gauntlet sword. Courtesy Musée Guimet, Paris, catalogue number 35.554. 
a golden lower-arm cover)..$^{18}$ Such pattas also exist with elephant heads at the handle, but on two near contemporary miniatures the handle of one of Shivaji's pattas can clearly be seen to have been a boar's head. ${ }^{19}$ With that Shivaji put himself in a tradition of Hindu kings employing the boar as a symbol, most notably the kings of Vijayanagar, whose emblem was a boar and sword accompanied by the sun and moon (the sun and the moon signifying eternity, as in the phrase "as long as the sun and moon will shine"). ${ }^{20}$ Ancient India scholar Heinrich von Stietencron argues that the image of the boar was employed in North India as a symbol of "the deliverance from foreign oppression and the fresh foundation for ancient religion and sacred custom (dharma)" as early as the Gupta period. ${ }^{21}$

It seems that Shivaji's use of the boar engendered some sort of counter-symbolism from the Bijapur-side. This is evident on the bastion built for the lion gun shown in the introduction to this chapter. The inscription on the bastion yields the date 1069 AH (1658-9 CE) during which year a large scale campaign was started against Shivaji culminating in the dispatch of Afzal Khan early in the next year. ${ }^{22}$ In 1658 the sultan was still a minor under the regency of his mother Khadija Sultana, and I think this is what we see in the relief to the left of the inscription: a lion cub following either his deceased father Muhammad Adil Shah or his mother the regent (although it must be noted that both the lion and the cub are male). To the right of the inscription we see a lion trampling an elephant accompanied by a monkey.

${ }_{18} \mathrm{NA}$, Herbert de Jager and assistant Nicolaes Clement at 'Waligondewaron' to Pulicat (?) 10.8.1677, VOC 1328: 620v.

19 Both miniatures were made a few years after Shivaji's death but probably go back to one or more examples made during his lifetime. The miniature in British Museum album 1974-617-011 can be dated on the basis of the biographical details given in the Dutch captions of the whole series to between May 1682 and October 1685. The portrait in Guimet (no. 35.554) was also done after the death of Shivaji, probably, based on the captions of the other Golkonda miniatures with which it seems to form a series, between April 1683 and October 1685. The Dutch captions are given in Ivan Stchoukine, Les Miniatures Indiennes de l'époque des Grands Moghols au Musée du Louvre (Paris, 1929). In other Golkonda miniature series of this period (Staatsbibliothek Berlin, Amsterdam Rijksmuseum, former Prince of Wales Museum Mumbai) Shivaji also wears a patta with a covered handle of a similar shape but the details are not worked out. In the "Manucci album" in the Bibliothèque Nationale in Paris the gauntlet is bejewelled but not clearly of an animal shape. For the Golkonda albums in general and pictures of the Berlin, Amsterdam, Guimet and Manucci Shivaji portraits, see Lunsingh Scheurleer, "Witsenalbum." Large pictures of the British Museum and Mumbai museum miniatures are in Saryu Doshi, Shivaji and facets of Maratha Culture (Bombay, 1982) dust jacket and p. ix (the picture on p. x is of the Manucci Shivaji, not the Guimet Shivaji).

${ }^{20}$ Michell, Architecture and Art of Southern India, 155-6. Bes, "Setupatis," 566.

21 "Political Aspects of Indian Religious Art," Visible Religion 4-5 (1985-6) 16-36, there 19-22.

22 Cousens, Bijapur, 30; Sarkar, Shivaji and His Times (5th ed. Calcutta, 1952) 59-68. 

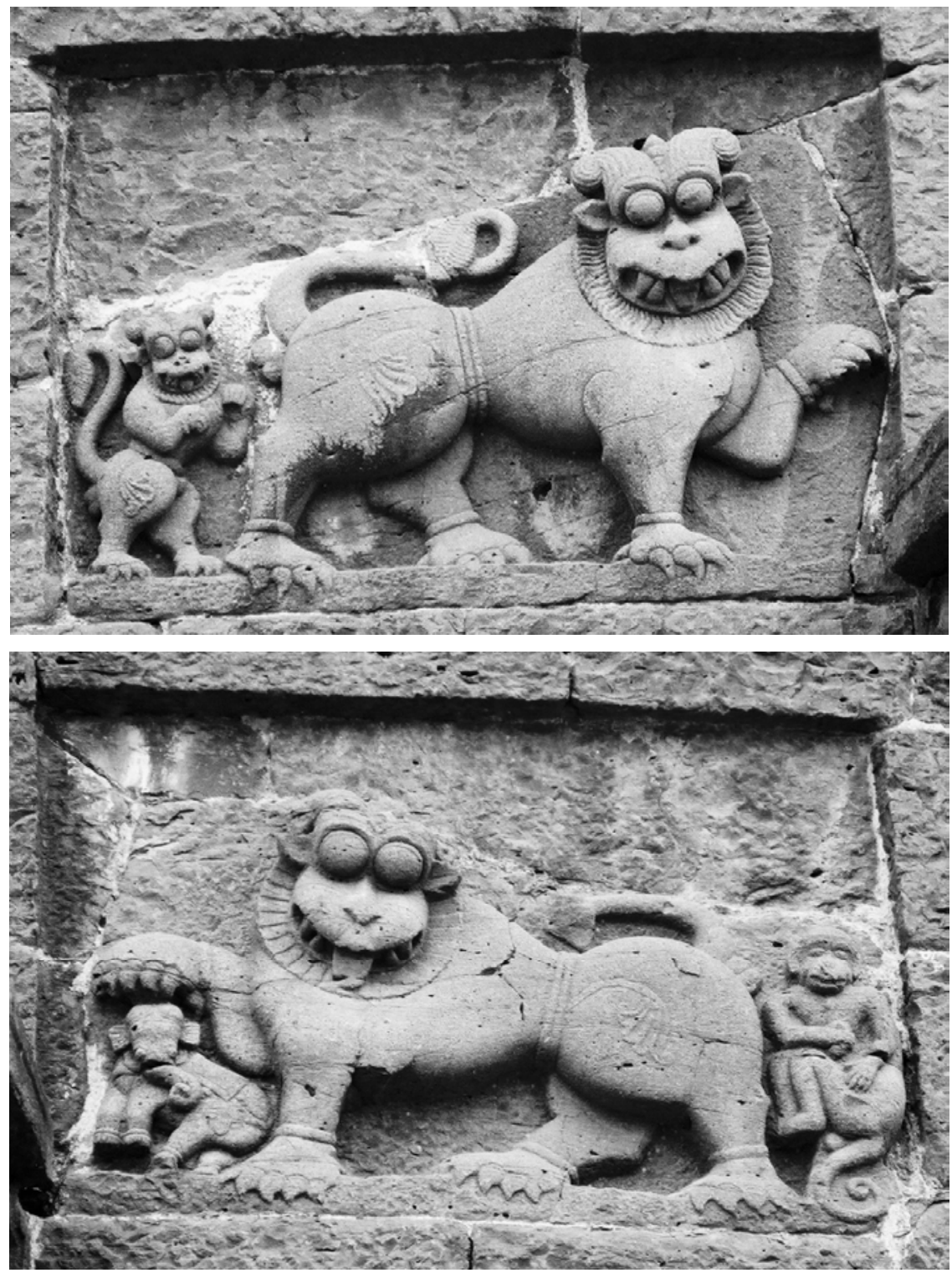

Reliefs to the left (top) and right (bottom) of the inscription at the Sharza Bastion. The reliefs elaborate on the symbolism of the Monarch of the Field gun, for which the bastion was built.

The significance of the monkey is found through a Mughal miniature of circa 1600, which displays a similar monkey in a tree with a boar lying dead below. This is explained by Toby Falk and Simon Digby with a reference to a story from the Iyar-i Danish, in which a monkey initially aids his friend the boar by shaking fruit from a tree, but the insatiable and ungrateful boar 
later tries to attack the monkey and is felled by a branch of the tree, which breaks under the boar's weight. ${ }^{23}$

Such animal stories were certainly well known in the Deccan at the time and understood as metaphors. As has been seen at the beginning of Chapter 2, they could be about harmony between people, but they could also be about violence. In the Deccani Urdu rendition of the Tuti Nama (tales of a parrot) composed by Golkonda poet laureate Ghawwasi we find several stories of different animals killing each other. ${ }^{24}$ Moreover, from Van Twist's description of Bijapur we know that the voracious symbolism of the Monarch of the Field gun for which the bastion was built was not wasted on seventeenth-century Bijapurians and possibly interpreted in terms of a struggle against infidels. Van Twist identified the maker of the gun as a Roman (obviously a misinterpretation of the word Rumi, meaning Ottoman, which was used in an inscription on the gun to refer to the maker) and recorded a story that apparently circulated about its making. According to this story the Roman not only sacrificed his own son to the gun but also refused to be paid for its making and in lieu of payment threw the king's Brahmin accountant, who had come to enquire about the payment, into a fire prepared in the casting pit, adding somewhat enigmatically "that the fire that had digested the money and copper would give him the bill." 25

Turning from Shivaji's enmities to his and Paramananda's sense of belonging or "sense of place": it seems that the Anupurana located the home of Shivaji in the Sahyadris, now better known as the (northern part of the) Western Ghats, but also in the "Deccan." An important passage in this respect seems to be that in which Shivaji's grandfather was said to be born in the lands of the Deccan, ruling as a "Maharashtrian" or Maratha king over the country of Maharashtra and ruling "completely" in the Sahyadri region (1.42-47). Thus Shivaji could claim roots in the Sahyadris, Maharashtra and the Deccan. At the very beginning of the poem, in verse 1.24, Shivaji was called the king of Deccan (Dakshinatyo maharajah) by Paramananda, but the dense forests of the Sahyadris were to be seen as his refuge, the "lair of Shivaji the lion" (17.13-14, 26.15, 28.55-56, 28.73, 29.4, 29.29-33). At the birth of Shivaji not only many Vedic deities were present but also Nairrta, the guardian of the south-western direction, emphasising Shivaji's bond with the western Deccan, the location of the Sahyadris (6.4247). The Deccan was also, but much less explicitly, celebrated as a region that deserved to be protected, as in the aforementioned passage in which Malik Ambar was seen as a defender of the Deccan, where the days when

23 Toby Falk, Simon Digby and Michael Goedhuis, Paintings from Mughal India (London, 1979) 39.

${ }^{24}$ Ghawwasi, Tuti-nama, ed. Mir Sa'adat Ali Rizvi (Hyderabad, 1357 AH [1939 CE]).

25 Van Twist, "Generale beschrijvinghe," 76. 
Ibrahim Adil Shah of Bijapur and Malik Ambar of Ahmadnagar were in control were in effect portrayed as a golden age of the Deccan (8.5-8). The text also had it that the south was the most difficult direction for the mlecchas to conquer (5.29). ${ }^{26}$

It seems, however, that Paramananda used the term Deccan mostly in a sense more restricted than the modern usage. The above usage might have included the Bijapur as well as the Ahmadnagar domains, but in some places it was clearly used specifically for the former Ahmadnagar domains, the land of Paramananda's hometown Nevase (colophons of chapters $3,4,6,9$ etc.), for instance where the text mentioned "Deccan rajas," meaning those Hindu sardars that served the Nizam Shah of Ahmadnagar $(1.59-60,5.51-53)$. And in fact the term Deccan disappears from the text altogether with the demise of the Nizam Shahs. Nowhere in the Amupurana do we gain the impression that what we would now call the eastern Deccan, the domains of the Qutb Shah were included in the term "Deccan." The Qutb Shah was mentioned only once in the text as one of the Muslim kings that Shivaji was not obeying, where Afzal Khan said: "you serve not, nor have you regard / for the Adil Shah or Qutb Shah / nor even the mighty Mughal king" (21.29).

Comparing Paramananda's usage of the term Deccan with Mughal and European sources of the seventeenth century, we find that there also the term was mostly used in a restricted sense but sometimes in a more general sense. ${ }^{27}$ In ancient texts the term Dakshinapatha seems to have signified more of a direction or dig — to be conquered in a digvijaya — than a fixed area, ${ }^{28}$ and from a Mughal perspective "Dakhan" was originally relative to the southern frontier of the Mughal empire. ${ }^{29}$ This reflected in the usage by some Europeans. In the log of his overland trip from Surat to Masulipatnam in the early seventeenth century Pieter van den Broecke used the term Decan strictly for the domains of the Nizam Shah. ${ }^{30}$ After the fall of the Nizam Shahs in 1633 Europeans often called the Adil Shahi domains the kingdom of Deccan, in conformity with the way Muhammad was styled in some inscriptions put up by his nobles. ${ }^{31}$ Heda used the term to mean the whole of what we would now also call the Deccan, where he said: "this

${ }^{26}$ Laine, on the contrary, argues that the text makes no mention of Maharashtra or Marathas as such, and that Shivaji employed classical pan-Indian symbols, not regional ones. Laine, Shivaji, 12.

${ }_{27}$ Compare the restricted and wider usages of the term "Hindustan" which Chris Bayly describes for the eighteenth and early nineteenth century in Origins of Nationality, 41-2.

${ }^{28}$ I benefited greatly from a discussion on this subject between J.C. Heesterman and B.D. Chattopadhyaya at the occasion of a talk by the latter in Leiden in May 2003.

${ }^{29}$ Gordon, Marathas, 10.

${ }^{30}$ Van den Broecke, Pieter van de Broecke in Azië, 1: 138, 144, 146, 153, 157; 2:309.

31 E.g. "the queene of Decann," BL, Raybagh to Surat (probably) 19.11.1659 o.s., G/31/1: 70; Schouten, Aanmercklijke voyagie, a: 245. The inscriptions relating to Afzal Khan cited in Chapter 2 are examples of inscriptions referring to Muhammad as ruler of the Deccan. 
whole country of Deccan has made peace with the king of Agra, to wit these three kings, Adil Shah, Malik [sic, but de facto king of the Nizam Shahi domains] and Qutb Shah." 32 After the conquest of the area by Aurangzeb this wider usage of the term seems to have become the general usage. Looking back to that conquest in 1702, an inscription commissioned by a Mughal administrator at Bhir in northern Maharashtra recorded that in the twenty-fifth year of his rule Aurangzeb ordered "the august sojourn in the Dakhan" and conquered the realms of Bijapur, Hyderabad and Adoni ${ }^{33}$ and many fortresses from Raigarh to Gingee. ${ }^{34}$ Thus the restricted usage to mean either the Ahmadnagar or the Bijapur sultanate was never exclusive, but seems to have been overtaken in frequency only at the end of the century.

In the 1670s, however, before the fall of Golkonda and Bijapur, the restricted usage was still the more common. The way Paramananda employed the term is akin to the way it was used by Fryer. In one passage, somewhat similar to that in which Paramananda seems to describe a golden age of the Deccan, Fryer spoke of the days when the Deccan (Duccan) was "entire" and the three Deccan sultans were of one mind, a unity lost together with "Duccan," now suddenly denoting only Ahmadnagar. When speaking about his 1670s present, however, Fryer used the term loosely for the Adil Shahi domains and expresses the view that Deccan at one point consisted of two halves, part under the Nizam Shahs and the remainder under the Adil Shahs, the latter now ruling over "what is left of Duccan": "reaching north to Jeneah [Junnar], south to Porto Novo, bounded east with Gulconda, west with the ocean." 35

The Burban-i Qati' dictionary, composed at the court of Abdullah Qutb Shah in the middle of the seventeenth century, covered all these meanings. Not only was dakan "the top of a mountain" the term also designated — "in Hindi" — the south as opposed to the north, and besides an obscure Arabic meaning the word also connoted a specific state (velayati), which we must assume to mean the Bijapuri state. ${ }^{36}$ Similarly Ahmad's Hadiqat, also written from the perspective of the court of Abdullah, both contrasted the Deccan as a whole to the north called Hindustan and applied the term to the realm of Bijapur, for instance in the context of the wedding

\footnotetext{
32 NA, Cornelis Heda at Nauraspur to Masulipatnam 14.1.1603, VOC 1056: 135.

33 The reason Adoni is mentioned here as a realm is probably that the fortress of Adoni, in the east of the realm of Bijapur, became something of a capital to the Deccani faction in Bijapur during the 1670s, when, moreover, the Habshi leader of the faction Sidi Mas'ud seems to have been running the area as his private kingdom. Bhimsen, Tarikh, 106; Zubairi, Basatin, 452.

${ }^{34}$ Ed. and trans. by S.S. Hussain in Epigraphia Indica: Arabic and Persian Supplement (1977) 99102. My translation differs slightly from that given by the editor.

${ }^{35}$ Fryer, New Account, 2: 46-67.

36 Tabrizi, Burban-i Qati', s.v. dakan.
} 
of Abdullah's sister Khadija Sultana to Muhammad. ${ }^{37}$

The term Deccani as a noun or adjective, which in present-day academic writing is almost singularly applied to Deccani Muslims as opposed to Muslims of foreign descent, also seems to have had a wide semantic range in the seventeenth century. Johan van Twist, in his description of Bijapur (which he called "the kingdom of Konkan or Deccan"), mentioned Deccanis in a few places in the form of Decanijs, Decanders or Decangus. In his diary he also mentioned the language he calls Decans, probably the language of the bazaars of the kingdom ranging between the literary languages of Marathi and Deccani Urdu. It seems that Van Twist applied the term Deccanis to the speakers of this Deccani Urdu/Marathi, since he distinguishes them from Baniyas, who are of Gujarati origin, and from Canariins, speakers of Kannada. In one place, however, he wrote that the population of Bijapur consisted of both Decaniins and Canariins, while in another he wrote that it consisted of "Deccanis, Moors and Gentus." 38 The work of the Mughal historian Khafi Khan, who served Aurangzeb during the later part of his reign, offers another interesting range of meanings. While in the majority of places the term Deccanis (Dakaniyan, Dakaniba, mardom-i Dakan) seems to be a synonym for Bijapuris, in other the author applied it to the men of Golkonda and sometimes to a coalition of both, and in still others to the followings of Maratha chiefs, as where he spoke of "the Deccanis of the wretched Shivaji." Elsewhere again, the term was used for Muslims from the Deccan (whose ways in war were shameful) as opposed to those from the north. In this sense Deccanis could be distinguished from Marathas, as where Khafi Khan spoke of the many new mansabdars, Deccanis and Marathas, entering the imperial army. ${ }^{39}$ In short, the term Deccanis applied to any of a range of groups depending on the context.

What meanings of Deccan and Deccani then was Shivaji referring to in his letter to Maloji Ghorpade? First of all it is necessary to amend somewhat the translation of the fragment quoted at the outset of this section, taking into account the preceding line. Shivaji wrote that: "He [the Qutb Shah] has entrusted such plenipotentiary powers and esteem to us as

\footnotetext{
37 Ahmad, Hadiqat us-Salatin, 81, 156 and passim (see also Chapter 2).

${ }^{38}$ For the latter the original diary has "Deccanis, Gentus and Moors." It is not clear whether Van Twist uses the word Gentu here in the sense of Hindu or that of Telugu (or even Dravidian), in the first case we should read "Deccanis, [both] Moors and Gentus." Van Twist, "Generale beschrijvinghe," 76-83; Idem, daily record of embassy to Bijapur sub datis 5.1 and 20.3.1637, VOC 1122: 469v, 499. For Van Twist's use of the term Gentu, see Appendix I.

${ }^{39}$ Khafi Khan, Muntakbab (Persian text ed. Maulavi Kabir ud-Din Ahmad 1874), examples from the part treating the period of Aurangzeb: Deccanis = Bijapuris: 192-8, 205, 236-37, 322, = Golkondans: 303-5, 330, 335, 339, = both: 317, = men of Maratha chiefs: 120, 302, 519, = Muslims from Deccan: 303-5, 396, 432. Quotation from the translation, 126.
} 
to increase the own padshabi as much as we may increase [it] [and] to destroy that of the Pathans. It should be ensured that the padshabi of the Deccan remains in our Deccani hands!" 40 If my translation of this fragment is correct, the following may be noted about Shivaji's wording of it:

At first glance it appears from the nexus made in the last line between the Pathans or Afghans and the padshabi of the Deccan that the combination of those two terms here designated the realm of Bijapur, since that is what the Afghans were controlling at the time. This interpretation would accord well with Shivaji's statement directed at the leader of the Afghan faction in Bijapur as reported by Fryer, "I, not he am a member of Visiapour." However, in the first sentence, the phrase "the own padshahi" is somewhat ambiguous and it may be that the usage of the reflexive pronoun apali, "one's own," as it occurs here in a clause with an impersonal verb, was deliberately so. The only obvious feature of the use of "the own" in this sentence is that it is opposed to "that of the Pathans," clearly marking off the self from the Pathans. Moreover, the plenipotentiary powers that Shivaji referred to were derived from the Qutb Shah, not from the Adil Shah or from himself, which is made quite explicit by very terms used: " $k u l$ mansaba wa madar," which I rendered above as "plenipotentiary powers and esteem." A mansab in seventeenth-century parlance designated a rank of service under a padshah, and so it would appear from this phrase that Shivaji had become a feudatory of the Qutb Shah instead of one of the Adil Shah, however nominally. In other parts of the letter it is made quite explicit that Shivaji intended a wholesale takeover of the Adil Shahi padshabi by the Qutb Shah and, to encourage Maloji to desert Bijapur and join the Qutb Shah, Shivaji brought to bear the sorry state of the Bijapur padshahi, being captive to the Pathans. He also cited the historical example of how his father Shahji exchanged his allegiance to the Nizam Shah for allegiance to the Adil Shah and how Shahji then introduced Maloji's father to that court. Shivaji also promised a kaulaca farman from the Qutb Shah. Such letters, generally referred to as qaul namas, were criss-crossing the Deccan at the time and promised the recipient continuance of his land revenue rights and his rank, and/or an improvement on these if he exchanges his allegiance from $x$ to the sender of the letter (see Ch.2). To conclude this paragraph it can be said that padshabi referred to as "the own" in Shivaji's letter is the Qutb Shah's padshabi.

Secondly, in his wording, Shivaji clearly included himself in the category to which the adjective Deccani applied and thus seems to have considered himself a Deccani, but it does not quite become clear as to who else he included. In the part of the letter following the lines on the Deccan 
and the Deccanis, Shivaji made much mention of Marathas, a category in which he also included himself, but which was more restricted than the category of Deccanis. As Stewart Gordon shows, the term Marathas was at the time by no means used for all Marathi speakers but only for a group of noble families of the western Deccan. ${ }^{41}$ It seems that Shivaji employed the term in precisely that way, and viewed these Maratha families, such as the Ghorpades, as an elite that could replace the Afghan elite. This appears from the fragments "whatever Maratha people are of our caste [jati], they should be taken into league and should be introduced to the Qutb Shah" (which introduction would not be physically possible if he meant all Marathi speakers) and "considering it is proper to do good to the Marathas of our caste." Elsewhere in the letter Shivaji wrote that "Lord Qutb Shah and we and all the Deccanis should join together...you Marathas are ours" (or more loosely translated, "you Marathas are our kith and kin"). From this fragment it would appear that Shivaji was excluding himself ("we") and the Qutb Shah from the category of Deccanis, unless we read "and all the [other] Deccanis," which could well be a secondary reading of this phrase. The Maratha sardars in any case seem to be included in the phrase "our Deccani hands," but from the letter it is not all that clear which other "disjointed members" of Bijapur - to whom Shivaji's patriotic appeal was directed according to Fryer - and which people outside Bijapur might be included. It is well possible that Shivaji chose to use the term precisely because it was so vague and open-ended, in order to broaden the scope of his appeal, and to even draw in people such as the Qutb Shah from outside Bijapur.

Thus we find that Shivaji presented the Karnatak campaign as beneficial to all parties in the Deccan except the Afghans or the Foreign faction at Bijapur, and seems to have played the card of Deccani patriotism very heavily in the run-up to his Karnatak campaign, which leaves us to wonder whether this appeal was new to Shivaji and to what extent it superseded other legitimations for campaigns that we find in the Anupurana.

In the latter work, the motive for Shivaji's campaign in the Konkan (in 1661) was quite simply given as artha, the money/power of Sanskrit discourse. In a speech to his ministers on the eve of that campaign, Shivaji praised artha elaborately as the root of every good thing and maintained that he would first have to extract riches before he could attack the Mughals (28.30-41). Although the struggle against the Mughals was presented as the ulterior motive, as it was in the letter to Maloji, the purport of the Anupurana's legitimation was somewhat more down to earth, with lists of the various goods obtained from the conquests and a description of Shivaji's capacity to see hidden treasures (30.7-23).

${ }^{41}$ Gordon, Marathas, 14-7. 
The presentation of Shivaji's relation to his Konkan conquests in the Anupurana is also slightly different from the presentation of his relation to the Deccan in the letter to Maloji. In the Anupurana the conquered regions were not described as naturally belonging to Shivaji — and this should be seen in connection with Paramananda's restricted sense of Shivaji's Deccan homeland outlined above - since after his conquests in the Konkan he was said to have "returned to his own lands [swarashtra]" (30.26). He did, however, have a purifying effect on the region "which had become impure / because of its long contact with Yavanas" (29.68, 30.10). That motif also comes to the fore in the description of Shahji's campaign in the Karnatak, which we may see as a precursor to Shivaji's campaign thither. By conquering the rajas of Kerala and the Karnatak in the service of the Adil Shah, Shahji "made the kingdom of Adil Shah like that ruled by Lord Ramah himself.” (5.19-20).

\section{ACTIONS OF SHIVAJi AND His ANTAGONISTS}

The political situation in 1674, the year of Shivaji's coronation is pretty much summed up in two short reports. In February the EIC factors in Bombay reported that "wee are advised from the deputy president and councell of Surrat, that Dillul Ckaune [Dilir Khan] one of the great Mogulls generalls hath lately received a rout bye Sevagee and lost 1,000 of his Pattans and Sevagee about 5 or 600 of his men; The warr between the king of Vizapore and Sevagee still continues, but not vigoriously carried on, the great umbrawes [umara', nobles] who are neither friends to the king nor enimyes to Sevagee keep it on foot out of polity [opportunism] and selfinterest." In October the Dutch factor in Vengurla, in the same letter in which he reported Shivaji's coronation, wrote that the Bijapuri Moors were not then taking any action against Shivaji, that time would tell if they were to start a campaign after the monsoon, and that it was said that (the Afghan) Bahlul Khan would be sent to the country of Madurai (the southern Karnatak) on behalf of Bijapur in order to punish some rebels. ${ }^{42}$

In February 1675, news reached the English at Surat that a peace treaty was on hand between the Mughal emperor Aurangzeb and Shivaji, according to which Shivaji was to deliver up some forts and send his son into Mughal service where he was to receive a rank of 5 to 6,000 horse, and that Shivaji would then be left secure in his holdings to the north-west of the Bhima. ${ }^{43}$ Less than one and a-half years later, however, a shift of (tentative) alliances was announced by the news that the sultan of Golkonda had mediated a peace between Shivaji and Bijapur. At the same

42 BL, Bombay Occurances 5.2.1674 (o.s.), E/3/34: 305v; NA, Letter Vengurla to Batavia 13.10.1674, VOC 1304: 409v.

43 ERS, Letter Surat to Company 13.2.1675 (o.s.), 2: 34. 
time it was rumoured that Shivaji had "some great designe" following the news that the "subtill fellow" Netaji had returned to him, who was apparently disenchanted with the Mughal Aurangzeb in whose service he had even converted to Islam, or in the words of the English factors at Rajapur, "hath been 10 yeares in the Mogulls Court, turned Moreman, but now remade a Hindue." 44

Meanwhile, in May 1676 the news came from Rajapur that Bahlul Khan had had "a bloody fight with the Decanns," in which he lost many men and important friends. The party of the Deccanis consisted of Sheikh Minhaj, Sidi Mas'ud and (Sayyid Makhdum) Sharza Khan, while Bahlul Khan "hath none sticks to him but the Pattans." ${ }^{45}$ In late '76 and early '77 the Dutch factors at Pulicat and Nagapattinam reported that the Bijapuri governor Sher Khan Lodi (an Afghan and Bahlul Khan's man in the Karnatak) and Nasir Muhammad Khan (a Habshi) commander in charge of the fortress of Gingee for Bijapur had put aside their earlier reported differences and were now jointly threatening Ekoji — Shivaji's brother and heir to Shahji's holdings in the Karnatak, also nominally serving Bijapur. Meanwhile Ekoji was also under threat from the nayaka of Madurai, from whose control he had just wrested Thanjavur. And in February 1677 it was reported that Sher Khan's campaign against Ekoji was said to be financed by the nayaka of Madurai. ${ }^{46}$

Also in February 1677 a report reached Pulicat from Hyderabad that Bahadur Khan (the supreme commander of the Mughal force in the Deccan) proposed an offensive alliance with the Qutb Shah against Bahlul Khan, and offered in return to procure a three-year exemption from tribute to the Mughal emperor. A month later it was reported from Hyderabad that there was great commotion at the Golkonda court after Bahlul Khan had been defeated, which defeat was made all but complete by Shivaji, and had offered the Dekkanijs gathered at Bijapur to hand the young prince and control over the kingdom to (the Habshi) Sidi Mas'ud on condition that he himself be allowed to depart for his holdings in the Karnatak. ${ }^{47}$

Then Shivaji started what has come to be known as his Karnatak campaign with a visit to Hyderabad, where he had a "very friendly" interview with the padshah Abul-Hasan on the 14th of March 1677, as was reported by the Dutch factors who were present at Hyderabad and met Shivaji in his tent at the time of his visit to the city. According to the same

${ }^{44}$ ERS, Letter Rajapur to Surat 24.7.1676 (o.s.), 2: 95.

${ }^{45}$ ERS, Letter Rajapur to Surat 9.5.1676 (o.s.), 2: 87-8.

46 NA, Memorandum by Nagapattinam council regarding Thomas van Rhee's planned journey to Thanjavur 14.12.1676 and letter Nagappattinam to Batavia 16.2.1677, VOC 1329: 1168-v, 1159 and letter Pulicat to Netherlands 6.2.1677, VOC 1324, 483v; Rao, Shulman and Subrahmanyam, Symbols of Substance, 314.

${ }^{47}$ NA, Letters Pulicat to Batavia 12.2.1677, VOC 1324: 498 and Masulipatnam to Batavia 18.3.1677, VOC 1328: 591v. 
report, the Dutch factors were among the people who accompanied Shivaji for a short distance when he left Hyderabad with his own 12,000 horsemen together with supporting troops provided by the Qutb Shah on the $11^{\text {th }}$ of April. 48

Again according to contemporary records, the Qutb Shah and his minister Madanna agreed on a "contract" according to which Golkonda was to contribute cavalry and infantry to Shivaji's campaign as well as 450,000 hons, on the condition that Shivaji would hand over to the Qutb Shah all the fortresses he would conquer in the Karnatak except the fortress of Vellore. But while the Golkondans delayed paying the final 200,000 of the 450,000 hons specified in the "contract," Shivaji held on to Gingee, which he took on the $25^{\text {th }}$ of May, and this seems to have soured the relationship somewhat. In the month of August Herbert de Jager reported from Shivaji's camp that, according to rumour, Shivaji might hand Gingee over to the Qutb Shah after all, "in order to give some satisfaction to that majesty, since he is continually trying to placate him with nice statements of submission and respect." In September, however, De Jager reported that the Qutb Shah was said to have formally released Gingee to Shivaji in order to maintain the friendship with him. ${ }^{49}$

From the letters of this Herbert the Jager, who was following the army in an effort to get the VOC's privileges confirmed by Shivaji in his capacity as the new lord of the Karnatak, we have an almost day-to-day report of the campaign between early August and early September 1677. It would be tedious to detail the daily progress here, but it seems that after Shivaji had successfully marginalised Sher Khan and forced him to take shelter with the lord of Ariyalur and had made the nayaka of Madurai agree to a considerable tribute, he turned on his heel following a meeting with his brother Ekoji:

Meanwhile it has transpired that the prince Ekoji, after having conferred with his brother Shivaji for a few days, has left quietly by night and with his troops in order to rid himself of the pressing claims that his brother was making to a due share of the means and effects that the father of both, Shahji, had left and that Ekoji had resumed under his administration. This departure was taken so badly by Shivaji that he has resolved to take all of his brother's lands, and has accordingly already sent orders and troops into his lands, and is bringing along Jagannath Pant, a Brahmin of the greatest influence with Ekoji, as well as others to clarify and demonstrate the aforementioned inheritance.

48 NA, Letter Pulicat to Batavia 30.7.1677, VOC 1324: 511-v/VOC 1328: 598v-9.

49 NA, Letters Masulipatnam to Batavia 2.9.1677, VOC 1328: 628v, Pulicat to Batavia 30.7.1677, VOC 1324: 512, Herbert de Jager and assistant Nicolaes Clement at "Waligondewaron" to Pulicat (?) 10.8.1677, VOC 1328: 622-v, Letter same at "Tiermamel" to Tengapatnam 6.9.1677, VOC 1323: 329; ERS, Letter Fort St. George to Company 19.6.1677 (o.s.), 2: 125 . 
After less than a month, however, Jagannath Pant managed to escape "very subtly" and return to Ekoji. ${ }^{50}$ Although there were rumours, about which more below, that a common front would be formed against Shivaji, an alliance between the princes of the Karnatak and Ekoji against Shivaji never materialised, and the nayaka of Madurai and the Marava king of Ramnad kept up the pressure on the borders of Ekoji's recently acquired lands, so that he was not in a position to send a large force against Shivaji. ${ }^{51}$

Meanwhile the progress of the Dutch envoys in procuring a qaul reconfirming the VOC privileges was suddenly hampered by the rumour that they were somehow connected with Sher Khan and the suspicion on the part of Shivaji and his ministers that the VOC factory at Tengapatnam harboured goods belonging to Sher Khan. When Herbert de Jager and his assistant took leave of Shivaji, it was granted coolly and with no more formality than the presentation of betel, while Shivaji reminded them that they would receive their qaul from his minister only after all persons and goods belonging to Sher Khan had been handed over. This was a marked contrast to the exceptionally stately welcome that the VOC envoys had initially received. The problem of the goods in the Teganapatam factory led Herbert de Jager into some cross-cultural reflection on the position of the individual in Indian law (the goods belonged to the son of an important administrator of Sher Khan), but was generally blamed by him on Shivaji's boundless need for cash, and apparently Mirza Muhammad Amin, attached as general to Shivaji's expedition on behalf of Golkonda, confided to De Jager that Shivaji owed his troops 200,000 hons, something that was also whispered among "Shivaji's own Marathic people." 52

Apart from an idea of his conquests and financial situation we also gain a glimpse from the Herbert de Jager reports of Shivaji's actions in the field of public relations and his policy towards the inhabitants of the conquered country. De Jager remarked in passing that Shivaji behaved very devoutly by visiting the more renowned temples in every place that he passed through in the Karnatak (but that the donations he made to these were far below his stature)..$^{53}$ In Shivaji's qaul as it was finalised just before the suspicions concerning the Teganapatam goods arose, all privileges granted by Sher Khan on behalf of Bijapur were confirmed except the right

\footnotetext{
50 Jadunath Sarkar has it that Jaganath and the other ministers were released, but the De Jager report is quite clear that Jaganath escaped three nights before writing, while De Jager was still in Shivaj's camp. Sarkar, Shivaji, 300.

${ }^{51}$ NA, Letters Pulicat to Batavia 7.8.1677, VOC 1328: 614, Herbert de Jager and assistant Nicolaes Clement at "Waligondewaron" to Pulicat (?) 10.8.1677, VOC 1328: 617-22-v, and at "Tiermamel" to Tengapatnam 6.9.1677, VOC 1323: 328-9.

52 Letter Herbert de Jager and assistant Nicolaes Clement at "Waligondewaron" to Pulicat (?) 10.8.1677, VOC 1328: 620-v; Letter same at "Tiermamel" to Tengapatnam 6.9.1677, VOC 1323: 328-9; Letter same at "Palliumkotte" to Tengapatnam 16.9.1677, VOC 1323: 330-3. ${ }^{53}$ NA, Report of mission to Shivaji 15.10.1677, VOC 1328: 668v.
} 
to buy and transport slaves,

since [he] has established [as] a fundamental rule of his government, that none of his subjects may be made into slaves, let alone be sold or transported, in order not to lack any inhabitants, with which these new conquests are sparsely enough provided, even though this tyrannical rule has already made many of the best inhabitants leave. ${ }^{54}$

Clearly Shivaji made efforts to live up to at least some of the standards set at his coronation, even if to some he would forever seem a tyrant. But just how revolutionary Shivaji's measure was can be gauged from the fact that a qaul granted by one of the hawaldars of his brother Ekoji concerning the newly opened VOC factory in "Trimelevaas" less than two years later merely noted the toll to be collected on slaves. The toll rate for a slave stipulated in the hawaldar's qaul was the average of the toll rates for a load of quality cloves and a load of mace. ${ }^{55}$

The Karnatak campaign came to an end late in 1677, when Shivaji seems to have made a spectacular rentrée in the heart of the Deccan by disturbing a tentative peace between Golkonda, Bijapur and the Mughal forces now under the Afghan commander Dilir Khan. ${ }^{56}$ This was after the struggle between the Deccanis and Afghans of Bijapur had culminated in a war of attrition near Gulbarga, also described at length in a VOC report. There the Afghans Dilir Khan of the Mughal empire and Bahlul Khan of Bijapur were pitted against the forces of Golkonda, along with such people as Sayyid Makhdum and Shaikh Minhaj, whom we know from other sources to have been champions of the Deccani cause in Bijapur. ${ }^{57}$ In the Mughal records this struggle resonates in some decrees on the promotion of officers whose rank was increased for bravery in the "war against the Hyderabadis and Deccanis." 58 At this juncture the Brahmin correspondent of the EIC reported from Hyderabad that some "Pattan cast Captains" refused, "by reason of their cast," to fight the Mughals and Bahlul Khan, so that their houses in town had to be kept under surveillance. ${ }^{59}$ Around the very end of the year 1677 Bahlul Khan died and early in 1678 the city of Bijapur, along with the custody of the young sultan, was taken over by the Deccani party under the Habshi Mas'ud Khan, but not before Shivaji had apparently made a — financial — bid for it according to a curious EIC

54 NA, De Jager and Clement at "Tiermamel" to Tengapatnam 29.8.1677, VOC 1323: 326v.

55 Contemporary Dutch translation qaul of Ekoji's great-hawaldar "Naregirie" Pandit to VOC 14.6.1679 in Heeres, Corpus, 3: 183-7.

56 NA, Letter "Pera Aijen," spy in the army of Shivaji's brother Shantaji in the Karnatak, to "Wiereragua Aijen" at Nagapattinam 2.1.1678, VOC 1324: 654; ERS, Letter Carwar to Surat 13.12.1677 (o.s.), 2: 148.

${ }^{57}$ NA, Letter Pulicat to Batavia 31.1.1678, VOC 1339: 953. Bhimsen, Tarikh, 106.

58 APSA, Tajwiz namas (decrees on promotion) 14 and 15 Rajab and 17 Sha'ban 21 Julus/ 1 and 2.9 and 4.10.1678, Mughal Records XXI 5097, 5116, 5578.

${ }^{59}$ ERS, Letter "Vira Ragavaya” to Langhorne 28.10 .1677 (o.s.), 2: 143. 
report. ${ }^{60}$

As to the response of Maloji Ghorpade to Shivaji's appeal to join the coalition against the Afghans, it seems that he forewent the offer and chose to remain loyal to the Adil Shahi dynasty (including its Afghan representatives). That, at least, is stated in a chronicle purportedly written at Maloji's court, the dating of which is unfortunately problematic. ${ }^{61}$ The first, quite certainly authentic, records we have after Shivaji's appeal are a series of farmans of October 1678 by which Mas'ud Khan showers favours on Maloji in the form of revenue rights. One of these farmans asks Sidi A'zam Akram and Sidi Salim, who can safely be assumed to be Habshis from the appellation Sidi and, as such, probably members of the Deccani faction, to vacate certain lands and hand them to Maloji. ${ }^{62}$ We can only speculate as to why these farmans were issued at this point. Possibilities are that they were a reward for Maloji's loyalty to the Adil Shahi state during the troubles, or that they were issued in connection with the conciliatory efforts by Mas'ud Khan as described in the Basatin us-Salatin, which is often used as the main source for the history of Bijapur in this period but was written at so late a date as to render all the information contained in it coloured by the lens of an entirely different era, for which reason I have tried to avoid recourse to it throughout this study. It is also possible that the documents were related to a renewed call to arms against the Afghans by Sidi Mas'ud issued in 1678 , for which the evidence would be another document in the Ghorpade archives that is discussed in appendix III. ${ }^{63}$

Discourses of CONTEMPORARIES ON SHIVAJI's MOtIVATION AND THAT OF HiS ANTAGONISTS

Ranajit Guha has in a very different context, namely that of the nineteenthcentury British Raj, made a distinction between primary, secondary and tertiary discourses. While the primary discourses capture the entropy of actions as I have tried to present it above, the secondary discourses attempt to make sense of the events and to aid the reader in understanding the situation (and the tertiary discourses are the ones historians write today). A

${ }^{60}$ ERS, Letters Carwar to Surat 16 and 23.1.1678 (o.s.), Surat to Company 21.1. 1678 (o.s.), Rajapur to Surat 3.4.1678 (o.s.), 2: 151-2, 160.

${ }^{61}$ The original Persian manuscript of the chronicle could not be located at the time of my visit to the Ghorpade family archives. A Marathi translation is in Apte, Mudhol, the "Bakhar" paginated separately, there 246-7; doubts cast on the date: Gajanan Bhaskar Mehendale, Shri Raja Sbivchatrapati vol. 1, pt. 2, bk. 1 (Pune, 1999) 405-6.

62 Three farmans (two original and one a contemporary copy) 28.8.1089/15.10.1678, in: Apte, Mudhol, appendix: 52-60; these farmans authentic: Mehendale, Shivchatrapati, vol. 1, pt. 2, bk. 1: $482-5$.

${ }^{63}$ Basatin, 453, 455. Richard Eaton has, in conversation, made me aware of the pitfalls of the Basatin. 
feature of Guha's secondary discourses is also that, unlike primary discourses, they are intended for a public readership and that they are often consciously historical. Historical consciousness, to be sure, was certainly on the rise in India in the seventeenth century. ${ }^{64}$

Moving a little beyond Guha's arguments, we may assume that, as contemporaries, the writers of these narratives had some idea of what motivated others at the time. That, in other words, they had a "working theory of human nature" as it found expression in the seventeenth-century Deccan, which served them to predict and interpret actions of others. ${ }^{65}$

The same could of course be said of the authors of the Dutch and English records of the above section, but those records are very much primary discourses in Guha's scheme, and the Dutch records do not reflect on Shivaji much beyond the observation that he was a grijpvogel, a rather odd expression that may be translated as "seizing bird," seizing every valuable thing that he could get his hands on and then flying off quick as a bird, although the word was also a synonym for "griffin," the mythical lioneagle. ${ }^{66}$

Sometimes however, the Dutch reports recorded the rumours that were going around concerning the motivations that contemporaries were attributing to the principal actors. At the height of the Karnatak campaign the VOC factors at Pulicat reported that Shivaji was generally said to have initiated the campaign mainly in order to avenge the offences carried out against his brother Ekoji by Sher Khan Lodi. It was also rumoured at some point that "the princes of Madurai and Mysore would have made a treaty, with the reciprocal provision not to pay money to Shivaji any more nor to be involved with him more closely, in order not to make him too powerful against all of them, that Ekoji Raja's ambassadors have finally been admitted at those courts, as well as at those of the Tevar and the visiadoors [lords] of Ariyalur and Ariyapallam and are working hard to create a league against his brother, but nothing can be said yet of the success." The fact that this was rumoured shows that there was a sense that Shivaji had to be resisted rather than welcomed by these Hindu rulers of the Karnatak. ${ }^{67}$

This is corroborated by the Chikka Deva Raja Binnapam, with which we come to the secondary discourses, where Chikka Deva Raja who ruled Mysore from 1672 to 1704, looked back on his lifetime's achievements. He mentioned that Shivaji plundered "Delhi" (the Mughal empire) like the

64 Ranajit Guha, "The Prose of Counter-Insurgency," 1-43. Jan E.M. Houben, "The Brahmin Intellectual: History, Ritual and 'Time out of Time'," Journal of Indian Philosopby 30 (2002) 463-479.

${ }^{65}$ Compare Pinker, The Blank Slate, 1-3.

${ }^{66}$ Woordenboek der Nederlandsche Taal, s.v. grijpvogel.

${ }^{67}$ NA, Letter Pulicat to Batavia 30.7.1677, VOC 1324: 511v; Letter De Jager and Clement at

"Palliumkotte" to Tengapatnam 16.9.1677, VOC 1323: 333. 
well-known pilferers of Sanskrit tradition Maya, Sambhara, Indrajit (son of Ravana) and Maricha, conquered Bijapur, crushed the ruler of Golkonda and took tribute from him and then turned to the Karnatak full of pride, but Chikka Deva Raja resisted him in such a way that confused Shivaji in the battlefield. ${ }^{6}$

While the motivation of Chikka Deva to oppose Shivaji is not mentioned and apparently self-evident, the motivation of Madanna to bestow such resources on Shivaji as he did is clearly something that needed explanation, on which the secondary discourses are duly divided. The Dutchman Havart, who was present in Hyderabad at the time of Shivaji's visit but who does not seem to have written his account of it until a number of years later, described Shivaji as a "barking dog" whose mouth was plugged with numerous gold lumps upon a threat to destroy the city, which Havart said was gripped with fear. ${ }^{69}$

A diametrically opposed picture is presented by the bakhar of Krisnaji Anant Sabhasad, generally taken to be the most authoritative of the so called bakhars or Marathi historical poems, because it was supposedly written less than twenty years after Shivaji's death in 1680 and that too under the auspices of Prahlad Niraji, son of the minister Niraji Raoji and himself Shivaji's envoy to Hyderabad during the Karnatak campaign. Recent research from an unexpected angle - numismatics to wit shows, however, that the final version of the text did not see the light until the mid-1720s. ${ }^{70}$ This text presents us with the following tableau: "the Badshah had adorned the whole city. Streets and lanes were all around coloured with a thin layer of kunkum powder and saffron. Festive poles and triumphal arches were erected and flags and standards hoisted in the city. Krors [literally: tens of millions] of citizens stood to have a look at the Raja [Shivaji]. The ladies welcomed him by waving innumerable lamps around him. Gold and silver flowers were showered upon the Raja." As was noted in Chapter 1, Havart was probably on terms more intimate with (Foreign) Muslims than with other inhabitants of Hyderabad, and the spirit of the city's inhabitants probably ranged between the states painted in Sabhasad's bakhar and Havart's work among different sections of the population.

There is, however, one point on which the texts agreed: that there was a considerable flow of gold running from the Qutb Shah to Shivaji. In fact, Sabhasad's bakhar stated that Shivaji came up with the idea of paying

68 K.G. Vasantha Madhava, "Shivaji in Kanara and Contemporary Kannara Works," in Chhatrapati Shivaji: Architect of Freedom, ed. Narayan H. Kulkarnee (Delhi, 1975) 150-68.

${ }^{69}$ Havart, Op en ondergang, 2:177-78.

${ }^{70}$ Shailendra Bhandare, "An Evaluation of the Sabhasad Bakhar as Source of Historical Information: A Numismatic Perspective," in Amiteshwar Jha ed. Proceedings of the $5^{\text {th }}$ International Colloquium on 'Medieval Indian Coinages: A Historical and Economic Perspective' (Nasik, 2001) 211-9. 
Abul-Hasan a visit while considering the options for financing a Karnatak campaign. Madanna and Abul-Hasan decided between them that Shivaji should be given whatever he wanted, after he had made an excellent impression which had prompted Abul-Hasan to send him a message saying, "you are honest." Thus it was clearly charm rather than threat that caused Madanna to disburse the gold according to the bakhar.

Still another motivation, and by far the most complicated, we find in François Martin's memoirs. Martin said that Madanna induced AbulHasan to invite Shivaji to conquer part of the Karnatak for him, but that he knew Shivaji would not keep his part of the deal, which was to surrender all the conquered fortresses to Golkonda. Madanna's real design was thus, according to Martin, "to put that part of the Karnatak back under the domination of the Hindus and to make himself a powerful protector of Shivaji by giving him the opportunity to make himself master of it." A few pages further he wrote: "that unfaithful minister had deceived his master with the intention of re-establishing the Gentiles in the Karnatak."”1

Khafi Khan, who does not seem to have started writing his history — from the "casket" of his memory — until after 1718,72 in some places also saw the wars of the Deccan in terms of Hindu-Muslim struggle. He made a sharp distinction between Hindus and Muslims, as is evident for instance in the famous passage on Shivaji's tolerance — "but he made it a rule that whenever his followers went plundering, they were not to desecrate mosques and the Book of Allah, nor seize the women. Whenever a copy of Qur'an fell into his hands he would keep it in all respect and honour and handed it over to some of his Muslim servants. No one from among his men had the courage of casting an eye on women of Hindus and Muslims captured by them" - which passage would only have made sense in the context of a struggle between Hindus and Muslims, in which the other party along with its religious sites and objects was not always accorded such good treatment. This view of Khafi of the Mughal-Maratha wars as a struggle between religions comes out most clearly in a passage on Sha'ista Khan's expedition against Chakna, a town belonging to Shivaji, which Sha'ista Khan renamed Islamabad after the conquest conducted by "the brave soldiers of Islam," who were "keeping the shields of the protection of God before their eyes," as well as "life-sacrificing ghazis." In other passages, however, the opponents were referred to not only as infidels, but more precisely as belonging to the qaum-i Marbata, the Maratha "nation," which was apparently seen as being very cohesive, because, according to Khafi Khan's account, any able-bodied male (abadi) from that qaum who was not in Mughal service was deemed a security threat to the Mughal

${ }^{71}$ Martin, Mémoires, 2: 89,95.

72 Anees Jahan Syed, Aurangzeb in the Muntakhab-al Lubab (Bombay, 1977) xv. 
presence in Pune when Sha'ista Khan was encamped there. ${ }^{73}$

On the other hand, the contrast between Deccani Muslims and Mughals also played a large role in Khafi Khan's account, as has already been suggested above in the discussion of the word Deccani. Not only were the ways in war of the Deccanis cowardly, the latter also connived with the Marathas, as when, around 1695, a Deccani noble notably belonging to the Mughal army, suggested to a Maratha commander to demand a high ransom for the Mughal troops he was detaining. We also glimpse the power of Deccani patriotism embodied in the Deccani language when, around 1685, Shaikh Minhaj and Rustam Rao, a cousin of Madanna, used that very language to make a strong statement against the surrender to the Mughals of any territory belonging to Golkonda. The contrast between Deccanis and Mughals could, however, also be cancelled by an appeal to their common Muslim-ness, as some Deccanis also did in $1685 .{ }^{74}$

The secondary narrative that sheds the clearest light on the events in 1677 is that by the Mughal administrative officer from the Kayastha caste named Bhimsen, who was present in the Deccan during the events. From these memoirs we gain the impression that, after the ascent to the throne of the child-king Sikandar in 1672, the internal affairs of Bijapur quickly spun out of control and that an important catalyst to the ensuing eddy was what Bhimsen calls a "national sentiment" on the part of the Afghans in the Deccan. Bhimsen's narrative runs as follows: Some two years after the installation of Sikandar disputes arose between the Afghans and Deccanis (at first mainly Deccani Muslims) in Bijapur, under the leadership of AbdulKarim Bahlul Khan and Khawas Khan respectively. After an attempt at reconciliation, Abdul-Karim treacherously killed the then captive Khawas Khan and tried to have Shaikh Minhaj, as another important leader of the Deccani faction, killed. Then Abdul-Karim scored a great victory over the Deccanis and the latter were dispersed. A Mughal army was sent to bring Abdul-Karim to Aurangzeb dead or alive to account for the murder, but Madanna came to Abdul-Karim's aid. During the long-drawn struggle between the Mughal army and that of Bijapur under Abdul-Karim, there was a role to play for Afghans "ki nazar-i hamqaumi dashtand." 75

The latter phrase is translated by V.G. Khobrekar and V.S. Bendre quite rightly as "who had their national sentiment working," and although the use of the term nationalism for this period may be contrary to some

\footnotetext{
${ }^{73}$ Khafi Khan, Muntakhab (translation) 125-8, 176; (Persian text) 121, 172.

${ }^{74}$ Khafi Khan, Muntakhab (translation) 305, 308, 429.

75 Bhimsen, Tarikh, 104-111. All three manuscripts of Bhimsen's Nuskha-i Dilkasha have this exact phrase so it is unlikely to be a later addition to the text as completed in 1120 $\mathrm{AH} / 1708-9 \mathrm{CE}$. In any case, as a terminus ante quem, one of the manuscripts is dated 1728 . BL, Ms I.O. Islamic 94: 72b; BL, Ms Or. 23: 67; BN, Supplément persane 259: 78; Charles Rieu, Catalogue of the Persian Manuscripts in the British Museum, vol. 1 (London, 1879) 271-2; C.A. Storey, Persian Literature: A Bio-Bibliographical Survey (London, 1927-39) 1: 558-9.
} 
modern historians' sensibilities, the term patriotism, which Chris Bayly deems suitable for the time and place presently under discussion, cannot apply to the Afghans in this case, as they were not defending a patria, but the interests of people of their shared (ham) ethnic group (qaum). The similarities between the European usage of the term nation (see Ch. 1) and the usage of qaum are striking: while Johan van Twist's description of India published in 1638 referred to the Rajputs as a natie, Mughal documents of the 1680s referred to certain people as belonging to the qaum-i Rajput. The Dutchman Van Twist further distinguished three nations amongst the Muslims in Gujarat, one of those being the Pathans, the others the Mughals and the Hindustanis. Therefore I see no objection to the use of the phrase "national sentiment," provided one keeps in mind that it is to refer to a nation in the sense of a group rather than a nation in the modern sense of a state belonging to such a group. ${ }^{76}$ The term patriotism is of course also applicable in this period, for instance to Shivaji's appeal to the true inhabitants of the Deccan. That group was not a qaum, but a mere jama'at (heap, collection, gathering, assembly), the term that Aurangzeb seems to have used for Deccanis or Deccani Muslims. ${ }^{77}$

To continue Bhimsen's narrative: with their national sentiment thus in view many Afghans of Bijapur rushed to the fortress of Naldurg in which some fellow Afghans were besieged, while the Afghans in the Mughal force "had sympathy for Abdul-Karim, he being a Pathan." The Mughal general Bahadur Khan then sent for the dispersed Deccani nobles of Bijapur and allied with Shivaji, thus building a Deccani coalition with a vast force to which Shivaji also contributed 4,000 troops (March 1677). This force proceeded to make peace with Abdul-Karim after Dilir Khan and Abdul-Karim "with all the Afghans" met with Bahadur Khan in great pomp. The move by Bahadur Khan to build this coalition might have been inspired by a desire to contain the Afghans, although Bhimsen did not say

76 Chris Bayly, Origins of Nationality, 1-8; Van Twist, "Generale beschrijvinghe," 54-55; APSA, Arz-o-Chahras (personal descriptions) 16 Muharram 29 Julus/13.12.1685 CE, Mughal Records XXIX 198-202. Muzaffar Abbas also defines qaum along the lines of the term nation but does not give any examples illustrating the homology/synonymy. Ayesha Jalal argues against Abbas that "the connotations of the word "nation" in popular discourse militate against its straightforward equation with the Urdu word qaum." Jalal seems to be referring especially to the territorial connotations. There are, however, quite a few modern academics, especially among those studying colonial Bengal, who use the term nation as distinct from or even in opposition to the state. Compare Partha Chatterjee, The Nation and Its Fragments: Colonial and Postcolonial Histories (Princeton/Delhi, 1993) and Pradip Kumar Bose, "Sons of the Nation: Child Rearing in the New Family," in Partha Chatterjee ed. Texts of Power: Emerging Disciplines in Colonial Bengal (Minneapolis, 1995) pp. 118-144. Jalal, Self and Sovereignty, 11-3; Muzaffar Abbas, Urdu mẽ qaumi sha'iri, 14-23.

77 At least in two of his orders in the eighteenth-century compilation ascribed to Hamid udDin Khan Bahadur, Ahkam-i 'Alamgiri (Persian text) 40-1. See Appendix II for an evaluation of this compilation. 
this. A key element in this story is however the affection between Dilir Khan and Abdul-Karim. Dilir Khan, whom Bhimsen served at the time that he was writing about, "would never consider any man other than the Afghans as a gentle or noble fellow," and was according to an inserted verse, "so intoxicated with the wine of love [for Karim] that he even broke the thread of his duties and responsibilities." Dilir Khan and Bahlul Khan wrote to Aurangzeb that Bahadur Khan was in league with the people of Deccan, and Bahadur Khan was consequently summoned to the court, while Dilir Khan was left in the Deccan and, in alliance with Abdul-Karim, invaded Golkonda. After a war of attrition, Dilir Khan decided it better to retreat to Gulbarga to forage, especially in view of the illness of AbdulKarim, but the retreat turned into a disaster for the Afghans - at which point Bhimsen inserted his verse about Dilir's love. The end of this episode was that Dilir Khan and the Deccanis made peace, Abdul-Karim reconciled with Sidi Mas'ud, the new leader of the Deccani faction in Bijapur who was a Habshi just as the late Khawas Khan, Abdul-Karim died, and Bahadur Khan was restored to imperial favour. At this point the Bijapuri Afghans were in a rather destitute situation, which they blamed on their new commander, the son of Abdul-Karim. The Afghans heaped their new commander with abuse, which inspired Bhimsen to comment: "if they could treat their own clansmen thus, one can imagine how they must have oppressed others." Finally Asad Khan was sent by Aurangzeb to quell the turbulent Afghans. ${ }^{78}$

Bhimsen's account of the rapprochement of Shivaji and AbulHasan/Madanna is separate from his account of these events but it is not difficult to locate Shivaji's routing of the Bijapuri Afghan commander Sher Khan Lodi in the Karnatak, and more importantly his appeal to Deccani patriotism at the outset of the campaign in the context of the strife between Deccanis and Afghans in Bijapur. Neither is it difficult to surmise that the strength of the "national" feelings of the Afghans in a way strengthened the bond of their opponents, spawning a suddenly reified binary of Afghans versus Deccanis. Rereading Martin's account with this in mind I noticed that according to this author, Madanna first conceived his scheme, mentioned above, after he had received some envoys from Nasir Muhammad Khan who had decided to hand Gingee and the surrounding lands to the sultan of Golkonda rather than surrender them to Sher Khan, which decision was "animated by the hatred that there had always been between de Pathans and the Deccanis." Moreover, according to the same author, "Nasir Muhammad who only searched for ways to keep Sher Khan from mastering Gingee," changed nothing about the conditions decided between Shivaji and the Qutb Shah and welcomed Shivaji as soon as he set

${ }^{78}$ Bhimsen, Tarikh, 110-121. 
foot in the Karnatak. Thus it seems that Shivaji did not just buy out Nasir Muhammad Khan - the general view of the secondary literature - but was handed Gingee on account of a successful appeal to Deccani patriotism. ${ }^{79}$

\section{CONCLUSION}

In connection with Shivaji's visit to Hyderabad, Bhimsen wrote of the hilagari, deceit or trickery, with which Shivaji fooled the "otherwise very discerning and dexterous" Madanna as well as Abul-Hasan. ${ }^{80}$ But whether Shivaji's Deccani patriotism was heartfelt or a "trick" is ultimately irrelevant to the purpose of this study. What matters is that Shivaji deemed an appeal to Deccani patriotism a useful instrument of policy, which can only have been occasioned by an idea that people might be willing to act on that appeal. And indeed some of the evidence, especially in the secondary narratives points to the salience of Deccani patriotism. The case of Nasir Muhammad as described by Martin brings this point home most vividly.

But the salience of Deccani patriotism was also a function of the historical circumstances, and the handover of Gingee by Nasir Muhammad in a way represented the high water mark of it, as the Deccani alliance collapsed shortly afterwards and Nasir Muhammad died a disappointed death when Shivaji did not hand over Gingee to the Qutb Shah and he himself was not given the lands in Golkonda's territories that he had been promised in lieu..$^{81}$ Moreover, although the 1670 s Deccani patriotism built on earlier formations outlined in Chapter 2, it was also clearly a reaction against the activities of the Afghans and their group loyalties. It would take us too far to explain where these strong Afghan loyalties originated - it seems that they had existed for a long time - but apparently the progressive collapse of Bijapur had opened the possibility for these loyalties to come into play, or to phrase it less deterministically, the Afghans at this point saw a possibility to play out their group loyalties. Ten years earlier, an appeal by the Bijapuri Afghan commander Sharza Khan to Dilir Khan, which the Italian Niccolao Manucci renders as: "valorous and loyal general, Diler Khan! I do not write to Raja Jai Singh but to you, we being of one race and of and of one faith," apparently met with a rather lukewarm response and a reference to the authority of Aurangzeb. ${ }^{82}$

But how did Shivaji's appeal to Deccani patriotism at this point square with other strands of the discourse emanating from his court, the discourses on the need to acquire artha, on the need to trample the darkness

\footnotetext{
${ }^{79}$ Martin, Mémoires, 88-90. Compare Sarkar, Shivaji, 293.

${ }^{80}$ Bhimsen, Nuskha-i Dilkasha in BL, Ms. I.O. Islamic 94: 56v-7 and Ms. Or. 23: 54.

81 Martin, Mémoires, 95.

82 Manucci, Storia do Mogor, 2: 131.
} 
symbolised by elephants and most importantly on the mlecchas/Yavanas? Restricting the question to the latter, this discourse was obviously directed at a narrower audience than the Deccani patriotism discourse. Paramananda's epic was framed as a narration by himself to an audience of Brahmins in Benares. Another indication of the audience at which the epic was directed was the use of the classical code words Yavana and mleccha, which was only one among many of the Sankritic conventions to which the text adhered. But the contradiction with the discourse on Deccani patriotism may not have appeared as glaring as it does today; the Afghans after all did fit the label Yavanas on the count of their religion and their foreignness. Moreover, on deconstruction, it appears that there were many layers in the epic, one of which exalted the Deccan, however restricted, and even allowed for the Muslim Malik Ambar to be called "a brilliant setting sun" on account of his defence of the Deccan (8.5-8). The different layers of Shivaji's discourse resonate in Martin's account, with his view of Shivaji as both Madanna's instrument to put the Hindus back in charge of the Karnatak and Nasir Muhammad's instrument to keep the Pathans out of Gingee.

The main thing to conclude about group loyalties/social identities in this period is that they were not merely "shaped in fundamental ways by political struggles and processes" - as Nicholas Dirks writes about caste — ${ }^{83}$ but themselves determined politics. If we look at the practices in the records we often find a muddle of continually shifting alliances, but looking at the way contemporaries tried to make sense of events in their secondary narratives we start to see how the ideologies of the involved played a role in these events, precisely because these writers made sense of events on the basis of the ideologies as they were reported to them.

But, although Richard Eaton and Sheldon Pollock have argued against the post-structuralist or post-orientalist view that discourses of self and other are an exclusively modern phenomenon in India, and Pollock has even gone so far as to surmise that these discourses are "potentially no less effective than any other fact or event," 84 the most favoured view (thus with the notable exception of Pollock), and one that unites post-structuralists and empiricists, is that ideologies of identity did not inform practice in early modern India. The present central stance in the historiography of medieval and early modern history is worded by B.D. Chattopadhyaya: "the ideological parameters are not absent even when political-economic

${ }^{83}$ Dirks, Castes of Mind, 13.

${ }^{84}$ Richard M. Eaton, “(Re)imag(in)ing Other²ness”; S. Pollock, "Deep Orientalism?” 102. Pollock does not, however, himself test his case against the record of practices, but enjoins others in classical Indology to confront the gap between "real dreams of power" and "real power," or between what Georges Duby terms "the history of ideologies" and "the history of lived social relations," ibidem 103-4. 
expediency seems to explain events with great clarity; however, at the same time, ideological parameters do not represent permanently bounded space either." 85 In other words, the ideologies of identity that Chattopadhyaya is speaking of were somehow present in the same historical space as the events, but they were too fluid to have a significant impact on the events. The representations discussed by Chattopadhyaya, however, are distributed over seven centuries and will certainly have fluctuated and changed much over such a long period, and what looks fluid from the present day vantage point may well have looked rigid to the involved. That, at least, seems to be the case with the Deccani-Afghan dichotomy in the six-year span under discussion here. The present chapter embodies an attempt to take the recognition of the importance of the ideologies of identity in early modern South Asia a step further and make this conceptual lame duck of "Social Identity in the Old Regime" 86 operational.

Wading further into this epistemological morass, a short note seems in order on how the division between ideology and practice was reified in the case of South Asia. It seems that the scholars who posit the primacy of practices for the medieval and early modern period are engaged in a reaction, on the one hand against Hindu majoritarianist/nationalist historians such as Sita Ram Goell, who by taking the statements of epic and courtly histories as fact conflate ideological representation and practice, and on the other hand against structuralist approaches. ${ }^{87}$ One of the main representatives of the latter, Louis Dumont, wrote of his concern "to distinguish fundamental values and ideas from everything else, the ideological from the non-ideological, or rather the more conscious or more valorized from the less conscious or valorized." The post-structuralists, following Foucault (who unilaterally declared irrelevant the question as to whether he was a structuralist), took the primacy of ideology/discourse to a different level of analysis, but nevertheless retained it and then reserved it for the modern period, while the empiricists were never keen on allowing ideology much of a role in the precolonial period because, to use Chattopadhyaya's phrase, "political-economic expediency seems to explain events with great clarity." It seems that we have come to a point where the thick black line running through some of Dumont's diagrams signifying the threshold of consciousness has been transposed to the schema in which pre-modern and modern India are divided, the first designated the realm of practice and unconsciousness, the latter the realm of ideology and consciousness. In fact Bernard Cohn, often seen as a precursor by post-

\footnotetext{
${ }^{85}$ Chattopadhyaya, Representing the Other? 83.

${ }^{86}$ Chapter title in Dirks, Castes of Mind.

87 Compare Cynthia Talbot, Precolonial India; Chattopadhyaya, Representing the Other?; Richard M. Eaton, "Temple Desecration and Indo-Muslim States," Journal of Islamic Studies 11 (2000) 283-319 and "(Re)imag(in)ing Other²ness"; Dirks, Castes of Mind.
} 
structuralists, said as much when he set the investigation of British discourse on India rolling, "what had been unconscious now [in the nineteenth century] to some extent becomes conscious." 88

Thus we are left in the current state of the historiography on identity in India, with the paradoxical situation that postmodernists and empiricists find themselves united in positing the primacy of practice for precolonial India. The key to understanding this paradox is their combined effort to defuse the power of identity ${ }^{89}$ in the face of casteism and Hindu majoritarianism by continual restatements of the axiom of social constructionism. To be more precise, it is the unwillingness to probe beyond the construction of identities into the question as to why identities - as ideologies - constitute a necessary accompaniment to social practice in the first place that leads to the conclusion that they are ultimately dispensable, whether constructed in power/discourse or in the practice of power. It is to this unwillingness that Steven Pinker refers as "the modern denial of human nature." ${ }^{00}$ However much I share this enlightenment hope of the brotherhood of man and am as such fully inside Western discourse, I do not think that projecting an image of ourselves as noble savages onto an Indian past will be helpful. Rather I agree with Steven Pinker that acknowledging human universals, including the unflattering ones, will be the first step towards a better world, which belief will upon deconstruction no doubt appear as merely the highest stage of Western discourse geared towards preparing the world for enlightenment values.

Outside what has in recent years become something of a field, "identity-studies," the relation between ideology and practice has been less strained, and I would like to cite what Velcheru Narayana Rao, David Shulman and Sanjay Subrahmanyam have written — with a flourish about this relation and suggest their approach as a way out of the "practical pre-modern identities" paradigm: "Conflict is not merely an arena for the calculations of Realpolitik; it is also a stage for the dramatic demonstration of the real. And what was most real, it would appear, for the last Nayaka king of Thanjavur - as for many of his counterparts in the contemporaneous Nayaka elite - was the effective living out of the primary values of extreme devotion, commitment to honour, individual fame, and vainglorious heroics which, taken together, moulded into a

${ }^{88}$ Louis Dumont, Homo Hierarchicus: The Caste System and Its Implications (Chicago, 1980) 2323. Foucault, Order of Things, xiv and passim. Paul Rabinow, however, maintains that: "Although Foucault was temporarily caught up in some of the structuralist vocabulary of the moment, he never intended to isolate discourse from the social practices that surround it." Paul Rabinow, "Introduction," in idem ed. The Foucault Reader (New York, 1984) 1-29, there 9-10; Cohn, "The Census," 229.

${ }^{89}$ Manuel Castells, The Power of Identity, vol. 2 of The Information Age (Malden, MA. 1997).

${ }_{90}$ Pinker, The Blank Slate. 


\section{nurturing matrix of illusion, point a path to transcendence." 91}

A final example of the intimate connection of Shivaji's ideologies to his practices, or of the nigh impossibility to separate the two, is the following passage from his qaul granted to VOC ambassador Herbert de Jager in 1677. In it Shivaji puts his proscription of the slave trade discussed above in the context of a radical (and ideological) break with the past:

In the days of the Moorish government it was allowed for you to buy male slaves and female slaves here [the Karnatak], and to transport the same, without anyone preventing that. But now you may not, as long as I am master of these lands, buy male or female slaves, nor transport them. And in case you were to do the same, and would want to bring [slaves] aboard, my men will oppose that and prevent it in all ways and also not allow that they be brought back in your house; this you must as such observe and comply with. ${ }^{92}$

Even if Shivaji's measure was motivated, as Herbert de Jager suggests, by a concern about revenues (which would be less if there were fewer inhabitants) rather than a concern for the welfare of the potential slaves, it is quite impossible to distinguish in this passage the practical measure from the patriotic appeal conveyed by it, directed as it is against Muslim rulers allowing the slave trade and Europeans carrying slaves off to foreign parts, unless one would want to argue that Shivaji was not planning to enforce the measure despite his assurance that his men would do so "in all ways."

But it is by no means my intention to argue that in the late

91 Rao, Shulman and Subrahmanyam, Symbols of Substance, 312.

92 Contemporary Dutch translation of qaul Shivaji to VOC 26.6 accounting year 1078 (i.e. 1088 A.H.)/26.8.1677, VOC 1339: 1010; a copy of this translation (with two minor errors) from the Amsterdam Contractboek is published in Heeres, Corpus, 3: 61-5. A somewhat different version is found in the Zeeland Contractboek. Since many of the local terms differ between these translations, it is possible that Shivaji's qaul was issued in two languages (which was not unusual), possibly Persian or Marathi and a language common in the area, either Telugu or Tamil, and that the translations are based on different language versions. Where "Amsterdam" has diwan and kotwal, "Zeeland" has hawaldar and talaiyari respectively. The latter would seem to be the local language version as the last term is of Tamil origin (see Yule and Burnell, Hobson-Jobson s.v. Taliar) and hawaldar a Persian term that had come into general usage along the northern Coromandel coast in the Qutb Shahi period. It is also possible that when the translation was copied into the Zeeland Contractboek around 1773, the terms were updated, although this seems far-fetched. The Zeeland Contractboek has for the above passage: "Before now this land has been among the Moorish dominions [onder 't Moors gebied and then you were free to buy and sell male and female slaves, but such shall no longer be allowed as my people have orders to prevent the same. If you would, however, still want to do it they will also not allow that you will bring the same [slaves] in your house or ship, but they will take them take them from you and set them free [op vrije voeten stellen]." It should be noted, however, that Shivaji did not abolish the practice of slavery but merely the procurement of slaves in his dominions - a situation somewhat comparable to the period in the nineteenth century when slave trade had been abolished in the western hemisphere but slave-keeping was still allowed. Only a few lines before the injunction against slave procurement it is written in Shivaji's qaul that the kotwals or talaiyaris of the harbour towns are responsible for retrieving any runaway slaves belonging to the Dutch. 
seventeenth century the national sentiments and patriotic ideologies described above were the only important ideologies. The valour of undying loyalty to a king undoubtedly remained important, as D.V. Apte argues for the case of Maloji Ghorpade and John F. Richards for the case of Bhimsen. ${ }^{93}$ Such ideologies of loyalty are also present to a limited extent in the Suryavamsha Anupurana, for instance where Shahji is said to have still wished to serve the Nizam Shahi dynasty of Ahmadnagar, but nevertheless went over to the Adil Shah, which rupture is duly accounted for by an intervention of the god Shiva $(8.5-8,9.10-21)$. The conflict between the ideologies of undying service to the king and of national — as well as interpersonal - love is embodied by Dilir Khan, who, in the words of Bhimsen, forsook his duty to the emperor for the wine of love. The same conflict is embodied in the apology for William of Orange, written in the seventeenth century and now the Netherlands' national anthem, which stated that William would be "loyal to the fatherland until death," but at the same time "always honoured the king of Spain," even when he was deeply involved with the struggle to rid the Netherlands of his exactions in the sixteenth century.

${ }^{93}$ Apte, Mudhol, 163; John F. Richards, "Norms of Comportment among Imperial Mughal Officers" in Barbara Daly Metcalf ed. Moral Conduct and Authority: The Place of Adab in South Asian Islam (Berkeley, 1984) 255-289, there 270-89. 


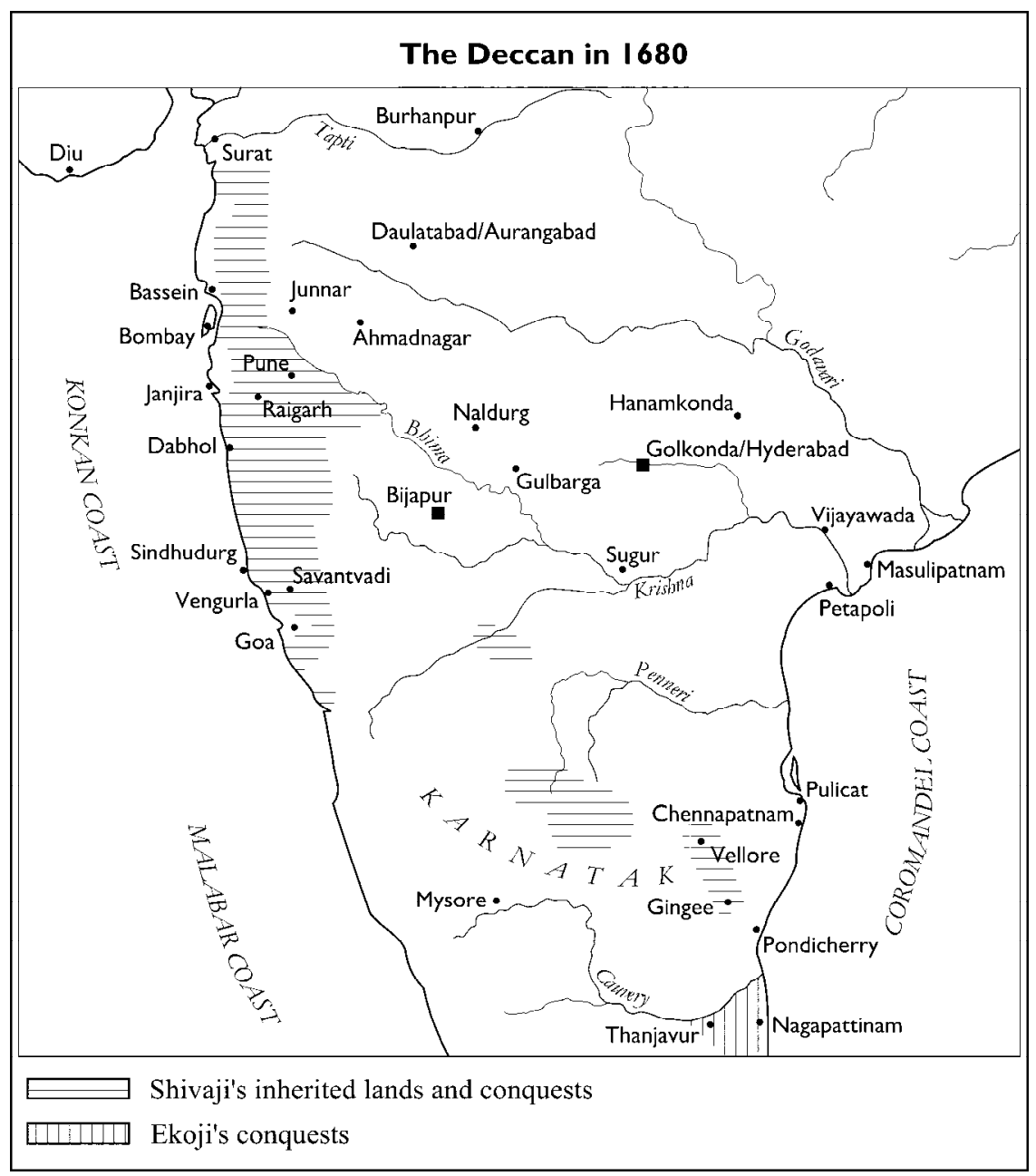




\title{
CHAPTER 5 \\ ANXIETY IN AURANGZEB'S DECCAN \\ MARATHAS, SIDIS AND KEIGWIN'S REBELLION 1683-84
}

\author{
Nature obliges us to preserve ourselves \\ Captain Keigwin, January 1684
}

\section{INTRODUCTION}

The only monograph on Keigwin's rebellion to have seen the light of day is that by Ray and Oliver Strachey, published in the early twentieth century. The authors ascribe the cause of the rebellion mainly to a clash of financial and commercial interests between Englishmen of Bombay and the higher EIC cadre at Bombay, Surat (to which the Bombay factory was responsible) and London. More precisely: the garrison was poorly paid and private trading interests were obstructed by the policies of Sir Josiah Child at London and John Child at Surat (perceived by the rebels as brothers, though they were not $)^{1}$ and their man at Bombay, Charles Ward, who happened to be the brother-in-law of John Child. Certainly all those personal affinities and antipathies and financial and commercial grievances played a role in the rebellion, and John Child seems to have taken it so personally that he did not eat for two days when he received a message from Bombay half a year into the revolt. ${ }^{2}$ But there are also some issues of identity and "othering" that make this case highly relevant to the present study and that I will argue may have played a much more important role in the revolt. The revolt was not a mere spat among Englishmen, but rather shows the significant extent to which the English at Bombay were integral to Deccan society.

When the news of the Rebellion reached Surat in the middle of January 1684, the Dutch factors noted:

We have learned that within Bombay there has since some time been a great estrangement between the Governor of that place named Mr Ward and the Commander of the English militia there called Mr Keigwin for reason, according to what is divulged, that said master Ward has not for 15 months wanted to make out

1 BL, Letter Keigwin to Mr Harbin 12.01.1684, E/3/43: 301-22. Compare Strachey and Strachey, Keigwin's Rebellion (1683-4): An Episode in the History of Bombay (Oxford, 1916) 162-3. Against the Stracheys' evidence that the Childs were not related, W.S. Desai argues that the two were "kinsmen," though not brothers. Bombay and the Marathas up to 1774 (Delhi, 1970) 224.

${ }^{2}$ NA, Surat daily record, sub datis 29.5 and 27.7 .1684 , VOC 1398: 471v, 473. According to the same source, Child tried to suppress the news that made him unwell and it may be for that reason that the EIC records on the Keigwin Rebellion show significant gaps. 
the least provision to the soldiers, although that was requested and recommended by several, but he would not listen to anyone. Wherefore it has come to pass that the aforementioned Commander with some of the most prominent of his subalterns surprised him one night as he lay sleeping in his room, forcibly taking [him] as well as some of his followers [and] put them in custody, claiming that he was maintaining an extraordinary correspondence with the robber Sambhaji by continually writing letters and that they had learned that he was intending to treacherously hand over the aforementioned stronghold [Bombay]. ${ }^{3}$

Thus the proclaimed anxiety about Ward's secret plans involving the Maratha king Sambhaji, son of Shivaji, was a key element in the revolt and, as the twentieth-century historian W.S. Desai shows, it was a firm belief of the mutineers that the island, or rather seven islets, of Bombay was in great danger because of the neglected state of its defences and troops and the irresponsible behaviour of Ward and Child as representatives of the Company. ${ }^{4}$ When the Rebellion broke in the early hours of the $27^{\text {th }}$ of December 1683, the mutineers declared Bombay for King Charles II, and its inhabitants subject to his pleasure rather than that of the Company. On the first day, Captain Richard Keigwin was proclaimed the new Governor of Bombay island by acclamation. The rebellion was to last until November 19th 1684, when admiral Grantham, come from England as a representative of the king, persuaded the mutineers to lay down their arms. ${ }^{5}$

Almost since Bombay had been transferred to the English by the Portuguese as a part of the dowry of Catherine de Braganza in 1665, the factors in Bombay had felt themselves stuck between a rock and a hard place. While from the sea-side the Sidis, or Habshis, of Janjira had their pressing requests, on the land-side the Marathas under Shivaji and from 1680 under Sambhaji proved constantly threatening friends. Moreover, as will be shown in more detail below, the antagonism between these two powers themselves ran increasingly deep. Any indulgence to one party could incur the English the wrath of the other. The same dilemma was, to a somewhat lesser extent, faced by the Dutch at Vengurla. The situation of both companies was further complicated by the fact that they had trading posts in the Mughal dominions, most importantly in Bengal and at Surat, and the Sidi styled himself admiral of the Mughal fleet (since 1661) and received an annual stipend for the service. The balance of power between the two was such that after Shivaji occupied the tiny island of Khanderi, strategically situated at the southern entrance to the bay known as Bombay

${ }^{3}$ NA, Surat daily record, sub dato 15.1.1684, VOC 1383: 628.

${ }^{4}$ Desai, Bombay, 33.

${ }^{5}$ Strachey and Strachey, Keigwin's Rebellion, 79-83, 141-51. 
Harbour in 1679, Sidi Qasim, entitled Yaqut Khan, ${ }^{6}$ occupied its even smaller twin Underi. ${ }^{7}$

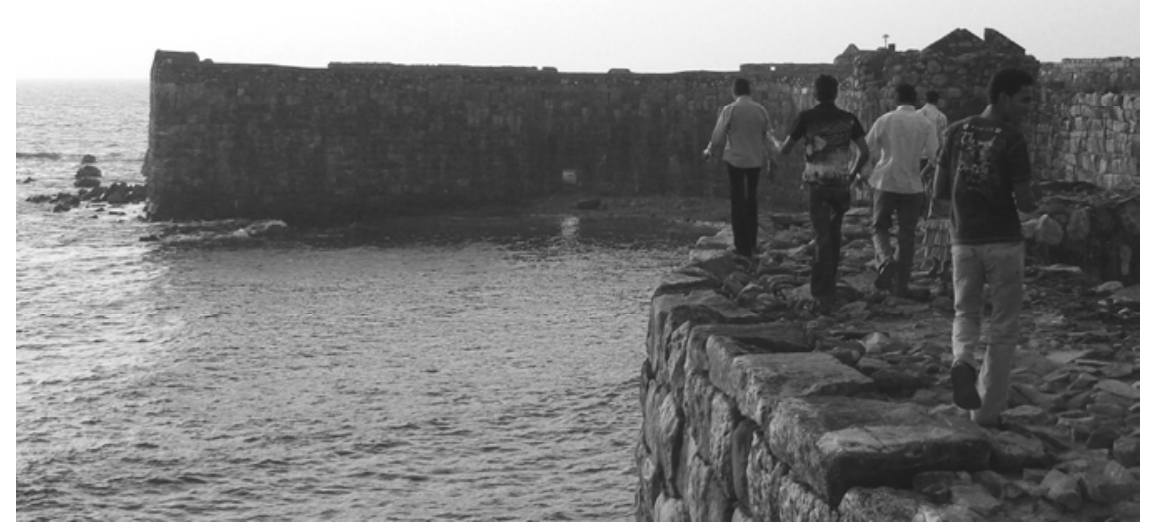

The fortress of Sindhudurg, built by Shivaji on an islet just outside the port of Malvan, with tourists.

Only two months before the Bombay Rebellion, Sambhaji put the Maratha fleet on a more solid footing and divided it into five squadrons. The VOC factor at Vengurla fitted the five subadars $^{8}$ of the fleet upon their request with sea-passes, to be used in case of an encounter with a VOC vessel. The passes commence: "As Sambhaji Raja, king of the Konkan lands is now openly at war with the Portuguese nation and the Great Mughal, who both are about to put their naval powers to sea against said Sambhaji, his highness has, in order to secure his harbours, also fitted out a fleet of small and large vessels in order to be able to deal blows to his enemies where possible even at sea." 9

Indeed, we do find a fleet of the Mughal separate from that of the Sidi operating on the Konkan coast in 1684, mainly, it seems, to provision

${ }^{6}$ The Mirat-i Abmadi noted that the Sidis of Janjira all bore the title Yaqut Khan after the first to take service under the Mughal emperor, but Sidi Qasim is the first we see the title employed with in contemporary records. Khafi Khan consequently referred to Sidi Qasim as Sidi Yaqut or Sidi Yaqut Khan. Ali Muhammad Khan, Mirat-i Ahmadi (translation) 244; Khafi Khan, Muntakhab, passim.

7 Desai, Bombay, 1-34; Robert Orme, Historical Fragments of the Mogul Empire, of the Morattoes, and the English Concerns in Indostan (1782; modern ed. by J.P. Guha: Delhi, 1974) 7-8.

${ }^{8} \mathrm{It}$ is interesting that this Persian term for the head of a suba or province should be used for the heads of the squadrons. The Ajnapatra of 1716 (see below) uses the term sarsubha for them, which is of the same derivation. Ramachandrapant Amatya, "The Ajnapatra or Royal Edict: Relating to the Principles of Maratha State Policy," trans. S.V. Puntambekar, Journal of Indian History 8 (1929) 83-105 and 207-33, there 229.

${ }^{9}$ NA, Sea-pass to Sambhaji's fleet 26.10.1683, VOC 1406: 839v-40. 
the land forces. ${ }^{10}$ Moreover, in the autumn of 1684, after the Portuguese had during the summer months maintained an alliance with Sambhaji, which reportedly shocked Aurangzeb, the latter put to sea a large fleet of three hundred vessels with a budget of 140,000 rupees to make war on the Portuguese "since Sambhaji was his permanent enemy."11 Until then Aurangzeb had mainly relied on the Sidi for his fleet on the western shore of the subcontinent, but now there was talk at the Mughal court of cutting the Sidi's budget. It was said that the new governor of Surat Salabat Khan would no longer approve the annual budget for the Sidi's fleet, "because the king only wastes money and great expenses without reaping the least benefit, with the cost of that fleet amounting annually to a sum of 4 lakhs of rupees." 12

It seems that the increased naval activity of the land powers in 1683-4 came about in reaction to the growing European influence on the coast of India. That the Mughals under Aurangzeb realised the potential of a naval power base such as the Europeans had is evidenced by Aurangzeb's request for Dutch advice and assistance in the war with the English in 1689-90, as well as the attempts in the second half of the 1690s to make Europeans responsible for safety on the high seas. ${ }^{13}$ Earlier, in the late 1670s, Abul-Hasan of Golkonda requested a Dutch carpenter to build him a yacht like the ones he had seen at Masulipatnam to sail around a tank in the interior of the kingdom, thus adapting the concept of seafaring to a land-locked mentality. Aurangzeb similarly conducted an experiment in a tank with a warship built by an Italian. According to Manucci, Aurangzeb concluded from the trial, "that to sail over and fight on the ocean were not things for the people of Hindustan, but only suited to European alertness and boldness," and abandoned his project to launch a navy. That was, however, early in Aurangzeb's reign and the naval project was apparently revived in the run-up to Aurangzeb's Konkan campaign of 1684, in a

${ }^{10}$ NA, Letter Cochin to Batavia 11.4.1684, VOC 1406: 785; Narrative by Robbert Lindsaij of some sudden occurrences at Vengurla 28.2.1685, VOC 1416: 1459-v. Provisioning the army was a central concern to the Mughal commanders. Gommans, Mughal Warfare, 192 and passim.

${ }^{11}$ NA, Surat diary sub datis 17.7, 23 and 30.8 and 24.9.1684, VOC 1398: 472Bv, 475-6.

12 NA, Surat diary sub dato 3.11.1684, VOC 1398: 479v; "Novelles" Barcelore 24.10.1684, VOC 1396: 560v-1. The Sidi's subsidy was apparently paid out of the Surat treasury. It is possible that Salabat Khan was merely trying to get back at the Sidi, since it seems that the latter had also been in the running for the governorship of Surat, although it also seems that in the preceding year there had already been a delay in the Sidi's pay that had caused the Sidi to suspend activity until he received the money. NA, Surat diary sub dato 4.10.1684, VOC 1398: 476; Orme, Fragments, 86.

${ }^{13} \mathrm{NA}$, Letter of Bacherus, former ambassador to Aurangzeb, at Draksharama to Company, VOC 1510: 40v-1; Ashin Das Gupta, Indian Merchants and the Decline of Surat c. 1700-1750 (Wiesbaden, 1979) 98-101. 
significant break with the land-locked outlook in military affairs of earlier (and later) Mughals. ${ }^{14}$

Not only did the Indian land powers come to appreciate European naval power in this period, the 1680s also saw a gross overestimation of that power on the part of some Europeans. John Child, whose opposition to a firm stance against the powers of India earned him such a bad name with the Bombay rebels, five years after the Rebellion made true the Bombay rebels' fears of his irresponsibility by displaying the exact opposite behaviour and declaring war on the Mughal empire. That was the time Aurangzeb called for Dutch assistance, which was not forthcoming, but the war ended in a humiliating peace for the English all the same and one of the terms set by the Mughals was, significantly, the removal of Child. Meanwhile the Dutch declared war on the kingdom of Golkonda in 1686. That move against a large land kingdom was somewhat less irresponsible, since Golkonda already lay prostrate at the hands of the Mughals, but similarly unprecedented in the Indian subcontinent. And the Portuguese war on the Marathas of 1683-4 led the French observer Mr. DeslandesBoureau to comment that the Portuguese, "have made a mistake that they will never be able to repair, that is to have let their weakness show to the Indians." 15

Returning to the moment of the Bombay Rebellion, it seems that Sambhaji's newly launched fleet did not upset the balance of power between the Sidi and the Marathas, but the rebels of Bombay feared that Ward's dealings would. The Sidi's fleet comprised several large ships, including two men-of-war with which the Sidis closely identified judging from their names Ja'far us-Sidi "bounty of the Sidi" and Nasr us-Sidi "deliverance of the Sidi," besides smaller sailing gurabs and a small type of galley. The Maratha fleet, on the other hand, seems to have consisted only in a large number of the small gurabs and galleys. ${ }^{16}$ This led to the following stand-off as described by the Dutch factor in Vengurla only days before the Rebellion broke: while the Sidi's fleet roamed along the coast of Konkan it was closely tracked by Sambhaji's fleet just off the coastline, "where the ships of the Sidi cannot reach it and the lesser vessels [of the Sidi] dare not land this country's vessels, so that both do nothing but occasionally waste large amounts of gunpowder and cannon balls vainly from afar, so that it is

${ }^{14}$ Havart, Op-en ondergang, 2: 97-9; Manucci, Storia do Mogor, 2: 42; For the Konkan campaign see below. For the basically land-locked mentality of Mughal warfare see Gommans, Mughal Warfare, 162-6.

${ }^{15}$ Desai, Bombay, 35-46; BN, Letter Deslandes at Surat to Clairambault (?) in Paris 30.1.1685, Coll. Clairambault 1017: 87; For the VOC war against Golkonda see Chapter 6.

${ }^{16}$ NA, Surat diary sub dato 3.11.1684, VOC 1398: 479v. Compare Roy, Mughal Navy, 148, 150,154 . The gurabs used on the Konkan coast, though etymologically related, were different from the Arabian and Gulf region ghurabs and propelled by sail, although occasionally also by oars. Yule and Burnell, Hobson-Jobson, s.v. grab. 
the best of wars in which no one dies or gets hurt." The rebels, however, claimed to have uncovered a scheme by Ward which would have completely upset this balance and have left Bombay without any scope to hold its own in the middle. According to the VOC factory diary, Keigwin wrote to the Mughal governor and others at Surat that Ward, "was planning a transformation by handing the city of Bombay to the robber Sambhaji and, in order to facilitate the execution of his design, had tried to imprison the Mughal's naval admiral Sidi Qasim."17

We also find these fears worded in documents written by the mutineers themselves. In their long and chaotic list of complaints to King Charles, the mutineers voiced the apprehension of being overtaken by either the Sidi or the Marathas. The first eight points of the complaints all concern the unassertive behaviour of the Company officials in the face of the surrounding powers. While the first point concerns an occasion when "his majesties flag" was struck before a Portuguese admiral, half of those first points are in some way concerned with offences to the English by the Sidi and the Mughal fleet, who were said to practically own the islands without the walls of the fort. In point number two the view was expressed that the Sidi or the Mughal would soon take the fort, but one of the later points spoke of "a potent enemie," who "has laid all the Portugueze country in ashes and is now within one hour saile of us having taken Caranjah, Ellephanta and attempted Salsett [all within Bombay Harbour] which iff he taken wee may expect him in a minnite," which referred to the Marathas engaged in their struggle with the Portuguese.

Ward was accused of letting all this happen — just as his predecessor had, still according to the complaints, backstabbed Keigwin's attempts to forestall Shivaji's takeover of Khanderi and the Sidi's takeover of Underi - and of even aiding and abetting the activities of the Marathas and the Sidis. The eighth point concerns the suspicion, already mentioned, that Ward had a plan to sell Bombay "to the Mogull, Sombajee or any," in collusion with Josia Child, "the emperor of the Company." Ward is also supposed to have said that the Company could not care "if Bombay were as far under as above water, or that the Turke, Moore, Sevajee or any had possession of Bombay."18

The concerns about the onslaught of the Marathas on the Portuguese lands were also expressed in a private letter of Keigwin intercepted by the negotiators from Surat, and in a letter of Keigwin's close

17 NA, Letter Vengurla to Cochin 22.12.1683, VOC 1396: 675-678; Surat daily record, sub dato 19.1.1684, VOC 1383: 628. Sidi Qasim often stayed at Bombay, see below.

18 BL, Complaints to his Majesty 27.12.1684, E/3/43: 369-76v. This document, along with some other documents, must have been drafted before the rebellion as is apparent from Church's testimony to the negotiators from Surat. Oral report of Church aboard the Rainbow off Bombay 25.01.1684, E/3/43: 320v. 
collaborator ensign Thorburne to one of the negotiators. ${ }^{19}$ Moreover, the rebels apparently feared sale of their physical selves along with the fort. In his oral report to the negotiators John Church, junior chaplain at Bombay, remembered the speech made by John Thorburne to the troops on the day of the revolt as follows:

Gentlemen and ffellow souldiers, it is now two months since we have had our Commissions taken from us by order of the English East India Company, for petitioning to them for what was our due; and it is well knowne the Deputy Governor would have sould the island and us to Sombazee Rajah for 40,000 Pagodas, and you see, Gentlemen, what a potent Enemy he is against the Portugueze, having taken most of their Country; and wee do not know how soone he may attempt the island, and there is no provision laid in for us. Wee are therefore resolved not to suffer these abuses any longer, but revolt to his Majestie, taking all into possession for his use. ${ }^{20}$

Keigwin himself words this primordial fear as follows: "Nature obliges us to preserve ourselves especially when wee are plainly exposed to sale and to the fury of an enimy." 21

Was this the proto-anxiety of the members of a proto-empire, foreshadowing the anxiety of empire stemming from the suspected yet denied likeness to the Self and potential strength of the colonial Other, that scholars such as Sara Suleri, Nigel Leask, Homi Bhabha and Kate Teltscher speak of for the colonial period?22 Or was it that the Marathas implemented tactics (notably the use of a navy) which mirrored the Company's own that "incensed" the English against the Marathas, as Chris Bayly argues in the case of Tipu Sultan's state a century later?23 Or is the cause of the rebels' anxiety rather more to be found in their identification with the locality of Bombay, including its non-English inhabitants?

\section{THE DECCAN ELECTRIFIED}

The seventeenth century saw instability and troubles spreading decade by decade from the north-western corner of the Deccan and slowly enveloping the whole of the Deccan. After years of slow Mughal penetration across the Vindhyas, closely watched by the three Deccan sultanates, the Mughals divided Ahmadnagar between themselves and Bijapur, but periodically

${ }_{19}$ BL, Letters Keigwin to Mr Harbin 12.01.1684; Zinzan, Day, Gosfright to Child etc. in Surat 17.01.1684; Thorburne to Day 16.01.1684, E/3/43: 301-22.

${ }^{20} \mathrm{BL}$, Oral report of Church aboard the Rainbow off Bombay 25.01.1684, E/3/43: 320-1. Quoted in Strachey and Strachey, Keigwin's Rebellion, 79-80. My italics.

${ }^{21} \mathrm{BL}$, Keigwin to negotiator Zinzan 16.01.1684, E/3/43: 311v.

22 Kate Teltscher, India Inscribed: European and British Writing on India 1600-1800 (Delhi, 1997) 7, 109-56; Homi Bhabha, The Location of Culture (London, 1994) 43-4, 66-85.

${ }_{23}$ Teltscher, India Inscribed, 238; Chris Bayly, Imperial Meridian: the British Empire and the World, 1780-1830 (Harlow, 1989) 59-60. 
continued to try to undermine Bijapur and Golkonda. Then Shivaji started his activities, slowly increasing his radius which eventually came to encompass the whole Deccan in 1677 (see Ch. 4). Shivaji's realm was, however, never stable as he was quite relentlessly fought by the Mughals and Bijapur. The height of the troubles arrived in 1682 in the person of Aurangzeb, who was in pursuit of his rebellious son Prince Akbar. "Aurangzeb's arrival in the Deccan," in the words of H.K. Sherwani "electrified the whole atmosphere," 24 and the Bombay rebellion was not the only revolt to be played out in the western Deccan in the immediately following years.

Aurangzeb himself also regarded his entry into the Deccan in 1682 as a crucial moment, referring to it twenty-five years later as the germination of his "jihad in the way of God." 25 Prince Akbar meanwhile, was, in the words of the VOC Cochin factors, "taking side for and with the Heathens." 26 Akbar was, according to the Ma'asir-i 'Alamgiri, first persuaded to revolt against his father by the rebellious Rajputs of southern Rajputana and evidently both the Rajputana phase and the Deccan phase of his rebellion were bound up with religious issues.

The revolt of the Rajputs had followed closely on the imposition of the jiziya (or poll tax on protected non-Muslims) by Aurangzeb in 1679, which is one of the most hotly debated topics in Indian history. Satish Chandra argues, against Jadunath Sarkar, that Aurangzeb's imposition of the jiriya did not alienate Hindus since the number of Hindu mansabdars grew in the period after it, but this does not detract from the fact that the southern Rajputana revolt, as described in the Ma'asir-i 'Alamgiri, started right after the imposition of the jiziya and that the jiziya played an important part in (the end of) it. Chandra not only argues against the idea that Aurangzeb alienated the Hindus of his empire but also against the view of Zahiruddin Faruki and I.H. Qureshi that the spirit of opposition amongst Hindus (especially the Marathas) led to an appeal by Aurangzeb to Muslims through pious gestures such as the imposition of the jiziya. Since Chandra wrote in 1969, it has become a cliché to say that the images of Self and Other are mutually supportive, which means that nowadays we would be prone to assume that the positions of Sarkar and Faruki/Qureshi, which seemed mutually exclusive to Chandra, are both true. That is to say Hindus alienated Aurangzeb and Aurangzeb alienated Hindus.

Contemporaries, however, generally connected the measure to Aurangzeb's piety. Musta ‘id Khan wrote: "as all the aims of the religious emperor were directed to the spreading of the law of Islam and the

\footnotetext{
24 Sherwani, Qutb Shabi, 641.

${ }^{25}$ BL, Letter Aurangzeb to Bidar Bakht [ca. 1706] in Inayatullah Khan ed. Abkam-i 'Alamgiri, Ms. I.O. Islamic 3887: 74v.

${ }^{26} \mathrm{NA}$, Cochin to Netherlands 3.1.1684, VOC 1406: 834.
} 
overthrow of the practices of the infidels, he issued orders that ... in obedience to the Qur'anic injunction 'till they pay commutation money (jiziya) with the hand of humility,' jiziya should be collected." 27 More than ten years after the imposition the Dutch ambassador Johannes Bacherus also linked the emperor's piety to his adherence to Islamic precepts or law, when he wrote to his superiors about the exemption he had obtained at the court from the payment of the "troublesome poll tax they call jiziya" for all VOC dependents in the former Golkonda domains. That exemption "in view of the law, and the piety [beijligheijt of his majesty, was really something special." 28 Similarly, the contemporary poet Mahir Akbarabadi (a Hindu convert to Islam, d. 1678-9) in his panegyric Gul-i Aurang, extolled Aurangzeb's adherence to the shari' $a$ :

If [the poet] Urfi would have lived in his [Aurangzeb's] reign he would have made Shari his nom de plume. ${ }^{29}$

That is to say: Aurangzeb had replaced 'urf, or royal grace (that is: whim) by shari'a.

The measure of the imposition of the jiziya was not a matter of ideology-without-practice, although servants of the Imperial government were exempted right away. ${ }^{30}$ The parwana concerning the exemption obtained by Bacherus, issued by the prime minister Asad Khan under close

27 Muhammad Saqi Musta'id Khan, Ma'asir-i 'Alamgiri, trans. Jadu-nath Sarkar (1947; photogr. reprint Delhi, 1986) 108-11, 122, 128 and compare Khafi Khan, Muntakbab (translation) 265-6; Satish Chandra, "Jizyah and the State in India during the 17th Century." JESHO 12 (1969) 322-40. Compare and contrast S.M. Azizuddin Husain's summary of the debate on the causes of the Rajputana revolt in Structure of Politics under Aurangzeb 1658-1707 (Delhi, 2002) 132-51.

${ }^{28}$ NA, Letter Bacherus to Netherlands 4.12.1692, VOC 1510: 43v. Azizuddin Husain argues that the imposition of the jiziya by Aurangzeb was un-Islamic because the Mughal state was basically not Islamic, because the position of the Hindus as zimmis was dubious and because a number of Hindus had joined the army which would be a ground for suspension of the jiziya. What matters, however, is that Aurangzeb believed it to be in accordance with the shari ${ }^{\prime} a$ and thus with Islam, as Azizuddin Husain also argues and as is evident from the above quotation of Musta'id Khan and the number of times shari'a is referred to in what seems to be the preamble to the order instituting the jiziya. Azizuddin Husain, Structure, 107117. For the discussion in the Mughal empire on the status of the Hindus see Friedmann, "Islamic Thought." The text of Aurangzeb's order survives in the Mirat-i Abmadi, a good translation is in Syed, Aurangzeb, xxviii-xxxii. Lokhandwala in his translation of the Mirat-i Ahmadi treats the text more as a summary of the original farman than as the literal text, 264-5. Azizuddin Husain, ibidem, 121.

${ }^{29}$ Quoted in Azizuddin Husain, Structure, 176-7 (my translation). D.N. Marshall, Mughals in India: A Bio-bibliographical Survey, Supplement (Delhi,1996) 110. Azizuddin Husain (ibidem) also quotes another poet as saying that "the prevalence of shar in his reign" was such that during the fast of Ramzan not even an orchard was permitted to drink, unfortunately Azizuddin Husain does not give a date or source for this verse.

30 The Mirat-i Abmadi noted that imperial servants were exempted and Iswar Das noted that Rajputs in imperial service were exempted. Mirat-i Ahmadi (translation) 265; M. Athar Ali, The Mughal Nobility under Aurangzeb (rev. ed.; Delhi, 1997) 26. 
supervision of Aurangzeb, makes no bones of mentioning thrice, in different wordings, Bacherus' request to be freed from the "troubles and violence" suffered from the collectors of the tax. ${ }^{31}$ In his discussion of the reasons for the success of the Marathas, Bhimsen waxes on the subject of the oppressive revenue system in the Mughal domains and singles out the collectors of the jiziya: "Of their oppression and cruelty what may one write? For no description can suffice...." Prince Akbar is also supposed to have written to his father: "On the Hindu community [firqa] two calamities have descended, the exaction of jiziza in the towns and the oppression of the enemy in the country." 32

At the same time Prince Akbar was himself a Muslim and through his role as a champion of Hindus he symbolised the age when Muslim rulers still appealed successfully to the loyalty of Hindu subjects, in other words, the golden age of Malik Ambar outlined in the Suryavamsha Anupurana. It is for that reason not surprising that Akbar's revolt received a second lease of life in the Maratha domains. After the failure of the rise against his father in concert with the Rajputs of southern Rajputana in 1681, and of an attempt to cross to Persia from Vengurla by sea, where he narrowly escaped the Sidi, Akbar was propped up by Sambhaji, along with his military commander Durga Das Rathor, a Rajputana Rajput. Still in September 1684 Akbar managed to threaten Surat while Aurangzeb was in a tight spot in Ahmadnagar, and in 1687 rumours about his actions abounded in a beleaguered Golkonda. ${ }^{33}$

Beside the Akbar and Keigwin rebellions, a third rebellion in this electrified atmosphere was that of the Savants of the Wadi region north of Goa in which Vengurla is also situated. The reasons for this revolt against Sambhaji in early 1685 will be discussed in some more detail in the next chapter. For now it suffices to note that the Savant zamindars rose in collusion with the Portuguese and with Shah Alam's army that was penetrating the Konkan in the efforts against Akbar. ${ }^{34}$

\footnotetext{
${ }^{31}$ NA, Parwana of Asad Khan 26 Zu'l-Hija 33 Julus/10.10.1689, HR 40:37, another copy HR 43; contemporary Dutch translation in Heeres, Corpus, 3: 514-6. See Jos Gommans, Lennart Bes and Gijs Kruijtzer, Dutch Sources on South Asia c. 1600-1825, vol. 1 (Delhi, 2001) 373.

32 Bhimsen quoted in Habib, Agrarian System, 347-8 (based on Ms. Or. 23); copy of letter attributed to Akbar quoted in Chandra, "Jiziyah," 340. Compare Syed, who attributes the fall of the empire to the measure in Aurangzeb, xxviii-xxxii.

${ }^{33}$ Musta'id Khan, Ma'asir-i 'Alamgiri, 122-6, 240; NA, Vengurla to Cochin 22.12.1683, VOC 1396: 675-8; Surat diary sub dato 13.9.1684, VOC 1394: 475v; Pulicat to Van Rheede 19.4 and 6.10.1687, VOC 9709 n.p. Khafi Khan's narrative, on the contrary, suggests that Akbar received a lukewarm welcome with Sambhaji and left for Iran only shortly after that. Khafi Khan, Muntakhab (translation) 288-94.

${ }^{34}$ NA, Narrative by Lindsaij of occurrences at Vengurla 28.2.1685, VOC 1416: 1460v-63. Compare S.K. Mhamai, The Sawants of $W$ adi and the Portuguese (Delhi, 1964) 6.
} 
The EFfect of WARfare on the Non-Combatant Population

Warfare in South Asia was possibly less bloody and certainly more negotiable or subject to negotiation than warfare in Europe, ${ }^{35}$ but the, however bloodless, pressure applied by passing armies in extracting negotiated contributions was considerable. Armed campaigns might also bring devastation of the countryside as well as famine and disease (see Chapter 2, 3 and Epilogue) but most of all they brought the fear of loss of goods or freedom.

Contributions to passing armies seem to have been considered normal. While Shah Alam's army was camped outside Hyderabad around the turn of 1685 (see Chapter 6), Bahadur Khan was, according to the French private merchant Mr. Guesty writing from Hyderabad, granted the "care of the rich," assisted by Muhammad Ibrahim as his local informant, which meant that he took all the wealth that he could get his hands on from the "Brahmins and the other Gentile castes" and took a quarter to a third from the Muslims. ${ }^{36}$ The Dutch factors were after much negotiation forced to accept the contribution of 50,000 hons, but since the factory as such did not possess these funds, the contribution had to be paid mainly with the goods that two Hindu merchants had secured, or thought they had secured, in the factory just before the arrival of Shah Alam. Seemingly surprised that their indignation was not shared by the two merchants, the factors remarked that the merchants "did not, upon notification, in the least complain about this." 37

The approach of an army, or the rumour of the approach of an army, was for the population of the villages and smaller towns, always a reason to flee. Of the many examples of such events in the East India Company archives, four should suffice here. In December 1659 the washers (of newly produced textiles) "and other poor people" had run away from Rajapur within the sultanate of Bijapur because of the proximity of the Bijapur army, while Shivaji captured nearby Panhala. Later, in September 1677, Herbert de Jager and Nicolaes Clement remarked in their

35 Gommans, Mughal Warfare and "The Embarrassment of Political Violence in Europe and South Asia, c. 1100-1800", in Violence Denied: Violence, Non-Violence and the Rationalization of Violence in South Asian Cultural History, ed. J.E.M. Houben and K.R. van Kooij (Leiden, 1999) 287-317.

${ }^{36}$ BN, Letter entitled "Summary of the most notable occurances in the entering and stay of the army of the Mughal in the lands of the king of Golkonda, principally in Bagnagar [Hyderabad]," dated Hyderabad 20.4.1686, Collection Clairembault 1017: 69-v. Although the author is not mentioned in this (contemporary copy of the) letter, it is clearly Mr. Guesty, who was Martin's correspondent in Hyderabad at this time, and who, though a private merchant, also arranged farmans for the French Company. Martin, Mémoires, 450. A variant version of the above-mentioned passage is to be found in Martin, Mémoires, 417, with a reference to Guesty as the source on 415.

${ }^{37}$ NA, Letter Hyderabad to Masulipatnam 7.12.1685, VOC 1411: 610-7v. 
journey after Shivaji's army: "throughout our steady progress we have noticed that the richest of this country have in all places absconded, with only the poor and barren communities remaining, although of these people a large part have [also] fled, since they are not spared in the extortion of pennies, it being certain that that sovereign [Shivaji] is in great need of cash." 38 Although earlier, while Shivaji was still receiving financial support from the Qutb Shah, Herbert de Jager had noted that Shivaji was "keeping such strict order amongst his men that no one is caused the least nuisance." It seems, as De Jager indeed suggested, that Shivaji only resorted to enforced contributions in places he did not intend to keep. ${ }^{39}$

The Maratha levy of a fourth or chauth outside the areas directly under their control, which had a regular system of revenue collection described in great detail by André Wink, is too well known to devote much space to here. ${ }^{40}$ W.S. Desai evaluates some events at the very end of the seventeenth century thus: "The Marathas did not care who the owners of the territory or property were. They had not only to carry on a war with a relentless foe, but also to find sustenance for themselves and for their horses. Plunder had become a profession with them." 41 The Sidis of Janjira, similarly, seem to have levied some sort of protection money from the villages and towns along the Konkan coast, to supplement their regular income from the emperor. Other sources of income for the Sidis were opium and slave trade. The slaves were apparently also procured or "plundered" 42 from amongst the population along the Konkan coast. ${ }^{43}$ In any case a visit of the Sidi's fleet was not a welcome event for the population of the coast, as the following, our third example, shows:

... and because one did not know what ships these were, except for the news that the Mughal fleet had approached "Singemaseer," which led everyone to conclude that it was the robber Sidi Yaqut Khan, which caused such consternation in

38 BL, Letter Rajapur to Surat 9.12 .1659 (o.s.), G/31/1: 85; ERS, Letter Rajapur to Surat 4.2.1660 (o.s.), 1: 5; Letter Herbert de Jager and assistant Nicolaes Clement at "Palliumkotte" to Tengapatnam 16.9.1677, VOC 1323: 332v.

39 NA, Letter Pulicat to Batavia 30.7.1677, VOC 1324: 512; Also, in a letter (first published by V.K. Rajwade and possibly authentic) to his officers near Dabhol, Shivaji instructed his officers not to become "greater pests than the Mughals" on pain of severe punishment. Letter Shivaji to officials and army officers at Halvarna 12 Safar, Shuhur San 1074/29.5.1673 (English translation) in Sardesai, Shivaji Souvenir, 150-2.

40 Wink, Land and Sovereignty and "Maratha Revenue Farming," Modern Asian Studies 17 (1983) 591-628.

${ }^{41}$ Desai, Bombay, 50.

42 "I went on board the Siddy, where after some talk, I espied some slaves they had. I askt them where they plundered them, and he told me Nagoun River." ERS, Letter Keigwin at Underi/Khanderi to Bombay 3.12.1679, 2: 264.

43 ERS, Letter Bombay to Surat 31.10.1673,1: 309; BL; Deposition of Thomas Pettitt and Thomas Bigott et al. against Henry Smith 20.8.1683, E/3/43: 96-7; BL, Complaints to his Majesty 27.12.1684, E/3/43: 369-76v (point 6); NA, Letter Sidi Yaqut Khan to VOC at Cochin 6.12.1684, VOC 1416: 1475v-6; Orme, Fragments, 27. 
Vengurla that all the inhabitants with pack and sack came to flee around the [VOC] lodge, which caused no small alarm.... [upon which the factors sent a Dutch helmsman to the ships to tell the Sidi] and to tell him to be pleased to keep good order and to announce that in case his robbing seamen would come on land that they should refrain from any hostilities such as had occurred the previous year to the lodge...meanwhile we did our best to keep the fleeing people off and out of the lodge, which did not help much because the moat around the lodge was mostly filled up with people, in the night around nine or ten o'clock the helmsman returned and brought the news that they were Portuguese. ${ }^{44}$

Over a decade earlier, after Shivaji's troops had been worsted by the Sidi's sacking of Dabhol and neighbouring places, the French traveller Abbé Carré had also encountered empty villages and towns in the region as well as hiding inhabitants gripped with fear of the Sidis. Writes Carré, "It was not necessary to tell them [his retinue] to keep good watch, as the stories the inhabitants told them of the Sidi's people alarmed them so much that all night no one thought of sleeping." 45

In his The Political Economy of Commerce, Sanjay Subrahmanyam devotes much space to refuting the view propounded by Michael Pearson and K.N. Chaudhuri and others that merchants stood far apart from the fiscal-military elite in the Mughal empire and other South Asian states, including those of the Deccan. Quoting Chaudhuri that "the spectre of arbitrary expropriation was never far off from the scene of pre-modern commerce," Subrahmanyam goes on to argue that "these views ... are often used to support the contention that European enclaves such as Madras and Bombay grew in the late seventeenth and early eighteenth centuries, precisely because they — by providing the umbrella of a European legal structure - gave to Asian merchants the protection they did not enjoy from Oriental Despots." 46 Subrahmanyam is right to point out that not only European harbour towns could offer the necessary protection to merchants, but in war-torn periods, as the 1640 s were around Chennapatnam and the 1670 s and 80 s around Bombay, the towns under the shelter of European guns offered more protection from expropriation than other places.

Certainly there were many portfolio-capitalists in the seventeenthcentury Deccan as Subrahmanyam shows and, moreover, the protection

\footnotetext{
44 NA, Narrative by Lindsaij of occurrences at Vengurla 28.2.1685, VOC 1416: 1459-v.

45 Abbé Carré, The travels of the Abbé Carré in India and the Near East, 1672 to 1674, trans. Lady Fawcett, ed. Charles Fawcett and Richard Burn (London, 1947-8) 1: 195-7.

46 Subrahmanyam, Political Economy, 298-342, especially 298-9. Pearson seems to have come back on the statements attacked by Subrahmanyam, writing in his 2003 book that European established ports, like Madras and Bombay, did not outcompete "native ports" and that "Mumbai was set up by the British in the 1660s, but it took seventy years for it to overtake the great port of Surat. The coup de grace was military rather than commercial: in 1759 Surat was taken over by the British.” Pearson, Indian Ocean, 145, see also 305 note 14.
} 
awarded to merchants by the Deccan sultans was very extensive - in the heydays of the sultanates. In 1614 for example, the sultan of Golkonda would force the Dutch to return to an Armenian merchant the goods he had stowed aboard a Portuguese ship that was subsequently captured by the Dutch. ${ }^{47}$ However, as was shown in the previous section, times had changed; the western Deccan was in a state of flux and merchants were always the first to fall victim to the irregular revenue collection practices of passing armies.

Many people during this period seem to have been in search of a peaceful and prosperous environment. Historians opposing Habib's thesis that the peasantry in the Mughal empire was impoverished by the oppressive revenue system, have remarked that rural populations were highly mobile and as such able to negotiate a better position. ${ }^{48}$ Which brings us to the fourth example of civilians fleeing armies, dating from the time when the country around Thanjavur had suffered from the conquest of Thanjavur by Ekoji and his subsequent struggle with the nayaka of Madurai in league with Sher Khan Lodi (see Ch. 4):

...the inhabitants, as was mentioned earlier, are mostly impoverished and have fled, but if Ekoji Raja were to get on peaceful terms with the neighbouring rulers and the inhabitants will be treated well, the trade would in all appearance improve and the looms would again as before come into action. Many of the weavers being [currently] pressed to look for a better country, would without doubt in case of a peaceful and soft/delicate government again long for their fatherland, the more so because at present the paddy [harvest] has succeeded well throughout Thanjavur and is available at a civil price. ${ }^{49}$

In other words, the contemporary Dutchman who made this forecast had the impression that a peaceful environment was an important factor in economic prosperity — also in India.

\section{THE REPUBLIC OF BOMBAY}

Amid the troubles in the Konkan starting in the 1660s with the Sidis of Janjira joining the Mughals and Shivaji's campaign in the region, Bombay was an island of relative calm and rose quickly to prosperity in the 1670s. Fryer estimated that since the Portuguese days the population had increased by 50,000 to a total 60,000 when he was in Bombay halfway through the decade, and by the time of the Rebellion Keigwin boasted in a letter to

\footnotetext{
${ }^{47}$ NA, Letters Masulipatnam to Bantam 1.8.1613, VOC 1056: 146-8 and 16.8.1614, VOC 1057: 129-v.

48 E.g. Subrahmanyam, Political Economy.

${ }^{49} \mathrm{NA}$, Report of Thomas van Rhee and Pieter Outshoorn van Sonnevelt concerning trip to Ekoji at Thanjavur 6.1.1677, VOC 1329: 1178v.
} 
Charles II that the population was as high as $100,000.50$ Wrote the Bombay council in 1677:

For about 2 dayes journey up the hill between the Moguls and Sevagys dominions lies a perpetual seat of war, so that no merchant can passe without apparent hazard of being plundered, so that wee cannot expect merchants should land their goods here without knowing where or how to dispose of them, that wee often wondred how so considerable a custom could be annually raised, and wee can attribute it to nothing but the justice, freedome, and security people injoy here above other places, many families of Braminys dayly leaving the Portuguezes territories and repaire hither frightened by the Padrees, who upon the death of any person force all his children to be Christians; and even some of the chiefest who still live at [Portuguese] Bassein and others build them houses here, therein placing their wives and children against a time of danger. ${ }^{51}$

Apparently many traders found Bombay safer than the country torn between the Mughals and Shivaji and preferable to the Portuguese who meddled in religion, at least in the view of an Englishman. Bombay also seems to have been unique among the English factories, something of a republic (in the sense that public interest mattered). This state of affairs seems to have been due to several factors including, apart from the English claim to outright sovereignty over the island, the fact that the English had to take into account the interests of the Portuguese already settled there, ${ }^{52}$ the personality of Aungier (Governor of Bombay and President at Surat from 1669 until 1677), 53 and the continual need to defend the island.

The transition of Bombay to English royal and then EIC administration in 1665 and 1668 respectively was not smooth. There seems to have been considerable opposition from the Portuguese inhabitants, including the Jesuits at Bandra just outside the area claimed by the English as belonging to Bombay, which is in line with our conclusion from Chapter 1 that the European nations were exceedingly antagonistic in the East. ${ }^{54} \mathrm{~A}$ year after the initial transfer of the island, the Portuguese viceroy singled out Henry Gary, born a Venetian citizen of English parents who served the EIC on and off, who briefly became governor of Bombay for the king in

\footnotetext{
50 Fryer, New Account, 1: 177; Strachey and Strachey, Keigwin's Rebellion, 15.

51 SBSHS, Letter Bombay to Company 24.1.1677, 1: 120.

52 See also Mariam Dossal, "Continuity and Change: The Portuguese Presence in British Bombay, c. 1660-1860," in Anthony Disney and Emily Booth ed. Vasco da Gama and the Linking of Europe and Asia (Delhi, 2000) 403-18.

${ }^{53}$ See Phiroze B.M. Malabari, Bombay in the Making (London, 1910) 115-45.

${ }^{54} \mathrm{BN}$, Enquiry into the Portuguese at Bombay on behalf of Viceroy 3.2.1668, Fonds Portuguaise 33: 259; SBSHS, Letter Surat to Bombay 1.3.1671, 1: 57-8; Danvers, Portuguese Records, 64-74. For the continued opposition of the Jesuits at Bandra and their alleged support of the Sidi's siege of Bombay in 1689 see Ovington, A Voyage to Surat in the Year 1689, ed. H.G. Rawlinson (London, 1929) 95-6 and John Burnell, Bombay in the Days of Queen Anne, ed. T. Sheppard et al. (London, 1933) 58 note1.
} 
1667-8 and was later to play a substantial role in Keigwin's Rebellion, as "an awful heretic" and "great enemy of the Portuguese nation," who would be behind such things as the English usurping the islet of Mahim and obliging the Roman Catholics to take an oath denying the jurisdiction of the Pope over them..$^{5}$

Aungier, however, managed to appease the "general disquiet" among the Portuguese population by recognising all property rights in return for a fixed annual quit-rent. When some of the Portuguese continued to grumble against EIC rule, Aungier convened a general assembly of the chief representatives of the "Povo," the Portuguese term for people, parishioners or inhabitants, at which the agreement was laid down in a document often referred to in later times as Aungier's convention. It included important guidelines for the future government of Bombay. The governor and council declared "their earnest and infeigned desire to promote the public good, peace and tranquillity of the Isle, and to unite the hearts of the inhabitants in a firm and indissoluble tie of obligation to His Sacred Majesty and the Honorable Companys Service." 56

Moreover, the non-European segments of the population were also heard and their interests taken into account. In a description of Bombay Aungier stressed the role of the religious freedom enjoyed at Bombay as an inducement to Hindus to settle there, and wrote that religious freedom was "either totally denied or much restrayned in other parts." Speaking with much respect of the Parsis, Aungier also hoped that his having given permission to create a "bureing place," would attract a greater number of them to the town. ${ }^{57}$ Interestingly enough, Aungier's boasts about the religious freedom in Bombay and its growing affluence are echoed in a letter of around 1672 by the Portuguese viceroy: "They are now making a large and opulent city of the island, and those who go there are those with open consciences; our places and towns are being deserted." When at the end of the 1670s the viceroy drew up a long list of complaints about the things the English at Bombay were doing that were in his view contrary to the original capitulations, it included such things as allowing native Christians to return to heathenism, forbidding church ministers to punish them, ordering crosses to be pulled down, and permitting the erection of temples and mosques. ${ }^{58}$

In December 1673 a number of Baniya merchants from Surat felt confident enough that their conditions for settling in Bombay would be met, to have a list drawn up by Bhimji Parakh, one of the Company's

55 Danvers, Portuguese Records, 68-9; Strachey and Strachey, Keigwin's Rebellion, 10-1, 44, 83; Compare Orme, Fragments, 93.

56 SBSHS, Agreement between Aungier and the People of the Island 16.7.1674, 2: 383-7.

${ }_{57}$ BL, Description of Bombay by Aungier 15.12.1673, E/3/34: 278-9v.

${ }^{58}$ Danvers, Portuguese Records, 70, 73. 
brokers. The list consisted of three main points. The first asked for free exercise of religious, marriage and funerary rites. The second asked that goods would not be confiscated in the event of their of leaving the island and "that justice may be executed among us, by judges approved by ourselves and of our owne sect, but if any of us injure or prejudice any Englishman then we may be subject to their lawes." The third point asked that inheritances would go to those appointed by testament "and not after the Portugall manner; their estates confiscated and their infants forced to become xtians [Christians]," and that "in the Jentue streets no other nation may inhabit, that may prejudice their rights," besides some tax privileges. ${ }^{59}$

A few years earlier the Baniyas of Surat had already appealed to the English for permission to move to Bombay, when their community felt it suffered grave oppression at the hands of the qazi of Surat, such as demands for protection money for places of worship and forced circumcisions of prominent Baniyas. At the time, Aungier thought such a mass exodus would incur Aurangzeb's wrath and he suggested that the Baniyas appeal to the Mughal provincial governor at Ahmadabad, which according to the report about 8,000 Baniya heads of households did. Aungier did, however, promise that at a later stage they might convey themselves to Bombay "by degrees" and he seems to have honoured the 1673 request. Aungier was also very forthcoming in meeting Bhimji's request — which also shows the latter's concern with religion — to have a printer sent from England "to have some of the Ancient Braminy Writings in Print." Aungier noted in support of the request and in a sympathetic yet what may now seem proto-Orientalist vein, "'tis not improbable that this curiosity of his may tend to a common good, and by the industry of some searching spirits produce discoverys out of those or other ancient manuscripts of these partes which may be useful or at least gratefull to posterity." (The board of directors in London meanwhile thought that the printing press "may be a means to propagate our religion whereby soules may be gained as well as Estates.") In any case, however one wants to interpret the English report of the religious disputes at Surat of 1670 or their support for Bhimji's press, the list drawn up by Bhimji Parakh speaks volumes about the liberties the Baniyas felt they did not enjoy in the Portuguese, or for that matter the Mughal, cities. ${ }^{60}$

A similar but more elaborate list of articles was drawn up by Nima Parakh, a Baniya resident of Diu (but prospective resident of Bombay) in 1677, included the same emphasis on separate — dharmic — space for the Hindu (and Jain) castes. It stated "that noe Englishman, Portuguez or other

\footnotetext{
${ }^{59}$ BL, Baniya merchants' request to EIC 20.12.1673, E/3/34: 297.

${ }^{60}$ ERS, Letter Surat to Company 26.11.1669, Letter Surat to Company 9.1.1671, Letter Bombay to Surat 12.9.1673, Letter London to Surat 8.3.1676, 1: 136-40, 187, 282-3 and 2: 183.
} 
Christian, nor Mahomitan, shall be permitted to live within their compound, or offer to kill any living creature there, or doe the least injury or indignity to them; and if any shall presume to offend them within the limits of their said compound upon their complaint to the Governor or Deputy Governor, the offenders shall be exemplary punished." Nima Parakh's list also includes an article, a sign of the insecurity of the times, "that in the event of war, or any other danger which may succeed, he shall have a warehouse in the Castle to secure his goods, treasure, and family therein." The articles were readily agreed to by Aungier, or drawn up in a meeting with him, and the Bombay council amended the list only slightly. On the non-financial points the council concluded that all these rights were already in place in Bombay, such as the right to have disputes between caste members adjudicated by caste members. The latter right had been settled by Aungier in a declaration establishing that each of the "so many nations" on the island was to have an elected chief or consul to act as intermediary between the council and the people of that group and to arbitrate in controversies within the group. ${ }^{61}$

Yet despite the emphasis on living apart under separate administration that some inhabitants desired and the English were willing to cater to, something of a civil society also developed in Aungier's days. Bombay town north of the fort was according to Fryer inhabited "confusedly" by people whom he lists as "English, Portugueze, Topazes [Christians of part Portuguese descent], Gentues, Moors, and Cooly Christians, most fisherman [i.e. Christian Kolis, a caste mostly employed in fishing and menial services]." 62 Aungier's plan to form a militia for the defence of the island, probably on the model of the English incorporations, seems to have been especially important in bridging the divides to. The militia was to be trained by Company officers and to be composed of all the landowners. About one and a-half years after the plan was first mooted Aungier reported that he had raised 600 men. A further 100 landowners who were Brahmins and Baniyas "being never accustomed to beare armes, are willing to contribute in money." Besides the landowners the Bhandaris, a group of people tending the coconut groves, also contributed some 300 volunteers to the island's forces, while, according to Fryer a few thousand others "would make a shew, but not to be relied on, should it come to the push." From this we can conclude that there was a serious and shared public interest in the defence of the island. ${ }^{63}$

61 SBSHS, Proposals touching the island of Bombay by Aungier and the Surat council 5.2.1671, Articles granted to Nima Parakh by Aungier and council at Surat [ca. March 1677], Letter Bombay to Surat 3.4.1677, Letter Surat to Bombay 26.4.1677, 1: 54, 111-3, 129-30.

${ }^{62}$ Fryer, New Account, 1: 172.

63 MSA, "Warden's Selections" vol. 15: 299 (pencil 297); SBSHS, Letter Bombay to Company 24.1.1677, 1: 119-20; Fryer, New Account, 1: 170-1. 
The success of Aungier in creating a Bombay identity is reflected in the claim of the Rebels of 1683 to be acting on behalf of whole population of the island, to which effect a list of articles was drawn up "that the English and Portuguese swore to observe by the trinity, baptism and passion, and the Moors and Gentues by their most rigid oaths." The first of these articles stated that the inhabitants "unanimously" appointed Keigwin as the Governor of the island for the king and the third article rearticulated the freedom of religion on the island. The eleventh article stated that Keigwin was to govern in such a way "as may be acceptable to God, honourable to the king and pleasing to the people." The claim to "unanimous consent" and authorisation signed "by all the English, Portuguese, Moores, Gentues, Parsees etc." is repeated in several letters of the rebels. ${ }^{64}$

These were no hollow words. On their embassy to Sambhaji (see below) the Bombay mutineers endeavoured to obtain (and succeeded in obtaining) redress for several cases in the past years in which goods of Indian merchants of Bombay had been taken or had not been paid for by officers of Sambhaji. Moreover, the most important creditors of the revolt, by financing Keigwin's garrison, were "Cowes Moody" and "Girder Roopgee." 65 And in August the Dutch noted in the Surat diary: "People are lost for words to praise the present Bombay government, with both the foreigners [d'uitheemsche] and inhabitants [inwoonders] receiving full contentment, and the place is well stocked from all quarters." ${ }_{60}$

Finally, and this seems to be at the root of the grievances of the mutineers against the Company, the mutineers considered themselves to an extent rooted in Bombay. In a sense they had become, in the phrase Fryer used for the Portuguese cassados, "naturalized" to the country. ${ }^{67}$ In a final note appended to the list of complaints addressed to the king at the outset of the Rebellion, the mutineers deplored what they saw as a reversal of the original Company policy on the island "encourageing all to marry, build and purchase what hortas [plantations] they could that the natives might bee bought out," and that the Company was now trying to replace these settled men with "such as shall have theire sole dependence on them, to be kicked

${ }^{64} \mathrm{BL}$, English translation of the oath of allegiance to Keigwin in Portuguese of ca. 28.12.1683, E/3/43: 278-v; Letters Keigwin to Mr Harbin 12.01.1684 and Thorburne to Day 16.01.1684, E/3/43: 301-22.

${ }^{65} \mathrm{BL}$, Translated order Sambhaji to subadar and majmu'adar of Kolaba concerning goods of "Ventue Darmojee" April 1684; idem to "Gondagee Zadoo" Chief Captain of the fleet concerning goods of "Faguy Mamood" and "Magee Tank" and bill of "Simpavara" April 1684; Propositions Keigwin to Grantham to be signed 20.11.1684, Mss Eur Orme OV 118: $103-108 \mathrm{v}$.

${ }^{66} \mathrm{NA}$, Surat daily record, sub dato 5.8.1684, VOC $1398: 373 \mathrm{v}$.

${ }^{67}$ Fryer, New Account, 1: 180. 
out att pleasure and kept in thrauldome and povertie." 68 Unlike Child and Ward who could not care "if Bombay were as far under as above water," the mutineers cared for the place they had settled down in - as a result of the Aungier's wish that the EIC would "plant and strengthen your hopefull island with a more plentifull colony of English" 69 — and from that care also stemmed their anxiety over the security of Bombay. They, unlike Child and Ward, were stuck in Bombay.

\section{FEAR OF THE Sidis AND tHE ANTAGONISM BETWEEN MARATHAS AND Sidis}

But there was also another strand in the revolt, a strand that was less directed at a harmonious coexistence with the Indians within and without Bombay and more directed at conflict with both the Sidis and the Marathas, though mostly with the former. This strand was represented by Henry Smith, second to Ward until a few months before the rebellion, who was at some point accused of being the author of the rebellion, although it is unlikely that he was. Henry Smith is supposed one day in June 1683 to have ordered a ship to fire at a Sidi ship, and on the next day to have incited captain Consett to go and buy slaves from the Sidis (in violation of the proclamation against buying slaves from the Sidis issued by Ward), which resulted in Consett being thrown overboard along with his mate. The latter offence by the Sidis occurs high up in the list of complaints to the king, where the act of slave buying is extenuated with the phrase "to buy a slave or two." 70 Through the proto-colonial arrogance of Smith we see the main motivations for the Bombay English' antagonism toward the Sidis: fear of plunder and fear of enslavement, fears that were also harboured by the Marathas, along with that of conversion.

BOMBAY IN BETWEEN-An annually recurring stressful situation was the "wintering" of the Sidi's fleet in Bombay Harbour during the monsoon. This tradition started in 1674, when Sidi Sumbul took refuge from a storm in the Harbour. The Sidi apparently had to emphasise his Mughal credentials before Aungier admitted him on certain conditions. In that first year there seems to have been little problem: Shivaji was at first offended but satisfied by the President's explanation, and the spending power of the Sidi and his men was welcome to Bombay. ${ }^{71}$

${ }^{68} \mathrm{BL}$, Complaints to his Majesty 27.12.1684, E/3/43: 373v.

${ }^{69} \mathrm{BL}$, Description of Bombay by Aungier 15.12.1673, E/3/34: 278v-9.

${ }^{70} \mathrm{BL}$, Attestation of Inigo Burniston charging Smith to be the author of the Rebellion 15.4.1684 E/3/44: 23-4; Deposition of Thomas Pettitt and Thomas Bigott et al. against Henry Smith 20.8.1683, E/3/43: 96-7; Complaints to his Majesty 27.12.1684, E/3/43: 36976v. Strachey and Strachey, Keigwin's Rebellion, 70-3, 92-3.

${ }^{71}$ ERS, Bombay Occurances 28.4 .1674 (o.s.) 1: 342-3; BL, Letter Aungier (?) to Sidi Sumbul 9.5.1674 (o.s.), Mss. Eur. Orme OV 114: 188-189v (pencil). 
Such harmony was, however, exceptional. A year earlier, the factors at Bombay had been most vexed by the Sidi's occupation of the opposite shore of the Harbour belonging to Shivaji (known as the Corlahs) against his promise "upon his prophets and his alcoran" to respect Bombay's neutrality and never to attack the Corlahs. Aungier complained of the dishonour this brought to "the Company and nation" and called the Sidi a "more base, ungratefull and vilanous enemy to us than Sevagee, or any other roague in India," and avowed he was quite prepared to sink the Sidi to the bottom even if he would go down with him, were he not tied by Company interests. After some twenty days had passed, however, he noted that the Sidi had not been able to do much damage to Shivaji except "plundering a few open villages to seaward, and burning a few Cajan houses, and takeing a few Corumbines slaves, which is the worst he can doe." 72 But the tension remained and the Sidi was unpopular with the English to the extent that in April 1677 an ensign Thorpe ignored orders not to attack friendly vessels and took a Sidi boat. The Bombay council itself devoted all of May and June to try to dissuade Sidi Sumbul from wintering in the Harbour, but finally acquiesced upon orders from Surat. ${ }^{73}$

Sidi Qasim, who after the 1677 monsoon took over charge of the fleet from his brother Sumbul on the emperor's orders and after English mediation - "we were willing to be mediators in this business that we might be rid of them both" - seems to have continued the annual "wintering" at Bombay. Complaint number 5 of the Bombay rebels concerned an incident during the Sidi's stay through the past monsoon, when two Englishmen were killed and one wounded and the murderer escaped "and all the moors repaired to the East India House, the lodgings of the Siddee the Moore'[s] Admiral, with a resolution to protect the murderers." Ward - and this was the essence of the complaint - kept deliberating, but finally sent a message. Yet, "the Siddies answer was fitt to the deputy governor['s] messengers who were Banians (a timerous people unfitt to treat between soldiers) that he should not find them Banians, and that the deputy governor was hot that night and the next morning would be cooler." Enough to provoke even the most stoic, wrote the mutineers. Later, Ward was given the option to send as messengers an English officer and a Portuguese who spoke "Moores" (i.e. some form of Urdu) ${ }^{74}$. Ward

72 ERS, Letters Bombay to Surat 12 and 31.10.1673, 1: 295-6, 305-6; Orme, Fragments, 22. The Kunbis or Kunambis were a caste of cultivators. Fryer, New Account, 1: 174 note 6.

${ }^{73}$ MSA, Letters Bombay to Surat 22.4, 2.5 and 18.5.1677, Bombay Outward Order Book 4: 30-34.

${ }^{74}$ Compare a remark about the young Jan van Nijendaal that he "is getting to have a reasonable knowledge of the Moorish language [Moorse sprake], as he is practicing it also, and busy learning to write Persian." NA, Report of visit to Hyderabad by Backer and De Bont 18.1.1663, VOC 1242: 857v. 
sent them on their way with some forceful language but the Sidi kept procrastinating and failed to have the murderers delivered. ${ }^{75}$

As was already noted in the previous section, one of the first things the Bombay mutineers did was to send Captain Gary as an ambassador to Sambhaji to establish an alliance against the Sidi. At first Sambhaji, in his own translated words, "condescended" to the proposals, but after Thomas Wilkins was sent as ambassador along with Rama Sinay and had "given me to understand all," Sambhaji agreed to most of their proposals, including the original one made by Gary:

You desired the first captain to tell me that there was a difference between you and the Siddee desiring my assistance by which you shall be enabled to chastise him which very much concerns me, he being my principal enemy, and you being in friendship with me, I say he who is your friend or enemy is also mine, and considering the same, you may with your power destroy this enemy Siddee, for I am endeavouring the same on this side, If occasion be I shall not fail to help you by all manner of means, It being convenient that you should destroy this enemy, by which our friendship shall be more encreased. I shall not be more large. ${ }^{76}$

There seems to be little to show of an actual offensive by the Bombay mutineers against the Sidi, but one thing they did was turn the Sidi out of the Harbour when he arrived at the start of the monsoon intent on wintering there. ${ }^{77}$ In any case, the entente established by Keigwin laid the basis for a relationship between Bombay and the Marathas that was to last at least a decade. Maratha soldiers played a substantial role in the defence of Bombay during the siege of 1689-90. The Bombay factors noted in retrospect that, "the next thing that hindered the Siddi encroaching upon us, was an unexpected supply of soldiers from Sambhaji Raja and other places, which if not arrived in good time little had wanted of being routed, but this made us stand our ground." 78

CONQUEST, ENSLAVEMENT, CONVERSION-Were the remarks about the Sidi's enslaving the local people or his attitude to Baniyas merely projections of the Europeans' prejudices and fears? It seems from the phrasing of the

\footnotetext{
${ }^{75}$ ERS, Letters Surat to Bombay 9.6.1676 and Bombay to Surat 9.10 and 21.10.1677, 2: 91, 141-43; BL, Complaints to his Majesty 27.12.1684, E/3/43: 369-76v (point 5).

${ }_{76}$ BL, Translated order Sambhaji to Keigwin, [April 1684], Mss Eur Orme OV 118: 68-9v (pencil).

77 Strachey and Strachey, Keigwin's Rebellion, 97-8. (apparently based on an Orme manuscript, which I have not been able to trace).

78 Desai, Bombay, 44-6. Letter Bombay to Company 15.1.1691, quoted ibidem. Sambhaji had been executed and replaced by Rajaram before the start of the siege. It seems that the Maratha soldiers were not so much sent by Rajaram on his own account as hired by the English, although Desai also quotes an entry from the Bombay diary that suggests the soldiers were brought from Ramraja directly by one of his subadars.
} 
passage about the Baniya messengers that the mutineers at least shared the Sidi's contempt for Baniyas. But what about the report on the panic that accompanied the rumour of the arrival of the Sidi's fleet at Vengurla; was that merely a Dutch "discourse" authorising the author's anxieties about the Sidis through their projection onto the local populace in a sort of silent heterology? Comparing the European accounts to Maratha and Mughal accounts of the Sidi is in order to answer that question.

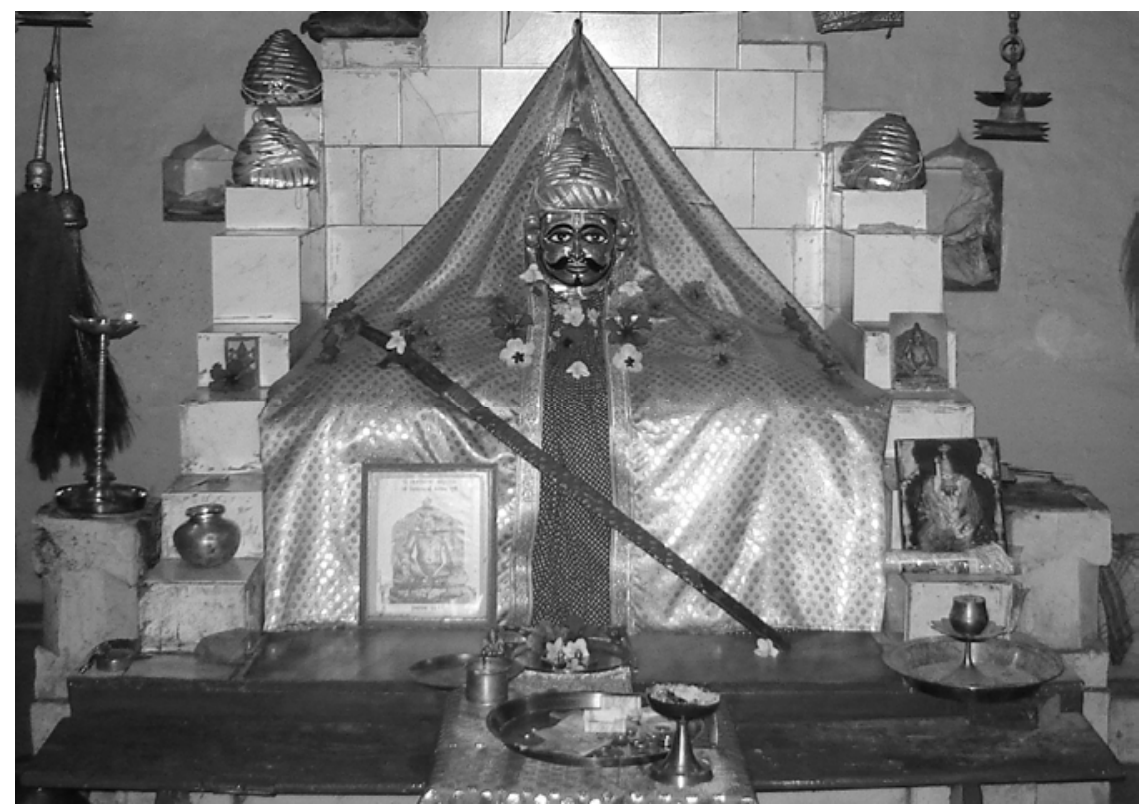

The deified Shivaji (Shivarajeshvar) in a temple built by his son Rajaram in Sindhudurg in $1695 .{ }^{79}$ Perhaps the first three-dimensional representation of Shivaji, it signalled the beginning of a commemorative tradition.

In a text produced at the court of the Maratha king Sambhaji II in 1716 we find anxieties similar to those represented in the European sources. Although this Ajnapatra was written over thirty years after the start of Aurangzeb's invasion and almost a decade after his death, it reflects extensively on that period to which the author Ramachandrapant Amatya seems to have been a witness. Thus we could classify the text as a secondary narrative. After a discussion of Shivaji as the founder of the kingdom (swaraja) the Ajnapatra discusses the rule of his son (probably Rajaram; Sambhaji I seems to be glossed over) who put the kingdom back on track by conciliating the "chief ministers, sardars and other servants, high and low, of the kingdom... [and] attracting the hearts of all, and not

${ }^{79}$ George Michell, Blue Guide: Southern India (London, 1997) 153. 
allowing them to hate one another." As his first great military deed it lists his victory over the Sidis, referred to as Shyamalas, literally "dark blues":

Further with a view to bring under his control this Kingdom by his valour he thought of subduing first the adjoining enemy who was like a disease in the stomach. The Shyamalas were truly the cause of harm to the state. They were the means of fulfilling the evil designs of the lord of the Yavanas [the Mughal emperor]. On account of the Shyamalas the successes of the chief enemy were at first great, nay during the adverse times [of Aurangzeb's invasion] the Shyamalas conquered several territories and forts. Even the chief place Raigad which was the seat of the throne was captured by them. Having caused troubles to Brahmanas and all other people they forcibly converted them...At first the late revered great king [Shivaji], the ornament of state, checked the Shyamalas. On that occasion the Shyamalas were supported by the Tamras [Mughals] and therefore the Shyamalas remained as a power. Otherwise what was there to make the Shyamalas exist in spite of his efforts. A place or country when invaded by others continues to exist with outside help. ${ }^{80}$

To put these statements into some perspective it is useful to compare the Ajnapatra's view of the Sidis with its view of the Europeans. While the subject of the European presence is treated mainly under the heading merchants, they are also listed as enemies of Shivaji (along with many others including a number of Maratha sardars) and the text noted that the European strength lies in "navy, guns and ammunition." The text enumerates the Europeans as follows: "the Portuguese [Firangi] ${ }^{81}$ and the English [Ingra] and the Dutch [Valand; elsewhere also Valande] and the French [Fransis] and the Danes [Dingmar] and other hat-wearing [topokar] merchants." The Ajnapatra goes on to note that these merchants are unlike other merchants:

Their masters, every one of them, are ruling kings. By their orders and under their control these people come to trade in these provinces. How can it happen that rulers have no greed for territories? These hat-wearers have full ambition to enter into these provinces to increase their territories, and to establish their own opinions [religion]. Accordingly at various places they have already succeeded in their ambitious undertakings. Moreover this race of people is obstinate. Where a place has fallen into their hands they will not give it up even at the cost of their lives.

However, while great care was to be taken in allowing them to build something, they should be allowed to carry on their trade, considering the

\footnotetext{
80 Amatya, "Ajnapatra," 81-91.

81 Though the term "Franks" was used of Europeans in general as was seen in Chapter 1, it stuck especially to the Portuguese. Ketelaar's Hindustani vocabulary, written some eighteen years before the Ajnapatra glosses Europeer as Frangie and Portugees as Fringi. NA, Grammar of Hindustani and Persian by Ketelaar, Sypestyn Collection (suppl.) 2: 11-2.
} 
importance of commerce to the prosperity of the kingdom: "If they live in this way by accepting the above conditions it is well; if not, there is no need of them. It is enough if they occasionally come and go, and do not trouble us; nor need we trouble them." 82

In the Ajnapatra we see a hierarchy of evil similar to that found in the Suryavamsha Anupurana. The "chief enemy" were the Mughals, but the Sidis were their aides and since they had their headquarters within the boundaries of the swaraj they were "like a disease in the stomach." After eliminating the Sidis, Rajaram directed his attention at other internal enemies, the various obstinate zamindars like the Savants, so that "the kingdom became free from thorns." Rajaram then turned his attention once more to "his inmost object of conquering the country occupied by the Yavanas, of destroying the Yavana confederacy and of beating down the Yavana predominance which had taken root in the east, west and south by sending large armies." 83 The hierarchy of evil established by the Ajnapatra thus looks like this: first the Sidis of Janjira, second the independent minded Maratha sardars and other zamindars, third the "Yavana confederacy" in general, and then came the Europeans who were both pest and boon and should be manipulated in such a way that the latter aspect prevails. In the last chapter it was noted that in the Anupurana Habshis were seen as the more benign Muslims. Their rise to the position of principal enemy can be explained from the developments after ca. 1674 when the Anupurana was written. First of all after 1686 there was no longer a Deccani faction in Bijapur and, secondly, the antagonism between the Habshis based at Janjira and the Marathas had only increased.

Khafi Khan traced the bitter enmity or hatred ('adawat-i shadid) between the Habshis of Janjira and Shivaji to an engagement in the early days of the Sidis' Mughal service when they drowned one hundred Maratha men of Shivaji's fleet at Danda-Rajpuri. Khafi Khan took care to note that he himself spent a long time in the area and heard the accounts of Shivaji's contest with the Sidis from locals and from Sidi Qasim himself. One of those accounts was that of the Sidis taking a fort and, in spite of a promise of their protection, enslaving and converting all the young men and handsome women, while releasing the remaining women and killing the remaining men. "From that day such a fear of the Abyssinians overawed the heart of Shiva and other infidels that he considered it a good fortune to be able to keep the fort of Rahiri [Raigarh] only." Shivaji invested enormously in a siege of Danda-Rajpuri and Janjira. On his embassy to Raigarh, Henry Oxinden suggested to Shivaji's minister Niraji Pant that it

\footnotetext{
82 Amatya, "Ajnapatra," 86-7, 212-4. The remark that Europeans will not give up a place once granted the right to build something meshes with Grotius' pacta sunt servanda principle, see Chapter 1.

83 Amatya, “Ajnapatra," 91-2.
} 
might be advantageous for everyone, especially traders, if Shivaji and the Sidi were to conclude a peace, "but he would not be persuaded it was for his Masters [Shivaji's] interest to raise a siege which hath cost him soe much blood and treasure, especially now he hath such hopes of gayning the place, and therefore told me it would be in vaine to move it to the Rajah, who was resolved to take that Castle lett it cost him what it will." 84

The resultant tense situation between the two groups around 1684 has already been outlined above; after that time the antagonism seems to have continued unabated, while relations between the Sidis and the Mughals soured. The author known as Abul-Fazl Ma'muri, who seems to have been active in various positions, such as news writer, in Aurangzeb's administration of the Deccan, ${ }^{85}$ noted that "the Habshis had become so dominant over the Marathas that Sambha feared the name of the Habshis." Yet he also wrote that the Marathas sometimes took Sidi ships, from their newly established sea fortresses. Ma'muri further noted that the relationship between Aurangzeb and the Sidi became clouded after the siege of Bombay during the Anglo-Mughal war of 1689-90, because the Sidi's role in the siege was insufficiently recognised by the emperor's plenipotentiaries after the peace between the emperor and the English was renewed. Ma'muri alleged that the Sidi became somewhat lax in countering the operations of the kafirs, which supposition echoes in Khafi Khan's narrative, where it said that the Sidi became disheartened because he was slighted. ${ }^{86}$ Although such souring of the relationship between the Mughals and the Sidi is not reflected in the Ajnapatra, the tenacity with which the English held on to Bombay is. In any case the Ajnapatra reflected anxieties similar to those of the Bombay mutineers with respect to the Sidis.

Another aspect of the relationship between the Sidis and the Marathas the Ajnapatra addressed was the alleged forcible conversion of "Brahmins and all other people." We do not find this allegation in the writings of the Bombay mutineers, but in 1689 "Abdellalla" alias John Stevens reported that he and a number of other Englishmen captured by the Sidi were forced to convert to Islam, and, as the report of his deposition does not fail to mention thrice, that entailed circumcision. After their conversion the Sidi took these Englishmen into his service. It is possible that the Sidi aimed to make them more loyal by cutting their ties with the English through conversion. In any case the English factors seem

${ }^{84}$ Khafi Khan, Muntakhab (translation) 227, 230; ERS, Report by Henry Oxinden of embassy to Raigarh 13.6.1674, 1: 371. The first event may have taken place in 1672, see Orme, Fragments, 22.

85 Storey, Persian Literature, 1: 594-5. Syed argues that Ma'muri was possibly not one author and also shows in what way Ma'muri's text was an important source for Khafi Khan. Syed, Aurangzeb, 22-6.

86 BL, Ma'muri, Aurangzeb Nama, Ms. Or. 1671: 159v-160. Khafi Khan, Muntakbab (translation) 419, 421. 
to have frowned on "Abdellalla", considering the great emphasis Stevens puts on the force involved in his conversion and the humble note with which he ended the deposition, hoping for their kindness in allowing him to return. ${ }^{87}$ This reserved attitude towards, or distancing from, converts is also represented in a remarkable passage in the Muntakhab ul-Lubab where Khafi Khan described his interview with the English governor of Bombay in 1696. Khafi Khan argued that the Mughal ship at the centre of the controversy was indeed captured by Englishmen, telling the governor:

I heard from them [acquaintances who were on board] that at the time of the plunder of the ship and their arrest, there was a party of men, who appeared from their faces and dresses to be English men. They had scars of wounds on their bodies and hands and they said in their own language: "These are the scars of the wounds we received at the time of the siege of Sidi Yaqut; but today the blots of those scars have been wiped off our hearts [i.e. we have taken revenge]." A person who was their fellow traveller and who knew Hindi and Persian, translated their words to my friends. On hearing my words, he [the English governor] burst into laughter and said: "It is perfectly correct. They must have said so, but they are those English men who were wounded and taken prisoner by Yaqut Khan during the siege. Some of them deserted us, became Muslims and took service with that Abyssinian. They stayed with him for some time and fled away. As they could not show their faces to us, they went over to the men of Denkmar [Denmark] also called Sakanas and joined their service... and have become their assistants in piracy.

Khafi Khan concluded by noting that he did not believe the governor's attempt to shift the blame, though he also seems to have appreciated the promptness of the reply (or at least so he told the governor). However, without venturing into more detail about the affair, it may be noted that conversion is here mooted as an insuperable boundary, a loss of face with respect to the original community, yet one that, in this case, paradoxically strengthened the converts' Christian or European identity as they became former converts. ${ }^{88}$

As has been noted in Chapter 1, the adoption of Islam was also considered an important legal boundary, and Sidi Qasim symbolically expressed the crossing of that boundary through his sharing food with converts. Among the signs of the Sidi's piety such as donating to Mecca

${ }^{87}$ BL, "Deposition of John Stevens (Alias Abdellalla since circumsized) whoe ... came from the Siddys Battery" 21.12.1689, E/3/48: 91-92v.

${ }^{88}$ Khafi Khan, Muntakhab (translation) 422-5. In any case Henry Every, the pirate who captured the Mughal ship, seems to have seen himself as a staunch upholder of Englishness or Protestant Christianity. While he had just captured a Spanish ship and left its French crew on shore to fend for themselves, he writes: "I have never as yett wronged any English or Dutch [who shared a faith as well as a head of state] nor never intend whilst I am Commander." Every signed this note, written half a year before his capture of the Mughal ship, “An Englishman's Ffreind.” Letter Every to an EIC ship commanders, 28.2.1695, in Biddulph, Pirates of Malabar, 18-9. 
and Medina, Ma'muri also lists the "salvation" (najah) of every thirteenth of the slave boys collected from amongst the "sons of the so-called Marathas." The Sidi turned the selected boys into hafizes, knowing the Qur'an by heart, and

every [cycle of] forty Thursday nights he listened to a recitation of the complete Qur'an $^{89}$ by them and fed sweet and East African dishes that were broken in the name of the Prophet of God to the meritorious [among them] and at the time of [the month] Safar he made a common distribution of food to one to two hundred from the group of students of the skill, [and] every one that he liked ate the meal together with them and was a guest-friend. ${ }^{90}$

The resultant view of slavery and conversion as two mutually exclusive yet closely linked undesirable phenomena is expressed in Sambhaji's treaty with Keigwin, where article 18 stipulates "that the English shall buy none of my people belonging to my dominions, to make them slaves or Christians." In which phrase the repetition of "my" is noteworthy. ${ }^{91}$

NUANCES-The picture I have sketched here of the hatred between the Sidis and the Marathas as the motor of their wars must be nuanced, however. Firstly it should be noted that there were also considerable material incentives to propel the Deccan wars. There was a considerable social and economic investment of certain (partly) militarily oriented groups in the activity of warfare itself in early modern India, as Dirk Kolff and Jos Gommans have demonstrated. In our case this is borne out by the declaration of John Stevens/“Abdellalla", just returned to the English at Bombay fortress in 1689, "that the Syddy saith that he hath noe intentions of storming the ffortt, should he stay here seaven \& 7 yeare, for the king and some particular merchants maintaine him and his army." 92

Secondly, it is necessary here to note the ambiguities of the relation between Marathas and Sidis. Just as Shivaji had throughout his royal period employed a Muslim, Daulat Khan, as his admiral, three of the five subadars of Sambhaji's fleet in 1683 were Muslims, and one of them seems to have been a Sidi, named Sidi Ahmad. ${ }^{93}$ In the previous year there was also one Sidi Misri, a relative of Sidi Sumbul, serving with the Maratha fleet under Daulat Khan. He had gone over to the Marathas upon his removal from a

${ }^{89}$ Forty days was the normal period required to read the Qur'an in its entirety, although in the month of Ramazan it was read in thirty. Hughes, Dictionary of Islam, 492, 517.

90 BL, Ma'muri, Aurangzeb Nama, Ms. Or. 1671: 160.

91 BL, Translated articles granted by Sambhaji to Keigwin's ambassadors, undated [April 1684], Mss Eur Orme OV 118: 92-97v (pencil).

92 J.J.L. Gommans and D.H.A. Kolff, "Introduction," in eidem eds. Warfare and Weaponry in South Asia 1000-1800 (Delhi, 2001); BL, "Deposition of John Stevens (Alias Abdellalla since circumsized)" 21.12.1689, E/3/48: 92v.

93 NA, Sea-pass to Sambhaji's fleet 26.10.1683, VOC 1406: 839v-40; Daulat Khan is mentioned passim in ERS. 
commanding post in the Sidi's fleet, presumably at the order of Sidi Qasim after his takeover from Sidi Sumbul. Sidi Misri was subsequently mortally wounded in an encounter with Sidi Qasim in the sight of Bombay.94 Although this may have been an episode in an ordinary family feud, Sidi Misri was, nevertheless, welcome on the Maratha side. It seems, however, that the Muslim predominance in the command of the Maratha fleet ended around 1684 since by then we find one "Gondagee Zadoo" named as "Chief Captain" of the Maratha fleet and it is well known that from the early 1690s an important part of the fleet was led on an independent course by a Maratha named Kanhoji Angria. ${ }^{95}$ So although in the period under discussion here the role of Muslims and Sidis in the Maratha navy was reduced, the presence of Muslims and Sidis in the fleet makes it clear that the opposition between the Sidis and the Marathas was not impermeable, but that does not mean that it was unimportant, let alone non-existent.

A strange incident in the 1677 shows how a boundary-crossing could merely serve to underline the boundaries between Sidis and Marathas. As narrated in a letter of the Bombay council, a Brahmin "and two or three more" (?) from a village on the mainland near Bombay offered their services to the Sidi and said they could deliver him some quality prisoners from their village, and after his agreement indeed delivered him four Brahmins, the principal men of the village. Because a Bombay Koli boatman and "rogues," also from Bombay, had been involved in the kidnapping, the Maratha subadar of the mainland threatened a boycott of Bombay, on which the council swiftly took action and had the kidnapped four released by the Sidi. ${ }^{96}$ Why did the Brahmin want to cross over to the Sidi and get him some Brahmin hostages? We can only guess, but it is clear that the Maratha-Sidi boundary was at the heart of the affair.

\section{CONCLUSION}

The period around the year 1684 was axial in the history of the Konkan in many respects. Not only did the Konkan see three "revolts" in this short time frame, namely that of the English factors in Bombay against the EIC, that of Prince Akbar against his father the Mughal emperor, and that of local zamindars against the Bhonsla dynasty, the year also saw the synthesis of European sea power and Indian land power through the launch of largescale navies by the land-powers of the western Deccan and by the heightened involvement of Europeans in the conflicts of these powers. Moreover the year marked a new phase in the long-drawn conflict between the Sidis of Janjira and Marathas at sea, and it is possible that Kanhoji

\footnotetext{
94 Orme, Fragments, 77-8.

${ }^{95}$ Desai, Bombay, 47.

96 SBSHS, Letter Bombay to Surat 27.6.1677, 1: 133.
} 
Angria, an important player in the conflict from the 1690s, started his career as a maritime commander just then. ${ }^{97}$ The focus of this chapter was, however, the Bombay rebellion, the story of which encapsulates the synthesis of Europe and Asia that was taking place on the west coast of India. As J.C. Heesterman observes: "The littoral forms a frontier zone that is not there to separate or enclose, but which rather finds its meaning in its permeability." "98 The existence of a Bombay identity, which had emerged in the short period of Aungier's administration and came to fruition in the Bombay Rebellion is clear testimony to that.

The category of the "natural" was invoked frequently in this period in relation to matters of freedom. A few months before the rebellion one Inigo Burniston is supposed to have said, in defence of the proclamation against buying slaves from the Sidi, that it was "unnaturall in any one to buy those people who were forced away from their relations and dwellings as they were." 99 Naturalness was also invoked in relation to government: as has been seen in the last chapter, Fryer wrote that Shivaji promised he would free the Decanis from "a more unnatural slavery," while Dev Savant in the words of the VOC factor of Vengurla saw it as a sign of the unnaturalness of Sambhaji's government that he appointed the son of Rupaji Bhonsla only months after he had ordered the blinding of the father. ${ }^{100}$ Clearly the EIC government of Bombay did not appear natural to its inhabitants in 1683, while the mutineers had become "naturalised" like the Portuguese before them. Their own administration could address the local issues they found most pressing much more directly than the EIC superiors who faced a much more complicated diplomatic picture.

The most pressing issues to the mutineers were clearly the threat from the Marathas and that from the Sidis, and at first glance it might seem that the English fears of those groups are the standard fare of European (proto-)colonialism. The anxiety about the Sidis in particular would confirm the view of Nabil Matar (following Edward Said) that Muslims were the eternal enemy of Europeans in Asia and that that enmity was the result of a long standing European discourse on Islam. Michael Pearson (following Richard Hall, Bailey Diffie and George Winius) also explains the excessive violence of the Portuguese against Asians and against Muslims in particular

\footnotetext{
${ }^{97}$ That is if the "Gouinde Cano" mentioned in the Dutch sea-pass as a subadar of Sambhaji's fleet is indeed Kanhoji Angria. NA, Sea-pass to Sambhaji's fleet 26.10.1683, VOC 1406: $839 \mathrm{v}-40$. Kanhoji Angria's early career is shrouded in obscurity. Compare and contrast Manohar Malgonkar, Kanhoji Angrey, Maratha Admiral (New York, 1959) 9-15, $42-7$.

${ }^{98}$ J.C. Heesterman, "Litoral et intérieur de l'Inde, " Itinerario 1 (1980) 89. Quoted in Pearson, Indian Ocean, 38.

99 BL, Deposition of Thomas Pettitt and Thomas Bigott et al. against Henry Smith 20.8.1683, E/3/43: 96-7.

100 NA, Narrative by Lindsaij of occurrences at Vengurla 28.2.1685, VOC 1416: 1462v.
} 
from the Portuguese experience before the naval expansion into Asia. ${ }^{101}$ I would argue rather that the anxieties reviewed in this chapter show that English at Bombay were part of Deccan society, for the fear of the Sidis was widely shared among the coastal population. The Marathas also were feared by the English in the same way that any armed force in the region was feared by merchants.

Moreover, to counter both perceived threats to Bombay's security, the mutineers made use of an existent and salient group boundary in the region, marked by conversion, enslavement and other forms of violence: the boundary between Sidis and Marathas. The solution of the mutineers was simple and local: the smaller, yet most detested, enemy was to be confronted and the enemy's enemy was to become an ally. The alignment by the mutineers of Bombay along the boundary between the Sidis and Marathas shows that that was the overarching boundary in this frontier region, more important than the boundary between Europeans and nonEuropeans, something that is also born out by the fact that the English in Bombay revolted against other Englishman and by the fact that the English rebels received the support of the non-English population of Bombay.

What is more, the anxiety of Keigwin and his men was not so much the anxiety of the top-dog but more the anxiety of the underdog as they felt strangulated and put at great risk by the policies of their EIC superiors in the midst of the increasing instability in the region. A comparison to the revolts of the "creole" (born locally but of foreign descent) elites in the Americas around 1800 against their mother countries presents itself; fear is also counted among the causes of the drive for independence in the Americas by Benedict Anderson in his famous Imagined Communities (though he emphasises other factors in explaining the forms these revolts took). Indeed the sentiments of the English at Bombay seem to be akin to the "creole nationalisms" of the Americas - according to Anderson the first nationalisms - which also came to claim the "Indians" as fellow "citizens" of the creole elite in the newly formed states. But in the Bombay case the fear was not of a subject population, as it was (paradoxically) in the Americas around $1800 .{ }^{102}$ The fear of the English at Bombay was perhaps more akin to the Great Fear that Georges Lefebvre ascribes to the peasantry and townsfolk of France in the final days of the ancien régime than to the anxiety of empire that Bhabha, Suleri and others ascribe to Europeans in the colonial period. The grande peur that swept France in the second half of July 1789 drew on an existing fear of brigands, which suddenly became very acute in the already volatile situation, just as in our case. Moreover, the fear of brigands quickly developed into a backlash

101 Matar, Turks, Moors and Englishmen. Pearson, Indian Ocean, 124-6.

102 Benedict Anderson, Imagined Communities : Reflections on the Origins and Spread of Nationalism, (rev. ed.; London, 1991) 47-65. 
against the rural aristocracy, just as the fear in Bombay turned against Ward and Child. ${ }^{103}$ The late seventeenth century was a timeframe quite distinct from the colonial period and possessed of its own anxiety provoking processes, mainly the military chaos enveloping the Deccan.

The role of religion in all this was quite important. In chapters two and four religion was seen as only one factor among the many that could separate or unite people, though certainly one of the more important such factors. In this chapter religion came to the fore as a motivation for state policy, revolt and migration. Aurangzeb's attitude towards the non-Muslims of his realm was a decisive factor in the events of this period, as will be elaborated in the Epilogue. The Portuguese meddling in the religious affairs of their subjects was also a factor in the rise of Bombay, as the Portuguese viceroy himself was even willing to admit. The other force in the coast invested in conversion, the Sidi polity, was feared by many of the coastal inhabitants.

To the Englishmen at Bombay and Surat religion also was an important factor in their outlook. Gary for instance seems to have seen Roman Catholics as fifth-columnists of the Portuguese. Aungier was also no stranger to Protestant zeal and was, for instance, concerned that the children of Englishmen married to Portuguese mestizo women would turn out Roman Catholics, and proposed measures to prevent that. Moreover, just as Gary seems to have been, he was concerned about the loyalty of the Roman Catholic soldiers employed by the Company on the island and lamented the fact that there were so few on the island of the "true" - i.e. Protestant — religion and that so many were languishing in the blindness wherewith the Catholic priests enchanted them. Aungier's intolerant pronouncements and acts, however, seem to have been limited to Roman Catholics. His tolerance towards non-Christian religions is well attested by his acts and the way he spoke highly of the Parsis and their "ancient religion." 104

As Fryer noted and as is evident from the petitions of the Baniyas cited above, moreover, Aungier's toleration did make a difference to the Baniyas of Surat and elsewhere who were not only looking for a suitable place for their businesses but also for a place where they could best live their dharma. Fryer mocked the solemn declarations of religious tolerance at Bombay as "fopperies," licensed out of "policy." Yet he too recognised that it was an important factor in the growth of the population of Bombay, noting that "both the Moors and Portugals despise us for it." 105 And a

103 Georges Lefebvre, La grande peur de 1789 (Paris, 1932).

104 Malabari, Bombay, 128-9; BL, Description of Bombay by Aungier 15.12.1673, E/3/34: $278-9 \mathrm{v}$.

105 Fryer, New Account, 1: 177, 181. For a discussion of the use of the term "policy" see the next chapter. 
century later Aungier's administration was remembered by the anonymous author of An Historical Account of Bombay precisely for attracting people to the town by its mildness and tolerance. ${ }^{106} \mathrm{In}$ a sense Aungier was the Akbar of Bombay at the time that Aurangzeb became the Cromwell of the Mughal empire.

Finally, the sentiments of the Englishmen in Bombay at the time of the Rebellion must be contrasted to those of the Dutchmen in India in the early seventeenth century highlighted in Chapter 1 . Two contrasts are most striking. Firstly, the Dutchmen saw themselves confronted with a European enemy and emphasised their belonging to a European nation, while the Englishmen of Bombay saw themselves confronted with a local enemy and emphasised their local identity. Secondly, while most Dutchmen in the early century were very dependent on the VOC as the fount of their "capabilities" in the Asian environment, the Englishmen at Bombay could well do without the EIC and saw it rather as an obstacle to their commerce and safety. The example of the English in Bombay shows once more that identification and biases of Europeans in seventeenth-century India were as context dependent as among any group in India, but were nevertheless strongly felt. 


\title{
CHAPTER 6 \\ MADANNA, AKKANNA AND THE BRAHMIN REVOLUTION IN GOLKONDA 1674-86*
}

\begin{abstract}
...you yourself can imagine which government serves the king best, ours or that of the Moors; ours being fullheartedly devoted to the welfare of the country, while we are not people who have or seek other countries, but that of the Moors is only to the end of becoming rich and then to leave for those places which they consider to be either their fatherland or holy. ${ }^{1}$
\end{abstract}

Akkanna, 1683

\section{INTRODUCTION}

Or, at least, that is how the words of Akkanna, brother of the Brahmin prime minister of Golkonda Madanna, were reported by Dutch East India Company employee Michiel Janszoon in 1683. The quotation is part of a seven-page report of a private interview that Janszoon had with Akkanna (the only other person present being a fanner) in August 1683. Janszoon, who spoke Telugu well, ${ }^{2}$ made a transcript of the interview no more than a few days afterwards and sent it off to Masulipatnam in spite of Akkanna's request, twice repeated, not to reveal the true topic of their conversation to anyone. Janszoon's superior in Masulipatnam sent it secreto modo on to his

* An earlier version of this chapter appeared as an article in JESHO 45 (2002). The present version relates to that article as follows: firstly, many minor mistakes have been corrected, e.g. the regent of Sugur turns out to be female rather than male. The article version also had a reference to the brothers' allegiance to Tulja Bhawani of Tuljapur, but that was based on two translations of a Persian document, which in the original, as it turns out has Bijapur, not Tuljapur. Secondly, some important sources have been added, most notably the VOC accounts of the Savant revolt and Madanna's confrontation with Abul-Hasan over elephant fights and some material that reflects on the penetration of the struggle between the court factions to the local level. Finally, the conclusion has been emended to accommodate the ambiguities of Madanna's policy, which I now see as a conflict between different roles rather than the result of an ideal compromised in practice. Also, in the article version I saw the early modern period too much as a unity.

1 “...gij kunt selfs wel bedencken welcke regering den coning meest dienstigh is, d'onse of die der Mooren, zinde d'onse van gantscher herten tot welvaren van't lant, dewijl wij geen luijden sijn die andere landen bebben of souken maar die van de Mooren is om alleen rijck te werden en dan nae die plaatsen te vertrecken, diese of haar vaderlant, of voor heijlig houden."

2 "...to the extent that he could sufficiently express his intent in it and did not need a translator," Havart, Op-en ondergang, 2: 185. 
superiors in Batavia, with the recommendation: "of many matters never heard and worth reading." 3

As we have it, the quotation contains three points that appear as anomalies in the perspective of the "fluidity-view" on precolonial South Asia and on premodernity in general. Akkanna's statement contains hints of an idea that there were two antagonistic religious communities in Golkonda. Secondly, Akkanna seems to be expressing some sort of nationalism, of the kind for which Chris Bayly reserves the term "patriotism." Thirdly, we can see in this statement some distinction between private and public domains, in that "they" are supposed to be after personal gain, whereas "we" are after the common good. ${ }^{4}$ This study may in its entirety be seen as an effort to place the above quotation that contains so many surprises for those with a training in history.

How then should we view Janszoon's statement of Akkanna's statement? De Certeau's view of the European heterology as a one-way street is certainly unsatisfactory because it minimises the role of sensory input. The problem of how Indian views and knowledge systems were "translated" by Europeans has occupied many scholars in recent years. Mohamad Tavakoli-Targhi has pointed out the "genesis amnesia" of Orientalism, or how Europeans scholars forgot that the knowledge of the so-called pioneers of Orientalism came about in dialogue with Asian teachers. Many scholars, including Nicholas Dirks, are willing to allow only a minor role for Indians, as "informants," in the formation of colonial knowledge complexes. Recently, however, William Pinch, following Chris Bayly, has argued that ideas early modern and early colonial Europeans in India had about Indian people, customs etc. relied heavily on the substance of essentialising representations developed by Indians at both Indo-Muslim and Hindu courts. ${ }^{5}$

The idea that Europeans were so charged with discourse when they came to India that their sensory apparatus was dysfunctional is not supported by the constant comparison of sources put forward in this study. We may further cite the very insightful statement of the English private trader or interloper Alley, who witnessed a sati in Masulipatnam in 1665:

The merchants are a mixture of Moores and Banjans, some of them are men of very considerable estates, these latter sort of people puts mee in mind of a story I

\footnotetext{
${ }^{3}$ NA, Letters Hyderabad to Masulipatnam 9.9.1683, VOC 1405: 1370-3 and Masulipatnam to Batavia 7.10.1683, VOC 1387: 1567.

4 These elements feature prominently in a debate on modernity in JESHO: Peter van der Veer, "The Global History of 'Modernity'," JESHO 41 (1998) 285-94 and David Washbrook, “The Global History of 'Modernity': A Response to a Reply,” JESHO 41 (1998) 295-311.

5 Tavakoli-Targhi cited in Behl, "Ethnographer in Disguise"; Dirks, "Colonial Histories and Native Informants"; Chris Bayly, Empire and Information, 20-30; Pinch, "Same Difference."
} 
have read in Highlands Geography of a sort of women after the desease of their husbands (who are always burnt and not burried) voluntary leap in the same fire, and there consume with them to ashes, which story some 4 days since I persionally saw verifyed, by a woman who in age not exceeded 17 yeare, in person comely, bedeckt with a world of jewells, and set of for the purpose who being brought (by the Braminies, or priest with them, pyps and drums) to the place where her husband lay burning, without the least sign of dread or fear, suddanely leapt into the flames, where she with her husband in halfe an hower time were consumed to ashes, a straing kind of proofe of a womans affection to her husband. 6

In other words, a halfway educated man like Captain Alley could very well distinguish between Highland's proposition about sati and his own visual perception, and would combine the two to form an opinion ("strange"), rather than arrive with an immutable notion resistant to perception. ${ }^{7}$ Moreover, the text spells surprise at the confirmation of discourse emanating from Europe rather than a "looking for confirmation."

\section{SOME BIOGRAPHICAL DATA}

Tradition, as laid down in the texts collected by the British Colonel Mackenzie at the end of the eighteenth century, has it that Madanna and Akkanna were born to "Pengala Banooge Timayamah" or "Banoojee puntooloo" and his wife in the town of Hanamkonda in the district of Warangal. ${ }^{8}$ There were some daughters and four sons in the family, of whom the eldest was called Vessanna. ${ }^{9}$ The following piece of gossip, noted in 1682 by VOC factor Jan van Nijendaal, may provide some insight into the relation of the brothers to each other and the rest of the family: "[Akkanna] has so much influence on account of the heart of his brother [Madanna] who doesn't dare speak against him so as not to disturb his old mother who loves Akkanna especially."10

As is stated in one of the Mackenzie tracts, Madanna and Akkanna are popular forms of Madhava Bhan(u)ji and Akkarasu Bhan(u)ji

${ }^{6}$ RGS, Alley Journal sub dato 25.6.1665, 23.

7 According to Steven Pinker "the ability to entertain propositions without necessarily believing them - to distinguish 'John believes there is a Santa Claus' from 'There is a Santa Claus' - is a fundamental ability of human cognition." The Blank Slate, 215. Of course differing attitudes to authority, "communis opinio" and "conscience" have in different cultures led to varying valorisations of propositions put forward by other people.

8 BL, "The Annals of Condaved" (translation ca. 1800 of original ca. 1735), Mackenzie gen. 7: 47-109, there 47; BL, "Some Account of Akana and Madana Chief Ministers of Tanasha Badshaha of Golconda" (ca. 1800), Mackenzie unb. VII, 25: 38-45, there 38.

9 BL, "Some Account," Mackenzie unb. VII, 25: 47. For Vessana see below. Different: Abdul Majeed Siddiqui, History of Golcunda (Hyderabad, 1956) 232.

10 “Question points" answered by Van Nijendaal 3.5.1682, VOC 1378: 2038v-9. 
respectively. ${ }^{11}$ In the case of Madanna this is corroborated by a contemporary Dutch translation of a Qutb Shahi farman that ends "affirmed by Madanna's own signature...the king's beloved Madoun Bhansije."12 The popular "Madanna" is formed by attaching the Telugu suffix anna, which expresses respect, to the first part of the name. In addition Madanna used the title Pandit, as is attested by another Dutch translation. ${ }^{13}$ With this knowledge, at least ten original farmans can be definitively ascribed to Madanna. In his parwangi or authorisation of these farmans Madanna called himself either Madaw Pandit, ${ }^{14}$ or Madaw Bhanji. ${ }^{15}$ The former combination with the title "Pandit," which was a term for Brahmin priests and so emphasised his caste, he used only in two out of the ten extant original farmans.

The Telugu literary sources pertaining to the figure of Gopanna, alias Ramadas, said to be a nephew of Madanna and Akkanna, are contradictory on the matter of their sectarian affiliation, as has been pointed out by the philologist E. Vasumati. One way to resolve these contradictions seems to assume that Madanna and Akkanna were brothersin-law rather than brothers, but the (late) source that says so is unreliable. ${ }^{16}$ A better way is to assume that they were Smartas, who honour both Shiva and Vishnu as well as Surya. This would also explain the fact that in the miniature portraits in the so-called Witsen Album, which provides a snapshot of the Golkonda court in late 1677, ${ }^{17}$ Akkanna dons the

11 Mahalingam, trans. Mackenzie Manuscripts: Summaries of the Historical Manuscripts in the Mackenrie Collection (Madras, 1976) 2: 212.

12 Translated farman 18.11.1095/28.10.1684, VOC 1429: 1087.

${ }^{13}$ Translated farman Ramazan 1085/November-December 1674 in Heeres, Corpus, 2: 528-9.

14 One of these, dated Ramazan 1085/November-December 1674, is reproduced and transcribed in Bert G. Fragner ed. "Ein Privilegium aus Golkonda für die Niederländische Ostindische Kompanie," in Festgabe an Joseph Matuz, ed. Christa Fragner and Klaus Schwartz (Berlin, 1992) 57-76, but in the transcription Madaw is misread as Mallu. A fragment of the other is reproduced in G.L. Balk, F. van Dijk, D.J. Kortlang eds. The Archives of the Dutch East India Company (VOC) and the Local Institutions in Batavia (Jakarta) (Leiden, 2007) 207.

${ }^{15}$ Farmans 14.7.1085 and 25.8.1086 AH in Bharata Itihasa Samshodaka Mandala Quarterly (1932) 13, no. 3: 69-72; Farmans 18.8.1092 and 12.3.1095 AH in Yusuf Husain Khan, P. Sitapati and M.A. Nayeem, eds. and transs. Farmans and Sanads of the Deccan Sultans (rev. ed. Hyderabad, 1980) 55-7; Four farmans (not edited), dated 4.8.1087, 23.1.1088 and two 12.7.1090 AH, are kept in a separate folder marked "Tana Shah" in the APSA.

${ }^{16}$ E. Vasumati, Telugu Literature in the Qutub Shabi Period (Hyderabad, n.d. [ca. 1960]) 261-3. It is also unlikely that not one of the European sources would have noticed that they were brothers-in-law rather than blood brothers if they really had been such, while for instance Sharif ul-Mulk is always qualified as the brother-in-law of the king in the Dutch sources, as in the memoirs of Martin, and the latter [Mémoires, 2: 245] calls the governor of Onderkonda a brother-in-law of Madanna.

17 The Witsen Album miniatures and their captions are published in Lunsingh Scheurleer, "Witsenalbum." They have earlier been dated to 1686 and 1685 (see pp. 189-93), but a comparison of the summary information the portrait captions provide about the then current positions of Muhammad Ibrahim, Bahlul Khan and Sayyid Makhdum Sharza Khan to the events describe in Chapter 4 and the present chapter, suggests December 1677. 

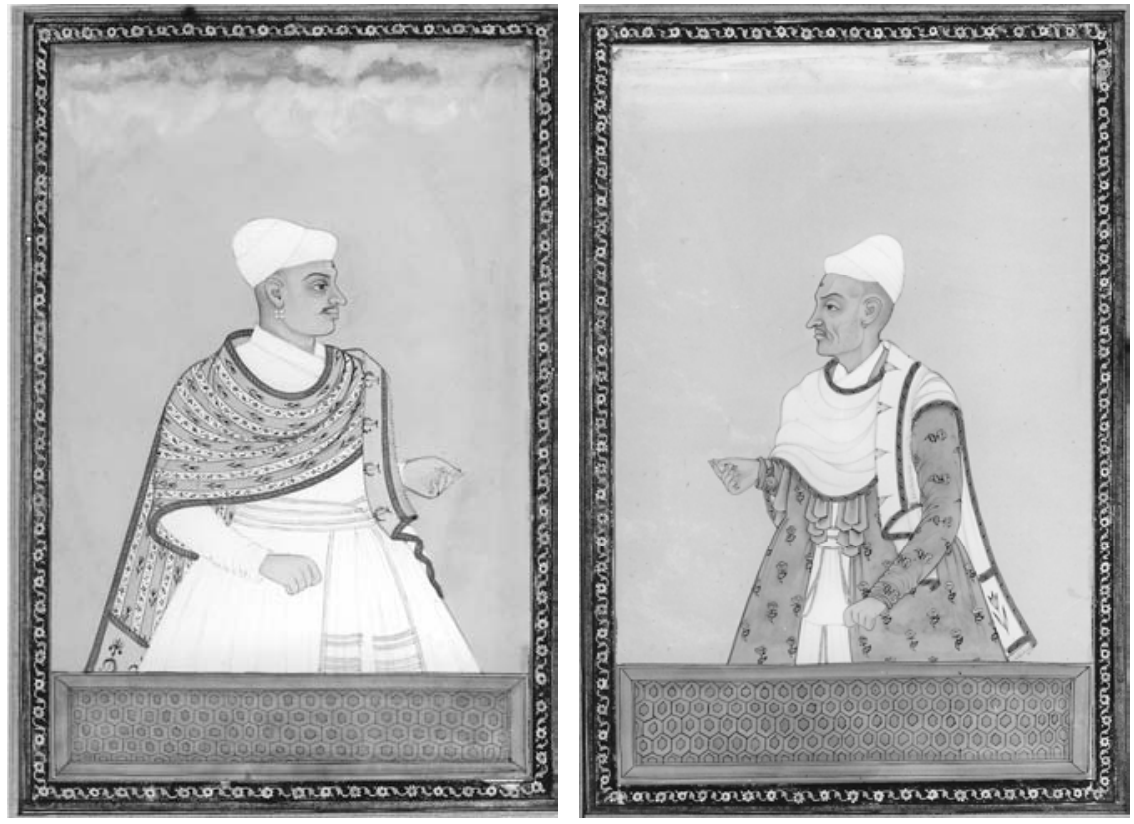

Akkanna (left) and Madanna (right) as represented in the Witsen Album, numbers 38 and 37. Courtesy Rijksmuseum Amsterdam.

horizontal sectarian marks connected with the cult of Shiva on his forehead, while Madanna's marks consist of a red dot in an ochre circle and a thin U-shaped black line, which suggests a Smarta and/or subtly Vaishnava leaning (sometimes indicated with a thick white U-shape). ${ }^{18}$ This division of religious duties between the brothers is also found in other similar contemporary miniature series, except in one where Madanna also has a Shaiva mark. ${ }^{19}$ Moreover, what seems to have been the main temple in Hanamkonda, ${ }^{20}$ the putative birthplace of the brothers, was a Smarta temple. It may have functioned as such until the conquest of Golkonda by Aurangzeb, when - as local oral tradition has it - the statues of Surya and Vishnu were removed.

Whether Madanna and Akkanna were Maratha or Telugu Brahmins has been a matter of some debate between Maharashtrian and Andhra historians. ${ }^{21}$ While their names and dress are certainly ambiguous pointers,

18 RP, Witsen Album (RP-T-00-3186); H.V. Nanjundayya and L.K. Ananthakrishna Iyer, The Mysore Tribes and Castes (Mysore, 1928) 2: 307-8; Jadunath Sarkar says the brothers were Vaishnavas. History of Aurangzib, vol. 4, (2d ed. Calcutta, 1930) 421.

19 Musée Guimet, Miniatures 35.491 (Madanna usual) and 35.499 (Akkanna usual); British Museum, Miniature album 1974-6-17-011: 23 (Madanna usual); BN, Miniature album SmithLessouëf 232: 19v (Madanna with Shaiva mark).

${ }^{20}$ Founded in 1163 by Rudradeva Kakatiya. Talbot, Precolonial India, 128.

${ }^{21}$ Compare K.V. Bhupala Rao, The Illustrious Prime Minister Madanna (Hyderabad, [1984]) 35-

9 and Gurty Venkata Rao, review of Qutbshabi of Golcondab in the Seventeenth Century, by C.V. 

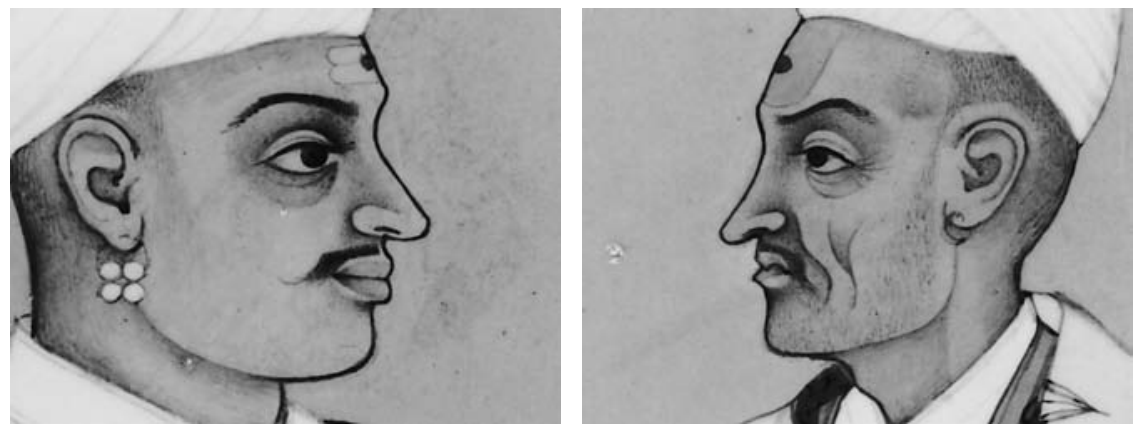

\section{Details of the Witsen Akkanna and Madanna. Courtesy Rijksmuseum.}

there are some factors that taken together seem to indicate that Madanna and Akkanna were not Telugu Brahmins. The bilingual farmans that were signed by Madanna in Persian on the Persian side, end with a date in Modi script on the side that for the remainder is in Telugu, in exactly the same style as many dates in the documents of the eighteenth-century Maratha kings of Thanjavur. ${ }^{22}$ S.R. Kulkarni points out that some records he apparently found in the possession of descendants of Akkanna and Madanna, are written in Marathi in Modi script. ${ }^{23}$ So they may have belonged to one of the branches of the Maharashtrian Brahmins, which is not to say that their family may not also have been based in the Telingana plateau for generations so that Madanna and Akkanna would have spoken fluent Telugu besides Marathi. In fact, according to Havart, Madanna was so intelligent, "that he could at a glance read out a letter written in for instance the Heathenish language in the Persian or Hindustani language, and again from those into another, in accordance with the king's pleasure or convenience." 24

Madanna and Akkanna started their career in Hyderabad in the service of Sayyid Muzaffar, who was a central figure in the government during the later reign of Abdullah (r. 1626-72) and the man who brought

Bendre, Journal of the Andhra Research Historical Society 9 (1934) 57-8; Sanjay Subrahmanyam says they were Telugu Brahmins. "Iranians Abroad: Intra-Asian Elite Migration and Early Modern State Formation," JAS (1992) 51: 358.

22 Compare Elisabeth Strandberg, ed. and trans. The Modi Documents from Tanjore in Danish Collections (Wiesbaden, 1983). The farmans in the "Tana Shah" folder in APSA (see note 34) are all bilingual (Persian and Telugu) and bear dates in this style. That it was not common practice at the time for Telugu documents to be dated in Modi or in standard Devanagari, as K.V. Bhupala Rao [Madanna, 36-7] argues, can be seen from the many Telugu documents left by Johannes Bacherus in 1693, for whose archive see Gommans, Bes and Kruijtzer, Dutch Sources on South Asia, 1: 370-7, and from a gift deed in Telugu and Persian of 26.7.1090/2.9.1679, APSA, Hazrat Banda Nawaz collection no. 56.

23 S.R. Kulkarni, "Marathi Manuscripts of Hyderabad, Their Value and Importance," Salar Jung Museum Bi-Annual Research Journal 27-28 (1990-91) 1-2. I have not been able to trace these records.

${ }^{24}$ Havart, Op-en ondergang, 2: 219. 
Abul-Hasan to the throne. ${ }^{25}$ On the seventh of January 1674 Abul-Hasan placed Sayyid Muzaffar and his sons under house arrest, apparently because he had become too powerful and had made his own house into the court. The day after his arrest the state records, accounts and treasury as well as royal carpets, tents, weaponry etc. were transported from the Sayyid's house to the royal palace. Madanna, from one day to the next, became the sultan's main representative instead of the Sayyid's. The first of the farmans signed by Madanna mentioned above is dated 14.7.1085 AH/14.10.1674 CE. In the middle of July 1675 rumours circulated "among the Moors" that the Sayyid would return to power, but these soon went away and Madanna emerged "more honoured and feared than before." 26

Finally, a fact that has caused much confusion in the historiography is the date of the murder of Madanna and Akkanna. This event is generally said to have taken place in March 1686 ever since Jadunath Sarkar suggested such based on a remark about the severed heads of the brothers in the Ma'asir-i 'Alamgiri. ${ }^{27}$ From two elaborate reports concerning the murder in the VOC archives, which will be dealt with in greater detail below, it becomes evident that the event took place in the last days of October 1685. Also, the statement in a November letter from EIC personnel in Masulipatnam that "Madanna and Accana are certainly cut off" should be taken literally. ${ }^{28}$ The precise date may well be the one given in the Mackenzie "Annals of Condaved," namely Monday 2 (Shukla) Karttika of the year Krodhana, 29 October 1685. ${ }^{29}$

\section{THE ECONOMIC CONDITIONS}

With the large-scale introduction of revenue farming, i.e. payment of a lump sum for the right to collect a certain levy or the land revenue over a certain area, the Deccan may be said to have been "ahead" of North India, where the Mughal empire still relied largely on the system of jagirs, that is land revenue assignments in lieu of payment for services. Although the difference between these two systems should not be overestimated, ${ }^{30}$ the separation of land revenue collection from military service made possible the rise of non-combatant groups in Golkonda as early as the seventeenth century, while "the rise of the men of the pen" in Hindustan is generally

\footnotetext{
${ }^{25}$ Havart, Op- en ondergang, 2: 212-3, 218-20; Khafi Khan, Muntakhab (Persian text) 312.

26 NA, Letters Hyderabad to Masulipatnam 26.1.1674, VOC 1302: 424-6v, Pulicat to Netherlands 22.11.1674, VOC 1299: 497 and Masulipatnam to Batavia 16.7 and 10.9.1675, VOC 1313: 205, 219v.

27 Sarkar, Aurangzib, 4: 420.

${ }^{28}$ BL, Letter Masulipatnam to Fort St. George 11.11.1685 (o.s.), factory records G/26/8: 41.

${ }^{29}$ BL, "Annals of Condaved," Mackenzie gen. 7: 47.

30 Subrahmanyam, "Iranians Abroad," 359.; see also Chapter 2.
} 
attributed to the eighteenth century. ${ }^{31}$ The word "ahead" is purposely used here as a reference to the perception of revenue farming as one of the mainstays of the "portfolio capitalists" who are, as the use of the word capitalists indicates, now perceived as a harbinger of some sort of modernity in the economies of seventeenth-century South and eighteenthcentury North India. ${ }^{32}$

Sanjay Subrahmanyam argues that the great influx of Iranians into the Deccan was related to their skill in administering revenue farms, and that the decrease of this migratory flow toward the end of the seventeenth century might be related to the rise of a new class of Brahmins who possessed similar skills, which they are seemingly suggested to have picked up from the Iranians. ${ }^{33}$ It may well be, however, that Brahmins and people from writer castes were always more suited to accounting and land revenue administration, undistracted by ideals of military bravery as they were (this admittedly bold generalisation will be substantiated below), and that it was other qualities that initially gave the Iranians an advantage, but later became redundant.

Firstly, it is only from this highest level of the administration that Subrahmanyam draws his examples of successful Iranian revenue farmers/portfolio-capitalists in Golkonda. Certainly the (three) men governing the major parts of the country were very much connected to the higher levels of the administration and most importantly the military, while it is possible to construe their holdings as "farms." 34 The sar-lashkars, literally "heads of the army," who governed the Golkonda Karnatak in the south and the Srikakulam area in the north, played an important role in the revenue collection of their provinces. ${ }^{35}$ The position of sar-khayl, literally "head of the cavalry" but translated by Martin as "chancellor," seems to have been connected with the revenue of the coastal area of the kingdom. ${ }^{36}$

On the supra-local level of the administration of Golkonda there seems to have been a division between policing duties and land-revenue collection - at least in the early part of the century - comparable to the division of duties on the provincial level in the Mughal empire. In

31 Compare Chris Bayly, Rulers, Townsmen and Bazaars: North Indian Society in the Age of British Expansion, 1770-1780 (Cambridge, 1983) 14-5.

32 Bayly, Rulers, Townsmen and Bazaars; Subrahmanyam, "Aspects of State-Formation," $357-$ 77.

33 Subrahmanyam, "Iranians Abroad," 357-8.

34 Compare Subrahmanyam, Political Economy, 332, "State Formation," 368-9 and "Iranians Abroad," 347-8.

35 This is clear from the many instances in which the sar-lashkears of the Karnatak are mentioned in connection with revenue arrangements of individual villages in the Mackenzie "local tracts." Mahalingam, Mackenzie Manuscripts, 2: 68, 171, 240, 241, 255-57.

36 Martin, Mémoires, 2: 245; Streyensham Master, The Diaries of Streyensham Master 1675-1680, ed. Richard Carnac Temple (London, 1911) 2: 179; NA, Memorandum Governor Pavilioen to successor 17.10.1665, VOC 1254: 695. Contrast Sherwani, Qutb Shabi, 510. 
Golkonda this division seems to have coincided with a division of tasks between Muslims and Brahmins. An early seventeenth-century Dutch account stated: "The Governors, or Farmers, are usually Brahmins or banyans, in my judgement the most crafty and cunning nation in India ... You find few Moors troubling themselves with farms or administration, except as Supervisors, [to see] that the Governors duly fulfil their obligations, and also to endeavour to benefit themselves." ${ }^{37}$ Thus while the positions generally held by Muslims on this intermediate level were no doubt rewarding, they were not "farms." It is also doubtful that Muslims and Brahmins generally did the same thing but at different levels of the administration (supra-local and local respectively), as John Richards and Subrahmanyam suggest. ${ }^{38}$ It is very well possible that the position of sarsamt was mostly held by Muslims, but the area under his discretion was probably not larger than that under a bawaldar, a position mostly held by Brahmins. ${ }^{39}$ More importantly, it appears from some notes in Havart's $O p$ en ondergang that the sar-samts were not directly involved in the land revenue collection - at least not in the later part of the century. ${ }^{40}$

During the course of the seventeenth century, the word "Brahmin" became almost synonymous with financial administration and bookkeeping, and Brahmins became indispensable to any kind of financial administration in the Deccan. In the material of the East India Companies many references can be found to "the Brahmin of so-and-so," meaning his or her bookkeeper or representative. From his 1640s Tamil-Brahmin perspective it appeared to Venkatadhvarin that the turn to accountancy was a particularity of Brahmins of the Deccan. In the section on Maharashtra of his satirical poetic travelogue, the more cynical of the two voices in the text waxes on the degeneracy of the local Brahmins-turned village accountants, and in the section on Andhra he laments: "In every village the Shudra lives like a lord / while at his side, the Brahmin-turned servant / recites his accounts [rather than the Vedas]." ${ }^{41}$ And as early as the first part of Abdullah's reign (1626-72) the Habshi minister Mansur Khan left all his official duties to Brahmins "who became all-powerful in the administration." ${ }^{42}$ By 1678 even a mosque in Hyderabad could not do

37 Dutch “Anonymous Relation” (ca. 1614) in Moreland, Relations of Golconda, 82.

38 John F. Richards, Mughal Administration in Golconda (Oxford, 1975) 22-6; Subrahmanyam, "Aspects of State-Formation," 368-9.

39 Compare Havart, Op-en ondergang, 1: 228 and Sherwani, Qutb Shabi, 511-3. For the samt or sima see: Alan Butterworth and Venugopaul Chetty, "Territorial divisions," in A Collection of the Copperplates and Stones in the Nellore District (1905; reprint Delhi, 1990) 3: 1490-3 and Mahalingam, Mackenzie Manuscripts, 2: 320, 322.

${ }^{40}$ Havart, Op-en ondergang, 2: 116-8.

41 Venkatadhvarin, La Visvagunadarsacampu, 63-69; Discussed in Rao, Shulman and Subrahmanyam, Symbols of Substance, 1-12, whence the above translation was adapted from page 7 and note 9 .

42 Ahmad, Hadiqat, quoted in Sherwani, Qutb Shahi, 507, 509. 
without a "writing Brahmin" (newishanda bahman). ${ }^{43}$

Madanna neatly fits this Brahmin-accountant mould. His father was probably involved in the revenue administration of the area around Hannamkonda, ${ }^{44}$ and some of the European sources suggest that Madanna rose to power principally because of his ability to set the kingdom's finances in order. The Dutch Governor Pits wrote in 1681: "for to furnish money and apply subtle methods to that end the Brahmins are acting the boss, and they reveal themselves to be expert masters therein and therefore it is mostly they that are used to that purpose also in the Mohammedan kingdoms, although few in such high charges and with such sovereign powers as Madanna and Akkanna." 45

In any case Madanna's principal office throughout his period in government was that of majmu'adar shabi, the king's collector or bookkeeper. This is evident from the signatures under the farmans issued by Madanna as well as the caption of his portrait in the Witsen Album. There is no evidence that his position was ever officially described as peshwa or that he held the title of Mir Jumla, as is often assumed. ${ }^{46}$ From the position of majmu'adar Madanna did, however, manage to gain control of the majority of state affairs and, most importantly, over the king's ear, as is evident from the title (also borne by his farmans) of Mahram-i Asrar-i Shahinshabi or Mahram-i Asrar-i Zill Allahi, "Confidante of the Secrets of the King of Kings/Shadow of God."

Akkanna's principal office was a similar one. From the caption of his portrait in the Witsen Album can be gathered that at that time he was shahnawis-i kull-i qalamraw-i sultan, "chief bookkeeper of the crown estate," and although he later became sar-lashkar as well (see the next section), he clearly retained that office until the end, since the inscription on the edge of his portrait in the $O p$ - en ondergang refers to both positions. Akkanna however also became a major portfolio entrepreneur, with two or three trade ships at sea in $1685 .{ }^{47}$

It appears that the brothers grew to be so powerful that the sultan was in effect pensioned off. In early 1683, news reached Aurangzeb that Abul-Hasan had entrusted his kingdom to Madanna and Akkanna (and engaged himself only in blatant vice and intoxication). ${ }^{48}$ Things seem to

43 Farman 1089/1678-79 inscribed on the mosque of Mian Mishq in Hyderabad, in Syed Ali Asgar Bilgrami, Landmarks of the Deccan (1927; photogr. reprint Delhi, 1992) 81-4.

${ }^{44}$ BL, "Some Account," Mackenzie unb. VII, 25: 38.

${ }^{45}$ NA, Letter Pulicat to Batavia 5.10.1681, VOC 1378: 1546v.

46 E.g. Siddiqui, History, 233; Sherwani, Qutb Shabi, 626.

${ }^{47}$ Lunsingh Scheurleer, "Witsenalbum," 235-6; Havart, Op- en Ondergang, 2: opposite 220; NA, List of ships arrived at Pulicat 10.10.1683, VOC 1405: 1356v and Letter Akkanna to Linganna 20.9.1685, VOC 1411: 482v-4.

${ }^{48}$ Khafi Khan, Muntakbab (Persian text) 292-3. The advent of the news, according to Khafi Khan, coincided with the escape of the Mir Hashim, a son of Sayyid Muzaffar, which can be 
have come to a point where the sultan had to go to Madanna's house to ask for money. Five such visits were noted in the VOC records over the period April-September 1683, along with the items Abul-Hasan received on the visits. ${ }^{49}$ In September 1685 it was rumoured in Masulipatnam that the sultan had absolutely no say in state matters anymore, and that he had transported everything, including the royal seal, to Madanna on the condition that he receive 150,000 rupees a month. ${ }^{50}$ This seems to be the basis for Martin's statement that Madanna took the revenue collection of the whole kingdom in farm (en ferme). ${ }^{51}$

Though Madanna may have been a product of the revenue farming system, as soon as he had the power he started to turn it about. Havart, who was employed at the VOC factories in Hyderabad and Masulipatnam during Madanna's rule, wrote:

The bawaldar (or the overseer) used to take Masulipatnam with its subordinate lands in farm, for some hundred and fifty thousand ducatons a year, which he had to furnish, whatever the income, failing which he would be incredibly pestered, beaten or even killed. In the year 1676 Mister Madanna has introduced another practice. Now the hawaldar is on a salary, he has twelve hundred ducatons a year, free cost, free servants, and pomp and circumstance, and then so much inspection that he would not be able to embezzle so much as a penny; whatever he is honoured with in a concealed fashion/unofficially [onder den hand] is his, but whatever is given to him openly, comes to the royal treasury. 52

Although it is not clear to what extent these reforms were implemented, the fact that they were on some scale is confirmed by the Mackenzie tract called "Some Account of Akana and Madana," which stated that Madanna and Akkanna managed the revenue affairs "of different Soobas for every village" in amani, that is collection of the revenues without (too many) intermediaries..$^{53}$ In the spirit of Madanna's reforms the distinction between private and public domains, between personal gain and the duties of office, which was noted in Akkanna's words quoted at the outset, is markedly present.

As has been noted in Chapter 2, such revenue reforms had been part of the patriotic programme in the Deccan since the days of Malik

dated to March 1683 from its description in the VOC archives. NA, Letter Masulipatnam to Batavia 13.8.1683, VOC 1387: 1409-10.

${ }^{49}$ NA, Letters Masulipatnam to Batavia 13.8 and 7.10.1683, VOC 1387: 1411v, 1563v-4v.

50 “Novelles" Masulipatnam September 1685, VOC 1411: 216v.

${ }^{51}$ Martin, Mémoires, 2: 36.

52 Havart, Op-en ondergang, 1: 225. The obligation to pass on the large public presents (probably peshkash) as opposed to the small private (onder den hand) presents (probably na:r) is also referred to elsewhere by Havart [Op-en ondergang, 2: 201]. Streyensham Master says about a sum of ready money presented to the Governor of Masulipatnam privately (in 1679) that it "will be much more acceptable then a greater sum publicly." Master, Diaries, 2: 156.

${ }^{53}$ BL, "Some Account," Mackenzie unb. VII, 25: 41v. 
Ambar, and a brief comparison with Shivaij's rule in this respect is in order here. In what Stewart Gordon calls the most discussed paragraph in Maratha history, found in Sabhasad's bakhar, it is stated that Shivaji dispensed with the system of land revenue assignments and also broke the power of the zamindars by making direct arrangements with the village headmen. According to Gordon such could only have been the case for central Maharashtra and not for the more outlying areas of Shivaji's realm. ${ }^{54}$ But the following quotation, another heterology from the VOC-archives, seems to confirm that even as far as the Savantvadi area adjacent to Goa, Shivaji's influence was felt in this respect. The narration by Dev Savant, one of the five Savant zamindars who revolted against Sambhaji in early 1685 (see Chapter 4) gives an interesting insight into how the zamindars experienced Shivaji's rule:

Having sat down [in the Dutch lodge in Vengurla] and having a conversation with him, he narrated that they had not started this work of rebellion without good reason, since they were people whose ancestors in the [Savant] lineage had in olden days governed as freelords in the provinces Coudewaer [Kudawar?], Phonda, Bicholim, Kudal and Rajapur and enjoyed the revenues thereof, as long as they paid their annual quota to the king of Bijapur as their overlord, who than placed his Moorish governors in these lower regions and provinces, in order for everything to function as it should, but with the rise of Shivaji and his conquest of these lower regions, all their freedoms and profits had been withheld from them and they were only given such income - mainly in times of emergency — as Shivaji and his son or successor Sambhaji considered fit. From that time onwards they had been powerless to maintain their right, but now in this juncture when Sambhaji is being cornered by the Mughals to such extent, their intent was to catch up on the arrears and to harm Sambhaji as much as was in their power..$^{55}$

\section{THE FACTIONS}

The social transition manifested itself first of all in a factional struggle at court, where the opposition of the Brahmin faction to the Muslim or Iranian faction took the place of the traditional opposition between Deccani and Foreign Muslims. Most of the twentieth-century writings on Golkonda's history note the replacement, during the rule of Madanna and Akkanna, of a number of Muslims in administrative positions with Brahmins. ${ }^{56}$ This started immediately after the rise to power of Madanna, which seems to be the reason why Martin and the Director-General of the French Company, François Baron, apply the term "revolution" to the

\footnotetext{
${ }^{54}$ Gordon, Marathas, 84-6.

${ }^{55} \mathrm{NA}$, Narrative by Lindsaij of occurrences at Vengurla 28.2.1685, VOC 1416: 1460v-3.

${ }^{56}$ For instance: Sherwani, Qutb Shahi, 627-30 and Richards, Mughal Administration, 40-3.
} 
event. ${ }^{57}$ But the struggle became more acrimonious in the later years of Madanna's administration.

We must return briefly to Madanna's intensive involvement in Bijapur politics that was seen from the Maratha angle in Chapter 4. Madanna's involvement seems to have started with a campaign to support Abdul-Karim Bahlul Khan in the summer of 1676, when the Mughal forces came to get him for the murder of Khawas Khan in (see Chapter 4). Madanna seems to have personally led this campaign together with Muhammad Ibrahim, but Madanna returned early and was received with much prestige (too much according to the grandees informing our Dutch source). After Abdul-Karim aligned himself with the Afghans in the Mughal force, and the Deccani nobles of Bijapur broke away, Madanna supported the Deccani faction. ${ }^{58} \mathrm{He}$ seems to have heeded Shivaji's call to keep the Deccan in Deccani hands, as has been discussed in Chapter 4. According to an overview of the income and expenditure of the Golkonda treasury for the year 1676-77, which seems to have been drawn up by a Mughal spy, both the "men of the Maratha Shivaji" and "the men of Bijapur" received financial support from Golkonda in that year. ${ }^{59}$ During and after his visit to Hyderabad in March 1677, Shivaji was showered with

\footnotetext{
57 Baron quoted in Adrian Duarte, "An Estimate of Madanna from the French Records," Journal of Indian History 12 (1932) 300; Martin, Mémoires, 2: 19; J. Ovington also uses the word "revolution" but has left the factional struggle out of his story, clearly in order to portray the king as the prime mover, for the account by Ovington, who was Chaplain to King William, appears to be firmly rooted in the European "mirror for princes" tradition. J. Ovington, "The History of the Late Revolution in the Kingdom of Golconda," in A Voyage to Suratt in the Year 1689 (London, 1696) 525-52.

${ }^{58}$ NA, Letter Pulicat to Batavia 2.2.1677, VOC 1324: 484v-5; Bhimsen, Tarikh, 111.

59 This is the document translated by Sherwani in History of the Qutb Shabi Dynasty, 655-6, and by Bhupala Rao in Madanna, 224-31. There are, however, two problems with these translations. Firstly, "Bijapur" should be read where the translations have "Tuljapur," and secondly the year given on the budget should be interpreted as 1676-77, not 1685-86. The date given on the one extant copy of this document is $1097 \mathrm{AH}$, corresponding with November 1685-October 1686, cannot be correct, for two of the recipients of funds mentioned in it were dead by that time. Shivaji died in 1680, Shah Raju II, the pir of AbulHasan died before May 1682 (compare NA, Question points answered by Nijendaal 3.5.1682 VOC 1378: 2039 and contrast Bilgrami, Landmarks, 74-5, who has 1684). I am therefore presuming that the date on the copy is a case of "hypercorrection" on the part of the scribe. As may be seen in Madanna's farman that is now in Berlin and Havart's note on it (Op-en ondergang 3: 11 note 4), there was a system of accounting (daftari) years in use in the Deccan, which antedated the actual year by ten. Assuming that the scribe was aware that such a system of antedating was in use in Golkonda, we may speculate that he post-dated the document by ten years, but that the operation was unnecessary, as the original did not use the daftari system (it seems likely from the heading where Golkonda is referred to as a "suba of the dar ul-jibad," that the original was a Mughal spy's report). Thus we arrive at the year $1087 \mathrm{AH}$ as the correct date, that is March 16, 1676 through February 4, 1677. Salar Jung Museum, History Ms. 327 (cat. nr. 377): 241-3. Sabhasad's bakhar also clearly stated that the Qutb Shah was already paying Shivaji before his visit to Hyderabad. Sen ed. Sabhasad Bakhar, 118-20.
} 
gold, as was described in Chapter 4.

The disappointment at the Golkonda court over Shivaji's keeping all his Karnatak conquests to himself seems to have brought about a change in Madanna's policies, however, and Madanna's preferred tactic became keeping the Mughals content with money instead of fighting them. This policy became most pronounced in the years that Madanna's power reached its zenith. When a Mughal army under Bahadur Khan loomed close to Hyderabad in 1683, this hardly caused any concern in that city according to the VOC personnel:

In Golconda [Hyderabad] no special preparations are made except that the castle, which has become very dilapidated since [the start of] the reign of the present king, is being stocked up with some provisions, the daft Brahmins do not know of any military affairs, they let all bounce on the purse and know how to deflect all wars with money and blindfold the rulers, as can be seen from the substantial amounts of money that have been sent to Aurangzeb over a short period. ${ }^{60}$

The money sent over the months of March through July amounted to 855,000 rupees, plus a load of mangoes with the last instalment (Aurangzeb was very fond of mangoes - or so it appears from one of his letters to Bidar Bakht — and perhaps Madanna had knowledge of this proclivity). This amount was sent over and above the enormous annual peshkash remitted to the emperor. ${ }^{61}$

The war with the Mughals, or the dilemma of whether or not to fight, seems to have become the main issue on which the discord between the two factions centred. A measure of the vicissitudes of the struggle between the parties at the Golkonda court and its relation to the war issue was the position of Muhammad Ibrahim. He was originally appointed sarkhayl by Madanna, but in 1676 was "promoted" (the Dutch personnel doubted whether such could be called a promotion) to the position of sarlashkar of the Karnatak. In 1677-78 he was fighting the war against the Mughals as (general) sar-lashkar and in 1682 he was again demoted to the position of sar-khayl, which he remained until his defection in late October 1685. ${ }^{62}$ In 1683, however, rumours circulated that he would again be

${ }^{60} \mathrm{NA}$, Letter Masulipatnam to Batavia 13.8.1683, VOC 1387: 1415.

${ }^{61}$ Ibidem 1412v-3; BL, Letters Aurangzeb to Bidar Bakht [ca. 1706] in Inayatullah Khan ed. Abkeam-i 'Alamgiri Ms. I.O. Islamic 3887: 87, 89. Although the peshkeash was set at 200,000 hons in 1636, the amount seems to have increased to 5,000,000 rupees (ca. 650,000 old hons) in the period of Madanna. Compare Sherwani, Qutb Shabi, 436, 656. The amount of $16,222,278$ rupees cited by Richards as arrears on the peshkeash in 1687 would thus amount to not much more than three years' payments, and to say that "Abul Hasan had paid little that was not forced from him" is stretching the point somewhat. Richards, Mughal Administration, 48 note 2 .

${ }^{62}$ NA, Letters Masulipatnam to Batavia 23.3.1676, VOC 1320: 666v, Masulipatnam to Batavia 13.8.1683, VOC 1387: 1411, Hyderabad to Masulipatnam 7.12.1685, VOC 1411: 


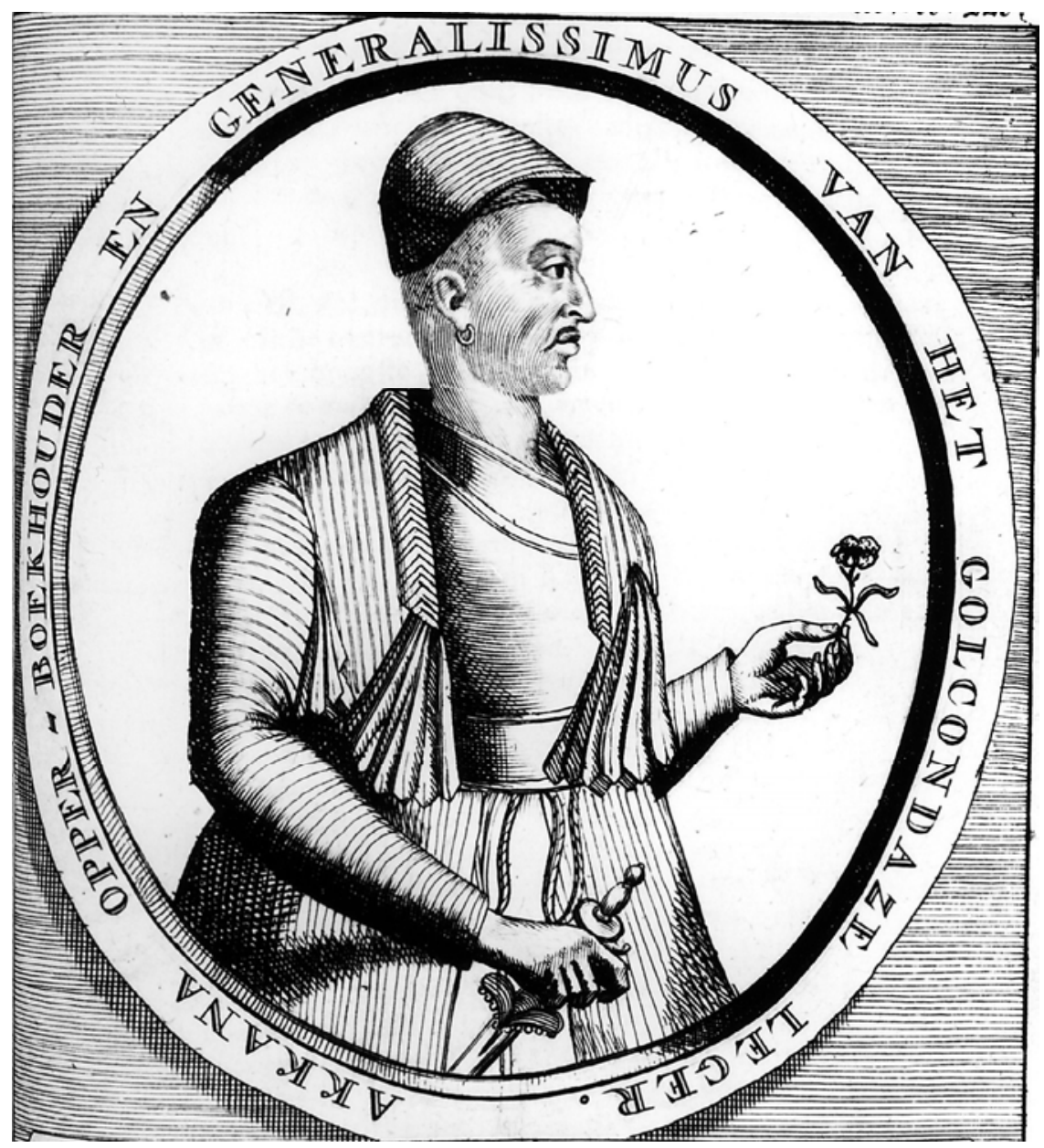

Portrait of Akkanna with sword in Havart's Op- en ondergang, 2: opposite 220. Courtesy Leiden University Library, catalogue number 456 B7. Compare the posture of Khawas Khan in the miniature shown on page 79.

invested with the supreme command in order to take the army to the border and stave off an invasion by the Mughals. "But," as the VOC personnel commented, "these are some promises, of which the fulfilment has yet to be seen, or rather is unlikely to be seen, as long as the Brahmins Madanna and Akkanna rule." 63

In 1682, in what seems to have been a move to forestall any warlike behaviour by the army, Akkanna was appointed sar-laskar instead of

610; Madras factory records 17.5.1682 (o.s.), cited in Sarkar, Aurangzib, 4: 421; and see note 37.

${ }^{63}$ NA, Letter Masulipatnam to Batavia 13.8.1683, VOC 1387: 1411v. 
Muhammad Ibrahim. ${ }^{64}$ Hence, Akkanna can be seen with a sword in his picture in Havart's Op-en ondergang, whereas such an attribute is absent from his $1677 / 78$ picture in the Witsen Album. Havart comments that Akkanna held the position of sar-lashkar "despite the fact that he was as capable of handling the sword as the iron is capable of swimming, and he had never seen a battle except in a painting." 65 Madanna's cousin Yenganna, entitled Rustam Rao, was also appointed to a high position in the army. ${ }^{66}$

In these later years, Madanna could, in the words of Havart, "truly pass for a good Golcondan politique," 67 that is, a civilian administrator as opposed to a military one, as well as "a skilful and fine man, who knows how to achieve his goal and to adjust to the times." 68 The word politique was, moreover, connected with those subordinating religion to considerations of the state during the Dutch Revolt. ${ }^{69}$ In 1684 Abul-Hasan even ridiculed Madanna's politique behaviour. The occasion was an impromptu attempt by Abul-Hasan to put on an elephant fight while he was taking leisure in his Lingampalli garden with his harem (vrouwenhuijs). The Mughal ambassador, however, threatened to leave the city and notify Aurangzeb, for elephant fights were an imperial prerogative that was jealously guarded by Aurangzeb, ${ }^{70}$ when:

Madanna also tried to induce the king to refrain therefrom, since it could create great trouble, over which the king, annoyed, said to his grandees in order to ridicule Madanna: "I see that Madanna is a good Mughal ambassador," upon which Akkanna brought his majesty in a better temper... and immediately arranged everything necessary for the fighting in his own garden, and requested the king to agree to have it there. Meanwhile his master of ceremonies Samanna satisfied the ambassador with a gratuity of 5,000 rupees and thus it took course, without further objection. ${ }^{71}$

The attitude of co-operation and non-aggression toward the Mughals did not, however, bring about an alliance between the Brahmin faction and the Mughals. On the contrary, the Brahmins in the city feared the power of the Mughal ambassador. At the hour when the ambassador, at the order of Aurangzeb, liberated Sayyid Muzaffar from his house arrest in March 1683,

${ }^{64}$ Madras factory records ,17.5.1682 (o.s.), cited in Sarkar, Aurangzilb, 4: 421.

${ }^{65}$ Havart, Op-en ondergang, 2: 219-20.

${ }^{66}$ ERS, Letter "Vira Ragavaya" to William Langhorne 19.9.1677 (o.s.), 2: 137; Shah Nawaz Khan and Abdul-Hayy, Ma'asir ul-Umara', trans. H. Beveridge and Baini Prashad (reprint Delhi, 1979) 2: 7.

${ }^{67}$ Havart, Op-en ondergang, 2: 220.

68 Dictionnaire de L'Academie française, (Paris,1694) s.v. politique; available from http://www.lib.uchicago.edu/efts/ARTFL/projets/dicos/.

${ }^{69}$ Woordenboek der Nederlandsche Taal, s.v. politiek. Israel, Dutch Republic, 96, 205.

${ }^{70}$ Hamid ud-Din Khan Bahadur, Abkam-i 'Alamgiri (translation) 57.

${ }^{71}$ NA, Letter Hyderabad to Masulipatnam 26.4.1684, VOC 1405: 1610v-1. 
no Brahmin ventured into the street. ${ }^{72}$ Two years later, when a Mughal army under Aurangzeb's son Shah Alam approached the city, their fears proved well founded.

At that time, according to Havart, Madanna and Akkanna left their town houses to take refuge in the fortress, where they were killed by Sidi Makta and some other slaves at the order of "an old woman." The account of Khafi Khan is more or less the same. While on their way home from the darbar, the brothers were killed by one Jamshid and some other slaves. According to him, the murder was commissioned by Saruma and Jani Sahiba, who wielded supreme power in the palace and had been the main wives of Abdullah (and thus must have been of considerable age). VOC sources refer to Sidi Makta as a Caffer (African) or more specifically, an Abasinse Kaffer, who had been offended and/or removed from some office by Madanna a year earlier. ${ }^{73}$ Havart and Khafi Khan further agree that Abul-Hasan was not informed of the scheme beforehand, ${ }^{74}$ and that the heads of Madanna and Akkanna were sent to Shah Alam. ${ }^{75}$

On the day that Madanna and Akkanna were murdered "many" Brahmins lost life and stock. ${ }^{76}$ According to the report of the VOC personnel in Hyderabad, some twelve prominent Brahmins lost their lives in the ensuing tumult. The report of the peon "Dauwelsu" said that there was plundering in Hyderabad spreading as far as Almaspet some fifty kilometres down the road to Masulipatnam, "but only among the Brahmins." "Talenkie Wenkana" and "Sastoegan," two other peons in the service of the VOC, reported: "that some Brahmins around Almaspet have been robbed of their goods and lives, some have fled from Golconda [Hyderabad], and some Brahmins that were in the government have here

72 NA, Letter Masulipatnam to Batavia 13.8.1683, VOC 1387: 1410.

73 NA, Letter Hyderabad to Masulipatnam 7.12.1685 and letter "Talenkie Wenkanna" and "Sastoegan" to Masulipatnam received 5.11.1685, VOC 1411: 252, 607v-8v; Daily record of Masulipatnam sub dato 8.3.1686, VOC 9720 (unfoliated).

${ }^{74}$ The sources can be divided in two equal portions over this issue. Half are of the opinion, or suggest, that the sultan was actively involved or knew about the murder beforehand, while the other half believe that the sultan was bypassed. In the second group come, apart from Havart and Khafi Khan, Bhimsen, the eighteenth-century "Annals of Condaved," and the report by the Dutch factors in Hyderabad (see below). In the first group come Manucci, Musta'id Khan and the report by "Dauwelsu" (see below) as well as Iswar Das (cited by Krishnaswami Aiyangar) and the very late "Some Account." A balanced view is provided by Martin and his source Guesty, who asserted that it was not known whether the sultan consented to the old lady's command. Bhimsen, Tarikh, 148; BL, "Annals of Condaved," Mackenzie gen. 7: 48; Manucci, Storia do Mogor, 2: 274-6; Musta'id Khan, Ma'asir-i 'Alamgiri, 167; S. Krishnaswami Aiyangar, "Abul Hasan Qutub Shah and His Ministers, Madannna and Akkanna," Journal of Indian History (August 1931) 138; BL, "Some Account," Mackenzie unb. VII, 25: 43; Martin, Mémoires, 416; BN, Letter [of Mr. Guesty] Hyderabad 20.4.1686, Collection Clairembault 1017: 69-v.

${ }^{75}$ Havart, Op-en ondergang, 2: 224. Khafi Khan, Muntakbab (Persian text) 308.

${ }^{76}$ Khafi Khan, Muntakbab (Persian text) 308. 
and there, where they were fleeing, been locked up by the regents and hawaldars of those places." 77

These events are clearly related to the advent of the Mughal army. One of the conditions offered for peace by Shah Alam was according to Khafi Khan: "making powerless and imprisoning Madanna and Akkanna, which two brothers were the cause of the mean rebellion [ fasad] of the inhabitants of Hyderabad." Havart describes the two as "the Misters brothers Madanna and Akkanna, against whom the Mughals were extremely embittered, and to whom they ascribed the cause of the war." ${ }^{\prime} 8$ The enormously expensive temple complex devoted to Shiva that Akkanna had built at Maheshwaram, 27 kilometres south of Hyderabad, was one of the first buildings to be destroyed when Shah Alam came to town, an event which confirms Richard Eaton's thesis that temple destructions by Muslim invaders generally concerned temples with a strong connection to ruling figures. ${ }^{79}$ Although the immediate cause for the murder of the brothers themselves may have been high treason on their part (as will be discussed below), clearly some disaffected elements in Golkonda society saw a chance to dispossess the Brahmin faction on the approach of the Mughal forces.

However, VOC sources show that after the departure of Shah Alam, little over a month after he arrived, Abul-Hasan took matters in hand and the Brahmin faction managed to regain power. This sequence of events is reflected in the "Annals of Condaved," where "the slaughter of the bramins" by the "mhlechmaloo" (mlecchas, i.e. Muslims) is said to have been terminated by Abul-Hasan as soon as he awoke from the stupor of a drink administered to him by a lady of the harem, after which he put a surviving Brahmin, Persupati Venkatadri, at the helm..$^{80}$ Several Brahmins came to the foreground in the period from November 1685 to October 1686. Initially Persupati Venkatadri became the prime mover at the court alongside a certain Venkarapiti, who was appointed majmu'adar to replace the murdered Madanna in exchange for 100,000 hons. In April 1686, however, Vessanna, the eldest brother of Madanna, was invested with the dignities formerly

\footnotetext{
77 NA, "Oral report by one of the Company's peons named Dauwelsu" 6/7.11.1685, VOC 1411: 254v-6; Letter "Talenkie Wenkanna" and "Sastoegan" to Masulipatnam received 5.11.1685, VOC 1411: 252.

${ }^{78}$ Havart, Op-en ondergang, 2: 224; Khafi Khan, Muntakhab (Persian text) 308.

${ }^{79}$ NA, Letter Hyderabad to Masulipatnam 7.12.1685, VOC 1411: 607v; Daily record of mission to the court, sub dato 6.4.1686, VOC 1424: 983, 988; Havart, Op- en ondergang, 2, 223; BL, "Some Account," Mackenzie unb. VII, 25: 43v-4v; Eaton, “Temple Desecration," 283319; A plan of the buildings is in S.P. Shorey, In Search of Monuments: An Atlas of Hyderabad's Protected Monuments (Hyderabad, 1993) 76. The only inscriptions left at the site are the sixteen names of Shiva, in Telugu script, around the tank.

${ }^{80}$ Literally the account says that he was appointed "deewaunee of his revenues" by AbulHasan, but see the next lines. BL, “Annals of Condaved," Mackenzie gen. 7: 48-9.
} 
belonging to Madanna after he had donated 200,000 hons. ${ }^{81}$

THE InVOLVEMENT OF THE EUROPEAN NATIONS AND THEIR RENEGADES IN THE FACTIONAL STRUGGLE

Immediate upon Madanna's coming to power, Martin claims, the Dutch gained his favour and prevented other Europeans (or at least the French) from getting anything done at court. No sooner had the French taken San Thome (whence Golkonda had ousted the Portuguese earlier) to establish their headquarters there than the VOC and Golkonda united to oust them, which was accomplished in October 1674. This was, we should remind ourselves, only two years after Louis XIV had invaded but failed to take the Dutch Republic. But while the French, who had betaken themselves to English protection in Chennapatnam, received a proposal from a Brahmin to arrange a settlement with the sultan for them to be allowed to settle in San Thome in exchange for 100,000 hons, the VOC factors wrote a letter to Madanna requesting the complete destruction of the town. The letter was drawn up with the aid of Muhammad Ibrahim and commenced: "That Mirza Ibrahim was a very experienced and sensible person, who has made 19 sea voyages, and knew all Christian nations well and was completely aware of the situation of San Thome..." The sultan was sufficiently impressed by the letter to order the immediate destruction of San Thome, which was indeed effected in late 1675, not sparing its monumental Catholic church devoted to Saint Thomas. The Dutch even offered to assist in its demolition according to Martin. While it is significant that the Dutch called in the help of the Iranian Muhammad Ibrahim, this does not mean that their relations with Madanna were bad, as the struggle between the Muslim and Brahmin factions at court was yet to peak and this was before Muhammad Ibrahim's first demotion. ${ }^{82}$

The first glitch in the good relations between the Brahmin ministers and VOC representatives came in 1683 when there was a quarrel between the second factor of Hyderabad, Theunis Carstensz, and Akkanna. This quarrel involving Carstensz had been stemmed by the time Janszoon had the secret interview with Akkanna, no doubt owing to the diplomatic skills of Janszoon, who was contrasted to Carstensz and described as "sensible" by Akkanna in a letter to the zamindar Madappa concerning the quarrel. ${ }^{83}$ The major fall out came in July 1685 when the factors in

\footnotetext{
81 NA, Letter Hyderabad to Masulipatnam 7.12.1685, VOC 1411: 624v-5; Extract of daily record of the journey to the court, sub dato 21.4.1686, VOC 1423: 493; Daily record of the journey to the court, sub datis 31.3 and 7.4.1686, VOC $1424: 976 \mathrm{v}, 989 \mathrm{v}$.

82 Martin, Mémoires, 2: 7-25. NA, Letter Hyderabad to Pulicat 12.8.1675, VOC 1313: 223v-4v.

83 NA, Letter Akkanna to Madappa 27.4.1683, VOC 1405: 1334-6v; NA, Letter Masulipatnam to Batavia 13.8.1683, VOC 1387: 1408v-9. An example of Janszoon's
} 
Hyderabad accused Akkanna of having illegitimately extorted goods (mainly copper) worth a stunning 145,030 hons. This accusation was believed by the superiors in Pulicat and Batavia - and hence it has found credence with the twentieth-century historians Tapan Raychaudhuri and, to a lesser extent, Sinnappah Arasaratnam — ${ }^{84}$ until April 1686, when at the end of a mission which failed to obtain compensation from the sultan, some documents were discovered in the house of the Hyderabad-based merchant Chodenda, who had played a central role in the affair. ${ }^{85}$ The letters revealed that it was in fact the Dutch factors at Hyderabad Jan van Nijendaal, Carstensz and Janszoon who lost the money in successive private trade enterprises. At that point, however, it was too late and the Company felt compelled to go to war with Golkonda to save face. The fact that Akkanna was not to blame had to be concealed, especially from the English, to whom the highest body of the VOC felt compelled to justify the actions against Golkonda. This seems to have been one of the secrets of the Company that neither Daniel Havart nor for that matter Pieter van Dam or François Valentijn were allowed to reveal in their books. ${ }^{86}$ Another reason for Havart to conceal the truth - and Governor Joris Pits hardly doubted that he was aware of the true circumstances - was his close relation with his father-in-law Jan van Nijendaal and the Van Nijendaal family. Similarly suspect are all statements about Akkanna and Madanna made by Janszoon, Carstensz, Chodenda and Havart's patron Willem Carel Hartsinck after July 1685 , when the accusation was invented. ${ }^{87}$

After the death of the brothers in October 1685 the VOC became very much involved in the factional struggle at court. The Muslim faction seemed willing to give in to the demands of the VOC concerning the 140,000 hons that the VOC alleged had been stolen by Akkanna, while the

diplomatic skills was his effort to greet Shah "Alam "in the way of the land," while Europeans normally insisted on greeting in the less humble European style. NA, Letter Hyderabad to Masulipatnam 7.12.1685, VOC 1411: 620.

${ }^{84}$ Raychaudhuri, Jan Company, 68-70. Arasaratnam is somewhat more sceptical of the role of the Dutch, but his assertion that Akkanna protected Chodenda from the Dutch is unfounded. Sinnappah Arasaratnam, Merchants, Companies and Commerce on the Coromandel Coast 1650-1740 (Oxford, 1986) 70.

85 Martin, Mémoires, 2: 19, 241, 385-6, 405; NA, Letter Hyderabad to Masulipatnam 12.7.1685, VOC 1411: 181v-8v; "Calculation of what has been extorted from Chodenda" 6.2.1686, VOC 1411: 663-4; Translations of letters found at Chodenda's house, only one of which is dated (6.10.1094/28.9.1683), and of a farman of Abul-Hasan 18.11.1095/ 27.10.1684, VOC 1429: 1084v-7.

${ }^{86}$ Havart mentions promising not to reveal any Company secrets as a condition for access to the VOC archives in the introduction to his $O p$ - en ondergang.

87 NA, Letter Pulicat to Batavia 27.6.1686, VOC 1429: 1057v-81v; Pieter van Dam, Beschryvinge van de Oostindische Compagnie, ed. F.W. Stapel (The Hague, 1927-39) vol. 2, pt. 2: 165-8; François Valentijn, Oud en Nieun Oost-Indiën (Dordrecht, 1724-26) 5: 67; Havart, Open ondergang, 2: 154-64, 187-90; Havart, Persiaansche secretaris, "Opdracht" (dedication). 
Brahmins remained intransigent. ${ }^{88}$ When a large delegation of the VOC arrived in Hyderabad to voice the complaints in March 1686, Mir Husaini Beg, who had been appointed sar-khayl after the defection of Muhammad Ibrahim, intimated that he "had always been a friend of the Company, and would not presently fail to be of help to the Mr. Commissioner in everything that he might require of him, also that he, if the times had not thus changed and the Moorish [government] been transformed into a Brahmin government, would have invited the Mr. Commissioner for dinner a day after his arrival and provided him with robes of honour and all pleasures." 89

In October 1686, some months after the VOC had gone to war over the issue and occupied Masulipatnam, Mir Husaini Beg was invested with the "whole government" as well as the governorship of a large part of the coastal regions, and Vessana and the other Brahmins were made responsible to him. The day after his investiture he called for the factors of the VOC and promised to pay their minimum demand of 50,000 hons although he too remained convinced that the Dutch demands were illegitimate. Abul-Hasan sent a farman in which he intimated that he had changed the government in order to placate the Dutch, but the factors in Hyderabad doubted "whether this is not more to please Aurangzeb who indeed is an arch-enemy of the Brahmins." The merchant Chodenda also expressed the opinion that the sultan had installed Mir Husaini Beg for fear that Aurangzeb might discover that the Brahmins were still in government. ${ }^{90}$

The other European nations seem to have been less involved in the party struggle at court, but an incident in the autumn of 1683 involving the EIC and an English private trader illustrates that the party struggle at court reached down to the local level of administration. When the private trader Captain Alley, whom we saw observing a sati above, tried to establish a trading post at Devarampatnam, the EIC factors at Petapoli requested governor Haidar Khan of the district, which fell under Muhammad Ibrahim, to remove these "interlopers" and paid him a substantial sum to do so. Haidar Khan duly removed Alley's party from Devarampatnam, but Alley applied to the officials of an adjacent district that fell under Akkanna and requested that the jurisdiction over Devarampatnam be transferred from Hydar Khan to one Sinkarappa. The issue came to a head at the court

\footnotetext{
${ }^{88}$ NA, Letter Masulipatnam to Batavia 29.8.1686, VOC 1429: 1102v-3.

89 Daily record of the journey to the court, sub dato 31.3.1686, VOC 1424: 966v. Havart quotes this passage with slight variations. Havart, Op- en ondergang, 2: 156.

90 NA, Letter from the Armenian merchant 'Choodja Abenous' 6.10.1686, Letter from the factors at Hyderabad 5 and 7.10.1686, translated farman of Abul-Hasan 18.11.1097/7.10.1686, Letter from Chodenda 6.10.1686 and notes of Laurens Pit, all inserted in daily record of Masulipatnam, VOC 9720 (unfoliated) sub datis 11 to 14.10.1686.
} 
and Muhammad Ibrahim was said to have written to Haidar Khan:

that the interlopers had made application to Accana, Madonas brother and offered him 21,000 pagodas [hons], to Syncrapa 5,000, and to Tattoraz governor of Ammonamole 1,000, to procure a phirmaund [farman] from the king for their settlement and farther that the cirkell [Muhammad Ibrahim] had earnestly besought Accanna, not to befriend the interlopers at all, or if hee would not consent to that, yet not permitt them to settle in his government, whereto Accanna answered there was no reason the king should loose so much profitt.

The end of the matter was that the interlopers were allowed to settle in a village within the district of Haidar Khan in exchange for the payment of 21,000 hons into the royal treasury and another 5,000 to Muhammad Ibrahim. ${ }^{91}$

\section{THE SOCIAL IDENTITIES}

There was thus clearly a conflict between two social groups, both relatively elite, in Golkonda in the 1670s and 1680s. The conflict was a "realistic" conflict in the sense that it was a competition for real power and real resources (the revenue), but as the psychologists Tajfel and Turner have pointed out, an unequal division of status, power or resources does not by itself cause social conflict (N.B. in the twentieth century). Necessary preconditions are also that the people in the lower status group identify strongly with their "in-group" and see the higher status group as a relevant comparison group. Identification with the "in-group," has further been shown in various psychological experiments (on twentieth-century Western people) to increase when the hierarchy of two groups (a) is unstable, (b) is perceived as illegitimate and (c) when the objective and subjective prohibitions to passing from one group to the other are strong. ${ }^{92}$ While it appears clearly from the previous sections that the hierarchy between the two competing groups in Golkonda was very unstable, and from Akkanna's statement quoted at the outset of this article that the new hierarchy was perceived, by him at least, as more legitimate than the pre-revolution hierarchy, the third factor remains to be determined. Where exactly were the boundaries between the in-group and the out-group and how inclusive were these groups in the perception of Madanna and Akkanna? To what

${ }^{91} \mathrm{BL}$, Petapoli consultations in datis 7.8, 1-12.9, 25.10 .1683 and 15.8.1684, G/30/1: quire 1: 58-9, 62-5, quire 2: 22 (quotation sub dato 25.10); Letters Petapoli to Chennapatnam 7.8 and 12.9.1683, G/30/2: 40, 44-5. NA, Translated Telugu letter from the Company's Brahmin "Maderagie" 28.2.1684, VOC 1405: 1672-4.

92 Henri Tajfel and John C. Turner, "The Social Identity Theory of Intergroup Behavior," in Psychology of Intergroup Relations, ed. Stephen Worchel and William G. Austin (2d ed. Chicago, 1986) 7-24. Rupert Brown cites some experiments that support Tajfel and Turner's theory in Group Processes, Dynamics within and between Groups (2d ed. Oxford, 2000) 330-2. 
extent were the identities of the members of the Golkonda elite conscriptive and to what extent were they ascriptive?

The first question that should be looked at is: was it possible for Muslims to join the Brahmin faction, if for instance they were not "foreign"? There is some evidence that Madanna tried to enlist the support of the Deccani Muslims in the factional struggle against the Iranians. In the biography of Muhammad Ibrahim in the Ma'asir ul-Umara' it is said that he, as an Iranian, was an exceptional case because Madanna and Akkanna normally brought forward only their own caste men and Deccanis while they intrigued against the Mughals and against the Foreigners. ${ }^{93}$ The cases of maltreatment of individual Muslims by Madanna, as cited by Khafi Khan and Manucci, concern a Sayyid and an Iranian (thus non-Deccanis) respectively. ${ }^{94}$ The historian A.M. Siddiqui, writing in Hyderabad in the 1950s therefore concludes, precursory to the 1990s theories of patriotism and ethnicity, that "Madanna seems to have been animated by ultra patriotic favour tinged with a regional bias" by supporting Hindus and Deccani Muslims against the Foreigners. ${ }^{95}$ Madanna may however have deemed the Deccanis only the lesser of two evils. Khafi Khan, for instance, spoke of "much violence and oppression" done to Muslims (Musalmanan) by Madanna and Akkanna, while Martin on his second trip to Hyderabad deplores the near disappearance from the court of the great Persian, Pathan and Deccani office holders that formerly lent the court its splendour with their large retinues. ${ }^{96}$

It is well possible that sentiments against both foreigners and Muslims existed in the minds of Brahmins such as Madanna and Akkanna, and that these could be invoked separately or simultaneously. A sample of the complex interaction between the two sentiments is given by Akkanna in the private interview with Janszoon that was mentioned in the introduction. The occasion for the interview was Akkanna's and his brother's concern about a plan to support the renegade Mughal prince Akbar with money and provide him with transportation to Persia. This plan had been worked out, in collusion with the Persian envoy to the court, by the sultan and his brother-in-law, entitled Sharif ul-Mulk (who probably hailed from Iran, while Abul-Hasan was descended from a collateral, impoverished, line of the Qutb Shahi dynasty, which traced itself to the Qara Qoyunlu Turks), ${ }^{97}$

\footnotetext{
${ }^{93}$ Shah Nawaz Khan and Abdul-Hayy, Ma'asir ul-Umara', 2: 6.

${ }^{94}$ Khafi Khan, Muntakbab (Persian text) 311; Manucci, Storia do Mogor, 3: 124-5.

95 Siddiqui, History, 246-50.

${ }^{96}$ Khafi Khan, Muntakhab (Persian text) 292; Martin, Mémoires, 2: 251-2.

${ }^{97}$ For Sharif ul-Mulk see Martin, Mémoires, 2: 250; Havart, Op-en ondergang, 2: 218-19; Shah Nawaz Khan and Abdul-Hayy, Ma'asir ul-Umara', 2: 823-5. For Abul-Hasan see Havart, Open ondergang, 2: 214. Siddiqui also accepts the statement about the descent of Abul-Hasan by Havart, which is confirmed by an early nineteenth-century source. Sherwani's critque of
} 
and the aid of the VOC was necessary for its implementation. ${ }^{98}$

Apparently the sultan and Sharif ul-Mulk had tried to conceal the matter from Madanna and his brother. Akkanna's main reason for having the interview was thus to hear Janszoon's side of the story and to admonish him to report such matters in the future "so that we [Akkanna and Madanna] can guide you in these matters, because we are only after the king's advantage, to sustain him in his pleasures and to deflect all wars and inconveniences from him, against which [policy] the Muslims [Mooren] are trying to achieve the contrary, but the king has established us in his heart and believes us above all others. When there is a case however that spellbinds him, he seems to seek the council of his brother-in-law more than ours, so you should be careful." After this Akkanna related some of the king's follies, but he ended with restating his and his brother's loyalty to the king, followed by the remarkable statement already quoted: "for you yourself can imagine which government serves the king best, ours or that of the Moors; ours being fullheartedly devoted to the welfare of the country, while we are not people who have or seek other countries, but that of the Moors is only to the end of becoming rich and then to leave for those places which they consider to be either their fatherland or holy."

In Akkanna's view, Muslims were thus mainly defined by their foreignness. This confirms Cynthia Talbot's conclusions about the way Muslims were "inscribed" by the population of Andhra in the preceding centuries. ${ }^{99}$ Akkanna here seems to extend this foreign connection to both Foreign and Deccani Muslims, because he spoke not only of people having other countries but also those seeking other countries, and about the pull of fatherlands as well as of holy lands. Akkanna's views are in fact akin to what Mushirul Hasan calls the "myth of Muslim unity," the idea that all Muslims are part of a single community with its centre in the Arabian Peninsula. ${ }^{100}$ This myth was according to Hasan invented by the British colonial administrators in the nineteenth century, but it seems that already much earlier, in circumstances such as those in 1680s Golkonda, "Muslim unity" could be perceived.

Religion itself, however, did not play a great role in the disputes between the two groups in Golkonda. Interestingly, the Ma'asir-i 'Alamgiri spoke of collusion between the Hindus and the Iranians (meaning Shi'is) in

Siddiqui's discussion is somewhat unfair. See Siddiqui, History, 215-8; Sherwani, Qutb Shabi, 658-9 note 6.

${ }^{98}$ NA, Letters Masulipatnam to Batavia 13.8 and 7.10.1683, VOC 1387: 1414-5, 1564v-7.

99 Talbot, "Inscribing the Other."

100 Mushirul Hasan, "The Myth of Muslim Unity: Colonial and National Narratives," in Legacy of a Divided Nation: India's Muslims since Independence (London, 1997) 25-52. 
Golkonda, from which (Sunni) Islam suffered. ${ }^{101}$ As was argued in Chapter 2, both Shici and Hindu symbols were part of affirmations of belonging to the Deccan. Even Madanna once had a very expensive 'ashura' khana (pavilion for the celebration of the Shici festival of Muharram) built in Hyderabad, but this was "only to increase his fame," wrote Havart, "even though he mocks those useless things." 102

A second, related, question is what Akkanna means by "we" and "our government" in the above quotations, or in other words how he inscribes himself. Of course in the first instance the words "we" and "our" refer to just himself and his brother, but the words also seem to have some secondary implications. Would he have meant "we Brahmins" or "we Hindus"? "We Telugus" seems an option that can be discounted, because as is argued above, they were probably not Telugu Brahmins. Thus their patriotism would have been different from the Telugu ethnicity that Cynthia Talbot perceives in the period before 1650. ${ }^{103}$

"We Brahmins" seems a likely option, because both contemporary and eighteenth-century sources impart the impression that the brothers were much concerned with the dharmic duty (of a king) to feed and clothe the Brahmins. Martin describes the buildings for feeding Brahmins exclusively — that had been put up at regular intervals along the route between Masulipatnam and Hyderabad at the order of Madanna. ${ }^{104}$ A VOC report refers to an annual five-day celebration of Madanna's birthday on which food and clothes were distributed to Brahmins - a practice reminiscent of the custom of Hindu kings to distribute gifts on the anniversary of their inauguration. In Vijayawada alone, 3,000 saris and 4,000 cloths of other types were handed out on this occasion in 1682, for which Brahmins and their wives had come to the town from far and wide. ${ }^{105}$ Madanna is also reported to have fed many hundreds of Brahmins while staying in that city a few years earlier by an EIC employee, who also noted that some thought this a pretence for other business. ${ }^{106}$

The sources in the Mackenzie collection, which were collected and drawn up mainly by Brahmins, ${ }^{107}$ portray the rule of Madanna and Akkanna as a golden age. The "Annals of Condaved" stated that during their regime

${ }^{101}$ Musta'id Khan, Ma'asir-i 'Alamgiri, 174. Siddiqui quotes part of this passage out of context and translates "Islamiyan" as "Muslims," while clearly the adherents of orthodox Islam are meant as opposed to Shi is. See Siddiqui, History, 248-9. See also

102 Havart, Op-en ondergang, 2: 65-95 and Persiaansche secretaris, 70-4.

103 Talbot, "Inscribing the Other."

104 Martin, Mémoires, 2: 241.

105 NA, Report on inspection of the Nagulvancha factory, 27.4.1682, VOC 1378: 1928-v.

106 Master, Diaries, 2: 176.

107 Nicholas Dirks, "Colonial Histories and Native Informants: Biography of an Archive," in Orientalism and the Postcolonial Predicament: Perspectives on South Asia, ed. Carol A. Breckenridge and Peter van de Veer (Philadelphia, 1993) 292-301. 
the inhabitants of the kingdom "were in all happiness still performing all daily ceremonies," a phrase which suggests, as Richards rightly remarks, the sustenance of dharma. ${ }^{108}$ From the "Some Account," also part of the Mackenzie collection, one may gain the impression that the brothers became obsessed with the feeding of Brahmins, which they are said to have undertaken on a daily basis from Rameshvaram in the far south to Kashi (Benares) in the north, while the account also spoke of a great amount of in'ams (tax-free revenue assignments) granted to Brahmins and temples. ${ }^{109}$ Similarly the Telugu "local tracts" or "kaifiyaths" in the Mackenzie collection are replete with references to specific agraharas (villages whose income was reserved for the maintenance of Brahmins) instituted or renewed by Madanna and Akkanna and their cousin Linganna, the sarlashkar of the Karnatak, although the renewals often concerned only parts of villages, the remainder being resumed by the government. One kaifiyath said that the year after their rule ended a (limited) levy was imposed on the agrahara villages "one after another." Among these tracts there is also a curious story of how Linganna displayed his organisational skills to Madanna and Akkanna by having a feast ready for 12,000 Brahmins on the occasion of their visit to Tirupati. ${ }^{110}$

Akkanna's patronage of the cult of Shiva, which was less associated with Brahmins in Andhra (with the major exceptions of the Niyogi and Vaidiki Smartas) than with various Telugu groups of lower ritual status, could with difficulty be interpreted as an effort to gain the favour of such groups. There was also an attempted measure to introduce a legend devoted to Shiva (Uma Mahey suram) on half the hons, which normally bore a legend devoted to Vishnu as well as his image, seems to have aimed at giving both gods equal stature. 111 This may, however, have reflected the brothers' personal preferences more than a desire to placate Shaiva groups.

In any case, there are no indications that Madanna and Akkanna succeeded in gaining the loyalty of key Hindu groups other than Brahmins. Their relationship with some of the Hindu zamindars seems to have been less than good, which may have been due to the land revenue reforms introduced by Madanna, as was the case for the relation between Shivaji and the Savants. The "Some Account" story said that Akkanna got into an argument with Raja "Attamataroydoo" over the right of precedence in a narrow street. Afterwards Madanna reprimanded his brother for not giving

${ }^{108}$ BL, “Annals of Condaved,” Mackenzie gen. 7: 47; Richards, Mughal Administration, 40.

${ }^{109}$ BL, "Some Account," Mackenzie unb. VII, 25: 41-v.

110 Mahalingam, Mackenzie Manuscripts, 2: 75, 109, 207, 216, 240, 254-7, 264, 276. The latter story is to some extent confirmed by Martin's remark that Linganna was out of pocket after he and Akkanna had visited Tirupati. See Martin, Mémoires, 2: 224.

111 Linganna was however understanding of the reluctance of the VOC to implement the measure. NA, Letters Linganna to Pits 25.4 and 6.6.1683, VOC 1405: 1333v-4, 1341v-2v. 
proper respect to someone of higher rank, the raja having been appointed by the Mughal emperor as his newsletter writer in the Deccan (?!). The raja however remained inimical and, according to this story, became instrumental in the brothers' deaths. ${ }^{112}$ Another illustration of the enmity between the brothers and the major zamindars or samasthan rajas is the news noted down by the VOC personnel in March 1684 that a relative of Madanna and Akkanna was apprehended by the people of Rani Janamma, the regent mother of the minor samasthan raja of Sugur, because she had herself been taken into custody after she was tricked into coming to the court the year before. ${ }^{113}$ It further seems that during the final days of the Qutb Shahi sultanate a number of the samasthan rulers chose the side of the Mughals, just as the Savants on the west coast around the same time, though Janamma remained loyal to the Qutb Shahi dynasty. ${ }^{114}$

\section{The Problem of Loyalty}

With regard to the final stage of Madanna and Akkanna's career we need once more to look into the complex interaction between group loyalties and loyalty to a ruler. It has been noted in earlier chapters that there was a strong ideology of loyalty to the monarch in the states of early modern India, and that this was symbolised through such metaphors as eating someone's salt and robes of honour. Another metaphor used by some Muslim rulers was to express the relation to their service elite in the terms of a Sufi lineage. In the deed of submission of 1636, for instance, Abdullah of Golkonda was addressed as the "hereditary disciple" of the Mughal emperor. ${ }^{115}$ Madanna's title of Mabram-i Asrar or Confidante of the Secrets of the sultan also had strong Sufi connotations, harking back to Hafiz, and implied that Abu-Hasan and Madanna were to have an intimate spiritual/mystical relationship. ${ }^{116}$ It was, however, also noted that the counterpart of this personal loyalty was the mechanism André Wink calls fitna, by which one ruler would try to lure away people who were part of another ruler's state structure. In a way, Madanna's takeover of power at court from Sayyid Muzaffar is a classic example of this mechanism since Madanna accomplished this, according to Khafi Khan, by way of winning over the Sayyid's friends. ${ }^{117}$ The question is whether Madanna tried to repeat this act of namak harami (unfaithfulness to the salt) against Abul-

112 BL, "Some Account," Mackenzie unb. VII, 25: 42v-3.

113 NA, Letters Pulicat and Masulipatnam to Batavia 9.3 and 26.4.1684, VOC 1405: 1424, $1605 \mathrm{v}$.

114 Benjamin B. Cohen, Kingship and Colonialism in India's Deccan 1850-1948 (New York, 2007) 34-7.

115 Sherwani, Qutb Shahi, 436-7.

116 Compare Hafiz, Diwan, 1: 70, 98 (poems 27, 41).

117 Khafi Khan, Muntakbab (Persian text) 312. 
Hasan.

The classic article about Madanna and Akkanna written by S. Krishnaswami Aiyangar in 1931 suggests, on the basis of a summary translation of the $O p$ - en ondergang, that the account of Madanna given by Havart is diametrically opposed to that by Khafi Khan. ${ }^{118}$ Their versions of the circumstances of the murder however differ only slightly, as has been seen above. The only real point of difference between the two authors is the allegation of treason. Khafi Khan makes no mention of it, but Havart refers to treason in the poems that accompany the pictures of Madanna and Akkanna in his book. In the main text he is however more careful, and adds in brackets the qualification "at least that is alleged against them." 119 Havart's ambiguity can be explained by the fact that since he had probably left Coromandel in early October, ${ }^{120}$ he had to rely on the contradictory reports that were forwarded with the letters to Batavia and onward to Amsterdam. One is a summary of the factory diary by the factors at Hyderabad, the other a transcript of an oral report by a peon of the VOC called "Dauwelsu," a Hindu, to judge from his name. ${ }^{121}$ It should be noted that these are the only extant accounts by people who were actually in Hyderabad at the time of the fall of Madanna and Akkanna (Manucci had left just before). ${ }^{122}$

The report by the factors at Hyderabad is very similar to Havart's version, but there is no mention of treason on the part of Madanna and Akkanna. This is not for lack of detail, because Madanna's conversation with his assassin and the travails of the bodies and heads of the brothers are well spun out. Dauwelsu however elaborates the allegation of treason in great detail:

What I have heard while I was in Golkonda [Hyderabad] is this, that the Misters Madanna, Akkanna and the sar-khayl Muhammad Ibrahim, have written two letters to the son of Aurangzeb and [to] Bahadur Khan, namely the two brothers in unison and the sar-khayl separately one. The contents of Madanna and Akkanna's letter was that the Mughals, or more precisely the son of Aurangzeb named Shah Alam and his second in command Bahadur Khan, should just come with their armies and that they would present them with the keys of the kingdom, on the condition that they would leave to them the administration from there to the borders of Delhi [the Mughal empire].

However, both the letter of the brothers and that of Muhammad Ibrahim

\footnotetext{
118 Krishnaswami Aiyangar, "Abul Hasan and His Ministers."

119 Havart, Op-en ondergang, 2: 224-5.

120 H. Terpstra, "Daniël Havart en zijn Op- en ondergang van Coromandel," Tijdschrift voor Geschiedenis (1954) 67: 167 note 17.

121 NA, "Report Dauwelsu" 6/7.11.1685, VOC 1411: 254v-6; Letter Hyderabad to Masulipatnam 7.12.1685, VOC 1411: 607v-10.

122 This is evident from Manucci's comment appended to Dauwelsu's report.
} 
containing the conditions for his defection came into the hands of the army commander Sharza Khan, who sent them "to the governess of the expired king." Although the rest of Dauwelsu's report is rather confused, parts of it picked up on the way to Masulipatnam, the fact that, according to him, the area claimed by Madanna and Akkanna was that between Hyderabad and the border, thus comprising mainly of their native district of Warangal, lends his report some credibility.

The important point is that there were some contemporaries who thought it possible that Madanna and Akkanna would try to go over to the Mughal side. Moreover, Dauwelsu and Havart are not alone in mentioning the accusation of treason against Madanna. It is also aired in Martin's account, first by Muhammad Ibrahim on his departure to the Mughal camp and again by "one of the first ladies," while Bhimsen said that the councillors of Abul-Hasan thought Madanna had instigated Muhammad Ibrahim to cross over and wanted to go over himself as well. ${ }^{123}$ Furthermore, the notion of "treacherous letters" seems to have lingered in folklore. The "Annals of Condaved" mentions treacherous letters - be it from Aurangzeb to the old lady in the harem - and the author of the "Some Account" takes considerable pains to explain how a letter in handwriting exactly like Madanna's was forged by "Raja Attamattaroydou." 124 The contrast between Akkanna's ideas as represented by Janszoon and the way some contemporaries thought of his and his brother's possible treason brings out once more the two different conceptions of the state in seventeenth-century India, that of the state as cosmopolis and that of the state as patria.

\section{CONCLUSION}

"In their lives and their deaths," wrote Havart about Madanna and Akkanna, "[they] have not been unlike two prominent gentlemen who miserably lost their lives anno 1672." 125 Both the De Witt brothers and Madanna and Akkanna lost their lives in the chaos that enveloped their respective states at the approach of an enemy they had been trying to appease, with their bodies left to be mutilated by the rabble in The Hague and Hyderabad respectively. Also in both cases the enemy was expansionist and religiously intolerant (one of the most well-known acts of Louis XIV was the revocation of the Edict of Nantes in 1685, while Aurangzeb reimposed the jiriya in 1679).

What is more, here we have a seventeenth-century European who

123 Martin, Mémoires, 2: 416; Bhimsen, Tarikh, 148.

${ }^{124}$ BL, "Annals of Condaved," Mackenzie gen. 7: 48; BL, "Some Account," Mackenzie unb. VII, 25: 42v-3.

125 Havart, Op-en ondergang, 2: 220. Sarkar also makes this comparison. Aurangzib, 4: 417. 
stresses the similarities of two non-Europeans to Europeans rather than their otherness. Havart clearly saw Madanna the way politicians were seen in Europe. This meshes with the conclusions of Chapter 1 which addressed the question as to how European the European sources on seventeenthcentury India really were. It was concluded that the boundary between Europeans and Indians was not perceived of as a paramount boundary on either "side," between ca. 1630 and 1680 when a balance existed between the Islamicate states on the land and the European semi-states on the sea, so that there was no direct need for Europeans to paint Indians others as Others. Would that mean that Janszoon, like Havart, mainly sought to explain whatever Akkanna said to him on that afternoon in August 1683 in terms familiar to him, like the term vaderlant, with which many VOC-men were so obsessed as has also been seen in Chapter 1? But then, what was the familiar for the factors in Hyderabad, far removed as they were from the goings-on in the Netherlands? Van Nijendaal had settled in the city in 1661 at a very young age and Janszoon had already spent some fifteen years on the Coromandel coast before being sent thither. ${ }^{126}$

On the other hand, these Dutchmen in Golkonda were very involved in party politics at court and often more favourably inclined to Muslims than to Hindus (Chapter 1). Moreover, as has been seen in Chapter 5, the balance between the land states of India and sea states around it was upset in the 1680s. In Golkonda the balance seems to have tipped in July 1685, when the VOC personnel in Hyderabad invented the accusation of theft against Akkanna. Although the tipping point in the relation between the VOC and the Brahmin brothers came after Janszoon wrote his report on his private conversation with Akkanna, all of this serves to make Janszoon's report of Akkanna's statement suspect because the shifting power balance (in this case between Brahmins and Dutchmen) in combination with the existing boundary would increase the "othering" factor.

A further question that comes to mind is this: were the Europeans in Golkonda so powerful that they could have created or significantly reified (with their European mindset) the boundary between Brahmins and Muslims or were they merely aligning themselves along this rising boundary? ${ }^{127}$ As has been seen in Chapter 3, even in Chennapatnam the influence of the English on the boundary-formation between the Right and Left Hand castes was probably not as significant as it is often made out to be, so the influence on the so much larger entity Golkonda must have been

126 Havart, Op-en ondergang, 2: 167,184.

127 Subrahmanyam, for instance, seems to conclude that already in the late sixteenth century the Portuguese had "managed to drive a wedge" between Hindus and Muslims on the Malabar coast, that on the basis of a remark by Zain ud-Din Ma'abari that the enmity of the Franks there was directed solely at the Muslims. Subrahmanyam, "Taking Stock," 74. 
infinitely smaller and the latter option (aligning along an existing boundary) appears to be the more plausible.

Rather, the evidence cited in chapters two, four and five of Deccani patriotism, the growing rift between Hindus and Muslims and the sense of public and private, point towards the conclusion that the words in the Akkanna quotation are not so unlikely to have been an Indian's after all. It is more likely that Akkanna borrowed his notion of fatherlands from Shivaji's discourse of the 1670s than that Janszoon stamped his notion of his own fatherland on his report of Akkkanna's speech, rather than just substituting whatever term Akkanna may have used with its closest Dutch synonym. Although the VOC personnel in Golkonda wrote in a European language, their comments on the situation in the kingdom were not merely fractals of a European discourse.

If Madanna was indeed a patriot as the Akkanna quotation suggests, his patriotism differed from that of the 1630s Khawas Khan and Shivaji. Madanna's policy seems to have been motivated mainly by a desire for peace and stability, which was part of the reason why he was remembered in the Mackenzie documents as an upholder of dharma. The term politique that Havart applied to him implies the consciousness of those having a clear goal in mind, but also know that the route to it is not straight. As Havart's contemporary Pierre Bayle wrote in his famous dictionary: "politicians (politiques) must imitate those who navigate."128 After 1677, Madanna clearly realised that war was not the way to achieve the state he desired.

Madanna's rise to power was no accident, or the mere result of his personal skills (as Havart makes it seem), however. The revenue farming "system" in Golkonda had given rise to a class of Brahmin "men of the pen" in Golkonda about half a century before what has been called "the Brahmin Raj" became evident in other parts of South Asia. ${ }^{129}$ Madanna clearly needed the support of this Brahmin network. He continually strengthened his power base by inserting Brahmins in many positions in the revenue system and in the central bureaucracy. He also took upon himself the dharmic duty of the king to feed and clothe Brahmins all over the realm. From a twentieth-century perspective the "identity group" of Madanna and Akkanna may be said to have been medium sized, neither too particularistic (e.g. "we Niyogi Brahmins" or "we Deshasta Brahmins of the Pradhama Shakha") nor very general (e.g. "we Hindus").

The advancement of these traditionally pacific Brahmins in Golkonda went to the detriment of the "men of the sword," who were,

128 Pierre Bayle, Dictionnaire historique et critique, 5th ed. (Amsterdam, 1740) 2: 805; available from http://www.lib.uchicago.edu/efts/ARTFL/projets/dicos/.

${ }^{129}$ Compare Havart, Op- en ondergang, 2: 220-2 and “The 'Brahman Raj': Kings and Service People c. 1700-1830," in Susan Bayly, Caste, 64-96. 
certainly in the upper echelons, mainly Muslims. The animosity between Brahmins and Muslims (more than between Hindus and Muslims) that coincided or ensued conforms to the social identity theory of group behaviour in which the three factors of impermeability of group boundaries, perceived unfairness and instability play a major role. While the balance between the groups had been growing increasingly unstable for a long time, as is evident from the short period around 1640 when Brahmins took charge of state affairs, it was finally reversed with the "revolution" initiated by Madanna in 1674. That the previous situation was deemed unfair by Brahmins can be seen from Akkanna's remarks to Janszoon.

Madanna and Akkanna were loyal enough to Abul-Hasan (even if perhaps not in their final days) but somewhat in the way a parent is loyal to an irresponsible child. In at least two cases they tried to correct what they saw as foolish provocation of the Mughal emperor, the Akbar affair and the elephant fight affair. If we were to see this in terms of roles (following identity or role theory which is sometimes seen as being at odds with the social identity theory of Tajfel and Turner) we might say that Madanna and Akkanna defined themselves as responsible in comparison to Abul-Hasan and his clique. ${ }^{130}$ For his remarks on the irresponsibility of Abul-Hasan Akkanna could draw on that centuries old trope: the warmongering Muslim foreigner. ${ }^{131}$

${ }^{130}$ Compare Hogg, Terry and White, "A Tale of Two Theories"; Abdelal et al. "Treating Identity as a Variable," 10.

${ }^{131}$ Compare Talbot, "Inscribing the Other"; Chattopadhyaya, Representing the Other?; Pollock, "Ramayana and Political Imagination," 261-97. 


\section{CONCLUSION \\ HUMAN NATURE IN A SEVENTEENTH-CENTURY ENVIRONMENT}

And did God not check one set of people by means of another the world would indeed be full of mischief...

Qur'an 2: 251 (trans. Abdullah Yusuf

Ali)

Certainly identity in precolonial India was political, contingent and constructed, but was it less strongly felt than in the modern period, and was it less of a determinant of people's lives? The answer to those questions must certainly be no. When we look at the precolonial a half-century is easily taken for a modern-day decade. When scholars talk of the fluidity of precolonial identity they look at much longer stretches of time than when they talk of the rigidity of modern identities. Worse still, the early-modern period is often taken as a whole. A few examples of religious tolerance and hybrid culture suffice to brand the whole period free of the blemishes of identity. The present study has sought both to historicise and to dehistoricise early-modern identity in India.

The precolonial is somehow always measured by different standards. Perhaps Indian identities developed in the colonial period precisely as Gerald Aungier deemed necessary for the administration of Bombay: "[to be] free from that confusion which a body composed of so many nations will be subject to, it were requisite that ye severall nations at present inhabiting or hereafter to inhabit on the island of Bombay be reduced or modelled into so many orders or tribes."' Yet the myopia of much present-day scholarship, already discussed in various places, entails that the colonial modelling of tribes and orders is described in the greatest detail, while the genesis, propagation and occasional obsolescence of the mental boundaries that were the "nations" of the precolonial period receive scant attention. My point is that those were just as important and difference-making as identities today. But because of the lack of serious study and various political reasons already discussed, early modern identities are generally seen as less than modern identities: less intense, less well demarcated, of a lesser scale, mere event rather than system or mere ideology without practice. With the exception of scale, none of these hold true.

1 SBSHS, Proposals touching the island of Bombay by Aungier and the Surat council 5.2.1671, 1: 54. 
While it may an interesting and useful exercise to trace the development of a particular identity through time, it is important not to confuse the content of identities with their intensity. For every place and period, it is necessary first to determine what the paramount identities and concomitant boundaries were, only then to "measure" those with the awkward tools the historian has (sources), rather than take some presentday identity and conclude that it was "less" (which leads to such anachronistic views as that of the Age of Partnership or Age of Contained Conflict critiqued in Chapter 1). The boundary of the Deccani identity, for instance, shifted considerably through the early modern period. It came into being at the court of the Bahmani sultans, as an expression of the opposition of "local" Muslims to "foreign" Muslims, and as such seems to have reached its apogee in the death of Mahmud Gawan in 1481. At the end of the sixteenth century it was revived in the context of the Mughal incursions into the Deccan as an expression of the opposition between local nobles and Mughal nobles. As such it reached its apogee in the career of Malik Ambar. In the course of the seventeenth century, the Deccani identity became more inclusive and truly patriotic. It became a label for those Muslims, such as Khawas Khan, who espoused a programme of decreasing the distance between the Bijapur elite and the state's commoners, which categories corresponded to a large extent to the categories of Muslims and Hindus. Finally, during the days of Shivaji, it came to actually include Hindus. In that form the Deccani identity reached its most rigid state in the clashes with the Afghans of Bijapur. So, for the purpose of a comparison to modern identities, the various forms of Deccani identity are best measured at the Bahmani court around 1481, in Malik Ambar's camp at the gates to the Deccan in the early seventeenth century, or in the theatres of war spread over the area of collapsing Bijapur in the mid-1670s. ${ }^{2}$

An explanation for such shifts in the content of identities is that, just as today, people had multiple identities, which often shared some meaning or content but might also be at odds with each other in certain situations. $^{3}$ In Chapter 4 we saw the example of Shivaji who invoked both his Deccani identity and his Hindu identity, which only partly overlapped. Another case in point was the Habshi identity, which had a strong ascriptive component, ${ }^{4}$ which was matched by equally strong conscriptive

${ }^{2}$ In that sense Chapter 2 is something of a failed chapter and I would recommend reading the chapters about Mahmud Gawan and Malik Ambar of Richard Eaton's Social History of the Deccan as complimentary to Chapters 2 and 4 of this study.

3 Peter J. Burke suggests this relation between change and multiple identities for the individual level (on the basis of data on the various roles of modern women), but it may be extended to the group level. Burke, "Identity Change," Social Psychology Quarterly 69 (2006) $81-96$, there 81,85 .

${ }^{4}$ See Chapter 5 and Eaton, Social History, 126-7. 
dimensions. Beside Habshi, Habshis could be loyal subject, patriot and Muslim. In this study we have seen the staunchest Deccani patriots among the Habshis (Sidi Mas'ud, Nasir Muhammad), as well as the most zealous Muslims (Sidi Qasim), as well as the most loyal servants of the sultans who could be relied on to kill Khawas Khan and Madanna and Akkanna. But all these Habshis were not one and the same protean person. In situations where different boundaries were paramount different Habshis drew on different aspects of Habshi identity.

Moreover it is necessary to distinguish between personal loyalties and group loyalties. The boundaries between states and patronage networks — not to be confused with the boundaries between social groups - were somewhat fluid in early modern India, as André Wink has argued. The more cosmopolitan the state, the more fluid were its boundaries. Furthermore, the more cosmopolitan one's conception of the state, the easier it was to cross its boundaries. That was the contrast Akkanna sketched before Janszoon, the contrast between those invested in the land and those "who have or seek other countries." Although loyalty is also a role or identity, a change of king or patron did not generally entail a change of social group. The Left Hand castes did not become Brahmin or English by accepting the patronage of Venkata or Baker respectively. By putting their loyalty in with the Mughal emperor or the sultans of Bijapur or Golkonda, nobles did become Mughal, Adil Shabi or Qutb Shahi respectively, but without giving up their other social identities — as we have seen in plenty examples. Because many states in early modern India were cosmopolitan, however, there was a lot of state boundary crossing which - apparently — appears to modern scholars as the crossing of group boundaries.

The relationship between conflict and identity was complex. While the potential for group conflict might increase identification and demarcation, rigid group boundaries did not necessarily lead to continual conflict. Some of the most obvious boundaries in precolonial India were the sexual boundaries created to reserve Brahmin, Muslim and Christian women for Brahmin, Muslim and Christian men respectively. Evidence for the latter two boundaries was discussed in Chapter 1, while the Brahmin boundary is attested by many European travellers. These boundaries appear to have been very inflexible yet not necessarily sites of conflicts. In his discussion of the sexual relations between Muslims, Jews and Christians in medieval Aragon, David Nirenberg asks the important question as to whether heightening taboos on sexual interaction might serve to render other types of interaction less conflictual, and comes to the conclusion that this was partly the case. And it appears that in seventeenth-century India also, despite or owing to the sexual boundary between them, elite Muslims and Europeans often got along quite well, as did the Brahmin accountants 
and the Muslim kings they served until the decade between 1677 and 1687. Yet, as Nirenberg also argued, the sexual boundaries between Iberian Jews, Muslims and Christians could be invoked in an "economy of accusation" in cases where other, mostly financial, issues between people of these sexually separated groups played a role. ${ }^{5}$ As has been seen in Chapter 1, clearly demarcated boundaries, such as the sexual boundary between Christians and Muslims, did not cause conflict, but conflict could reinforce boundaries, though not necessarily sexual ones, as was the case between the Dutch and the Portuguese.

All the conflicts reviewed in this study, may be seen to have had some material basis in a dispute over real resources. The Dutch and the Portuguese fought over access to the Indian Ocean trade, the court factions of chapters two and six strove to control the state and its revenues, just as control of the Deccan with its revenues was at the heart of the matter of chapter four, while in the revolt of chapter five a central issue was how much money was to be spent on the defence of the island of Bombay. In chapter three the relation between material conditions and honour was also evident and as such already discussed.

Yet, like impermeable boundaries, unequal divisions of status, power or resources do not by themselves cause social conflict. It is the possibility of change in the relation between groups that turns a conflict of interests into a conflict, or as the psychologists Tajfel and Turner put it: the people in the lower status group should see the higher status group as a relevant comparison group. ${ }^{6}$ The crucial moment is that at which the other emerges as Other.

Returning to the case of Chapter 3 and going over the points psychologists have found in twentieth-century experiments to increase identification with a certain "in-group," we find that the seventeenth century was no different. In the twentieth-century experimental set-ups it was found that identification with the own group increases when the hierarchy of two groups is unstable and perceived as illegitimate, and crossing between the groups is difficult. ${ }^{7}$ All these three factors were also present in 1652 Chennapatnam where identification with the Left Hand and Right Hand had certainly become strong. Firstly, having been laid down in a number of inscriptions well before the seventeenth century, it seems that the boundary between the Right Hand and Left Hand had been centuries in the making and was therefore not easy to cross, as the case of Naga Pattan proves. Secondly, Appadurai, Stein and Brimnes have all

\footnotetext{
${ }^{5}$ David Nirenberg, "Religious and Sexual Boundaries in the Medieval Crown of Aragon," in Christians, Muslims, and Jews in Medieval and Early Modern Spain, ed. M. Meyerson and E. English (Notre Dame, 1999) 141-60 and Communities of Violence, 127-65.

${ }^{6}$ See the section "The Social Identities" in Chapter 6.

7 See the section "The Social Identities" in Chapter 6.
} 
pointed to the rapid growth of Chennapatnam - or towns in the region in general - as a factor in destabilising the balance between Left Hand and Right Hand groups there. ${ }^{8}$ Thirdly, the conflict centred on what the Right Hand saw as the unjustly inflated status of the Left. In Chapter 6, similarly, the most important factor in the emergence of the conflict between the Brahmin and Muslim elites of Golkonda seems to have been the becoming unstable of the balance between the groups, from which a sense of injustice ensued. In short, our seventeenth-century situations conform to models developed for twentieth-century situations.

In the development towards instability the role of government is of course important. If government is weak the balance between groups is more likely to become unstable, which is Brimnes' conclusion for the eighteenth-century Coromandel coast European enclaves. However, pursuing this line of thought can also lead into a petitio principii: a government may be perceived as weak precisely because there is strife amongst groups of its subjects, or the strife might be the cause of the weakness of the government, or the two movements towards more vehement strife and weaker government may reinforce each other. In any case the two often go hand in hand, a development that will be looked at more closely in the Epilogue.

Rather than from any one particular factor like the role of the government or the vicissitudes of trade, the group conflicts under review here were produced from a dialectic between a long-term discourse marking the boundaries between two groups and particular societal dynamics that upset the balance between those two groups. And rather than one long period of fluidity, namely the precolonial, and one long period of hardening group boundaries, namely the colonial and postcolonial, the evidence suggests that there were many peaks followed by downswings in group conflicts throughout both eras. The short-term peaks are sustained, also in the precolonial period, by long-term discourses in which boundaries are not as marked as at the height of disputes as in 1650s Chennapatnam or 1680s Hyderabad, but are marked nevertheless. It is also possible to perceive middle-long-term developments within those longterm discourses of othering, as I tried to visualise in the graph in Chapter 3 and will try to show for the antagonism between Hindus and Muslims in the Epilogue.

Such discourses of othering form part of the ideology and behaviour - or in short: the culture — of any group and they are the reason there can be no minimal group experiments in history. Perhaps it is true that, in a sense, culture springs from identity, or to phrase it as Kwame 
Appiah does: identity has priority to culture. This is certainly borne out by minimal group experiments such as the Robbers Cave experiment. ${ }^{9}$ In our 1650s Chennapatnam case too there was a discourse of fairness or a sort of humanitarianism that seems to have instantly developed as a common culture on the Right Hand side, in opposition to the businesslike attitude of the Left Hand. Yet in the world outside the laboratory there were and are always pre-drawn boundaries that remain sites for conflict over long periods of time or develop and blend into other boundaries, as I have also tried to show in the Chennapatnam case as well as in Chapter 2. What many scholars have tried to do over the past thirty years, to imagine a precolonial India in which group boundaries were minimal, or invented for each conflict, is counterfactual.

The evidence concerning Shivaji's coronation is very ambiguous in this respect. On the one hand one might use his becoming a Kshatriya as an argument for the fluidity of caste, as he did after all cross caste boundaries, but one could just as easily argue that his change of caste, and with that the distinction between his old and new castes, was apparently sufficiently important to a) be deemed necessary and b) cause such a brouhaha among the Brahmins that it reached the Dutch records. The present study is an attempt to perceive long-term developments in identities and at the same time allow for the sense of invention that is so often found in the sources.

Identity is a dialogue between ascription and conscription, and there is always a disjunction between conscriptive and ascriptive identities. There is always the presence of that gaze embodied in a societal discourse, in the case of precolonial India often a brahminical gaze embodied in a brahminical discourse. In this respect the living of the categories of Right and Left was not so different from that of the varna categories in the colonial period. The Right and Left categories provided a framework for collective status striving in 1650 Chennapatnam and precolonial South India more generally, just as varna did in British India. Efforts to fix the status of others in perpetuity (a clamour to fix things back to a perceived status quo ante) were in both eras matched by efforts to obtain recognition of an improved status for the own group. Sometimes the efforts to obtain recognition of an increased rank were somewhat successful, as was the case for the Left Hand in 1650s Chennapatnam, Shivaji at Raigarh in 1674, or the Kayastha attempts to obtain a status close to that of Brahmins from H.H. Risley and other Census Officers in the late nineteenth century. Other efforts were less successful however, as in the case of the Telikis' bid for Kshatriya status, the centuries of striving for Brahmin status by the Panchala artisan castes, or the late nineteenth-century efforts, in the form

${ }^{9}$ Appiah, Ethics of Identity, 64. 
of petitions and books, on the part of members of the Palli caste to be recognised collectively as Kshatriyas by the British authorities. Brahminical discourse often proved resistant as did the opposition of out-groups to improvements in status. The latter is well attested by the continued opposition of the Right Hand to the inflated status of the Left in 1650s Chennapatnam, and can be illustrated with endless examples from the colonial and postcolonial period ranging from a Panchala man being literally branded by the Chief of Nargund in Dharwar for wearing his dhoti in the Brahminical fashion and the responses of Indian scholars to the inflated status of the Kayasthas in Risley's list in the nineteenth century to the insistence on separate dining facilities for Brahmins at the Congress college near Madras in the 1920s and, more recently, the vehement protest against the Mandal proposals concerning reservation for backward castes. ${ }^{10}$

Thus we must either conclude that the formations and divisions presented in this study "assume an anachronistically modern appearance" (as Burton Stein notes about the Right and Left hand division in thirteenthcentury Tamil Nadu) ${ }^{11}$ and as such expressions of the increased societal complexity called early modern, or that they are expressions of a universal human quality. On the basis of the present study it is not possible to conclude either way. To do so it would also be necessary to study some cases for the pre-early modern period. What we can safely conclude, however, is that these formations and divisions pre-dated colonialism. Still I lean heavily towards the universalist position on the basis of the growing literature that suggests just that, and on the basis of the explanatory power that the hypothesis of human nature has.

At the same time this book reflects on itself by showing the European roots of the idea of human nature (which is not to say that analogous concepts do not have a long history in Asian traditions). Chapters one and five saw a number of ways in which the category of the natural was invoked with relation to group behaviour by our seventeenthcentury agents. Captain Keigwin summed up the ideas presented in this conclusion in his phrase "nature obliges us to preserve ourselves." But the fact that our usage of the word nature has a European history need not detract from its validity.

The twin emphases in this study on human nature and consciousness may seem contradictory, yet it is no more of a paradox than the twin emphases of post-structuralism on the radical constructedness and

\footnotetext{
10 For the examples from the precolonial see Chapter 3, for the other examples see Thurston, Castes and Tribes, s.v. Palli or Vanniyan; Jan Brouwer, The Makers of the World: Caste, Craft and Mind of South Indian Artisans (Delhi, 1995) 9-10; Cohn, "The Census," 245-8; Dirks, Castes of Mind, 210-7, 255-96.

11 Stein, Peasant State, 180.
} 
unconscious operation of all discourses. ${ }^{12}$ To put it in terms of a metaphorical platitude, while few would want to posit the feeling of appetite or hunger as a social construct (though some would go so far) we can still be conscious of that feeling when it occurs, and also, on occasion, put it off ("I am hungry now but want to finish x before grabbing a bite"). While xenophobia is different from the sensation of hunger, the two phenomena arguably share one feature, namely their universality. At present, cognitive scientists are starting to find that it is not so much the unconscious but the conscious that needs to be explained - although the latter should not be over-mystified. We may, with Daniel Denett, simply view consciousness as the outcome of a competition for priority among content-carrying events in the brain..$^{13}$ It is this stream of alternatives put forward in the brain that I have tried to highlight here.

While there is no doubt that new things are constantly entering the domain of the conscious, especially since the European enlightenment, the idea that Indians were ever unconscious of the identities and differences between people around which so much of day-to-day practice is and was evidently built seems untenable. The problem of the consciousness of the divide between the British and the non-British colonial elite in India plays a central role in Amitav Ghosh' novel The Glass Palace, with the slow realisation by the officer Arjun that he is "not quite" British, even if part of the army chain of command. Ghosh positions his novel in the tradition of Foucault and Cohn where he has Arjun think: "it was as though he and his peers had been singled out to pay the price of a monumental inwardness." Later Arjun realises that his commanding officer, a Scotsman, had realised well before him that the consciousness of British dominance or the "spirit of independence" would come over the Indian army - "You knew it before we did. You knew because you made us." But perhaps it was more the consciousness that there was a need to unite against the British, or that an Indian state without the British was possible, than the consciousness that the British were foreign or domineering per se that brought about the end of the empire. I hope to have shown here that Indian groups in the

${ }^{12}$ In this respect also, Foucault led the way. While referring to his work as archaeology, an uncovering of the unconscious attitudes behind successive Western "epistemai," in the last chapter of The Order of Things he also commends scholars to deploy ethnology and linguistics to topple "the modern episteme," by finding things in non-Western societies that do not fit that episteme. Subsequently many have been eager to seek out the differences between nonWestern and Western constructions of the world and only few have taken the trouble to look for shared ways of perceiving. Foucault, Order of Things, xxi-ii, 373-83.

13 Daniel C. Dennett, Sweet Dreams: Philosophical Obstacles to a Science of Consciousness (Cambridge, 2006) 161 and passim. 
seventeenth century (if not always) were keenly aware whether the group in power was their own or some other. ${ }^{14}$

Identity was, however, not only universalised but also historicised in this study by showing that the content changes continually (but cannot be created ex nibilo) and that identities build on other identities (Dutch on Protestant, Deccani on Hindu, Hindu on Deccani, Maratha on Deccani, etc.). A particularly important development in our period was the coincidence of territory with group with state on a greater scale than before, which development started slightly later in India (before it was cut off by European colonialism) than in Europe (where it built on colonial confrontations, see Chapter 1). The Epilogue takes a closer look at the confrontation between personal loyalty-based states and nation- or qaumbased states in the eighteenth century. 


\section{EPILOGUE \\ AURANGZEB/SHIVAJI AND THE EIGHTEENTH CENTURY}

The quarrel lighted such a fire

That everything got burned in its heat

Ali Muhammad Khan, $1761^{1}$

The present study may be deemed reactionary in that it marks a return to two colonial ideas: that India was a country of communities and that India was in a permanent state of war in the period preceding British rule. The latter is an important point in Seeley's argument that the British were drawn into India through the conflicts of Indian states, an idea shared by many early nationalists. ${ }^{2}$ This does not mean that Seeley's statement that Muslim rule itself had broken "the tie of nationality" so that "the state lost its right to appeal to patriotism" applies. ${ }^{3}$ Many Muslim-ruled states successfully appealed to the loyalty of a large part of the population for a long period, as has been seen in Chapter 4 for instance. But it must immediately be added that in the late seventeenth century the attitude of people like Madanna and Akkanna and Shivaji to even such champions of the Deccani cause as AbulHasan or Malik Ambar was highly ambiguous as is evidenced by Akkanna's pronouncements to Janszoon and by Paramananda's Suryavamsha Anupurana. The last quarter of the seventeenth century, moreover, saw a significant increase in the area affected by conflict. Shivaji exported the implosion of Bijapur that stemmed from the strife between the Deccanis and the Afghans to the remainder of the Deccan and the Karnatak with his campaign of 1677, while Aurangzeb involved the entire subcontinent in the Deccan struggles.

After a protracted period of steadily growing Mughal involvement in the Deccan, the 1680s saw an explosion of activity that led to the discomfiture of the remaining Deccan sultanates. As has been seen in Chapter 5, Aurangzeb's introduction of the jiziya in 1679 led quite directly to the revolt of the Rajputs of southern Rajputana, as described in the Ma'asir-i 'Alamgiri. That revolt led in turn to the rebellion of Prince Akbar, which in turn led to the coming to the Deccan of Aurangzeb, which led to

\footnotetext{
1 About a riot between Hindus and Muslims in Ahmadabad (see below) Mirat-i Abmadi (translation) 358.

2 Bernard S. Cohn, "Representing Authority in Victorian India" in Eric Hobsbawn and Terence Ranger eds. The Invention of Tradition (Cambridge, 1992) 165-7; Partha Chatterjee, Nationalist Thought and the Colonial World: A Derivative Discourse (London, 1986) 85-6; J.R. Seeley, The expansion of England; two courses of lectures (London, 1885) 189-244.

${ }^{3}$ Compare Chris Bayly, Origins of Nationality, 9, 28-9; Seeley quoted ibidem.
} 
the Balkanisation ${ }^{4}$ of the Deccan, with no group having a separate territory. That in turn led to the "eighteenth century," which was in India, if anything, a period of decentralisation or regional centralisation. ${ }^{5}$

\section{AN AXIAL DECADE}

Something had changed in the decade 1677-87. In the Introduction it has already been noted that all the Hindu-Muslim riots that we know of from the historical record of the Deccan and North India occurred after this decade. But what is more, the wave of tolerance and explicit religious syncretism that had swept the Islamic courts of India around the turn of the sixteenth century, and which reverberated through the seventeenth century, had come to an end. While Akbar became firmly committed to his philosophy of Sulb-i Kull or Total Peace in the final decades of the sixteenth century, Ibrahim II Adil Shah flirted with the cult of the goddess of learning and the arts Sarasvati, and Muhammad Quli Qutb Shah wrote his boundary-crossing poems. The religious outlook of that generation of kings is sometimes popularly called "bindolmani," a contraction of Hindu and Musalman made into an abstract noun. Yet it must be noted that in denying the importance of boundaries between religions, these rulers were also confirming their sense of the self, as when Muhammad Quli stated:

You give encouragement to Hindu practices — that is the accusation.

Yet the idol-house also bows like us [haman].

The "us" in this verse can only be interpreted as "the Muslim community," with whom Muhammad Quli here clearly identified. And although there are at least five of such poetic statements by him (of which one was quoted in the Introduction), ${ }^{6}$ there are also verses in which he expressed his desire to eradicate kufr in the name of Haidar/Ali, one of which commences:

Muhammad's faith is paramount, so set the Hindu hordes to flight! ${ }^{7}$

${ }^{4}$ This term is often invoked with reference to the "end game" of colonialism, that is for British attempts to Balkanise India. Compare Sugata Bose and Ayesha Jalal, Modern South Asia: History, Culture, Political Economy (London, 1998) 241.

5 Ibidem, 50-6. Gommans, Mughal Warfare, 202-3. The 1980s saw an extensive debate on the eighteenth century out of which came various theories on the nature of the early modern Indian state including Wink's fitna-thesis and the first applications of the idea of portfoliocapitalism. See Seema Alavi, "Introduction," in The Eighteenth Century in India, ed. idem (Oxford, 2002) 1-41.

${ }^{6}$ Quoted and translated in Luther, Prince, 36. My translation of the above verse differs, however.

${ }^{7}$ Muhammad Quli, Kulliyat, first collection (Narmẽ): 32. Quoted and translated by Matthews, "The Kulliyat," 44. Another such line (about breaking or raping kufr in the name of Ali) quoted in Masud Husain Khan and Ghulam Omer Khan eds. Dakani Urdu ki lughat (Classical Dakani Urdu Dictionary) (Hyderabad, 1969) s.v. kufr bhajan. 
Muhammad is here of course both the author and the prophet. Similarly, Akbar, in his final years, seems to have returned to a religious policy and practice acceptable to the Islamic mainstream, while Ibrahim Adil Shah had a Qur'anic verse (3:60) inscribed on one of the doorways to his tomb stating that Abraham/Ibrahim was always a Muslim and never of the idolaters. And of course there occurred in the early seventeenth century and in deliberate proximity to the Mughal court, Sirhindi's so-called Naqsbandi reaction, which was, if anything, a plea for a renewed marking of the boundaries of Islamic orthodoxy. Yet still in the middle decades of the seventeenth century the Mughal prince and brother of Aurangzeb Dara Shukoh wrote his Majma " ul-Babrain or "co-mingling of the two oceans" and a translation of the Upanishads. In those works he asserted that there is no fundamental difference between Islam and Hinduism, and even that ancient Indian scriptures are essential for understanding Islam and idols can play an essential role in the development of religious consciousness. ${ }^{8}$

But such royal voices fell silent after 1687. Maybe after Aurangzeb and Shivaji it was simply no longer possible for the political elite to experiment quite so freely and uninhibitedly with religious boundaries in India, or at least not in the way in which it had been done previously. While both Madanna and Shivaji were dedicated to a space that was in a sense public and above religious differences, they were also engaged in a contest over which group should sustain the public space. It is at precisely this point that Shivaji's discourses on Deccani patriotism and on Hindu dharma intersect. Both he and Madanna were in favour of a space that should be accessible to all, but governed by Hindus. That much becomes clear from Madanna's remark to Janszoon and from Shivaji's drawing a connection between slave trade and Muslim rule. As Chris Bayly notes about eighteenth-century North India, there was an "ecumene" or a platform on which people from different religious denominations and castes could exchange views and news, but there were also power imbalances between those groups. ${ }^{9}$ Aurangzeb was engaged on the opposite side of the contest, also, in fact, dedicated to a rule of law independent of his person. So much

8 Iqtidar Alam Khan, "Akbar's Personality Traits and World Outlook - A Critical Reappraisal." In Akbar and His India, ed. Irfan Habib, 79-96; Douglas E. Streusand, The Formation of the Mughal Empire (Delhi, 1989) 122, 137-8; Eaton, Sufis of Bijapur, 89-105; Abbas, Urdu mẽ qaumi sha'iri, 43; David W. Damrel, “The 'Naqshbandi Reaction' Reconsidered," in Beyond Turk and Hindu, ed. David Gilmartin and Bruce B. Lawrence (Gainesville, 2000) 17698; Friedmann, "Islamic Thought." Friedmann there compares Dara Shukoh to the mideighteenth century Islamic thinker Jan-i Janan, who is also seen as a proponent of the conciliatory attitude towards Hindus, but whose views in that respect turn out to be far less far-reaching than Dara Shukoh's. Friedmann also argues that in the period after the execution of Dara Shukoh at the behest of Aurangzeb in 1659 the uncompromising attitude to Hinduism gained the upper hand in Indo-Islamic thought (as expressed in Persian and Arabic). Ibidem, 84-7. My argument here, however, is concerns the political elite.

${ }^{9}$ Chris Bayly, Empire and Information, 180-211. 
becomes evident also from Aurangzeb's institution of shari wakils all over the empire to handle da'wa shari or legal claims against the emperor himself. ${ }^{10}$ As Mahir Akbarabadi wrote, Urfi would have been called Shar ${ }^{\circ}$ in his reign (see Chapter 4).

Yet the public space that Madanna, Shivaji and Aurangzeb seem to have been invested in only partly overlaps with the modern idea of the public sphere as distinguished from the private sphere. There was clearly an idea of a public good (which is perhaps quite ancient) which in our period entailed the idea that there were public funds that should not be misappropriated: viz. Madanna's measures regarding tax-collecting officials and Aurangzeb's earning an income for himself by copying Qur'ans and sewing prayer caps (though that also seems to have been based on a Qur'anic injunction). ${ }^{11}$ Yet Aurangzeb also took a keen interest in the work of his mubtasibs or censors of morals, ${ }^{12}$ and with that in the interference in what we would now call private. And while Aurangzeb is supposed to have written/quoted the words "lakum dinkum wali din," "for you is your faith and for me is mine," in the context of the distinction between the Shic $i$ and Sunni marhabs, he actively interfered to uphold the boundaries of Islam as will be seen below. ${ }^{13}$

Perhaps it was precisely the tension between Aurangzeb's ideological underpinnings of empire that entailed the practice of jiziya on the one hand and his growing reliance on Hindu men of the pen and of the sword that came with the expansion into the South on the other that, in the final instance, proved the undoing of the empire. It has been noted that the proportionate number of Hindu mansabdars grew in Aurangzeb's time. ${ }^{14}$ This, it seems, was due to a long-term process of the rise of Hindu scribal groups and to the need somehow to accommodate the men of the sword of the conquered territories. However, there was a clear "glass ceiling" to the rise of Hindu mansabdars under Aurangzeb. When the Rajput Jai Singh was appointed by prince Bidar Bakht as his deputy in Malwa in 1705, Aurangzeb wrote that a Rajput could not ordinarily be given the position of Governor or even that of faujdar. ${ }^{15}$ Moreover, although mansabdars were exempted, the jiziya must have made it painfully clear that non-Muslims could be part of the Mughal elite, but only almost. As Khafi Khan wrote some time after Aurangzeb's reign had ended, the imposition of the tax was

\footnotetext{
${ }^{10}$ Khafi Khan, Muntakhab (translation) 251.

11 See "Aurangzeb's Last Will and Testament" in Hamid ud-Din Khan Bahadur, Abkam-i 'Alamgiri (translation) 46-49.

12 Sarkar, History of Aurangzib, vol. 3 Northern India 1658-1681 (3 $3^{\text {td }}$ ed.; Calcutta, 1928) 81-84; Sarkar, Mughal Administration (4th ed.; Calcutta, 1952) 25-6; BL, Letter Aurangzeb to Bidar Bakht [ca. 1706] in Inayatullah Khan ed. Abkam-i 'Alamgiri Ms. I.O. Islamic 3887: 87-v.

${ }^{13}$ Hamid ud-Din Khan Bahadur, Abkam-i 'Alamgiri translation, 88 and Persian text, 49.

14 Athar Ali, Mughal Nobility, 30-7.

15 Athar Ali, Mughal Nobility, 26.
} 
done, "with a view to suppress the infidels, and make clear the distinction between the dar ul-harb en de muti" ul-Islam," that is between the rebellious areas and the areas that were muti, obedient or submissive, to Islam. To be sure, Aurangzeb did not introduce the distinction between Hindus and Muslims or between Hindu and Muslim officials. As has been argued in the Introduction, the distinction was already marked in the beginning of the seventeenth century by the closure of the jama on different sides - a dress code that was still generally adhered to in the late seventeenth century, with the notable exception of Shivaji who appears to have flouted it judging by his miniature portraits. ${ }^{16} \mathrm{New}$ was that the distinction was marked by humiliation, which was in fact, as Musta id Khan noted, in accordance with the Qur'anic injunction "till they pay commutation money (jiziya) with the hand of humility." The way in which it should be collected was also stipulated in Aurangzeb's order: "The zimmi should come on foot to pay the jizia-tax, and should remain standing while the collector is sitting. The collector should place his hand over the hand of the zimmi and say ' $O$ zimmi pay the jizia'." 17 As is also stipulated there, a zimmi was not to send a deputy to pay the tax and the extant imperial newsletters refer to an occasion in 1694 when an official in the service of a mansabdar tried to obtain permission to send a deputy but was reminded that payment of the jiriya was a privilege and must, therefore, be made in person. ${ }^{18}$ Also, in an order of ca. 1701 to Firuz Jang as given in a now well-known collection of anecdotes concerning orders of Aurangzeb, the latter made explicit that humiliation was the purpose of his imposition of the jiziya by stating that the last word of the Qur'anic injunction "they are humbled," was not to be replaced by "they deserve to be excused" even if (pretended) exigency so demanded. But then, Aurangzeb considered humility (before God) a prime virtue, which he not only tried to practice himself but also tried to instil in his officers - to "keep their feet in the mud" — as is evident from many of his remarks in writing that the compiler found worthy of inclusion among the anecdotes. Taking stock of his own accomplishments he is supposed to have noted:

I have angered God and not pleased mortals, I have [merely] consumed a quantity of water and fodder.

And to prince Mu'azzam (Shah Alam) he wrote: "Manliness does not consist in audacity and recklessness, but in breaking one's self." 19

\footnotetext{
16 With the exception of his "Manucci" miniature and one in BN, Smith-Lessouëf 232, all his more or less contemporary miniatures depict him with his jama closed to the right.

${ }_{17}$ Musta'id Khan, Ma'asir-i 'Alamgiri, 108; Khafi Khan, Muntakbab (translation) 258-9; Syed, Aurangzeb, xxviii-xxxii.

18 Azizuddin Husain, Structure, 119.

${ }^{19}$ Hamid ud-Din Khan Bahadur Abkam-i 'Alamgiri (translation) 63, 79, 107, 116, $127-8$ and passim (translation of Aurangzeb's verse adapted from Persian text, 67; Azizuddin Husain
} 
The jiziya therefore signified the "not quite" 20 of the Mughal empire after 1679. Hindu intellectuals were highly conscious of the implications of jiriya taxes; the renowned Sanskrit scholar Kavindracarya Sarasvati from Maharashtra, who was at one point in the service of Dara Shukoh, earned himself a collection of laudatory poems from Sanskrit poets and intellectuals for having convinced Aurangzeb's and Dara's father Shah Jahan to rescind the jiziza that was then only specifically levelled from pilgrims to Allahabad and Benares. ${ }^{21}$ Moreover, right after the imposition of the jiziya by Aurangzeb, large Delhi crowds besieged the emperor with supplications for days, at the jharoka balcony — the traditional place for appeals to royal favour - and en route to the mosque to the extent that the crowds had to be dispersed violently so that the emperor could proceed. That is, according to Khafi Khan, while according to Manucci "all the highplaced and important men at the court opposed themselves to this measure. They besought the king most humbly to refrain."

This opposition both popular and elite does not seem to have disappeared once people grew accustomed to the measure. An earthquake that took place shortly after the imposition of the jiriya was seen at the court as a sign that the earth was opposing itself to the measure (though Aurangzeb supposedly argued that the earth was showing its joy), while a series of earthquakes in August and September 1684 led Brahmins at Surat to predict the demise of Aurangzeb. ${ }^{22}$ Such a prediction would not likely have been made about a loved and admired king. In Bhimsen's memoirs, moreover, one can trace a progressive disenchantment with the Mughal administrative apparatus in the later period of Aurangzeb's reign, encompassing, as was noted in Chapter 5, a critique of the jiriya collection. Bhimsen retired from service around 1689 amidst the increasing upheaval of the Deccan, but after his friends convinced him that retirement was not good, took up service under a Hindu raja who was also a mansabdar. This meant that Bhimsen was still to serve the empire indirectly, but at least the new position "freed my mind from the harassment of the collectors and writers of government." It is unclear, though, whether Bhimsen was here

\footnotetext{
rightly commends that verse to the attention of historians in Structure, 180). The emphasis on humility would support Sarkar's attribution of this abkam collection to Hamid ud-Din Khan, who after Aurangzeb's death lived close to Aurangzeb's grave for a while, donning a darvish's dress and sweeping the tomb. Ma'asir ul-Umara 1: 613. See also Appendix II.

20 Compare Homi Bhabha's hackneyed argument about skin colour and administrative servants of European colonial empires in The Location of Culture.

21 Pollock, "Death of Sanskrit," 407.

22 Khafi Khan, Muntakhab (translation) 258-9; Manucci, Storia do Mogor, 3: 274-77; NA, Surat daily record, sub datis 21 and 22.8 and 19,20 and 23.9.1684, VOC 1398: 475-6. Compare Athar Ali, Mughal Nobility, 99.
} 
talking of some harassment that befell him after he had left imperial service or of a generally harassing experience in the imperial administration..$^{23}$

The section of the Deccani Muslim (petty) ashraf that was to remain without employment after the conquest was also spiteful towards the new administrative elite that included so many Hindus on the one hand, and towards the strict religious regime of the emperor on the other, as will be seen below. The ambiguous position of the Deccani Muslims was highlighted dramatically by the treatment of Hyderabad's Muslim population by Shah Alam around the turn of 1685, when they were first awarded preferential treatment and taxed at a much lower rate than the Hindu citizenry, but were later exposed to all-out looting along with the rest of the population after some Deccani Muslims had attacked Shah Alam's

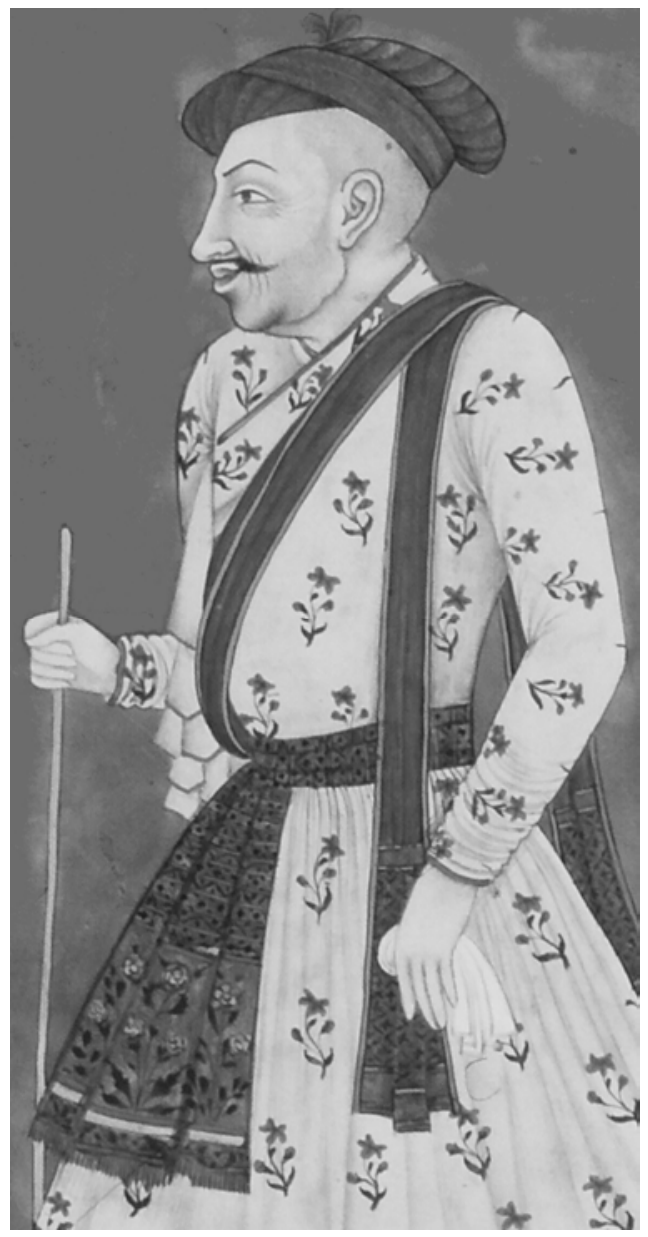
supply train. ${ }^{24}$ From these events it seems that Shah Alam felt himself betrayed, having perceived the Muslims of Hyderabad as natural allies, but finding that their Deccani affinities prevailed over their Islamic affinities. The decade 1677-87 proved a watershed for Muslims as well as Hindus of the Deccan.

Madanna as represented in the Smith-Lessouëf 233 album, folio 12. Courtesy Bibliothèque Nationale de France.

In the last chapter it was noted that the administration of Madanna and Akkanna was remembered as a golden age by eighteenth-century Brahmins. Some people, however, seem to have

${ }^{23}$ Bhimsen, Tarikh, 166-8, 176. Comp. Richards, "Norms of Comportment," 270-1, 286-9.

${ }^{24}$ BN, Letter [of Mr. Guesty] Hyderabad 20.4.1686, Collection Clairembault 1017: 69-v. 
remembered Madanna differently. The Smith-Lessouëf 233 album of miniature portraits illustrates this point. The portrait shown here can be identified as Madanna's on the basis of the stick with a small horn at the lower end that all prime ministers of Golkonda carry in their portraits in Smith-Lessouëf 232 and 233, as well as on the basis of the characteristic puckers around his mouth. This portrait differs greatly from earlier portraits, made during Madanna's lifetime, and is more of a caricature than a portrait. Madanna here has a sly grin, mean eyes, his head drawn between the shoulders and a paunch bulging over his belt. It is clear that he was not popular with the painter. It is also significant that unlike many of the other portraits in this series made between 1690 and 1702, this portrait is not similar to, or based on, an example in the Smith-Lessoueff 232 series, which was made around 1680. Here lay the initial stages of the division of memories of a divisive period. ${ }^{25}$

\section{A BLEAK CENTURY}

The conquest of Bijapur and Golkonda was marked, as if to symbolise that it was the end of an era, by a great famine and cholera epidemic. Although famines had also attended the Mughal campaign in the Deccan of 1635 as well as Aurangzeb's arrival in the Deccan in 1683, the magnitude of the famine of 1687 seems to have been much greater. Daniel Havart narrated many of the horrors that occurred in Masulipatnam when the rice prices had multiplied twentyfold and that of a chicken fifty or sixtyfold, while the price of human beings moved in the opposite direction, as people hoped to be saved from starvation by slavery. Although he was not himself present on the Coromandel coast at the time, Havart quoted two letters from Masulipatnam, one of which reported that the number of dead in the area was estimated at 500,000. ${ }^{26}$ Johannes Bacherus wrote about his voyage from Masulipatnam to Hyderabad in January 1689 that, "at that time all [of us] had seen before our eyes, lamentably, how by sword and starvation that great area and the villages were so direly depopulated, and no six villages to be found with a dozen households, except the king's very large Hayatnagar,

\footnotetext{
$25 \mathrm{BN}$, Smith-Lessoueff 233; The album has a note in front stating that the miniatures were collected in 1694 by Cornelis de Bruijn, but he does not yet seem to have been in the region at that time, see also Lunsingh Scheurleer, "Witsenalbum." It is noteworthy that Madanna's jama in this miniature closes on the right, as opposed to all other miniatures of him where it closes on the left, as was proper for Hindus. Madanna also has a golden turban here, as opposed to the white ones in earlier portraits, but in this series the attire of those portrayed is generally more garish than usual. It may also be noted that hajv or satire became a popular genre in literature just around this time. See Azizuddin Husain, Structure.

${ }_{26}$ Havart, Op-en Ondergang, 1: 213-5; BL, consultations Petapoli April 1687, G/30/1: quire 4: 38. The last two decades of the seventeenth century also saw famine and pestilence in Gujarat, Das Gupta, Indian Merchants, 134 note2.
} 
that every traveller was necessitated to bring along his own food along." 27 In a chronogram of the year $1099 \mathrm{AH}$ (1687-88 CE), a late eighteenthcentury Sufi hagiography squarely attributed the cholera epidemic that struck the Bijapur plateau: bud waba' az Mughal — "the cholera came from the Mughals." A census of Bijapur taken on behalf of Aurangzeb showed that the city had lost over half of its former population in the few years after conquest. 28

The turmoil created between Aurangzeb and Shivaji in the Deccan ricocheted to the north and ruined the empire. Ashin Das Gupta has carefully documented the breakdown of order in the heartland of the Mughal empire that spelled the decline of Surat and notes: "Insecurity within the empire was already marked at the turn of the century. The aged emperor Aurangzeb was rapidly sinking into senility and the generationlong campaign in the Deccan was closing in futile exhaustion. News and rumour from the imperial camp poured into Surat in an unbroken stream, causing an occasional nervous spasm." 29 A letter of Aurangzeb in his last years, included in the collection put together by his close aide Inayatullah Khan, stated: "there is no province or district, where the grovelling infidels have not raised a tumult and since they are not chastised, they have established themselves everywhere. Most of the country has been rendered desolate and if any place is inhabited, the peasants there have probably come to terms with the 'robbers' [ashqiya, official Mughal name for the Marathas]..."30 Thus, by the end of Aurangzeb's reign, the empire was quite universally perceived as a ruin, even by the emperor himself. The Poet Muhammad Hashim Taslim wrote:

I have laid to waste cities and mansions of desire in India

When it comes to devastation, my destiny/twilight is no less than Alamgir's [Aurangzeb's]. ${ }^{31}$

To be sure the eighteenth century saw many islands of prosperity amidst the continuous struggles of the Mughal successors against Marathas in south and north. The late eighteenth and early nineteenth-century reports about islands of prosperity such as the heartlands of the Maratha Peshwas or the domains of the wazir of Awadh, can be contrasted with an equally great number of stories of devastation, of which William Dalrymple quotes

\footnotetext{
${ }^{27} \mathrm{NA}$, Bacherus to XVII 4.12.1692, VOC 1510: 24-v.

${ }^{28}$ Eaton, Sufis of Bijapur, 270.

${ }^{29}$ Das Gupta, Indian Merchants, 139.

${ }^{30} \mathrm{BL}$, Inayatullah Khan ed. Abkam-i 'Alamgiri, Ms. I.O. Islamic 3887: 61v. This translation adapted from Habib, Agrarian System, 350-1. For Inayatullah Khan and his compilations see: Shah Nawaz Khan and Abdul-Hayy, Ma'asir ul-Umara, 1: 680-2.

31 Quoted in Azizuddin Husain, Structure, 177, 180 (translation adapted by me). Azizuddin Husain does not give the sources for these verses.
} 
two concerning the central Deccan. ${ }^{32}$ While the former occasioned the 1980s revisionism of the eighteenth century, the latter inspired the gloomy view of that century in all previous writing, between the days of Seeley, that is the 1880s, and the 1980s (with possible exceptions of the art historian Herman Goetz and the Indonesia specialist J.C. van Leur).

Whatever tint one chooses to colour the economic and cultural life of eighteenth century, the fact remains that after two centuries without major military incursions, South Asia experienced the invasion of Nadir Shah in 1739 as well as the encroachment by the Frenchmen and Englishmen who exported their European struggle to the south of the Indian subcontinent. But rather than reduce the destruction of the Mughal empire to material factors or a class struggle occasioned by material deprivation - as Irfan Habib famously does in his Agrarian System of Mughal India $-{ }^{33}$ one must allow for the role and power of identity. That is to say, one must allow for the role of ideologies of difference in the million mutinies that brought about the discomfiture of the empire.

Of course contests over resources played a large role in identity formation (as was noted in Chapter 6), but the sheer force of ideologies of identity at this time can only be explained with a reference to human nature. While human nature does not explain the fall of the Mughal empire, nor its rise, it does explain why so many risings against the Mughals came in the guise of identities not directly related to material struggle. It explains for instance why so many peasant movements consisted in religious brotherhoods - as noted by Habib. ${ }^{34}$ Not only was religion the main ideological area to be affected by Aurangzeb's administration, the sense of kinship imparted by these movements was necessary to motivate people to rise.

Many Deccani poets expressing themselves in Urdu lamented the bad state of incomes and the economy, as well as the demise of religion and righteousness, in Bijapur and Golkonda in the troubled times following their fall. The Bijapuri Ansari complained in a ghazal that all was now in the grip of kufr, and that the ashraf were not what they used to be, with even judges taking bribes. Ansari seems to have assigned the cause of this misery to imperial overstretch, and ended his ghazal with a pun on Aurangzeb Alamgir's name "world conquest [dunyagir] is no mere bribe; you simply don't have the time." In a similar vein an anonymous contemporary Sufi

32 Compare Richard Barnett, North India between Empires: Awadh, the Mughals and the British 1720-1801 (Berkeley, 1980) 172 note 21; Wink, "Maratha Revenue Farming," 594. Dalrymple, White Mughals, 81-2.

${ }^{33}$ Habib, Agrarian System, 317-52.

34 Ibidem, 332-3. Compare also Ranajit Guha, who goes so far as to state that, for the colonial period, religiosity was the central modality of peasant consciousness. "Prose of Counter-Insurgency," 37. 
poet marked the advent of the twelfth century AH (commencing $1688 \mathrm{AD}$ ) by cursing Aurangzeb to hell. The poet blamed him for the bribe-taking and dishonesty of his officials and the gains made by the Hindu men of the pen that were the subject of Chapter 6, of whom the poet mentions Kayasthas, Khatris and Brahmins. Moreover, even among the men of the sword dhoti wearers (that is: Hindus) would "have become an estranged retinue." And meanwhile, the poet alleges, "North Indian Leatherworkers, Tanners, and Untouchables, Washermen, Oil-sellers, and Gardeners - all have become rulers." The poet thus matches a contempt for Hindus in general with one for the lowest castes among the Hindus, to which the above-mentioned professions belonged, and that contempt with his scorn for the emperor and the "the orthodox leaders," who "explain that Aurangzeb's rule is just." The poem is a kaleidoscope, or rather kakoscope, of seventeenth-century stereotypes, brought into sharp relief by the dire economic circumstances. ${ }^{35}$

The Sufi poet Mahmud Bahri also had his reasons to announce prophetically the twelfth century $\mathrm{AH}$ as he did: "Oh brother the twelfth century has come, good has been exchanged for bad." Bahri himself had witnessed the fall of Bijapur and the commencement of Mughal administration in Hyderabad, and in that very first year of the twelfth century became a recluse in his native Gogi east of Bijapur. And, as he himself narrated, when he was still in Bijapur his unorthodox Sufi leanings had been investigated by a qazi, who was purging the city on behalf of the new government and who "had already slain one dervish for saying things contrary to Islamic Law." Bahri was sympathetic to the majzubs, Sufis unattached to any of the orders and generally quite "wild," and made pronouncements similar to Muhammad Quli Qutb Shah, Ibrahim Adil Shah and Dara Shukoh on the unity of devotion. After he had retreated to Gogi he noted that if he were to return to Bijapur he might end up as Mansur al-Halaj who was notoriously brought to death in tenth-century Baghdad for going one step too far in his Sufic practices by ecstatically exclaiming "I am God." Thus the new dispensation came with increased policing of the boundaries of Islam and one of the few contemporary poets writing in Deccani Urdu who hailed Aurangzeb's conquest, Shaikh Dawud Za'ifi, did so precisely because he saw Aurangzeb as a "builder of Islam." 36

\footnotetext{
35 Ansari's poem reproduced in Abbas, Urdu mẽ qaumi sha'iri, 52. The anonymous poem, which was woven into a lengthy so-called chakki nama, is quoted in translation in Eaton, Sufis of Bijapur, 272. For a discussion of the date and authorship of the poem see ibidem, 273, note 75. Compare Jalal, Self and Sovereignty, 12.

${ }^{36}$ Bahri's poem on the twelfth century reproduced in Abbas, Urdu me qaumi sha'iri, 52-3. For Bahri's life and work, see Eaton, Sufis of Bijapur, 256-64. For Za'ifi see Mas'ud Husain Khan, "Dakhni Urdu," in Sherwani Joshi eds. Medieval Deccan, 2:17-34, there 31.
} 
Bahri was in a sense a "classical loser" like La Rochefoucauld, who lost out in the cause against French absolutism in the mid-seventeenth century and, in the words of Félix Hémon, "sought consolation in the delicate joy of observing, in the bitter pleasure of remembering." ${ }^{37}$ One might also argue that Bahri's statement on the twelfth century is merely a tangent of the Indic discourse on the kali yuga (black age) -- and later in the poem Bahri indeed mentioned the desertion of dharma - that had been part of the mental landscape for many centuries, in any case among Hindus. Still another way to view Bahri's satire would be as further evidence of the emergence of a public sphere, in so far as it related to conceptions of government and just and unjust rule. ${ }^{38}$ However, all that seems insufficient to explain the magnitude of the wave of this kind of laments in the shabr-i ashub or "city in turmoil" genre in the late seventeenth and early eighteenth century that Ayesha Jalal and others have noted. Along with Bahri, a number of poets wallowed in bitter observations about the present bad state of society, whether they assigned the blame to Aurangzeb's depredations or the rise of new men, or to the combination of those two factors. ${ }^{39}$

Among these Muslim poets expressing themselves in Urdu there was clearly a consciousness that times had changed and a world had been lost to them as access to resources (the revenue, state positions) in the early eighteenth century continued to shift away from Muslim ashraf and toward Marathas, Brahmins and others. ${ }^{40}$ This was especially true for the western half of the subcontinent, where states arose that were based around the kind of groups that were designated "qaum" already in the seventeenth century: the Marathas in Maharashtra and Gujarat, the Afghans in the Kabul valley, the Jats west of Delhi, the Sikhs (also mostly Jats but with a strident religious ideology) in the Punjab, the Rajputs in Rajputana. East of Delhi successor states based around lineages of Mughal nobles established themselves in Awadh, Bengal and at Hyderabad and Arcot. At the frontier between these two halves of the subcontinent some Afghans warriors and horse traders managed to establish small states. ${ }^{41}$ Yet even in the Mughal

\footnotetext{
37 Compare Wolfgang Schivelbusch, Die Kultur der Niederlage: Der Amerikanische Süden 1865, Frankreich 1871, Deutschland 1918 (Berlin, 2001) 14; Hémon quoted ibidem, 346.

38 Chris Bayly argues that in Indo-Muslim thought the notion of government (sarkar) came to hold a virtue beyond the will of the king of the moment, although it is not clear to me when the term sarkar came into common usage (in fact my impression is that it came into common usage only in the nineteenth century), but it is certainly true that as Bayly argues, the "Indo-Muslim conception of government embodied sophisticated concepts of just and unjust rule, zulum (“oppression"), which could be introduced into popular debate." Empire and Information, 184.

39 Jalal, Self and Sovereignty, 11-4; Abbas, Urdu mẽ qaumi sha 'iri, 49-51.

${ }_{40}$ Compare Jalal, Self and Sovereignty, 13 and Shackle, "Beyond Turk and Hindu."

${ }^{41}$ A. C. Banerjee and D. K. Ghose, eds. A Comprehensive History of India, vol. 13 (Delhi, 1978); J.S. Grewal, The Sikhs of the Punjab (Cambridge, 1990); Gordon, Marathas; Clifford E.
} 
successor states the Muslim elite was dependent on Hindu bankers and zamindars, perhaps to a larger extent than the Mughal empire had been. ${ }^{42}$

Thus while the balance of power continued to shift away from Muslims and religious boundaries hardened, sudden outbreaks of violence between religious groups became possible. The first riot between Hindus and Muslims on record for the Deccan and North India occurred on the festival of Holi in 1714 in Ahmadabad, located, rather significantly, at the head of the Dakshinapatha, or high road leading into the Deccan, and in those years mangled between the Mughals and the Marathas. The memory of that riot prompted Ali Muhammad Khan to insert the verse quoted at the beginning of this chapter. It was followed by a near-riot in the same city centring on cow-slaughter in 1716 and a number of riots between Hindus and Muslims in North India and Kashmir in the 1720s. ${ }^{43}$ Yet my point is not that the eighteenth century was a century of pervasive Hindu-Muslim conflict, but that it was one of pervasive and uncontained group conflict. With so many groups defined along lines of religion, language, region of origin or occupation (not to say caste or class), or a mix of several of these, competing over resources and no one group being able to contain the others, insecurity and chaos remained, until the Mughal successor states and the qaum-based states established some sort of entente around the midcentury. Even then, the balances of power remained volatile, of which Frenchmen and the EIC notoriously took advantage.

While a causal relation between A) communalism and B) colonialism is hard to establish as it is, many have tried to explain A from B. But now that it seems that A preceded B, should that causal relation be reversed? The early successes of the English Company in gaining control of territory and revenue were all booked in the east of the subcontinent among the non-qaum based states. The Mughal successor states seem to have lacked whatever measure of cohesion the qaum-based states had. In the second half of the eighteenth-century, in a shabr-i ashub type poem, Lakshmi Narayan "Shafiq" seems to have lamented a tripartite division of Hyderabad society where he wrote that in the days of the six (sic) padshabs of the Deccan everyone was happy, "whether peasant, soldier, or noble of

Bosworth, The New Islamic Dynasties (Edinburgh, 1996) 335-9; Muzaffar Alam, The crisis of Empire in Mughal North India; Awadh and the Punjab $1707-48$ (Delhi, 1986); Susan Bayly, Saints, Goddesses and Kings; Muslims and Christians in South Indian Society 1700-1900 (Cambridge etc. 1989); Jos J.L. Gommans, The rise of the Indo-Afghan Empire, c. 1710-1780 (Leiden, 1995); Joseph E. Schwartzberg, ed. A Historical Atlas of South Asia (New York, 1992).

42 P.B. Calkins, "The Formation of a Regionally Oriented Ruling Group in Bengal: 17001740," Journal of Asian Studies 29 (1970) 799-806; Karen Leonard, "The Hyderabad Political System and its Participants," Journal of Asian Studies 30 (1971) 569-582.

43 Mirat-i Ahmadi (translation) 333-4, 358-9, 371. Compare Chris Bayly, "Pre-History," $194-$ 201. Khafi Khan seems to conflate the riot of 1714 and the near riot of 1716, see Haider, "A 'Holi Riot',' 131-3. 
repute." This tripartite division drew on two binary oppositions, that between the military classes (amir, sipabi) and the protected (raiyat) and that between amir and commoner, the former generally Muslim, the latter in majority Hindu. Shafiq wondered further whether it was jealousies or failing governance that had brought the present enmities. ${ }^{44}$ This lack of cohesion allowed the Mughal successor states to be more easily cajoled into accepting arrangements and treaties allowing the French and British a share of the revenue in return for military support against the qaum-based states and each other. The list of dates of arrangements and treaties is all too familiar: Bengal 1765, Awadh 1773, Hyderabad 1753 ("Northern Sarkars" to the Frenchman De Bussy) and 1766 (the same to the English), Arcot 1763. In fine by 1798, the start of what Seeley calls the second phase of British expansion, all of the former Mughal successor states were more or less under British control. ${ }^{45}$ The westerly qaum-based states, however, came under British control later and in a manner involving more physical violence. Muslim-ruled Mysore which went down in a blaze of violence seems an exception that proves the rule, though Tipu also appealed to France for assistance. ${ }^{46}$

Of course there was a certain amount of loyalty the Mughal successor states commanded, but the eighteenth century is different from the period of the heyday of the Mughal empire when Abul-Fazl could write confidently that Hindus were as loyal to the state as Muslims. ${ }^{47}$ As has been shown in the last three chapters, in the late seventeenth century a consciousness had taken root in many regions that Hindu dispensation was preferable to Muslim dispensation. Shivaji's discourse on Deccani patriotism, while distinguishing between different Muslims also, perhaps ultimately, preferred Hindu dispensation over Muslim dispensation, even of the Deccani variety. The same idea transpires through the ambiguities of Prince Akbar's Rebellion and Madanna's politique stance.

A person like Tipu Sultan was fully aware of the rift between Muslims and Hindus at the time. In 1785 he sent a letter to his representatives in Pune to tell them that rather than champion the cause of Muslims in that place they should consider the dissensions between Hindus and Muslims there beneficial to Islam because they would weaken the Peshwa state - implicit in which adhortation was of course a perception of

\footnotetext{
${ }^{44}$ Shafiq's poem reproduced in Abbas, Urdu mẽ qaumi sha iri, 56-7.

${ }^{45}$ Compare Chris A. Bayly, Indian Society and the making of the British Empire (Cambridge, 1988); Seeley, 269-70; Bayly allows the above argument in some measure for Bengal and Arcot. Chris Bayly, Origins, 28-9.

46 Dalrymple, White Mughals. Kate Brittlebank suggests that Tipu successfully sought recognition of his legitimacy from his Hindu subjects despite "an Islamicising drive." Kate Brittlebank, Tipu Sultan's Search for Legitimacy: Islam and Kingship in a Hindu Domain (Delhi, 1997) 130 and passim.

${ }^{47}$ Chandra, "Jizyah," 332.
} 
the weakness of his own state. The fact that the representatives of a Muslim ruler felt it necessary to protect the rights of Muslims in a Maratha/Brahmin-ruled state (in a marriage dispute) is also remarkable. ${ }^{48} \mathrm{It}$ reflects the idea that every group - distinguished by religion or otherwise - in a state is responsible for its own affairs (akin to the Ottoman millet principle) coupled with a sense of extraterritoriality also present in the dispute over the Dutch girl who had turned Muslima in Chapter 1 and the instances in which Aurangzeb held the European company governors responsible for pirates of their nation. However one wants to view such principles, they cannot be regarded as a guarantee for a state easily capable of withstanding external pressure.

Thus communalism in the widest sense but also in the narrow sense contributed to the advance of colonialism in India, which does of course not make colonialism a restorer of stability. Colonialism may well have exacerbated already-existing antagonisms as well as created some new ones. Nor does that conclusion answer the question as to what ultimately mattered more: the push or the pull, the aggressive imposition of the British or the invitation to conflict by Indian states, and that is well beyond the scope of this epilogue. However, it is certain that the interplay between European nationalisms and Indian identities mattered, ${ }^{49}$ and already before the halfway point of the century the Kashmiri observer Khwaja AbdulKarim contrasted the "perfect unity of the Franks" to the internal dissension that characterised the fading Mughal empire. In verse, he wrote:

Wealth grows out of coordinated acts, its lack comes out of disunity. ${ }^{50}$

Every dichotomy between human groups has those who remember a past in which the dichotomy did not exist. As the painters and weavers of Madras observed in Chapter 3, the reification of the Right/Left boundary in Madras brought "disturbance" in the town that was not there previously. And the European nations, however unified they might appear in India also had their share. Wrote a former Dutch statesman in 1813, looking back at the late eighteenth century which brought French occupation: "thirty years

48 Translation of letter Tipu Sultan to Nur Muhammad Khan and Muhammad Ghiyas, 5 "Wâsaaey"/14.9.1785, in William Kirkpatrick trans. and ed. Select Letters of Tippoo Sultan to Various Public Functionaries (London, 1811). Compare and contrast Brittlebank, Tipu Sultan's Search, 35.

${ }^{49}$ William Dalrymple's White Mughals poignantly shows how important ant-French feelings were in policy decisions of EIC officials regarding Indian states, as well as how Indian states played the European nations against each other in the late nineteenth century.

50 To be sure, the context makes it clear that the author did not mean to say that all Europeans were perfectly united, but that the different European qaums or firqas he distinguished were. Alam and Subrahmanyam, Indo-Persian, 280-90. 
of undisturbed peace had completed the miracle of the Netherlands' greatness; when all of a sudden strife lit its torch, and waved it around terribly, till all was ablaze...Such was the cost to us of our lamentable divisions." The gist of that passage is comparable to the message of early Indian nationalists, namely that internal divisions had brought on foreign occupation, while the phrasing of the passage in terms of a fire metaphor brings to mind Ali Muhammad Khan's verse quoted at the top of this chapter. ${ }^{51}$

That again brings to mind the Whitean tragedy modern academic discourse has made out of the putative emergence of caste and the HinduMuslim divide in the colonial period. It may be said that the present study has merely preponed the tragedy of that tragedy (although I would say it is more about a universal tragedy endlessly repeating itself). And even that is not new: at the beginning of the modern period, in 1809, in another petition to the British, Hindus of Benares already blamed Aurangzeb for having demolished a once-existing harmony between the religious communities in the town along with a temple. ${ }^{52}$ However, celebrating a past unity or lamenting its demise is one thing, recognising our weaknesses and dealing with them is another ${ }^{53}$ — which brings me to another note on the ethics of writing.

\section{THE ETHICS REVISITED}

Concerning the ethics of describing seventeenth-century struggles and antagonisms that to some seem relevant to today's communalist politics in India, something has already been said in the Introduction and at the end of Chapter 4, but a short further note is in order here. As was noted in the Introduction, there is a strong tendency in the mind of the public as well as that of historians to see groups in a more or less far away past as ancestors of modern groups and to in effect identify the two. The consequence is that some feel that some parts of history must be blotted out or covered up to accommodate the needs of the putative present-day descendants of those involved in the events concerned. Although heritage is often seen as a source of pride, which Muslims may take in the glories of al-Andalus or the Taj Mahal and the Dutch in their Golden Century with its trading empire in the East, ${ }^{54}$ the reverse side of the "heritage paradigm" is the "blame para-

\footnotetext{
51 Matthijs Lok, ““Op een gelijksoortige klip schipbreuk leiden.' De politieke argumentatie van voormalige napoleontische bestuurders in de grondwetscommissie van 1814," Leidschrift 19 no. 3 (2004) 89-105, there 98.

52 Chris Bayly, Empire and Information, 207.

${ }^{53}$ Jonathan Israel, Bayle Lecture, www.pierrebayle.nl/lectures/israel/israel_lecture_uk.html.

${ }_{54}$ Compare David Lowenthal, Possessed by the Past: the Heritage Crusade and the Spoils of History (New York, 1996).
} 


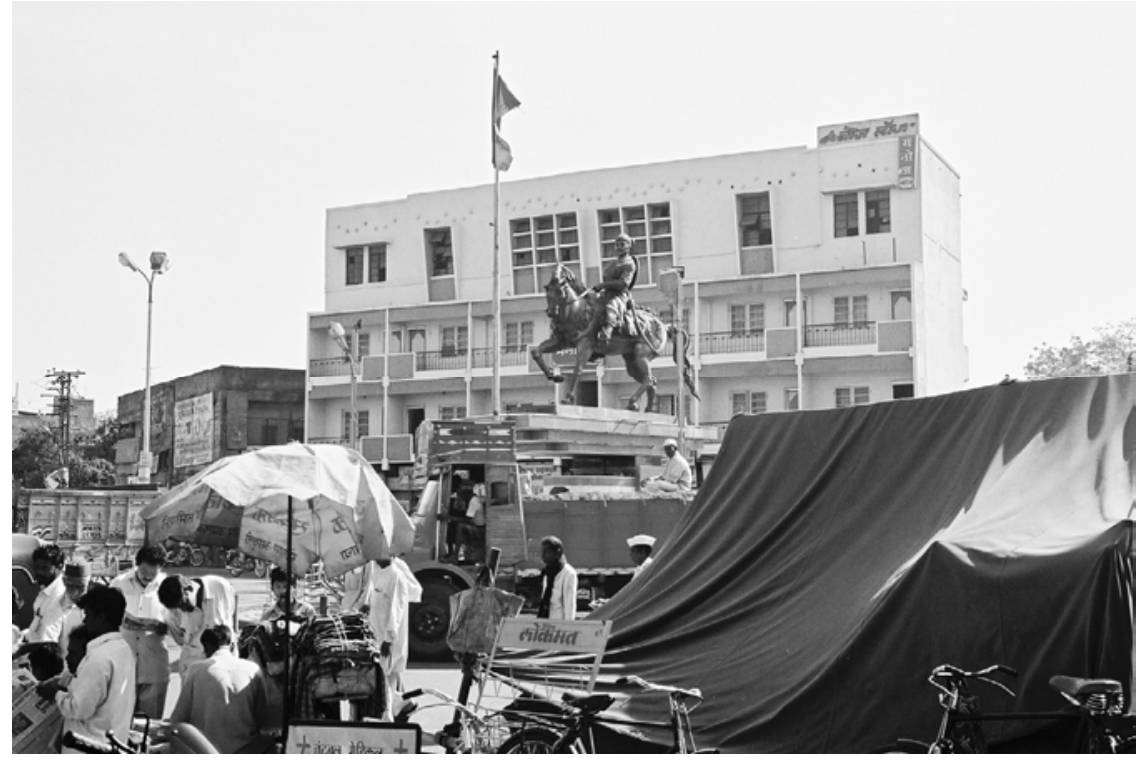

Modern statue of Shivaji at Sholapur, an orange flag atop.

digm." As was noted in the Introduction there is a strong tendency among academics to assign the blame for present divisions of Indian society to British colonialism, and there is an equally strong tendency among Hindu nationalists to assign the blame for many things to the Muslims.

While it may be useful for nation building project to lay the blame for unfortunate past and present events with an outside force, an important problem of the blame paradigm is that blame tends to spill over or become deflected, as the following two examples illustrate. Nicholas Dirks finds in the penultimate chapter of his book on the British invention of caste in India (though it allows for a very minor role of precolonial Indians), that "a blanket condemnation of colonial history can now be affiliated in peculiar ways to a critique of the postcolonial state" and that his own work "that was motivated by a particular critique of colonial history has been aligned with and used to support of a serious critique of Mandal [i.e. of the reservation policy proposed by Mandal]." During a "writers retreat" in the honour of V.S. Naipaul at Neemrana in 2002, a lady held a lengthy diatribe against British colonialism, which prompted an interruption from Naipaul: "You know as well as I that British rule was not half as bad as Muslim rule. Would you refrain from these banalities?" 55

Avishai Margalit, already referred to in the Introduction, argues that an "ethical community" is obliged to remember and that the memories 


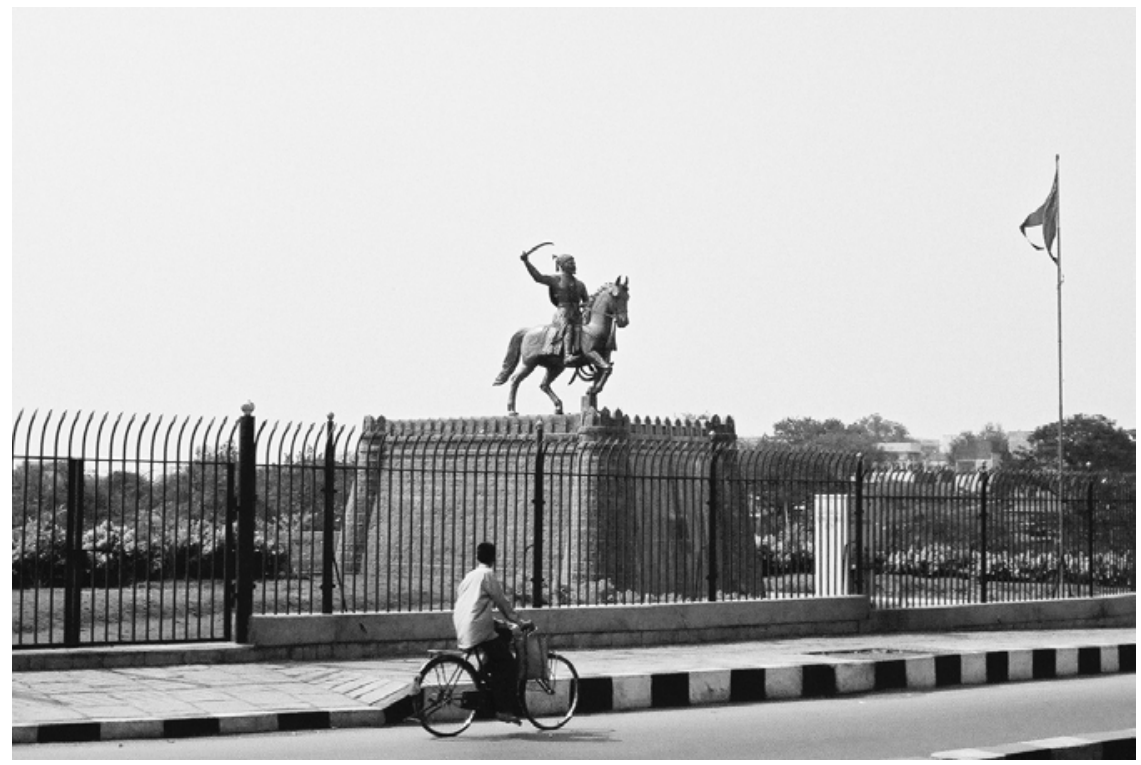

Modern statue of Shivaji behind a fence in Hyderabad, with orange flag.

entertained by such a community will be "charmed," or enchanted in the Weberian sense. Thus, "democracy can and should include backwardlooking emotions and attitudes as well, such as forgiveness and gratitude." However, if a nation is divided, as any human community tends to be divided into smaller communities (see Chapter 2 and 3), how does one partition its memories? Margalit's distinction between "ethics" for use within a community and "morality" for use outside it is untenable if one considers that any community is part of a still larger community, a problem that Margalit faces on page 143, where he writes that the "people we hate" are also part of the network of thick relations to which ethics, and not morality, apply. By implication the ethical obligation to remember in an emotionally charged way is also untenable. All the more so, because over time the importance of boundaries shifts from one boundary to the other; while at one point the boundary between religious affiliation may be the most salient, at another it may be the boundary between this and that locality. After a period it becomes impossible to tell which memory belongs to whom: is the memory of the Mughal empire Indian or Muslim? Is the memory of Pharaonic Egypt "white" or "black"? The question "whose memory is it anyway?" sums up the problem of group definition and formation that Margalit confronts insufficiently, accepting group boundaries as given. It is certainly true that "it is easier to create a class with common economic interests than with a shared memory," and I agree that social constructs are rigid, in fact that is one of the main arguments of the present study, but they are rigid only at a given point in time. It seems, however, 


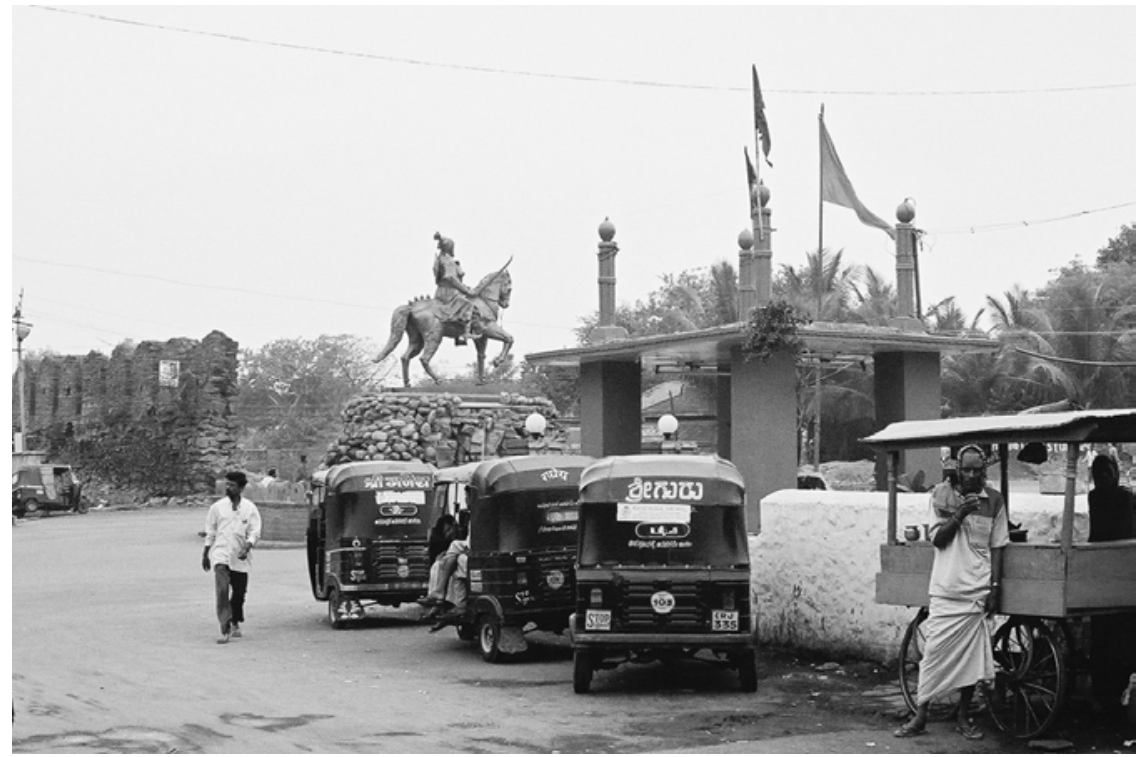

Modern statue of Shivaji breaching the old city wall of Bijapur. In front is a shrine for a Muslim saint, painted green. Green and orange flags are the medium for a battle over sacred space and heritage.

that my disagreement with Margalit stems mainly from the fact that the collective memories his work is mainly concerned with are of more recent events (most particularly the holocaust) than the memories presently under consideration. Introducing a 100-year time limit for the period to which emotions such as forgiveness and gratitude apply, as I would like to suggest here, partly solves the problem of group definition, because a claim to certain grandparents is more easily sustained than a claim to a group of seventeenth-century ancestors. A hundred years is also about the absolute temporal limit that anyone with a first-hand experience or memory of the events concerned may still be alive. ${ }^{56}$

56 Margalit, Ethics. Quotations from pages 12 and 71. Compare also Appiah's critique of heritage and Margalit in Ethics of Identity, 137, 151. Just as I was coming to the conclusion that eighty years would suffice, that is around the maximum span of an adult life or the period that anybody who has actively partaken in whatever events that need be remembered may still be alive, various articles appeared in Dutch newspapers concerning the commemoration of the Second World War and the need for Turkey to take responsibility for the Armenian genocide in the final days of the Ottoman empire, now ninety years ago. While a few years ago there was talk in the Netherlands of abolishing the yearly commemoration by two minutes of silence, now (that is in a period of national reorientation after the murder of Theo van Gogh) everyone stressed the need to continue. One front-page article was entitled: "Babies are also war witnesses." At about the same time, Germany opened the new holocaust monument, symbolising its will not to forget, as the chairman of the Bundestag put it. Later, a picture appeared on the front page of three Armenian ladies of 93, 95 and 97 years old attending a hearing on the subject of the Armenian genocide in the 
To sum up the ethical aspects of the Conclusion and Epilogue: the denial of human nature is in certain academic circles connected paradoxically with the implicit belief in heritage, in the present case that South Asian Muslims carry the heritage of the Mughals and sultans and that white Europeans and Americans carry the heritage of colonialism. The heritage view of the past will be dealt with satisfactorily by limiting to eighty or a hundred years the period for which a nation or group of people must carry the blame for past events. Beyond those eighty or a hundred years, memory must become retrospection, a historical effort also important but not a ground for or grounded in hatred or love. Certainly, this will require a considerable conscious effort of intention, which some may deem unfeasible. Yet even if the effects of certain events are still traceable centuries later, as was argued here with regard to the actions of Aurangzeb, there can be no ethical or moral ground for blaming his descendants or the descendants of his co-religionists. To quote Nobel Prize-winner Amartya Sen:

There is no intrinsic reason why a defence of India's secularism must take a position on what, say, the Moghals did or did not do. The "guilt" of Muslim kings, if any, need not be "transferred" to the 140 Muslims who live in India today. ${ }^{57}$

Rather than bicker over the nature of the Mughal heritage, we need to reconceive Aurangzeb, Shivaji and their contemporaries as history, samples of human behaviour to be explained rather than evaluated, and themselves part of an explanation of what followed.

\footnotetext{
American Congress. However, the choice between eighty and a hundred years is not very relevant to our present case, which consists in events of 400 to 200 years ago. Paul Scheffer, "Hoe om te gaan met witte vlekken in het verleden: geweten en vergeten gaan niet samen," 23.4.2005 Mark Duursma, "Baby's zijn ook oorlogsgetuigen," 4.5.2005 Michel Kerres, "Betonblokken tegen het vergeten," 7.5.2005, Photo AP with article "Armeense genocide splijt VS en Turkije," 11.10.2007 all in NRC Handelsblad.

57 The Argumentative Indian: Writings on Indian History, Culture and Identity (London, 2005) 311-2.
} 


\section{APPENDIX I \\ DUTCH USAGE FOR MUSLIM AND HINDU}

For reasons specified in chapters one and six, many Dutchmen in India adopted a Muslim-centric view of India and with that the classification of its population into Muslims and non-Muslims. In the South Asian context the term Moors (Mooren) almost invariably meant Muslims but occasionally, when more emphasis was required on religious beliefs as such, the term Mohammedans (Mabometisten etc.) was used. The other inhabitants of India with their various religious ideas and practices were classed as Heathens (Heijdenen), or as Jentieven, a term that, like its English equivalent Gentu, arose in the Indian context from the Portuguese gentio from the Latin term gentilis as used in the Vulgate to refer to non-Jews. ${ }^{1}$

The terms "Heathen" and "Gentu" applied to the professors of what the Central Asian traveller Mahmud Balkhi around 1630 called the kesh-i Hindu'i, the Indian or Hindu religion. Thus Van Twist wrote in 1638 "the inhabitants and natives of Gujarat used to be Heathens, called by the common name of Hindou; but after they had been dominated by Tamerlane, they have in part become Mohammedans." Similarly, in Ketelaar's vocabulary written at the end of the century, Dutch Heyden was equated with the "Hindustani" word Hindou, and in 1684 factors spoke of a "Sientieff or Hindouwer." Geleynssen, however, writing around 1625, noted: "these Rajputs are not Moors, nor Heathens, they are called Hindoes."2

The term Gentu could, in a more specific sense, also refer to the Telugu language or a native speaker of it. Thus, Wouter Schouten speaks of the Gentijfse heijdens inhabiting Tengapatnam on the southern Coromandel coast. Jentieven does also occur in this secondary sense in Van Twist's "Generale beschrijvinghe," as the authors of Hobson-Jobson note, but Van Twist also seems to have used the word in the more general sense as when he applied it to the Holi festival. ${ }^{3}$

The terms Moorish and Heathen/Gentu were sometimes used loosely to indicate objects or persons having some relation with the states of Muslim or Hindu rulers respectively. ${ }^{4}$ Thus the "Moorish lands" of the Deccan were occasionally contrasted to the "Heathen lands" south of it.

\footnotetext{
${ }^{1}$ Yule and Burnell, Hobson-Jobson, s.v. Gentoo; New Oxford Dictionary of English, s.v. gentile.

2 Alam and Subrahmanyam, Indo-Persian Travels, 143, 155. NA, Grammar of Hindustani and Persian by Ketelaar, Sypestyn Collection (suppl.) 2: 11-12. NA, resolutie Surat 22.1.1684, VOC 1383: 629. Gelynssen, Remonstrantie, 54, 69, 72; Van Twist, "Generale beschrijvinghe," 29-30. See also Yule and Burnell, Hobson-Jobson s.v. Hindoo.

3 Yule and Burnell, Hobson-Jobson, s.v. Gentoo. Schouten, Aanmercklijke voyagie, b: 181; NA, Diary of embassy by Van Twist sub dato 11.3.1637, VOC 1122: 493.

${ }^{4}$ E.g. NA, Letter Adolf Thomas at Pulicat to Amsterdam 29.3.1616, VOC 1061: 177v and Report on mission to Thanjavur by Thomas van Rhee and Pieter Outshoorn van Sonnevelt 6.1.1677, VOC 1329: 1178v. NA, Letter Gerrit Backer at Masulipatnam to Batavia 29.5.1660, VOC 1233: 58.
} 
Although the Dutch generally distinguished carefully between Muslim and Hindu (or more specifically Brahmin) governors of the administrative divisions of Golkonda, I found one instance in which the phrase "Moorish regents" seems to have included some governors with Hindu names, being representatives of the Golkonda state.

Finally the terms Moorish and Heathen/Gentu were sometimes used for building and dress styles. Schouten and Baldaeus spoke of the fortress of Thirupapuliyar as being built in the Heathen manner. ${ }^{5}$ The "cabaya" and the type of trousers that went with it could, on the other hand, be described as Moorish. ${ }^{6}$ It is especially in this application to styles that the seventeenth-century Dutch usage of "Moorish" and "Heathen" resembles to the usage by modern scholars of the terms "Islamicate" and "Indic". 


\section{APPENDIX II \\ AURANZEB ON STRATAGEM}

At the top of Chapter 4 is a quotation of Niccolao Manucci about Aurangzeb's hollow words. The emperor seems to have had something of a reputation for stratagem. In 1683 VOC factor Willem Hartsinck doubted that the rebellious prince Akbar would be able to stay out of his father's reach even under Maratha protection, "because his father is a cunning old fox." 1 Although Chapter 4 is not so much about intentional deception, as about an often supposed unconscious disjunction between discourses and actions in the precolonial period, Aurangzeb's statements about intentional deception (if authentic) do shed light on seventeenth-century consciousness of the relation between actions and words. But since Chapter 4 did not seem to afford a suitable space for these considerations along with the consideration of their authenticity, they are briefly presented here.

In orders to various people, Aurangzeb is supposed to have written the following about the congruence or non-congruence of his actions and pronouncements: in the 1670s: "One cannot rule without practicing deception. The clear text of the holy Traditions [of Muhammad] is ' $W$ ar is stratagem '...in the opinion of the common herd, cunning and deception are greatly scorned. As God himself in His Holy Word [i.e. the Qur'an] has ascribed cunning to His holy self, saying 'God is the best of plotters', it is contrary to the Qur'an to consider stratagem as blameable. Besides in governing Kabul this quality is most beneficial and excellent." However, concerning de deathbed of Ruhullah Khan around 1692, when Aurangzeb deemed his sudden adherence to the Sunni creed mere taqiya (prudent concealment of one's religious beliefs): "the late Khan during his lifetime had made deception [bazi dadan - playing tricks] his characteristic. And at his death, too, he pursued this detestable habit to the end." Finally, nearing the end of his life in 1706 Aurangzeb wrote: "In the so many days of my past life there has been no difference in my words [?]. God willing up to the day of my removal to the eternal home, there will be no difference between my words and acts." If authentic, it would seem from these statements that Aurangzeb's view took a U-turn in his later years, which is quite possible. In any case it appears that Aurangzeb was fully conscious of the relation between his words and his deeds. ${ }^{2}$

Although these orders of Aurangzeb, carefully edited by Jadunath Sarkar as Abkam-i 'Alamgiri and translated by him as Anecdotes of Aurangzeb, seem authentic, it is difficult to establish if their wording is also exactly

\footnotetext{
${ }^{1}$ NA, Letter Masulipatam to Batavia 13.8.1683, VOC 1387: 1414v-15. See also Chapter 5.

${ }^{2}$ Hamid ud-Din Khan Bahadur [ascribed to], Abkam-i 'Alamgiri/ Anecdotes of Aurangzib, trans. by Jadunath Sarkar (4th ed; Calcutta, 1963) 28-9, 85-6, 109-10, 123-5 and Persian text, ed. Jadunath Sarkar (2d ed; Calcutta, 1926) 81.
} 
preserved in the four-odd extant manuscripts, and the anecdotal contexts given in this abkam (orders) collection seem somewhat muddled. The attribution of this collection to Hamid ud-Din Khan is also unsure and Irfan Habib deems this collection unreliable (in contrast to the abkam collection by Inayatullah Khan, also cited here in various places). ${ }^{3}$ It must further be noted that the first of the quotations from Aurangzeb given in the paragraph above is only present in one of the manuscripts.

${ }^{3}$ Habib, Agrarian System, 417. See also footnotes and 19 and 30 of the Epilogue. 


\section{ON THE AUTHENTICITY OF SHIVAJI'S AND SIDI MAS'UD’S LETTERS TO MALOJI GHORPADE}

There are many alleged letters of Shivaji around, but the authenticity of nearly all of them is difficult to assess. Some may be the product of eighteenth-century historical romance, or, as seems to be the case with Shivaji's famed letter to Jai Singh, poetical renditions of an original text. ${ }^{1}$ Too often these letters are cited as evidence without due inquiry into their antecedents. Most of Shivaji's letters have come down to us as "copies"; very few survive in the original. It is thus hard to tell whether Shivaji really wrote to Jai Singh that Muslims "are demons in the guise of men" or whether the vocabulary of his letters became less Persianate and more Sankritic in the course of his life, both of which claims are made in the secondary literature. ${ }^{2}$ This is not to say that there is no value in later renditions of Shivaji's written utterings - for example for a study such as Laine's into the development of the image of Shivaji - but as I am concerned here with a discussion of seventeenth-century concerns, I find any such potholes on the imagined road there rather detracting. But then it would be a shame to give up on the seventeenth-century sources and disparage this "sort of quest for historical detail contained in authentic documents,"3 especially since there is a great desire to know what Shivaji was really like, even, it would appear, amongst self-pronounced poststructuralists.

The original of the letter to Maloji Ghorpade seems to have survived into the twentieth century, although no-one seems to have seen it in the past eighty-odd years. It was first taken note of in the modern period by a British officer in Genealogy of Marratta Chiefs, published as a lithograph around 1827. The officer (possibly John Briggs) ${ }^{4}$ writes:

The first authentic account of this branch of the Bhonsla family [the Mudhol Ghorpades] is to be found in an original letter from Shivaji to Maloji Ghorpade, dated Bhagnuggur, when he was forming a connexion with the king of Golkonda. This curious document is in the hands of Govindráv Ghorpade, together with a vast number of Persian papers, the authenticity of which, when compared with other documents of the same time, cannot, for a moment be doubted. ${ }^{5}$

\footnotetext{
${ }^{1}$ Note by the editor in G.S. Sardesai ed. Shivaji Souvenir (Bombay, [1927]) 169.

2 Compare Sheldon Pollock, "Ramayana and Political Imagination in India," JAS 52 (1993)

261-97; Madhav M. Deshpande, Sanskrit and Prakrit: Sociolinguistic Issues, vol. 6 of MLBD Series in Linguistics (Delhi, 1993) 121.

${ }^{3}$ Compare Laine, Shivaji, 80.

${ }^{4}$ Mehendale, Sbivchatrapati, vol. 1, pt. 2, bk. 1: 393 note 83.

5 Genealogy of Marratta Chiefs (n.p, n.d. [1827]) 20-22. The date 17.1.1827 appears in the heading of the index. The same text is also published in: W. Forrest ed. Selections from the
} 
The anonymous British officer follows this up by a paragraph-long summary of the contents of the letter, from which there can be no doubt that he is dealing with the same text that we are presently concerned with. After the death of the above-mentioned Govind Rao, his junior brothers Vyankat Rao and Lakshman Rao may have divided the archives, in any case the letter was next noticed in Baroda, in which state the lands inherited by Lakshman Rao were located. ${ }^{6}$ In the early twentieth century the great Maharashtrian historian V.K. Rajwade published the full Marathi text of the letter in support of his argument that Shivaji was able to write, arguing that the last line of the letter was in his own hand. Rajwade does, however, not seem to have seen the letter for himself but states that a Maharashtrahistory-minded friend of the Prabhu writer caste copied the letter for him from the original then apparently in the "Chitnis archives" in Baroda. ${ }^{7}$ The text has later been republished in a work less rare than the Shri Sarasvati Mandir bimonthly, and two translations have also appeared. ${ }^{8}$

In conclusion, it may be assumed that the extant text of this particular letter of Shivaji is authentic, since two history-minded people were independently convinced that the document to which it evidently goes back was the original, and since one of those two wrote at such an early date. Even the Pune historian Gajanan Mehendale, who is very critical of many documents originating from the Ghorpade family archives (which critique I share only to an extent), thinks that this letter is probably authentic. ${ }^{9}$

Finally a note is in order on another letter, kept in the Ghorpade archives and rejected as a forgery by Gajanan Mehendale, which seems closely related to the one discussed above as it also enjoins Maloji to join the struggle against the Afghans at Bijapur and mentions Shivaji as having "exposed that the Afghans have in fact usurped the Adil Shahi [state]."10 The letter was first published by Balkrishna, and has generally been attributed to the Qutb Shah. The letter, however, starts with the title or form of address Umarat o Ayalat Panah, which is probably a reference to the

Letters, Despatches, and Other State Papers Preserved in the Bombay Secretariat: Maratha Series, vol. 1, pt. 3 (Bombay, 1885) 657-698, there 666-7.

${ }_{6}^{6}$ Compare Mudhol Rajvamsh ka Prachin Itihas (Mudhol, [ca. 1911]) 62; Brochure Mudhol State. (Ancient and Modern History) [n.d.; after 1929, before 1947].

7 V.K. Rajwade, "Shivajici Saksharta," Shri Sarasvati Mandir Dvaimasik Pustak 5 (Shaka 1827) 5-6 (Margshirsh and Magh or alternatively: issue nos. 21-2), paginated separately.

8 Full text: Pralhad Narahar Deshpande ed. Chatrapati Shivaji Maharajanci patre (Dhule, 1983) 202-5; Translations: Sardesai ed. Shivaji Souvenir, 146-9. Bal Krishna, Shivaji the Great, vol. 2, pt. 1 (a.k.a. pt. 3) (Kolhapur, 1939) 281-84. The latter is the more precise translation.

${ }_{9}^{9}$ Mehendale, Shivchatrapati, vol. 1, pt. 2, bk. 1: 393-4.

${ }_{10}$ Compare Mehendale, Shivchatrapati, vol. 1, pt. 2, bk. $1: 477-480$. For the full Persian text, with Marathi and English translations, see: Apte, Mudhol, appendix "parishiste," document no. 20. For a photograph of the document and an English translation, see Balkrishna, Shivaji Album (Bombay, [1930]) document no. 5. 
sender rather than the addressee. Sidi Mas'ud Khan is referred to by this title elsewhere, so he might have been the sender. Another courtly letter from the period of Sidi Mas'ud's ascendancy, published and deemed authentic by Mehendale and co-editors, starts with nearly the same sequence, namely "Alijah Umarat o Ayalat Panah to ... [titles and name]" and is written in a similar hand. ${ }^{11}$ An attribution of the Ghorpade letter to Mas'ud Khan rather than the Qutb Shah would take care of most of Mehendale's critique (which he has in a friendly way invited me to challenge), except that concerning the date at the bottom and the use of Urdu diacritical marks in the text (a small b over the retroflex $\mathrm{r} / \mathrm{d}$ of Ghorpade and four dots over the retroflex t of Marhata).

The fact that the date at the bottom of the document is before the year mentioned in the main text as de year of Shivaji's call to arms (Shuhur San 1076/CE 1675), may be explained by the common usage of accounting years that were ten years behind (compare for instance the qaul of Shivaji mentioned in the conclusion of the present chapter and some farmans of Madanna discussed in Chapter 6) or by a confusion of Shuhur San and Hijri dates. Both explanations would change the date from 1079 to 1089 Hijri, which is CE 1678, which would make perfect sense. Only the use of the Urdu diacritics remains somewhat odd - but then again they could have been added later and, moreover, no-one has exhaustively investigated when the use of Urdu diacritics started in the Deccan, although it is generally thought to have started in the mid-eighteenth century.

As a sort of qaul nama from Mas'ud Khan, the document would be closely related to the three farmans issued by Mas'ud Khan to Maloji in 1678 briefly discussed in Chapter 4, which are quite certainly authentic. If the document currently in the Ghorpade archives is not the original document, my guess would be that there once was a document similar to the one we have at present, possibly still around at the time when the anonymous British officer had a look at the Ghorpade archives, which was "updated" at some point later in the nineteenth century or in the early twentieth century. To be on the safe side, I have not involved this document in the discussion in Chapter 4. Its contents do, however, mesh with the argument presented there.

11 Gajanan B. Mehendale, Ravindra Lonakar and Ninad Bedekar, Adilshabi pharmane (Pune, 2007), document 37. 


\section{A NOTE ON USAGE}

TRANSLITERATION AND SPELLING_For the transliteration of Persian and Arabic words Steingass' dictionary has been followed except in the transition between the parts of Persian and Arabic compounds, where ...i is replaced by $\ldots-i$ and ...u ' $l$ - by $u l$ - etcetera. For Indic words the system of Snell and Weightman's Teach Yourself Hindi is followed with substitution sh for ś so as to resolve the conflict with Steingass' transliteration.

Diacritical marks other than ',' and the tilde have, however, been omitted. Also, in the transliteration of names considerable liberty has been taken in order to avoid cluttering the text with too many apostrophes and unpronounced letters at the end (thus Abdul-Karim, Ramadas and Khawas Khan instead of 'Abdu 'l-Karim, Ramadasa and Khawass Khan). Terms like Brahmin, sultan and raja that have found their way into the OED are spelled accordingly and also not transliterated in a precise way or italicised.

Geographical names are spelled in accordance with the Lonely Planet India and Bangladesh Road Atlas as far as the subcontinent is concerned, and according to whim for the rest of the world.

QUOTATIONS-In quotations from English primary sources, the punctuation and capitalisation has in some place been altered, but the spelling has been left as found. In quotations from other languages the spelling of names and foreign terms has been adapted to the usage in the main text, as outlined above. Punctuation and capitalisation have also been altered or added in such translations. In quotations from modern scholarly works the spelling of Indian terms has been left unchanged but for the omission of diacritical marks.

TENSES-To impart some sense of the depth of time and highlight the imaginary boundary between the modern and the early modern or the colonial and the precolonial, I have refrained from using the historical present for authors writing before 1800, but reserved it for modern authors. Thus Heda wrote, Foucault writes. This also because I do not engage in a discussion with the early authors as I do with the modern authors and because I think the statements of seventeenth-century authors should be construed as history, not heritage.

DATES_-Dates are according to the Gregorian calendar, occasionally indicated as CE (Common Era), unless marked by the abbreviations o.s. (old style) for the Julian calendar or AH (Anno Hijrae) for the Islamic calendar or an explicit reference to a different calendar. 


\section{LIST OF ABBREVIATED REFERENCES}

ACE Panduronga S.S. Pissurlencar ed. Assentos do Conselho do Estado, vol. 1: 1618-33. Goa, 1953.

APSA Andhra Pradesh State Archives

BL British Library

BM British Museum

BN Bibliothèque Nationale

ERS English Records on Shivaji (1659-1682). Shivaji Tercentenary Memorial Series, vol. 4. Puna, 1931.

EFI William Foster ed. The English Factories in India. [1]: 1618-1621. [2]: 1622-1623. [3]: 1624-1629. [4]: 1630-1633. [5]: 1634-1636. [6]: 1637-1641. [7]: 1642-1645. [8]: 1646-1650. [9]: 1651-1654. [10]: 1655-1660. [11]: 1661-64. [127: 1665-1667. [13]: 1668-1669. Oxford, 1906-1927.

MSA Maharashtra State Archives

NA National Archives, The Hague

PSA Punjab State Archives

RGS Royal Geographical Society, London

RP Rijksprentenkabinet, Rijksmuseum, Amsterdam

SBSHS George W. Forrest ed. Selections from the Letters, Despatches and Other State Papers Preserved in the Bombay Secretariat: Home Series. Bombay, 1887.

VOM Henry Davison Love, Vestiges of Old Madras 1640-1800: Traced from the East India Company's Records Preserved at Fort St. George and the India Office, and from Other Sources. 3 vols. and Index. London, 1913. 


\section{REPOSITORIES OF UNPUBLISHED SOURCES}

Andhra Pradesh State Archives, Hyderabad

- Mughal Records

- Hazrat Banda Nawaz Collection

- Qutb Shahi Farmans

Archaeological Museum, Bijapur

Bibliothèque Nationale, Paris

- Manuscrits occidentaux

- Collection Clairambault

- Fonds portuguaise

- Manuscrits orientaux

- Supplément persane

- Collection Smith-Lessouëff

British Library, London

- East India Company Records

- Correspondence with the East (E)

- Factory Records $(\mathrm{G})$

- European Manuscripts of Asia, Pacific and Africa Collections (Mss. Eur.)

- Mackenzie General and Miscellaneous Collections (Mackenzie gen.)

- Mackenzie Unbound Mss. (Mackenzie unb.)

- Orme Manuscripts (Orme)

- India Office Islamic Manuscripts (Mss. I.O. Islamic)

- Oriental Manuscripts (Mss. Or.)

British Museum, London

Ghorpade Royal House of Mudhol, Family Archives, Pune

Guimet Museum, Paris

Maharashtra State Archives, Mumbai

- Bombay Outward Order Book

- Warden's Selections

National Archives, The Hague

- Archives of the Hoge Regering van Batavia (HR)

- Sypestyn Collection

- Archives of the Verenigde Oostindische Compagnie (VOC)

Punjab State Archives

- Persian Manuscripts of the former Kapurthala Library

Rijksprentenkabinet, Rijksmuseum, Amsterdam

Royal Geographical Society, London

Salar Jung Museum and Library, Hyderabad

- History Manuscripts (Persian)

Utrecht University Library 


\title{
SELECT BIBLIOGRAPHY
}

\author{
SOURCES WRITTEN BEFORE 1800
}

(see also the List of Abbreviated References)

Ahmad, Nizam ud-Din. Hadiqat us-Salatin. Edited by Sayyid Ali Asghar Bilgrami. Hyderabad, 1961.

Ali Muhammad Khan, Mirat-i Ahmadi. Edited by Syed Nawab Ali, 2 vols. Baroda, 1927-8. Translation by M.F. Lokhandwala. Baroda, 1965.

Amatya, Ramachandrapant. "The Ajnapatra or Royal Edict: Relating to the Principles of Maratha State Policy." Translated by S.V. Puntambekar, Journal of Indian History 8 (1929): 83-105 and 207-33.

Baldaeus, Philippus. Naannkeurige beschryvinge van Malabar en Choromandel, der zelver aangrenzende ryken en het machtige eyland Ceylon. Nevens een omstandige en grondigh doorzochte ontdekeking en wederlegginge van de afgoderye der Oost-Indische beydenen. Amsterdam, 1672.

Bhimsen, Nuskha-i Dilkasha or Tarikh-i Dilkasha [before 1728]. BL, Ms. I.O. Islamic 94 [before 1804]; BL, Ms. Or. 23 [1728]; BN, Supplément persane 259 late $18^{\text {th }}$ century]. Translation by Jadunath Sarkar and others in Sir Jadunath Sarkar Birth Centenary Commemoration Volume: English Translation of Tarikh-i Dilkasha (Memoirs of Bhimsen relating to Aurangzib's Deccan Campaigns), ed. V.G. Khobrekar. Bombay, 1972.

Bilgrami, Syed Ali Asgar. Landmarks of the Deccan: A Comprehensive Guide to the Archaeological Remains of the City and Suburbs of Hyderabad. 1927; photogr. reprint Delhi, 1992.

Broecke, Pieter van den, Pieter van de Broecke in Aqië, 2 vols, ed. W.Ph. Coolhaas. Werken Linschoten Vereniging, 63-4. The Hague, 1962-3.

Danvers, F.C. Report to the Secretary of State for India in Council on the Portuguese Records Relating to the East Indies Contained in the Archivo da Torre do Tombo and the Public Libraries at Lisbon and Evora. London, 1892.

Elliot, H.M. and John Dowson. The History of India as Told by its Own Historians, 8 vols. 1867-77; photogr. reprint Delhi, 1990.

Fragner, Bert G. "Ein Privilegium aus Golkonda für die Niederländische Ostindische Kompanie." In Festgabe an Josef Matuz: Islamkundliche Untersuchungen, vol. 150, ed. Christa Fragner and Klaus Schwarz, 57-76. Berlin, 1992.

Fryer, John. A New Account of East India and Persia being Nine Years' Travels 1672-81. Edited by William Crooke, 2 vols. London, 1909.

Geleynssen de Jongh, W. De Remonstrantie van W. Geleynssen de Jongh. Edited by W. Caland. Werken uitgeven door de Linschoten-Vereeniging. The Hague, 1929.

Ghawwasi. Kulliyat-i Ghawwasi. Edited by Muhammad bin Umar. Hyderabad, 1959. Hafiz, Diwan-i Hafir, ed. Parwiz Natel Khanlari. 2d ed. Teheran, 1362 Hijri Shamsi. 
Hamid ud-Din Khan Bahadur [ascribed to], Ahkam-i 'Alamgiri. Edited by Jadunath Sarkar (2d ed; Calcutta: M.C. Sarkar \& Sons, 1926) and translated by idem as Anecdotes of Aurangrib. 4th ed. Calcutta, 1963.

Havart, Daniel. Op-en ondergang van Cormandel. ...ook Op-en ondergang der Koningen, die zedert weynige jaren, in Golconda, de hoofd-stad van Cormandel geregeerd hebben (3 parts in 1 volume). Amsterdam, 1693.

$\mathrm{H}$ [avart], D[aniel]. Persiaansche secretaris of een nette beschryving van de stijl die de Persianen gebruiken in hare brieven en notariale stukeken; als ook van de feest-en vierdagen der Mubammedanen door het gehele jaar in het Koninkryk Golconda. Amsterdam, n.d.

Heeres, J.E., ed. Corpus diplomaticum Neerlando-Indicum. Bijdragen tot de taal- landen volkenkunde van Nederlandsch-Indië, 6 vols. The Hague, 1907-55.

Hawkins, William. "Relations of the Occurrents Which Happened in the Time of His Residence in India." In The Hawkins' Voyages, edited by Clements R. Markham, 389-442. London, 1878.

Hume, David. A Treatise of Human Nature. Edited by David Fate Norton and Mary J. Norton. Oxford, 2001.

Inayatullah Khan, ed. Ahkam-i 'Alamgiri. BL, Ms. I.O. Islamic 3887 [not to be confused with the Ahkam-i 'Alamgiri by Hamid ud-Din Khan].

Khafi Khan (Muhammad Hashim Khan). Muntakhab ul-Lubab. Edited by Maulavi Kabir ud-Din Ahmad, vol. 2. Calcutta, 1874. The section on the era of Aurangzeb translated by S. Moinul Haq as Khafi Khan's History of 'Alamgir. Karachi, 1975.

Khan, Yusuf Husain, P. Sitapati and M.A. Nayeem, eds. and transs. Farmans and Sanads of the Deccan Sultans (1408-1687 A.D.). Revised ed. Hyderabad, 1980.

Khare, Ganesh Hari. Persian Sources of Indian History, vol. 5 pt.1. Pune, 1961.

Khobrekar, V.G. ed. Records of the Shivaji Period. Chhatrapati Shri Shivaji Maharaj Coronation Tercentenary Commemoration vol. 1. Bombay, 1974.

Mahalingam, T.V., trans. Mackenzie Manuscripts: Summaries of the Historical Manuscripts in the Mackenzie Collection. Vol. 2: (Telugu, Kannada and Marathi). Madras, 1976.

Ma'muri, Abul-Fazl, Aurangzeb Nama [ca. 1710?]. BL, Ms. Or. 1671 [1829].

Manucci, Niccolao. Storia do Mogor, or, Mogul India, 1653-1708. Translated by William Irvine, 4 vols. Delhi, 1981.

Martin, François. Mémoires de François Martin, Fondateur de Pondichéry (1665-1694). Edited by A. Martineau, vol. 2. Paris, 1932.

Master, Streyensham. The Diaries of Streyensham Master 1675-1680 and Other Contemporary Papers Relating Thereto. Edited by Richard Carnac Temple, vol. 2. London, 1911.

Moreland W.H., ed. and trans. Relations of Golconda in the Early Seventeenth Century. London, 1931.

Muhammad Quli Qutb Shah. Kulliyat-i Muhammad Quli Qutb Shah. Edited by Sayyid Mohi al-Din Qadri Zor. Hyderabad, 1940. 
Musta'id Khan, Muhammad Saqi. Ma'asir-i 'Alamgiri: A History of the Emperor Aurangzib-'Alamgir (reign 1658-1707 A.D.). Translated by Jadu-nath Sarkar. 1947; photogr. reprint Delhi, 1986.

Nazim, M. Bijapur Inscriptions. Memoirs of the Archaeological Survey of India, vol. 49. 1936; photogr. reprint Delhi, 1999.

Nieuhoff, Johan. Zee en lant-reize, door verscheide gewesten van Oostindien. Amsterdam, 1682.

Orme, Robert. Historical Fragments of the Mogul Empire, of the Morattoes, and the English Concerns in Indostan from the Year MDCLIX. 1782; modern ed. by J.P. Guha: Delhi, 1974.

Paramananda. Shrishivabharatam. Edited by Purushottamashastri Ranade and Vasudevashastri Marathe. Pune, 1930. Translated as The Epic of Shivaji: Kavindra Paramananda's Sivabharata, by James Laine in collaboration with S.S. Bahulkar. Hyderabad, 2001.

Roe, Thomas. The Embassy of Sir Thomas Roe to the Court of the Great Mogul 1615-1619, as Narrated in His Journal and Correspondence. Edited by William Foster. London, 1899.

Rogerius, Abraham. De Open-deure tot het Verborgen Heydendom. Edited by W. Caland. The Hague, 1915.

Schouten, Wouter. Aanmercklijke voyagie gedaan door Wouter Schouten naar Oost-Indien. Amsterdam, 1676.

Shah Nawaz Khan and Abdul-Hayy. Ma'asir ul-Umara'. Translated by H. Beveridge and Baini Prashad. Reprint Delhi, 1979.

Shahaji, Sati-dana-shuramu translated as "Take my Wife." In Classical Telugu Poetry, an Anthology, translated and introduced by Velchuru Narayana Rao and David Shulman, 354-80. Delhi, 2002.

Tabrizi, Muhammad Husain ibn-i Khalaf. Burban-i Qati. Edited by Muhammad Mo'in. Teheran, 1951-63.

Terry, Edward. A voyage to East-India: wherein some things are taken notice of in our passage thither, but many more in our abode there, within that ... rich and most spacious empire of the great Mogol ... London, [1655].

Twist, Johan van, "Generale beschrijvinghe van Indien." In vol. 2 of Begin ende voortgangh der Oost-Indische Compagnie. Edited by I. Commelin. Amsterdam, 1646.

Venkatadhvarin. Un poème satyrique sanskrit: La Visvagunadarsacampu de Venkatadhvarin. Translated and introduced by Marie-Claude Porcher. Pondichery, 1972.

Wassenaer, Nicolaes van, Historisch verhael van aller gedencwaerdiger gheschiedenissen, die bier en daar in Europa...van den beginne des jaars 1621 voorgevallen zijn, 21 vols. Amsterdam, 1622-1635.

Zain ud-Din, Tohfat ul-Mujahidin. Edited by David Lopez as História dos Portugueses no Malabar por Zinadim. Lisbon, 1899. Translated by J. Rowlandson as Tohfut ulMujabideen. London, 1833. 
Zuhuri, Muhammad Zuhur bin, Muhammad Nama [between 1641 and ca. 1650], PSA, Persian Ms. M/727 [1781] (of which I consulted a xerox copy in a private collection in the UK). Summary translation by Bhagwat Dayal Verma in: "History in Muhammad Nama." In Shivaji-Nibandhavali 2: 71-134. Pune, 1930.

\section{SOURCES WritTEN AFTER 1800}

Abbas, Muzaffar. Urdu mẽ qaumi sha ‘ri. Lahore, 1978.

Abdelal, Rawi, Yoshiko M. Herrera, Alastair Iain Johnston, Terry Martin. "Treating Identity as a Variable: Measuring the Content, Intensity, and Contestation of Identity" (2001). Available from www.people.fas.harvard.edu/ johnston/identity.pdf.

Alam, Muzaffar and Sanjay Subrahmanyam, Indo-Persian Travels in the Age of Discoveries 1400-1800. Cambridge, 2007.

Alavi, Rafi Ahmad. Studies in the History of the Medieval Deccan. Delhi, 1977.

Appadurai, Arjun. "Right and Left Hand Castes in South India." Indian Economic and Social History Review 11(1974): 216-59.

Appiah, Kwame Anthony. The Ethics of Identity. Princeton, 2005.

Apte, D.V. Mudhol Samstancya Ghorpade Gharanyaca Itihas. Pune, 1934.

Athar Ali, M. "The Mughal Polity - A Critique of Revisionist Approaches." Modern Asian Studies 27 (1993): 699-710.

—. The Mughal Nobility under Aurangzeb. Rev. ed. Delhi, 1997.

Azizuddin Husain, S.M. Structure of Politics under Aurangzeb 1658-1707. Delhi, 2002.

Bayly, Chris A. Rulers, Townsmen and Bazaars: North Indian Society in the Age of British expansion, 1770-1780. Cambridge, 1983.

—. "The Pre-History of 'Communalism'? Religious Conflict in India, 1700-1860." Modern Asian Studies 19 (1985): 177-203.

-. Empire and Information: Intelligence Gathering and Social Communication in India, 17801870. Cambridge, 1996

-. Origins of Nationality in South Asia: Patriotism and Ethical Government in the Making of Modern India. Oxford, 1998.

Bayly, Susan. Caste, Society and Politics in India from the Eighteenth Century to the Modern Age. The New Cambridge History of India, vol. 4, no. 3. Cambridge, 1999.

Beck, Brenda E.F. "The Right-Left Division of South Indian Society." Journal of Asian Studies 29 (1970): 779-98.

-. Peasant Society in Konku: A Study of Right and Left Subcastes in South India. Vancouver: University of British Columbia Press, 1972.

Behl, Aditya, “An Ethnographer in Disguise: Comparing Self and Other in Mughal India." In Notes on a Mandala: Essays in Honour of Wendy Doniger, ed. Laurie L. Patton and David L. Haberman. New York, 2008. 
Bes, Lennart. "The Setupatis, The Dutch, and Other Bandits in Eighteenth Century Ramnad (South India)." Journal of the Economic and Social History of the Orient 44 (2001): 540-574

Bhabha, Homi. The Location of Culture. London, 1994.

Bhandare, Shailendra. "An Evaluation of the Sabhasad Bakhar as Source of Historical Information: A Numismatic Perspective." In Proceedings of the $5^{\text {th }}$ International Colloquium on 'Medieval Indian Coinages: A Historical and Economic Perspective, 'ed. Amiteshwar Jha, 211-9. Nasik, 2001.

Bhupala Rao, K.V. The Illustrious Prime Minister Madanna. Hyderabad, [1984].

Biddulph, John. The Pirates of Malabar and An Englishwoman in India Two Hundred Years Ago. 1907; photogr. repr. Delhi, 1992.

Binder, Leonard. Islamic Liberalism: A Critique of Development Ideologies. Chicago, 1988.

Boogaart, Enst van den. Het verbeven en verdorven Azië; woord en beeld in het Itinerario en de Icones van Jan Huygen van Linschoten. Amsterdam/Leiden, 2000.

Peter Borschberg, "De Societate Publica cum Infidelibus': Ein Frühwerk von Hugo Grotius." Zeitschrift der Savigny-Stiftung für Rechtsgeschichte, Romanische Abteilung 115 (1998): 355-93.

Bourdieu, Pierre. Outline of a Theory of Practice. Cambridge, 1977.

Brimnes, Niels. Constructing the Colonial Encounter: Rigbt and Left Hand Castes in Early Colonial South India. Richmond, 1999.

Brittlebank, Kate. Tipu Sultan's Search for Legitimacy: Islam and Kingship in a Hindu Domain. Delhi, 1997.

Brown, Rupert. Group Processes, Dynamics within and between Groups. 2d ed., Oxford, 2000.

Cannadine, David. Ornamentalism: How the British Saw Their Empire. New York, 2001.

Certeau, Michel de. Heterologies: Discourse on the Other. Translated by Brian Massumi, foreword by Wlad Godzich. Manchester, 1986.

Chandra, Satish. "Jizyah and the State in India during the $17^{\text {th }}$ Century." Journal of the Economic and Social History of the Orient 12 (1969): 322-40.

Chatterjee, Partha. Nationalist Thought and the Colonial World: A Derivative Discourse. London, 1986.

Chattopadhyaya, Brajadulal. Representing the Other? Sanskrit Sources and the Muslims (Eighth to Fourteenth Century). Delhi, 1998.

Cohn, Bernard S. "The Census, Social Structure and Objectifation in South Asia." In idem, An Antbropologist among Historians and other Essays, 224-54. Delhi, 1987.

Cousens, Henry. Bijapur and its Architectural Remains: With a Historical Outline of the Adil Shabi Dynasty vol. 37 of Imperial Series, Archaeological Survey of India. 1916; photogr. repr. Delhi, 1996.

Dalrymple, William. White Mughals: Love and Betrayal in Eighteenth-Century India. London, 2003.

Das Gupta, Ashin. Indian Merchants and the Decline of Surat c. 1700-1750. Wiesbaden, 1979. 
Dennett, Daniel C. Sweet Dreams: Philosophical Obstacles to a Science of Consiousness. Cambridge, Mass. 2006.

Desai, W.S. Bombay and the Marathas up to 1774. Delhi, 1970.

Dijk, L.C.D. van, Zes jaren wit het leven van Wemmer van Berchem, gevolgd door Iets over onze vroegste betrekkingen met Japan. Amsterdam, 1858.

Dirks, Nicholas B. "Colonial Histories and Native Informants: Biography of an Archive." In Orientalism and the Postcolonial Predicament: Perspectives on South Asia, ed. Carol A. Breckenridge and Peter van der Veer, 279-313. Philadelphia, 1993.

-. Castes of Mind: Colonialism and the Making of Modern India. Princeton, 2001.

Eaton, Richard M. Sufis of Bijapur 1300-1700: Social Roles of Sufis in Medieval India. Princeton, 1978.

—. "(Re)imag(in)ing Other ${ }^{2}$ ness: A Postmortem for the Postmodern in India." Journal of World History 11 (2000): 57-78.

-. "Temple Desecration and Indo-Muslim States." Journal of Islamic Studies 11 (2000): 283-319.

- A Social History of the Deccan, 1300-1761 (Eight Indian Lives). The New Cambridge History of India, vol. 1.8. Cambridge, 2005.

Foucault, Michel, The Order of Things: An Archaeology of the Human Sciences. New York, 1971.

Friedmann, Yohanan. "Islamic Thought in Relation to the Indian Context." Purusartha (special issue: Islam et Société en Asie du Sud) 9 (1986): 79-91.

Fukuyama, Francis. Trust: The Social Virtues and the Creation of Prosperity. New York, 1996.

Gelder, Roelof van. Het Oostindisch avontuur Duitsers in dienst van de VOC (1600-1800). Nijmegen, 1997.

Gommans, Jos. Mughal Warfare: Indian Frontiers and High Roads to Empire 1500-1700. Warfare and History. London, 2002.

Gommans, Jos, Lennart Bes and Gijs Kruijtzer. Dutch Sources on South Asia c. 16001825. Vol. 1: Bibliography and Archival Guide to the National Archives at the Hague (The Netherlands). Delhi, 2001.

Gordon, Stewart. The Marathas 1600-1800. The New Cambridge History of India vol. 2., no. 4. Cambridge, 1993.

Goron, Stan and J.P. Goenka. The Coins of the Indian Sultanates: Covering the Area of Present-day India, Pakistan and Bangladesh. Delhi, 2001.

Guha, Sumit, "The Politics of Identity and Enumeration in India c. 1600-1990." Comparative Studies in Society and History 45 (2003): 148-167.

Guha, Ranajit. "The Prose of Counter-Insurgency," in Subaltern Studies, vol.2. edited by idem. Delhi, 1983.

Habib, Irfan. The Agrarian System of Mughal India (1556-1707). London, 1963.

Haider, Najaf. “A 'Holi Riot' of 1714: Versions from Ahmedabad and Delhi." In Living Together Separately, ed. Mushirul Hasan and Asim Roy, 127-44. Delhi, 2005. 
Hardt, Michael and Antonio Negri. Empire. Cambridge, 2000.

Hasan, Mushirul. "The Myth of Muslim Unity: Colonial and National Narratives." In Legacy of a Divided Nation: India's Muslims since Independence, 25-52. London, 1997.

Heesterman, J.C. "The Conundrum of the King's Authority." In Kingship and Authority in South Asia, ed. J.F. Richards, 1-27. Madison, 1978.

Hogg, Michael A., Deborah J. Terry and Katherine M. White. "A Tale of Two Theories: A Critical Comparison of Identity Theory with Social Identity Theory." Social Psychology Quarterly 58 (1995): 255-69.

Houben, Jan E.M. "The Brahmin Intellectual: History, Ritual and 'Time out of Time'." Journal of Indian Philosophy 30 (2002): 463-479.

Hughes, Thomas Patrick, A Dictionary of Islam. 1885; photogr. reprint Delhi/Ottawa, 1996.

Irschick, Eugene. Dialogue and History: Constructing South India 1795-1895. Berkeley, 1994.

Israel, Jonathan I. The Dutch Republic: Its Rise, Greatness, and Fall 1477-1806. Oxford, 1995.

Ittersum, Martine Julia van, Profit and Principle: Hugo Grotius, Natural Rights Theories and the Rise of Dutch Power in the East Indies, 1595-1615. Leiden, 2006.

Jalal, Ayesha. Self and Sovereignty: Individual and Community in South Asian Islam since 1850. London, 2000.

Kanaka Durga, P.S. "Identity and Symbols of Sustenance: Explorations in Social Mobility of Medieval South India." Journal of the Economic and Social History of the Orient 44 (2001): 141-74.

Khalidi, Omar. "The Shi'ites of the Deccan: An Introduction." In Glances on Shi'ite Deccan Culture, ed. Biancamaria Scarcia Amoretti, special issue of Rivista degli Studi Orientali 64 (1990): 5-16.

Koch, Ebba. Shah Jahan and Orpheus: The Pietre Dure Decoration and the Programme of the Throne in the Hall of Public Audiences at the Red Fort of Delhi. Graz, 1988.

Kolff, Dirk H.A. "La nation chrétienne à Suratte." In La femme dans les sociétés coloniales, ed. J.L. Miège. Aix en Provence, 1984.

-. Naukar, Rajput \& Sepoy: the Ethnohistory of the Military Labour Market in Hindustan, 1450-1850. Cambridge, 1990.

Kolff, D.H.A. and H.W. van Santen, "Inleiding." In eidem eds. De geschriften van Franciso Pelsaert over Mughal Indië, 1627; kroniek en remonstrantie. The Hague, 1979.

Krishnaswami Aiyangar, S. "Abul Hasan Qutub Shah and his Ministers, Madanna and Akkanna." Journal of Indian History (August 1931): 91-142.

Laine, James W. Sbivaji: Hindu King in Islamic India. New York, 2003.

Lassner, Jacob, The Middle East Remembered: Forged Identities, Competing Narratives, Contested Spaces. Ann Arbor, 2000.

Lefèvre-Agrati, Corinne. Pouvoir et elites dans l'empire moghol de Jahangir (r. 1605-1627). PhD thesis EHESS Paris, 2005. 
Lorenzen, David N. "Who Invented Hinduism?" Comparative Studies in Society and History 41 (1999): 630-59.

Lunsingh Scheurleer, Pauline. "Het Witsenalbum: zeventiende-eeuwse Indiase portretten op bestelling." Bulletin van het Rijksmuseum 44 (1996): 167-254.

Lunsingh Scheurleer, Pauline and Gijs Kruijtzer. "Camping with the Mughal Emperor: A Golkonda Artist Portrays a Dutch Ambassador in 1689." Arts of Asia 35 (2005) no. 3: 48-60.

Matthews, D.J. "The Kulliyat of Muhammad Quli Qutb Shah: Problems and Prospects." In Urdu and Muslim South Asia: Studies in Honour of Ralph Russell, ed. Christopher Shackle. London, 1989.

Mehendale, Gajanan Bhaskar. Shri Raja Shivchatrapati vol. 1, pt. 2, bk. 1. Pune, 1999.

Moreland, W.H. The Agrarian System of Moslem India. 1929; photogr. reprint Delhi, 1990.

Narendra Luther. Prince, Poet, Lover, Builder: Muhammad Quli Qutb Shah, the Founder of Hyderabad. Delhi, 1991.

Malabari, Phiroze B. M. Bombay in the Making: Being Mainly a History of the Origin and Growth of the Judicial Institutions in the Western Presidency, 1661-1726. London, 1910.

Margalit, Avishai. The Ethics of Memory. Cambridge, Mass. 2004.

Matar, Nabil. Turks, Moors, and Englishmen in the Age of Discovery. New York, 1999.

Michell, George, Architecture and Art of Southern India: Vijayanagara and the Successor States. The New Cambridge History of India vol. 1, no. 6. Cambridge, 1995.

Michell, George and Mark Zebrowski, Architecture and Art of the Deccan Sultanates. The New Cambridge History of India, vol. 1, no. 7. Cambridge, 1999.

Mines, Mattison. The Warrior Merchants: Textiles, Trade and Territory in South India. Cambridge, 1984.

Molesworth, J.T., George Candy and Thomas Candy. A dictionary, Marathi and English. 2d ed. 1857; photogr. reprint New Delhi, 1989.

Nayeem, M.A. External Relations of the Bijapur Kingdom (1489-1686 A.D.): A Study in Diplomatic History. Hyderabad, 1974.

Nirenberg, David. Communities of Violence: Persecution of Minorities in the Middle Ages. Princeton, 1996.

Pagden, Anthony. Lords of All the World: Ideologies of Empire in Spain, Britain and France. New Haven, 1995.

Pandey, Gyanendra. "Can a Muslim be an Indian?" Comparative Studies of Society and History (1999): 608-29.

Pearson, Michael. The Indian Ocean. London, 2003.

Peters, Marion and Ferry André de la Porte. In steen geschreven; leven en sterven van VOC-dienaren op de kust van Coromandel in India. Amsterdam, 2002.

Petievich, Carla. When Men Speak as Women: Vocal Masquerade in Indo-Muslim Poetry. Delhi, 2007.

Phukan, Shantanu. "The Rustic Beloved: Ecology of Hindi in a Persianate World." Annual of Urdu Studies 15, no. 1 (2000): 3-30. 
Pinch, William R. "Same Difference in India and Europe." History and Theory 38 (1999): 389-407.

Pollock, Sheldon. "Ramayana and Political Imagination in India." Journal of Asian Studies 52 (1993): 261-97.

- . "Deep Orientalism? Notes on Sanskrit and Power beyond the Raj." In (eds.), Orientalism and the Postcolonial Predicament, ed. C.A. Breckenridge \& P. van der Veer, 76-133. Philadelphia, 1993.

—. "The Death of Sankrit." Comparative Studies in Society and History 43 (2001): 392426.

-. "A Pre-Colonial Language in a Post-Colonial World." Interview by Gijs Kruijtzer, IIAS Newsletter 36 (March 2005): 1, 4-5.

-. TheLanguage of the Gods in the World of Men: Sanskrit, Culture and Power in Premodern India. Berkeley, 2006.

Ramaswamy, Vijaya. "Artisans in Vijayanagar Society." Indian Economic and Social History Review 22 (1985): 417-44.

Rao, Velcheru Narayana, David Shulman, Sanjay Subrahmanyam. Symbols of Substance: Court and State in Nayaka Period Tamil Nadu. Delhi, 1992.

Raychaudhuri, Tapan. Jan Company in Coromandel 1605-1690: A Study in the Interrelations of European Commerce and Traditional Economies. The Hague, 1962.

Richards, John F. Mughal Administration in Golconda. Oxford, 1975.

—. "Norms of Comportment among Imperial Mughal Officers." In Moral Conduct and Authority: The Place of Adab in South Asian Islam, ed. Barbara Daly Metcalf, 255-89. Berkeley, 1984.

Roberts, Michael. "Submerging the People? Post-Orientalism and the Construction of Communalism." In Explorations in the History of South Asia: Essays in Honour of Dietmar Rothermund, ed. Georg Berkemer et al., 311- 23. Delhi, 2001.

Roche, Patrick A. "Caste and the British Merchant Government in Madras, 16391749." Indian Economic and Social History Review 12 (1975): 381-407.

Sardesai, G.S., ed., Shivaji Souvenir. Bombay, [1927].

Sarkar, Jadunath. History of Aurangzib. vol. 3 Northern India 1658-1681 (3 ${ }^{\text {rd }}$ ed.; Calcutta: Sarkar, 1928), vol. 4: Southern India 1645-1689. 2d ed. Calcutta, 1930.

—. Shivaji and His Times. 5th ed. Calcutta, 1952.

Sas, N.C.F. van. De metamorfose van Nederland; van oude orde naar moderniteit 1750-1900. Amsterdam, 2004.

Schmidt, Benjamin. "The Hope of the Netherlands: Menasseh Ben Israel and the Dutch Idea of America." In The Jews and the Expansion of Europe to the West 1450 to 1800, ed. Paolo Bernardini and Norman Fiering, 87-106. New York, 2001.

Sen, Amartya. "Capability and Well-Being." In The Quality of Life, ed. Martha Nussbaum and idem. Oxford, 1993.

—. On Economic Inequality. Enlarged ed.; Oxford, 1997. 
Shackle, Christopher. "Beyond Turk and Hindu: Crossing the Boundaries in IndoMuslim Romance." In Beyond Turk and Hindu: Retbinking Religious Identities in Islamicate South Asia, ed. David and Bruce B. Lawrence, 55-73. Gainesville, 2000.

Sherwani, H.K. History of the Qutb Shahi Dynasty. Delhi, 1974.

Sherwani, H.K. and P.M. Joshi eds., History of the Medieval Deccan (1295-1724) vol. 1 (Mainly Political and Military Aspects) vol. 2 (Mainly Cultural Aspects). Hyderabad, 1973-4.

Shouri, Arun. Eminent Historians: Their Technology, Their Line, Their Fraud. Delhi, 1998.

Siddiqui, Abdul Majeed. History of Golcunda. Hyderabad, 1956.

Smith, Anthony D. The Ethnic Origins of Nations. Oxford, 1986.

Stein, Burton. Peasant State and Society in Medieval South India. Delhi, 1980.

Storey, C.A. Persian Literature: A Bio-Bibliographical Survey. Vol. 1 Qur'anic Literature; History. London, 1927-39.

Strachey, Ray and Oliver Strachey. Keigwin's Rebellion (1683-4): An Episode in the History of Bombay. Oxford, 1916.

Subrahmanyam, Sanjay. "Aspects of State Formation in South India and Southeast Asia." Indian Economic and Social History Review 23 (1986): 357-77.

—. The Political Economy of Commerce: Southern India 1500-1650. Cambridge, 1990.

-. "Iranians Abroad: Intra-Asian Elite Migration and Early Modern State Formation." Journal of Asian Studies 51 (1992): 340-64.

—. "Reflections on State-making and History-making in South Asia, 1500-1800." Journal of the Economic and Social History of the Orient 41 (1998): 382-416.

- "Forcing the Doors of Heathendom: Ethnography, Violence and the Dutch East India Company.” Amsterdam, 2002 Wertheim Lecture.

- "Taking Stock of the Franks: South Asian Views of Europeans and Europe, 1500-1800," Indian Economic and Social History Review 42 (2005): 69-100.

- From the Tagus to the Ganges. Explorations in Connected History. Delhi, 2005.

Syed, Anees Jahan. Aurangzeb in the Muntakhab-al Lubab. Bombay, 1977.

Tajfel, Henri and John C. Turner. "The Social Identity Theory of Intergroup Behavior." In Psychology of Intergroup Relations, Stephen Worchel and William G. Austin ed., 7-24. 2d ed. Chicago, 1986.

Talbot, Cynthia. "Inscribing the Other; Inscribing the Self: Hindu-Muslim Identities in Pre-Colonial India." Comparative Studies in Society and History 37 (1995): 692-722.

- Precolonial India in Practice: Society, Region, and Identity in Medieval Andhra. Oxford, 2001.

Teltscher, Kate. India Inscribed: European and British Writing on India 1600-1800. Delhi, 1997. 
Terpstra, H. De opkomst der Westerkwartieren van de Oost-Indische Compagnie (Suratte, Arabië, Perzië). The Hague, 1918.

—_."Daniël Havart en zijn Op- en ondergang van Coromandel." Tijdschrift voor Geschiedenis 67 (1954): 165-89.

Thurston, Edgar. Castes and Tribes of Southern India, 7 vols. Madras, 1909.

Vajpeyi, Ananya. "Excavating Identity through Tradition: Who Was Shivaji." In

Traditions in Motion: Religion and Society and History, ed. Satish Saberwal and Supriya Varma (Delhi, 2005), 240-71.

Vasumati, E. Telugu Literature in the Qutub Shabi Period. Hyderabad, [ca. 1960].

Veer, Peter van der. "The Global History of 'Modernity'." Journal of the Economic and Social History of the Orient 41 (1998): 285-94.

Washbrook, David. “The Global History of 'Modernity': A Response to a Reply." Journal of the Economic and Social History of the Orient 41 (1998): 295-311.

Willigen, A van der, Les artistes de Harlem: notices historiques avec un précis sur la gilde de St. Luc. Haarlem/The Hague, 1870.

Wilson, Eric, "Erasing the Corporate Sovereign: Inter-Textuality and an Alternative Explanation for the Publication of Hugo Grotius' Mare Liberum (1609)." Itinerario 30 (2006): 78-103.

Winius, George D. and Marcus P.M. Vink. The Merchant-Warrior Pacified: The VOC (The Dutch East India Company) and its Changing Political Economy in India. Delhi, 1991.

Wink, André. "Maratha Revenue Farming." Modern Asian Studies 17 (1983): 591 628.

-. Land and Sovereignty in India: Agrarian Society and Politics and the Eighteenth-Century Maratha Svarajya. Cambridge, 1986.

Yule, Henry and A.C. Burnell, Hobson-Jobson: The Anglo-Indian Dictionary. $2^{\text {nd }}$ ed. 1902; photogr. repr. Delhi, 1994.

Zimmermann, Francis. "Géométrie sociale traditionelle; castes de main droite et castes de main gauche en Inde du Sud.” Annales E.S.C. 29 (1974): 1381-1401.

Zubairi, Muhammad Ibrahim. Basatin us-Salatin. Hyderabad, 1892-3. 


\section{INDEX}

Abdul-Karim Bahlul Khan (Bijapur minister), 158, 181-3, 236

Abdullah Qutb Shah (r. Golkonda 162672), 77, 85, 88-9, 92-4, 97, 99, 102, 111, $168,229,240,250$

Abul-Fazl (Mughal minister), 100, 278

Abul-Hasan Qutb Shah (r. Golkonda 167287), 86, 172-3, 180, 183-4, 194, 224-55, 265

Afghans, 40, 84, 91, 99, 103, 157-8, 170-86, 236, 246, 257, 265, 276-7, 290

Africa(ns) see Habshis, Sidis, East Africa

Afzal Khan (Bijapur commander), 101-2, 159, 164, 167

Ahmad, Nizam ud-Din (Golkonda chronicler), 77-8, 81-3, 85, 93-4, 98-9, 168

Ahmadnagar (city), 4, 104, 153, 190, 200

Ahmadnagar (sultanate), 32, 55, 79-80, 84$5,89,92-3,98,153,155,160,167-8$, 189,197

Akbar (Mughal emperor 1556-1605), 60, $62,80,92,100,103,223,266-7$

Akbar (son of Aurangzeb), 198, 200, 219, 246, 255, 265, 287

Akkanna (Golkonda minister), 224-7, 2289, 230-7, 238, 239-55, 258, 265, 271

Ali Adil Shah I (r. Bijapur 1558-79), 29

Ali Adil Shah II (r. Bijapur 1656-72), 130, 160, 164, 165

Alley (English interloper), 225-6, 244-5 animal metaphors and symbolism, 24, 32, 66, 74, 154-5, 160, 161-3, 164, 165, 166, 178,287

Appadurai, Arjun (anthropologist), 106, 108, 132, 147-8, 259-60

Appiah, Kwame (modern philosopher), 2, 139, 261, 283

architecture styles, 79-80, 286

reliefs, 154, 155, 161, 162-4, 165

Shici symbols in, 90

Armenians, 35, 37, 45, 204, 244, 283

art see architecture, paintings

ascription (others considering a person part of a group), 5-6, 68, 108, 117, 125, 131 45, 182, 191, 221, 246, 257, 261
Aungier, Gerald (EIC employee), 205-11, 220, 222-3, 256

Aurangzeb (Mughal emperor 1658-1707), 9, 61, 91, 93, 99, 157, 168-9, 172-3, 1814, 194-5, 198-200, 216, 219, 223, 228, $233,237,239,244,251-2,265-84,287-8$

Bacherus, Johannes (Dutch ambassador), 61, 65, 122, 194, 199-200, 229, 272

Bahadur Khan (Mughal commander), 173, 182-3, 210, 237, 251

Bahmani sultanate, 3, 75-6, 103, 257

Baker, Aaron (EIC employee), 113-39, 144, 151, 258

Baniyas (merchant caste rooted in Gujarat), 15, 40, 43-4, 83, 106, 169, 206-8, 212-3, 222, 232

Bari Sahiba see Khadija Sultana

Bassein (seaport), 4, 104, 190, 205

Batavia (VOC headquarters, Java), 37, 4851, 58, 62, 64, 66-7, 69, 225, 243, 251

Batavians (putative Dutch ancestors), 72

Bayly, Chris (modern historian), 9, 10, 14, 158, 167, 182, 197, 225, 267, 276, 278

Bayly, Susan (modern historian), 2, 143, 254

Beck, Brenda (anthropologist), 108, 122, 146

Berchem, Wemmer van (Dutch naval commander), 31-4, 45, 47, 53-5, 57, 67, 71-4

Beri Chettis (merchant caste), 15, 63, 107, 117-8, 120, 124-6, 139

Bhatta (title for Brahmins or bards), 115, 141-3

Bhima (river), 172, 190

Bhimsen (retired Mughal memoirs writer), 181-4, 189, 200, 240, 252, 270

Bible, 23, 36, 44, 60, 133, 285

Bidar (city), 4, 94, 97, 104

Bijapur (city and suburbs), 4, 20-32, 37-9, 47, 57-8, 60, 79, 80-1, 82, 89-91, 94-5, $97,104,155,190,273,275,283$

Bijapur (sultanate), 3, 18-103, 104, 108, 153-90, 197-8, 201, 215, 224, 235-6, 257-8, 265, 272, 274-5, 290-1

Bombay (seaport), 14-6, 52, 172, 190, 191 223, 256, 259 
boundaries

general, 1-2, 5-6, 15, 19, 33-7, 50, 83-6, 103, 108, 131-50, 152, 221, 255-63, 279 crossing of, 8, 50-2, 73, 217, 219, 258, 266

cross-cultural understanding of, 15, 5263, 69

ethical, 33-44, 281-2

relative, 6, 18-74, 103, 253-4, 257-8, 282 religious, 8, 33-7, 44-7, 50-2, 88, 102-3, 217, 258-9, 266-77

sexual, 44-7, 49, 258

Brahmins (first varna), 15-6, 40, 42-4, 82-3, $85,105-53,159,166,174,176,185$, 201, 205, 208, 214, 216, 219, 224-55, 258-62, 270-1, 275-6, 279, 286, 292

Brimnes, Niels (modern historian), 107, 109, 116, 118, 127-8, 148-9, 259-60

British (group after 1707), 8-9, 14, 42, 106, 127-8, 131-2, 138, 141, 145, 148, 151, $177,187,226,247,261-3,265-6,278$ 81, 289-91

Broecke, Pieter van der (VOC employee), 41-3, 92, 167

Burhan-i Qati`(dictionary), 3, 62, 168

Cannadine, David (modern historian), 38, 151

caste

definition, 105

contemporary use, 105-7, 114, 118, 123-6, 129, 132-3, 137, 152, 176 general, 4, 9, 78-9, 101, 105-52, 171, 185-7, 201, 207-8, 211, 227, 231, 246, $253,258,261-2,267,275,277,280-1$, 290

categorisation and classification, 5-8, 15, 64-5, 108, 131-45, 225, 256, 261, 277-8, 285

Catholics see Roman Catholics

Central Asia, 10, 76, 87-9, 285

Certeau, Michel de (modern philosopher), 12-3, 68, 225

Chattopadyaya, B.D. (modern Sanskrit scholar), 101, 167, 185-6

chavadi (shelter or hall of justice), 111, 11920, 128

Chennapatnam (town), 15-6, 39, 47, 86, 104, 105-20, 121, 122-52, 190, 203, 242, 253, 259-62
Chetti (title for merchants, especially the Beri Chettis) see Beri Chettis

Child, John (EIC employee), 191-2, 195, 210, 221

Christians, 13, 28-9, 32-74, 132, 205-8, 217 $8,222,242,258-9$

churches and Madraspatnam fishermen, 124 Jews and Christians in one, 62 contrast between Catholic and Protestant, 59-60

Muslim appreciation of Protestant, 59 Catholic destroyed, 242

class, 8, 38, 50, 122, 131, 148, 231, 254, $274,277-8,282$

classification see categorisation

Cohn, Bernard (anthropologist), 6-7, 131, 186-7, 263

colour

see skin colour

commensality see food

consciousness, 8, 10, 16-7, 38, 71, 103, 178, 185-6, 254, 262-3, 267, 274, 276, 278, 287-8

conscription (a person considering him/herself part of a group) see ascription

conversion, 26, 29, 37, 45-6, 48, 50-1, 56, $60,64,73,173,199,210,214-8,221-2$

Coromandel coast, 3, 4, 7, 24, 31, 38-40, $45,47,51,64,66,68,71,104,105,110$, $114,117,140,142,188,190,251,253$, 260,272

Dabhol (seaport), 4, 58, 104, 190, 202-3

Dakshinapatha (route), 3, 4, 92, 167, 277

Dalrymple, William (modern writer), 14, $64,273,279$

Deccan (term), 3, 105, 166-72

Deccani Urdu (language), 86-9, 103, 166, 169, 181, 211, 274-5

Deccanis (group), 4, 75-104, 157-8, 168-86, 215, 235-6, 246-7, 254, 257-8, 264-5, $267,271,274-5,278$

deception, 184, 250, 287-8

defection

Damarla brothers, 112

Deccan zamindars, 250 
Dutch sailors and soldiers 50-2, 73

Madanna suspected, 251-2

Maloji Ghorpade enticed, 170, 177

Muhammad Ibrahim 237, 244, 250-2

Nasir Muhammad, 183-5

Portuguese mestizos, 33, 35

Shahji, 170, 189

Sidi Misri, 218-9

Yaqut Khan Nizam Shahi, 93 see also boundaries (crossing), fitna, qaul

Desai, W.S. (modern historian), 191-2, 202, 212

dharma (the divinely ordained order), 113 , 133, 141-4, 156, 159-61, 164, 207, 222, 248-9, 254, 267, 276

Dilir Khan (Mughal commander), 172, 176, 182-4, 189

Dirks, Nicholas (anthropologist), 2, 185-6, 225,281

Diu (seaport), 4, 104, 190, 207

dress

see material manifestations

Dumont, Louis (anthropologist), 152, 186

Dutch (group), 3-4, 15-6, 18-74, 83, 87, 967, 102, 109, 122, 173-7, 179, 188, 192, 194-5, 199, 209, 213-4, 217, 223, 236-7, 239, 242-4, 253, 259, 264, 279-80,

Dutch (language) 23, 36, 42, 50, 61-2, 71, 105, 164, 188, 200-1, 203-4, 220, 227, 232, 254, 285-6

Dutch Republic 18-32, 37, 48, 52, 58-9, 64, 69-71, 148, 189, 242, 253, 280, 283

East Africa, 58, 75, 218

Eaton, Richard (modern historian), viii, 6, 9, 29, 75-6, 84, 92, 103, 105, 131, 140, 177, 185, 241, 257

EIC (English Company), 36, 45, 106, 11016, 119-20, 125, 127-8, 135-6, 157, 172, 176, 190-7, 205-11, 219-23, 244, 248, 277, 279

EIC archives, 36, 106-7, 131, 134, 172-7, 191, 201, 230, 294

Ekoji (half-brother of Shivaji), 51, 173-8, 204

England, 31, 34

English (group), 3, 15-6, 29, 31, 34-7, 39, 43, 45-6, 51-68, 86, 96, 102, 105-52, 153, 157, 172-7, 191-223, 225, 242-5, $253,258,274-8$
English (language), 111, 124, 135, 217, 285, 292

Europeans (term) contemporary use, 37, 69, 214 see also Christians, Franks, Huns, mlecchas experiments

psychological, 7, 145, 245, 259

minimal group, 108-9, 145-52, 260-1

and history, 105, 145-50, 260-1

factors (persons running the factories or trading stations of the European

companies)

and private trade, $24,32,38,69,115$, 131, 243

and interlopers, 244-5

Christian solidarity, 36-7, 43, 51, 63-4

famine, 98, 112, 201, 272

farman (written royal order), 21-2, 61-2, 78, 81, 97, 101, 130, 170, 177, 199, 201, 227, 229, 230, 233, 236, 243, 244-5, 291

fatherland (Dutch term vaderlant), 18, 22-3, 26, 28-9, 32-3, 43, 69-72, 189, 204, 224, 247,254

firqa (type of group), 200, 279

fitna, 73, 90, 93, 102, 133, 250, 266

food

and loyalty, 83-4, 102, 137, 250

and purity, 39-41, 108, 122, 137

(not) eating together, 39-41, 151, 217-8

feasts, 39, 218, 248

foraging, 95, 183, 273

poisoned, 60

Foreigners (Afaqis)

see Westerners

Foucault, Michel (modern philosopher), 2, 6-7, 131, 146, 156, 186-7, 263

France, 13, 18, 54, 148, 221, 276, 278-9

Franks (term for Europeans or Portuguese), 29, 61-2, 159, 214, 253, 279

French (group), 16, 34, 38, 43, 54, 68, 195, 201, 203, 214, 217, 274, 276-8, 279

French (language), 106

French Company 3, 201, 235, 242

Gawan, Mahmud (Bahmani minister), 76, 257

Geleynssen de Jongh, Wollebrant (VOC employee), 38-9, 43, 59, 285 
Gentus (term for Hindus or Telugus), 15, $41,56,65,96,169,208-9,285-6$

German (language), 20, 23

German empire, 18-20, 25

Germans, 20

Gerritsz, Gerrit (Dutch drifter), 24, 28, 47, 73,85

Ghawwasi (Deccani poet), 88-92, 103, 166 ghazis (fighters on the frontier of Islam), 100, 180

gifts

honorary to inferior (tashrif, khil'at), 83, $118,129,244,248,250$

private to equal or superior (tohfa, na₹r), $22,25,32,57,85,89,118,131,137$, 234, 237

public to superior (peshkeash), 94, 131, 173-4, 179, 234, 237

Gingee (fort), 104, 168, 173-4, 183-5, 190

Goa (capital of Portuguese Estado), 3, 4, 20-1, 23, 28, 51, 55, 57-8, 61, 64, 66, 85, 104, 190, 200, 235

Goldsmiths (caste), 115, 125, 140

Golkonda (fort), 4, 8, 104, 190, 244

Golkonda (sultanate) 1, 3-4, 8, 39, 52-4, 57, 61-2, 66, 71, 74, 85, 89, 91-3, 95-6, 989, 104, 105, 108, 110-1, 131, 164, 166, 168-184, 194-5, 198-200, 204, 224-55, 258, 260, 272, 274, 286, 289

Gommans, Jos (modern historian), viii, 66, 194-5, 218

Greenhill, Henry (EIC employee), 113-39, 144

Grotius (Dutch jurist), 26-34, 43-4, 56, 67, $71,76,215$

group boundaries see boundaries

Guelders (province of Netherlands), 31

Guesty (French private merchant), 106, 201, 240

Guha, Ranajit (modern historian), 177-8, 274

Guha, Sumit (modern historian), viii, 6, 65

Gulbarga (city), 4, 104, 130, 176, 183, 190

Habib, Irfan (modern historian), 96, 204, 274, 288

Habshis (East Africans), 74-105, 160, 168, 173, 176-7, 183, 192, 215-7, 232, 240, 257-8, 289-91
Hafiz (14 ${ }^{\text {th }}-$ c. Persian poet), 87, 90, 218, 250

Hanamkonda (town), 190, 226, 228

Hartsinck, Willem Carel (VOC employee), $49,251,287$

hatred between groups, 1, 21-2, 43, 128, 183, 215, 218, 284 interpersonal, 77, 132

Havart, Daniel (VOC employee), 13, 41, 42, 43, 68, 71, 73, 89-92, 95, 179, 224, 229, 232, 234, 238, 239-44, 246, 248, 251-4, 272

hawaldars (type of administrators), 52, 176, 188, 232-4, 241

Haze, Hans de (VOC employee), 28, 38-9, 43

Heathens (term for Hindus), 15, 35, 39, 63, $65,198,206,229,285-6$

Heda, Cornelis Claesz (Dutch painter), 18$74,76,83,85,167-8$

Heesterman, J.C. (Indologist), viii, 136, 167,220

heritage, 11-7, 157, 280-4, 292

heterologies, 12-3, 30, 68, 159, 213, 225, 235

Hind (term for India), 28, 88

Hindi (languages), 88, 101, 168, 217

Hindu (Persian term), 15, 28, 87-8, 99, 101, 264, 266, 285-6

Hindus, 3-17, 32, 40-68, 84-92, 98-105, $138,145,155-89,198-201,206-7,225$, 246-55, 257, 260, 264-86

Hindustan (term for North India), 167-8, 194

Hindustani (language), 229, 285 see also Ketelaar's vocabulary

Hindustanis (group), 182

Hollanders (term for Dutchmen), 20, 27-8, $32,37,56,61-2,68,128$

homosexuality/homoeroticism, 13, 44, 47, 87-8

human nature see nature

Huns (term for Europeans), 137

Hyderabad (city), 39, 41, 49, 53, 64, 71, 901, 95, 106, 168, 173-4, 176, 179, 184, 201, 229-54, 260, 271-2, 275, 282

Hyderabad (state), 276-8

Iberians (term for Spanish+Portuguese), 67 
Ibrahim Adil Shah II (r. Bijapur 15791626), 20-2, 24-5, 27-9, 57-8, 76-8, 80, $90,101,160,167,266-7,275$

identity

definition, 5

general, 2, 5-6, 9-10, 139, 151, 185-7, 255-64, 274, 293

development of Deccani, 86-92, 103, 153, 157-172, 184, 257, 264

development of Dutch, 18-73, 264

development of Bombay, 191, 204-10, 220

Dutch and Bombay contrasted, 223

ideology, 34, 67, 74, 83, 122, 158, 185-9, $199,250,256,260,268,274,276$

Iran (region), 57, 76, 246 see also Persia

Iranians, 3, 7, 28, 43, 75-6, 80, 84-5, 89, 103, 231-2, 235, 246

see also Persians

Italians, 16, 37-8, 45, 57, 59-60, 194

Ittersum, Martine van (modern historian), viii, 30, 71

Ivie, Thomas (EIC employee), 113, 115, 120, 122-3, 135

Jager, Herbert de (VOC employee), 174-6, 188, 201-2

Jahangir (Mughal emperor 1605-27), 7, 45$6,51,56,60,62,74,80,87$

Jains (group), 40, 43, 59, 207

Jalal, Ayesha (modern historian), 182, 266, 276

jama'at (type of group), 103, 182

Janjira (island fort), 215, 190 see also Sidis

Janszoon, Michiel (VOC employee), 224-5, 242-3, 246-7, 252-5, 258, 265, 267

jati (type of caste), 107, 171

Jews, 19, 26, 33, 44-5, 47-8, 54, 59, 62, 67, $148,258-9,285$

jihad, 27-9, 37, 93, 198, 236, 293

jiziya (poll tax for non-Muslims), 59, 198200, 252, 265-70

Junnar (town), 4, 104, 168, 190

kafirs (unbelievers), 8, 15, 84, 94, 130, 216, 293

Kanappa (Chennapatnam officer), 106-45

Kannada (language), 4, 75, 89, 105, 107, 169
Karnatak (region), 112, 157, 171-85, 188, 190, 231, 237, 249, 265

Kayasthas (writer caste), 181, 261-2, 275, 290

Keigwin (Bombay rebel), 191-223, 262

Ketelaar's vocabulary, 75, 214, 285

Khadija Sultana Bari Sahiba (Bijapur queen), 49, 50, 66, 69, 76, 82-3, 94, 101, 164, 165, 169

Khafi Khan (Mughal historian), 169, 180-1, 193, 200, 215-7, 233, 240-1, 246, 250-1, 268, 270, 277

Khawas Khan (Bijapur minister d. 1635/6), 76-104, 238, 254, 257-8, 292

Khawas Khan (Bijapur minister d. 1676), 78, 181-3, 236

Khorasan (Iranian region), 40, 76, 88, 97

kbutba (mosque sermon), 95, 100

Kolff, Dirk (modern historian), viii, 2, 35, 140, 218

Kolis (caste), 208, 219

Komatis (merchant caste), 15, 117-23

Konkan coast, 4, 32, 104, 169, 171-2, 190, 193-5, 200, 202, 204, 219

Kshatriyas (second varna), 108, 141-4, 2612

kufr (unbelief), 102, 156, 266, 274

kula $(m)$ (type of caste), 45, 105, 107

Laine, James (modern religion scholar), 156, 159, 167, 289

Latin (classical language), 16, 23, 26, 31, 60, $71-2,285$

law

Indian and European compared, 175

international, 30-1, 33-4, 215

jurisdiction, 47-9, 109, 111, 126, 129-31, 203, 206-7, 217, 244, 278-9

natural, 30-1, 43, 70

on intercourse, 13, 44

on marriage, 44-9, 64

Roman, 44

royal verdict, 130-1, 203-4

shari' $a, 59,93,198-9,267-8$

shastric, 143-4

VOC, 64

Lorenzen, David (modern religion scholar), 8,159

Louis XIV (r. France 1643-1715), 18-9, 242, 252

love 
for a group, 58, 62, 284

for a land, 23, 90

interpersonal, 1, 87, 90, 99, 119, 183, 189, 226-7

Sufi, 1,88

Madanna (Golkonda minister), 174, 17985, 224-7, 228-9, 230-55, 258, 265, 267$8,271,272,278,291$

Madigas (caste), 122, 137, 144

Madurai (nayaka state), 172-5, 178, 204

Mahabharata (classical epic), 101, 160, 162

Maharashtra (region), 5, 157, 166-8, 228-9, 232, 235, 270, 276, 290

Malabar coast, 4, 9, 28-9, 41, 55, 57, 104, 190, 253

Malik Ambar (Ahmadnagar minister), 32, $55,57,62,85,92-3,98-9,160,166-8$, 185, 200, 234, 257, 265

Maloji Ghorpade (Maratha sardar), 157, 160, 169-72, 177, 189-90, 288-90

Mandal reservation policy, 262, 281

mansab (position in state apparatus), 170

mansabdars (mansab holders), 169, 198, 268 70

Manucci, Niccolao (Italian traveller), 16-7, 153, 164, 184, 194, 240, 246, 251, 26970,287

Mappillas (group), 29, 55

Marathas (caste or Marathi speakers in general), 5, 8, 78-80, 85, 92-3, 98, 101, 156-71, 175, 180-1, 191-221, 228-9, 235-6, 264, 273, 276-7, 279, 287, 289-91

Marathi (language), 4, 75, 78, 89, 102, 105, 157, 169, 171, 177, 179, 188, 229, 290, 294

Margalit, Avishai (modern philosopher), 1, 11, 43, 281-3

Martin, François (French Company employee), 43, 89, 106, 180, 183-5, 201, 227, 231, 234-5, 240, 242, 246, 248, 252

Masulipatnam (seaport), 4, 19, 21-5, 28, 32, 38-9, 41, 43, 47-9, 52-5, 57, 63, 66-7, 69, 91, 96, 104, 105, 114, 167, 190, 194, 224-5, 230, 234, 244, 248, 252, 272

Matar, Nabil (modern historian), 13, 15, 220

material manifestations of difference general, 151

dress, 7, 34, 214, 228, 262, 269-70, 272, 286 hair, 125, 150

sacred thread, 141, 143, 151

sectarian marks, 228, 229

sword as attribute, 79, 162-3, 238

memory

general, 1, 10-11, 276, 281-4

bitter, 36, 275-80

flashbulb, 145

of a golden age, 141, 167-8, 222-3, 235, 248-9, 200, 254, 271, 279-80

of Chennappa, 111

of Madanna, 248-9, 254, 271, 272

of Malik Ambar, 93, 98, 167-8, 200

mestizos (group), 35, 37, 39, 44, 51, 64, 222

Methwold, William (EIC employee), 35-6, 62-3

Miraj (town), 4, 95, 104

mir jumla (office/title), 57, 81, 233

see also Muhammad Sacid Ardistani

mixed descent

of Jahangir, 46

of Khawas Khan? 78-9

of Marije Cornelis Heda? 23, 44

of Rathakaras, 141-3

see also mestizos

mlecchas (barbarians), 159, 167, 185, 241

Mohammedans (term for Muslims), 15, 48, $68,233,285$

Moors

term for (Indian) Muslims, 15, 28, 32, 36, 38, 41-3, 45, 48-9, 51, 53, 63, 65, 68, $74,169,172,188,196,208-9,211,222$, 224-5, 230, 232, 235, 244, 247, 285-6 term for Africans (probably), 72

Moorish language, 211

mosques

and Muhammad Adil Shah, 100

Brahmin accountant of, 232-3

building styles, 79-80

in Bombay, 206

in Sanskrit text, 159

not to be desecrated, 29, 180

Shici symbols in, 90 , shunned by Shi' is, 91,95

Sunnis and Shi' is in one, 62

Mughal empire, 3, 8-9, 14, 21, 24, 35-6, 413, 45, 52-3, 56-7, 59-60, 62, 65-6, 74, 79, 82, 84-5, 89-102, 104, 122, 153-255, 257-8, 265-84

Mughals (group), 214, 257-8, 268-70, 273, 276, 278 
Muhammad Adil Shah (r. Bijapur 1626-56), 48, 58, 61, 73, 74-104, 159-60, 164, 165 167,169

Muhammad Ibrahim (Golkonda commander), 201, 227, 236-7, 239, 242, 244-6, 251-2

Muhammad Quli Qutb Shah (r. Golkonda 1580-1612), 1, 8, 16, 83-4, 86-90, 266, 275

Muhammad Qutb Shah (r. Golkonda 161226), 34, 50, 53-4, 57, 204

Muhammad Sa id Ardistani Mir Jumla (Golkonda commander), 111-2, 115, 119, 124, 126-9, 131, 133, 136

Murari Pandit (Bijapur commander), 82-3, 93-4, 99, 102-3

Muslims, 3-17, 28-104, 130, 145, 153-89, 198-201, 215-86

Mustafa Khan (Bijapur minister), 39, 4951, 58-9, 61, 76-104, 160

Musta'id Khan (Mughal chronicler), 198200, 230, 240, 247-8, 265, 269

Mysore (city and state), 104, 178, 190, 278

Naga Pattan (Chennapatnam

“Goldsmith"), 115-25, 134, 140, 259

Nagapattinam (seaport), 4, 21, 104, 173, 190

Naldurg (fort), 182, 190

Nasir Muhammad Khan (keeper of Gingee), 173, 183-5, 258

nation (type of group), 15, 19-20, 28, 30, $32,35-8,41,43,53,55-8,61-5,68-73$, 105-6, 110-1, 136, 180-2, 193, 205-8, 211, 232, 242-4, 256, 264, 269, 279, 282, 284

nationalism/national sentiment, 9-10, 14,

31, 70-2, 156, 181-3, 186, 189, 221, 223, $225,265,279-81$

nature

Dutch, 23, 70, 73

human, 1-2, 11, 30-1, 105, 156, 178, 187, 191, 220, 262, 274, 284

natural law, 30-1, 43, 70

natural(ised) to India, 45, 158, 209, 220

nawab (representative of the sovereign), 25,

57-8, 111-2, 115, 119, 126-7, 131, 136

nayaka (military/fiscal officer, a ruler or a title for certain groups), 109, 139, 187

Netherlands (entire), 18-21, 26, 30, 37, 44, 189
Netherlands (northern)

see Dutch Republic

Netherlanders, 20, 21, 61

Nijendaal, Jan van (Havart's father-in-law), 42, 211, 226, 243, 253

Niraji Pant (Shivaji minister), 153, 215, 179

Oil-pressers/sellers (caste), 78, 142, 275

othering

definition, 6

general, 6, 12, 15, 19, 64, 67-8, 72, 145, 158, 191, 253, 260

Ottoman empire, 18, 52, 59, 196, 279, 283

Ottomans (group), 18, 52, 93, 166

paintings

at Versailles, 18-9, 68

Brooklyn kalamkari, 7

Golkonda miniature series 78-9, 164,

227, 238, 269, 271-2

made by Heda, 21

made for Bacherus, 122

Mughal miniatures, 7, 80, 165-6

portrait of Ibrahim II, 101

Smith-Lessouëf albums, 228, 269, 271, 272

Witsen Album, 78, 79, 227-8, 228-9, 233, 239

Pallis (caste), 117, 120, 123, 141, 149, 151, 262

Panchalans (members of five artisan castes), 115, 261-2

Pandit/Pant (title for Brahmins), 227

Paraiyans (caste), 117, 126

Paramananda (Sanskrit poet), 143, 158-2, 166-8, 171-2, 185, 189, 200, 215, 265

Parsis

see Zoroastrians

parwana (order issued by a minister), 61-2, 199-200

parwangi (authorisation for a farman), 21, 81, 227

Pathans (term for Afghans), 99, 157, 170, 176, 182-3, 185, 246patriotism, 19-31, 70-3, 92, 95-9, 103, 153-89, 225, 234, 246-8, 254, 257-8, 265, 267, 278

Persia (Safavid state), 7, 20, 37, 39, 50, 801, 91, 95-7, 200, 246

Persian (language), 3, 15, 43, 61-2, 88-9, 100-1, 111, 159, 177, 188, 193, 211, $217,224,229,267,289-90$ 
Persians (term for Iranians), 34, 38, 85-6, 131, 246

Petapoli (town), 38-9, 47, 96, 190, 244

pilgrimage

to Sufi shrines, 3,130

to Mecca, 3, 8, 49, 57, 83, 247

to Benares and Allahabad, 270

Pinker, Steven (cognitive scientist), 2, 178, 187, 226

Pollock, Sheldon (modern Sanskrit scholar), viii, 6, 10, 17, 75, 141, 185

Pondicherry (town), 3, 43, 190

Pope (head of Roman Church), 18-9, 27, 30, 34, 52, 59, 72, 206

Portugal 19, 27, 46, 67, 192

Portuguese (language), 25, 35, 51-2, 64, 78, 85-6, 106, 206, 209, 285

Portuguese (group), 3-4, 14-5, 18-74, 78, $80,83,85,109,113,120,124,192-7$, 200, 203-9, 211, 214, 220, 222, 242, 253, 259

private see public

Protestants, 19-20, 26-7, 35, 37, 58-9, 72, $217,222,264$

public

interest, 72, 98, 120, 158, 205-6, 208, 267-8, 276

distinction from private, $26,98,158$, $225,234,254,267-8,276$

as audience, 13, 98, 102, 158, 162, 178

puja (Hindu religious rite), 140

Pulicat (seaport), 4, 31-3, 35, 39, 41, 45, 514, 56, 61, 63-8, 104, 109-10, 112, 128, 141, 149, 173, 178, 190, 243

qaul (promise or promissory document) 84$5,101,109-11,115,125,140,170,175$ -

6, 188, 291

qaum (type of group), 61-2, 101, 180-2, 264, 276-9

qaæi (Islamic judge), 93, 207, 275

Qur'an, 44, 87-8, 91, 180, 198-9, 218, 256, 267-9, 287

Raigarh (fort), 143, 153, 154, 155, 161, 162, $168,190,214-5,261$

Rajaram (Maratha king 1689-1700), 212, 213, 215

Rajputana (region, now Rajasthan), 198-9, 200, 265, 276
Rajputs (military caste), 2, 46, 65, 99, 106, 140, 143, 158, 182, 198-200, 265, 268, 276, 285

revenue collection direct (zabt, amani), 95-9, 111, 234-5, 249-50

farming, 95-9, 230-4, 254, 293

assignments (jagirs, muqasas), 84, 101, $170,177,230-1$

tribute (from zamindars, samasthan rajas), 202, 235, 249-50, 294

alienation (in'am), 110, 130, 249

by armies, 201-4

deemed oppressive, 95-9, 102, 200, 204, 274

reforms of, 95-9, 234-5, 249-50

as object of contention, 245, 259, 276-8 see also gifts

riots

general, 148

Hindu-Muslim, 9, 265, 277

Left-Right, 125, 132-3, 147-51

Sunni-Shici, 91

Roe, Thomas (English ambassador), 46, 57, $59-60,62$

Roman Catholics, 18, 20, 25-8, 35, 52, 5960, 72, 206, 222

Rustam Rao (Golkonda commander), 181, 239

Sabhasad (bakhar writer), 179-80, 235-6

Sachariassen, Pieter (convert to Islam), 48$51,58,67,73,102$

Said, Edward (modern scholar), 12-3, 15, 87,220

Sambhaji I (Maratha king 1681-9), 192-6, 200, 209, 212-3, 218, 220, 235

Sambhaji II (Maratha king 1712-60), 213

Sanskrit (classical language), 16, 74-5, 86, 89, 101, 107, 137, 158-9, 171, 179, 207, 270

San Thome (seaport), 4, 33, 39, 104, 109 $10,112-3,133,135,242$

sardars (military leaders, members of the Maratha service nobility), 85, 92, 99, 157, 159-61, 167, 171, 213-5

Sarkar, Jadunath (modern historian), 175, 198, 228, 230, 252, 287

Savant dynasty, 200, 215, 220, 224, 235, 249-50

Savantvadi (town), 190, 235 
Sayyid Muzaffar (Golkonda minister), 229$30,233,239,250$

Sayyids (descendants of Muhammad), 92, 131, 173, 176, 227, 229-30, 233, 239, 246, 250

Schouten, Wouter (Dutch traveller), 40-1, 43, 87, 89, 167, 285-6

Sen, Amartya (economist), 65, 69, 284

Shah Alam (son of Aurangzeb), 200-1, 240-1, 251, 269, 271

Shah Jahan (Mughal emperor 1628-57), 60, $74,85,91,93-7,99,270$

Shahaji (r. Thanjavur 1684-1711), 122, 137, 144

Shahji (father of Shivaji), 153-4, 157-60, 170, 172-4, 189

Shaivas (Shiva devotees), 228, 249

Sher Khan Lodi (Bijapur commander), 173-5, 178, 183, 204

Shi' is and Shi ism, 62, 84, 86, 90-2, 95, 103, 247-8, 268, 287

Shivaji (Maratha sardar, and king 1674-80), ix, 8-10, 17, 76, 85, 101, 142-4, 153-61,

162-3, 164-90, 192, 196, 198, 201-5, 210-1, 213, 214-6, 218, 220, 235-7, 249, 254, 257, 261, 265, 267-9, 273, 278,

281-3, 284, 289-91

Shudras (fourth varna), 138, 141-2, 151, 232

Sidis synonym for Habshis? 75 of Janjira, 43, 191-224, 258

Sidi Mas'ud (Bijapur minister), 168, 173, 177, 183, 258, 289-91

Sidi Qasim Yaqut Khan (Janjira commander), 43, 193, 196, 202-3, 211, 215-9, 258

Sidi Sumbul (Janjira commander), 210-1, 218-9

Sikandar Adil Shah (r. Bijapur 1672-86) 176, 181

Sindhudurg (island fort), 190, 193, 213

skin colour, $34,78,79,86-8,103,160,214$, 270

slaves

different skin colours, 87

Habshi, 75-80, 240

making, 119, 128, 210-2, 218-21, 272

metaphorical, 119, 150, 158, 220

trade, 119, 128, 176, 188, 202, 210, 267

trade opposed, 119, 128, 176, 188, 210, 218, 220, 267
Smartas (group), 227-8, 249

sodomy, 13, 44, 47 see also homosexuality

sources compared contemporary and later, 11-7, 156-91 different manuscripts, 36-7, 69, 181, 188,288

European and Indian, 11-7, 131-50, 225-6, 253

South-East Asia, 39, 54, 67, 69-70, 116

South-East Asians, 7

Spain, 18-20, 25-7, 30, 32, 34, 44, 52, 54, $56,67,70,72,189,259$

Spanish (group), 26, 30, 34, 38, 52, 54, 56, $58,67,71-2,217$

Spanish (language), 71-2

Subrahmanyam, Sanjay (modern historian), viii, 11-2, 16, 20, 29, 65-6, 88, 138, 187, 203, 229, 231-2, 253

Sugur (samasthan), 190, 224, 250

Sufism, 3, 8, 88, 91-2, 129-31, 250, 273-5

Sunnis and Sunnism, 59, 62, 84, 90-2, 95, 248, 268, 287

Surat (city), 4, 35-8, 41, 45, 52-3, 62-3, 97, 104, 152, 167, 172, 190-6, 200, 203-7, 211, 222, 270, 273

Stein, Burton (modern historian), 107-8, 146-8, 259, 262

Tajfel, Henri (psychologist), 5, 152, 245, 255, 259

Talbot, Cynthia (modern historian), 9, 107, $142,247-8$

Tamil (language and speakers), 4, 7, 41, 105, 107, 113, 137, 141, 148-9, 188, 232 taxation see revenue, jiziya

Telugu (language and speakers), 4, 45, 65, 75, 88-9, 105, 107, 109, 115, 122-3, 135, 140, 142, 169, 188, 224, 227-9, 241, 245, 248-9, 285

temples

and Brahmins, 114, 117, 137-8, 144, 228, 249

and Shivaji, 144, 175, 213

building of, 115-6, 133, 144, 206, 241

destruction of, 101-2, 159, 241, 280

looting of, 146

Sufic appreciation of, 8, 266-7

status in Islamic realm, 59

Tengapatnam (seaside town), 175, 285 
thanadar (chief constable), 28, 58

Thanjavur (city and state), 104, 122, 173, 187, 190, 204, 229

Timmanna (Chennapatnam organiser), 115-139

Tipu Sultan (Mysore ruler 1782-99), 197, 278-9

Tranquebar (seaport), 104, 127, 149

translation by contemporaries, $23,28,36$, 42, 50, 61-2, 105, 111, 123-4, 135, 188, 212, 217, 227, 229, 267

"Treijbeck," Thomas (Englishman in Bijapur), 37, 102

tribute see gifts, revenue

trust, 1, 6, 18, 23, 26-7, 51, 55-6, 61, 83-6, $136,139,158,162$

Turks, 3, 7, 18, 75, 87, 89, 196, 246

Turner, John (psychologist), 5, 152, 245, 255, 259

Twist, Johan van (Dutch ambassador), 24, 37, 39-40, 48-50, 57-62, 67, 74, 76-8, 81-5, 93-5, 98-9, 102, 166, 169, 182, 285

Vaishnavas (Vishnu devotees), 228

Vaishyas (third varna), 108, 141-2

varnas (the four classical castes), 107-8, 141, 143-4, 261

Vengurla (seaport), 4, 49, 104, 172, 190, 192-3, 195, 200, 202-3, 213, 220, 235

Venkata (EIC contractor), 106-45, 258

Venkatadhvarin (Sanskrit poet), 137-8, 232

Vellore (city-fort), 55, 104, 109, 174, 190

Venice, 25, 37, 57, 205

Vijayanagar (city), 4
Vijayanagar (great kingdom), 3, 40, 45, 55, 63, 75, 105, 109-11, 146, 148, 164

Vijayawada (town), 142, 190, 248

VOC (Dutch Company), 16, 18-74, 83, 967, 174-6, 178, 188, 193, 195, 199, 224, $234,238,242-4,247,249,253-4$

VOC archives, 35, 38, 50, 94, 131, 143, 162, 172-8, 196, 198, 201, 230, 234-5, 240, 241, 243, 248, 254, 261, 296

Ward, Charles (EIC employee), 191-2, 196, 210-1, 221

Westerners (Gharbis), 75-104, 246

Wink, André (modern historian), viii, 73, 84, 90, 133, 143, 202, 250, 258, 266

Witsen Album see paintings

world conquest classical trope, 161, 162, 167, 274 licensed by Pope, 19, 34, 72

Dutch liberation, 28, 30-1, 54, 67 pacta sunt servanda, 31, 215

Yavanas (term for Muslims), 158-60, 172, $185,214-5$

zamindars (holders of hereditary revenue collection rights, often styled rajas), 96, 157, 160, 167, 172, 200, 215, 219, 235, 242, 249-50, 270, 277

zimmis (protected non-Muslims) 59, 199, 269

Zoroastrians, 59, 206, 209, 222

Zuhuri, Zuhur bin (Bijapur chronicler), 77, 81-2, 94, 100, 102, 103 